UNIVERSIDADE DE SÃO PAULO

FACULDADE DE ECONOMIA, ADMINISTRAÇÃO E CONTABILIDADE DEPARTAMENTO DE ADMINISTRAÇÃO PROGRAMA DE PÓS-GRADUAÇÃO EM ADMINISTRAÇÃO

EFEITOS DA INTERNACIONALIZAÇÃO DE CARTEIRAS NO MERCADO DE CAPITAIS BRASILEIRO

Leticia Lancia Noronha Bellato Orientador: Prof. Dr. José Roberto Ferreira Savoia 
Profa. Dra. Suely Vilela Sampaio

Reitora da Universidade de São Paulo

Prof. Dr. Carlos Roberto Azzoni

Diretor da Faculdade de Economia, Administração e Contabilidade

Prof. Dr. Isak Kruglianskas

Chefe do Departamento de Administração

Prof. Dr. Lindolfo Galvão de Albuquerque

Coordenador do Programa de Pós-Graduação em Administração 
LETICIA LANCIA NORONHA BELLATO

\section{EFEITOS DA INTERNACIONALIZAÇÃO DE CARTEIRAS NO MERCADO DE CAPITAIS BRASILEIRO}

Dissertação apresentada ao Departamento de Administração da Faculdade de Economia, Administração e Contabilidade da Universidade de São Paulo como requisito para obtenção do título de Mestre em Administração.

Orientador: Prof. Dr. José Roberto Ferreira Savoia 


\section{FICHA CATALOGRÁFICA}

Elaborada pela Seção de Processamento Técnico do SBD/FEA/USP

Bellato, Letícia Lancia Noronha

Efeitos da internacionalização de carteiras no mercado de capitais brasileiro / Letícia Lancia Noronha Bellato. -São Paulo, 2007.

$247 \mathrm{p}$.

Dissertação (Mestrado) - Universidade de São Paulo, 2007 Bibliografia

1. Mercado de capitais 2. Investimentos 3. Administração de carteiras I. Universidade de São Paulo. Faculdade de Economia, Administração e Contabilidade. II. Título.

$$
\text { CDD - } 332.041
$$


À minha família;

Dedico ao meu avô materno, Chiquito Noronha, e a minha avó paterna, Anna Bellato, com quem aprendi ainda criança, ao procurar reproduzir o mundo no aprendizado cotidiano da casa, 0 significado maior e o gosto pela modelagem. Através deles, homenageio toda minha família, por quem sou absolutamente apaixonada. À minha irmã Livia, companheira em todos os momentos. 
Agradeço aos incentivos que foram primordiais em minha vida, desde o Colégio Dante Alighieri, no qual, pelas mãos do presidente Giannandrea Matarazzo, recebi menção honrosa por desempenho escolar.

Agradeço à FEA e ao Laboratório de Finanças que propiciaram estrutura necessária para que esta dissertação fosse desenvolvida.

Devo dizer da minha admiração pelo papel da FAPESP e do CNPq e que sou grata a ambas as instituições, respectivamente pelo apoio na Iniciação Científica e agora nesta dissertação.

Agradeço à ANBID e à Casa das Garças pelo Prêmio de Mercado de Capitais para Projetos de Dissertação 2006, que representou grande estímulo para mim.

Sou intensamente grata ao Prof. Sanvicente por ter me iniciado na área de Finanças, tanto me orientando na Iniciação Científica, quanto no Trabalho de Conclusão de Curso de Graduação. Ao Prof. Siqueira devo o treino disciplinar no aprimoramento cotidiano da pesquisa científica. Sou grata também ao Prof. Alexandre di Miceli pela confiança na co-autoria de trabalhos e ensinamentos.

Agradeço ao apoio nos momentos difíceis e aconselhamentos do Prof. Abraham Yu, Cidinha, Mauro Ruiz e Edna do IPT, Prof. Capocchi e Prof. Oda. Agradeço sempre os ensinamentos e incentivo dos professores Marcelo Finger do IME, Nicolau Reinhard, Geraldo Toledo, Ana Cristina Limongi e Maria Aparecida Gouvêa e especialmente do Prof. Securato.

Muito me ajudaram o Valdir da Seção de Alunos da Graduação, a Valéria e o Francisco da Secretaria de Pós-Graduação, a Érica da FIA, a Eloísa e a Fabiana da Secretaria da PósGraduação em Administração, muito especialmente a Carol e a Joyce da área de Finanças e aos funcionários da biblioteca, com cuja generosidade contei todo tempo.

Ao Luiz Felipe de Andrade e Edson Kojo do Unibanco Asset Management que generosamente me acolheram para o trabalho este ano, sem deixar de compreender a importância de incentivar minha ligação com a Universidade durante o mestrado, minha sincera gratidão.

Agradeço ao Prof. Almir e Prof. Paulo Gala da FGV-SP pelas críticas e sugestões valiosas para o aprimoramento desta dissertação.

Aos amigos Eduardo Paiva e Flávia pela primordial ajuda no desenvolvimento do trabalho.

Reservo ao Prof. Savoia, meu orientador, que me norteou, me acompanhou e consolidou com esta dissertação minha vocação por Finanças, minha eterna gratidão.

À minha família e amigos que me acompanharam e entenderam meus períodos de ausência.

Agradeço a Deus por ter me dado a chance de participar da alegre e indescritível sensação que é viver e estar impregnada do encantamento acadêmico em buscar produzir conhecimento para uma melhor condição humana. 


\section{RESUMO}

Esta dissertação analisa os benefícios da diversificação internacional, advindos de uma maior abertura a investimentos no exterior, sob a perspectiva dos investidores institucionais brasileiros. Primeiramente, será desenvolvida uma revisão da literatura existente, abordando os benefícios da diversificação internacional, bem como algumas experiências de países que realizaram a internacionalização das carteiras locais e os resultados macroeconômicos advindos destas. Foram examinadas empiricamente as mudanças de posição das fronteiras eficientes para diferentes graus de abertura a investimentos em ações estrangeiras. Como principal análise empírica foram compostas carteiras internacionais eficientes, otimizadas pelo critério de média-variância, considerando o risco cambial. Os resultados indicaram uma redução do risco da carteira doméstica pela alocação em ações estrangeiras. Concluiu-se que o grau em que os benefícios do investimento externo em termos de retorno e diversificação poderiam ser utilizados foi limitado pela regulamentação, em detrimento do desempenho da carteira dos investidores institucionais. Finalmente, uma gradual mas decisiva diminuição das restrições a investimentos no exterior é recomendada. 


\begin{abstract}
This work analyzes the international diversification benefits of an increase in the limits for foreign investing from the perspective of Brazilian institutional investors. We examine empirically the efficient frontiers position after portfolio restrictions on overseas investments were progressively eased. As the main empirical analysis, efficient international portfolios were constructed, optimized by the mean-variance model, considering exchange risk. First, we present a literature review of international diversification and discuss the experience of some countries in the process of internationalizing domestic portfolios and its macroeconomic implications. The results indicate a risk reduction of the domestic portfolio by adding international stocks. We conclude that, in Brazil, the degree to which the benefits of foreign investment in terms of returns and diversification may be utilized for portfolio objectives were limited by regulation, to the detriment of performance of institutional investor's portfolio. Finally, a gradual but decisive loosening of restrictions on foreign investments is recommended.
\end{abstract}




\section{SUMÁRIO}

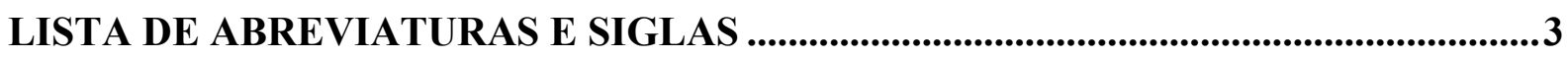

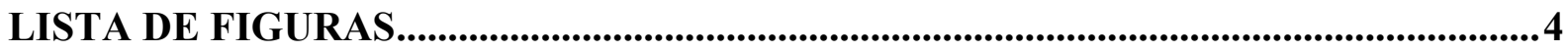

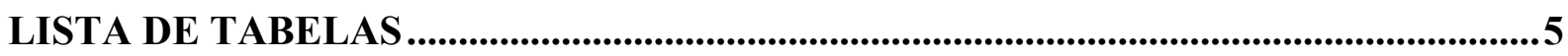

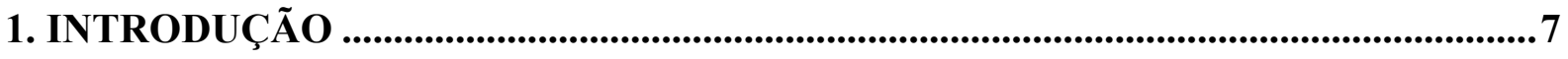

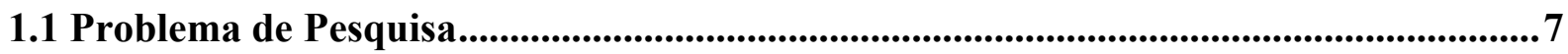

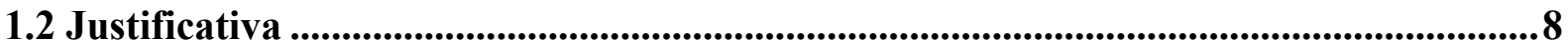

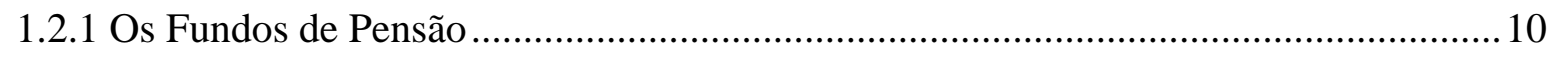

1.2.2 O Processo de Liberalização no Brasil ..................................................................... 11

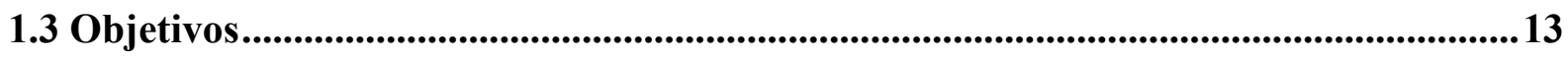

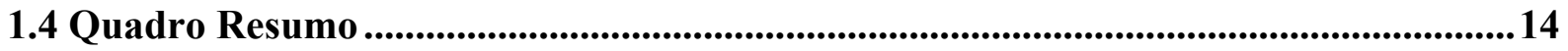

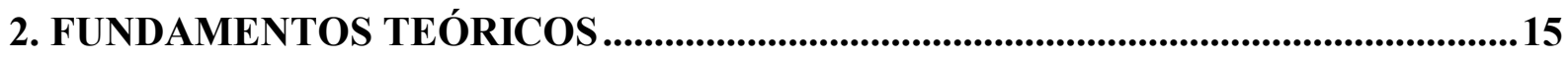

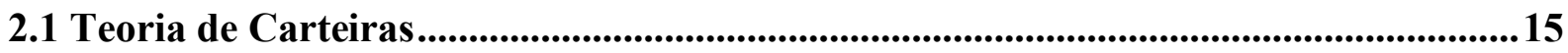

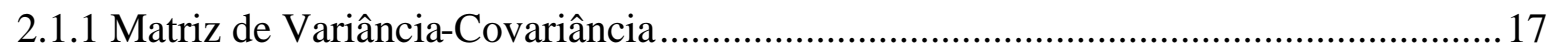

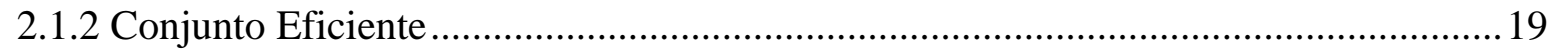

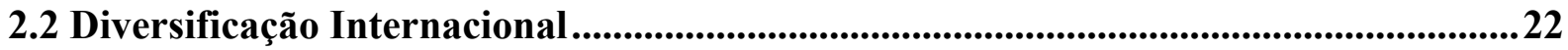

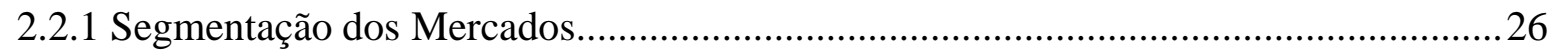

2.2.2 Justificativas para a Diversificação Internacional ...................................................27

2.2.3 Fatores de Risco nos Investimentos Internacionais ...............................................29

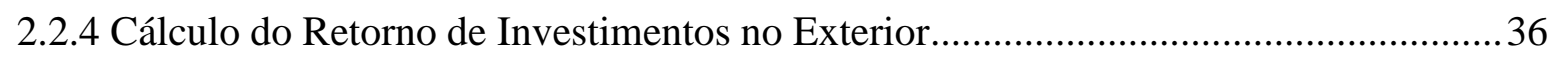

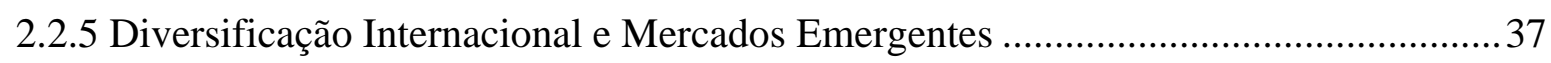

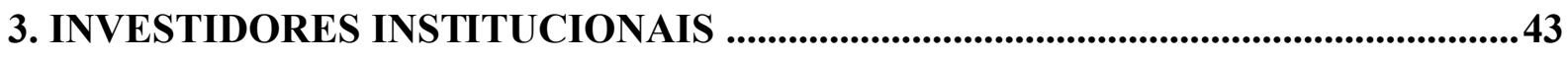

3.1 Legislação e Alocação das Carteiras de Investidores Institucionais no Mundo ..........47

3.2 Experiências de Internacionalização de Carteiras em Outros Países...........................55

4. LEGISLAÇÃO BRASILEIRA SOBRE INVESTIMENTOS DOS INVESTIDORES

INSTITUCIONAIS.........................................................................................................................55

4.1 Legislação Brasileira sobre Investimentos dos Fundos de Pensão ..................................57

4.2 Legislação Brasileira sobre Aplicações no Exterior dos Investidores Institucionais .63

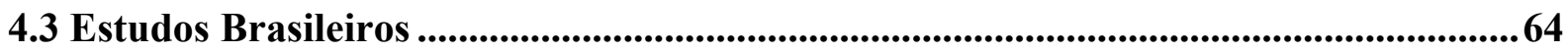


5. METODOLOGIA. .66

5.1 Objetivos e Aspectos Metodológicos 67

5.2 Amostra Preliminar 71

6. RESULTADOS . 73

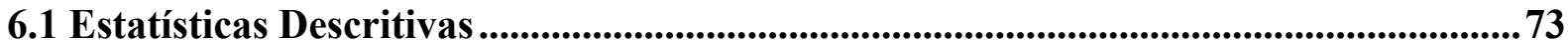

6.2 Matrizes de Correlações..........................................................................................76

6.3 Fronteiras Eficientes do Mercado de Ações ..............................................................81

6.4 Carteiras dos Investidores Institucionais Otimizadas...................................................82

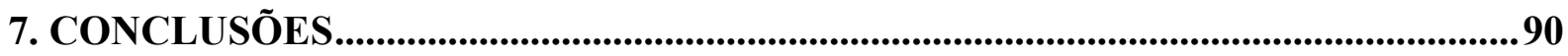

8. REFERÊNCIAS BIBLIOGRÁFICAS _..............................................................92

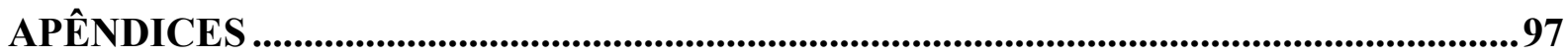

APÊNDICE A - MATRIZES DE CORRELAÇÕES ENTRE OS ATIVOS .......................... 98

APÊNDICE B - MATRIZES DE CORRELAÇÕES ENTRE OS RETORNOS MENSAIS DOS ÍNDICES DE MERCADO DE AÇÕES (PROCESSAMENTO DOS DADOS NO SOFTAWARE STATA)

APÊNDICE C - RETORNO, RISCO E PESOS DOS ATIVOS NAS CARTEIRAS DA FRONTEIRA EFICIENTE FORMADA POR ÍNDICES DE MERCADOS DE AÇÕES ....120

APÊNDICE D - FRONTEIRAS EFICIENTES DE FUNDOS DE PENSÃO COM RETORNOS EM MOEDA LOCAL PARA DIFERENTES GRAUS DE ABERTURA PARA INVESTIMENTOS NO EXTERIOR

APÊNDICE E - FRONTEIRAS EFICIENTES DE FUNDOS DE PENS ÃO COM RETORNOS EM REAIS PARA DIFERENTES GRAUS DE ABERTURA PARA INVESTIMENTOS NO EXTERIOR

APÊNDICE F - FRONTEIRAS EFICIENTES COM RETORNOS EM MOEDA LOCAL PARA DIFERENTES GRAUS DE ABERTURA A INVESTIMENTOS NO EXTERIOR DADOS RETORNOS DAS CARTEIRAS DA FRONTEIRA EM INTERVALOS DE 0,05\%

APÊNDICE G - FRONTEIRAS EFICIENTES COM RETORNOS EM REAIS PARA DIFERENTES GRAUS DE ABERTURA A INVESTIMENTOS NO EXTERIOR DADOS RETORNOS DAS CARTEIRAS DA FRONTEIRA EM INTERVALOS DE 0,05\% 


\section{LISTA DE ABREVIATURAS E SIGLAS}

ANBID: Associação Nacional dos Bancos de Investimento

ANDIMA: Associação Nacional das Instituições do Mercado Financeiro

Bovespa: Bolsa de Valores de São Paulo

CDI: Certificado de Depósito Interbancário

CMN: Conselho Monetário Nacional

CVM: Comissão de Valores Mobiliários

EFPC: Entidades Fechadas de Previdência Complementar

EViews: Econometric Views

FIEX: Fundo de Investimento no Exterior

FMI: Fundo Monetário Internacional

IGP-M: Índice Geral de Preços - Mercado

IMA: Índice de Mercado Andima

INPC: Índice Nacional de Preços ao Consumidor

MATLAB: Matrix Laboratory

NTN-C: Nota do Tesouro Nacional - série C

OCDE: Organização para Cooperação e Desenvolvimento Econômico

PIB: Produto Interno Bruto

SELIC: Sistema Especial de Liquidação e Custódia

TR: Taxa Referencial 


\section{LISTA DE FIGURAS}

Figura 1 - Conjunto das Curvas de Indiferença de um Indivíduo ......................................... 16

Figura 2 - Conjunto de Carteiras Compostas por Combinações entre Duas Ações ................. 19

Figura 3 - Conjunto Viável de Carteiras Construídas com Diversas Ações.............................20

Figura 4 - Relação entre a Variância do Retorno de uma Carteira e o Número de Títulos na Carteira

Figura 5 - Diferentes Fronteiras Derivadas de Várias Oportunidades de Investimento ...........28

Figura 6 - Diversificação Internacional Com e Sem Risco Cambial .........................................30

Figura 7 - Taxas de Retornos dos Índices de Mercado de Ações em 2001 .............................32

Figura 8 - Relação PIB per capita e Capitalização de Mercado como Porcentagem do PIB ...40

Figura 9 - Ativos Internacionais dos Fundos de Pensão como \% dos Fundos Administrados.50

Figura 10 - Fronteira Eficiente com base nas Oportunidades de Investimento dos Índices de Mercado em Moeda do Próprio País ............................................................................. 81

Figura 11 - Fronteira Eficiente com base nas Oportunidades de Investimento dos Índices de

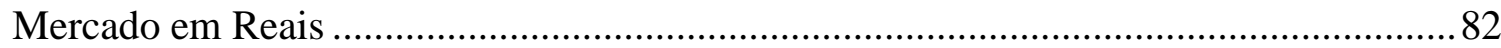




\section{LISTA DE TABELAS}

Tabela 1 - Porcentagem de risco que pode ser eliminado em uma carteira de ações escolhidas aleatoriamente.

Tabela 2 - Risco País medido por Rating de Risco do PRS Group 34

Tabela 3 - Variáveis Utilizadas pelo PRS para o Rating de Risco 35

Tabela 4 - Capitalização de Mercado das Bolsas de Valores de Mercados Emergentes 39

Tabela 5 - Correlações de Retornos entre Mercados Emergentes e o Mercado Brasileiro.

Tabela 6 - Ativos Administrados pelos Investidores Institucionais nos Países Desenvolvidos 44

Tabela 7 - Ativos dos Investidores Institucionais (\% do PIB) 46

Tabela 8 - Diversificação Internacional das Carteiras dos Investidores Institucionais nos......47

Tabela 9 - Limites de Investimentos e Alocação dos Fundos de Pensão - 2001/2002. 49

Tabela 10 - Alocação dos Ativos de Seguradoras de Vida no final de 2002 ..........................51

Tabela 11 - Limites de Aplicações das EFPC's conforme Resolução CMN 3.121/03 ..............61

Tabela 12 - Amostra de Índices de Mercado de Ações Internacionais 72

Tabela 13 - Retorno Médio Mensal e Desvio-Padrão dos Retornos Mensais dos Índices de Mercado de Ações em termos de Reais

Tabela 14 - Retorno Médio Mensal e Desvio-Padrão dos Retornos Mensais dos Índices de Mercado de Ações em termos da moeda de cada país ....

Tabela 15 - Retorno Médio Mensal e Desvio-Padrão dos Retornos Mensais dos Ativos .75

Tabela 16 - Retorno Médio e Desvio-Padrão dos Retornos Mensais dos Ativos para cada Ano da Amostra.

Tabela 17 - Coeficiente de Correlação entre os Retornos Mensais, em termos de Moeda Local, dos Índices de Mercado de Ações

Tabela 18 - Coeficiente de Correlação entre os Retornos Mensais, em termos de Reais, dos Índices de Mercado de Ações

Tabela 19 - Matrizes de Correlações entre os Ativos Nacionais para os Períodos Analisados

Tabela 20 - Mínimo Risco das Carteiras dado o Retorno para cada Limite de Aplicação em Ações Estrangeiras, considerados Retornos em Moeda Local, para o período de 2000 a 2005 
Tabela 21 - Pesos dos Ativos em Carteiras da Fronteira Eficiente com Retornos em Moeda Local para o Período de 2000 a 2005 com Limitação de 10\% a Aplicações no Exterior 84

Tabela 22 - Mínimo Risco das Carteiras dado o Retorno para cada Limite de Aplicação em Ações Estrangeiras, considerados Retornos em Moeda Local, para o período de 2001 a 2006

Tabela 23 - Pesos dos Ativos em Carteiras da Fronteira Eficiente com Retornos em Moeda Local para o Período de 2001 a 2006 com Limitação de 10\% a Aplicações no Exterior 86

Tabela 24 - Mínimo Risco das Carteiras dado o Retorno para cada Limite de Aplicação em Ações Estrangeiras, considerados Retornos em Moeda Local, para o período de 2003 a 2006

Tabela 25 - Mínimo Risco das Carteiras dado o Retorno para cada Limite de Aplicação em Ações Estrangeiras, considerados Retornos em Reais, para o período de 2000 a $2005 . . .88$

Tabela 26 - Mínimo Risco das Carteiras dado o Retorno para cada Limite de Aplicação em Ações Estrangeiras, considerados Retornos em Reais, para o período de 2001 a 2006 ... 88

Tabela 27 - Mínimo Risco das Carteiras dado o Retorno para cada Limite de Aplicação em Ações Estrangeiras, considerados Retornos em Reais, para o período de 2003 a 2006...89

Tabela 28 - Pesos dos Ativos em Carteiras da Fronteira Eficiente com Retornos em Reais para o Período de 2003 a 2006 com Limitação de 10\% a Aplicações no Exterior 89 


\section{INTRODUÇÃO}

\subsection{Problema de Pesquisa}

O trabalho seminal de Markowitz (1952) representou a base do que se chamou de Moderna Teoria de Finanças. O estudo abordou, por meio de um modelo de período único, a questão de seleção de carteira ótima, visando máximo retorno esperado e mínimo risco.

A moderna teoria de carteiras abrange as melhores oportunidades de investimento, com base na relação risco/retorno, pressupondo que, geralmente, os investidores são avessos ao risco. Essa teoria sugere que deter uma carteira diversificada de ativos no mercado doméstico pode eliminar o risco não sistemático resultante de diferentes performances individuais das empresas e setores, mas não o risco sistemático resultante da economia como um todo.

Em um mercado mundial de capitais eficiente e integrado, a aplicação numa carteira mundial seria uma estratégia racional, conforme o Teorema da Separação (Tobin, 1958) - todo o investidor teria uma carteira ótima composta por alguma combinação entre o ativo sem risco e a carteira de todos os ativos existentes no mercado (Copeland e Weston, 2005). Assim, o risco sistemático pode ser minimizado.

Isso acontece, pois os valores dos títulos de empresas no país tendem a variar em conjunto por serem afetados pelos mesmos fatores econômicos locais, o que é refletido nos elevados coeficientes de correlação entre os retornos dessas ações.

Dessa forma, os mercados de capitais estrangeiros oferecem possibilidades de diversificação, podendo potencializar o desempenho, ajustado pelo risco, de uma carteira puramente doméstica, desde que os mercados nacionais tenham um comportamento razoavelmente independente, identificado por baixos coeficientes de correlação com relação aos outros países.

Por sua vez, o grau de independência de um mercado de ações, comparado a outros, é diretamente determinado pela força da vinculação entre a atividade econômica e as políticas governamentais entre esses países. 
Segundo Copeland e Weston (2005), os investidores, tanto institucionais como individuais, devem considerar a possibilidade de expandir seus investimentos de modo a ultrapassar os limites geográficos de seus países, ao menos devido a um maior número e diversidade de possibilidades de investimento disponíveis. Se o universo de ativos disponíveis para investir for maior que os ativos de um país, os investidores poderão ter a possibilidade de reduzir o risco de suas carteiras pela diversificação internacional.

Francis (1991) aponta um grande número de pesquisas, além das pioneiras de Grubel (1968) e Levy e Sarnat (1970), que apresentam evidências sobre os benefícios da diversificação internacional.

Solnik (1974) fornece estimativas empíricas do risco de carteiras diversificadas internacionalmente e estabelece comparação com as carteiras domésticas. Embasado em dados semanais de ações dos oito maiores países europeus e dos Estados Unidos, concluiu que carteiras diversificadas internacionalmente conteriam um décimo do risco de uma ação típica e metade do risco de uma carteira bem diversificada em ações puramente norte-americanas, aplicando a variância dos retornos como medida de risco. $\mathrm{O}$ autor também identificou que a diversificação intersetorial produzia resultados inferiores que a diversificação ao longo de países.

\subsection{Justificativa}

Diversos autores demonstram a tendência de internacionalização das carteiras (Aggarwal et al.,1995). O Fundo Monetário Internacional, por exemplo, estima que, em 1991, mais de $\$ 2.5$ trilhões de ativos estavam em posse de investidores estrangeiros. No início de 1994, dados do Baring Securities evidenciavam que uma em cada quatro transações no mundo envolvia um investidor, ou um vendedor estrangeiro, ou uma ação estrangeira.

Solnik (1996) relata que, apesar dos Estados Unidos representarem 35\% da capitalização de mercado mundial em 1994, é comum observar fundos de pensão norte-americanos detentores de 10 a $15 \%$ dos ativos investidos internacionalmente.

Argumentos favoráveis à diversificação internacional podem advir de circunstâncias de países e de ineficiências do mercado global de capitais. O próprio mercado acionário doméstico pode 
apresentar uma diversificação insuficiente pelo fato de ser dominado por um pequeno número de grandes empresas.

Reisen (1997) argumenta que a alta volatilidade dos retornos dos ativos em países em desenvolvimento combinada com a baixa tolerância ao risco dos pensionistas sugere que os benefícios da diversificação internacional aplicam-se particularmente aos fundos de pensão de países em desenvolvimento. Reisen e Williamson (1997) afirmam que a diversificação internacional pelos fundos de pensão produz a integração dos mercados acionários.

Bacha e Chrysostomo (2005) citam o caso do Chile que apresenta um mercado de capitais bem desenvolvido atualmente. Os investimentos no exterior no Chile começaram a ser permitidos em 1990 na ordem de 2,5\% dos ativos. Em 1992 a parcela passou para 9\% e houve aprovação de investimento de uma parte em renda variável. Esse limite chegou a $20 \%$ em 1999 e a $30 \%$ em 2002, dos quais o máximo consentido para ações e renda fixa é de $15 \%$ e $20 \%$, respectivamente. A permissão para investir no exterior é ressaltada como importante fonte de diversificação, especialmente pelo Chile apresentar um mercado de ações concentrado.

Outro ponto relevante é levantado por Leite e Sanvicente (1994) que constatam correlações muito baixas entre os mercados emergentes e algumas elevadas correlações negativas. $\mathrm{O}$ coeficiente de correlação encontrado entre o Financial Times-Actuaries World Index - para empresas de mercados desenvolvidos - e os retornos do mercado brasileiro foi igual a 0,06 .

Da mesma forma que os mercados emergentes constituem alternativa promissora para investidores de países desenvolvidos, essa fraca associação também revela oportunidades de diversificação de risco para investidores brasileiros, caso componham suas carteiras com ações de outros mercados.

Leite e Sanvicente (1994) atentaram para necessidade de investigar como tal fato pode influenciar o potencial de diversificação implícito nos baixos coeficientes de correlação. Constataram que a média dos coeficientes de correlação do índice Bovespa com os demais índices - que, no período de 1986 a 1993, era de 0,052 - elevou-se dramaticamente para 0,283, no sub-período de 1991 a 1993, refletindo uma perda potencial de redução de riscos. 
Dessa forma, cabe verificar como se apresenta atualmente a possibilidade de redução de riscos através da diversificação internacional das carteiras.

Além disso, Bacha e Chrysostomo (2005) indicam que a experiência internacional convida à discussão sobre a atratividade de incrementar o grau de integração internacional do mercado de capitais brasileiro. Argumenta-se que a implementação gradual da possibilidade de os investidores institucionais locais aplicarem suas reservas no exterior ajudaria a aumentar a competição por esses recursos e a estimular uma melhoria da governança corporativa das empresas brasileiras. Além disso, evitaria, em cenário de elevada informalidade, que um rápido crescimento das carteiras levasse a valorização excessiva dos papéis domésticos e a indesejada concentração do mercado.

\subsubsection{Os Fundos de Pensão}

Os fundos de pensão têm apresentado um rápido crescimento em diversos países, inclusive no Brasil, desempenhando um importante papel na economia. As entidades de previdência privada, além da função de complementar o papel da seguridade básica oferecida pelo governo, exercem uma relevante atividade de promover a acumulação de poupança interna, alavancando diversos segmentos econômicos, o mercado acionário nacional e oferecendo financiamentos de longo prazo. Devido à acumulação de altos volumes em carteira, os fundos de pensão são atualmente o mais importante investidor institucional no país, sendo a gestão de seus investimentos um importante fator para a manutenção de seu equilíbrio financeiro e operacional (Leal et. al., 2001).

Roldos (2004) também ressalta que a crescente diferença entre a demanda de ativos pelos fundos de pensão e a oferta de opções de investimento nos mercados emergentes, combinada com restrições à política de investimentos dos fundos, pode causar significativas distorções na precificação dos ativos, concentração na exposição a riscos e bolhas de preços. A fim de salvaguardar os participantes dos fundos de riscos do mercado de capitais, muitos países aplicam severas restrições à aplicação das carteiras, em particular de deter ações e ativos internacionais.

Além disso, muitos países também adotaram fortes restrições na porcentagem do capital de companhias ou títulos de renda fixa que os fundos podem investir. Porém, quando os 
mercados de ações são pequenos, como é o caso da maioria dos países da América Latina, com limitado número de companhias qualificadas, o rápido crescimento dos fundos de pensão irá atingir esses limites, aumentando o risco de formação de bolhas de preços.

Limites regulatórios de investimentos em ações e em ativos internacionais podem também distorcer os preços dos ativos e ampliar a volatilidade nos preços. Um efeito do volume investido pelos fundos relativamente ao tamanho dos mercados locais é que os preços serão distorcidos e os fundos podem ser capazes de influenciá-los individualmente. Isso freqüentemente resulta em falta de liquidez para os fundos, já que estes não podem vender os ativos sem pressionar ainda mais os preços. Além disso, os limites a investimentos no exterior resultam em controles de saídas de capitais que impõem um abismo entre os preços dos títulos locais e estrangeiros.

Para Roldos (2004), essa crescente defasagem demanda contínuos e coordenados esforços para melhorias na estrutura regulatória tanto para os fundos de pensão quanto para os mercados de títulos. Um relaxamento gradual dos limites de investimentos em ativos no exterior melhoraria as oportunidades de diversificação dos fundos de pensão e a estabilidade dos mercados financeiros produzindo impactos pouco relevantes para o desenvolvimento dos mercados de capitais locais.

\subsubsection{O Processo de Liberalização no Brasil}

Quanto ao cenário atual no Brasil, durante os anos 90, o Brasil flexibilizou sua conta de capital, paralelamente ao processo de abertura comercial e o crescimento dos fluxos de entrada de capitais. Tal avanço foi um processo gradual de estabelecimento de novas regras sobre os fluxos de entrada e saída de capitais.

Arida (2003a e 2003b) defende a liberalização na conta de capital sob o argumento de que existe uma relação entre a incerteza da possível adoção de controles de capitais no futuro e o risco. Esta incerteza poderia elevar a percepção de risco, resultando na elevada taxa de juros interna observada no Brasil. Esta última limita a política fiscal que, conseqüentemente, tem que produzir elevados superávits primários. 
Apesar da grande liberalização dos anos 90, Arida, Bacha e Lara-Resende (2004) apontam que o sistema resultante não significa livre ou irrestrita conversibilidade. Os autores listam várias limitações do sistema corrente, como a de que a conversibilidade atual se baseia em regras de autoridades monetárias ao invés de leis. Portanto, podem ser suspensas a qualquer momento.

Arida (2003a, 2003b) defende a mudança na legislação para que seja assegurada a conversibilidade irrestrita da moeda. Enfatiza que a livre conversibilidade deve ser adotada imediatamente, mas anunciada previamente e implementada gradualmente, acompanhando também alguns indicadores macroeconômicos e mudanças institucionais, como a independência do Banco Central.

Outros autores, como Bresser-Pereira e Nakano (2003), advogam contra a liberalização da conta capital, por acreditarem que abertura financeira somente pode ajudar países que não estão fortemente endividados e que tenham alcançado estabilidade macroeconômica.

Goldfajn e Minella (2005) ressaltam que os principais marcos do controle de capitais no Brasil foram: i) o significante avanço da liberalização desde os anos 90; ii) as medidas restritivas do período de 1993-1996, que visavam, sobretudo, a redução de grandes entradas de capitais e não reverteram a tendência de liberalização; iii) a conversibilidade da moeda aumentou significativamente; iv) a situação corrente pede simplificação do mercado de câmbio e eliminação da burocracia existente, e v) os avanços alcançados na última década (por meio de muitas regras) devem ser consolidados em uma lei a ser aprovada no Congresso.

A liberalização dos investimentos no exterior por pessoas físicas e jurídicas no Brasil foi regulamentada recentemente pelo Banco Central pela Circular 3.328 de 10 de outubro de 2006. O primeiro passo no sentido da flexibilização do mercado de câmbio foi dado em 2005, com a aprovação do Conselho Monetário Nacional de uma série de medidas para simplificar as operações de câmbio, regulamentadas por meio a Resolução 3.265 de 6 de maio de 2005.

Quanto às restrições existentes a residentes no Brasil em investimentos no exterior anteriormente tínhamos: i) possibilidade de adquirir bonds ou outros títulos de dívida somente por meio de fundos de investimentos offshore dedicados (FIEX); ii) autorização para investir 
somente em bolsas de países do Mercosul, e iii) serem permitidos a comprar Depositary Receipts emitidos por empresas sediadas no Brasil e BDRs - Brazilian Depositary Receipts.

\subsection{Objetivos}

Estudos brasileiros anteriores sobre diversificação internacional, como o de Zanette (1995) e Cabello (2002), são focados nas vantagens de investir em mercados emergentes, por parte de países desenvolvidos. Diferentemente, esta dissertação busca analisar a internacionalização de carteiras sempre amparada no ponto de vista do investidor brasileiro.

Elton e Gruber (2003) enfatizam que o país de domicílio do investidor afeta os retornos esperados e o risco, incluindo os coeficientes de correlação, resultantes da diversificação internacional, devido às variações de taxa de câmbio.

Dessa forma, o trabalho investigará quais seriam os benefícios no que tange a redução de risco e aumento de retornos para carteiras de investimento em ações brasileiras pela introdução de ações estrangeiras, considerando tanto carteiras com hedge como sem hedge.

A análise será realizada com base em vários exemplos de graus de liberalização da internacionalização de carteiras brasileiras. Também buscará identificar quais mercados externos oferecem maior potencial de diversificação de riscos para investimentos em carteira no Brasil.

Finalmente, serão analisados possíveis impactos da internacionalização das carteiras para o mercado de capitais brasileiro e serão estudados exemplos de países que liberalizaram os fluxos de capitais para o exterior.

Este trabalho está estruturado da seguinte forma: as seções 2, 3 e 4 consistem na revisão bibliográfica, com a apresentação de pesquisas relevantes realizadas principalmente nos mercados americano e brasileiro. A seção 5 apresenta a metodologia do estudo empírico. $\mathrm{Na}$ seção 6 os resultados são mostrados e analisados. A seção 7 apresenta as conclusões do estudo. 


\subsection{Quadro Resumo}

\begin{tabular}{|c|c|c|}
\hline Pergunta Problema & Objetivo do Trabalho & Metodologia \\
\hline \multirow{3}{*}{$\begin{array}{l}\text { Quais os efeitos da } \\
\text { Internacionalização de } \\
\text { Carteiras para os } \\
\text { Investidores } \\
\text { Institucionais } \\
\text { Brasileiros? }\end{array}$} & $\begin{array}{l}\text { Verificar quais mercados } \\
\text { oferecem aos investidores } \\
\text { brasileiros maior possibilidade } \\
\text { de reducão de riscos pela } \\
\text { diversificação internacional }\end{array}$ & $\begin{array}{l}\text { Matriz de Correlações entre } \\
\text { os Retornos dos Îndices de } \\
\text { Mercado Mundiais com os } \\
\text { do Índice Bovespa }\end{array}$ \\
\hline & $\begin{array}{l}\text { Determinar quais seriam os } \\
\text { pesos de cada índice de } \\
\text { mercado nas melhores carteiras } \\
\text { a serem formadas globalmente } \\
\text { para cada nível de risco }\end{array}$ & $\begin{array}{l}\text { Determinação da fronteira } \\
\text { eficiente global }\end{array}$ \\
\hline & $\begin{array}{c}\text { Quantificar os benefícios em } \\
\text { termos de redução de risco e/ } \\
\text { ou aumento de retorno para } \\
\text { carteiras brasileiras com a } \\
\text { gradual internacionalização } \\
\text { destas }\end{array}$ & $\begin{array}{l}\text { Construção da fronteira } \\
\text { eficiente para cada grau de } \\
\text { abertura e compará-las com } \\
\text { a fronteira eficiente apenas } \\
\text { com ações brasileiras }\end{array}$ \\
\hline \multirow[t]{2}{*}{$\begin{array}{l}\text { Quais os efeitos dos } \\
\text { Investimentos Externos } \\
\text { em Carteira para o } \\
\text { Mercado de Capitais } \\
\text { Brasileiro? }\end{array}$} & $\begin{array}{c}\text { Analisar os impactos de uma } \\
\text { Internacionalização de Carteiras } \\
\text { para o Mercado de Capitais } \\
\text { Brasileiro }\end{array}$ & Pesquisa Bibliográfica \\
\hline & $\begin{array}{l}\text { Discutir os aspectos } \\
\text { regulatórios da } \\
\text { internacionalização dos } \\
\text { portfolios }\end{array}$ & $\begin{array}{l}\text { Estudo de casos ocorridos } \\
\text { em outros países }\end{array}$ \\
\hline
\end{tabular}




\section{FUNDAMENTOS TEÓRICOS}

\subsection{Teoria de Carteiras}

A moderna teoria de carteiras estuda as melhores oportunidades de investimento com base na relação risco e retorno, pressupondo que em geral os investidores são pessoas avessas ao risco, ou seja, sempre preferem suportar menos risco para um dado nível de retorno esperado nos seus investimentos (Nakamura, 1998).

Quando a teoria de carteiras foi escrita por Markowitz ainda não havia recursos de informática que viabilizassem sua aplicação, o que requer milhares de cálculos e grandes bancos de dados. Sharpe, na década de 60, concebe o Single Index Model que reduziu o drasticamente o número de computações exigidas pelo modelo de Markowitz ao relacionar os retornos de todas as ações aos retornos do índice de mercado, ao qual a grande maioria delas está correlacionada (Leite e Sanvicente, 1994).

Sharpe, Lintner e Mossin (1964) chegam ao modelo do Capital Asset Pricing Model (CAPM), que especifica as condições de equilíbrio no mercado de títulos de renda variável e fixa e dá à teoria financeira a indispensável integração e generalização (Leite e Sanvicente, 1994).

Apesar do risco total de uma carteira ser medido pela variância dos retornos das carteiras, Sharpe (1964) demonstra que, em equilíbrio, um ativo individual é precificado para refletir sua contribuição ao risco total (ou risco sistemático), que é medido pela covariância de seu retorno com o retorno da carteira de mercado composta por todos os ativos.

Sharpe (1964) conclui que carteira super-eficiente é igual ao próprio mercado. Além disso, o CAPM também estabelece que a diferença entre o retorno esperado para um ativo e o retorno do ativo livre de risco é diretamente proporcional ao seu beta - covariância do ativo em relação ao mercado.

Para exemplificar, dentro de um contexto de período único, o retorno de um ativo é dado por:

$$
\begin{aligned}
& R=\frac{P_{f}-P_{i}}{P_{i}} \\
& P_{f}=\text { Preço da ação no fim do período }
\end{aligned}
$$


$P_{i}=$ Preço da ação no início do período

Como o comportamento dos preços dos ativos com risco é incerto, os retornos são tratados como variáveis aleatórias descritas por seus momentos. Os dois primeiros momentos de uma variável são a média e a variância que, do ponto de vista dos investimentos em ativos financeiros, correspondem ao retorno esperado e ao risco, respectivamente.

A teoria econômica da escolha prega que um investidor escolhe entre oportunidades pela especificação de séries de curvas, chamadas funções utilidade ou curvas de indiferença. As preferências individuais são representadas graficamente através das curvas de indiferença, cujos pontos compreendem um mesmo nível de satisfação.

A construção das curvas de indiferença de um investidor está baseada na Teoria da Escolha ou da Preferência e na Teoria da Utilidade em que são avaliadas as preferências em condições de incerteza (Securato, 1993).

\section{Figura 1 - Conjunto das Curvas de Indiferença de um Indivíduo}

\section{Retorno Esperado}

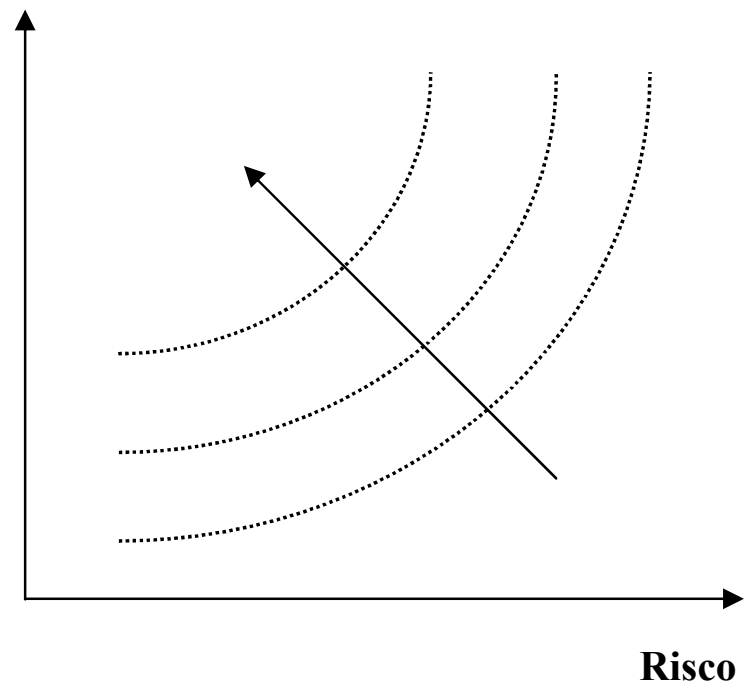

Fonte: Nakamura, 1998.

A Figura 1 apresenta as curvas de indiferença em um plano de média-variância, correspondendo às medidas de risco e desvio-padrão de retornos de ativos com risco. 
As diversas curvas de utilidade de um indivíduo não se interceptam e cada uma delas representa um nível diferente de satisfação. O conjunto de curvas de indiferença de um dado indivíduo forma o que é denominado mapa de indiferença.

Quando se traçam as curvas de indiferença estão implícitas as suposições de insaciedade e aversão ao risco dos investidores. Os indivíduos sempre preferem, sem limites, mais riqueza que menos. A suposição de aversão explica o fato das curvas de indiferença serem convexas e positivamente inclinadas, significando que os investidores avessos ao risco exigem um maior retorno quando do aumento do risco envolvido.

Quanto mais alta a curva de indiferença de um dado investidor, maior será sua satisfação. A seta da Figura 1 indica o sentido no qual aumenta-se a satisfação.

Ao contrário dos indivíduos avessos ao risco, os investidores com tendência ao risco buscam correr risco e possuem curvas de indiferenças côncavas e negativamente inclinadas. Quanto aos investidores neutros, suas preferências são representadas por linhas horizontais no plano média-variância.

Além disso, existem diferentes graus de aversão ao risco, identificados pela declividade das curvas de indiferença do indivíduo. Quanto mais positivamente inclinadas são as curvas, maior será o grau de aversão ao risco do investidor.

\subsubsection{Matriz de Variância-Covariância}

O retorno esperado de uma carteira é dado simplesmente pela média ponderada dos retornos dos ativos individuais, tomando como pesos as proporções de cada ação na carteira:

$$
\bar{r}_{p}=\sum_{i=1}^{N} x_{i} \cdot \bar{r}_{i}
$$

onde:

$\overline{r_{p}}=$ retorno esperado da carteira;

$\overline{r_{i}}=$ retorno esperado do título $\mathrm{i}$;

$x_{i}=$ proporção do valor inicial investido no título $i$ dentro da carteira;

$N$ = número de títulos na carteira. 
Uma medida do grau de incerteza dos retornos é a variância ou o desvio-padrão. O cálculo do desvio-padrão é dado por:

$$
\sigma_{p}=\sqrt{\sum_{i=1}^{N} \sum_{j=1}^{N} x_{i} \cdot x_{j} \cdot \sigma_{i j}}
$$

onde:

$\sigma_{p}=$ desvio-padrão dos retornos da carteira $p$;

$\sigma_{i j}=$ covariância entre os retornos dos títulos i e j;

A variância de uma carteira corresponde à média ponderada dos elementos da matriz de variância-covariância das ações por ela composta. Essa matriz é composta pelas variâncias dos retornos de cada ação, localizadas na diagonal principal, e pelas covariâncias entre os retornos das ações, situadas fora da diagonal principal. A covariância mede a intensidade com a qual duas variáveis estão associadas.

$$
\operatorname{Cov}=\left(\begin{array}{cccc}
\sigma_{1}^{2} & \sigma_{21}^{2} & \cdots & \sigma_{n 1}^{2} \\
\sigma_{12}^{2} & \sigma_{2}^{2} & \cdots & \sigma_{n 2}^{2} \\
\vdots & \vdots & \ddots & \vdots \\
\sigma_{1 n}^{2} & \sigma_{2 n}^{2} & \cdots & \sigma_{n}^{2}
\end{array}\right)
$$

A matriz de variância-covariância é quadrada e simétrica. Assim, o número de termos fora da diagonal principal cresce muito mais rapidamente que o número de termos na diagonal. Como a variância do retorno de uma carteira é dada pela soma dos valores de todas as células, temos que a variância da taxa de retorno de uma carteira formada por muitos títulos depende mais das covariâncias do que das variâncias dessas ações.

Para se estimar o retorno esperado e a variância de uma carteira formada por $N$ títulos, o número total de parâmetros a serem considerados é igual a $\left(N^{2}+3 N\right) / 2$, decompostos nos elementos:

$$
\begin{array}{ll}
N & : \text { retornos esperados } \\
N & : \text { variâncias } \\
\frac{\left(N^{2}-N\right) / 2}{\left(N^{2}+3 N\right) / 2} & : \text { covariâncias } \\
\text { : total de parâmetros }
\end{array}
$$


Por exemplo, tomando-se uma carteira com 90 ações, necessitam ser estimados 4185 parâmetros, sendo 90 retornos esperados, 90 variâncias e 4005 covariâncias.

\subsubsection{Conjunto Eficiente}

Posições de investimento são assumidas com o intuito de se obter uma taxa de retorno esperada. Os investidores procuram minimizar os desvios ineficientes e relação à taxa de retorno esperada. A diversificação é essencial para a criação de um investimento eficiente porque pode reduzir a variabilidade dos retornos em torno da taxa de retorno esperada.

Um indivíduo que estiver considerando a possibilidade de aplicar numa carteira que envolva dois títulos defronta-se com um conjunto de oportunidades, ou conjunto viável, que neste caso será formado por uma curva. Na Figura 2 são representados o retorno esperado e o risco que se pode obter através de diferentes combinações de duas ações. O investidor poderá atingir qualquer ponto da curva selecionando a combinação apropriada de títulos, o qual será escolhido de acordo com o risco que o investidor pretende assumir, porém sempre dentro do conjunto eficiente.

Figura 2 - Conjunto de Carteiras Compostas por Combinações entre Duas Ações

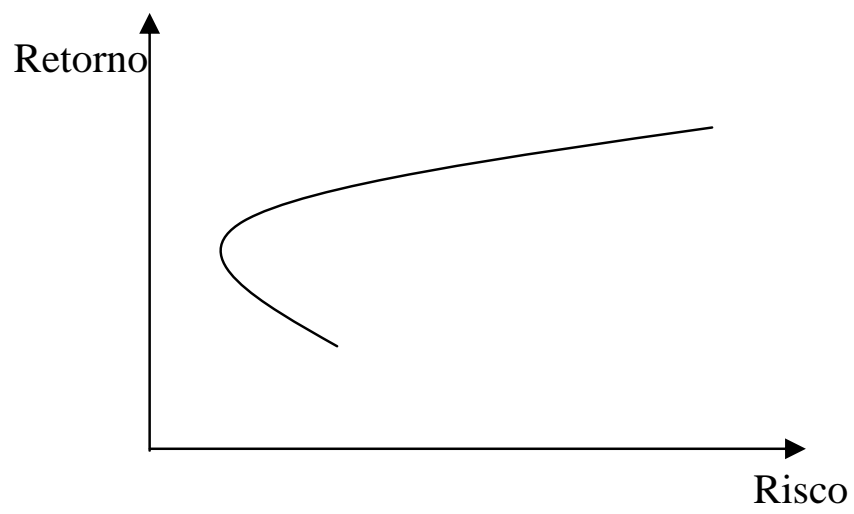

Como os investidores geralmente aplicam em mais de duas ações, precisa-se considerar a mesma curva quando há mais de duas ações em uma carteira. A área à direita da curva na Figura 3 representa o conjunto de oportunidades ou conjunto viável quando consideramos a existência de várias ações. Essa área corresponde a todas as combinações possíveis de retorno esperado e desvio-padrão para uma carteira. Existe uma quantidade de combinações infinita, porém todas as combinações possíveis situam-se numa região limitada. 
Quando há somente duas ações envolvidas, todas as combinações situam-se sobre uma única curva. Ao contrário, quando há muitos títulos a considerar, as combinações ocupam toda uma região. Entretanto, deve-se notar que o investidor desejará estar em algum ponto do limite superior dessa região. O limite superior é chamado de conjunto eficiente. Qualquer ponto abaixo do conjunto eficiente produziria retorno esperado menor e teria o mesmo desviopadrão de um ponto situado no conjunto eficiente. Deste modo, nenhum investidor escolheria algum ponto abaixo do conjunto eficiente. Assim como no caso em que os investidores aplicam em carteiras com dois tipos de ações, a carteira escolhida dentro da fronteira eficiente dependerá do grau com o qual investidor pretenderá se arriscar.

Figura 3 - Conjunto Viável de Carteiras Construídas com Diversas Ações

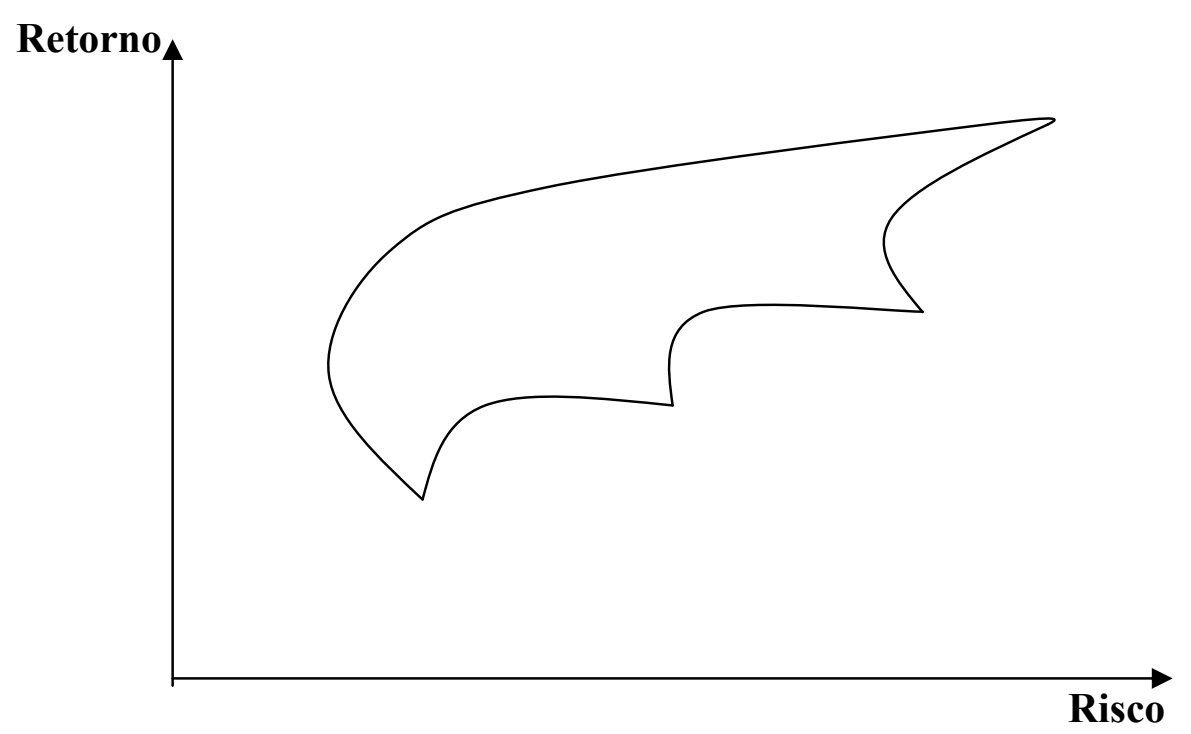

Supõe-se que todas as oportunidades de investimento existentes estão representadas no desenho da Figura 3. Ações individuais localizam-se na porção abaixo e à direita do desenho das oportunidades de investimento.

As ações individuais, por conterem ambos os riscos sistemático e não sistemático, são investimentos não eficientes. Somente carteiras derivadas da diversificação de Markowitz têm seu risco não sistemático ou específico reduzido a zero e podem alcançar a fronteira eficiente.

As melhores carteiras do ponto de vista de risco e retorno estão situadas na borda superior e à esquerda do conjunto viável, que corresponde às carteiras com máximo retorno para um dado risco, após considerar as carteiras com menor risco para um dado nível de retorno. O conjunto 
eficiente é, portanto, o conjunto de carteiras que satisfazem conjuntamente as condições: o máximo retorno esperado para cada nível de risco e o mínimo risco para cada nível de retorno esperado.

A identificação das carteiras que fazem parte da fronteira eficiente pode ser feita por meio de programação quadrática, tal como proposto originalmente por Markowitz (1959).

A Figura 3 pressupõe que todas as ações incluídas no conjunto eficiente possuem risco. Alternativamente, a abordagem de Markowitz, definindo a existência do conjunto eficiente, pode ser expandida mediante a introdução da possibilidade de se negociar um ativo livre de risco.

Tobin (1958) foi um passo além de Markowitz mostrando como identificar qual carteira eficiente deveria ser escolhida por um investidor individual. $\mathrm{O}$ autor considera que o investidor deve dividir seus fundos entre o investimento em um ativo seguro e líquido ou letras do tesouro americano e em ativos com risco, carteiras formadas por títulos ou ações.

A seleção da carteira ótima, para um dado investidor, será dada pelo ponto de tangência entre uma das curvas de seu mapa de indiferença com o conjunto eficiente. Tal ponto de tangência determina uma solução única na medida em que a figura a que corresponde o conjunto eficiente é geralmente positivamente inclinada e côncava.

Tobin (1958), assim, propõe que o problema de seleção de ativos para uma carteira seja dividido em estágios com diferentes níveis de agregação: primeiramente dentro e depois entre as categorias. Essa proposição é conhecida como Teorema da Separação. Essa mostra que se um investidor tem acesso a um ativo livre de risco, a escolha da carteira ótima de ativos com risco fica independente de sua predisposição ao risco. Em suma, o que vai diferenciar um investidor com maior tolerância ao risco de um investidor com menor tolerância é o percentual do ativo livre de risco que cada um mantém em sua carteira. 


\subsection{Diversificação Internacional}

$\mathrm{O}$ administrador de carteiras que busca investimentos eficientes trabalha com dois tipos de estatística: o retorno esperado e o risco. O retorno esperado e o risco para ativos individuais são dados exogenamente determinados e analisados pelo analista de carteiras. O objetivo da análise de carteiras é desenvolver uma carteira que tenha o máximo retorno a qualquer nível de risco que o investidor julgar apropriado. É suposto que todas as informações disponíveis ao analista de valores mobiliários sejam resumidas nos indicadores risco-retorno para descrever os investimentos candidatos (Francis (1991)).

O retorno esperado de uma carteira é a média ponderada dos retornos esperados das ações individuais. Já o desvio-padrão do retorno da carteira é menor que a média ponderada dos desvios dos títulos isolados. O resultado diferente para o desvio-padrão é devido à diversificação.

A diversificação de Markowitz $(1952,1959)$ pode ser definida como a combinação de ativos que possuem correlação menor que positiva perfeita de modo a reduzir o risco sem sacrificar os retornos, pois neste caso, o desvio-padrão do retorno da carteira será menor do que a média ponderada dos desvios dos títulos individuais.

O benefício da diversificação será menor se houver correlação positiva entre o retorno das ações. Quando a correlação for igual a 1, o desvio-padrão dos retornos de uma carteira é igual à média ponderada dos desvios-padrão dos retornos das ações.

O efeito da diversificação acentua-se à medida que a correlação diminui. Isso acontece porque, como por exemplo, no caso de títulos com retornos negativamente correlacionados enquanto um título tende a valorizar-se, o outro cai e deste modo o risco da carteira diminui. No entanto, na prática, na maioria dos casos há correlação positiva entre os pares de títulos.

Os indivíduos optariam por uma carteira diversificada porque um investidor típico é uma pessoa com aversão ao risco e, dessa maneira, evitam riscos desnecessários como o risco nãosistemático de uma ação. 
A variância do retorno de uma carteira com apenas um título é exatamente a variância do retorno desse título. A variância da carteira cai com a inclusão de cada vez mais títulos, o que evidencia o efeito da diversificação. Porém, a variância do retorno de uma carteira nunca pode cair a zero. Seu mínimo é igual à covariância entre os retornos de cada par de títulos (Ross et. al., 2002).

Como a variância do retorno da carteira converge assintoticamente para a covariância entre os retornos de cada par de títulos, cada título adicional ajuda a reduzir o risco. As covariâncias tornam-se assim, mais importantes à medida que acrescentamos mais ações à carteira.

Figura 4 - Relação entre a Variância do Retorno de uma Carteira e o Número de Títulos na Carteira

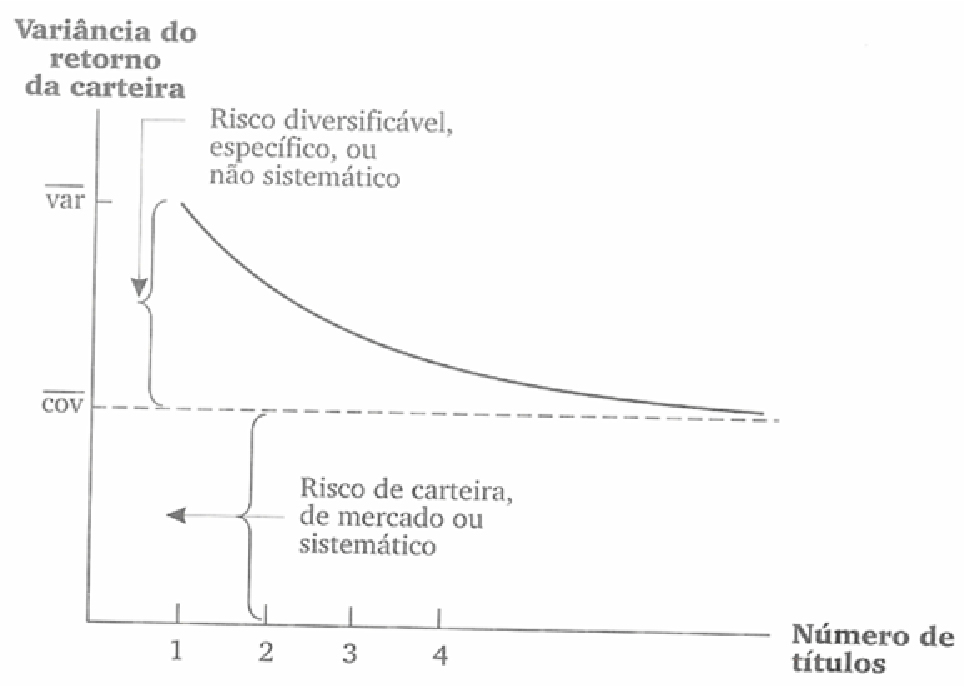

Fonte: Ross et. al. (2002)

Sharpe (1972) sugere que a variação total dos retornos de uma carteira pode ser dividida em duas formas: variação sistemática, resultado da covariância dos retornos das ações individuais com os retornos de mercado; e variação não sistemática, atribuída às peculiaridades das ações individuais, em outras palavras, a porção da variação dos retornos da ação não atribuível à variação dos retornos de mercado.

Se a covariância entre retornos de pares de ações individuais originar-se somente como resultado de suas comuns correlações com os retornos de mercado, então segue que a redução na variação do retorno de uma carteira, fruto de aumento da diversificação deve ser inteiramente função da redução da porção não sistemática do risco total. 
Para um indivíduo que possui uma carteira diversificada, o risco total de uma ação individual não é importante. Ao considerar a adição de uma ação a uma carteira diversificada, o indivíduo preocupa-se com a parte do risco que não pode ser eliminada por meio da diversificação, risco este, que pode ser encarado como a contribuição de uma ação ao risco de toda uma carteira, medida mais corretamente por seu beta.

A moderna teoria de carteiras, no entanto, sugere que deter uma carteira diversificada de ativos no mercado doméstico pode eliminar o risco não sistemático resultante de diferentes performances individuais das empresas e setores, mas não o risco sistemático resultante da economia como um todo (Davis (2002)).

Isso acontece, pois os valores dos títulos de empresas locais tendem a variar em conjunto por serem afetados pelos mesmos fatores econômicos nacionais, como oscilações da oferta de moeda, de taxas de juros, mudanças de política fiscal e variações das taxas de crescimento da economia, o que é refletido nos elevados coeficientes de correlação entre os retornos dessas ações.

O mercado de ações doméstico pode ser ele mesmo pobremente diversificado, sendo dominado por um pequeno número de ações, ou desnecessariamente exposto a um tipo de risco. Se a moeda doméstica tende a se depreciar, os retornos reais em ativos estrangeiros irão aumentar correspondentemente, e vice-versa no caso de apreciação (embora no longo prazo, retornos reais serão equalizados se a paridade de poder de compra funcionar). Outras economias podem ter mais sucesso em termos de crescimento que as economias domésticas e então oferecer maiores retornos totais. Similarmente, poderá existir uma maior produtividade marginal do capital em países em que os salários são baixos, o que pode ser atrativo para os investidores. Para investidores em alguns mercados, o investimento internacional pode ser estimulado por uma falta de certos instrumentos no mercado local como títulos indexados. Igualmente, o investimento internacional evita o risco de falência catastrófica dos mercados financeiros domésticos devido a guerras, revoluções ou outros desastres.

A parcela de risco não diversificável varia de acordo com o mercado, como pode ser visto em Elton e Gruber (2003); a porcentagem do risco que pode ser eliminada em uma carteira amplamente diversificada composta por ações ordinárias varia de país para país: 


\begin{tabular}{lr}
$\begin{array}{c}\text { Tabela } 1 \text { - Porcentagem de risco que pode ser eliminado } \\
\text { em uma carteira de ações escolhidas aleatoriamente }\end{array}$ \\
\hline Estados Unidos & 73.0 \\
Inglaterra & 65.5 \\
França & 67.3 \\
Alemanha & 56.2 \\
Itália & 60.0 \\
Bélgica & 80.0 \\
Suíça & 56.0 \\
Holanda & 76.1 \\
Ações Internacionais & 89.3 \\
\hline Fonte: Elton e Gruber (2003)
\end{tabular}

Uma carteira grande e diversificada carrega apenas $20 \%$ do risco de uma ação típica na Bélgica e cerca de $27 \%$ na Alemanha. O potencial de diversificação é pouco inferior em nosso mercado. Estudo de Brito (1989) faz um exame do efeito da diversificação, procurando focar na questão do tamanho da carteira necessário para a obtenção dos benefícios da diversificação. No estudo foram empregados dados de cotações diárias de ações negociadas na Bolsa de Valores do Rio de Janeiro, abrangendo análises anuais durante o período de 1973 a 1979. Segundo Brito (1989), o efeito da diversificação chegou a $60 \%$ no Brasil no período de 1973 a 1979. Bellato e Sanvicente (2003) chegaram a um risco diversificável de 55\% de uma ação típica numa carteira de ações diversificada no mercado de capitais brasileiro para dados do período de 1997 a 2002.

Como a eficácia da diversificação do risco de uma carteira varia de um país a outro, a diversificação internacional é particularmente útil para fins de redução de risco de carteiras em mercados com maior risco não diversificável.

Em um mercado mundial de capitais eficiente e integrado, a aplicação numa carteira mundial seria uma estratégia racional, conforme o teorema da separação (Tobin, 1958), pois todo o investidor teria uma carteira ótima composta por alguma combinação entre o ativo livre de risco e a carteira de todos os ativos existentes no mercado (Copeland e Weston, 2005). Assim, o risco sistemático pode ser minimizado.

Para Copeland et. al. (2005), investidores, tanto institucionais como individuais, devem considerar a possibilidade de expandir seus investimentos além dos limites geográficos de seus países, ao menos devido a um maior número e diversidade de possibilidades de 
investimento disponíveis. Se o universo de ativos disponíveis para investir for maior que os ativos de um país, mesmo que esse seja grande como o dos Estados Unidos, os investidores poderão ter a possibilidade de redução de risco de suas carteiras pela diversificação internacional.

Dessa forma, mercados de capitais estrangeiros oferecem possibilidades de diversificação para potencializar o desempenho, ajustado pelo risco, de uma carteira puramente doméstica, desde que os mercados nacionais tenham um comportamento razoavelmente independente, identificado por baixos coeficientes de correlação.

Por sua vez, o grau de independência de um mercado de ações, comparado a outros, é diretamente determinado pela debilidade da vinculação entre a atividade econômica e as políticas governamentais entre esses países.

\subsubsection{Segmentação dos Mercados}

Muitos fatores continuam a contribuir para a segmentação dos mercados financeiros. Primeiro, as demandas persistentes por proteção que os governos dificilmente resistem, regulamentações governamentais contra o fluxo livre de fundos entre fronteiras nacionais serão provavelmente não inteiramente eliminadas. Essas regulamentações talvez desapareçam gradualmente na maioria dos países mais industrializados, mas continuarão a serem mantidas na maioria dos outros mercados financeiros. Um segundo grupo de barreiras que contribuem para a segmentação dos mercados financeiros é de impostos no fluxo de fundos entre países como aqueles entre residentes e não residentes. Além disso, variações internacionais na eficácia das leis e regulamentações contra práticas não justas, como o uso em benefício próprio de informações privilegiadas e front running, constituem outras fontes de anomalias que contribuem para a segmentação dos mercados financeiros. Riscos de câmbio e políticos em investimentos internacionais que são não-diversificáveis também podem levar a custos e fricções que contribuam para a segmentação dos mercados financeiros. Além disso, desvios significativos e persistentes das taxas de juros e das condições de paridade de poder de compra podem levar a uma segmentação dos mercados financeiros. Por fim, existem diferenças internacionais significativas nos custos e na confiabilidade das informações usadas para avaliarem-se ativos. Essas podem se basear em diferenças nas práticas de disclosure, nos 
procedimentos contábeis e na disponibilidade de dados corporativos e de mercado ao longo dos países (Aggarwal (1995)).

\subsubsection{Justificativas para a Diversificação Internacional}

Da mesma forma que os países emergentes por possuírem baixo grau de integração de suas economias e seus mercados financeiros com economias e mercados mais desenvolvidos constituem alternativa promissora para investidores de países desenvolvidos, essa fraca associação também revela oportunidades de diversificação de risco para investidores brasileiros ao compor suas carteiras com ações de outros mercados tanto emergentes como desenvolvidos.

Os investidores, tanto institucionais como individuais, devem considerar a possibilidade de expandir seus investimentos de modo a ultrapassar os limites geográficos de seus países, replicando o modelo tradicional de diversificação de carteiras. Francis (1991) aponta um grande número de pesquisas, além das pioneiras de Grubel (1968) e Levy \& Sarnat (1970), que apresentam evidências sobre os benefícios da diversificação internacional.

Solnik (1974) fornece estimativas empíricas do risco de carteiras diversificadas internacionalmente e estabelece comparação com as carteiras domésticas. Embasado em dados semanais de ações dos oito maiores países europeus e dos Estados Unidos, concluiu que carteiras diversificadas internacionalmente conteriam um décimo do risco de uma ação típica e metade do risco de uma carteira bem diversificada em ações puramente norte-americanas, aplicando a variância dos retornos como medida de risco. $\mathrm{O}$ autor também identificou que a diversificação intersetorial era inferior à diversificação ao longo de países. 
O efeito da diversificação internacional na fronteira eficiente de Markowitz é o de que conforme o número de países nos quais são realizados investimentos aumenta, mais as fronteiras eficientes desejáveis tornam-se atingíveis (Francis (1991)). Levy e Sarnat (1970) mostraram que a carteira que apresenta maior taxa de retorno a qualquer nível de risco tende a ser composta por investimentos de muitos países, conforme Figura 5:

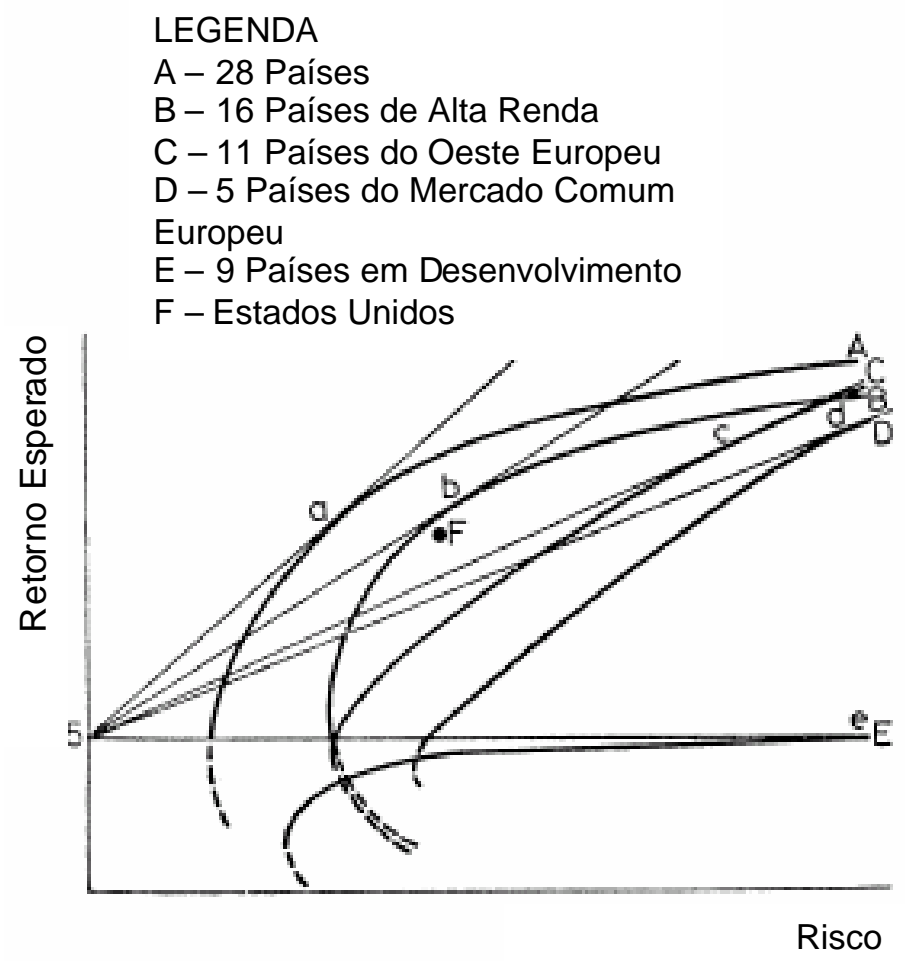

Fonte: Levy e Sarnat (1970)

Figura 5 - Diferentes Fronteiras Derivadas de Várias Oportunidades de Investimento

Hunter e Coggin (1990) encontraram que a diversificação internacional pode reduzir o risco de um investimento em $56 \%$ do nível que poderia ser obtido usando apenas diversificação nacional.

Para Elton e Gruber (2003), a baixa correlação entre os mercados de ações, de títulos de renda fixa de longo prazo e de títulos de renda fixa de curto prazo, é a maior evidência a favor da diversificação internacional. A baixa correlação sugere que a diversificação internacional pode reduzir o risco das carteiras. Bodie e Kane et. al. (2002) também chamam a atenção para os baixos coeficientes de correlação entre índices de ações de um país e carteiras de títulos de renda fixa de outros países, sugerindo que carteiras balanceadas entre ações e renda fixa gozariam de fortes benefícios da diversificação. 
Os argumentos da teoria de finanças para investimentos estrangeiros, segundo Davis (2002), aplicam-se fortemente a mercados emergentes. Em muitos países em desenvolvimento, os mercados financeiros podem ser pouco desenvolvidos, oferecendo somente depósitos em banco. Mesmo em lugares onde estes são ativos, o mercado de títulos pode ser altamente vulnerável a políticas ou a choques externos, levando a uma inflação alta e variável que prejudica o valor dos ativos financeiros domésticos. Se a moeda local tende a depreciar em virtude da inflação, os retornos reais dos ativos estrangeiros irão aumentar, ao menos temporariamente. Até mesmo pequenos países da OCDE, o mercado de ações doméstico pode ser pobremente diversificado, sendo dominado por um pequeno número de empresas ou desnecessariamente expostos a um tipo de risco. Existirão muitas empresas no exterior nas quais o investimento reduziria o risco. Particularmente mercados pequenos em países em desenvolvimento podem ser voláteis e com baixa liquidez tanto por suas características inerentes quanto pela entrada e saída de investidores institucionais estrangeiros (Davis e Steil, 2001).

\subsubsection{Fatores de Risco nos Investimentos Internacionais}

As oportunidades de investimentos internacionais não se vêem livre do risco ou do custo de análises especializadas. Os fatores de risco que são únicos aos investimentos internacionais são o risco cambial e o risco específico de cada país.

As vantagens do investimento internacional são provavelmente reduzidas por muitos fatores institucionais, políticos e psicológicos. As flutuações nos preços, portanto, representam apenas parte do risco de um investimento estrangeiro, desde que o investimento possa também se relacionar com possíveis imposições de controles cambiais e restrições de capital e de investimento estrangeiro. Mais importante nesse aspecto são os riscos cambiais, especialmente no cenário atual de instabilidade monetária internacional. Uma maneira de remover o risco cambial investimentos internacionais é fazendo hedge desses investimentos. Em muitos casos, o risco cambial pode ser removido pela compra de contratos futuros de câmbio. Se, por outro lado, um investidor em ativos estrangeiros não se protege contra flutuações, ele estará especulando nas moedas. O risco cambial tem seus benefícios e essa especulação pode ser bem rentável. O investidor pode também fazer um hedge do 
investimento inicial comprando contratos futuros de câmbio, removendo assim a maioria dos riscos cambiais (Davis, 2002).

Resultados de Solnik (1995) mostram que o risco de uma carteira não protegida contra risco cambial é maior que a carteira não protegida. Porém, seu risco total continua bem menor que de uma carteira doméstica comparável. Percebe-se que, por exemplo, os detentores de ações estrangeiras se beneficiaram da desvalorização do dólar. Uma carteira internacional não protegida é certamente um bom meio de hedge contra desvalorizações do dólar.

Figura 6 - Diversificação Internacional Com e Sem Risco Cambial

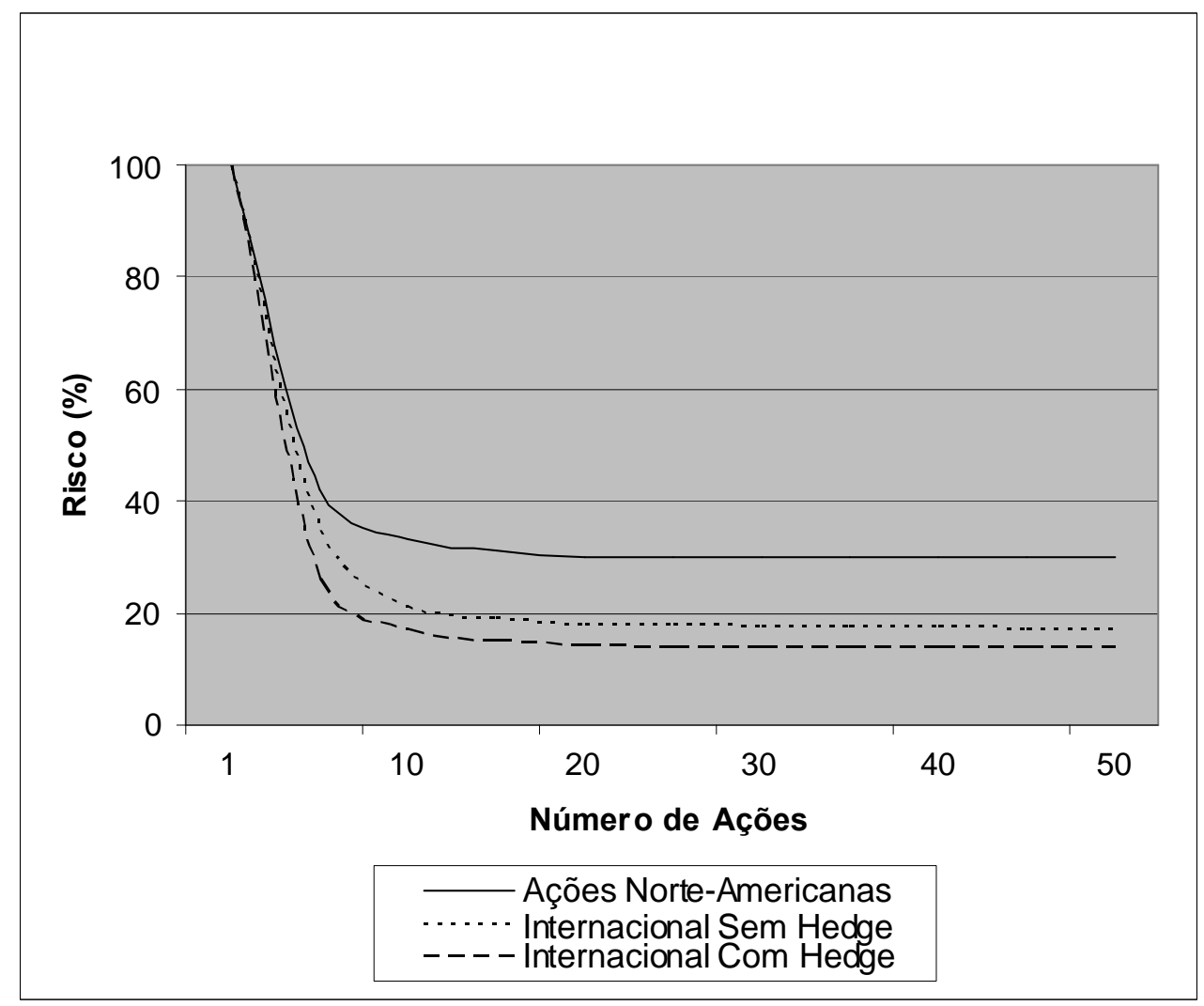

Fonte: Solnik (1995)

Os resultados empíricos de estudos como de Eun e Resnick (1988) e Jorion (1989) dão suporte à idéia do hedge de moeda. Para Eun e Resnick (1988) os investidores de países desenvolvidos podem melhorar a performance das carteiras internacionalmente diversificadas pela tentativa de eliminação do risco cambial, já que nesses países o risco cambial é responsável por grande parte do risco total das carteiras. 
Já Hauser e Marcus (1994) encontraram que sob certas condições, o hedge pode não ser benéfico, como é o caso de hedge de moeda de mercados emergentes de alto risco. Isso acontece, pois, nos países emergentes, especialmente na América Latina, a covariância entre as variações nos preços das ações e das moedas é negativa. Assim, investidores norteamericanos ao investir em mercados emergentes encontram menor volatilidade que os investidores domésticos nesses mercados.

Bodie e Kane et al. (2002) compararam o desvio-padrão dos retornos em moeda local e em dólares de 45 países no período de 1997 a 2001 e concluíram que na maioria dos casos são muito próximos, reforçando a noção que fazer hedge do risco cambial não é uma ação crucial para carteiras internacionais bem diversificadas. Além disso, mostra que os coeficientes de correlação entre retornos com hedge (moeda de origem) e sem hedge (dólares) são muito similares, confirmando que fazer hedge de moeda não é uma questão relevante ao diversificar-se internacionalmente. Além disso, os coeficientes de correlação entre índices de ações de um país e carteiras de renda fixa de outro são muito baixos, sugerindo que as carteiras balanceadas entre ações e renda fixa teriam grande benefício pela diversificação internacional.

Os mesmos autores calcularam os coeficientes de correlação entre carteiras de ações com hedge, entre as sem hedge e da mesma forma para carteiras de títulos de renda fixa. Os coeficientes de correlação encontrados para o período de 1997-2001 foram bem maiores que no convencional conhecimento, indicando que as correlações entre os mercados vêm crescendo. Esses resultados levantam a questão se o aumento nas correlações se deve ao período da amostra ou à globalização e ao aumento da integração entre os mercados de capitais em que se esperaria um aumento das correlações. Enquanto não existem dúvidas de que um período amostral de cinco anos é muito curto e limita a precisão, o fato de aumento das correlações entre fronteiras sugere que a globalização e a integração dos mercados são a mais plausível causa.

Em recente artigo, Statman e Scheid (2005) mostraram que investidores norte-americanos continuam a ter os benefícios de acrescentar ativos internacionais em suas carteiras, apesar do aumento dos coeficientes de correlação entre os Estados Unidos e os demais mercados nas últimas décadas. 
Figura 7 - Taxas de Retornos dos Índices de Mercado de Ações em 2001

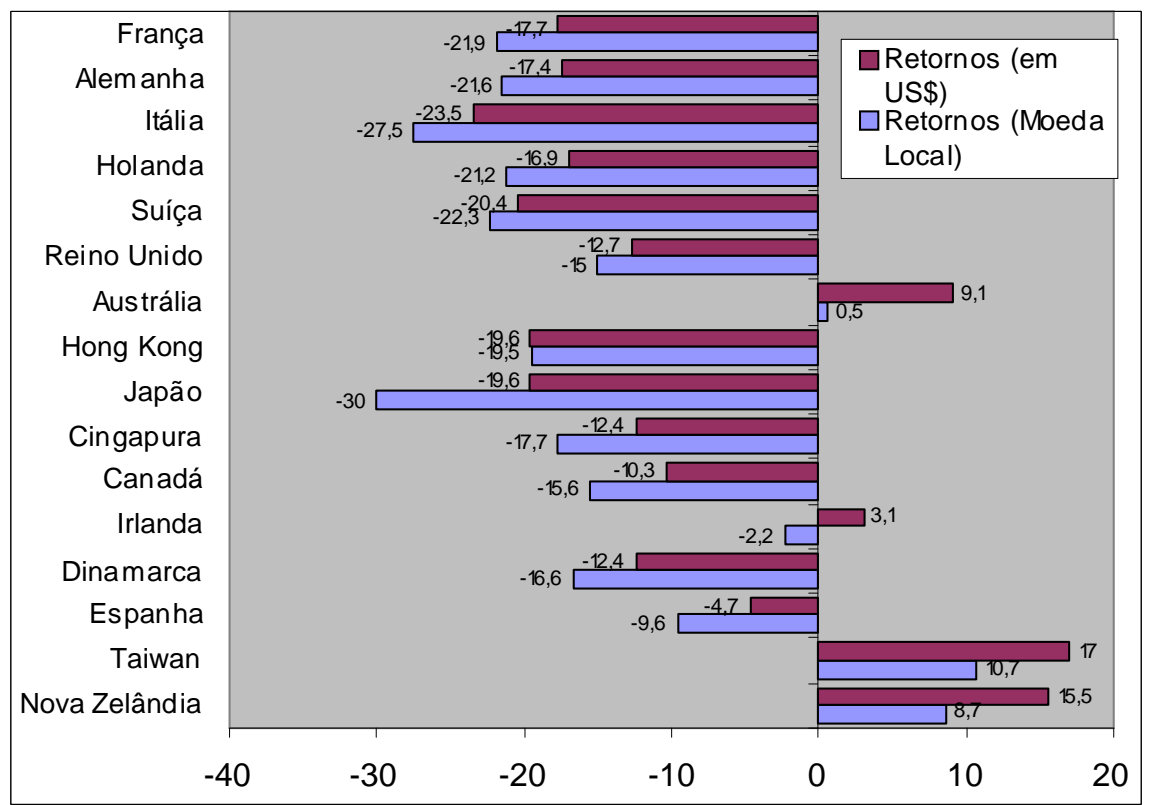

A Figura 7 apresenta as taxas de retorno dos índices dos mercados de ações de diversos países para 2001. As barras escuras descrevem retornos em moedas locais, enquanto que as barras claras representam retornos em dólares (moeda do país de origem do investidor), ajustados pelos movimentos das taxas de câmbio. Fica claro que as flutuações das taxas de câmbio no período tiveram grandes efeitos nos retornos denominados em dólar para muitos países.

Nesse contexto de carteiras internacionais, o risco cambial pode ser em grande parte diversificável. Isso fica evidente pelos baixos coeficientes de correlação encontrados por Bodie e Kane et. al. (2002). Isso ficou reforçado quando o risco de uma carteira com hedge foi comparado com o risco de uma carteira sem hedge. Portanto, investidores passivos com carteiras internacionais bem diversificadas não precisam preocupar-se em fazer hedge da exposição em moedas estrangeiras.

Bodie e Kane et. al. (2002) revelaram que mudanças nas taxas de câmbio não são altamente correlacionadas entre países. Essa característica sugere que quando as carteiras internacionais são bem diversificadas, o componente da taxa de câmbio sobre o risco total será efetivamente diminuído. Outra característica que iria fazer o risco cambial diversificável é a baixa correlação entre as mudanças nas taxas de câmbio e retornos das ações nas moedas de origem. 
O investidor pode fazer um hedge do risco de taxa de câmbio usando contratos futuros em moeda estrangeira. Os contratos futuros de moeda obrigam a entrega ou o recebimento de uma moeda por outra a uma estipulada taxa de câmbio. Isto eliminaria o risco futuro envolvido na conversão da moeda estrangeira de volta para a moeda local.

Além do risco cambial, nesse caso, existe também o risco específico de cada país. A princípio, as análises de títulos nos níveis macroeconômico, setorial e da firma específica são similares em todos os países. Essas análises buscam prover estimativas dos retornos esperados e do risco dos ativos individuais e carteiras. Alcançar a mesma qualidade de informações sobre ativos de países estrangeiros é por natureza mais difícil e mais caro. Além disso, o risco de obter informações falsas ou equivocadas é bem maior.

No passado, quando os investimentos internacionais eram novidade, o risco adicional era referido como risco político e sua avaliação era uma arte. Conforme os investimentos estrangeiros aumentaram e mais recursos foram utilizados, a qualidade das análises relativas aumentou. Uma organização importante nesta área é o Political Risk Services Group que criou uma metodologia de avaliação do risco de países. A análise de risco da PRS resulta de uma composição de ratings de risco em uma escala de 0 (maior risco) a 100 (menor risco) de uma amostra de 140 países. Os países são então ordenados pelo composto de medidas de risco e divididos em cinco categorias: risco muito baixo (100-80), baixo risco (79.9-70), risco moderado (69.9-60), alto risco (59.9-50). Para ilustrar, a Tabela 2 mostra o lugar de alguns países da amostra do PRS International Country Risk Guide de março de 2005. 
Tabela 2 - Risco País medido por Rating de Risco do PRS Group

\begin{tabular}{|c|c|c|c|c|c|}
\hline $\begin{array}{c}\text { Rank em } \\
\text { Mar/05 }\end{array}$ & País & $\begin{array}{c}\text { Rating de Risco } \\
\text { Mar/05 }\end{array}$ & $\begin{array}{c}\text { Rating de Risco } \\
\text { Abr } / 04\end{array}$ & $\begin{array}{c}\text { Variação } \\
\text { no Período }\end{array}$ & $\begin{array}{c}\text { Rank em } \\
\text { Abr } / 04\end{array}$ \\
\hline 1 & Noruega & 92,0 & 92,3 & $-0,3$ & 1 \\
\hline 2 & Luxemburgo & 90,0 & 90,3 & $-0,3$ & 3 \\
\hline 2 & Suíça & 90,0 & 91,0 & $-1,0$ & 2 \\
\hline 4 & Suécia & 88,5 & 87,0 & 1,5 & 7 \\
\hline 5 & Cingapura & 88,3 & 87,8 & 0,5 & 5 \\
\hline 7 & Dinamarca & 87,0 & 86,5 & 0,5 & 9 \\
\hline 9 & Canadá & 86,3 & 87,0 & $-0,8$ & 7 \\
\hline 11 & Áustria & 85,0 & 86,0 & $-1,0$ & 13 \\
\hline 13 & Japão & 84,5 & 86,3 & $-1,8$ & 11 \\
\hline 13 & Holanda & 84,5 & 86,3 & $-1,8$ & 11 \\
\hline 19 & Austrália & 83,0 & 82,3 & 0,8 & 20 \\
\hline 19 & Hong Kong & 83,0 & 84,0 & $-1,0$ & 14 \\
\hline 19 & Taiwan & 83,0 & 81,8 & 1,3 & 22 \\
\hline 22 & Alemanha & 82,5 & 82,3 & 0,3 & 20 \\
\hline 25 & Reino Unido & 81,8 & 84,0 & $-2,3$ & 14 \\
\hline 27 & Coréia do Sul & 81,5 & 79,8 & 1,8 & 28 \\
\hline 30 & Chile & 80,5 & 78,3 & 2,3 & 35 \\
\hline 35 & Itália & 79,5 & 79,0 & 0,5 & 30 \\
\hline 37 & Malásia & 79,0 & 80,0 & $-1,0$ & 26 \\
\hline 37 & Portugal & 79,0 & 78,0 & 1,0 & 38 \\
\hline 37 & Espanha & 79,0 & 77,3 & 1,8 & 41 \\
\hline 41 & França & 78,5 & 78,3 & 0,3 & 35 \\
\hline 43 & Estados Unidos & 77,3 & 77,5 & $-0,3$ & 40 \\
\hline 46 & China & 76,5 & 77,0 & $-0,5$ & 42 \\
\hline 46 & Rússia & 76,5 & 75,3 & 1,3 & 50 \\
\hline 51 & México & 75,8 & 74,0 & 1,8 & 56 \\
\hline 60 & Polônia & 73,8 & 75,0 & $-1,3$ & 51 \\
\hline 60 & Tailândia & 73,8 & 76,5 & $-2,8$ & 46 \\
\hline 63 & África do Sul & 73,3 & 73,0 & 0,3 & 60 \\
\hline 65 & Costa Rica & 73,0 & 73,3 & $-0,3$ & 59 \\
\hline 67 & Israel & 72,8 & 72,5 & 0,3 & 61 \\
\hline 68 & Índia & 71,8 & 72,0 & $-0,3$ & 65 \\
\hline 71 & Uruguai & 71,0 & 66,5 & 4,5 & 86 \\
\hline 73 & Irã & 70,5 & 71,3 & $-0,8$ & 68 \\
\hline 74 & Guatemala & 70,3 & 70,8 & $-0,5$ & 40 \\
\hline 75 & Egito & 70,0 & 70,8 & $-0,8$ & 70 \\
\hline 77 & Brasil & 69,5 & 67,5 & 2,0 & 79 \\
\hline 81 & Peru & 68,8 & 70,0 & $-1,3$ & 43 \\
\hline 86 & Argentina & 67,8 & 67,3 & 0,5 & 81 \\
\hline 86 & Paraguai & 67,8 & 63,8 & 4,0 & 98 \\
\hline 89 & Turquia & 67,3 & 63,3 & 4,0 & 101 \\
\hline 92 & Equador & 67,0 & 64,3 & 2,8 & 95 \\
\hline 96 & Bolívia & 66,3 & 66,0 & 0,3 & 88 \\
\hline 103 & Venezuela & 64,5 & 62,0 & 2,5 & 107 \\
\hline 105 & Colômbia & 64,3 & 61,8 & 2,5 & 108 \\
\hline 105 & Cuba & 64,3 & 63,8 & 0,5 & 98 \\
\hline 107 & Coréia do Norte & 63,8 & 48,5 & 15,3 & 135 \\
\hline 140 & Iraque & 24,0 & 40,3 & $-16,3$ & 138 \\
\hline
\end{tabular}

Fonte: International Country Risk Guide (PRS Group) 
A composição do rating de risco é uma média de três medidas: risco político, risco financeiro e risco econômico. O risco político é medido de uma escala de 0-100, enquanto os riscos econômico e financeiro são medidos numa escala de 0-50. As três medidas são somadas e divididas por dois para obter o composite rating. As variáveis utilizadas pela PRS para determinar o rating de risco composto pelas três medidas são mostradas na Tabela 3.

Tabela 3 - Variáveis Utilizadas pelo PRS para o Rating de Risco

\begin{tabular}{lll}
\hline Variáveis de Risco Político & Variáveis de Risco Financeiro & Variáveis de Risco Econômico \\
\hline Estabilidade do Governo & Dívida Externa (\% PIB) & PIB per capita \\
Condições Socioeconômicas & Serviço da Dívida Externa (\% PIB) & Crescimento real anual do PIB \\
Perfil de Investimento & Conta Corrente (\% das exportações) & Taxa de Inflação Anual \\
Conflitos Internos & Liquidez Líquida em meses de importação & Resultado Orçamentário (\% PIB) \\
Conflitos Externos & Estabilidade da Taxa de Câmbio & Balanço em Conta Corrente (\% PIB) \\
Corrupção & & \\
Militares na Política & & \\
Tensões Religiosas & & \\
Legislação e Ordem & & \\
Tensões Étnicas & & \\
Responsabilidade Democrática & & \\
Qualidade Burocrática & & \\
\hline
\end{tabular}

Outras organizações também fornecem este tipo de avaliação. Com estas informações, o investidor atual pode estar bem equipado para adequadamente analisar os riscos envolvidos no investimento internacional.

A última barreira para um completo desenvolvimento dos fundos multinacionais tanto em termos de seus investimentos e de seus subscritores é o medo de que alguns países possam inesperadamente impor controles cambiais e restrições a saída de recursos. Muitos governos, como o da França e o do Reino Unido, têm recentemente se refugiado a medidas desse tipo em períodos de crise monetária. A única maneira de reduzir o impacto dessas potenciais ameaças à liquidez do fundo seria investir proporcionalmente à parcela subscrita de seus residentes.

Parece que meios adequados e estruturas para investimento em ações estrangeiras podem ser encontrados mesmo nesses tempos de incerteza monetária internacional.

A maioria dos fundos mútuos europeus é internacionalmente diversificada. Além disso, alguns deles se especializaram em investir em países específicos. Portanto, é claramente fácil 
para os europeus deter uma carteira bem diversificada. O mesmo logo acontecerá com os Estados Unidos e Japão.

\subsubsection{Cálculo do Retorno de Investimentos no Exterior}

De acordo com Elton e Gruber (2003), a primeira motivação para deter uma carteira diversificada é reduzir o risco. O risco total da carteira irá depender, no entanto, não somente no número de ativos incluídos na carteira, mas também do risco de cada título individualmente e do grau de correlação entre eles. Assim, o risco não depende somente dos coeficientes de correlação, mas também do desvio-padrão do retorno. Deve ser enfatizado que o desvio-padrão, quando calculado para índices de mercado, é uma medida de risco para uma carteira bem diversificada, consistindo somente de ativos transacionados no país em questão.

O retorno de um investimento em ativos estrangeiros varia devido à oscilação dos preços dos ativos no próprio mercado local e devido a ganhos e perdas cambiais. Em alguns casos o risco total será menor que o risco doméstico. A redução na correlação, quando as taxas de câmbio são levadas em consideração, ocorre quando a correlação entre as flutuações do câmbio e os movimentos do mercado local for negativa nos períodos em análise.

O risco cambial acontece devido às taxas de câmbio mudarem no tempo, afetando o retorno de um investidor em um mercado estrangeiro. O risco cambial e o risco doméstico são relativamente independentes e o desvio-padrão é não aditivo. Portanto, o risco total para o investidor é muito menor que a soma dos riscos cambial e doméstico.

Embora baixas correlações indiquem fortemente que a diversificação internacional é compensadora, um alto desvio-padrão pode ser um impeditivo a esta estratégia.

O retorno dos investimentos estrangeiros é afetado pelo retorno dos ativos dentro de seu próprio mercado e pela variação da taxa de câmbio entre a moeda do próprio título e a moeda do país de origem do investidor. Portanto, o retorno de um investimento estrangeiro pode ser bem diferente que simplesmente o retorno no próprio mercado do ativo e pode diferir de acordo com o domicílio do investidor. Dessa forma, do ponto de vista de um investidor 
brasileiro, por exemplo, seria conveniente expressar a moeda estrangeira em termos da quantidade de reais que ela custa.

O retorno para um investidor brasileiro pode ser dividido em um componente de retorno no país de origem do ativo e outro ao retorno devido a ganhos e perdas cambiais:

$$
\left(1+R_{U S}\right)=\left(1+R_{x}\right)\left(1+R_{H}\right)
$$

Simplificando: $R_{U S}=R_{x}+R_{H}+R_{x} R_{H}$

Usando esta aproximação, teremos a seguinte expressão em termos de retorno esperado e desvio-padrão dos retornos para um ativo estrangeiro:

$$
\begin{aligned}
& \bar{R}_{U S}=\bar{R}_{x}+\bar{R}_{H} \\
& \sigma_{U S}=\left[\sigma_{x}^{2}+\sigma_{H}^{2}+2 \sigma_{H x}\right]^{1 / 2}
\end{aligned}
$$

O desvio-padrão de retornos de ativos estrangeiros $\left(\sigma_{U S}\right)$ é muito menor que a soma do desvio-padrão do retorno em seu mercado doméstico $\left(\sigma_{H}\right)$ mais o desvio-padrão dos ganhos e perdas cambiais $\left(\sigma_{x}\right)$. Essa relação resulta de dois fatores. Primeiro, existe uma correlação muito baixa entre os ganhos e perdas cambiais e os retornos em um país. Segundo, elevar-se ao quadrado os desvios-padrão, soma-los e depois tirar a raiz quadrada da soma é menos que adiciona-los diretamente. Portanto, o desvio-padrão do retorno expresso em reais é consideravelmente menor que a soma dos desvios-padrão das perdas e ganhos cambiais e o desvio-padrão dos retornos do ativo na sua moeda de origem.

\subsubsection{Diversificação Internacional e Mercados Emergentes}

O Banco Mundial definiu como países desenvolvidos (alta renda) em 2000, aqueles que apresentaram renda per capita acima de $\$ 9300$, e seus índices de mercado geralmente se apresentam como menos arriscados que aqueles de países emergentes. O Banco Mundial listou 52 países desenvolvidos em 2000, muitos dos quais como bolsas muito pequenas. Os 25 países com maior capitalização de mercado, ou seja, maior somatório das ações emitidas por cada empresa da bolsa multiplicadas por suas respectivas cotações, perfazem juntos $79 \%$ do produto doméstico bruto em 2001. O peso dos Estados Unidos na carteira de ações mundial 
cresceu de 37\% em 1996 para 49\% em 2001, enquanto o Japão decresceu de 24\% para 11\%. Os pesos dos cinco países seguintes no ranking depois dos Estados Unidos (Japão, Reino Unido, França, Alemanha e Suíça) somaram 39,2\% em 2001, fazendo com que o peso dos Estados Unidos no universo desses seis países fosse de 62\%. Claramente, as ações norteamericanas não compreendem uma carteira diversificada de ações.

Para uma estratégia passiva se poderia argumentar que uma carteira de ações de apenas seis países com as maiores capitalizações de mercado constituiria 79,2\% da carteira mundial em 2001 e talvez fosse suficientemente diversificada. Esse argumento não irá valer para carteiras de gestão ativa que procuram alavancar os investimentos por meio de ativos promissores. Carteiras de gestão ativa naturalmente irão incluir muitos ativos ou, até mesmo, índices de mercados emergentes.

A Tabela 4 mostra dados dos 20 maiores países emergentes. O mais notável deles é a China com uma capitalização de mercado de $\$ 170$ bilhões ( $0,66 \%$ da capitalização mundial) em 2001, cujo crescimento no período de 1996 a 2001 foi de 651\%. Esses 20 países detêm 16\% do PIB mundial e juntamente com os 25 países mais desenvolvidos representam 95\% do PIB mundial. A capitalização de mercado desses países como porcentagem do PIB varia de 3\% (Venezuela) a 90\% (África no Sul), sugerindo que esses países devam mostrar um significativo crescimento nos próximos anos, mesmo na ausência de espetacular crescimento do PIB. 
Tabela 4 - Capitalização de Mercado das Bolsas de Valores de Mercados Emergentes

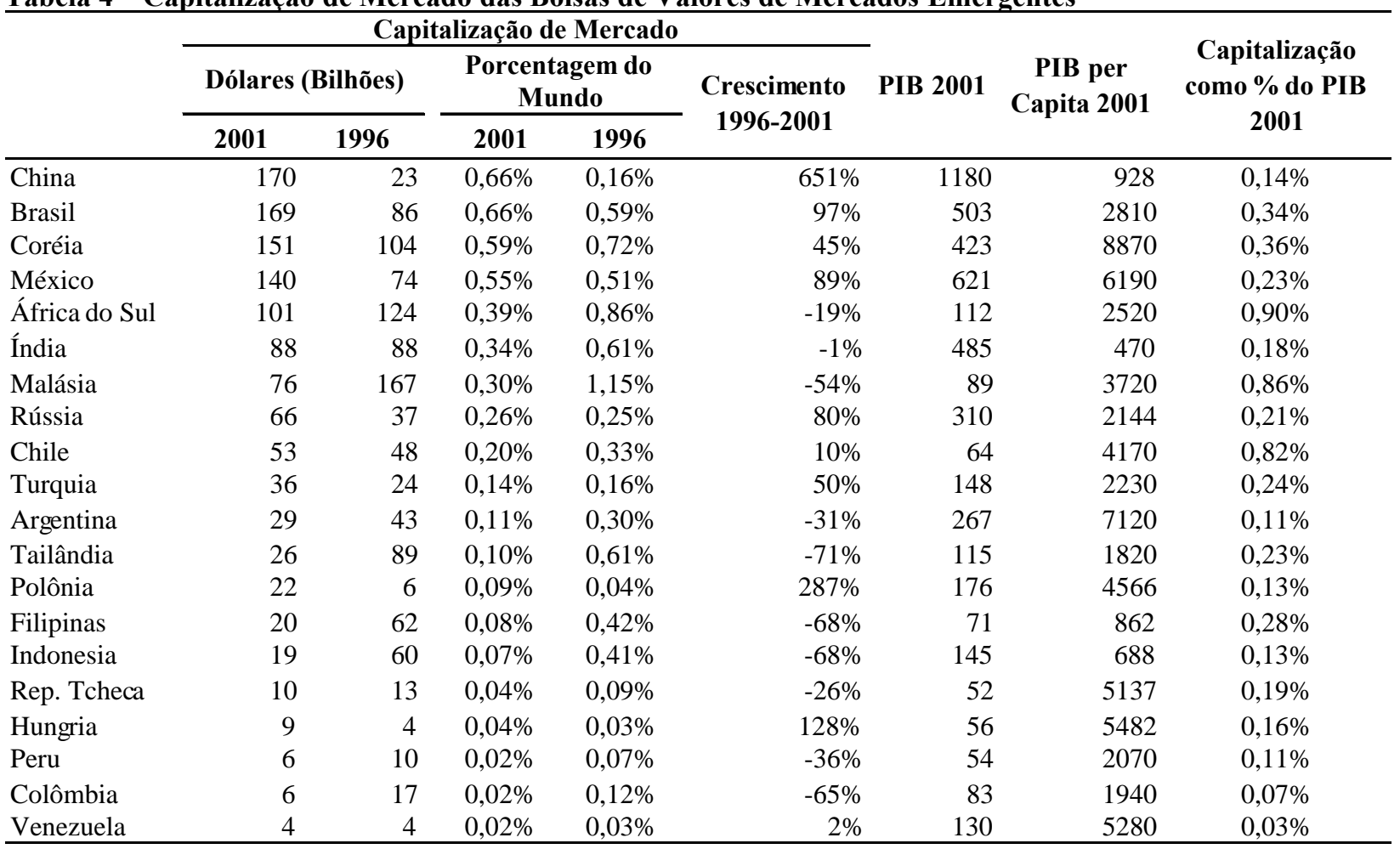

Fonte: Bodie et. al. (2002)

O crescimento da capitalização nos mercados emergentes durante o período de 1996-2001 foi muito mais volátil que o aumento em países desenvolvidos, sugerindo que tanto o risco como os benefícios nesse segmento do globo podem ser substanciais.

A visão contemporânea do desenvolvimento econômico é de que as maiores necessidades para o avanço econômico são códigos desenvolvidos de leis comerciais, instituições e regulamentações que possibilitem os cidadãos ater, capitalizar e negociar legalmente os ativos. Como corolário, espera-se que o desenvolvimento dos mercados de ações sirva como catalisador do enriquecimento da população, isto é, países com maior capitalização relativa e ações tenderão a ser mais ricos.

Bodie e Kane et al. (2002) estimaram regressão linear relacionando a razão entre a capitalização de mercado e o PIB e o aumento do PIB per capita. O coeficiente de determinação foi de $35 \%$ e o coeficiente de 0.73 , sugerindo que um aumento e $1 \%$ na razão entre capitalização de mercado e PIB está associado a um aumento do PIB per capita de $0.73 \%$. É notável que nenhum dos 25 países mais desenvolvidos do mundo está abaixo da reta de regressão. Apenas os países emergentes de baixa renda estão abaixo da reta. Países como Venezuela e Noruega, que estão acima da reta, exibem maior PIB per capita que o previsto 
pela regressão, pois desfrutam do petróleo como riqueza que contribui para renda da população.

Figura 8 - Relação PIB per capita e Capitalização de Mercado como Porcentagem do PIB

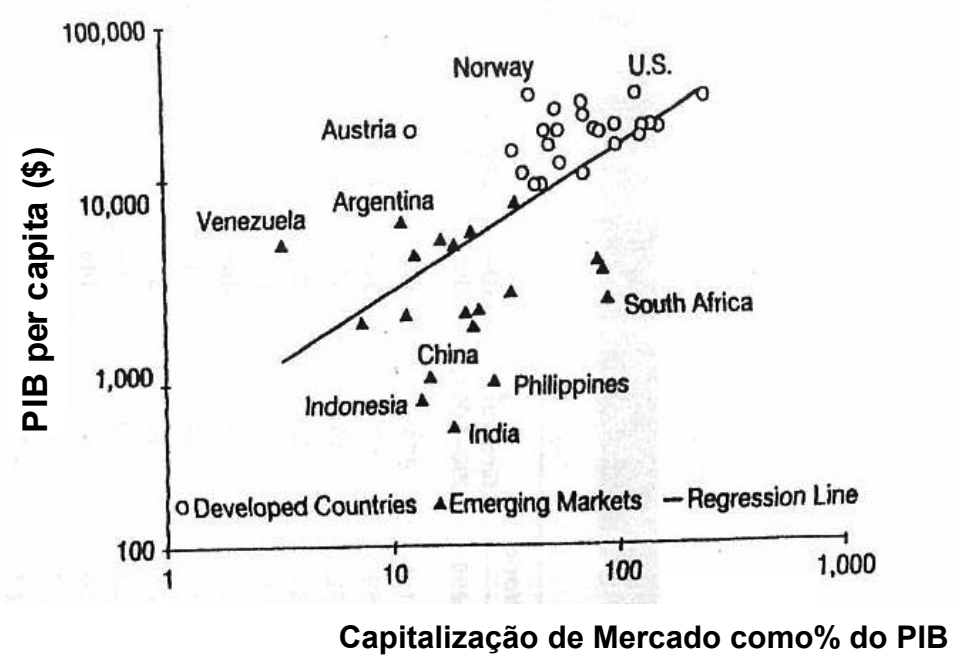

Fonte: Reproduzido de Bodie et. al. (2002)

Seria de se esperar que a maioria dos investidores, particularmente os institucionais e investidores profissionais, tivessem a consciência das oportunidades oferecidas pelo investimento internacional. No entanto, na prática, investidores notavelmente priorizam ações domésticas a uma estratégia de indexação neutra e dão menor importância às ações estrangeiras, chegando até mesmo a ignorá-las. Essa constatação veio a ser chamada de homecountry bias. Apesar do contínuo aumento do investimento estrangeiro, esse viés continua a dominar as carteiras.

Leite e Sanvicente (1994) relatam correlações muito baixas entre os mercados dos países emergentes e até algumas elevadas correlações negativas como, por exemplo, entre Zimbabwe e Venezuela (-0,57). Apresentam dados produzidos pelo Internacional Finance Corporation para os cinco anos encerrados em setembro de 1993 e os reportados por Rudd (1991) sobre as correlações dos outros mercados emergentes com o mercado brasileiro: 
Tabela 5 - Correlações de Retornos entre Mercados Emergentes e o Mercado Brasileiro

\begin{tabular}{lcc}
\hline Mercado & Rudd (1991) & IFC (1993) \\
\hline Argentina & $-0,21$ & $-0,18$ \\
Chile & 0,58 & 0,23 \\
Colômbia & 0,00 & 0,14 \\
Grécia & 0,20 & 0,19 \\
Índia & 0,03 & 0,10 \\
Indonésia & - & 0,11 \\
Jordânia & 0,26 & $-0,09$ \\
Coréia do Sul & $-0,16$ & $-0,12$ \\
Malásia & 0,51 & 0,16 \\
México & 0,33 & 0,06 \\
Nigéria & 0,54 & $-0,10$ \\
Filipinas & 0,04 & 0,25 \\
Portugal & 0,2 & 0,22 \\
Taiwan & 0,31 & 0,14 \\
Tailândia & 0,27 & 0,06 \\
Turquia & 0,54 & 0,15 \\
Venezuela & $-0,06$ & $-0,18$ \\
Zimbabwe & $-0,12$ & 0,07 \\
\hline
\end{tabular}

Fonte: Leite e Sanvicente (1994)

A Tabela 5 indica que carteiras dedicadas aos mercados emergentes poderiam ser formadas de maneira que apresentassem riscos extremamente baixos. Os dados mostram que alterações pouco significativas ocorreram nas correlações entre o mercado brasileiro e outros mercados emergentes durante o período relatado, no qual o Brasil acelerou o processo de abertura a investidores estrangeiros.

O coeficiente de correlação encontrado entre o Financial Times-Actuaries World Index (para empresas de mercados desenvolvidos) e os retornos do mercado brasileiro foi igual a 0,06 .

Leite e Sanvicente (1994) ressaltam também que, ao se considerar o potencial de diversificação que é oferecido por um mercado, deve-se levar em consideração como os movimentos de preços das ações aí negociadas estão correlacionados com o índice do próprio mercado. Em mercados onde essa associação for forte, o risco sistemático será muito importante dada a elevada proporção de risco não-diversificável.

Rudd (1991) procedeu, para quantificar tal aspecto, análises de regressão em que a variável dependente era o retorno de cada ação de mercados emergentes pertencente ao índice global da IFC e a variável independente era o retorno da carteira formada por todas as ações de cada mercado com pesos iguais. Os coeficientes de determinação obtidos indicariam o potencial de diversificação dentro de cada país. $\mathrm{Na}$ maioria dos países encontrou-se menor 
heterogeneidade entre as ações do próprio mercado em relação ao verificado nos Estados Unidos $(0,3)$, ressaltando a maior importância do mercado como um todo nesses países. Leite e Sanvicente (1994) encontraram um coeficiente de determinação para uma amostra de 164 empresas brasileiras negociadas na Bolsa de Valores de São Paulo no período de 1984 a 1993 de 0,3186, coeficiente menor que o encontrado por Rudd (1991) de 0,41.

Segundo Roll (1992) apud Leite e Sanvicente (1994), a correlação entre retornos de mercados emergentes e retornos de mercados desenvolvidos é baixa e existem tantas diferenças de volatilidade entre mercados depois de se levar em conta inflação e taxas de câmbio devido:

a. Diferenças entre índices nacionais quanto ao número de ações e ao grau de diversificação das carteiras dos índices: a volatilidade dos retornos está inversamente relacionada ao número de ações incluídas e diretamente ao grau de concentração do índice;

b. Os mercados nacionais refletem as características da estrutura setorial desses países e quanto mais internacionalizados forem os setores e mercados, maior será a proporção da variância de seus retornos que será explicada por um índice mundial do setor. Encontrou-se que, em média, $40 \%$ da variância é explicada pelo setor;

c. As taxas de câmbio foram responsáveis por cerca de $23 \%$ da variância dos mercados; 


\section{INVESTIDORES INSTITUCIONAIS}

Davis e Steil (2001) definem os investidores institucionais como instituições financeiras especializadas que administram poupanças coletivamente em nome de pequenos investidores voltadas a objetivos específicos em termos de riscos aceitáveis, maximização de retornos e exigências de maturidade.

Para Vittas (1998), os investidores institucionais são grandes organizações que investem recursos no propósito de garantir retornos e segurança para os indivíduos que representa: acionistas, investidores individuais e pensionistas. Em geral, os investidores institucionais compreendem entidades de previdência, fundos de investimentos e companhias seguradoras.

Algumas características gerais são comuns a todos os investidores institucionais. De uma perspectiva macroeconômica, esses investidores provêem um grande volume de recursos para o mercado de capitais que são utilizados tanto pelas empresas como pelo Estado. Sob a perspectiva microeconômica, os investidores institucionais provêem as famílias de um tipo de risco e da ação em grupo por meio de fundos, possibilitando a elas um melhor trade-off entre risco e retorno do que geralmente é possível por meio de investimentos diretos. A gestão conjunta de recursos permite que, na questão dos ativos, os investidores institucionais transacionem em grandes volumes. Isso permite a eles aplicar em investimentos indivisíveis, como imóveis ou parcerias, conseguir economias de escala (taxas de administração mais baixas) e cobrir os custos de uma administração de recursos profissional (Maurer, 2003).

A literatura internacional revela que a participação dos investidores institucionais na acumulação da poupança doméstica dos países cresceu extraordinariamente durante as últimas décadas. Além disso, esses investidores têm tido um papel crucial no desenvolvimento dos mercados de capitais, tanto nos países desenvolvidos como nos países em desenvolvimento (Medeiros, 2006).

Os investidores institucionais tipicamente investem em ativos como ações, títulos de renda fixa, que estão disponíveis em mercados de capitais grandes e líquidos, tanto nacionalmente quanto internacionalmente, e em instrumentos do mercado monetário. Apenas parte dos recursos é investida em ativos menos líquidos, como em propriedades e participações, que não estão listadas em bolsas de ações. O processo de investimento dos recursos detidos pelos 
investidores institucionais é gerido por administradores de recursos internos ou externos, profissionais que desenvolvem e implementam estratégias para gestão dos ativos. Em termos de maturidade, a maioria dos investidores institucionais casa ativos e passivos que são diferentes dos instrumentos convencionais de dívida. Finalmente, o negócio dos investidores institucionais é sujeito à ampla regulação financeira (Maurer, 2003).

Apesar das características comuns, os investidores institucionais diferem quanto aos negócios e às regulamentações a que estão sujeitos. As principais diferenças derivam dos tipos de incerteza quanto ao tamanho e ao timing de seus passivos financeiros (Maurer, 2003).

O crescimento da indústria profissional de gestão de ativos é uma característica chave das mudanças estruturais no sistema financeiro internacional. Ele representa um desenvolvimento que tem implicações para muitos aspectos diferentes no cenário financeiro: modificações no mercado, colocação de títulos, fluxos internacionais de capitais, estabilidade do mercado, organização industrial e governança corporativa. A importância dos investidores institucionais para o sistema financeiro global fica evidente a partir do volume de ativos financeiros administrados (Tabela 6), que excedem o PIB agregado dos países desenvolvidos considerados. Ao mesmo tempo, a distribuição irregular dos ativos ao longo dos países é um indicativo do considerável espaço para crescimento, particularmente na Europa Continental (BIS, 1998).

Tabela 6 - Ativos Administrados pelos Investidores Institucionais nos Países Desenvolvidos

\begin{tabular}{lcrr}
\hline & 1993 & 1997 & 2001 \\
\hline & (como \% do PIB dos países desenvolvidos) & & \\
Investidores Institucionais & $\mathbf{9 4 , 7}$ & $\mathbf{1 2 4 , 2}$ & $\mathbf{1 4 7 , 2}$ \\
Companhias Seguradoras & 36,3 & 43,5 & 47,3 \\
Entidades de Previdência Complementar & 27,7 & 37,1 & 40,3 \\
Fundos de Investimento & 21,0 & 32,7 & 47,0 \\
Outros Investidores Institucionais & 9,7 & 10,8 & 12,6 \\
\hline Fonte: Borenstein ${ }^{2}$ al. 2006 & &
\end{tabular}

Os fundos de pensão têm sido tradicionalmente o mais importante componente, com ativos excedendo $50 \%$ do PIB em um grande número de países. Os ativos das companhias seguradoras, especialmente ativos de seguros de vida, raramente excedem $30 \%$ do PIB, enquanto os fundos de investimentos têm representado até o momento menos de $20 \%$ do PIB na maioria dos países. Recentemente os ativos dos fundos de investimentos cresceram rapidamente nos Estados Unidos e em outros países. Na verdade, os ativos dos fundos de 
investimentos nos Estados Unidos atualmente excedem 50\% do PIB, apesar de que parte dos recursos representam investimentos realizados pelas entidades de previdência. Além disso, com o crescimento dos planos privados de previdência, a tradicional distinção entre entidades de previdência e fundos de investimentos tem se tornado confusa. Em 1996, os planos de aposentadoria de todos os tipos representavam 35\% dos ativos dos fundos de investimentos nos Estados Unidos, enquanto os planos de aposentadoria investiam nos fundos de investimentos $19 \%$ de seus ativos (Vittas, 1998).

O crescimento dos ativos detidos por investidores institucionais tem sido notável em todos os segmentos da economia global. Nas economias desenvolvidas, os ativos das entidades de previdência e fundos de investimentos aumentaram de aproximadamente $80 \%$ do PIB em 1997 para 112\% do PIB em 2003 (Borensztein et. al., 2006).

Os investidores institucionais são menos importantes nos países emergentes, mas o crescimento dos ativos nesses mercados tem sido rápido também, de $18 \%$ do PIB para $30 \%$ do PIB no período de 1997 a 2003. Em meados dos anos 1990, os investidores institucionais da América Latina detinham em ativos aproximadamente 10\% do PIB regional e, dessa forma, seus ativos representavam uma parcela muito menor do PIB que a média dos investidores institucionais nos países emergentes. No período de 1997 a 2003, o tamanho dos ativos dos investidores institucionais na América Latina cresceu mais rapidamente que os de investidores institucionais nos demais países emergentes e, até 2003, o agregado dos ativos dos investidores institucionais na América Latina era quase idêntico ao dos outros países emergentes. Esse rápido crescimento se deve ao fato da criação de fundos de previdência privados em países latino-americanos em meados dos anos 90 (Borensztein et. al., 2006).

Nos países desenvolvidos, os fundos de pensão e as companhias seguradoras têm sido os maiores investidores institucionais, apesar de os montantes investidos pelos fundos de investimentos ter crescido mais rapidamente. A importância relativa, em termos de total de ativos, de diferentes tipos de investidores institucionais varia de país para país. As companhias seguradoras são relativamente mais importantes no Reino Unido e Japão, os fundos de pensão, no Reino Unido, enquanto os fundos de investimentos prevalecem nos Estados Unidos (Borensztein et. al., 2006). 
Os países da América Latina com maior presença de investidores institucionais são o Chile e o Brasil (ver Tabela 7). O Chile foi o primeiro país na região a privatizar seu sistema previdenciário, e os ativos de seus investidores institucionais chegam a $88 \%$ do PIB, com os fundos de previdência privada administrando o equivalente a $60 \%$ do PIB. No Chile, as companhias seguradoras cresceram juntamente com fundos de pensão, primeiramente porque garantem tanto o rendimento da aposentadoria quanto o seguro de vida para os contribuintes. Os fundos de investimentos, apesar de muito menores, continuam detendo 9\% do PIB chileno em ativos administrados. Na Argentina, os fundos de previdência privada são os maiores investidores institucionais, com ativos totalizando $12 \%$ do PIB, enquanto as companhias seguradoras administram ativos equivalentes a 5\% do PIB, e os fundos de investimentos detêm ativos representando $1 \%$ do PIB. O Brasil é um caso particular, já que os fundos de investimentos são os maiores investidores institucionais no país e seus ativos representam quase $30 \%$ do PIB. Os ativos dos fundos de investimentos também são substanciais na Colômbia, onde são equivalentes a $23 \%$ do PIB, mais que o dobro dos ativos administrados pelas entidades de previdência (Borensztein et. al., 2006).

Tabela 7 - Ativos dos Investidores Institucionais (\% do PIB)

\begin{tabular}{lrrrr}
\hline & $\begin{array}{c}\text { Companhias } \\
\text { Seguradoras }\end{array}$ & $\begin{array}{c}\text { Entidades de } \\
\text { Previdência }\end{array}$ & $\begin{array}{c}\text { Fundos de } \\
\text { Investimentos }\end{array}$ & Total \\
\hline Países Desenvolvidos & 45.40 & 50.40 & 47.20 & 143.00 \\
Argentina & 4.60 & 12.00 & 1.00 & 17.60 \\
Brasil & 2.80 & 14.80 & 28.40 & 46.00 \\
Chile & 19.90 & 59.10 & 8.80 & 87.80 \\
Colômbia & 1.00 & 10.30 & 23.30 & 34.60 \\
México & 1.70 & 5.80 & 5.80 & 13.30 \\
Peru & 2.20 & 11.00 & n.d. & n.d. \\
Média dos Países Latino- & & & $\mathbf{1 3 . 4 6}$ & $\mathbf{3 9 . 8 6}$ \\
Americanos & $\mathbf{5 . 3 7}$ & $\mathbf{1 8 . 8 3}$ &
\end{tabular}

Vittas (1998) mostra a inter-relação entre o crescimento dos investidores institucionais e o desenvolvimento dos mercados de capitais, concluindo que a experiência dos países latinoamericanos sugere largo potencial para um processo interativo entre os investidores institucionais e os mercados de capitais. Os investidores institucionais podem agir como uma força contrabalanceadora à posição dominante dos bancos comerciais, e assim, promover competição e eficiência nos mercados financeiros. Podem também estimular a inovação financeira, modernizar os mercados de capitais, conduzir a um aumento da transparência e fortalecer a governança corporativa. 
Devido ao horizonte de tempo dos ativos que as entidades de previdência privada detêm, elas são potenciais compradoras de títulos privados de longo prazo. O crescimento dos fundos dessas entidades pode não contribuir diretamente para o crescimento agregado da poupança, mas pode certamente aumentar as fontes de financiamento a longo prazo para investimentos produtivos. Se esse potencial tornar-se-á efetivo ou não, irá depender principalmente do ambiente em que essas instituições irão operar (Studart, 2000).

\subsection{Legislação e Alocação das Carteiras de Investidores Institucionais no Mundo}

O grande aumento nos fluxos de capitais internacionais ao longo dos últimos anos também se refletiu na composição das carteiras dos investidores institucionais. Nota-se que, geralmente, os investimentos em ações tendem a ser mais diversificados internacionalmente que os em renda fixa, devido ao fato de que, após o ajuste pelo risco cambial, os títulos estrangeiros não oferecem os mesmos benefícios de diversificação no longo prazo como as ações. A porcentagem de ativos estrangeiros nas carteiras das entidades de previdência são maiores, enquanto as companhias seguradoras tendem a ser o grupo menos diversificado geograficamente. Enquanto a participação dos investimentos dos mercados emergentes vem crescendo nos últimos anos, os ativos estrangeiros detidos por investidores institucionais de países desenvolvidos tendem a estar concentrados nesse mesmo grupo de países (Davis e Steil, 2001).

Tabela 8 - Diversificação Internacional das Carteiras dos Investidores Institucionais nos Países Desenvolvidos em 1996

\begin{tabular}{|c|c|c|c|c|c|c|c|}
\hline \\
\hline & \multicolumn{2}{|c|}{$\begin{array}{c}\text { Entidades de } \\
\text { Previdência }\end{array}$} & \multicolumn{2}{|c|}{$\begin{array}{c}\text { Companhias } \\
\text { Seguradoras* }\end{array}$} & \multicolumn{2}{|c|}{ Fundos de Investimentos } & \multirow{3}{*}{$\begin{array}{c}\text { Capitalização de } \\
\text { mercado como } \\
\% \text { do } \\
\text { mundo*** }\end{array}$} \\
\hline & Total $* *$ & Ações & Total** & Ações & Total** & Ações & \\
\hline & \multicolumn{6}{|c|}{ como $\%$ da classe ativos } & \\
\hline Estados Unidos & 11 & 16 & 7 & 4 & 7 & 10 & 45 \\
\hline Japão & 23 & 35 & 13 & 10 & - & - & 16 \\
\hline Alemanha & 4 & 21 & - & - & - & - & 4 \\
\hline França & - & - & 1 & 1 & - & - & 3 \\
\hline Itália & - & - & 15 & 40 & 16 & 34 & 1 \\
\hline Reino Unido & 28 & 28 & 18 & 19 & 15 & 16 & 9 \\
\hline Canadá & 17 & 37 & 26 & 30 & 37 & 40 & 3 \\
\hline Austrália & 20 & 27 & 22 & 29 & - & - & 2 \\
\hline Holanda & 30 & 58 & 18 & 21 & 7 & 9 & 2 \\
\hline Suécia & 6 & 27 & 16 & 36 & 20 & 23 & 1 \\
\hline Suíça & 16 & 33 & - & - & 49 & 51 & 2 \\
\hline
\end{tabular}


Um aspecto da diversificação internacional de carteiras de investidores institucionais que é facilmente mascarada pelos números é a assimetria entre o investidor e as perspectivas do receptor, especialmente nos mercados emergentes. A alta concentração de ativos institucionais em alguns dos países mais desenvolvidos financeiramente contrasta com relativo pequeno tamanho de muitos mercados receptores. Essa assimetria, combinada a um nível baixo de fluxos que têm caracterizado historicamente os investimentos nas economias emergentes, enfatiza o potencial para instabilidade na medida em que o ajuste marginal das carteiras pelos investidores pode facilmente atingir um evento de primeira ordem para o receptor. Assim, por exemplo, um hipotético aumento de $1 \%$ dos investimentos em ações por investidores institucionais em países do G-7 fora dos mercados domésticos iria representar um pouco mais de $1 \%$ da capitalização de mercado total em 1995. Os mesmos fluxos seriam equivalentes a $27 \%$ da capitalização de mercado em economias asiáticas, e a mais de $66 \%$ dos mercados de ações da América Latina (BIS, 1998).

No tocante à legislação internacional, salvo exceções, investimentos diretos no exterior são permitidos, conforme pode ser observado na Tabela 8. A aplicação de parte dos recursos em outros países reflete o emprego da teoria de seleção ótima de carteiras (diversificação) em nível global. Em alguns países, os ativos internacionais representam menos de $10 \%$ dos recursos (como na França e na Alemanha), enquanto em outros, como Estados Unidos, Inglaterra, Japão, Canadá, Suíça e Austrália, as entidades de previdência têm aproximadamente $20 \%$ de seus recursos aplicados em ativos internacionais (Boulier, 2003). De acordo com a legislação brasileira, aplicações diretas no exterior sempre foram proibidas, talvez em função da dificuldade de fiscalizar tais investimentos e da necessidade de formação de poupança interna ${ }^{1}$. Seguindo os moldes observados internacionalmente, há restrição de inversão de $10 \%$ em títulos emitidos pela patrocinadora, além de restrições quanto a aplicações conjuntas realizadas pelo fundo de pensão e sua patrocinadora (Rieche, 2005).

\footnotetext{
1 A rigor, é possível aplicar por vias indiretas e de forma restrita (atualmente, é permitido aplicar até $10 \%$ dos recursos em quotas de fundos de dívida externa e até 3\% em ações emitidas por empresas com sede no exterior que atendam ao disposto no Art. 22 do regulamento anexo a Resolução 3.121, com redação alterada pelo Art $1^{\circ}$ da Resolução 3305).
} 
Tabela 9 - Limites de Investimentos e Alocação dos Fundos de Pensão - 2001/2002 (como porcentagem do total de ativos administrados)

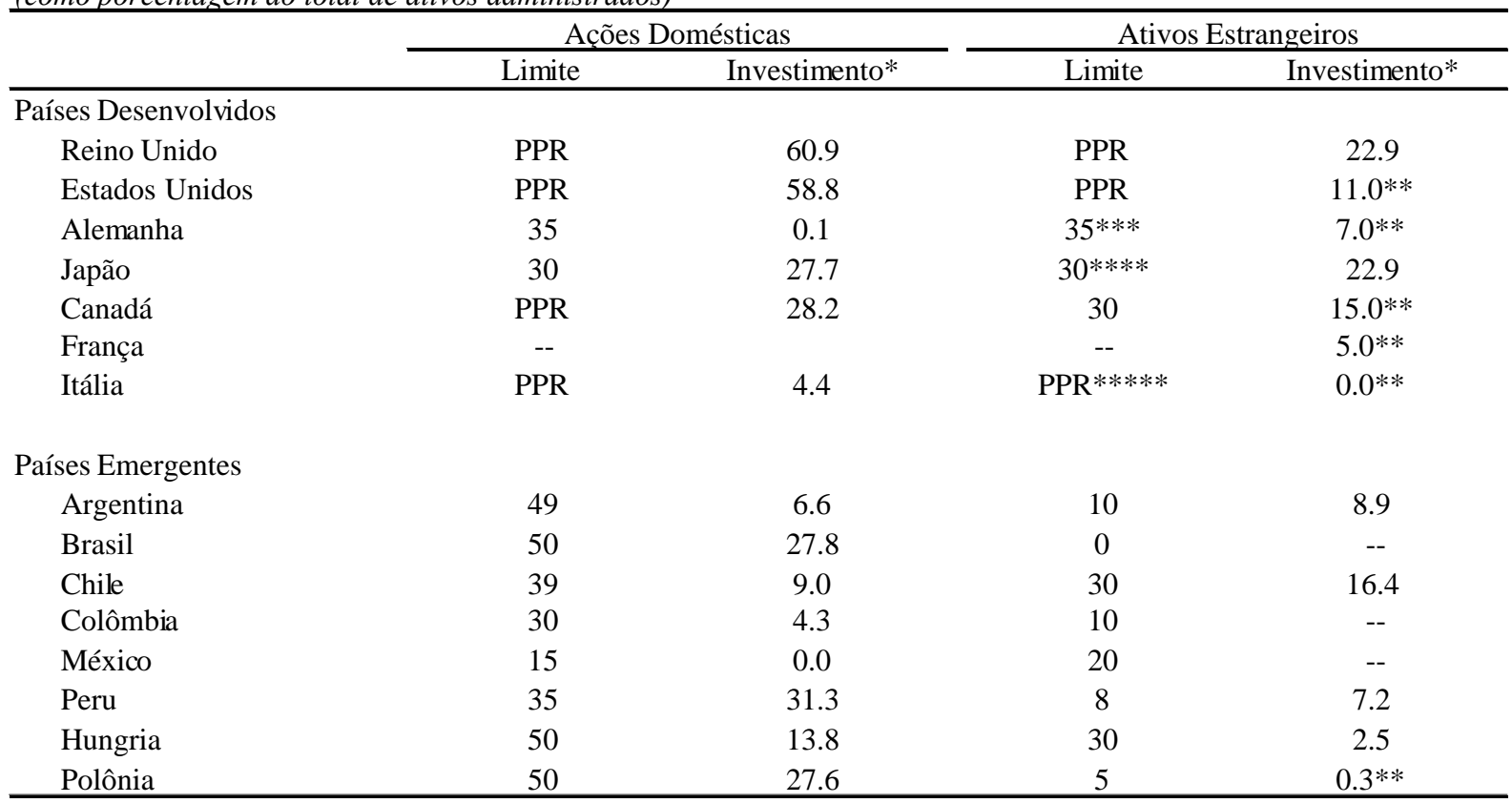

Fonte: Roldos (2004) e OECD (2006)

PPR $=$ Prudent Person Rule

* Dados para Países Desenvolvidos referem-se ao final de 2001 e Países Emergentes final de 2002.

**Dados de 1998

*** $6 \%$ em ações estrangeiras de países fora da UE, $5 \%$ em títulos de renda fixa fora da EU

***** Sem limites para fundos de pensão de empregados

******Ativos não da OECD negociados em mercados regulares limitados a 5\% (proibidos se negocidaos em mercados não regulares)

Regulamentações sobre investimentos parecem não ser o principal impedimento para investirse em mercados emergentes. Um recente estudo da OCDE mostra que apenas a Alemanha e a Itália impõem fortes restrições a ativos estrangeiros (Yermo, 2003). Na Alemanha, as entidades de previdência podem investir apenas $10 \%$ dos ativos em ações e em títulos estrangeiros de países não pertencentes à União Européia. Na Itália, o teto para ações e títulos estrangeiros de países não pertencentes à OCDE é de 5\% dos ativos. As entidades de previdência, no entanto, podem investir até $50 \%$ dos ativos em mercados emergentes membros da OCDE como México, Coréia, e países em acesso à União Européia. Por outro lado, não existem limites de investimento no Japão, Reino Unido e nos Estados Unidos, os três países que representam a maioria dos ativos na indústria de fundos de previdência (ChanLau, 2004).

Boulier (2003) mostra que alguns países, pelo seu contexto econômico, têm elevadas proporções de ativos internacionais, como é o caso de Hong Kong e da Irlanda. Outros países apresentam proporções de ativos estrangeiros inferiores a 10\%. Esse é o caso da França que, 
por tradição, permanece voltada a suas próprias empresas, e da Alemanha, que financia a empresas locais com os fundos de pensão.

Destaquemos a forte resistência da França e da Alemanha, ao contrário de outros países europeus mais naturalmente internacionais, como a Suíça e a Holanda. Já países como os Estados Unidos, a Inglaterra, os Países Baixos, o Canadá, a Suíça e a Austrália detêm aproximadamente $20 \%$ de ativos internacionais.

Figura 9 - Ativos Internacionais dos Fundos de Pensão como \% dos Fundos Administrados

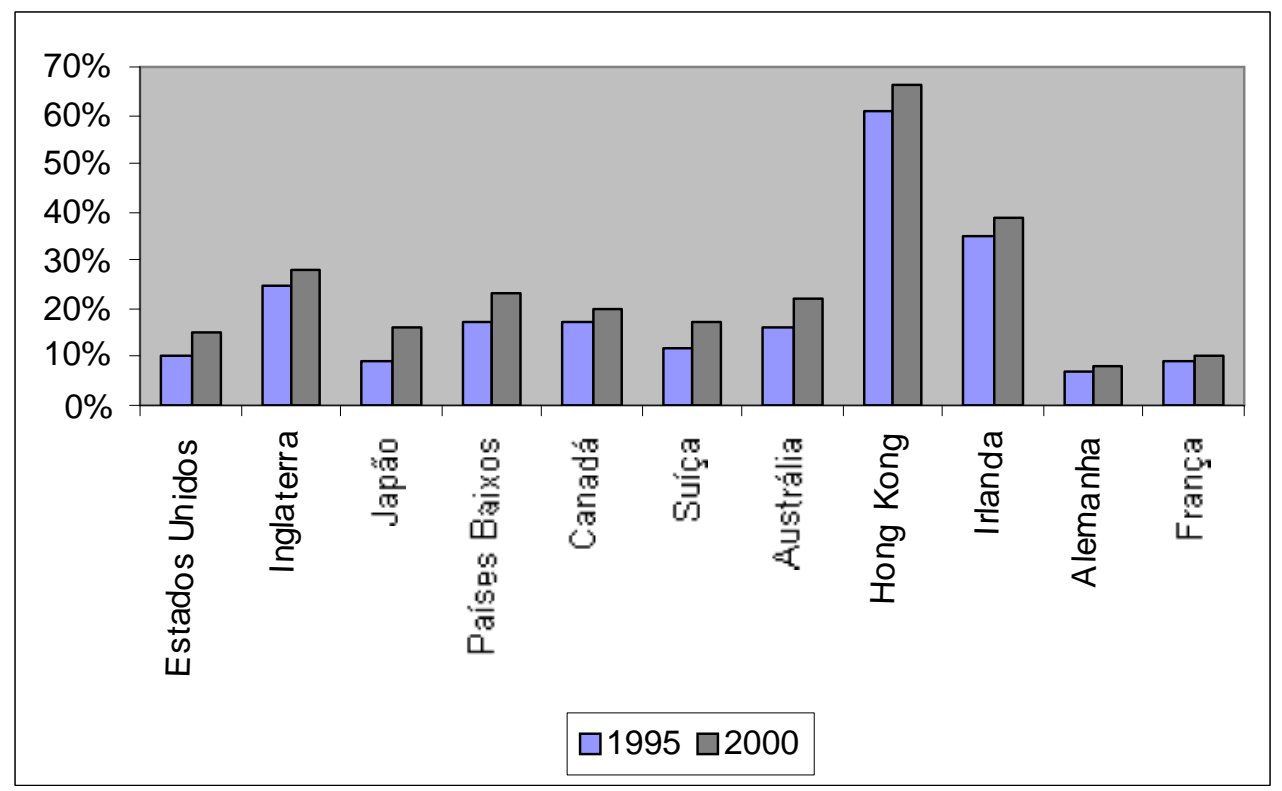

Fonte: Boulier (2003)

Boulier (2003) justifica que certos países, como, por exemplo, a Holanda, invistam internacionalmente, já que apresentam montantes investidos nos fundos de pensão superiores a capacidade da bolsa de valores do próprio país.

No final de 1994, 10\% dos fundos de pensão estavam em investimentos internacionais e em 1996, 12\%. Atualmente a projeção para vários fundos é de 20\% a 25\% (Boulier, 2003).

As restrições de investimento também apresentam um papel importante na formação das carteiras das companhias seguradoras. A Tabela 10 mostra a alocação das carteiras para seguradoras de vida de vários mercados emergentes. Com exceção de Hong Kong, África do Sul e, em algum grau, de Cingapura, a maioria dos países apresentam forte viés para instrumentos de renda fixa devido a limites expressos em regulamentações de investimento 
em ações e ativos reais e proibição de investimentos no exterior. Kong e Singh (2005) ressaltam que esse guia rigoroso pode não apenas restringir a alocação e ativos das companhias seguradoras, mas também afetar os custos dos seguros, dado que uma carteira bem diversificada pode ajudar a reduzir os juros e o risco de mercado.

Tabela 10 - Alocação dos Ativos de Seguradoras de Vida no final de 2002

\begin{tabular}{|c|c|c|c|c|c|c|c|c|}
\hline (como \% do Total) & $\begin{array}{c}\text { Caixa e } \\
\text { Depósitos } \\
\end{array}$ & Ações & Renda Fixa & $\begin{array}{c}\text { Ativos } \\
\text { Estrangeiros }\end{array}$ & Empréstimos & Imóveis & Outros & Total \\
\hline \multicolumn{9}{|l|}{ Ásia } \\
\hline Hong Kong* & 7 & 35 & 38 & 0 & 0 & 0 & 20 & 100 \\
\hline Coréia & 2 & 7,5 & 29,8 & 6,2 & 26,5 & 5,5 & 22,5 & 100 \\
\hline Malásia & 29 & 0 & 53 & 0 & 9 & 4 & 4 & 100 \\
\hline Cingapura & 8 & 3 & 52 & 21 & 10 & 5 & 1 & 100 \\
\hline Tailândia & 8 & 9 & 64 & 0 & 11 & 3 & 5 & 100 \\
\hline \multicolumn{9}{|c|}{ Europa Oriental e África } \\
\hline Hungria & 3 & 5 & 91 & 0 & 0 & 0 & 0 & 100 \\
\hline Polônia & 4 & 11 & 83 & 0 & 0 & 1 & 0 & 100 \\
\hline África do Sul & 7 & 48 & 15 & 14 & 0 & 5 & 10 & 100 \\
\hline \multicolumn{9}{|l|}{ América Latina } \\
\hline Argentina & 22 & 9 & 61 & 0 & 1 & 4 & 3 & 100 \\
\hline Brasil & 1 & 5 & 64 & 0 & 6 & 5 & 18 & 100 \\
\hline Chile & 3 & 14 & 51 & 2 & 20 & 7 & 2 & 100 \\
\hline Colômbia & 3 & 11 & 68 & 7 & 8 & 3 & 0 & 100 \\
\hline México & 2 & 6 & 80 & 0 & 3 & 7 & 3 & 100 \\
\hline Peru & 21 & 17 & 43 & 0 & 0 & 0 & 19 & 100 \\
\hline
\end{tabular}

Segundo Rieche (2005), pode-se comparar a legislação brasileira com os princípios estabelecidos pela OCDE para regulamentação de fundos de pensão, segundo os quais recomenda-se, no caso de regulamentações quantitativas, que nenhum nível mínimo de investimento seja estipulado para qualquer categoria de investimentos e que as aplicações em um dado ativo sejam limitadas como uma proporção dos recursos totais. Se envolverem riscos especiais, podem ser até mesmo proibidas, como os investimentos nas próprias patrocinadoras, que devem ser estritamente limitados ao máximo de $10 \%$ dos recursos.

Outras recomendações referem-se à possibilidade de se fazer uma lista exaustiva dos ativos nos quais se admitem aplicações, ao uso limitado de derivativos (deve se garantir que sejam usados para gerenciar riscos e não para gerar uma alavancagem desnecessária) e à possibilidade de realizar investimentos no exterior. No caso de regulamentações baseadas no prudent person rule, recomenda-se que sejam atribuídas maiores responsabilidades legais e financeiras a atos imprudentes dos fiduciários (Rieche, 2005). 
Países que não adotam limites de investimentos em ativos estrangeiros contam com o princípio do prudent person rule. A regra requer que os administradores dos fundos de pensão tomem decisões de investimento conscientes baseadas nas melhores práticas entre outras de grandes e prudentes investidores institucionais. Essa categoria de investidores inclui seguradoras, fundos mútuos e outras companhias de gestão de recursos. O prudent person rule provê os fundos de pensão um largo escopo de estratégias de alocação de ativos e permite o investimento ao longo de uma grande gama de ativos financeiros, incluindo ativos de mercados emergentes. O prudent person rule sugere a possibilidade de diferenças substanciais na alocação de ativos entre fundos de pensão nos diversos países. $\mathrm{Na}$ prática, acontece o contrário. As práticas de investimento podem ser responsáveis por similaridades encontradas ao longo das carteiras dos fundos de pensão (Chan-Lau, 2004).

Acredita-se que esta abordagem produziu retornos no longo prazo significativamente maiores que os produzidos por práticas mais restritivas. Savoia (2001) relata que durante o período de 1984 a 1998, foi observado um retorno médio anual de 10,67\% nos países que adotam o prudent person rule em comparação com um retorno médio anual de 5,92\% em países que adotam critérios quantitativos, com fortes restrições a determinados investimentos.

De forma geral, os países anglo-saxões, com tradição legal de Direito Consuetudinário (Common Law), adotam o princípio da prudência, no qual usualmente se estabelecem recomendações de caráter amplo e poucas restrições quantitativas. As obrigações básicas dos fiduciários envolvem prudência, diversificação e lealdade em relação aos interesses do fundo de pensão e de seus participantes. Além do Reino Unido e dos Estados Unidos, seguem essa linha a Austrália, o Canadá e a Irlanda e, mesmo nesses países, há restrições quantitativas quanto a inversões da EFPC em suas patrocinadoras, que variam entre $5 \%$ e $10 \%$ dos recursos. Alguns países que não são anglo-saxões também adotam esse princípio, como, por exemplo, Itália, Japão e Holanda (Rieche, 2005).

No Brasil, em que se segue o Direito Civil (Civil Law), tradicionalmente as regulamentações são quantitativas, ou seja, com estabelecimento expresso de limites quantitativos, embora nos últimos anos tenha se verificado uma combinação, ainda que não muito acentuada, entre os dois tipos de regulamentação. Os trabalhos com esse propósito sugerem que, na média, restrições quantitativas são onerosas, pois impedem que as carteiras apresentem alocação ótima, ao passo que são gerados retornos maiores quando se aplica o princípio da prudência. 
Contudo, tais estudos não são conclusivos, já que não levam em consideração outros fatores que podem afetar as regulamentações. Dessa forma, o desempenho dos investimentos, ainda que importante, não é a única medida de uma regulação bem-sucedida. Independentemente do formato adotado, a regulação deve garantir segurança aos participantes e assistidos do sistema de previdência complementar (Rieche, 2005).

Na América Latina, o mercado de capitais tem sido amplamente determinado pelas instruções governamentais que atingem cada aspecto das operações, do montante de contribuições que a indústria recebe até o investimento de ativos em fundos de pensões. A adoção de critérios meramente prudenciais tem sido evitada em decorrência das dificuldades de fiscalização e de responsabilização dos administradores que falham no cumprimento de suas funções (Savoia, 2001).

No Brasil, as condições de supervisão são precárias, a capacidade de inspeção é limitada e as punições legais dos agentes que falharam em proteger adequadamente os direitos dos participantes são leves e difíceis de serem aplicadas. Embora a intenção no médio prazo seja melhorar este cenário, não seria prudente imaginar um mercado totalmente livre no curto prazo. Neste ambiente, marcado por rápidas mudanças e acentuada inovação financeira, são esperadas mudanças da regulamentação para princípios prudenciais, acompanhados de alguns limites quantitativos (Savoia, 2001).

Na maioria dos mercados emergentes, a regulamentação dos fundos de pensão está baseada em limites quantitativos de investimento. Reguladores nos mercados emergentes consideram que os limites de investimentos protegem os direitos dos pensionistas melhor que as regulamentações baseadas no prudent person rule. Esse argumento pode ser defendido no sentido de que o baixo desenvolvimento e a falta de transparência dos mercados de ativos locais fazem deles suscetíveis a manipulação e ao excesso de volatilidade, e, os públicos em geral, como os administradores dos fundos, padecem de falta de sofisticação financeira (Chan-Lau, 2004).

As restrições de investimentos buscam pela certificação de um mínimo de diversificação das carteiras, diluindo os limites de concentração de propriedade e evitando o próprio investimento nas companhias patrocinadoras dos fundos de pensão. Os limites de investimento em ativos considerados de maior volatilidade, como ações, são mais restritos. Os 
fundos de pensão também devem investir somente em papéis de alta qualidade de crédito. Os fundos do México, por exemplo, não podem investir mais que 5\% dos ativos em títulos com rating A e investimentos em títulos high yield.

Investimentos em derivativos não são permitidos em muitos países por serem considerados excessivamente arriscados e complexos. O Chile é uma notável exceção, com ativa participação dos fundos de pensão em mercados de derivativos de moeda e de taxa de juros. $\mathrm{O}$ exemplo do Chile está sendo seguido pelo México, onde mudanças regulatórias recentes permitiram que os fundos de pensão passassem a usar derivativos em 2004. Medidas similares estão em estudo na Polônia e Hungria. Tabela 9 também mostra significantes restrições ao investimento em ativos estrangeiros. Razões que dão suporte a essas restrições incluem a suposição de que os administradores dos fundos de pensão não podem administrar adequadamente os riscos cambiais envolvidos nos investimentos no exterior. Mais importante, em muitos países existe uma crença difundida entre os governos, e às vezes repartida pelo público, que os escassos capitais domésticos devem ser investidos domesticamente. Muitos fundos de pensão na Ásia, por exemplo, não investem em ativos estrangeiros (Holzmann et. al., 2000).

Existem muitos argumentos convincentes, no entanto, contra o uso de restrições como ferramenta regulatória (Davis, 2001). Em particular, limites de investimento podem levar a carteiras sub-ótimas por restringir desnecessariamente escolhas. Os limites de investimento também implicam que os ativos sejam avaliados pelo nível de risco individual ao invés de sua contribuição para o risco total da carteira. Além disso, as restrições de investimento são inflexíveis e não podem acomodar rápidas mudanças nas condições financeiras e mudanças estruturais nos mercados financeiros.

Outro argumento contra o uso de limites de investimento é que são aplicados assimetricamente aos ativos emitidos por instituições privadas e aqueles emitidos por instituições públicas ou mistas. Como resultados, os fundos de pensão podem estar viesados por investir mais em títulos públicos do que ditaria a regra de alocação ótima. O tratamento assimétrico entre títulos públicos e privados impulsionou o aprofundamento e desenvolvimento dos mercados de títulos públicos locais. Esse desenvolvimento pode ter sido atingido ao custo de excessiva concentração de risco e baixos retornos para os fundos de pensão e o baixo desenvolvimento dos mercados de capitais locais (Chan-Lau, 2004). 


\subsection{Experiências de Internacionalização de Carteiras em Outros Países}

Davis (2001) chama a atenção de que os fluxos de capitais para outros países, como os produzidos pelo investimento em ativos estrangeiros, exercem pressão pela desvalorização da moeda local. No entanto, a neutralização dessas pressões é possível apenas até certo ponto. Se a saída de capitais é excessiva, as reservas oficiais podem ser insuficientes para manter o valor da moeda, forçando uma desvalorização. Em países em desenvolvimento, onde o capital é escasso, a estratégia de investimento no exterior pelos investidores institucionais pode criar facilmente distorções na taxa de câmbio. Além disso, relata que essa questão é mais importante onde, como resultado de reformas na previdência, os fundos de pensão tornaramse importantes veículos de acumulação de poupança e adquiriram grandes proporções.

Segundo Roldos (2004), apesar da importância dada ao desenvolvimento do mercado de capitais locais, algumas reformas previdenciárias geraram a necessidade do aumento dos limites a investimentos no exterior por motivos de diversificação das carteiras. Um exemplo deste caso é o Chile. Apenas uma década depois da introdução dos fundos de previdência privados é que estes puderam investir em ativos estrangeiros em até 3\%. O limite passou para 9\% em 1995, $12 \%$ em 1997, 20\% em 2001 e 30\% em junho de 2002. Os fundos de pensão não diversificaram de forma expressiva na primeira metade dos anos 90 por obterem elevados retornos dos ativos locais. Porém, dois anos seguidos de retornos negativos no mercado de ações local gerou uma grande realocação em ativos estrangeiros em 1997 e os fundos detém atualmente cerca de $25 \%$ de ativos estrangeiros. Isso também veio acompanhado de uma recuperação dos retornos dos fundos locais, auxiliado em parte pela depreciação da moeda local.

Em outros países que aumentaram os limites a investimentos no exterior, os gestores de fundos ficaram às vezes relutantes em aumentar a alocação em ativos estrangeiros. $\mathrm{Na}$ Hungria, por exemplo, onde o limite para investimentos no exterior é, há bastante tempo, de $30 \%$ do total de ativos, as alocações atuais estão abaixo de 5\% como resultado de experiências ruins de perdas com os resultados do estouro da bolha TMT. Na Colômbia, foi permitido aos fundos investirem em fundos de ações externos em abril de 2002, mas os participantes argumentam que as alocações estão abaixo de $2 \%$ pelo medo de não se conseguir atingir retornos mínimos, mesmo quando os fundos estão alocados no limite em títulos públicos. 
Roldos (2004) citam duas implicações macroeconômicas da diversificação internacional dos fundos de pensão. Primeiro, a redução dos limites para investimentos estrangeiros por fundos de pensão locais pressupões a remoção dos controles de saídas de capitais e cuidados devem ser tomados com as conseqüências macroeconômicas. Em particular, as experiências chilena e canadense mostraram uma repentina mudança na alocação dos fundos de pensão no exterior pode levar a uma substancial depreciação da moeda local. No Chile, um aumento da parcela de ativos estrangeiros de 2\% no final de 1997 para 12\% no final de 1999 foi associado a uma forte depreciação do peso chileno de $20 \%$. No Canadá, um aumento no limite de investimentos no exterior de $20 \%$ em janeiro de 2000 para $30 \%$ em janeiro de 2001 contribuiu, em alguma medida, para o aumento da saída de capitais e a $10 \%$ de depreciação do dólar canadense no período de janeiro de 2000 até janeiro de 2002. Segundo, a acumulação de ativos estrangeiros pelos fundos de pensão provê um hedge natural para empresas que possuem empréstimos no exterior, contribuindo para o mercado de derivativos e para uma posição agregada internacional mais balanceada.

Fischer (2006) fala da importância da liberalização da saída de capitais além da entrada de capitais em Israel. Como resultado da liberalização da conta capital e do rápido crescimento da economia e do bem sucedido setor high-tech, ocorreram grandes entradas de capitais, aproximadamente metade era investimento direto estrangeiro, e o restante investimento em carteira. Caso não fosse permitida a saída de capitais, haveria uma grande pressão na taxa de câmbio pelo saldo em conta corrente do país estar superavitário. Em 2005, as saídas de capitais em Israel perfaziam 9\% do PIB, aproximadamente igual às entradas de capitais. No começo do processo, os fundos de pensão, os fundos de investimentos e os investimentos das famílias israelenses eram totalmente domésticos. Como resultado da liberalização das saídas de capitais não houve pressão na taxa de câmbio por conta dos fluxos de capitais. 


\section{LEGISLAÇÃO BRASILEIRA SOBRE INVESTIMENTOS DOS INVESTIDORES INSTITUCIONAIS}

\subsection{Legislação Brasileira sobre Investimentos dos Fundos de Pensão}

Atualmente, o sistema previdenciário brasileiro está apoiado em três modalidades diferentes de regimes previdenciários: a Previdência Oficial, a Previdência Complementar Fechada e a Previdência Complementar Aberta.

Num primeiro pilar está o Regime Geral, um sistema de repartição, operado pelo Instituto Nacional de Seguro Social - INSS, destinado à grande maioria dos trabalhadores brasileiros, e os Regimes Próprios da União, Distrito Federal, Estados e de cerca de metade dos Municípios brasileiros, que congregam seus servidores públicos titulares de cargos efetivos. O segundo pilar é constituído pelos Fundos de Pensão, onde os participantes contribuem para planos capitalizados, tanto na forma de benefício definido, como na de contribuição definida. No terceiro pilar encontram-se as entidades abertas de previdência, controladas pelo sistema financeiro, que oferecem planos de previdência individual. Há, ainda, um pilar "zero", destinado a prover benefícios assistenciais a trabalhadores idosos, de forma a minorar a pobreza entre as populações carentes (Savoia, 2001).

Segundo Pinheiro et. al.(2005), a previdência complementar é regida, além da disposição constitucional, por duas Leis Complementares que a regulamentam (Leis Complementares $\mathrm{n}^{\circ}$ 108 e $\mathrm{n}^{\mathrm{o}} 109$, de 29 de maio de 2001) e por uma série de atos normativos infra-legais. É operada por entidades abertas de previdência complementar e algumas sociedades seguradoras (LC no 109/01, artigos 36 e 77), e por entidades fechadas de previdência complementar (LC n ${ }^{\circ}$ 109/01, artigos 31 e seguintes).

As entidades fechadas de previdência complementar (EFPC) são também chamadas de fundos de pensão, e são pessoas jurídicas de direito privado que têm como objeto a administração e execução de planos de benefícios de natureza previdenciária (Pinheiro et. al., 2005). Nos Fundos de Pensão, os participantes contribuem para planos capitalizados, tanto na forma de benefício definido, como na de contribuição definida. Os fundos de pensão com benefício definido garantem ao assalariado uma pensão calculada atuarialmente, de acordo com o tempo de contribuição e o salário. Já os fundos de contribuição definida recebem os pagamentos de contribuições voluntárias e facultativas, que são depositadas em contas individuais. Em ambas 
modalidades de planos há incentivos fiscais para as empresas e para os trabalhadores que pagam contribuições aos planos. Os fundos de pensão são voluntários, podendo ser organizados na forma de fundos patrocinados pelas empresas, ou na forma instituída, assemelhados aos multi-employer funds americanos (Savoia, 2001).

As EFPCs fazem parte do Sistema Financeiro Nacional (SFN) na qualidade de operadoras. A função de entidade de fiscalização e supervisão cabe à Secretaria de Previdência Complementar, enquanto a função de órgão normativo cabe ao Conselho de Gestão da Previdência Complementar (CGPC), órgão colegiado integrante da estrutura do Ministério da Previdência Social (Rieche, 2005).

Desde a edição da primeira norma regulamentadora da previdência complementar, a fixação das diretrizes referentes às aplicações dos recursos dos planos de benefícios administrados por fundos de pensão sempre esteve a cargo do Conselho Monetário Nacional - CMN, instituído pela Lei $n^{\circ} 4.595 / 64$ e que é o órgão máximo do Sistema Financeiro Nacional, tendo, entre outras atribuições, a de orientar a política creditícia e monetária do país (Pinheiro et. al., 2005).

O Conselho Monetário Nacional, durante o período 1977 a 1994, estabeleceu limites mínimos e máximos de aplicação por tipo de instrumento financeiro, passando a partir de então, a fixar somente limites máximos. O documento básico que regulamentava as entidades de previdência privada era a Lei 6435 de 1977, recentemente revogada pela Lei Complementar n $109 / 01$. Desde a regulamentação de 1977, houve um crescimento sistemático do número de instituições.

A Resolução 2109/94 do Conselho Monetário Nacional aboliu os limites mínimos para as aplicações das EFPP's. Essa resolução foi posteriormente modificada várias vezes, sendo que atualmente a Resolução 2829/01, alterada pela Resolução 2850/01 e posteriormente pela 3.121/03, estabelece as diretrizes pertinentes à aplicação dos recursos das entidades fechadas de previdência privada. A Resolução 2829/01 classifica os ativos em quatro classes (renda fixa, renda variável, imóveis e empréstimos e financiamentos), estabelecendo limites de recursos para alocação em cada um deles (Leal et. al., 2001). 
No campo específico da previdência complementar, a regulação dos investimentos dos fundos de pensão conheceu, para Pinheiro et. al. (2005), quanto aos limites de aplicação, duas fases: a primeira, de 1978 até 1994, e a segunda, que dura até hoje.

A primeira norma que regulou os investimentos dos fundos de pensão foi a Resolução do Conselho Monetário Nacional $n^{\circ}$ 460, de 23 de fevereiro de 1978, que tinha como principal característica a fixação de limites mínimos e máximos para aplicação em títulos públicos federais, ações de empresas e imóveis (Pinheiro et. al., 2005).

A regulação dos investimentos dos recursos dos planos de benefícios operados por fundos de pensão conheceu ainda uma segunda fase, iniciada a partir da Resolução do $\mathrm{CMN} \mathrm{n}^{\circ}$ 2.109/94, quando a regulação passou a se basear na definição apenas de limites quantitativos máximos de alocação de recursos, abandonando-se a idéia de limites mínimos, que poderiam causar, em muitos casos, distorções alocativas por não otimizarem a relação risco e retorno, na medida que impunha restrições mínimas de aplicação dos recursos. $\mathrm{O}$ abandono dos limites mínimos foi posteriormente confirmado pela $\mathrm{LC}^{\circ}$ 109/01, que proibiu o estabelecimento de aplicações compulsórias ou limites mínimos de aplicação (Pinheiro et. al., 2005).

Especificamente no campo dos investimentos, a nova legislação manteve no CMN a responsabilidade pelo estabelecimento de diretrizes para a aplicação dos recursos correspondentes às reservas, às provisões e aos fundos constituídos pelas entidades fechadas de previdência complementar (Pinheiro et. al., 2005).

Dando cumprimento a tal determinação legal, o CMN editou a Resolução $n^{\circ} 2829$, de abril de 2001, que estabeleceu a necessidade de elaboração anual de uma política de investimentos, que visa orientar os investimentos segundo as características e perfil das obrigações passivas do plano de benefícios, em que são avaliados os cenários macroeconômicos de curto, médio e longo prazos e a forma de seleção dos ativos, constituindo passo importante para se conhecer as perspectivas de aplicação dos recursos das entidades fechadas de previdência complementar (Pinheiro et. al., 2005).

A resolução trata também de limites máximos para determinados investimentos de forma a limitar a concentração em determinados segmentos ou ativos que possam comprometer o processo de acumulação de reservas (Pinheiro et. al., 2005). 


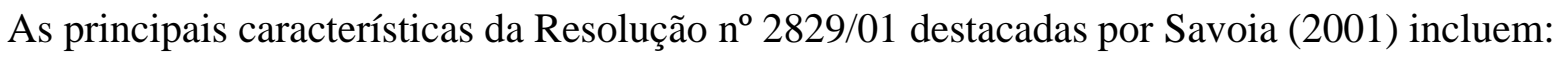

- Flexibilidade com relação às operações financeiras conduzidas no mercado brasileiro, incluindo operações com derivativos, que são raramente consideradas em outros países latino-americanos;

- Uma clara separação entre os fundos de pensão e suas patrocinadoras, que limitam o uso dos fundos para propósitos da própria patrocinadora;

- A necessidade da adoção de políticas de investimentos relacionadas ao risco, que são obrigatoriamente reportadas à agência de supervisão;

- Uma clara identificação dos ativos dos vários planos dentro dos fundos multi-planos, fazendo com que não exista espaço para "solidariedade" entre planos;

- Todos os gestores de fundos são responsáveis pela administração dos fundos de pensão;

- Aumento dos limites da participação de instrumentos de renda variável e estímulo para a compra de ações de companhias que seguem boas práticas de governança corporativa;

- Obrigatória implementação de modelos para gestão de risco versus retorno quando existe a conjunção de ativos e passivos.

Atualmente, a principal norma relacionada a investimentos de fundos de pensão é a Resolução CMN 3.121 e suas alterações. São quatro segmentos possíveis para aplicação dos recursos: renda fixa, renda variável, imóveis e empréstimos e financiamentos (Rieche, 2005). A Tabela 11 sintetiza os principais limites de aplicações da regulamentação de investimentos das entidades fechadas de previdência complementar (EFPC). 
Tabela 11 - Limites de Aplicações das EFPC's conforme Resolução CMN 3.121/03

\begin{tabular}{llc}
\hline \multicolumn{1}{c}{ Tipo de Aplicação } & \multicolumn{1}{c}{ Modalidades de Investimento } & Limite \\
\hline Renda Fixa - Baixo Risco de Crédito & Títulos de Emissão TN - Tesouro Nacional & $100 \%$ \\
& FIEX - Fundos de Investimento no Exterior & $10 \%$ \\
& FI, CDB, CPR-F, Debêntures, CRI, FIDC & $80 \%$ \\
Renda Fixa - Médio/ Alto Risco de Crédito & FI, CDB, CPR-F, Debêntures, CRI, FIDC & $20 \%$ \\
\hline & FI, Ações - Novo Mercado e Nível 2 da Bovespa & $50 \%$ \\
& Fl, Ações - Nível 1 da Bovespa & $45 \%$ \\
Renda Variável & FI, Ações - Não citados anteriormente & $35 \%$ \\
& Participação em SPE em inversão própria (\% patrimônio) & $20 \%$ \\
\hline Imóveis & Infra-Estrutura (FIEE, FIP, Debêntures SPE) & $20 \%$ \\
\hline Empréstimos e Financiamentos & Imóveis ( Desenvolvimento, Aluguéis e FI Imobiliário) & $14 \%$ \\
\hline & Empréstimos a participantes/ assistidos & $15 \%$ \\
\hline
\end{tabular}

Fonte: Pinheiro et. al. (2005)

Nos últimos anos, a legislação referente a investimentos tem passado por várias mudanças, seja para permitir a aplicação em novos instrumentos financeiros, seja para estabelecer a adoção de determinados procedimentos ou instrumentos de gestão de riscos. Em um intervalo de praticamente nove anos houve 21 resoluções do CMN referentes a aplicações de recursos de fundos de pensão, dentre as quais as principais foram: 2.324, 2.720, 2.829 e 3.121. A lista completa, entre novembro de 1996 e agosto de 2005, inclui ainda as seguintes: 2.405, 2.467, $2.518,2.716,2.791,2.801,2.810,2.818,2.850,2.922,3.002,3.055,3.116,3.142,3.232$, 3.241 e 3.305. Assim, Rieche (2005) alerta para que se tenha especial atenção, já que mudanças constantes nas normas demandam tempo para os ajustes necessários e podem até dificultar a gestão dos recursos, ou seja, pode-se obter o efeito oposto ao desejado.

Como visto acima, a regulação dos investimentos dos recursos de planos de benefícios administrados por fundos de pensão conheceu duas fases bem distintas. A primeira, em que havia a fixação de limites quantitativos mínimos e máximos, e a segunda, que vigora atualmente, em que apenas limites quantitativos máximos são impostos pelas Resoluções do CMN (Pinheiro et. al., 2005).

Por sua vez, o contexto econômico determinou a modificação do perfil de aplicação dos recursos pelos fundos de pensão, fazendo com que os recursos aplicados pelas entidades de previdência complementar no país estejam bastante concentrados em ativos de renda fixa, em detrimento daqueles do segmento de renda variável (Pinheiro et. al., 2005). 
No momento atual, coloca-se em discussão a passagem para uma terceira fase da regulação, em que se abre o debate, à luz da evolução natural da regulamentação dos investimentos observada nos países desenvolvidos, a respeito da elaboração de regras prudenciais, em que os limites quantitativos perdem importância, ganhando relevo, para seleção das opções de aplicação mais adequadas, as características próprias de cada plano de benefícios administrado por entidade fechada de previdência complementar (Pinheiro et. al., 2005).

Pinheiro et. al.(2005) ressalta a importância de uma incorporação de elementos da supervisão baseada na gestão dos riscos envolvidos com a atividade de administração de recursos financeiros dos participantes e assistidos dos planos previdenciários dos fundos de pensão nesse processo de transferência de normas quantitativas para normas de tipo qualitativas.

O primeiro passo nesse sentido foi dado em 2004, com a edição da Resolução do Conselho de Gestão da Previdência Complementar do Ministério da Previdência Social $n^{\circ} 13$, de $1^{\circ}$ de outubro de 2004, que estabeleceu princípios, regras e práticas de governança, gestão e controles internos que devem ser observados pelas entidades fechadas de previdência complementar (Pinheiro et. al., 2005).

Quanto à transparência, há a obrigatoriedade de formulação de uma política de investimentos anual, elaborada pela diretoria-executiva, aprovada pelo conselho deliberativo da EFPC e de ampla divulgação a todos os participantes, que, entre outras informações, deve conter: critérios para a alocação dos recursos entre os segmentos e os objetivos da gestão de cada limite; critérios para a contratação de pessoas jurídicas; avaliação do cenário macroeconômico (curto, médio e longo prazos); e a forma de análise dos setores em que se pretende investir. As EFPCs têm a obrigação de prestar informações aos participantes e assistidos referentes aos custos com a administração dos recursos e ao acompanhamento da política de investimentos (Rieche, 2005).

Já o controle de riscos é realizado por meio de exigências de diversificação, restrições, estímulo à adoção de práticas de boa governança corporativa, atribuição de responsabilidades e exigência de manutenção de sistema de controle e avaliação de riscos para cada plano de benefícios (Rieche, 2005). 
A Resolução 2829 procurou controlar o risco de crédito por meio das exigências de diversificação da carteira e da diferenciação dos limites máximos para aplicação em determinados ativos de acordo com análise de classificação de risco. Além disso, há limites mais flexíveis para aplicações em empresas que tenham aderido a padrões de boa governança corporativa, nos moldes dos Níveis 1, 2 e Novo Mercado da Bovespa. Por fim, as operações de derivativos só são permitidas na modalidade "com garantia", desde que haja prévia existência de procedimentos de controle e de avaliação dos riscos, mas são vedadas as operações de venda de opções de compra a descoberto (Rieche, 2005).

Com relação à gestão ativo-passivo, a Resolução 3.121 estabelece a incumbência aos administradores das entidades de determinar a aplicação dos recursos com vistas à manutenção do necessário equilíbrio econômico financeiro entre os seus ativos e o respectivo passivo atuarial e as demais obrigações. Por sua vez, o regulamento anexo à Resolução 3.121 enfatiza que os limites de alocação estabelecidos pela política de investimentos devem estar parametrizados de acordo com os compromissos atuariais (Rieche, 2005).

Por fim, as principais proibições referem-se a aplicações que fugiriam aos objetivos de longo prazo das EFPCs como atuação como instituição financeira no caso, por exemplo, de empréstimos à patrocinadora, prestação de fiança, aval ou aceite e operações day-trade, e aplicações alavancadas como em fundos de investimentos cuja atuação em mercados derivativos gerem exposição superior a uma vez o respectivo patrimônio líquido (Rieche, 2005).

\subsection{Legislação Brasileira sobre Aplicações no Exterior dos Investidores Institucionais}

Segundo relatório da ANDIMA sobre Investimentos Brasileiros no Exterior de fevereiro de 2006, os recursos garantidores das reservas técnicas não comprometidas das Sociedades Seguradoras, Sociedades de Capitalização e Entidades Abertas de Previdência Privada podem ser aplicados, entre outras alternativas, em investimentos de renda variável, observado nesse caso o limite máximo de $49 \%$, isolada ou cumulativamente, do total de recursos. Entre as opções de renda variável estão incluídos os investimentos em ações de emissão de companhias sediadas em países signatários do Mercosul ou em certificados de depósito dessas 
ações admitidos à negociação em Bolsa de Valores no país que, por sua vez, não podem exceder a $3 \%$ do montante total dos recursos garantidores.

A Instrução CVM 409/2004, que regulamenta os fundos de investimentos, diz que a aplicação no exterior de recursos oriundos de fundos de investimento, regulados pela CVM, obedecerá regulamentação expedida pelo Conselho Monetário Nacional. No entanto, não há norma específica sobre o assunto e, portanto, regulamentação complementar para as aplicações dos fundos no âmbito do Mercosul, anteriormente previstas na Instrução CVM n 326/2000, estão revogadas.

Quanto aos fundos de pensão, na subclasse renda variável outros descrita na Resolução CMN 3.121/03, com limitação de aplicação de 3\%, estão considerados os certificados de depósito, BDRs - Brazilian Depositary Receipts, ações de emissão de companhias sediadas no Mercosul, debêntures com participação no lucro, certificados ouro físico.

É importante ressaltar que os fundos de investimentos no exterior aplicam no mínimo $80 \%$ em títulos da dívida externa brasileira.

\subsection{Estudos Brasileiros}

Estudos brasileiros têm constatado que a imposição de restrições às aplicações dos recursos das seguradoras, entidades de previdência privada e das sociedades de capitalização tem imposto um custo a essas organizações, com implicações para o bem-estar de seus clientes. Isso em virtude de as restrições reduzirem a rentabilidade das aplicações e elevarem a exposição ao risco dessas organizações.

Pinto (1984) analisou o impacto das restrições impostas pela regulamentação sobre as aplicações das sociedades de investimento estrangeiro, das seguradoras e das entidades fechadas de previdência privada. Em 1984, a aplicação de recursos dos investidores institucionais era regulada pela Resolução CMN n ${ }^{\text {o }}$ 790/83, no caso das sociedades de investimento estrangeiro, pela Resolução CMN 794/83, no caso de entidades fechadas de previdência privada e pela Resolução $n^{\circ}$ 687/81, no caso das seguradoras. Os resultados mostraram que a regulamentação aumenta o risco das carteiras que podem ser constituídas 
pelos investidores institucionais, torna inatingíveis vários pontos da fronteira eficiente sem restrições e que as carteiras com baixos níveis de risco e retorno foram as mais afetadas devido a imposições existentes na época de alocações mínimas de ativos nas carteiras.

Mais recentemente, Costa (1998) examinou o impacto das Resoluções CMN no 2.286/96 e 2.324/96 sobre as aplicações das entidades de previdência privada, das seguradoras e das sociedades de capitalização. Foram utilizados dados de retornos reais mensais e as carteiras eficientes foram compostas por títulos públicos federais, ativos de renda fixa, ativos de renda variável e imóveis, para o período de janeiro de 1990 a junho de 1998. A metodologia adotada foi a de Markowitz desconsiderando-se as possibilidades de venda a descoberto e empréstimos a taxa livre de risco. A comparação da carteira de variância mínima da fronteira eficiente com a carteira efetivamente observada foi feita para o mesmo nível de risco, isto é, para a mesma variância. Os resultados corroboram o estudo de Pinto (1984) encontrando um maior custo da regulamentação para o segmento de menores retornos e risco da fronteira eficiente e movimentação da extremidade esquerda da fronteira eficiente para direita e para baixo num espaço risco-retorno pela regulamentação. $O$ custo real da regulamentação encontrado para Entidades Fechadas de Previdência Privada variou de 0,93\% ao ano a 1,29\% ao ano de acordo com o índice de preços utilizado como deflator. 


\section{METODOLOGIA}

O estudo pode ser classificado como quantitativo experimental (Richardson, 1989), pois procura avaliar o impacto em termos de retorno e risco das carteiras de investidores institucionais brasileiros decorrentes da possibilidade de investimento em ativos internacionais. Richardson ressalta que tal método é "[...] freqüentemente aplicado nos estudos descritivos, aqueles que, segundo Gil (1987), têm como “[...] objetivo primordial a descrição das características de determinada população ou fenômeno, ou, então, o estabelecimento de relações entre as variáveis".

Quanto aos fins, é de natureza descritiva e aplicada. Descritiva porque tem como objetivo principal a descrição de características de determinada população ou fenômeno, correlações entre variáveis e definir sua natureza (Vergara, 1998). As pesquisas descritivas possuem fatos que são "observados, registrados, analisados, classificados e interpretados, sem que o pesquisador interfira sobre eles, sendo os fenômenos estudados, mas não manipulados pelo pesquisador." (De Andrade apud Cabello, 2002). O estudo também é uma pesquisa aplicada, definida, segundo Vergara (1998), como fundamentalmente motivada pela necessidade de resolver problemas concretos, mais imediatos ou não.

Quanto aos meios, segundo Vergara (1998), é de natureza ex-post facto, pois se refere a fatos já ocorridos, não controláveis. De acordo com Gil (1987), na pesquisa ex-post facto, as situações reais - os preços de mercado - são tomadas como experimentais, trabalhando-se com elas como se houvesse controle sobre as variáveis. Assim, apesar de pesar de não se tratar de um experimento, o autor salienta que "[...] os procedimentos lógicos de delineamento ex-post facto são semelhantes as dos experimentos propriamente ditos.”. Neste estudo, as expectativas de retorno, as variâncias e as covariâncias dos retornos dos ativos são substituídas por seus valores históricos.

Considerando a classificação apresentada por Martins (2002), pode ser classificado como de abordagem empírico-analítica, com natureza descritiva e quantitativa. Os estudos com abordagem epistemológica empírico-analítica apresentam em comum a utilização de técnicas de coleta, tratamento e análise de dados marcadamente quantitativos, privilegiando estudos práticos. 


\subsection{Objetivos e Aspectos Metodológicos}

O estudo de benefícios da internacionalização de carteiras no mercado de capitais brasileiro foi realizado por meio de uma análise risco e retorno de carteiras que poderiam ser obtidas por investidores institucionais brasileiros, caso restrições de investimentos em ativos externos fossem gradualmente reduzidas.

Primeiramente, será otimizada a carteira composta por todos os índices de mercado ações pertencentes à amostra, de forma a obter a fronteira eficiente global composta por ações e poder identificar o peso de cada mercado na carteira. As carteiras que compõem a fronteira servirão de padrão por apresentarem os melhores retornos, dado um nível de risco ou o menor risco para um dado nível de retorno.

Posteriormente, serão obtidas as fronteiras, tanto para a atual restrição de investimento vigente no Brasil, como para possíveis exemplos de graus de possibilidade de investimentos em ações estrangeiras por investidores institucionais brasileiros. Buscar-se-á replicar uma carteira com todos os tipos de ativos em que normalmente as carteiras dos investidores institucionais ficam alocadas. Serão realizadas análises ex-post dos efeitos dos indicadores das carteiras ótimas em cada um desses cenários. Serão consideradas não permitidas vendas a descoberto.

Além disso, será calculada a matriz de correlações entre os índices de mercado dos diversos países, para que se possa verificar quais desses mercados apresentam maior potencial de diversificação de riscos das carteiras brasileiras, identificadas por baixas correlações positivas ou correlações negativas.

As otimizações foram calculadas através do software MATLAB ${ }^{\circledR}$ e a matriz de correlações realizada pelo software Stata.

Os desempenhos das carteiras ótimas obtidas, em cada estágio de liberalização, serão comparados ao da carteira da fronteira eficiente totalmente sujeita a restrições de investimentos no exterior. 
O período a ser analisado na pesquisa será de janeiro de 2000 a dezembro de 2006 em três sub-períodos: 2000 a 2005, 2001 a 2006 e 2003 a 2006.

$\mathrm{Na}$ análise do impacto da internacionalização de carteiras para os investidores institucionais brasileiros foi levada em consideração somente a diversificação internacional da parcela de ações da carteira. Além disso, considerou-se como legislação vigente, a total impossibilidade de aplicações no exterior, para fins de simplificação, já que apenas alguns investidores institucionais estão possibilitados de investir no exterior em um máximo de $3 \%$ da carteira e, de maneira bem restrita, em apenas países do Mercosul, ou BDRs, que apresentam um mercado bastante restrito no Brasil.

Uma dificuldade surgida foi a de abarcar todos os investidores institucionais quando da realização dos testes empíricos, uma vez que cada tipo de investidor institucional está sujeito a diferentes legislações. Porém, quanto ao investimento estrangeiro, a regulamentação apresenta-se bastante semelhante.

Dessa forma, utilizou-se como base as carteiras dos fundos de pensão, que são no Brasil o segundo tipo de investidor institucional em número de investimentos, porém são usualmente tratados de maneira agregada e não por classes de fundos como acontece com os fundos de investimentos, os maiores investidores institucionais no Brasil.

Assim, adotou-se a regulamentação dos fundos de pensão como representativa para considerar limitações de investimento nas demais classes de ativos, discriminadas na Resolução CMN 3.121/03 e suas alterações. As quatro classes de ativos por ela consideradas são: renda fixa, renda variável, imóveis e empréstimos/financiamentos.

Um grupo de índices do mercado financeiro foi selecionado, considerando as quatro classes de ativos e algumas subclasses juntamente com seus limites quantitativos máximos a fim de determinar as carteiras eficientes, de acordo com as opções de investimento destes fundos.

Os preços de fechamento para cálculo dos retornos dos índices de mercado utilizados no estudo foram obtidos no banco de dados da Economática, Bloomberg e SI-ANBID. Os dados foram coletados em reais e na moeda do próprio país. 
Para determinar a rentabilidade da renda variável foi utilizado como proxy o índice Bovespa com limite de aplicação de 50\%. Todos os dados sobre índices de mercado de ações foram coletados no Bloomberg.

No caso da renda fixa, caberia utilizar o índice IMA-Geral, construído pela ANDIMA como um índice médio de todos os índices da família de renda fixa, porém seus dados apresentamse disponíveis apenas a partir de dezembro de 2001. Assim, decidiu-se por utilizar o CDI para representar os títulos pós-fixados indexados à SELIC, o índice IRF-M da ANDIMA para representar os títulos pré-fixados e o IGPM mais um cupom para representar títulos indexados a índices de inflação. O cupom utilizado foi de $10 \%$ ao ano, que foi obtido pelo cálculo da rentabilidade acima do IGPM do índice IMA-C, composto por títulos públicos federais atrelados ao IGPM (NTN-C), no ano de 2004. O limite de alocação para os títulos do governo é de $100 \%$.

Além disso, considerou-se a subclasse de renda fixa de fundos de investimento no exterior, FIEX, que aplicam exclusivamente em papéis da dívida externa brasileira. A Resolução 3.034/2002 permitiu a alocação de até 10\% em quotas desses fundos. O histórico de retornos considerou a média dos retornos dos fundos de investimento no exterior com dados para todo o período de 2000 a 2006 presentes na base de dados SI-ANBID:

Quadro 1 - Amostra de Fundos de Investimento no Exterior

\begin{tabular}{ll}
\hline \multicolumn{2}{c}{ Quadro 1 - Amostra de Fundos de Investimento no Exterior } \\
\hline BB DIVIDA EXTERNA LP MIL FI & Bnstituição \\
BBM FIEX FI EM DIVIDA EXTERNA & BBM \\
BRADESCO BF FI DIVIDA EXTERNA & BRADESCO \\
BRADESCO FI DIVIDA EXTERNA & BRADESCO \\
FIE IB DIVIDA EXTERNA & ITAU \\
HSBC FIEX BRASIL SOBERANO & HSBC \\
ITAU INTERN FUND DIV EXT FICFI & ITAU \\
ITAU PERS FIEX III DIV EXT FICFI & ITAU \\
SANTANDER FI DIVIDA EXTERNA & BANCO SANTANDER BANESPA S.A. \\
UNIBANCO UFEX FI DIVIDA EXTERNA & UNIBANCO \\
\hline Fonte: SI-ANBID &
\end{tabular}

Em relação aos imóveis, foi calculada a média do rendimento dos fundos imobiliários que possuíam dados para todo período de 2000 a 2006 obtidos na base de dados SI-ANBID. Além disso, foram acrescentados fundos imobiliários registrados no site da Bovespa que também 
apresentavam rentabilidades disponíveis para o período considerado no estudo, chegando à seguinte amostra de fundos imobiliários:

Quadro 2 - Amostra de Fundos de Investimento Imobiliários

\begin{tabular}{ll}
\hline Fundo de Investimento Imobiliário & Administrador \\
\hline ABC PLAZA IMOBILIARIO & Rio Bravo Investimentos S/A DTVM \\
BRASILIO MACHADO & Unibanco União de Bancos Brasileiros S. A. \\
CENTRO TEXTIL & Unibanco União de Bancos Brasileiros S. A. \\
JK & Rio Bravo Investimentos S/A DTVM \\
FINANCIAL CENTER & Unibanco União de Bancos Brasileiros S. A. \\
PANAMBY & Banco Brascan S/A \\
SCP & Unitas DTVM S/A \\
TRADE CENTER & Banco Opportunity S/A \\
PATIO HIGIENÓPOLIS & Rio Bravo Investimentos S/A DTVM \\
\hline
\end{tabular}

Fonte: SI-ANBID e Bovespa

O limite de aplicação em imóveis passou a ser regressivo com a Resolução 2.324/97 e mudou diversas vezes com novas resoluções, mas o que vigorou foi um limite de 16\% em 2000, 2001 e 2002. Depois, alterou-se para 14\% em 2003 e a partir de 2006 mudou para $11 \%$ como previsto pela Resolução 3.121/03 e a partir de 2009 será de 8\%. Foi considerado na pesquisa um limite de investimento em imóveis de $14 \%$ pelo período de 2003 a 2005 constar de todos os sub-períodos analisados.

Por fim, quanto à classe de empréstimos e financiamentos a participantes, no caso de empréstimos tomou-se como base, pela disponibilidade de dados, a taxa cobrada pela Funcef, terceiro maior fundo de pensão do Brasil no final de 2006 em número de investimentos. A taxa de juros cobrada pela Funcef passou de 10,79\% ao ano mais a variação do INPC para 9\% ao ano em 2004 e em 2007 divulga no site que até junho de 2006 estaria cobrando 7,9\% ao ano. Assim, considerou-se, pelo período a ser analisado, uma taxa de $9 \%$ ao ano mais a variação do INPC. Para a subclasse financiamento imobiliário a participantes adotou-se TR mais $12 \%$ ao ano, de acordo com Leal et. al. (2001).

O limite de investimento em empréstimos a assistidos é de $15 \%$ e em financiamento imobiliário a participantes de $10 \%$. Porém, no conjunto, a classe de empréstimos de financiamentos não pode ultrapassar de $15 \%$ da carteira.

O Quadro 3 apresenta os limites máximos, as modalidades consideradas e o benchmark para cada classe de ativos: 
Quadro 3 - Limites Máximos Individuais e Benchmarks para os grupos de ativos

\begin{tabular}{|c|c|c|c|}
\hline Classe de Ativos & Modalidades & Benchmak & Limites \\
\hline \multirow[t]{3}{*}{ Renda Fixa } & Títulos Públicos & CDI & \\
\hline & & $\begin{array}{l}\text { IGPM + } 10 \% \text { a.a. } \\
\text { IRF-M }\end{array}$ & $100 \%$ \\
\hline & Fundos de Investimento no Exterior & FIEX & $10 \%$ \\
\hline Renda Variável & Ações & IBOV & $50 \%$ \\
\hline Imóveis & Imóveis & Fundos Imobiliários & $14 \%$ \\
\hline Empréstimos e Financiamentos & $\begin{array}{l}\text { Empréstimos a participantes } \\
\text { Financiamento imobiliário }\end{array}$ & $\begin{array}{l}\text { INPC }+9 \% \text { a.a. } \\
\text { TR }+12 \% \text { a.a. }\end{array}$ & $\begin{array}{l}15 \% \\
10 \%\end{array}$ \\
\hline
\end{tabular}

Além dos limites individuais por índices que representam classes de ativos, no caso de mais de um benchmark por grupo de ativos da Resolução CMN 3.121/03 foram considerados limites por grupo. No caso de renda fixa não foi utilizado já que a aplicação total é limitada a $100 \%$. Em relação a empréstimos e financiamentos foi acrescentada uma limitação conjunta de empréstimos e financiamentos imobiliários a participantes de $15 \%$. Além disso, quando considerada a possibilidade de investir em mercados de ações internacionais, colocou-se um limite total igual ao limite individual por país além da limitação conjunta de $50 \%$ em ações. Por exemplo, quando da hipótese de possibilidade de alocação em ativos estrangeiros de $20 \%$, considerou-se uma limitação individual por índice de mercado de ações estrangeiro de $20 \%$, uma conjunta de $20 \%$ contabilizando todos os índices internacionais, além de um de $50 \%$ em ações que acrescenta o índice Bovespa.

Nas simulações foram utilizados graus de abertura a investimentos em ativos estrangeiros de $10 \%, 20 \%, 30 \%, 40 \%$ e $50 \%$. As otimizações foram realizadas para os períodos de 2000 a 2005, 2001 a 2006 e 2003 a 2006.

\subsection{Amostra Preliminar}

Para construção da fronteira eficiente global composta por ações, foram coletados dados de preços mensais de índices de mercado de ações em reais e em moeda local no banco de dados da Bloomberg, para a obtenção posterior dos retornos mensais dos índices dos 24 países considerados na amostra: 
Tabela 12 - Amostra de Índices de Mercado de Ações Internacionais

\begin{tabular}{|c|c|c|c|}
\hline País & Índice de Mercado & Moeda & $\begin{array}{c}\text { Código Bloomberg da } \\
\text { Moeda } \\
\end{array}$ \\
\hline \multicolumn{4}{|l|}{ América } \\
\hline Argentina & Merval & Peso Argentino & ARS \\
\hline Brasil & Bovespa & Real & BRL \\
\hline Canadá & TSX Composite & Dólar Canadense & CAD \\
\hline Chile & Chile Stock Market Select & Peso Chileno & CLP \\
\hline Estados Unidos & S\&P 500 & Dólar EUA & USD \\
\hline México & México Bolsa & Peso Mexicano & $\mathrm{MXN}$ \\
\hline Venezuela & Venezuela Stock Mkt & Bolívar Venezuelano & VEB \\
\hline \multicolumn{4}{|l|}{ Europa } \\
\hline Alemanha & DAX & Euro & EUR \\
\hline Espanha & Spain MA Madrid & Euro & EUR \\
\hline França & CAC 40 & Euro & EUR \\
\hline Holanda & Amsterdam Exchanges & Euro & EUR \\
\hline Itália & Milan MIB Telematico & Euro & EUR \\
\hline Reino Unido & FTSE 100 & Libra Esterlina & GBP \\
\hline Suécia & OMX Stockholm 30 & Coroa Sueca & SEK \\
\hline Suíça & Swiss Market & Franco Suíço & $\mathrm{CHF}$ \\
\hline \multicolumn{4}{|l|}{ Ásia } \\
\hline Austrália & All Ordinaries & Dólar Australiano & AUD \\
\hline China & China SE Shang Composite & Renminbi Chinês & $\mathrm{CNY}$ \\
\hline Cingapura & Straits Times & Dólar de Cingapura & SGD \\
\hline Coréia do Sul & Kospi & Uon da Coréia do Sul & KRW \\
\hline Hong Kong & Hang Seng & Dólar de Hong Kong & HKD \\
\hline Índia & BSE Sensex 30 & Rúpia Indiana & INR \\
\hline Japão & Nikkei 225 & Iene & JPY \\
\hline Malásia & Kuala Lumpur Composite & Ringgit Malaio & MYR \\
\hline Taiwan & Taiwan Taiex & Dólar de Taiwan & TWD \\
\hline
\end{tabular}

Como moedas locais foram utilizadas aquelas que se apresentam como default no banco de dados da Bloomberg, apresentadas na Tabela 12. Cabe ressaltar que o período escolhido da amostra leva em consideração a introdução do euro no ano de 1999.

As taxas de retorno mensais dos benchmarks selecionados foram obtidas subtraindo-se o preço de fechamento do mês anterior do mês em questão e essa diferença foi dividida pelo preço do ativo no dia anterior:

$$
\mathrm{R}_{\mathrm{it}}=\frac{\mathrm{P}_{\mathrm{it}}-\mathrm{P}_{\mathrm{it}-1}}{\mathrm{P}_{\mathrm{it}-1}}
$$

onde Rit é o retorno do índice de mercado de ações no dia $t$ e $P_{i t}$ e $P_{i t-l}$ são os preços de fechamento do ativo $i$ do dia $t$ e do dia $t$-1, respectivamente. 


\section{RESULTADOS}

\subsection{Estatísticas Descritivas}

A fim de prover uma visão geral da amostra, as Tabelas 13 e 14 mostram o retorno médio mensal e o desvio-padrão dos retornos mensais dos índices de mercado de ações considerados no estudo em termos de reais e em moeda do próprio país, respectivamente.

Tabela 13 - Retorno Médio Mensal e Desvio-Padrão dos Retornos Mensais dos Índices de Mercado de

\begin{tabular}{lcccccc}
\multicolumn{1}{c}{ Período } & \multicolumn{2}{c}{ Aç̃oes em termos de Reais } \\
\cline { 2 - 7 } & $\begin{array}{c}\text { Retorno } \\
\text { Esperado }\end{array}$ & $\begin{array}{c}\text { Desvio } \\
\text { Padrão }\end{array}$ & $\begin{array}{c}\text { Retorno } \\
\text { Esperado }\end{array}$ & $\begin{array}{c}\text { Desvio } \\
\text { Padrão }\end{array}$ & $\begin{array}{c}\text { Retorno } \\
\text { Esperado }\end{array}$ & $\begin{array}{c}\text { Desvio } \\
\text { Padrão }\end{array}$ \\
\hline Alemanha & $0,50 \%$ & $5,94 \%$ & $0,80 \%$ & $5,85 \%$ & $1,29 \%$ & $5,42 \%$ \\
Argentina & $0,99 \%$ & $12,55 \%$ & $1,56 \%$ & $12,44 \%$ & $2,29 \%$ & $7,69 \%$ \\
Austrália & $1,33 \%$ & $5,63 \%$ & $1,57 \%$ & $5,47 \%$ & $1,08 \%$ & $3,98 \%$ \\
Brasil & $1,36 \%$ & $8,43 \%$ & $1,81 \%$ & $7,97 \%$ & $3,10 \%$ & $6,49 \%$ \\
Canadá & $1,28 \%$ & $6,04 \%$ & $1,16 \%$ & $5,77 \%$ & $1,10 \%$ & $5,16 \%$ \\
Chile & $1,32 \%$ & $5,97 \%$ & $1,67 \%$ & $5,90 \%$ & $1,76 \%$ & $4,81 \%$ \\
China & $0,33 \%$ & $8,12 \%$ & $0,96 \%$ & $9,22 \%$ & $0,83 \%$ & $8,63 \%$ \\
Cingapura & $0,71 \%$ & $6,74 \%$ & $1,09 \%$ & $6,11 \%$ & $0,99 \%$ & $4,78 \%$ \\
Coréia do Sul & $1,47 \%$ & $9,11 \%$ & $2,32 \%$ & $8,11 \%$ & $1,40 \%$ & $6,40 \%$ \\
Espanha & $1,04 \%$ & $5,40 \%$ & $1,53 \%$ & $5,12 \%$ & $1,40 \%$ & $4,36 \%$ \\
Estados Unidos & $0,35 \%$ & $5,03 \%$ & $0,35 \%$ & $4,93 \%$ & $0,01 \%$ & $3,82 \%$ \\
França & $0,54 \%$ & $5,33 \%$ & $0,65 \%$ & $5,37 \%$ & $0,77 \%$ & $4,81 \%$ \\
Holanda & $0,33 \%$ & $5,41 \%$ & $0,39 \%$ & $5,41 \%$ & $0,45 \%$ & $5,25 \%$ \\
Hong Kong & $0,53 \%$ & $6,46 \%$ & $0,71 \%$ & $6,16 \%$ & $0,67 \%$ & $5,16 \%$ \\
Índia & $1,48 \%$ & $7,90 \%$ & $2,22 \%$ & $7,49 \%$ & $2,31 \%$ & $6,97 \%$ \\
Itália & $0,76 \%$ & $6,08 \%$ & $0,83 \%$ & $5,67 \%$ & $0,81 \%$ & $5,11 \%$ \\
Japão & $0,29 \%$ & $7,94 \%$ & $0,63 \%$ & $7,17 \%$ & $0,57 \%$ & $5,99 \%$ \\
Malásia & $0,56 \%$ & $6,61 \%$ & $1,09 \%$ & $6,38 \%$ & $0,33 \%$ & $5,14 \%$ \\
México & $1,88 \%$ & $6,89 \%$ & $2,32 \%$ & $6,26 \%$ & $2,04 \%$ & $4,83 \%$ \\
Reino Unido & $0,44 \%$ & $4,99 \%$ & $0,63 \%$ & $5,04 \%$ & $0,39 \%$ & $4,25 \%$ \\
Suécia & $0,43 \%$ & $6,94 \%$ & $0,91 \%$ & $6,61 \%$ & $1,34 \%$ & $4,97 \%$ \\
Suíça & $0,98 \%$ & $5,37 \%$ & $0,76 \%$ & $5,28 \%$ & $0,65 \%$ & $4,51 \%$ \\
Taiwan & $0,12 \%$ & $8,97 \%$ & $1,20 \%$ & $8,50 \%$ & $0,52 \%$ & $7,38 \%$ \\
Venezuela & $1,36 \%$ & $12,74 \%$ & $2,16 \%$ & $12,82 \%$ & $2,74 \%$ & $13,15 \%$ \\
\hline
\end{tabular}

O retorno médio mensal no período de 2000 a 2005 variou de $0,12 \%$, no caso do Taiwan, até 1,88\% para o México em termos de reais. O desvio-padrão dos retornos mensais no período de 2000 a 2005 variou de 4,99\% para o mercado inglês a 12,74\% para o venezuelano. Excluindo os países latino-americanos, a Coréia do Sul obteve o maior desvio-padrão dos índices de mercado de ações da amostra, de 9,11\%.

No período de 2001 a 2006, o retorno médio mensal mínimo em termos de reais foi de $0,35 \%$ no caso dos Estados Unidos e o máximo de 2,32\% no caso do México. Já no período de 2003 
a 2006, o menor retorno médio mensal em termos de reais ocorreu no mercado norteamericano $(0,01 \%)$, e o maior, no mercado brasileiro $(3,10 \%)$.

O desvio-padrão médio para cada Índice de Mercado de Ações variou de 4,93\%, no caso dos Estados Unidos, até 12,82\% para a Venezuela no período de 2001 a 2006. Da mesma forma, o mercado venezuelano em termos de reais apresentou o maior desvio-padrão dos retornos mensais no período de 2003 a 2006, de 13,15\%, seguido pelo mercado chinês de ações com desvio padrão de $8,63 \%$, e o mercado norte-americano o menor desvio-padrão de 3,82\%.

Tabela 14 - Retorno Médio Mensal e Desvio-Padrão dos Retornos Mensais dos Índices de Mercado de Aç̃es em termos da moeda de cada país

\begin{tabular}{lcccccc}
\hline \multirow{1}{*}{\multicolumn{1}{c}{ Período }} & \multicolumn{2}{c}{$\mathbf{2 0 0 0}$ a 2005 } & \multicolumn{2}{c}{$\mathbf{2 0 0 1}$ a 2006 } & \multicolumn{2}{c}{$\mathbf{2 0 0 3}$ a 2006 } \\
\cline { 2 - 7 } & Retorno & Desvio & Retorno & Desvio & Retorno & Desvio \\
& Esperado & Padrão & Esperado & Padrão & Esperado & Padrão \\
\hline Alemanha & $-0,05 \%$ & $7,37 \%$ & $0,29 \%$ & $7,10 \%$ & $1,85 \%$ & $5,01 \%$ \\
Argentina & $2,14 \%$ & $12,56 \%$ & $2,96 \%$ & $12,36 \%$ & $3,23 \%$ & $8,05 \%$ \\
Austrália & $0,64 \%$ & $2,99 \%$ & $0,86 \%$ & $3,00 \%$ & $1,37 \%$ & $2,50 \%$ \\
Brasil & $1,36 \%$ & $8,43 \%$ & $1,81 \%$ & $7,97 \%$ & $3,10 \%$ & $6,49 \%$ \\
Canadá & $0,50 \%$ & $4,46 \%$ & $0,59 \%$ & $3,89 \%$ & $1,44 \%$ & $2,84 \%$ \\
Chile & $0,86 \%$ & $4,62 \%$ & $1,37 \%$ & $4,58 \%$ & $2,17 \%$ & $4,11 \%$ \\
China & $-0,24 \%$ & $5,63 \%$ & $0,58 \%$ & $6,88 \%$ & $1,65 \%$ & $7,02 \%$ \\
Cingapura & $0,23 \%$ & $5,57 \%$ & $0,74 \%$ & $4,98 \%$ & $1,73 \%$ & $3,08 \%$ \\
Coréia do Sul & $0,89 \%$ & $8,49 \%$ & $1,72 \%$ & $7,38 \%$ & $1,89 \%$ & $5,65 \%$ \\
Espanha & $0,38 \%$ & $5,34 \%$ & $0,91 \%$ & $4,93 \%$ & $1,94 \%$ & $3,21 \%$ \\
Estados Unido & $-0,06 \%$ & $4,38 \%$ & $0,18 \%$ & $3,99 \%$ & $1,03 \%$ & $2,41 \%$ \\
França & $-0,10 \%$ & $5,58 \%$ & $0,06 \%$ & $5,44 \%$ & $1,30 \%$ & $3,56 \%$ \\
Holanda & $-0,27 \%$ & $6,27 \%$ & $-0,15 \%$ & $6,19 \%$ & $1,00 \%$ & $4,55 \%$ \\
Hong Kong & $0,11 \%$ & $5,78 \%$ & $0,53 \%$ & $5,21 \%$ & $1,68 \%$ & $4,01 \%$ \\
Índia & $1,08 \%$ & $7,08 \%$ & $1,97 \%$ & $6,81 \%$ & $3,18 \%$ & $6,54 \%$ \\
Itália & $0,06 \%$ & $5,44 \%$ & $0,19 \%$ & $4,84 \%$ & $1,31 \%$ & $3,20 \%$ \\
Japão & $-0,12 \%$ & $5,58 \%$ & $0,43 \%$ & $5,02 \%$ & $1,55 \%$ & $4,26 \%$ \\
Malásia & $0,09 \%$ & $5,09 \%$ & $0,77 \%$ & $4,61 \%$ & $1,17 \%$ & $3,51 \%$ \\
México & $1,61 \%$ & $6,37 \%$ & $2,32 \%$ & $5,54 \%$ & $3,19 \%$ & $4,36 \%$ \\
Reino Unido & $-0,07 \%$ & $3,98 \%$ & $0,07 \%$ & $3,85 \%$ & $0,99 \%$ & $2,80 \%$ \\
Suécia & $-0,10 \%$ & $6,96 \%$ & $0,34 \%$ & $6,64 \%$ & $1,85 \%$ & $4,05 \%$ \\
Suíça & $0,23 \%$ & $4,36 \%$ & $0,20 \%$ & $4,24 \%$ & $1,39 \%$ & $3,20 \%$ \\
Taiwan & $-0,24 \%$ & $8,16 \%$ & $0,97 \%$ & $7,48 \%$ & $1,32 \%$ & $5,26 \%$ \\
Venezuela & $2,28 \%$ & $9,03 \%$ & $3,24 \%$ & $9,27 \%$ & $4,45 \%$ & $10,44 \%$ \\
\hline
\end{tabular}

Os retornos médios mensais e desvio-padrão dos retornos mensais calculados em termos da moeda de cada país refletem o que realmente ocorreu nesses mercados de ações, já que não se está considerando o risco cambial pela conversão para reais.

Quanto aos retornos dos índices de mercado de ações, ressalta-se que aqueles países com maiores retornos tenderiam a participar das carteiras ótimas já que o retorno da carteira é a média ponderada dos retornos dos ativos que a compõe. O retorno médio mensal em termos 
da moeda do próprio país variou, no período de 2000 a 2005, de $-0,27 \%$, no caso da Holanda, até o maior retorno médio mensal de 2,28\% no caso da Venezuela. O máximo retorno médio mensal entre os países da amostra nos períodos de 2001 a 2006 e de 2003 a 2006 também foi do mercado de ações venezuelano, de 12,36\% e 10,44\%, respectivamente. Já o mínimo retorno médio mensal em termos da moeda do próprio país no período de 2001 a 2006 ocorreu no mercado acionário holandês $(-0,15 \%)$ e no período de 2003 a 2006 no inglês $(0,99 \%)$, seguido pelo holandês $(1,00 \%)$.

O desvio-padrão dos retornos mensais dos índices de mercado de ações no período de 2000 a 2005, em termos da moeda de cada país, variou de 2,99\% no caso da Austrália até $12,56 \%$ no caso da Argentina. O Índice Bovespa apresentou um desvio-padrão dos retornos mensais de 8,43\% no período. Da mesma forma, no período de 2001 a 2006, o menor desvio-padrão da amostra ocorreu na Austrália (3,00\%) e o maior na Argentina (12,36\%). Já para os retornos mensais referentes a 2003 a 2006, o mínimo desvio-padrão aconteceu nos Estados Unidos $(2,41 \%)$ e o desvio-padrão máximo na Venezuela $(10,44 \%)$.

A Tabela 15 mostra as médias e os desvios-padrão dos retornos mensais de cada benchmark utilizado para representar as classes ou subclasses de ativos definidos na Resolução CMN 3.121/2003:

Tabela 15 - Retorno Médio Mensal e Desvio-Padrão dos Retornos Mensais dos Ativos

\begin{tabular}{ccccccc}
\hline & \multicolumn{2}{c}{$\mathbf{2 0 0 0}$ a 2005} & \multicolumn{2}{c}{$\mathbf{2 0 0 1}$ a 2006} & \multicolumn{2}{c}{$\mathbf{2 0 0 3}$ a 2006 } \\
\cline { 2 - 7 } & $\begin{array}{c}\text { Retorno } \\
\text { Esperado }\end{array}$ & $\begin{array}{c}\text { Desvio- } \\
\text { Padrão }\end{array}$ & $\begin{array}{c}\text { Retorno } \\
\text { Esperado }\end{array}$ & $\begin{array}{c}\text { Desvio- } \\
\text { Padrão }\end{array}$ & $\begin{array}{c}\text { Retorno } \\
\text { Esperado }\end{array}$ & $\begin{array}{c}\text { Desvio- } \\
\text { Padrão }\end{array}$ \\
\hline CDI & $1,44 \%$ & $0,22 \%$ & $1,41 \%$ & $0,24 \%$ & $1,41 \%$ & $0,27 \%$ \\
IGPM + CUP & $1,69 \%$ & $1,04 \%$ & $1,61 \%$ & $1,03 \%$ & $1,33 \%$ & $0,71 \%$ \\
IRF-M & $1,54 \%$ & $0,59 \%$ & $1,52 \%$ & $0,58 \%$ & $1,55 \%$ & $0,51 \%$ \\
FIEX & $1,37 \%$ & $3,61 \%$ & $1,02 \%$ & $3,74 \%$ & $0,30 \%$ & $3,35 \%$ \\
IBOV & $1,36 \%$ & $8,43 \%$ & $1,81 \%$ & $7,98 \%$ & $3,10 \%$ & $6,49 \%$ \\
IMOVEIS & $0,20 \%$ & $0,91 \%$ & $0,73 \%$ & $4,19 \%$ & $0,94 \%$ & $5,12 \%$ \\
EMPREST & $1,41 \%$ & $0,62 \%$ & $1,37 \%$ & $0,61 \%$ & $1,22 \%$ & $0,47 \%$ \\
FINANC & $1,17 \%$ & $0,10 \%$ & $1,17 \%$ & $0,10 \%$ & $1,18 \%$ & $0,11 \%$ \\
\hline
\end{tabular}

Nota-se que o retorno mensal médio e o desvio-padrão dos retornos mensais do CDI, IRF-M e dos financiamentos a participantes $(\mathrm{TR}+12 \%)$ permaneceram praticamente constantes nos três períodos analisados. Já os títulos públicos indexados ao IGPM, representados pelo IGPM mais o cupom, tiveram seu retorno e o risco diminuídos no último período. Os fundos de investimentos no exterior (FIEX) e os empréstimos a participantes tiveram queda nos retorno 
médios mensais ao longo dos períodos. Por fim, os imóveis e o índice Bovespa aumentaram sua rentabilidade média mensal nos períodos mais recentes. As estatísticas para cada ano da amostra são encontradas na Tabela 16.

Tabela 16 - Retorno Médio e Desvio-Padrão dos Retornos Mensais dos Ativos para cada Ano da Amostra

\begin{tabular}{|c|c|c|c|c|c|c|c|c|c|}
\hline & & CDI & IGPM+CUP & IRF-M & FIEX & IBOV & IMOVEIS & EMPREST & FINANC \\
\hline \multirow{7}{*}{$\begin{array}{c}\text { Retorno } \\
\text { Esperado }\end{array}$} & 2000 & $1.33 \%$ & $1.56 \%$ & $1.51 \%$ & $2.07 \%$ & $-0.26 \%$ & $0.51 \%$ & $1.14 \%$ & $1.10 \%$ \\
\hline & 2001 & $1.34 \%$ & $1.63 \%$ & $1.39 \%$ & $1.85 \%$ & $-0.52 \%$ & $0.32 \%$ & $1.48 \%$ & $1.14 \%$ \\
\hline & 2002 & $1.47 \%$ & $2.72 \%$ & $1.54 \%$ & $3.07 \%$ & $-1.03 \%$ & $0.34 \%$ & $1.89 \%$ & $1.20 \%$ \\
\hline & 2003 & $1.76 \%$ & $1.50 \%$ & $2.10 \%$ & $1.84 \%$ & $6.03 \%$ & $0.27 \%$ & $1.56 \%$ & $1.30 \%$ \\
\hline & 2004 & $1.26 \%$ & $1.79 \%$ & $1.20 \%$ & $-0.07 \%$ & $1.51 \%$ & $0.08 \%$ & $1.22 \%$ & $1.11 \%$ \\
\hline & 2005 & $1.46 \%$ & $0.90 \%$ & $1.50 \%$ & $-0.46 \%$ & $2.31 \%$ & $-0.31 \%$ & $1.14 \%$ & $1.18 \%$ \\
\hline & 2006 & $1.17 \%$ & $1.12 \%$ & $1.41 \%$ & $-0.11 \%$ & $2.57 \%$ & $3.70 \%$ & $0.95 \%$ & $1.11 \%$ \\
\hline \multirow{7}{*}{$\begin{array}{l}\text { Desvio- } \\
\text { Padrão }\end{array}$} & 2000 & $0.10 \%$ & $0.70 \%$ & $0.49 \%$ & $1.93 \%$ & $9.25 \%$ & $0.93 \%$ & $0.48 \%$ & $0.04 \%$ \\
\hline & 2001 & $0.16 \%$ & $0.44 \%$ & $0.71 \%$ & $3.04 \%$ & $9.90 \%$ & $0.66 \%$ & $0.26 \%$ & $0.07 \%$ \\
\hline & 2002 & $0.14 \%$ & $1.68 \%$ & $0.70 \%$ & $5.04 \%$ & $10.50 \%$ & $0.47 \%$ & $0.98 \%$ & $0.09 \%$ \\
\hline & 2003 & $0.23 \%$ & $1.03 \%$ & $0.40 \%$ & $4.09 \%$ & $6.65 \%$ & $0.34 \%$ & $0.75 \%$ & $0.13 \%$ \\
\hline & 2004 & $0.10 \%$ & $0.32 \%$ & $0.51 \%$ & $2.73 \%$ & $5.37 \%$ & $0.58 \%$ & $0.22 \%$ & $0.05 \%$ \\
\hline & 2005 & $0.11 \%$ & $0.54 \%$ & $0.25 \%$ & $3.27 \%$ & $7.47 \%$ & $1.72 \%$ & $0.33 \%$ & $0.06 \%$ \\
\hline & 2006 & $0.15 \%$ & $0.40 \%$ & $0.40 \%$ & $3.08 \%$ & $6.19 \%$ & $9.86 \%$ & $0.20 \%$ & $0.05 \%$ \\
\hline
\end{tabular}

A Tabela 16 mostra uma mudança no cenário da rentabilidade dos ativos brasileiros nos últimos anos, notadamente em 2006, com a queda da rentabilidade dos ativos de renda fixa e uma maior rentabilidade do mercado acionário brasileiro.

\subsection{Matrizes de Correlações}

As matrizes de correlações entre os vinte e quadro mercados foi calculada a partir de retornos mensais dos índices dos 24 países da amostra para os três períodos analisados no estudo (2000 a 2005, 2001 a 2006 e 2003 a 2006), tanto em reais, refletindo o ponto de vista do investidor brasileiro e considerando variações cambiais, quanto em moeda local, desconsiderando variações cambiais. As matrizes de correlações possibilitam neste caso a verificação de vantagens de redução de risco pela diversificação internacional, já que, a menos da existência de correlação positiva perfeita entre os ativos, existirão vantagens na diversificação de carteiras. 
Tabela 17 - Coeficiente de Correlação entre os Retornos Mensais, em termos de Moeda Local, dos Índices de Mercado de Ações

\begin{tabular}{lccc}
\hline País & $\mathbf{2 0 0 0}$ a 2005 & 2001 a 2006 & 2003 a 2006 \\
\hline Alemanha & 0,61 & 0,64 & 0,39 \\
Argentina & 0,28 & 0,28 & 0,44 \\
Austrália & 0,63 & 0,66 & 0,54 \\
Canadá & 0,70 & 0,69 & 0,58 \\
Chile & 0,46 & 0,52 & 0,35 \\
China & 0,14 & 0,17 & 0,23 \\
Cingapura & 0,49 & 0,54 & 0,37 \\
Coréia do Sul & 0,55 & 0,56 & 0,43 \\
Espanha & 0,64 & 0,65 & 0,33 \\
EUA & 0,68 & 0,71 & 0,59 \\
França & 0,61 & 0,64 & 0,40 \\
Holanda & 0,58 & 0,60 & 0,35 \\
Hong Kong & 0,69 & 0,64 & 0,52 \\
Índia & 0,54 & 0,55 & 0,42 \\
Itália & 0,52 & 0,60 & 0,34 \\
Japão & 0,44 & 0,42 & 0,34 \\
Malásia & 0,31 & 0,37 & 0,29 \\
México & 0,65 & 0,64 & 0,58 \\
Reino Unido & 0,63 & 0,65 & 0,43 \\
Suécia & 0,58 & 0,61 & 0,36 \\
Suíça & 0,50 & 0,56 & 0,36 \\
Taiwan & 0,44 & 0,48 & 0,25 \\
Venezuela & 0,25 & 0,31 & 0,33 \\
\hline & & &
\end{tabular}

Em relação ao período de 2000 a 2005, a Tabela 17 aponta que as menores correlações entre retornos dos mercados analisados aconteceram, em relação a países emergentes, entre Brasil e Venezuela e entre Brasil e Argentina. A baixa correlação encontrada para esses mercados corrobora os resultados obtidos por Leite e Sanvicente (1994).

A menor correlação no estudo foi em relação ao mercado chinês, correspondendo a 0,14 . Outra baixa correlação encontrada ocorreu entre o Brasil e a Malásia, de 0,31. Pode-se notar também uma alta correlação entre o mercado brasileiro e os países desenvolvidos, sendo a menor delas encontrada com o mercado japonês, de 0,44 , chegando a 0,70 com o mercado canadense e a 0,68 com o norte-americano. Outra alta correlação encontrada na análise ocorreu com o mercado de Hong Kong, de 0,69. Essa alta correlação pode ser reflexo do período estudo já que Cabello (2002), em análise de retornos mensais para o período de 1994 a 2000, encontra um coeficiente de apenas 0,28. 
As matrizes de correlações entre os retornos de todos os índices de mercado de ações da amostra são apresentadas nos Apêndices A e B. Estes revelam que a China, a Venezuela e a Argentina apresentam, no geral, baixas correlações com todos os países da amostra.

Em relação à significância dos coeficientes de correlação, observou-se que os coeficientes de correlação da maioria dos países foram significantes ao nível de 5\%, sendo a Venezuela e a China os países que apresentaram poucas correlações significantes em relação aos demais países (Apêndice B).

Os coeficientes de correlação entre os índices de mercado de ações para o período de 2001 a 2006 são bastante semelhantes aos do período de 2000 a 2005. Já no período de 2003 a 2006, as correlações entre o Índice Bovespa e os índices de mercado dos demais países no geral reduziram-se, principalmente em relação aos países desenvolvidos. No entanto, a correlação no mercado de ações brasileiro e argentino passou de 0,28 nos dois primeiros períodos para 0,44 entre 2003 a 2006.

Vale destacar também que as mais altas correlações em todos os períodos analisados foram em relação ao mercado norte-americano, ao canadense e ao mexicano.

A Tabela 18 apresenta as análises realizadas em termos de reais. Percebe-se que, no período de 2000 a 2005, a menor correlação do mercado brasileiro é encontrada com relação ao mercado chinês, de $-0,34$. Considerando a variação cambial, obtiveram também correlação negativa com os retornos do mercado brasileiro a Austrália, Cingapura, os Estados Unidos, o Japão, a Malásia, o Reino Unido, a Suíça e a Venezuela. 
Tabela 18 - Coeficiente de Correlação entre os Retornos Mensais, em termos de Reais, dos Índices de Mercado de Ações

\begin{tabular}{lccc}
\hline País & $\mathbf{2 0 0 0}$ a 2005 & $\mathbf{2 0 0 1}$ a 2006 & 2003 a 2006 \\
\hline Alemanha & 0,32 & 0,26 & 0,25 \\
Argentina & 0,14 & 0,14 & 0,29 \\
Austrália & $-0,02$ & $-0,07$ & 0,25 \\
Canadá & 0,12 & $-0,01$ & 0,19 \\
Chile & 0,08 & 0,09 & 0,29 \\
China & $-0,34$ & $-0,27$ & 0,03 \\
Cingapura & $-0,07$ & $-0,11$ & 0,03 \\
Coréia do Sul & 0,19 & 0,10 & 0,22 \\
Espanha & 0,13 & 0,01 & 0,11 \\
EUA & $-0,07$ & $-0,15$ & 0,01 \\
França & 0,14 & 0,07 & 0,18 \\
Holanda & 0,19 & 0,12 & 0,19 \\
Hong Kong & 0,10 & $-0,03$ & 0,14 \\
Índia & 0,08 & 0,06 & 0,26 \\
Itália & 0,02 & $-0,04$ & 0,11 \\
Japão & $-0,06$ & $-0,16$ & 0,12 \\
Malásia & $-0,27$ & $-0,29$ & $-0,05$ \\
México & 0,17 & 0,07 & 0,32 \\
Reino Unido & $-0,12$ & $-0,18$ & 0,13 \\
Suécia & 0,26 & 0,21 & 0,26 \\
Suíça & $-0,16$ & $-0,20$ & 0,13 \\
Taiwan & 0,08 & 0,05 & 0,07 \\
Venezuela & $-0,07$ & $-0,03$ & 0,18 \\
\hline & & &
\end{tabular}

Considerando o período mais recente, de 2003 a 2006, nota-se que os mercados que apresentaram maior potencial para redução de risco, identificados pelas baixas correlações com o mercado de ações brasileiro, foram o da Malásia, Estados Unidos, China, Cingapura, Espanha, Itália, Japão e Taiwan.

Percebe-se que as correlações entre os índices de mercado de ações no caso da análise em moeda local são bem mais estáveis ao longo dos períodos que a análise em com retornos em reais, já que a última também considera variações cambiais. Além disso, nota-se que as correlações com o mercado brasileiro quando consideradas os retornos dos índices de mercado de ações em reais foram, em geral, menores que quando desconsideradas variações cambiais.

As matrizes de correlações entre os ativos do mercado brasileiro calculadas para cada um dos três períodos estudados podem ser vistas na Tabela 19: 
Tabela 19 - Matrizes de Correlações entre os Ativos Nacionais para os Períodos Analisados

\begin{tabular}{|c|c|c|c|c|c|c|c|c|}
\hline 2000 a 2005 & CDI & IGPM+CUP & IRF-M & FIEX & IBOV & IMOVEIS & EMPREST & FINANC \\
\hline CDI & 1,00 & & & & & & & \\
\hline IGPM + CUP & 0,07 & 1,00 & & & & & & \\
\hline IRF-M & 0,59 & 0,08 & 1,00 & & & & & \\
\hline FIEX & 0,13 & 0,42 & 0,27 & 1,00 & & & & \\
\hline IBOV & 0,19 & 0,01 & 0,52 & 0,22 & 1,00 & & & \\
\hline IMOVEIS & 0,00 & 0,28 & 0,13 & 0,13 & 0,13 & 1,00 & & \\
\hline EMPREST & 0,32 & 0,82 & 0,21 & 0,27 & 0,09 & 0,24 & 1,00 & \\
\hline FINANC & 0,86 & 0,16 & 0,42 & $-0,05$ & 0,10 & $-0,04$ & 0,39 & 1,00 \\
\hline 2001 a 2006 & CDI & IGPM+CUP & IRF-M & FIEX & IBOVESPA & IMOVEIS & EMPREST & FINANC \\
\hline CDI & 1,00 & & & & & & & \\
\hline IGPM + CUP & 0,15 & 1,00 & & & & & & \\
\hline IRF-M & 0,55 & 0,09 & 1,00 & & & & & \\
\hline FIEX & 0,18 & 0,41 & 0,20 & 1,00 & & & & \\
\hline IBOV & 0,12 & $-0,02$ & 0,47 & 0,12 & 1,00 & & & \\
\hline IMOVEIS & $-0,20$ & 0,00 & 0,00 & 0,02 & 0,00 & 1,00 & & \\
\hline EMPREST & 0,39 & 0,82 & 0,22 & 0,30 & 0,05 & $-0,07$ & 1,00 & \\
\hline FINANC & 0,80 & 0,23 & 0,43 & 0,07 & 0,06 & $-0,09$ & 0,43 & 1,00 \\
\hline 2003 a 2006 & CDI & IGPM+ CUP & IRF-M & FIEX & IBOVESPA & IMOVEIS & EMPREST & FINANC \\
\hline CDI & 1,00 & & & & & & & \\
\hline IGPM + CUP & $-0,02$ & 1,00 & & & & & & \\
\hline IRF-M & 0,60 & $-0,04$ & 1,00 & & & & & \\
\hline FIEX & 0,15 & 0,23 & 0,02 & 1,00 & & & & \\
\hline IBOV & 0,09 & $-0,15$ & 0,43 & 0,00 & 1,00 & & & \\
\hline IMOVEIS & $-0,23$ & 0,00 & $-0,04$ & 0,03 & $-0,06$ & 1,00 & & \\
\hline EMPREST & 0,41 & 0,69 & 0,23 & 0,19 & $-0,05$ & $-0,11$ & 1,00 & \\
\hline FINANC & 0,82 & $-0,01$ & 0,54 & 0,08 & 0,05 & $-0,12$ & 0,40 & 1,00 \\
\hline
\end{tabular}

A tabela mostra uma correlação negativa entre o CDI e os fundos imobiliários, que vem aumentando nas matrizes de correlações de períodos mais recentes. No período de 2000 a 2005 a correlação dos retornos mensais do CDI e dos fundos imobiliários foi de -0,003, passando para - 0,20 no segundo período e para - 0,23 no terceiro. A correlação negativa entre esses ativos indica um potencial de redução de risco na carteira quando detidos conjuntamente em uma carteira.

O índice Bovespa apresentou suas mais altas correlações com o IRF-M $(0,52,0,47$ e 0,43 nos três períodos). Sua correlação com os demais ativos foi positiva e baixa ou negativa. Destacase a correlação de $-0,15$ entre o índice Bovespa e IGPM mais cupom no período de 2003 a 2006.

As mais altas correlações positivas foram entre o CDI e financiamentos a participantes de 0,86, 0,80 e 0,82 para cada um dos três períodos. Outra correlação positiva e alta ocorreu entre IGPM mais cupom e empréstimos a participantes $(\mathrm{TR}+12 \%)$. Além deles, o CDI e o IRF-M apresentaram correlações que variaram entre 0,55 e 0,60 . 
Os fundos imobiliários apresentaram correlações positivas muito baixas ou negativas em relação aos demais ativos. Além disso, elas parecem ter ficado mais baixas ou negativas em períodos mais recentes.

\subsection{Fronteiras Eficientes do Mercado de Ações}

Primeiramente foi calculada a fronteira eficiente para o período de 2000 a 2005, considerando apenas os índices de mercado de ações a fim de verificar qual seria a composição das carteiras ótimas compostas puramente por ações.

A fronteira eficiente obtida no MATLAB para os dados em moeda local, conforme moedas descritas na Tabela 12, que seria de interesse no caso de hedge cambial da carteira por um investidor brasileiro, está configurada no gráfico:

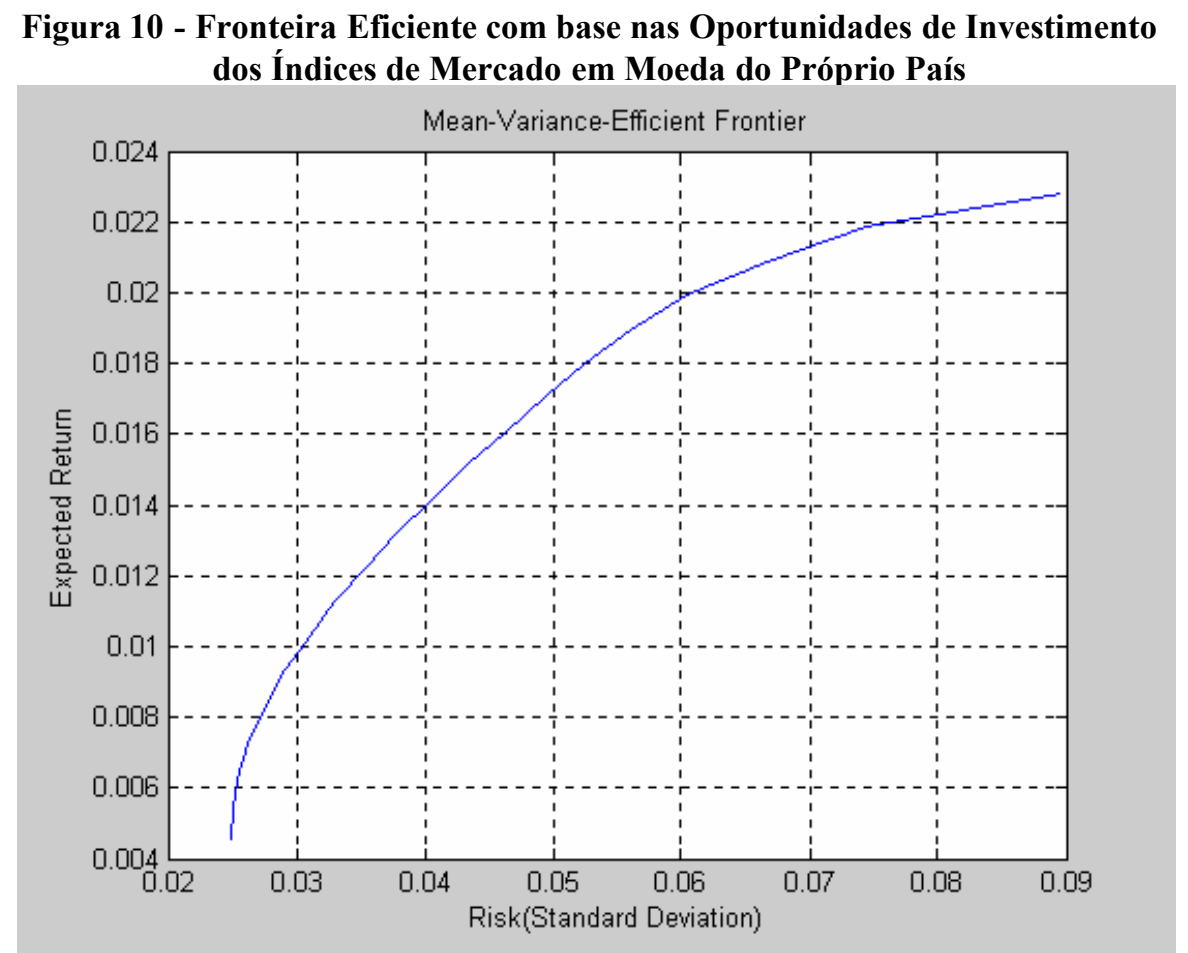

Já no caso de ser considerada a carteira de um investidor sem hedge, com retornos considerados em reais, tem-se: 
Figura 11 - Fronteira Eficiente com base nas Oportunidades de Investimento dos Índices de Mercado em Reais

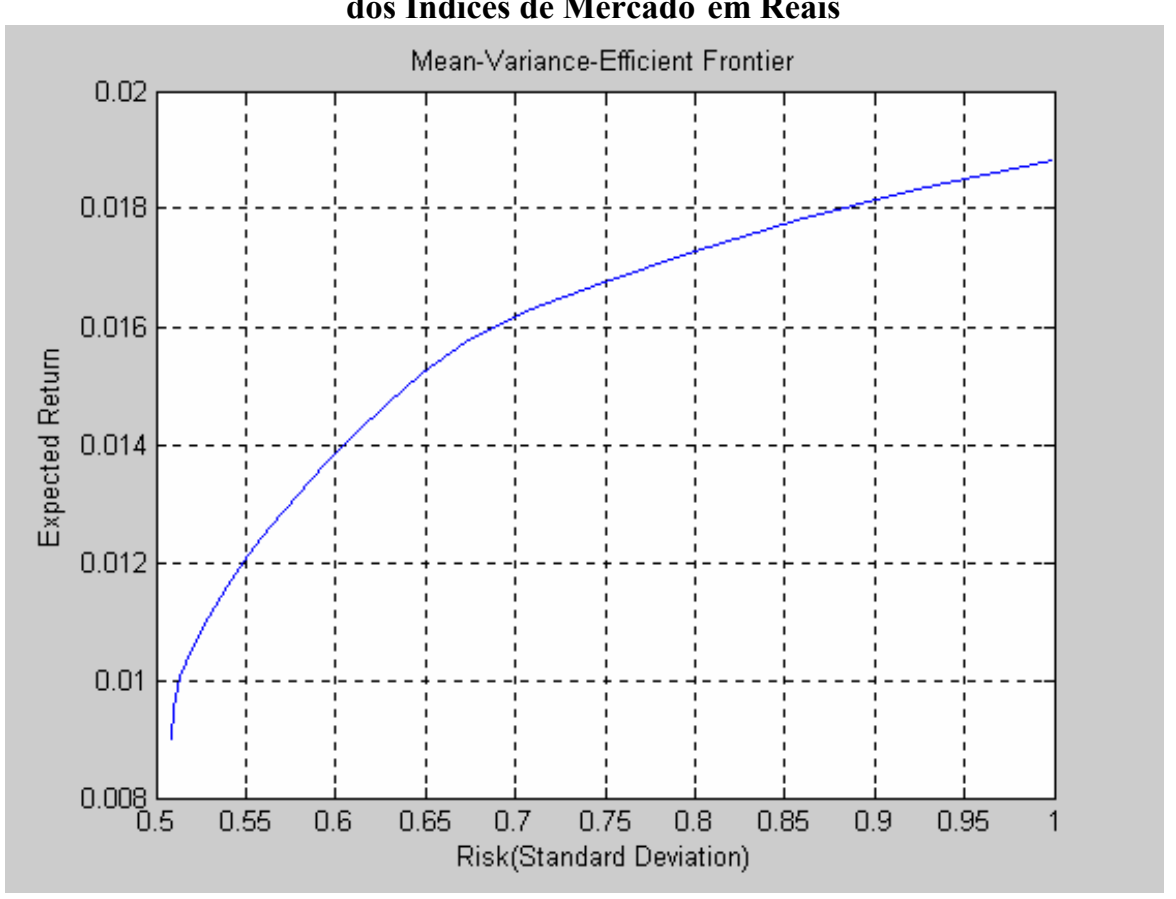

O mercado brasileiro no caso dos dados em moeda do próprio país, aparece com peso zero em todas as carteiras da fronteira eficiente. Já no caso da fronteira com base nos dados em reais, o índice Bovespa aparece praticamente em todas as carteiras da fronteira eficiente, chegando a um peso de quase $38 \%$ em um exemplo de carteira menos arriscada. Os retornos e riscos de dez exemplos de carteiras pertencentes às fronteiras eficientes e os pesos dos índices em cada uma delas pode ser encontrado no Apêndice C.

Vale ressaltar que a fronteira eficiente com dados em reais é mais factível para o investidor institucional brasileiro já que não existe hedge para todas as moedas dos mercados considerados.

\subsection{Carteiras dos Investidores Institucionais Otimizadas}

O procedimento de otimização foi realizado utilizando tanto retornos mensais em moeda local, como retornos mensais dos ativos em reais. As otimizações foram realizadas para os períodos de 2000 a 2005, 2001 a 2006 e 2003 a 2006. Nas otimizações para o período de 2000 a 2005, por exemplo, foram computadas as médias e a matrizes de covariância dos ativos no período de 6 anos entre 2000 e 2005. Consideraram-se não permitidas as vendas a descoberto. 
Primeiramente, foram otimizadas carteiras somente com os ativos nacionais e posteriormente com possibilidades graduais de investimentos no exterior de $10 \%, 20 \%, 30 \%, 40 \%$ e $50 \%$ (limite de investimento em ações pela Resolução CMN 3.121).

Os resultados em termos de risco e retorno das carteiras da fronteira eficiente para cada limite máximo de aplicação em ações estrangeiras, tanto no caso de retornos em moeda local como em reais, para os três períodos analisados foram resumidos nas Tabelas 20, 22, 24, 25, 26 e 27. A Tabela 20, a seguir, mostra os resultados obtidos para os retornos mensais em moeda local para o período de 2000 a 2005 :

\begin{tabular}{|c|c|c|c|c|c|c|}
\hline Retorno & $0 \%$ & $10 \%$ & $20 \%$ & $30 \%$ & $40 \%$ & $50 \%$ \\
\hline $1,35 \%$ & - & $0,20 \%$ & $0,20 \%$ & $0,20 \%$ & $0,20 \%$ & $0,20 \%$ \\
\hline $1,40 \%$ & $0,20 \%$ & $0,20 \%$ & $0,20 \%$ & $0,20 \%$ & $0,20 \%$ & $0,20 \%$ \\
\hline $1,45 \%$ & $0,22 \%$ & $0,22 \%$ & $0,22 \%$ & $0,22 \%$ & $0,22 \%$ & $0,22 \%$ \\
\hline $1,50 \%$ & $0,30 \%$ & $0,30 \%$ & $0,30 \%$ & $0,30 \%$ & $0,30 \%$ & $0,30 \%$ \\
\hline $1,55 \%$ & $0,43 \%$ & $0,42 \%$ & $0,42 \%$ & $0,42 \%$ & $0,42 \%$ & $0,42 \%$ \\
\hline $1,60 \%$ & $0,57 \%$ & $0,55 \%$ & $0,55 \%$ & $0,55 \%$ & $0,55 \%$ & $0,55 \%$ \\
\hline $1,65 \%$ & $0,81 \%$ & $0,72 \%$ & $0,72 \%$ & $0,72 \%$ & $0,72 \%$ & $0,72 \%$ \\
\hline $1,70 \%$ & - & $0,95 \%$ & $0,95 \%$ & $0,95 \%$ & $0,95 \%$ & $0,95 \%$ \\
\hline $1,75 \%$ & - & - & $1,26 \%$ & $1,26 \%$ & $1,26 \%$ & $1,26 \%$ \\
\hline $1,80 \%$ & - & - & $1,79 \%$ & $1,78 \%$ & $1,78 \%$ & $1,78 \%$ \\
\hline $1,85 \%$ & - & - & - & $2,41 \%$ & $2,41 \%$ & $2,41 \%$ \\
\hline $1,90 \%$ & - & - & - & - & $3,08 \%$ & $3,08 \%$ \\
\hline $1,95 \%$ & - & - & - & - & - & $3,77 \%$ \\
\hline
\end{tabular}

Dadas as carteiras de máximo e mínimo retorno de cada fronteira eficiente obtida para cada restrição de investimento no exterior, foram escolhidas algumas carteiras com diferentes retornos das fronteiras, de $0,05 \%$ em $0,05 \%$, para análise do impacto em redução de risco pela possibilidade de aplicação em ativos estrangeiros.

Os Apêndices D e E apresentam o risco, o retorno e os pesos dos ativos para dez carteiras de cada fronteira eficiente por limite de aplicação em ativos estrangeiros, para retornos em reais e em moeda do próprio país, respectivamente. Já os Apêndices F e G apresentam, dados os retornos em intervalos de $0,05 \%$ entre o retorno máximo e mínimo da fronteira eficiente em questão, o risco e os pesos dos ativos na carteira.

No caso do período de 2000 a 2005, com retornos dos ativos em moeda local e restrição de $50 \%$ de aplicações no exterior, a carteira de mínimo retorno da fronteira eficiente apresentou 
retorno de 1,35\% e a de máximo retorno foi de 1,98\% (Apêndice D). Dessa forma, os retornos da Tabela 20 variaram neste caso de $1,35 \%$ a $1,95 \%$.

Além disso, a Tabela 20 indica que a possibilidade de aplicação em ações estrangeiras, no período de 2000 a 2005 gerou opções de carteiras na fronteira eficiente com maiores retornos, já que o retorno das carteiras são a média ponderada do retorno dos ativos que as compõe e nesse período alguns índices de ações internacionais apresentaram maior rentabilidade que os ativos nacionais. Esta análise deve considerar o custo do hedge já que se trata de retornos em moeda de cada país.

A Tabela 20 mostra que no caso de carteiras com retorno esperado acima de 1,55\% ao mês, obter-se-iam vantagens em redução de risco das carteiras dada a possibilidade de aplicação no exterior. Neste caso percebe-se que um aumento porcentagem possível de investir-se no exterior acima de $10 \%$ não gerou mais redução de risco para os retornos das carteiras de retorno até $1,70 \%$, mas gerou carteiras com maiores retornos e risco.

Verifica-se pelo Apêndice D que os mercados que auxiliaram na redução de risco das carteiras com retornos mais baixos foram o australiano e o chinês, enquanto que os mercados da Argentina, México e Venezuela estavam presentes nas carteiras de maior retorno e risco. A Tabela 21 apresenta os pesos dos ativos nas carteiras para a limitação de $10 \%$ em ativos estrangeiros. Os pesos dos ativos nas carteiras para as demais limitações, dado o retorno, são encontradas no Apêndice F.

Tabela 21 - Pesos dos Ativos em Carteiras da Fronteira Eficiente com Retornos em Moeda Local para o Período de 2000 a 2005 com Limitação de 10\% a Aplicações no Exterior

\begin{tabular}{|c|c|c|c|c|c|c|c|c|c|c|c|}
\hline $\begin{array}{l}\text { Retorno } \\
\text { Esperado }\end{array}$ & Risco & CDI & $\begin{array}{l}\text { IGPM+ } \\
\text { cup }\end{array}$ & IRF-M & Argentina & Austrália & China & México & Venezuela & Imóveis & $\begin{array}{l}\text { Financiamento } \\
\text { a Participantes }\end{array}$ \\
\hline $1,35 \%$ & $0,20 \%$ & $82,69 \%$ & $2,03 \%$ & $0,00 \%$ & $0,00 \%$ & $0,46 \%$ & $0,44 \%$ & $0,00 \%$ & $0,00 \%$ & $4,39 \%$ & $10,00 \%$ \\
\hline $1,40 \%$ & $0,20 \%$ & $85,21 \%$ & $3,33 \%$ & $0,00 \%$ & $0,00 \%$ & $0,25 \%$ & $0,37 \%$ & $0,00 \%$ & $0,00 \%$ & $0,84 \%$ & $10,00 \%$ \\
\hline $1,45 \%$ & $0,22 \%$ & $94,64 \%$ & $5,36 \%$ & $0,00 \%$ & $0,00 \%$ & $0,00 \%$ & $0,00 \%$ & $0,00 \%$ & $0,00 \%$ & $0,00 \%$ & $0,00 \%$ \\
\hline $1,50 \%$ & $0,30 \%$ & $66,65 \%$ & $17,66 \%$ & $15,27 \%$ & $0,00 \%$ & $0,00 \%$ & $0,00 \%$ & $0,00 \%$ & $0,42 \%$ & $0,00 \%$ & $0,00 \%$ \\
\hline $1,55 \%$ & $0,42 \%$ & $37,19 \%$ & $28,10 \%$ & $33,71 \%$ & $0,00 \%$ & $0,00 \%$ & $0,00 \%$ & $0,00 \%$ & $1,01 \%$ & $0,00 \%$ & $0,00 \%$ \\
\hline $1,60 \%$ & $0,55 \%$ & $7,73 \%$ & $38,54 \%$ & $52,14 \%$ & $0,00 \%$ & $0,00 \%$ & $0,00 \%$ & $0,00 \%$ & $1,59 \%$ & $0,00 \%$ & $0,00 \%$ \\
\hline $1,65 \%$ & $0,72 \%$ & $0,00 \%$ & $58,45 \%$ & $37,86 \%$ & $0,19 \%$ & $0,00 \%$ & $0,00 \%$ & $0,33 \%$ & $3,17 \%$ & $0,00 \%$ & $0,00 \%$ \\
\hline $1,70 \%$ & $0,95 \%$ & $0,00 \%$ & $81,88 \%$ & $11,19 \%$ & $0,48 \%$ & $0,00 \%$ & $0,00 \%$ & $1,46 \%$ & $4,98 \%$ & $0,00 \%$ & $0,00 \%$ \\
\hline
\end{tabular}

A Tabela 21 mostra que a carteira eficiente com retorno esperado de 1,35\% apresentaria $0,90 \%$ em ações estrangeiras e a com retorno esperado de $1,70 \%$ deteria $6,92 \%$ em ativos externos. A análise do Apêndice D mostra que a carteira de máximo retorno da fronteira 
eficiente com limite de $10 \%$ a investimentos em ativos estrangeiros apresentaria aproximadamente $1,75 \%$ de retorno e $1,24 \%$ de risco e seria composta por $90 \%$ de IGPM mais cupom e $10 \%$ em ações do mercado venezuelano.

No que tange ao período de 2001 a 2006 para retornos em moeda local, tem-se, da mesma forma, uma redução de risco nas carteiras de menor retorno até abertura de $10 \%$ para investimentos externos e uma abertura maior geraria a possibilidade de maiores retornos com maiores riscos.

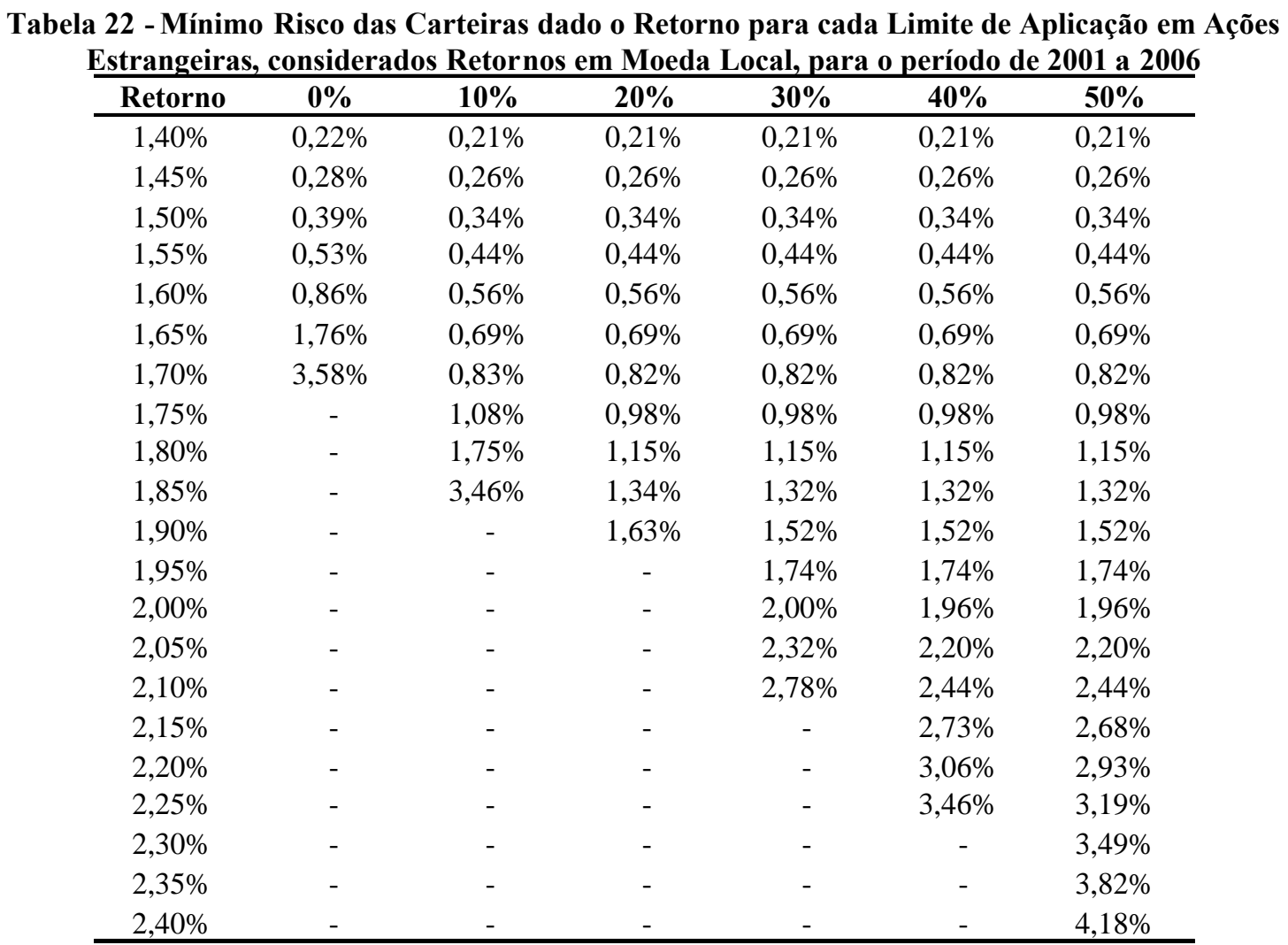

A Tabela 22 apresenta dados contidos no Apêndice D em que podem ser vistas as características de 10 das carteiras da fronteira eficiente, sendo a primeira delas a de menor risco e a última a de maior risco. Nota-se que, com a mudança de período analisado, o mercado de ações brasileiro passa a figurar nas carteiras de maior risco da fronteira eficiente. Além disso, percebe-se que os demais ativos das carteiras são os mesmos encontrados na Tabela 21 para o período de 2000 a 2005, já que se consideraram na Tabela 23 apenas os ativos que apareceram em alguma das 10 carteiras ao longo da fronteira eficiente para retornos em moeda local no período de 2001 a 2006 com limite de aplicação no exterior de $10 \%$. 
Tabela 23 - Pesos dos Ativos em Carteiras da Fronteira Eficiente com Retornos em Moeda Local para o Período de 2001 a 2006 com Limitação de 10\% a Aplicações no Exterior

\begin{tabular}{|c|c|c|c|c|c|c|c|c|c|c|c|c|}
\hline $\begin{array}{l}\text { Retorno } \\
\text { Esperado }\end{array}$ & Risco & CDI & $\begin{array}{l}\text { IGPM+ } \\
\text { cup }\end{array}$ & IRF-M & Argentina & Austrália & Brasil & China & México & Venezuela & Imóveis & $\begin{array}{l}\text { Financiamento } \\
\text { a Participantes }\end{array}$ \\
\hline $1,37 \%$ & $0,20 \%$ & $84,30 \%$ & $2,82 \%$ & $0,00 \%$ & $0,00 \%$ & $0,87 \%$ & $0,00 \%$ & $0,93 \%$ & $0,00 \%$ & $0,00 \%$ & $1,09 \%$ & $10,00 \%$ \\
\hline $1,42 \%$ & $0,23 \%$ & $90,71 \%$ & $7,13 \%$ & $0,00 \%$ & $0,00 \%$ & $0,00 \%$ & $0,00 \%$ & $0,68 \%$ & $0,89 \%$ & $0,12 \%$ & $0,47 \%$ & $0,00 \%$ \\
\hline $1,48 \%$ & $0,30 \%$ & $76,14 \%$ & $14,77 \%$ & $6,43 \%$ & $0,00 \%$ & $0,00 \%$ & $0,00 \%$ & $0,00 \%$ & $1,78 \%$ & $0,88 \%$ & $0,00 \%$ & $0,00 \%$ \\
\hline $1,53 \%$ & $0,40 \%$ & $52,03 \%$ & $23,70 \%$ & $20,17 \%$ & $0,00 \%$ & $0,00 \%$ & $0,00 \%$ & $0,00 \%$ & $2,47 \%$ & $1,63 \%$ & $0,00 \%$ & $0,00 \%$ \\
\hline $1,59 \%$ & $0,53 \%$ & $27,93 \%$ & $32,63 \%$ & $33,91 \%$ & $0,00 \%$ & $0,00 \%$ & $0,00 \%$ & $0,00 \%$ & $3,15 \%$ & $2,38 \%$ & $0,00 \%$ & $0,00 \%$ \\
\hline $1,64 \%$ & $0,66 \%$ & $3,82 \%$ & $41,56 \%$ & $47,66 \%$ & $0,00 \%$ & $0,00 \%$ & $0,00 \%$ & $0,00 \%$ & $3,84 \%$ & $3,13 \%$ & $0,00 \%$ & $0,00 \%$ \\
\hline $1,69 \%$ & $0,80 \%$ & $0,00 \%$ & $53,59 \%$ & $36,41 \%$ & $0,00 \%$ & $0,00 \%$ & $0,00 \%$ & $0,00 \%$ & $5,29 \%$ & $4,71 \%$ & $0,00 \%$ & $0,00 \%$ \\
\hline $1,75 \%$ & $1,06 \%$ & $0,00 \%$ & $72,94 \%$ & $17,06 \%$ & $1,28 \%$ & $0,00 \%$ & $0,00 \%$ & $0,00 \%$ & $0,91 \%$ & $7,81 \%$ & $0,00 \%$ & $0,00 \%$ \\
\hline $1,80 \%$ & $1,74 \%$ & $0,00 \%$ & $76,63 \%$ & $0,00 \%$ & $0,00 \%$ & $0,00 \%$ & $13,37 \%$ & $0,00 \%$ & $0,00 \%$ & $10,00 \%$ & $0,00 \%$ & $0,00 \%$ \\
\hline $1,85 \%$ & $3,58 \%$ & $0,00 \%$ & $50,00 \%$ & $0,00 \%$ & $0,00 \%$ & $0,00 \%$ & $40,00 \%$ & $0,00 \%$ & $0,00 \%$ & $10,00 \%$ & $0,00 \%$ & $0,00 \%$ \\
\hline
\end{tabular}

Quando se trata do período de 2003 a 2006, percebe-se uma redução de risco com a abertura de $10 \%$ a ativos estrangeiros para as carteiras de menor retorno esperado. Para carteiras com retorno esperado a partir de $1,70 \%$ ao mês uma possibilidade de aplicação no exterior de $20 \%$ contribui mais ainda com a redução de risco na carteira. A partir do retorno esperado de $1,95 \%$, a possibilidade de aplicar até $30 \%$ no exterior auxilia ainda mais na redução de risco da carteira em relação aos $20 \%$. Da mesma forma, para carteiras com retorno esperado a partir de $2,15 \%$ ao mês, poder aplicar $40 \%$ em ativos internacionais reduziria mais o risco da carteira que uma limitação de $30 \%$. A limitação de $50 \%$ passa a fazer sentido na redução de risco das carteiras para o período a partir do retorno esperado de 2,35\% ao mês. Neste caso, a possibilidade gradual de investir-se no exterior também aumentaria os retornos esperados máximos das carteiras de máximo retorno das fronteiras eficientes. 
Tabela 24 - Mínimo Risco das Carteiras dado o Retorno para cada Limite de Aplicação em Ações Estrangeiras, considerados Retornos em Moeda Local, para o período de 2003 a 2006

\begin{tabular}{|c|c|c|c|c|c|c|}
\hline Retorno & $0 \%$ & $10 \%$ & $20 \%$ & $30 \%$ & $40 \%$ & $50 \%$ \\
\hline $1,40 \%$ & $0,24 \%$ & $0,21 \%$ & $0,21 \%$ & $0,21 \%$ & $0,21 \%$ & $0,21 \%$ \\
\hline $1,45 \%$ & $0,29 \%$ & $0,23 \%$ & $0,23 \%$ & $0,23 \%$ & $0,23 \%$ & $0,23 \%$ \\
\hline $1,50 \%$ & $0,37 \%$ & $0,29 \%$ & $0,29 \%$ & $0,29 \%$ & $0,29 \%$ & $0,29 \%$ \\
\hline $1,55 \%$ & $0,48 \%$ & $0,36 \%$ & $0,36 \%$ & $0,36 \%$ & $0,36 \%$ & $0,36 \%$ \\
\hline $1,60 \%$ & $0,60 \%$ & $0,45 \%$ & $0,45 \%$ & $0,45 \%$ & $0,45 \%$ & $0,45 \%$ \\
\hline $1,65 \%$ & $0,74 \%$ & $0,54 \%$ & $0,54 \%$ & $0,54 \%$ & $0,54 \%$ & $0,54 \%$ \\
\hline $1,70 \%$ & $0,91 \%$ & $0,64 \%$ & $0,63 \%$ & $0,63 \%$ & $0,63 \%$ & $0,63 \%$ \\
\hline $1,75 \%$ & $1,08 \%$ & $0,75 \%$ & $0,73 \%$ & $0,73 \%$ & $0,73 \%$ & $0,73 \%$ \\
\hline $1,80 \%$ & $1,27 \%$ & $0,88 \%$ & $0,83 \%$ & $0,83 \%$ & $0,83 \%$ & $0,83 \%$ \\
\hline $1,85 \%$ & $1,46 \%$ & $1,02 \%$ & $0,93 \%$ & $0,93 \%$ & $0,93 \%$ & $0,93 \%$ \\
\hline $1,90 \%$ & $1,65 \%$ & $1,18 \%$ & $1,03 \%$ & $1,03 \%$ & $1,03 \%$ & $1,03 \%$ \\
\hline $1,95 \%$ & $1,84 \%$ & $1,35 \%$ & $1,14 \%$ & $1,13 \%$ & $1,13 \%$ & $1,13 \%$ \\
\hline $2,00 \%$ & $2,03 \%$ & $1,51 \%$ & $1,28 \%$ & $1,24 \%$ & $1,24 \%$ & $1,24 \%$ \\
\hline $2,05 \%$ & $2,23 \%$ & $1,69 \%$ & $1,42 \%$ & $1,35 \%$ & $1,35 \%$ & $1,35 \%$ \\
\hline $2,10 \%$ & $2,43 \%$ & $1,86 \%$ & $1,58 \%$ & $1,45 \%$ & $1,45 \%$ & $1,45 \%$ \\
\hline $2,15 \%$ & $2,62 \%$ & $2,04 \%$ & $1,74 \%$ & $1,57 \%$ & $1,56 \%$ & $1,56 \%$ \\
\hline $2,20 \%$ & $2,82 \%$ & $2,22 \%$ & $1,90 \%$ & $1,71 \%$ & $1,67 \%$ & $1,67 \%$ \\
\hline $2,25 \%$ & $3,02 \%$ & $2,40 \%$ & $2,07 \%$ & $1,85 \%$ & $1,78 \%$ & $1,78 \%$ \\
\hline $2,30 \%$ & $3,22 \%$ & $2,58 \%$ & $2,24 \%$ & $2,00 \%$ & $1,89 \%$ & $1,89 \%$ \\
\hline $2,35 \%$ & - & $2,76 \%$ & $2,41 \%$ & $2,15 \%$ & $2,01 \%$ & $2,00 \%$ \\
\hline $2,40 \%$ & - & $2,95 \%$ & $2,59 \%$ & $2,31 \%$ & $2,15 \%$ & $2,11 \%$ \\
\hline $2,45 \%$ & - & $3,13 \%$ & $2,76 \%$ & $2,48 \%$ & $2,29 \%$ & $2,22 \%$ \\
\hline $2,50 \%$ & - & - & $2,94 \%$ & $2,64 \%$ & $2,44 \%$ & $2,33 \%$ \\
\hline $2,55 \%$ & - & - & $3,14 \%$ & $2,83 \%$ & $2,61 \%$ & $2,49 \%$ \\
\hline $2,60 \%$ & - & - & - & $3,06 \%$ & $2,83 \%$ & $2,69 \%$ \\
\hline $2,65 \%$ & - & - & - & $3,32 \%$ & $3,09 \%$ & $2,94 \%$ \\
\hline $2,70 \%$ & - & - & - & $3,61 \%$ & $3,37 \%$ & $3,21 \%$ \\
\hline $2,75 \%$ & - & - & - & - & $3,68 \%$ & $3,51 \%$ \\
\hline $2,80 \%$ & - & - & - & - & $4,00 \%$ & $3,83 \%$ \\
\hline $2,85 \%$ & - & - & - & - & $4,34 \%$ & $4,16 \%$ \\
\hline $2,90 \%$ & - & - & - & - & - & $4,51 \%$ \\
\hline $2,95 \%$ & - & - & - & - & - & $4,86 \%$ \\
\hline
\end{tabular}

A Tabela 25 mostra que, para retornos em reais, caso tivesse sido permitido no mercado brasileiro que os fundos de pensão aplicassem $10 \%$ de suas carteiras em ações estrangeiras no período de 2000 a 2005, seria possível uma redução de risco de $0,57 \%$ para $0,54 \%$, para uma carteira de retorno esperado de $1,6 \%$ ao mês. 
Tabela 25 - Mínimo Risco das Carteiras dado o Retorno para cada Limite de Aplicação em Ações Estrangeiras, considerados Retornos em Reais, para o período de 2000 a 2005

\begin{tabular}{ccccccc}
\hline Retorno & $\mathbf{0 \%}$ & $\mathbf{1 0 \%}$ & $\mathbf{2 0 \%}$ & $\mathbf{3 0 \%}$ & $\mathbf{4 0 \%}$ & $\mathbf{5 0 \%}$ \\
\hline $1,40 \%$ & $0,20 \%$ & $0,20 \%$ & $0,20 \%$ & $0,20 \%$ & $0,20 \%$ & $0,20 \%$ \\
$1,45 \%$ & $0,22 \%$ & $0,21 \%$ & $0,21 \%$ & $0,21 \%$ & $0,21 \%$ & $0,21 \%$ \\
$1,50 \%$ & $0,30 \%$ & $0,29 \%$ & $0,29 \%$ & $0,29 \%$ & $0,29 \%$ & $0,29 \%$ \\
$1,55 \%$ & $0,43 \%$ & $0,41 \%$ & $0,41 \%$ & $0,41 \%$ & $0,41 \%$ & $0,41 \%$ \\
$1,60 \%$ & $0,57 \%$ & $0,54 \%$ & $0,54 \%$ & $0,54 \%$ & $0,54 \%$ & $0,54 \%$ \\
$1,65 \%$ & $0,81 \%$ & $0,75 \%$ & $0,75 \%$ & $0,75 \%$ & $0,75 \%$ & $0,75 \%$ \\
$1,70 \%$ & - & $1,05 \%$ & $1,05 \%$ & $1,05 \%$ & $1,05 \%$ & $1,05 \%$ \\
\hline
\end{tabular}

A Tabela 25 também indica que a possibilidade de os fundos de pensão investirem mais de $10 \%$ da carteira em ativos internacionais não reduziria mais o risco para um dado retorno. Isso se deve às altas taxas de juros dos títulos públicos que fez com que nesse período, os investimentos ficassem concentrados nos três ativos escolhidos para representarem a classe de renda fixa (CDI, IGPM+cupom e IRF-M). Os investimentos em mercados de ações externos, nas carteiras da fronteira eficiente, ocorreram no mercado chinês e no mexicano, conforme pode ser visto no Apêndice E.

Tabela 26 - Mínimo Risco das Carteiras dado o Retorno para cada Limite de Aplicação em Ações Estrangeiras, considerados Retornos em Reais, para o período de 2001 a 2006

\begin{tabular}{ccccccc}
\hline Retorno & $\mathbf{0 \%}$ & $\mathbf{1 0 \%}$ & $\mathbf{2 0 \%}$ & $\mathbf{3 0 \%}$ & $\mathbf{4 0 \%}$ & $\mathbf{5 0 \%}$ \\
\hline $1,40 \%$ & $0,22 \%$ & $0,21 \%$ & $0,21 \%$ & $0,21 \%$ & $0,21 \%$ & $0,21 \%$ \\
$1,45 \%$ & $0,28 \%$ & $0,25 \%$ & $0,25 \%$ & $0,25 \%$ & $0,25 \%$ & $0,25 \%$ \\
$1,50 \%$ & $0,39 \%$ & $0,33 \%$ & $0,33 \%$ & $0,33 \%$ & $0,33 \%$ & $0,33 \%$ \\
$1,55 \%$ & $0,53 \%$ & $0,44 \%$ & $0,44 \%$ & $0,44 \%$ & $0,44 \%$ & $0,44 \%$ \\
$1,60 \%$ & $0,86 \%$ & $0,57 \%$ & $0,57 \%$ & $0,57 \%$ & $0,57 \%$ & $0,57 \%$ \\
$1,65 \%$ & $1,76 \%$ & $0,79 \%$ & $0,79 \%$ & $0,79 \%$ & $0,79 \%$ & $0,79 \%$ \\
$1,70 \%$ & $3,58 \%$ & $1,25 \%$ & $1,05 \%$ & $1,05 \%$ & $1,05 \%$ & $1,05 \%$ \\
$1,75 \%$ & - & $2,87 \%$ & $1,34 \%$ & $1,34 \%$ & $1,34 \%$ & $1,34 \%$ \\
$1,80 \%$ & - & - & $2,37 \%$ & $1,67 \%$ & $1,67 \%$ & $1,67 \%$ \\
$1,85 \%$ & - & - & - & $2,23 \%$ & $2,04 \%$ & $2,04 \%$ \\
$1,90 \%$ & - & - & - & - & $2,44 \%$ & $2,43 \%$ \\
$1,95 \%$ & - & - & - & - & - & $2,86 \%$ \\
\hline
\end{tabular}

Já para retornos no período de 2001 a 2006, apresentados na Tabela 26, a permissão para investir-se $10 \%$ da carteira em ativos internacionais já possibilita também a redução máxima de risco da carteira até retornos esperados de 1,65\% ao mês. Também uma autorização para maior internacionalização das carteiras permite a ocorrência de carteiras com maiores retornos esperados, dado que alguns mercados de ações internacionais apresentaram maiores retornos que os ativos nacionais. 
Tabela 27 - Mínimo Risco das Carteiras dado o Retorno para cada Limite de Aplicação em Ações Estrangeiras, considerados Retornos em Reais, para o período de 2003 a 2006

\begin{tabular}{ccccccc}
\hline Retorno & $\mathbf{0 \%}$ & $\mathbf{1 0 \%}$ & $\mathbf{2 0 \%}$ & $\mathbf{3 0 \%}$ & $\mathbf{4 0 \%}$ & $\mathbf{5 0 \%}$ \\
\hline $1,40 \%$ & $0,24 \%$ & $0,22 \%$ & $0,22 \%$ & $0,22 \%$ & $0,22 \%$ & $0,22 \%$ \\
$1,50 \%$ & $0,37 \%$ & $0,34 \%$ & $0,34 \%$ & $0,34 \%$ & $0,34 \%$ & $0,34 \%$ \\
$1,60 \%$ & $0,60 \%$ & $0,56 \%$ & $0,56 \%$ & $0,56 \%$ & $0,56 \%$ & $0,56 \%$ \\
$1,70 \%$ & $0,91 \%$ & $0,86 \%$ & $0,86 \%$ & $0,86 \%$ & $0,86 \%$ & $0,86 \%$ \\
$1,80 \%$ & $1,27 \%$ & $1,21 \%$ & $1,21 \%$ & $1,21 \%$ & $1,21 \%$ & $1,21 \%$ \\
$1,90 \%$ & $1,65 \%$ & $1,58 \%$ & $1,58 \%$ & $1,58 \%$ & $1,58 \%$ & $1,58 \%$ \\
$2,00 \%$ & $2,03 \%$ & $1,96 \%$ & $1,96 \%$ & $1,96 \%$ & $1,96 \%$ & $1,96 \%$ \\
$2,10 \%$ & $2,43 \%$ & $2,34 \%$ & $2,34 \%$ & $2,34 \%$ & $2,34 \%$ & $2,34 \%$ \\
$2,20 \%$ & $2,82 \%$ & $2,73 \%$ & $2,72 \%$ & $2,72 \%$ & $2,72 \%$ & $2,72 \%$ \\
$2,30 \%$ & $3,22 \%$ & $3,13 \%$ & $3,13 \%$ & $3,13 \%$ & $3,13 \%$ & $3,13 \%$ \\
\hline
\end{tabular}

Quanto ao período de 2003 a 2006, o mercado de ações do Brasil apresentou o maior retorno em reais entre todos os mercados, fazendo com que, da mesma forma que ocorreu no período de 2000 a 2005, um consentimento para aplicar-se $10 \%$ das carteiras dos fundos de pensão em ativos estrangeiros já praticamente atenderia os pesos em ativos estrangeiros das carteiras da fronteira. Os pesos de dez das carteiras da fronteira eficiente estão apresentados na Tabela 28:

Tabela 28 - Pesos dos Ativos em Carteiras da Fronteira Eficiente com Retornos em Reais para o Período de 2003 a 2006 com Limitação de 10\% a Aplicações no Exterior

\begin{tabular}{|c|c|c|c|c|c|c|c|c|c|c|c|c|c|}
\hline $\begin{array}{l}\text { Retorno } \\
\text { Esperado }\end{array}$ & Risco & CDI & $\begin{array}{l}\text { IGPM+ } \\
\text { cup }\end{array}$ & IRF-M & Argentina & Brasil & China & Índia & México & $\begin{array}{l}\text { Reino } \\
\text { Unido }\end{array}$ & Venezuela & Imóveis & $\begin{array}{l}\text { Financiamento } \\
\text { a Participantes }\end{array}$ \\
\hline $1,37 \%$ & $0,21 \%$ & $72,99 \%$ & $13,87 \%$ & $0,00 \%$ & $0,00 \%$ & $0,00 \%$ & $0,31 \%$ & $0,00 \%$ & $1,31 \%$ & $0,51 \%$ & $0,00 \%$ & $1,02 \%$ & $10,00 \%$ \\
\hline $1,48 \%$ & $0,30 \%$ & $46,09 \%$ & $10,90 \%$ & $39,56 \%$ & $0,00 \%$ & $0,21 \%$ & $0,28 \%$ & $0,00 \%$ & $2,96 \%$ & $0,00 \%$ & $0,00 \%$ & $0,00 \%$ & $0,00 \%$ \\
\hline $1,59 \%$ & $0,53 \%$ & $0,00 \%$ & $4,41 \%$ & $90,04 \%$ & $0,00 \%$ & $1,16 \%$ & $0,00 \%$ & $0,00 \%$ & $4,00 \%$ & $0,00 \%$ & $0,39 \%$ & $0,00 \%$ & $0,00 \%$ \\
\hline $1,69 \%$ & $0,83 \%$ & $0,00 \%$ & $0,00 \%$ & $87,91 \%$ & $0,00 \%$ & $6,79 \%$ & $0,00 \%$ & $0,28 \%$ & $4,11 \%$ & $0,00 \%$ & $0,92 \%$ & $0,00 \%$ & $0,00 \%$ \\
\hline $1,80 \%$ & $1,21 \%$ & $0,00 \%$ & $0,00 \%$ & $80,48 \%$ & $0,19 \%$ & $12,78 \%$ & $0,00 \%$ & $1,31 \%$ & $3,89 \%$ & $0,00 \%$ & $1,35 \%$ & $0,00 \%$ & $0,00 \%$ \\
\hline $1,90 \%$ & $1,60 \%$ & $0,00 \%$ & $0,00 \%$ & $73,04 \%$ & $0,47 \%$ & $18,76 \%$ & $0,00 \%$ & $2,32 \%$ & $3,64 \%$ & $0,00 \%$ & $1,76 \%$ & $0,00 \%$ & $0,00 \%$ \\
\hline $2,01 \%$ & $2,00 \%$ & $0,00 \%$ & $0,00 \%$ & $65,59 \%$ & $0,76 \%$ & $24,73 \%$ & $0,00 \%$ & $3,33 \%$ & $3,40 \%$ & $0,00 \%$ & $2,18 \%$ & $0,00 \%$ & $0,00 \%$ \\
\hline $2,12 \%$ & $2,40 \%$ & $0,00 \%$ & $0,00 \%$ & $58,90 \%$ & $0,85 \%$ & $31,10 \%$ & $0,00 \%$ & $4,13 \%$ & $2,33 \%$ & $0,00 \%$ & $2,68 \%$ & $0,00 \%$ & $0,00 \%$ \\
\hline $2,22 \%$ & $2,81 \%$ & $0,00 \%$ & $0,00 \%$ & $52,43 \%$ & $0,88 \%$ & $37,57 \%$ & $0,00 \%$ & $4,88 \%$ & $1,04 \%$ & $0,00 \%$ & $3,21 \%$ & $0,00 \%$ & $0,00 \%$ \\
\hline $2,33 \%$ & $3,33 \%$ & $0,00 \%$ & $0,00 \%$ & $50,00 \%$ & $0,00 \%$ & $50,00 \%$ & $0,00 \%$ & $0,00 \%$ & $0,00 \%$ & $0,00 \%$ & $0,00 \%$ & $0,00 \%$ & $0,00 \%$ \\
\hline
\end{tabular}

A Tabela 28 indica que os mercados presentes nas carteiras de menor risco e retorno esperado são China, México e Reino Unido. Já nas carteiras de maior risco e retorno esperado aparecem os mercados argentino, brasileiro, indiano, mexicano e venezuelano. Neste período, a classe de ativos de maior retorno da amostra foi o de ações brasileiras representada pelo índice Bovespa, que teve todo seu limite de 50\% da carteira utilizado na carteira de maior retorno da fronteira eficiente. 


\section{CONCLUSÕES}

O objetivo da pesquisa foi identificar impactos nas carteiras dos investidores institucionais no Brasil a partir do investimento em ativos estrangeiros no período de 2000 a 2006. Além disso, analisar os mercados que gerariam maiores benefícios de diversificação pela inclusão nas carteiras. Esta análise buscou inovar no sentido de considerar a diversificação internacional do ponto de vista do investidor brasileiro e investigou os efeitos de alguns graus de abertura para aplicações no exterior da regulamentação atual dos fundos de pensão no desempenho das carteiras.

Os resultados obtidos demonstraram que a regulamentação, ao restringir aplicações no exterior, impediu a formação de carteiras de menor risco para um determinado nível de retorno e, ainda, a possibilidade da existência de carteiras com maiores retornos do que aquelas com investimentos apenas no mercado doméstico. Essa situação se agrava quando considerado período de análise mais recente onde a rentabilidade dos títulos públicos se reduz. Assim, o estudo mostra que a regulamentação vigente no período resultou numa menor eficiência na alocação dos recursos dos investidores institucionais.

Essa situação começou a ser mudada parcialmente agora em 2007, com o início da internacionalização das carteiras dos investidores institucionais. Em 30 de março de 2007, a fim de adequar os fundos de investimento para um cenário de menor rentabilidade dos títulos públicos, a CVM publicou a Instrução n 450, que altera a Instrução CVM no 409 de 2004, possibilitando ativos financeiros negociados no exterior representem até $20 \%$ dos fundos multimercados e $10 \%$ nas demais classes de fundos. A possibilidade de aquisição de ativos no exterior pelos fundos de investimento depende ainda de alterações na legislação cambial por parte do Banco Central do Brasil. Recentemente, a CVM propôs audiência pública relativa à criação de uma nova modalidade de fundo de investimento, destinada a investidores superqualificados, com disponibilidade de recursos superiores a $\mathrm{R} \$ 1$ milhão, passíveis de aplicar até $100 \%$ de seu patrimônio em ativos no exterior.

Com o mesmo objetivo, o Conselho Monetário Nacional (CMN) aprovou, no dia 30 de maio de 2006, um conjunto de mudanças na Resolução 3.121/03, referente à aplicação de recursos dos fundos de pensão. Diante das alterações introduzidas na legislação, que há mais de três anos regula a aplicação dos recursos dos fundos de pensão, o CMN optou por sua revogação e 
edição de uma nova resolução, a Resolução CMN 3.456/07. Entre as alterações está a permissão às entidades para adquirir cotas de fundos de investimento multimercados, dentro da carteira de renda variável, com limite de aplicação de até 3\% dos recursos garantidores do plano de benefícios, quando constituídos na forma de condomínio aberto, podendo investimentos no exterior nos termos da regulamentação baixada pela Comissão de Valores Mobiliários (CVM).

Dessa forma, parece que o Brasil caminha para uma redução dos limites quantitativos e espera-se que seja um começo no sentido de adotarem-se regras mais prudenciais a fim de possibilitar maior liberdade para que os gestores de recursos possam constituir carteiras mais eficientes para os investidores institucionais no Brasil. 


\section{REFERÊNCIAS BIBLIOGRÁFICAS}

AGGARWAL, R.; SCHIRM, D. C. Global Portfolio Management: risk management, market microstructure and implementation issues. San Diego: Academic Press, 1995.

ARIDA, P. "Ainda sobre a Conversibilidade". Revista de Economia Política, Vol. 23, n 3, julho-setembro, p. 135-142, 2003a.

ARIDA, P. "Por uma Moeda Plenamente Conversível". Revista de Economia Política, Vol. 23, n 3, julho-setembro, p. 151-154, 2003 b.

ARIDA, P.; BACHA, E. L.; LARA-RESENDE, A. "Credit, interest, and jurisdictional uncertainty: conjectures on the case of Brazil", In: F. GIAVAZZI; I. GOLDFAJN e S. HERRERA (Org.). Inflation Targeting, Debt and the Brazilian Experience: 1999 to 2003. Cambridge, M.A.: MIT Press, 2005.

BACHA, E. L.; CHRYSOSTOMO, L. O. (Org.). Mercado de Capitais e Crescimento Econômico: Lições Internacionais, Desafios Brasileiros. Rio de Janeiro: Contra Capa, 2005.

BELlATO, L. L. N.; SANVICENTE, A. Z. Determinação do Grau Necessário de Diversificação de uma Carteira de Ações no Mercado de Capitais Brasileiro. Anais do VII Seminário em Administração FEA-USP, 2004. Disponível em: <http://www.ead.fea.usp.br>. Acesso em 30 de outubro de 2006.

BIS. Sixty Eighth Annual Report, Chapter V: Asset prices and the asset management industry. Basel: Bank for International Settlements, 1998.

BODIE, Zvi; KANE, Alex; MARCUS, Alan J. Investments. 5th ed. Boston: McGrawHill/Irwin, 2002.

BORENSZTEIN, E., YEYATI, E. L. e PANIZZA, U. Living with Debt: How to Limit the Risks of Sovereign Finance. Economic and Social Progress in Latin America 2007 Report. Editado pelo Inter-American Development Bank. Harvard University, David Rockefeller Center for Latin American Studies, 2006.

BOULIER, Jean-François. Gestão Financeira dos Fundos de Pensão. São Paulo: Pearson Education, 2003.

BRESSER-PEREIRA, L. C. e NAKANO, Y. "Crescimento Econômico com Poupança Externa?” Revista de Economia Política, v. 23, n² 2, p. 3-27, abril/junho 2003.

BRITO, N. O. (Org.). "O efeito da diversificação do risco no mercado acionário brasileiro". Gestão de Investimentos. São Paulo: Atlas, 1989. 
CABELlO, L. A. V. Otimização de Carteiras Internacionais: Efeitos dos Países Emergentes e Risco Cambial. Porto Alegre, 2002. Dissertação (Mestrado em Administração) - Programa de Pós-Graduação em Administração da Universidade Federal do Rio Grande do Sul.

CAMPBELL, J. Y., LO, A. W. e MACKINLAY, A. C. The Econometrics of Financial Markets. Princeton, New York: Princeton University Press, 1997.

CHAN-LAU, Jorge A. "Pension Funds and Emerging Markets". IMF Working Paper No. 04/181, September 2004. Disponível em: <http://ssrn.com/abstract=605884>. Acesso em: 06 de julho de 2006 .

COPELAND, T. E.; WESTON, J. F.; SHASTRI, K. Financial Theory and Corporate Policy. $4^{\circ}$ edição. Pearson Addison Wesley, 2005.

COSTA, M. R. T. Previdência Privada, Seguradoras e Capitalização: o efeito da regulamentação. Rio de Janeiro, 1998. Dissertação (Mestrado em Administração) Instituto de Pós-Graduação e Pesquisa em Administração da Universidade Federal do Rio de Janeiro.

DAVIS, E. Philip. Pension Fund Management and International Investment - A Global Perspective. Discussion Paper PI-0206. Londres: The Pensions Institute, 2002. Disponível em: <http://www.pensions-institute.org/workingpapers/wp0206.pdf.>. Acesso em 19 de março de 2006.

DAVIS, P. E., STEIL, B. Institutional Investors. Cambridge, MA: MIT Press, 2001.

ELTON, E. J.; GRUBER, M. J. Modern Portfolio Theory and Investment Analysis. $6^{\text {a }}$ edição. New York: Wiley, 2003.

EUN, C. S.; RESNICK, B. G. "Exchange Rate Uncertainty, Forward Contracts and International Portfolio Selection". Journal of Finance, n. 43, v.1, pp. 197-215, March 1988.

EVANS, J. L.; ARCHER, S. H. "Diversification and the Reduction of Dispersion: An Empirical Analysis” Journal of Finance, v. 23, Dec. 1968, p.761-767.

FISCHER, S. "Financial Market Liberalization". The OECD Observer, pp. 37- 40, Sept. 2006.

FRANCIS, J. C. Investments: Analysis and Management, 5th. ed. New York: Mc GrawHill,1991. 
GIL, Antonio C. Métodos e Técnicas de Pesquisa Social. São Paulo: Atlas, 1987.

GOLDFAJN, I.; MINELlA, A. "Capital Flows and Controls in Brazil: What Have We Learned?" NBER Working Paper n. 11640, 2005. Disponível em: <www.nber.org/papers/w11640>.

GRUBEL, Hebert. "Internationally Diversified Portfolios: Welfare Gains and Capital Flows". American Economic Review, p. 1299-1314, Dec. 1968.

HAUSER, S., MARCUS M. e YAARI, U. "Investing in Emerging Stock Markets: Is It Worthwhile Hedging Foreign Exchange Risk?”. Journal of Portfolio Management, v. 20, n. 3, pp. 76-81, Spring 1994.

HOLZMANN, R.; MACARTHUR, I. W. ;YVONNE, S. "Pension Systems in East Asia and the Pacific: Challenges and Opportunities." Social Protection Discussion Paper $n^{\circ} .0014$. Washington, DC: World Bank, June 2000.

HUNTER, J. E.; COGGIN, T. D. "An Analysis of the Diversification Benefit from International Equity Investment". Journal of Portfolio Management, v. 17, n.1, pp. 3336, Fall 1990.

JORION, P."Portfolio Optimization in Practice". Financial Analysts Journal, n. 48, v. 1, pp. 68-74, January- February 1992.

LEAL, R. P. C.; SILVA, A. L. C.; RIBEIRO, T. S. Alocação Ótima de Ativos em Fundos de Pensão Brasileiros. Rio de Janeiro: Relatórios COPPEAD/UFRJ, v. 351, 2001.

LEITE, H. P.; SANVICENTE, A. Z. Índice Bovespa: um padrão para os investimentos brasileiros. São Paulo: Atlas, 1994.

LEVY, H.; SARNAT, M. "International Diversification of Investment Portfolios”. American Economic Review, n. 60, p. 668-692, September 1970.

MARKOWITZ, H. M. Portfolio Selection. Journal of Finance, v. 7, Mar. 1952, p.77-91.

MARTINS, G. A. Manual para Elaboração de Monografias e Dissertações. 3 ed. São Paulo: Atlas, 2002.

MAURER, R. "Institutional Investors in Germany: Insurance Companies and Investment Funds". CFS Working Paper n²003/14, June 2003. Disponível em: <http://ssrn.com/abstract=414100>. Acesso em: 06 de dezembro de 2006. 
DE MEDEIROS, O. R., "The Role of Institutional Investors as Providers of Long-Term Financing in Brazil". Working Paper, August 2006. Disponível em SSRN: <http://ssrn.com/abstract=925471 > . Acesso em 17 de dezembro de 2006.

NAKAMURA, W. T. Eficiência da carteira teórica do Índice Bovespa no contexto da Moderna Teoria de Carteiras. São Paulo, 1998. Tese (Doutorado em Administração) Programa de Pós-Graduação em Administração da Faculdade de Economia, Administração e Contabilidade da Universidade de São Paulo.

OCDE. Survey of Investment Regulations of Pension Funds. Paris: June 2006.

PINHEIRO, R. P.; PAIXÃO, L. A. e CHEDEAK, J. C. S. "Regulação dos investimentos nos fundos de pensão: evolução histórica, tendências recentes e desafios regulatórios". Revista de Previdência da UERJ, n.3, set. 2005.

PINTO, A. C. F. "Efeito da Regulamentação Econômica: O Caso dos Investidores Institucionais". Revista Brasileira de Mercado de Capitais, v.10, n.31, pp. 191-220, jul./set. 1984.

REISEN, H. "Liberalizing foreign investments by pension funds: positive and normative aspects". World Development, v. 25, n. 7, p. 1173-1182, 1997.

REISEN, H.; WILlIAMSON, J. "Pension Funds, Capital Controls and Macroeconomic Stability", in BODIE, Z. e DAVIS, P. Foundations of Pension Finance, Edward Elgar, 2000.

RICHARDSON, Roberto J. Pesquisa Social: Métodos e Técnicas. 2 ed. São Paulo: Atlas, 1989.

RIECHE, F. C. "Gestão de Riscos em Fundos de Pensão no Brasil: Situação Atual da Legislação e Perspectivas”. Revista do BNDES, Rio de Janeiro, v. 12, n. 23, pp. 219-242, jun. 2005.

ROLDOS, J. E. "Pension Reform, Investment Restrictions, and Capital Markets". IMF Policy Discussion Paper, $\mathrm{n}^{\circ} 04 / 4$, September 2004. Disponível em: <www.imf.org/external/pubs/ft/pdp/2004/pdp04.pdf >. Acesso em: 10 de julho de 2006.

ROSS, S. A.; WESTERFIELD, R.W. e JAFFE, J.F. Administração Financeira - Corporate Finance. São Paulo: Atlas, 2002.

RUDD, A. "International Investing: The case for Emerging Markets". In: ALIBER, Robert Z., BRUCE, Brian R. Global portfolios: quantitative strategies for maximum performance. Homewood: Irwin, 1991. 
SAVOIA, J. R. F. "Retirement Income Security In Brazil: Reforms in the Complementary Pension Funds Regime". In: Conferência de Pensão Privada OCDE, 2001.

SHARPE, W. F. "Capital Asset Prices: a theory of market equilibrium under conditions of risk". The Journal of Finance, v. 19, pp. 425-442, Sept. 1964.

SHARPE, W. F. "Diversification and Porfolio Risk". Financial Analysts Journal, v. 23, n. 6, pp.74-79, Nov/Dec. 1972.

SOLNIK, B. H. "Why Not Diversify Internationally Rather than Domestically?" Financial Analistys Journal, v. 30, n. 4, p. 48-54, May 1974.

SOLNIK, B. H. International Investments. 3nd ed. Reading, MA: Addison-Wesley Publishing Company, 1996.

STATMAN, M.; SCHEID, J. "Global Diversification". Journal of Investment Management, v. 3, n. 1, pp. 1-11, 2005.

STUDART, R. Pension funds and the financing productive investment: an analysis based on Brazil's recent experience. UN-CEPAL, Serie Financiamiento del Desarollo $\mathrm{n}^{\circ} 102$, LC/L.1409-P, August 2000.

TOBIN, J. "Liquidity preference as a behavior toward risk". Review of Economic Studies, pp. 65-86, February 1958.

VERGARA, Sylvia. C. Projetos e Relatórios de Pesquisa em Administração. 2 ed. São Paulo: Atlas, 1998.

VITTAS, D. "Institutional Investors and Securities Markets: Which Comes First?". World Bank Policy Research Working Paper $N^{\mathbf{0}}$ 2032, June 1998. Disponível em: <http://ssrn.com/abstract=597209>. Acesso: 30 de outubro de 2006.

YERMO, Juan. Survey of Investment Regulation of Pension Funds. Paris: OECD, 2003.

ZANETTE, J. Z. Otimização de Portfólios Internacionais Através da Abordagem de Média-Variância e o Efeito do Componente Brasil. Porto Alegre, 1995. Dissertação (Mestrado em Administração) - Programa de Pós-Graduação em Administração da Universidade Federal do Rio Grande do Sul. 


\section{APÊNDICES}

APÊNDICE A - MATRIZES DE CORRELAÇÕES ENTRE OS ATIVOS

APÊNDICE B - MATRIZES DE CORRELAÇÕES ENTRE OS RETORNOS MENSAIS DOS ÍNDICES DE MERCADO DE AÇÕES

APÊNDICE C - RETORNO, RISCO E PESOS DOS ATIVOS NAS CARTEIRAS DA FRONTEIRA EFICIENTE FORMADA POR ÍNDICES DE MERCADOS DE AÇÕES APÊNDICE D - FRONTEIRAS EFICIENTES DE FUNDOS DE PENSÃO COM RETORNOS EM MOEDA LOCAL PARA DIFERENTES GRAUS DE ABERTURA PARA INVESTIMENTOS NO EXTERIOR

APÊNDICE E - FRONTEIRAS EFICIENTES DE FUNDOS DE PENSÃO COM RETORNOS EM REAIS PARA DIFERENTES GRAUS DE ABERTURA PARA INVESTIMENTOS NO EXTERIOR

APÊNDICE F - FRONTEIRAS EFICIENTES COM RETORNOS EM MOEDA LOCAL PARA DIFERENTES GRAUS DE ABERTURA A INVESTIMENTOS NO EXTERIOR DADOS RETORNOS DAS CARTEIRAS DA FRONTEIRA EM INTERVALOS DE $0,05 \%$

APÊNDICE G - FRONTEIRAS EFICIENTES COM RETORNOS EM REAIS PARA DIFERENTES GRAUS DE ABERTURA A INVESTIMENTOS NO EXTERIOR DADOS RETORNOS DAS CARTEIRAS DA FRONTEIRA EM INTERVALOS DE $0,05 \%$ 


\section{APÊNDICE A - MATRIZES DE CORRELAÇÕES ENTRE OS ATIVOS}

\begin{tabular}{|c|c|c|c|c|c|c|c|c|c|c|c|c|c|c|c|c|}
\hline \multicolumn{17}{|c|}{ Matrizes de Correlações entre os Ativos com Retornos em Moeda de Cada País } \\
\hline $\begin{array}{l}2000 \text { a } 2005 \\
\text { CDI }\end{array}$ & $\begin{array}{l}\text { CDI } \\
1.00\end{array}$ & IGPM & IRF_M & FIEX & ALEMAN & RGENTIN & AUSTRALI. & BRASIL & CANADA & CHILE & CHINA & CINGAPUF & COREIA & SESPANHAE & & FRANCA \\
\hline $\begin{array}{l}\text { IGPM } \\
\text { IRF_M }\end{array}$ & $\begin{array}{l}0.07 \\
0.59\end{array}$ & $\begin{array}{l}1.00 \\
0.08\end{array}$ & 1.00 & & & & & & & & & & & & & \\
\hline FIEX & 0.13 & 0.42 & 0.27 & 1.00 & & & & & & & & & & & & \\
\hline ALEMANHA & 0.14 & -0.20 & 0.29 & -0.10 & 1.00 & & & & & & & & & & & \\
\hline ARGENTINA & 0.17 & 0.03 & 0.22 & 0.05 & 0.26 & 1.00 & & & & & & & & & & \\
\hline AUSTRALIA & 0.05 & -0.19 & 0.31 & -0.04 & 0.65 & 0.24 & 1.00 & & & & & & & & & \\
\hline BRASIL & 0.19 & 0.01 & 0.52 & 0.22 & 0.61 & 0.28 & 0.63 & 1.00 & & & & & & & & \\
\hline CANADA & 0.22 & -0.07 & 0.41 & 0.09 & 0.64 & 0.33 & 0.63 & 0.69 & 1.00 & & & & & & & \\
\hline CHILE & 0.28 & -0.01 & 0.32 & -0.02 & 0.49 & 0.17 & 0.49 & 0.47 & 0.50 & 1.00 & & & & & & \\
\hline CHINA & -0.07 & -0.16 & -0.13 & 0.01 & 0.05 & 0.02 & 0.00 & 0.12 & 0.15 & -0.02 & 1.00 & & & & & \\
\hline CINGAPURA & 0.16 & -0.17 & 0.33 & 0.02 & 0.60 & 0.43 & 0.68 & 0.50 & 0.59 & 0.38 & -0.08 & 1.00 & & & & \\
\hline COREIA_SUL & 0.10 & -0.24 & 0.37 & -0.02 & 0.61 & 0.38 & 0.67 & 0.58 & 0.66 & 0.51 & 0.08 & 0.54 & 1.00 & & & \\
\hline ESPANHA & 0.14 & -0.06 & 0.33 & 0.03 & 0.86 & 0.29 & 0.65 & 0.65 & 0.68 & 0.52 & -0.03 & 0.54 & 0.67 & 1.00 & & \\
\hline EUA & 0.18 & -0.03 & 0.35 & 0.06 & 0.83 & 0.23 & 0.64 & 0.69 & 0.80 & 0.53 & 0.06 & 0.59 & 0.64 & 0.77 & 1.00 & \\
\hline FRANCA & 0.12 & -0.16 & 0.25 & -0.04 & 0.95 & 0.23 & 0.66 & 0.61 & 0.70 & 0.51 & 0.05 & 0.56 & 0.59 & 0.85 & 0.84 & 1.00 \\
\hline HOLANDA & 0.08 & -0.20 & 0.29 & -0.01 & 0.93 & 0.20 & 0.69 & 0.57 & 0.65 & 0.47 & 0.04 & 0.60 & 0.62 & 0.82 & 0.80 & 0.94 \\
\hline HONG_KONG & 0.14 & -0.08 & 0.33 & -0.03 & 0.60 & 0.23 & 0.57 & 0.69 & 0.76 & 0.47 & 0.17 & 0.62 & 0.65 & 0.62 & 0.71 & 0.59 \\
\hline INDIA & 0.21 & -0.12 & 0.40 & 0.04 & 0.40 & 0.32 & 0.55 & 0.54 & 0.52 & 0.37 & 0.06 & 0.51 & 0.63 & 0.47 & 0.38 & 0.37 \\
\hline ITALIA & 0.14 & -0.04 & 0.25 & 0.03 & 0.85 & 0.33 & 0.60 & 0.53 & 0.65 & 0.51 & 0.05 & 0.56 & 0.60 & 0.82 & 0.73 & 0.87 \\
\hline JAPAO & 0.17 & -0.27 & 0.24 & -0.07 & 0.41 & 0.09 & 0.55 & 0.44 & 0.56 & 0.22 & 0.09 & 0.41 & 0.60 & 0.51 & 0.49 & 0.44 \\
\hline MALASIA & 0.27 & -0.15 & 0.22 & -0.06 & 0.36 & 0.26 & 0.25 & 0.30 & 0.29 & 0.42 & 0.03 & 0.43 & 0.34 & 0.29 & 0.30 & 0.29 \\
\hline MEXICO & 0.12 & -0.15 & 0.39 & 0.06 & 0.61 & 0.56 & 0.69 & 0.65 & 0.71 & 0.43 & 0.07 & 0.68 & 0.72 & 0.66 & 0.66 & 0.58 \\
\hline REINO_UNIDO & 0.13 & -0.15 & 0.31 & 0.00 & 0.86 & 0.19 & 0.62 & 0.63 & 0.69 & 0.56 & 0.02 & 0.55 & 0.59 & 0.80 & 0.86 & 0.88 \\
\hline SUECIA & 0.15 & -0.04 & 0.28 & -0.05 & 0.87 & 0.19 & 0.62 & 0.59 & 0.69 & 0.51 & 0.05 & 0.55 & 0.65 & 0.83 & 0.82 & 0.88 \\
\hline SUICA & 0.09 & -0.34 & 0.33 & -0.15 & 0.81 & 0.12 & 0.57 & 0.50 & 0.61 & 0.41 & 0.12 & 0.47 & 0.55 & 0.67 & 0.75 & 0.82 \\
\hline TAIWAN & 0.26 & -0.16 & 0.28 & 0.04 & 0.48 & 0.48 & 0.46 & 0.45 & 0.48 & 0.38 & 0.11 & 0.51 & 0.65 & 0.50 & 0.46 & 0.46 \\
\hline VENEZUELA & 0.22 & -0.07 & 0.10 & 0.14 & 0.07 & 0.20 & 0.04 & 0.25 & 0.23 & 0.17 & 0.13 & 0.06 & 0.21 & 0.09 & 0.17 & 0.09 \\
\hline IMOVEIS & 0.00 & 0.28 & 0.13 & 0.13 & 0.00 & -0.10 & -0.10 & 0.13 & 0.06 & -0.05 & 0.00 & -0.14 & -0.07 & 0.07 & 0.13 & 0.01 \\
\hline INPC & 0.32 & 0.82 & 0.21 & 0.27 & -0.05 & 0.20 & -0.14 & 0.09 & 0.06 & 0.08 & -0.10 & -0.04 & -0.07 & 0.07 & 0.07 & -0.05 \\
\hline TR & 0.86 & 0.16 & 0.42 & -0.05 & 0.08 & 0.06 & -0.01 & 0.10 & 0.10 & 0.24 & -0.15 & 0.04 & -0.04 & 0.03 & 0.08 & 0.06 \\
\hline
\end{tabular}

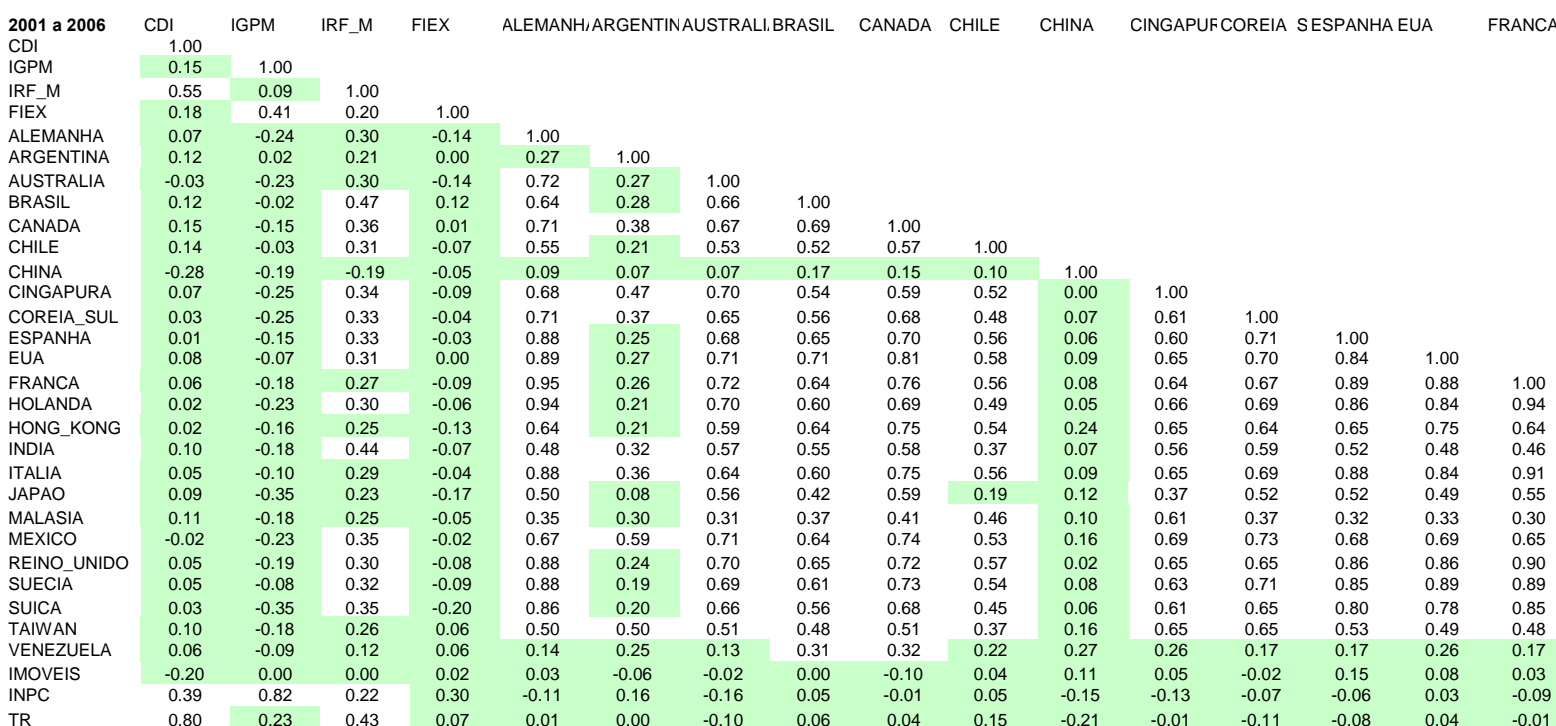

\begin{tabular}{|c|c|c|c|c|c|c|c|c|c|c|c|c|c|c|c|c|}
\hline \multirow{2}{*}{$\begin{array}{l}2003 \text { a } 2006 \\
\text { CDI } \\
\text { IGPM }\end{array}$} & \multirow{2}{*}{$\begin{array}{r}\text { CDI } \\
1.00 \\
-0.02\end{array}$} & \multirow{2}{*}{$\begin{array}{l}\text { IGPM } \\
1.00\end{array}$} & \multirow[t]{2}{*}{ IRF_M } & \multirow[t]{2}{*}{ FIEX } & \multicolumn{4}{|c|}{ ALEMANH/ARGENTINAUSTRALI، BRASIL } & \multirow[t]{2}{*}{ CANADA } & \multirow[t]{2}{*}{ CHILE } & \multirow[t]{2}{*}{ CHINA } & \multicolumn{2}{|c|}{ CINGAPUFCOREIA } & \multicolumn{2}{|c|}{ ESPANHA EUA } & \multirow[t]{2}{*}{ FRANCA } \\
\hline & & & & & & & & & & & & & & & & \\
\hline IRF_M & 0.60 & -0.04 & 1.00 & & & & & & & & & & & & & \\
\hline FIEX & 0.15 & 0.23 & 0.02 & 1.00 & & & & & & & & & & & & \\
\hline ALEMANHA & 0.12 & -0.43 & 0.35 & -0.37 & 1.00 & & & & & & & & & & & \\
\hline $\begin{array}{l}\text { ARGENTINA } \\
\text { AUSTRALIA }\end{array}$ & $\begin{array}{r}0.11 \\
-0.05\end{array}$ & $\begin{array}{l}-0.10 \\
-0.36\end{array}$ & $\begin{array}{l}0.32 \\
0.18\end{array}$ & $\begin{array}{l}-0.16 \\
-0.37\end{array}$ & $\begin{array}{l}0.32 \\
0.61\end{array}$ & $\begin{array}{l}1.00 \\
0.28\end{array}$ & 1.00 & & & & & & & & & \\
\hline $\begin{array}{l}\text { AUSTRALIA } \\
\text { BRASIL }\end{array}$ & $\begin{array}{l}-0.05 \\
0.09\end{array}$ & $\begin{array}{l}-0.36 \\
-0.15\end{array}$ & $\begin{array}{l}0.18 \\
0.43\end{array}$ & $\begin{array}{r}-0.37 \\
0.00\end{array}$ & $\begin{array}{l}0.61 \\
0.39\end{array}$ & $\begin{array}{l}0.28 \\
0.44\end{array}$ & 0.54 & 1.00 & & & & & & & & \\
\hline CANADA & 0.12 & -0.37 & 0.23 & 0.00 & 0.59 & 0.51 & 0.66 & 0.58 & 1.00 & & & & & & & \\
\hline $\begin{array}{l}\text { CHILE } \\
\text { CHINA }\end{array}$ & $\begin{array}{r}0.10 \\
-0.27\end{array}$ & $\begin{array}{l}-0.02 \\
-0.06\end{array}$ & $\begin{array}{l}0.26 \\
-0.11\end{array}$ & $\begin{array}{l}-0.25 \\
0.16\end{array}$ & $\begin{array}{r}0.45 \\
-0.04\end{array}$ & $\begin{array}{l}0.33 \\
0.17\end{array}$ & $\begin{array}{l}0.42 \\
0.07\end{array}$ & $\begin{array}{l}0.35 \\
0.23\end{array}$ & $\begin{array}{l}0.42 \\
0.16\end{array}$ & $\begin{array}{l}1.00 \\
0.08\end{array}$ & 1.00 & & & & & \\
\hline $\begin{array}{l}\text { CINGAPURA } \\
\text { COREIA }\end{array}$ & $\begin{array}{l}0.02 \\
0.10\end{array}$ & $\begin{array}{l}-0.39 \\
-0.47\end{array}$ & $\begin{array}{l}0.31 \\
0.30\end{array}$ & $\begin{array}{l}-0.25 \\
-0.17\end{array}$ & $\begin{array}{l}0.53 \\
0.69\end{array}$ & $\begin{array}{l}0.41 \\
0.33\end{array}$ & $\begin{array}{l}0.55 \\
0.55\end{array}$ & $\begin{array}{l}0.37 \\
0.43\end{array}$ & $\begin{array}{l}0.57 \\
0.65\end{array}$ & $\begin{array}{l}0.44 \\
0.39\end{array}$ & $\begin{array}{l}0.02 \\
0.02\end{array}$ & $\begin{array}{l}1.00 \\
0.56\end{array}$ & 1.00 & & & \\
\hline ESPANHA & -0.05 & -0.39 & 0.28 & -0.37 & 0.80 & 0.39 & 0.57 & 0.33 & 0.54 & 0.45 & -0.03 & 0.55 & 0.64 & 1.00 & & \\
\hline EUA & 0.08 & -0.26 & 0.30 & -0.18 & 0.78 & 0.39 & 0.62 & 0.59 & 0.68 & 0.50 & 0.05 & 0.54 & 0.65 & 0.68 & 1.00 & \\
\hline FRANCA & 0.03 & -0.46 & 0.28 & -0.35 & 0.93 & 0.30 & 0.68 & 0.40 & 0.68 & 0.48 & -0.04 & 0.54 & 0.73 & 0.80 & 0.74 & 1.00 \\
\hline HOLANDA & 0.00 & -0.54 & 0.27 & -0.33 & 0.89 & 0.17 & 0.63 & 0.35 & 0.60 & 0.37 & -0.09 & 0.55 & 0.73 & 0.76 & 0.68 & 0.93 \\
\hline HONG_KONG & -0.01 & -0.28 & 0.20 & -0.05 & 0.35 & 0.32 & 0.39 & 0.52 & 0.66 & 0.47 & 0.24 & 0.62 & 0.53 & 0.37 & 0.58 & 0.40 \\
\hline INDIA & 0.09 & -0.46 & 0.40 & -0.16 & 0.42 & 0.42 & 0.53 & 0.42 & 0.53 & 0.19 & -0.03 & 0.67 & 0.57 & 0.51 & 0.43 & 0.45 \\
\hline ITALIA & -0.02 & -0.27 & 0.27 & -0.21 & 0.74 & 0.40 & 0.51 & 0.34 & 0.64 & 0.45 & -0.02 & 0.52 & 0.65 & 0.75 & 0.64 & 0.78 \\
\hline JAPAO & 0.22 & -0.45 & 0.38 & -0.04 & 0.39 & 0.21 & 0.53 & 0.34 & 0.55 & 0.04 & -0.02 & 0.49 & 0.55 & 0.37 & 0.40 & 0.48 \\
\hline MALASIA & 0.02 & -0.22 & 0.12 & 0.00 & 0.24 & 0.28 & 0.37 & 0.29 & 0.45 & 0.42 & 0.25 & 0.57 & 0.43 & 0.31 & 0.39 & 0.26 \\
\hline MEXICO & -0.09 & -0.34 & 0.32 & -0.18 & 0.53 & 0.60 & 0.63 & 0.58 & 0.66 & 0.32 & 0.17 & 0.56 & 0.70 & 0.62 & 0.62 & 0.58 \\
\hline REINO_UNIDO & 0.01 & -0.39 & 0.23 & -0.33 & 0.72 & 0.34 & 0.57 & 0.43 & 0.57 & 0.48 & -0.09 & 0.51 & 0.63 & 0.69 & 0.67 & 0.75 \\
\hline SUECIA & 0.06 & -0.33 & 0.39 & -0.29 & 0.84 & 0.25 & 0.64 & 0.36 & 0.56 & 0.45 & 0.01 & 0.60 & 0.67 & 0.76 & 0.68 & 0.85 \\
\hline SUICA & 0.07 & -0.50 & 0.33 & -0.44 & 0.85 & 0.26 & 0.51 & 0.36 & 0.49 & 0.32 & -0.09 & 0.56 & 0.67 & 0.72 & 0.67 & 0.85 \\
\hline TAIWAN & 0.13 & -0.31 & 0.20 & 0.05 & 0.28 & 0.20 & 0.43 & 0.25 & 0.47 & 0.23 & 0.28 & 0.55 & 0.53 & 0.26 & 0.41 & 0.30 \\
\hline VENEZUELA & 0.10 & -0.07 & 0.16 & 0.12 & 0.14 & 0.40 & 0.08 & 0.33 & 0.36 & 0.25 & 0.33 & 0.44 & 0.19 & 0.13 & 0.34 & 0.16 \\
\hline $\begin{array}{l}\text { IMOVEIS } \\
\text { INPC }\end{array}$ & $\begin{array}{c}-0.23 \\
0.41\end{array}$ & $\begin{array}{l}0.00 \\
0.69\end{array}$ & $\begin{array}{l}-0.04 \\
0.23\end{array}$ & $\begin{array}{l}0.03 \\
0.19\end{array}$ & $\begin{array}{l}-0.02 \\
-0.20\end{array}$ & $\begin{array}{r}-0.11 \\
0.10\end{array}$ & $\begin{array}{l}-0.06 \\
-0.29\end{array}$ & $\begin{array}{l}-0.06 \\
-0.05\end{array}$ & $\begin{array}{l}-0.26 \\
-0.20\end{array}$ & $\begin{array}{l}0.00 \\
0.02\end{array}$ & $\begin{array}{l}0.12 \\
0.03\end{array}$ & $\begin{array}{r}0.04 \\
-0.26\end{array}$ & $\begin{array}{l}-0.07 \\
-0.26\end{array}$ & $\begin{array}{r}0.19 \\
-0.22\end{array}$ & $\begin{array}{r}0.05 \\
-0.07\end{array}$ & $\begin{array}{l}-0.02 \\
-0.28\end{array}$ \\
\hline TR & 0.82 & -0.01 & 0.54 & 0.08 & 0.13 & 0.00 & -0.06 & 0.05 & 0.00 & 0.20 & -0.18 & 0.03 & 0.06 & -0.04 & 0.13 & -0.03 \\
\hline
\end{tabular}




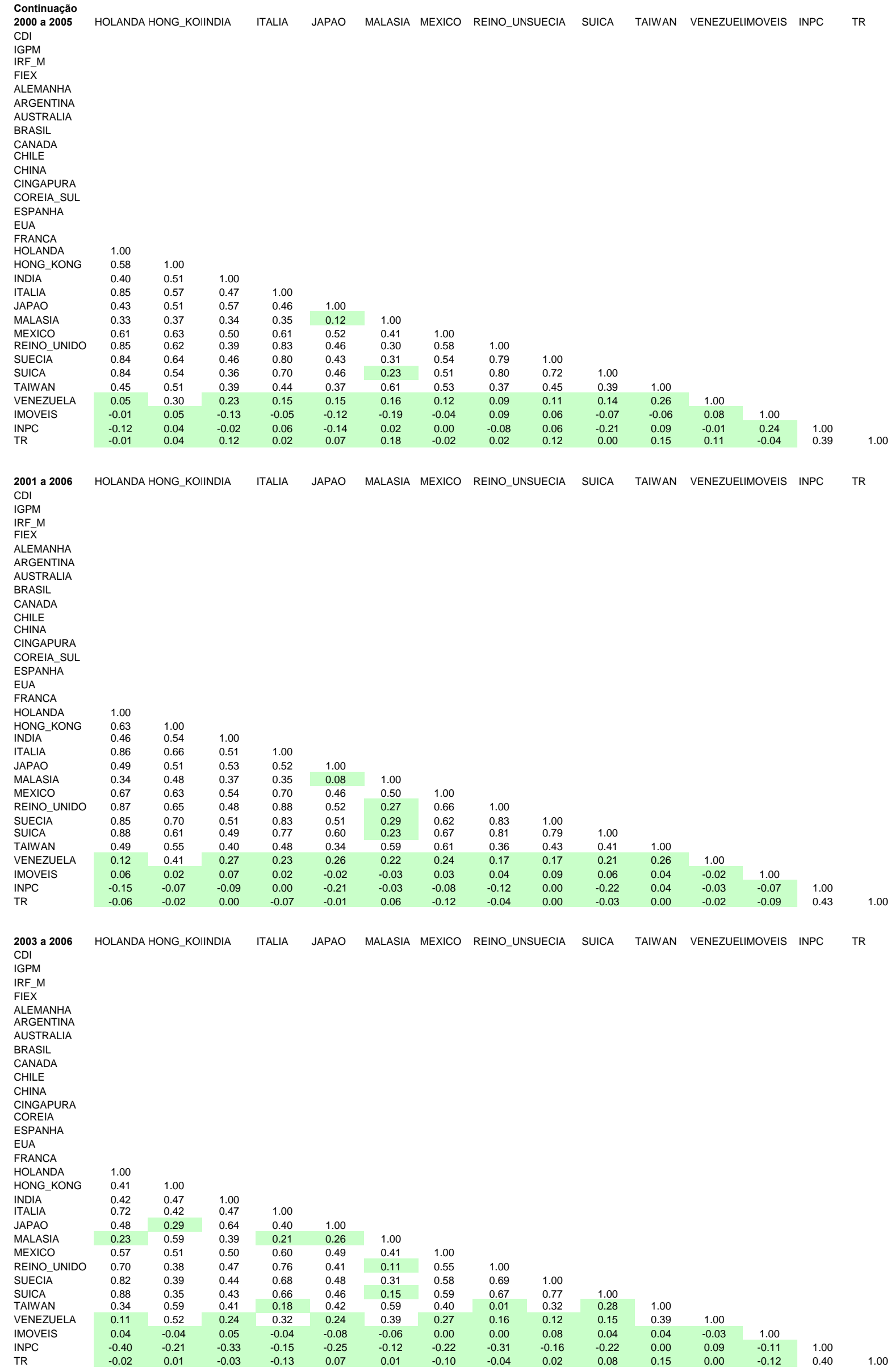




\begin{tabular}{|c|c|c|c|c|c|c|c|c|c|c|c|c|c|c|c|c|}
\hline \multicolumn{15}{|c|}{ Matrizes de Correlações entre os Ativos com Retornos em Reais } & EUA & FRANCA \\
\hline $\begin{array}{l}\text { CDI } \\
\text { IGPM }\end{array}$ & $\begin{array}{l}1.00 \\
0.07\end{array}$ & & & & & & & & & & & & & & & \\
\hline IRF_M & 0.59 & 0.08 & 1.00 & & & & & & & & & & & & & \\
\hline FIEX & 0.13 & 0.42 & 0.27 & 1.00 & & & & & & & & & & & & \\
\hline ALEMANHA & 0.07 & -0.11 & -0.07 & 0.06 & 1.00 & & & & & & & & & & & \\
\hline ARGENTINA & 0.14 & 0.21 & 0.05 & 0.06 & 0.15 & 1.00 & & & & & & & & & & \\
\hline AUSTRALIA & 0.01 & 0.04 & -0.12 & 0.22 & 0.50 & 0.24 & 1.00 & & & & & & & & & \\
\hline BRASIL & 0.19 & 0.01 & 0.52 & 0.22 & 0.31 & 0.14 & -0.01 & 1.00 & & & & & & & & \\
\hline CANADA & 0.11 & 0.03 & -0.06 & 0.28 & 0.54 & 0.28 & 0.79 & 0.11 & 1.00 & & & & & & & \\
\hline CHILE & 0.15 & 0.02 & -0.04 & 0.08 & 0.51 & 0.36 & 0.63 & 0.09 & 0.58 & 1.00 & & & & & & \\
\hline CHINA & -0.14 & -0.05 & -0.45 & 0.10 & 0.19 & 0.23 & 0.50 & -0.35 & 0.49 & 0.31 & 1.00 & & & & & \\
\hline CINGAPURA & 0.03 & -0.04 & -0.11 & 0.20 & 0.44 & 0.25 & 0.75 & -0.05 & 0.66 & 0.52 & 0.35 & 1.00 & & & & \\
\hline COREIA_SUL & 0.03 & -0.13 & 0.07 & 0.08 & 0.53 & 0.19 & 0.67 & 0.21 & 0.62 & 0.60 & 0.26 & 0.56 & 1.00 & & & \\
\hline ESPANHA & 0.03 & 0.13 & -0.15 & 0.24 & 0.74 & 0.31 & 0.75 & 0.11 & 0.70 & 0.65 & 0.38 & 0.53 & 0.61 & 1.00 & & \\
\hline EUA & 0.00 & 0.08 & -0.23 & 0.22 & 0.63 & 0.21 & 0.72 & -0.06 & 0.82 & 0.63 & 0.49 & $\begin{array}{l}0.67 \\
0.52\end{array}$ & $\begin{array}{l}0.63 \\
0.53\end{array}$ & $\begin{array}{l}0.72 \\
0.84\end{array}$ & $\begin{array}{l}1.00 \\
0.77\end{array}$ & \\
\hline FRANCA & 0.02 & 0.01 & -0.20 & 0.17 & 0.88 & 0.22 & 0.69 & 0.13 & 0.71 & 0.60 & 0.41 & 0.52 & 0.53 & 0.84 & 0.77 & 1.00 \\
\hline HOLANDA & -0.02 & -0.07 & -0.13 & 0.19 & 0.88 & 0.09 & 0.62 & 0.17 & 0.60 & 0.53 & 0.30 & 0.53 & 0.56 & 0.76 & 0.68 & 0.91 \\
\hline $\begin{array}{l}\text { HONG_KONG } \\
\text { INDIA }\end{array}$ & $\begin{array}{l}0.02 \\
0.12\end{array}$ & $\begin{array}{c}0.02 \\
-0.04\end{array}$ & $\begin{array}{l}-0.13 \\
0.04\end{array}$ & $\begin{array}{l}0.10 \\
0.15\end{array}$ & $\begin{array}{l}0.58 \\
0.35\end{array}$ & $\begin{array}{l}0.25 \\
0.35\end{array}$ & $\begin{array}{l}0.76 \\
0.66\end{array}$ & $\begin{array}{l}0.09 \\
0.08\end{array}$ & $\begin{array}{l}0.79 \\
0.58\end{array}$ & $\begin{array}{l}0.63 \\
0.53\end{array}$ & $\begin{array}{l}0.49 \\
0.36\end{array}$ & $\begin{array}{l}0.70 \\
0.60\end{array}$ & $\begin{array}{l}0.66 \\
0.62\end{array}$ & $\begin{array}{l}0.72 \\
0.55\end{array}$ & $\begin{array}{l}0.78 \\
0.47\end{array}$ & $\begin{array}{l}0.69 \\
0.43\end{array}$ \\
\hline $\begin{array}{l}\text { ITALIA } \\
\text { JAPAO }\end{array}$ & $\begin{array}{l}0.03 \\
0.08\end{array}$ & $\begin{array}{r}0.13 \\
-0.07\end{array}$ & $\begin{array}{l}-0.21 \\
-0.10\end{array}$ & $\begin{array}{l}0.22 \\
0.14\end{array}$ & $\begin{array}{l}0.74 \\
0.33\end{array}$ & $\begin{array}{l}0.29 \\
0.12\end{array}$ & $\begin{array}{l}0.72 \\
0.71\end{array}$ & $\begin{array}{l}-0.01 \\
-0.06\end{array}$ & $\begin{array}{l}0.70 \\
0.72\end{array}$ & $\begin{array}{l}0.62 \\
0.49\end{array}$ & $\begin{array}{l}0.47 \\
0.48\end{array}$ & $\begin{array}{l}0.58 \\
0.54\end{array}$ & $\begin{array}{l}0.52 \\
0.62\end{array}$ & $\begin{array}{l}0.85 \\
0.60\end{array}$ & $\begin{array}{l}0.71 \\
0.69\end{array}$ & $\begin{array}{l}0.88 \\
0.51\end{array}$ \\
\hline MALASIA & 0.10 & -0.03 & -0.25 & 0.08 & 0.31 & 0.22 & 0.53 & -0.28 & 0.48 & 0.55 & 0.50 & 0.62 & 0.40 & 0.46 & 0.56 & 0.44 \\
\hline MEXICO & -0.04 & -0.07 & -0.07 & 0.13 & 0.48 & 0.40 & 0.65 & 0.15 & 0.66 & 0.56 & 0.32 & 0.69 & 0.73 & 0.54 & 0.68 & 0.49 \\
\hline REINO_UNIDO & -0.07 & 0.03 & -0.31 & 0.12 & 0.65 & 0.26 & 0.75 & -0.11 & 0.74 & 0.65 & 0.56 & 0.65 & 0.49 & 0.80 & 0.86 & 0.84 \\
\hline SUECIA'- & 0.07 & 0.12 & -0.06 & 0.14 & 0.81 & 0.27 & 0.63 & 0.25 & 0.67 & 0.58 & 0.27 & 0.51 & 0.62 & 0.76 & 0.73 & 0.84 \\
\hline SUICA & -0.07 & -0.09 & -0.23 & 0.10 & 0.58 & 0.11 & 0.70 & -0.16 & 0.65 & 0.54 & 0.60 & 0.52 & 0.45 & 0.69 & 0.73 & 0.78 \\
\hline TAIWAN & 0.16 & -0.08 & -0.03 & 0.14 & 0.38 & 0.36 & 0.47 & 0.08 & 0.46 & 0.50 & 0.34 & 0.51 & 0.64 & 0.48 & 0.48 & 0.42 \\
\hline VENEZUELA & 0.13 & 0.01 & -0.11 & 0.19 & 0.32 & 0.35 & 0.44 & -0.07 & 0.49 & 0.45 & 0.33 & 0.40 & 0.32 & 0.50 & 0.52 & 0.46 \\
\hline IMOVEIS & 0.00 & 0.28 & 0.13 & 0.13 & -0.02 & -0.07 & -0.04 & 0.13 & 0.04 & -0.08 & -0.05 & -0.15 & -0.06 & 0.06 & 0.08 & 0.00 \\
\hline INPC & 0.32 & 0.82 & 0.21 & 0.27 & -0.08 & 0.20 & -0.07 & 0.09 & -0.03 & -0.02 & -0.12 & -0.08 & -0.08 & 0.05 & -0.03 & -0.07 \\
\hline TR & 0.86 & 0.16 & 0.42 & -0.05 & -0.01 & 0.13 & -0.10 & 0.10 & -0.02 & 0.08 & -0.20 & -0.10 & -0.12 & -0.08 & -0.10 & -0.05 \\
\hline
\end{tabular}

\begin{tabular}{|c|c|c|c|c|c|c|c|c|c|c|c|c|c|c|c|c|}
\hline $\begin{array}{l}2001 \text { a } 2006 \\
\text { CDI }\end{array}$ & $\begin{array}{l}\mathrm{CDI} \\
1.00\end{array}$ & IGPM & IRF_M & FIEX & ALEMANH, & RGENTIN & USTRALIIB & RASIL & CANADA & CHILE & CHINA & CINGAPUF & OREIA & ESPANHA & & FRANCA \\
\hline $\begin{array}{l}\text { IGPM } \\
\text { IRF_M }\end{array}$ & $\begin{array}{l}0.15 \\
0.55\end{array}$ & $\begin{array}{l}1.00 \\
0.09\end{array}$ & 1.00 & & & & & & & & & & & & & \\
\hline FIEX & 0.18 & 0.41 & 0.20 & 1.00 & & & & & & & & & & & & \\
\hline ALEMANHA & 0.03 & -0.13 & -0.14 & 0.09 & 1.00 & & & & & & & & & & & \\
\hline ARGENTINA & 0.10 & 0.19 & 0.03 & 0.04 & 0.15 & 1.00 & & & & & & & & & & \\
\hline AUSTRALIA & -0.01 & 0.03 & -0.21 & 0.22 & 0.56 & 0.25 & 1.00 & & & & & & & & & \\
\hline BRASIL & 0.12 & -0.02 & 0.47 & 0.12 & 0.26 & 0.14 & -0.07 & 1.00 & & & & & & & & \\
\hline CANADA & 0.11 & -0.01 & -0.19 & 0.29 & 0.60 & 0.29 & 0.83 & -0.01 & 1.00 & & & & & & & \\
\hline $\begin{array}{l}\text { CHILE } \\
\text { CHINA }\end{array}$ & $\begin{array}{r}0.08 \\
-0.25\end{array}$ & $\begin{array}{c}0.01 \\
-0.08\end{array}$ & $\begin{array}{l}-0.07 \\
-0.47\end{array}$ & $\begin{array}{l}0.12 \\
0.11\end{array}$ & $\begin{array}{l}0.57 \\
0.28\end{array}$ & $\begin{array}{l}0.38 \\
0.25\end{array}$ & $\begin{array}{l}0.67 \\
0.51\end{array}$ & $\begin{array}{l}0.09 \\
-0.27\end{array}$ & $\begin{array}{l}0.65 \\
0.50\end{array}$ & $\begin{array}{l}1.00 \\
0.35\end{array}$ & 1.00 & & & & & \\
\hline $\begin{array}{l}\text { CINGAPURA } \\
\text { COREIA }\end{array}$ & $\begin{array}{l}-0.01 \\
-0.02\end{array}$ & $\begin{array}{l}-0.09 \\
-0.14\end{array}$ & $\begin{array}{l}-0.17 \\
-0.04\end{array}$ & $\begin{array}{l}0.18 \\
0.13\end{array}$ & $\begin{array}{l}0.54 \\
0.60\end{array}$ & $\begin{array}{l}0.28 \\
0.18\end{array}$ & $\begin{array}{l}0.77 \\
0.67\end{array}$ & $\begin{array}{l}-0.11 \\
0.10\end{array}$ & $\begin{array}{l}0.65 \\
0.64\end{array}$ & $\begin{array}{l}0.65 \\
0.63\end{array}$ & $\begin{array}{l}0.39 \\
0.31\end{array}$ & $\begin{array}{l}1.00 \\
0.63\end{array}$ & 1.00 & & & \\
\hline $\begin{array}{l}\text { ESPANHA } \\
\text { EUA }\end{array}$ & $\begin{array}{l}-0.05 \\
-0.02\end{array}$ & $\begin{array}{l}0.06 \\
0.06\end{array}$ & $\begin{array}{l}-0.24 \\
-0.32\end{array}$ & $\begin{array}{l}0.27 \\
0.27\end{array}$ & $\begin{array}{l}0.77 \\
0.70\end{array}$ & $\begin{array}{l}0.28 \\
0.24\end{array}$ & $\begin{array}{l}0.77 \\
0.79\end{array}$ & $\begin{array}{l}0.01 \\
-0.15\end{array}$ & $\begin{array}{l}0.75 \\
0.84\end{array}$ & $\begin{array}{l}0.69 \\
0.69\end{array}$ & $\begin{array}{l}0.47 \\
0.50\end{array}$ & $\begin{array}{l}0.62 \\
0.73\end{array}$ & $\begin{array}{l}0.62 \\
0.69\end{array}$ & $\begin{array}{l}1.00 \\
0.83\end{array}$ & 1.00 & \\
\hline $\begin{array}{l}\text { FRANCA } \\
\text { HOLANDA }\end{array}$ & $\begin{array}{r}0.00 \\
-0.04\end{array}$ & $\begin{array}{r}0.01 \\
-0.08\end{array}$ & $\begin{array}{l}-0.26 \\
-0.19\end{array}$ & 0.19 & 0.89 & 0.24 & 0.72 & 0.07 & 0.76 & 0.63 & 0.44 & $\begin{array}{l}0.62 \\
0.60\end{array}$ & 0.58 & 0.88 & 0.83 & $\begin{array}{l}1.00 \\
0.92\end{array}$ \\
\hline $\begin{array}{l}\text { HOLANDA } \\
\text { HONG KONG }\end{array}$ & $\begin{array}{l}-0.04 \\
-0.04\end{array}$ & $\begin{array}{l}-0.08 \\
-0.03\end{array}$ & $\begin{array}{l}-0.19 \\
-0.26\end{array}$ & $\begin{array}{l}0.21 \\
0.11\end{array}$ & $\begin{array}{l}0.90 \\
0.60\end{array}$ & $\begin{array}{l}0.10 \\
0.24\end{array}$ & $\begin{array}{l}0.63 \\
0.78\end{array}$ & $\begin{array}{l}0.12 \\
-0.03\end{array}$ & $\begin{array}{l}0.65 \\
0.79\end{array}$ & $\begin{array}{l}0.56 \\
0.71\end{array}$ & $\begin{array}{l}0.34 \\
0.54\end{array}$ & $\begin{array}{l}0.60 \\
0.74\end{array}$ & $\begin{array}{l}0.61 \\
0.69\end{array}$ & $\begin{array}{l}0.80 \\
0.75\end{array}$ & $\begin{array}{l}0.74 \\
0.83\end{array}$ & $\begin{array}{l}0.92 \\
0.72\end{array}$ \\
\hline INDIA & 0.06 & -0.07 & 0.05 & 0.10 & 0.39 & 0.36 & 0.60 & 0.06 & 0.58 & 0.52 & 0.32 & 0.62 & 0.60 & 0.54 & 0.53 & 0.45 \\
\hline ITALIA & 0.00 & 0.11 & -0.26 & 0.24 & 0.79 & 0.30 & 0.73 & -0.04 & 0.78 & 0.65 & 0.49 & 0.67 & 0.57 & 0.90 & 0.81 & 0.91 \\
\hline $\begin{array}{l}\text { JAPAO } \\
\text { MALASIA }\end{array}$ & $\begin{array}{l}0.05 \\
0.01\end{array}$ & $\begin{array}{l}-0.11 \\
-0.04\end{array}$ & $\begin{array}{l}-0.19 \\
-0.28\end{array}$ & $\begin{array}{l}0.15 \\
0.16\end{array}$ & $\begin{array}{l}0.43 \\
0.35\end{array}$ & $\begin{array}{l}0.13 \\
0.26\end{array}$ & $\begin{array}{l}0.73 \\
0.62\end{array}$ & $\begin{array}{l}-0.16 \\
-0.29\end{array}$ & $\begin{array}{l}0.76 \\
0.59\end{array}$ & $\begin{array}{l}0.49 \\
0.58\end{array}$ & $\begin{array}{l}0.50 \\
0.53\end{array}$ & $\begin{array}{l}0.56 \\
0.77\end{array}$ & $\begin{array}{l}0.59 \\
0.47\end{array}$ & $\begin{array}{l}0.66 \\
0.55\end{array}$ & $\begin{array}{l}0.73 \\
0.62\end{array}$ & $\begin{array}{l}0.62 \\
0.49\end{array}$ \\
\hline $\begin{array}{l}\text { MIALAIA } \\
\text { MEXICO }\end{array}$ & $\begin{array}{l}0.01 \\
-0.13\end{array}$ & $\begin{array}{l}-0.04 \\
-0.12\end{array}$ & $\begin{array}{l}-0.28 \\
-0.15\end{array}$ & 0.14 & 0.52 & 0.40 & 0.66 & 0.07 & 0.63 & 0.63 & 0.36 & 0.69 & 0.73 & 0.56 & 0.69 & 0.55 \\
\hline REINO_UNIDO & -0.08 & 0.00 & -0.40 & 0.15 & 0.68 & 0.28 & 0.82 & -0.18 & 0.79 & 0.69 & 0.57 & 0.71 & 0.55 & 0.85 & 0.87 & 0.87 \\
\hline SUECIA & -0.01 & 0.09 & -0.08 & 0.15 & 0.84 & 0.28 & 0.65 & 0.21 & 0.69 & 0.60 & 0.33 & 0.57 & 0.64 & 0.79 & 0.78 & 0.86 \\
\hline SUICA & -0.05 & -0.06 & -0.30 & 0.14 & 0.65 & 0.17 & 0.77 & -0.20 & 0.76 & 0.59 & 0.56 & 0.65 & 0.55 & 0.81 & 0.82 & 0.81 \\
\hline TAIWAN & 0.05 & -0.09 & -0.10 & 0.21 & 0.43 & 0.39 & 0.53 & 0.05 & 0.50 & 0.52 & 0.40 & 0.63 & 0.65 & 0.53 & 0.53 & 0.47 \\
\hline VENEZUELA & 0.03 & -0.01 & -0.12 & 0.17 & 0.36 & 0.38 & 0.46 & -0.03 & 0.52 & 0.45 & 0.38 & 0.54 & 0.33 & 0.52 & 0.56 & 0.46 \\
\hline IMOVEIS & -0.20 & 0.00 & 0.00 & 0.02 & 0.01 & -0.04 & -0.06 & 0.00 & -0.10 & 0.03 & 0.08 & 0.01 & -0.01 & 0.12 & 0.06 & 0.00 \\
\hline INPC & 0.39 & 0.82 & 0.22 & 0.30 & -0.11 & 0.18 & -0.06 & 0.05 & -0.05 & -0.01 & -0.14 & -0.13 & -0.08 & -0.02 & -0.03 & -0.06 \\
\hline
\end{tabular}

\begin{tabular}{|c|c|c|c|c|c|c|c|c|c|c|c|c|c|c|c|c|}
\hline 2003 a 2006 & CDI & IGPM & IRF_M & FIEX & ALEMANH & RGENTIN & USTRALI, & RASIL & CANADA & CHILE & CHINA & CINGAPUFC & OREIA & ESPANHA & EUA & FRANCA \\
\hline $\begin{array}{l}\text { CDI } \\
\text { IGPM }\end{array}$ & $\begin{array}{r}1.00 \\
-0.02\end{array}$ & 1.00 & & & & & & & & & & & & & & \\
\hline IRF_M & 0.60 & -0.04 & 1.00 & & & & & & & & & & & & & \\
\hline FIEX & 0.15 & 0.23 & 0.02 & 1.00 & & & & & & & & & & & & \\
\hline ALEMANHA & 0.03 & -0.33 & -0.07 & 0.28 & 1.00 & & & & & & & & & & & \\
\hline ARGENTINA & 0.11 & -0.04 & 0.16 & 0.11 & 0.30 & 1.00 & & & & & & & & & & \\
\hline AUSTRALIA & -0.04 & -0.18 & -0.24 & 0.50 & 0.66 & 0.42 & 1.00 & & & & & & & & & \\
\hline BRASIL & 0.09 & -0.15 & 0.43 & 0.00 & 0.25 & 0.29 & 0.25 & 1.00 & & & & & & & & \\
\hline $\begin{array}{l}\text { CANADA } \\
\text { CHUE }\end{array}$ & $\begin{array}{l}0.12 \\
0.07\end{array}$ & $\begin{array}{l}-0.21 \\
-0.14\end{array}$ & $\begin{array}{l}-0.15 \\
-0.01\end{array}$ & $\begin{array}{l}0.62 \\
0.27\end{array}$ & $\begin{array}{l}0.65 \\
0.63\end{array}$ & $\begin{array}{l}0.33 \\
0.28\end{array}$ & $\begin{array}{l}0.86 \\
0.61\end{array}$ & $\begin{array}{l}0.19 \\
0.29\end{array}$ & $\begin{array}{l}1.00 \\
0.56\end{array}$ & & & & & & & \\
\hline $\begin{array}{l}\text { CHILE } \\
\text { CHINA }\end{array}$ & $\begin{array}{l}0.07 \\
-0.26\end{array}$ & $\begin{array}{l}-0.14 \\
-0.06\end{array}$ & $\begin{array}{l}-0.01 \\
-0.32\end{array}$ & $\begin{array}{l}0.27 \\
0.45\end{array}$ & $\begin{array}{l}0.63 \\
0.38\end{array}$ & $\begin{array}{l}0.28 \\
0.19\end{array}$ & $\begin{array}{l}0.61 \\
0.56\end{array}$ & $\begin{array}{l}0.29 \\
0.03\end{array}$ & $\begin{array}{l}0.56 \\
0.48\end{array}$ & $\begin{array}{l}1.00 \\
0.24\end{array}$ & & & & & & \\
\hline CINGAPURA & -0.09 & -0.28 & -0.21 & 0.46 & 0.61 & 0.29 & 0.73 & 0.03 & 0.68 & 0.56 & 0.48 & 1.00 & & & & \\
\hline COREIA & 0.00 & -0.42 & -0.05 & 0.26 & 0.64 & 0.21 & 0.58 & 0.22 & 0.59 & 0.49 & 0.31 & 0.62 & 1.00 & & & \\
\hline ESPANHA & -0.13 & -0.20 & -0.27 & 0.49 & 0.83 & 0.36 & 0.79 & 0.11 & 0.74 & 0.62 & 0.52 & 0.70 & 0.55 & 1.00 & & \\
\hline EUA & -0.04 & -0.20 & -0.29 & 0.60 & 0.79 & 0.15 & 0.73 & 0.01 & 0.79 & 0.59 & 0.49 & 0.80 & 0.61 & 0.84 & 1.00 & \\
\hline FRANCA & -0.06 & -0.27 & -0.24 & 0.43 & 0.93 & 0.28 & 0.77 & 0.18 & 0.78 & 0.64 & 0.50 & 0.72 & 0.65 & 0.89 & 0.88 & 1.00 \\
\hline $\begin{array}{l}\text { HOLANDA } \\
\text { HONG_KONG }\end{array}$ & $\begin{array}{l}-0.08 \\
-0.05\end{array}$ & $\begin{array}{l}-0.41 \\
-0.24\end{array}$ & $\begin{array}{l}-0.17 \\
-0.22\end{array}$ & $\begin{array}{l}0.34 \\
0.50\end{array}$ & $\begin{array}{l}0.92 \\
0.59\end{array}$ & $\begin{array}{l}0.17 \\
0.14\end{array}$ & $\begin{array}{l}0.70 \\
0.77\end{array}$ & $\begin{array}{l}0.19 \\
0.14\end{array}$ & $\begin{array}{l}0.70 \\
0.75\end{array}$ & $\begin{array}{l}0.61 \\
0.65\end{array}$ & $\begin{array}{l}0.41 \\
0.53\end{array}$ & $\begin{array}{l}0.70 \\
0.80\end{array}$ & $\begin{array}{l}0.72 \\
0.61\end{array}$ & $\begin{array}{l}0.82 \\
0.70\end{array}$ & $\begin{array}{l}0.85 \\
0.78\end{array}$ & $\begin{array}{l}0.94 \\
0.72\end{array}$ \\
\hline INDIA & 0.07 & -0.44 & 0.19 & 0.23 & 0.42 & 0.37 & 0.53 & 0.26 & 0.49 & 0.37 & 0.15 & 0.65 & 0.54 & 0.47 & 0.43 & 0.43 \\
\hline ITALIA & -0.09 & -0.10 & -0.24 & 0.52 & 0.81 & 0.35 & 0.75 & 0.11 & 0.79 & 0.60 & 0.49 & 0.71 & 0.55 & 0.90 & 0.82 & 0.90 \\
\hline JAPAO & 0.13 & -0.30 & -0.02 & 0.55 & 0.48 & 0.20 & 0.66 & 0.12 & 0.71 & 0.31 & 0.35 & 0.71 & 0.60 & 0.56 & 0.72 & 0.60 \\
\hline MALASIA & -0.07 & -0.20 & -0.30 & 0.52 & 0.50 & 0.21 & 0.74 & -0.05 & 0.66 & 0.51 & 0.6 & 0.80 & 0.5 & 0.63 & 0.73 & 0.62 \\
\hline MEXICO & -0.21 & -0.33 & -0.11 & 0.26 & 0.57 & 0.37 & 0.62 & 0.32 & 0.54 & 0.42 & 0.33 & 0.63 & 0.68 & 0.59 & 0.58 & 0.60 \\
\hline REINO_UNIDO & -0.16 & -0.25 & -0.38 & 0.43 & 0.79 & 0.25 & 0.79 & 0.13 & 0.76 & 0.61 & 0.52 & 0.73 & 0.53 & 0.86 & 0.85 & 0.90 \\
\hline SUECIĀ & -0.06 & -0.18 & -0.08 & 0.42 & 0.87 & 0.33 & 0.71 & 0.26 & 0.69 & 0.66 & 0.49 & 0.70 & 0.64 & 0.82 & 0.80 & 0.89 \\
\hline SUICA & -0.08 & -0.26 & -0.27 & 0.45 & 0.84 & 0.23 & 0.70 & 0.13 & 0.69 & 0.54 & 0.50 & 0.73 & 0.59 & 0.84 & 0.87 & 0.90 \\
\hline TAIWAN & 0.05 & -0.21 & -0.11 & 0.41 & 0.49 & 0.21 & 0.69 & 0.07 & 0.59 & 0.43 & 0.54 & 0.68 & 0.68 & 0.54 & 0.62 & 0.57 \\
\hline VENEZUELA & 0.04 & -0.12 & -0.03 & 0.32 & 0.41 & 0.35 & 0.44 & 0.18 & 0.45 & 0.33 & 0.33 & 0.60 & 0.29 & 0.49 & 0.50 & 0.46 \\
\hline IMOVEIS & -0.23 & 0.00 & -0.04 & 0.03 & -0.02 & -0.10 & -0.10 & -0.06 & -0.16 & 0.02 & 0.12 & 0.03 & -0.02 & 0.14 & 0.08 & -0.02 \\
\hline INPC & 0.41 & 0.69 & 0.23 & 0.19 & -0.23 & 0.14 & -0.17 & -0.05 & -0.18 & -0.16 & -0.04 & -0.31 & -0.31 & -0.20 & -0.22 & -0.25 \\
\hline TR & 0.82 & -0.01 & 0.54 & 0.08 & -0.04 & -0.01 & -0.13 & 0.05 & -0.03 & 0.09 & -0.21 & -0.20 & -0.09 & -0.21 & -0.10 & -0.19 \\
\hline
\end{tabular}




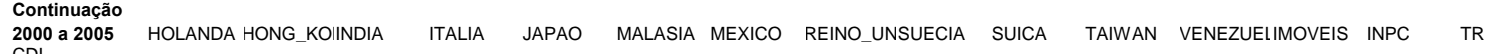
$\mathrm{CDI}$

IGPM

IRF_M

FIEX

ARGENTINA

AUSTRALIA

BRASIL

CANADA

CHILE

CHINA

COREIA_SUL

ESPANHA

EUA

FRANCA

HOLANDA $\quad 1.00$

HONG_KONG $\quad 0.63 \quad 1.00$

INDIA

ITALIA
JAPAO

MALASIA

REINO UNIDO

SUECIA

SUICA

TAIWAN

VENEZUELA

IMOVE

TR

$0.56 \quad 1.00$

$\begin{array}{ll}0.41 & 0.69 \\ 0.47 & 0.66\end{array}$

$\begin{array}{llll}0.37 & 0.56 & 0.65 & 0.56 \\ 0.49 & 0.63 & 0.49 & 0.53\end{array}$

$\begin{array}{ll}0.37 & 0.63 \\ 0.73 & 0.76 \\ 0.78 & 0.67\end{array}$

$\begin{array}{ll}0.78 & 0.67 \\ 0.73 & 0.68\end{array}$

$\begin{array}{llll}0.48 & 0.54 & 0.45 & 1.00\end{array}$

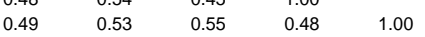

$\begin{array}{llllll}0.45 & 0.80 & 0.65 & 0.60 & 0.59 & 1.00\end{array}$

$\begin{array}{lllllll}0.50 & 0.75 & 0.47 & 0.34 & 0.49 & 0.69 & 1.00 \\ 0.45 & 0.75 & 0.62 & 0.50 & 0.42 & 0.83 & 0.61\end{array}$

$\begin{array}{llllllll}0.45 & 0.75 & 0.62 & 0.50 & 0.42 & 0.83 & 0.61 & 1.00\end{array}$

$\begin{array}{llllllllll}0.43 & 0.41 & 0.40 & 0.61 & 0.54 & 0.39 & 0.40 & 0.34 & 1.00 & \\ 0.40 & 0.57 & 0.41 & 0.41 & 0.42 & 0.57 & 0.38 & 0.53 & 0.31 & 1.00\end{array}$

$\begin{array}{rr}0.41 & 0.53 \\ -0.03 & 0.02\end{array}$

0.40
-0.13
-0.05

$\begin{array}{ll}-0.16 & -0.03 \\ -0.13 & -0.07\end{array}$

$\begin{array}{llll}0.05 & 0.04 & -0.14 & -0.04 \\ 0.02 & -0.07 & -0.05 & 0.02\end{array}$

$\begin{array}{lll}-0.04 & -0.11 & 0.06 \\ -0.15 & -0.14 & 0.03\end{array}$

$\begin{array}{rrrrr}-0.05 & -0.06 & 0.10 & 1.00 & \\ -0.21 & 0.05 & -0.02 & 0.24 & 1.00\end{array}$

2001 a 2006 HOLANDA HONG_KOINDIA

ITALIA

JAPAO MALASIA MEXICO REINO_UNSUECIA SUICA TAIWAN VENEZUELIMOVEIS INPC

CDI

IGPM
IRF M

FIEX

ALEMANHA

ARGENTINA

AUSTRALIA

BRASIL

CANADA

CHILE

CINGAPURA

COREIA

ESPANHA

EUA

FRANCA

HOLANDA $\quad 1.00$

HONG_KONG $\quad 0.66 \quad 1.00$

$\begin{array}{ll}\text { INDIA } & 0.41 \\ \text { ITALIA } & 0.82\end{array}$

JAPAO

MALASIA

MEXICO
REINO UNIDO

SUECIA

SUICA

TAIWAN

IMOVEIS

$\begin{array}{lll}0.61 & 0.56 & 1.00\end{array}$

$\begin{array}{llll}0.53 & 0.70 & 0.53 & 1.00 \\ 0.43 & 0.66 & 0.49 & 0.63\end{array}$

$0.43 \quad 0.66$

$0.64 \quad 0.63$

$\begin{array}{ll}0.54 & 0.62 \\ 0.77 & 0.79\end{array}$

$0.81 \quad 0.71$

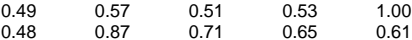

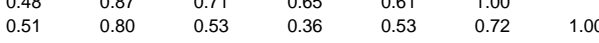

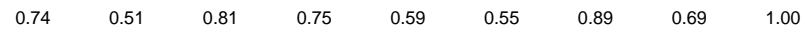

TR

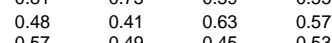

$\begin{array}{lll}0.45 & 0.61 & 0.44 \\ 0.41 & 0.59 & 0.42\end{array}$

$\begin{array}{llllllllll}-0.01 & -0.02 & -0.04 & 0.53 & 0.60 & 0.41 & 0.52 & 0.33 & 1.00 & \\ 0.03 & -0.16 & -0.05 & -0.1 & -0.02 & 0.07 & 0.01 & 0.02 & 0.01 & 1.00\end{array}$

$\begin{array}{ccccccccccc}0.03 & -0.16 & -0.05 & -0.10 & -0.13 & 0.02 & -0.16 & 0.02 & -0.02 & -0.07 & 1.00 \\ -0.10 & -0.07 & -0.03 & -0.19 & -0.12 & -0.05 & -0.09 & -0.06 & -0.06 & -0.09 & 0.43\end{array}$

2003 a 2006 HOLANDA HONG KOINDIA

IGPM

IRF M

FIEX

ALEMANHA

ARGENTINA

AUSTRALIA

BRASIL

CANADA

CHILE

CINGAPURA

COREIA

COREIA
ESPANHA

EUA

FRANCA

HOLANDA

HONG_KONG $\quad 0.71$

$\begin{array}{lll}\text { INDIA } & 0.44 & 0.46\end{array}$

$\begin{array}{llll} & 0.81 & 0.70 & 0.43\end{array}$

$\begin{array}{lll}\text { JAPAO } & 0.60 & 0.60\end{array}$

MALASIA

$\begin{array}{lll}\text { MEXICO } & 0.67 & 0.55\end{array}$

REINO_UNIDO $0.85 \quad 0.75$

$\begin{array}{lll}\text { SUECIA } & 0.84 & 0.68\end{array}$

TAIWAN

VENEZUELA

IMOVEIS

$\begin{array}{ll}0.58 & 0.73\end{array}$

\begin{tabular}{lll} 
& 0.03 & -0.01 \\
INPC & -0.38 & -0.26 \\
\hline
\end{tabular}

ITALIA JAPAO MALASIA MEXICO REINO UNSUECIA SUICA TAIWAN VENEZUELIMOVEIS INPC

1.00

$\begin{array}{llll}0.65 & 0.57 & 1.00 & \\ 0.44 & 0.58 & 0.61 & 1.00\end{array}$

$\begin{array}{lllll}0.44 & 0.57 & 0.51 & 0.45 & 1.00\end{array}$

$\begin{array}{llll}0.38 & 0.87 & 0.61 & 0.64 \\ 0.48 & 0.83 & 0.59 & 0.57\end{array}$

$\begin{array}{lll}0.83 & 0.59 & 0.57 \\ 0.85 & 0.61 & 0.59\end{array}$

$\begin{array}{ll}0.57 & 0.63 \\ 0.59 & 0.63\end{array}$

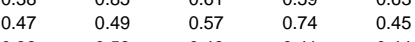

1.00

$0.81 \quad 1.00$

$\begin{array}{llll}0.45 & 0.47 & 0.82 & 1.00 \\ 0.44 & 0.55 & 0.46 & 0.56\end{array}$

$\begin{array}{lllll}0.44 & 0.55 & 0.46 & 0.47 & 0.26\end{array}$

$\begin{array}{llllllllll}0.11 & -0.02 & -0.04 & -0.02 & 0.02 & -0.03 & 0.07 & 0.02 & 0.04 & 0.00 \\ 0.0 .02 & -0.13 & -0.27 & -0.19 & -0.31 & -0.33 & -0.18 & -0.25 & -0.03 & -0.10\end{array}$

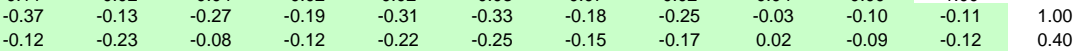




\section{APÊNDICE B - MATRIZES DE CORRELAÇÕES ENTRE OS RETORNOS MENSAIS DOS ÍNDICES DE MERCADO DE AÇÕES (PROCESSAMENTO DOS DADOS NO SOFTAWARE STATA)}

\section{Matriz de Correlações para Retornos em Moeda do Próprio País para o Período de 2000 a 2005}

\begin{tabular}{|c|c|c|c|c|c|c|c|}
\hline & Alemanha & Argent a & Austra a & Brasil & Canada & Chile & China \\
\hline Alemanha & 1.0000 & & & & & & \\
\hline Argentina & $\begin{array}{l}0.2739 \\
0.0208\end{array}$ & 1.0000 & & & & & \\
\hline \multirow[t]{2}{*}{ Australia } & 0.6429 & 0.2427 & 1.0000 & & & & \\
\hline & 0.0000 & 0.0414 & & & & & \\
\hline \multirow[t]{2}{*}{ Brasil } & 0.6099 & 0.2822 & 0.6263 & 1.0000 & & & \\
\hline & 0.0000 & 0.0171 & 0.0000 & & & & \\
\hline \multirow[t]{2}{*}{ Canada } & 0.6524 & 0.3424 & 0.6202 & 0.6955 & 1.0000 & & \\
\hline & 0.0000 & 0.0035 & 0.0000 & 0.0000 & & & \\
\hline \multirow[t]{2}{*}{ Chile } & 0.4569 & 0.1577 & 0.4828 & 0.4565 & 0.4596 & 1.0000 & \\
\hline & 0.0001 & 0.1890 & 0.0000 & 0.0001 & 0.0001 & & \\
\hline \multirow[t]{2}{*}{ China } & 0.0965 & 0.0443 & 0.0042 & 0.1396 & 0.1890 & -0.0513 & 1.0000 \\
\hline & 0.4234 & 0.7138 & 0.9725 & 0.2457 & 0.1144 & 0.6710 & \\
\hline \multirow[t]{2}{*}{ Cingapura } & 0.5605 & 0.4116 & 0.6677 & 0.4881 & 0.5580 & 0.3843 & -0.1076 \\
\hline & 0.0000 & 0.0004 & 0.0000 & 0.0000 & 0.0000 & 0.0009 & 0.3716 \\
\hline \multirow{2}{*}{ Coreia } & 0.5537 & 0.3528 & 0.6566 & 0.5543 & 0.5959 & 0.5200 & 0.0316 \\
\hline & 0.0000 & 0.0025 & 0.0000 & 0.0000 & 0.0000 & 0.0000 & 0.7935 \\
\hline \multirow[t]{2}{*}{ Espanha } & 0.8594 & 0.3006 & 0.6213 & 0.6408 & 0.6904 & 0.4428 & 0.0578 \\
\hline & 0.0000 & 0.0109 & 0.0000 & 0.0000 & 0.0000 & 0.0001 & 0.6319 \\
\hline \multirow[t]{2}{*}{ EUA } & 0.8046 & 0.2223 & 0.6406 & 0.6800 & 0.7777 & 0.5288 & 0.0483 \\
\hline & 0.0000 & 0.0624 & 0.0000 & 0.0000 & 0.0000 & 0.0000 & 0.6894 \\
\hline \multirow[t]{2}{*}{ Franca } & 0.9481 & 0.2405 & 0.6500 & 0.6129 & 0.7131 & 0.4690 & 0.1042 \\
\hline & 0.0000 & 0.0434 & 0.0000 & 0.0000 & 0.0000 & 0.0000 & 0.3870 \\
\hline \multirow[t]{2}{*}{ Holanda } & 0.9308 & 0.2098 & 0.6798 & 0.5780 & 0.6635 & 0.4342 & 0.0816 \\
\hline & 0.0000 & 0.0791 & 0.0000 & 0.0000 & 0.0000 & 0.0002 & 0.4990 \\
\hline \multirow[t]{2}{*}{ Hong_Kong } & 0.6203 & 0.2386 & 0.5582 & 0.6872 & 0.7666 & 0.4266 & 0.2203 \\
\hline & 0.0000 & 0.0451 & 0.0000 & 0.0000 & 0.0000 & 0.0002 & 0.0645 \\
\hline \multirow[t]{2}{*}{ India } & 0.4007 & 0.3238 & 0.5518 & 0.5420 & 0.5239 & 0.3582 & 0.0740 \\
\hline & 0.0005 & 0.0059 & 0.0000 & 0.0000 & 0.0000 & 0.0022 & 0.5394 \\
\hline \multirow[t]{2}{*}{ Italia } & 0.8352 & 0.3377 & 0.5569 & 0.5206 & 0.6610 & 0.4026 & 0.1537 \\
\hline & 0.0000 & 0.0040 & 0.0000 & 0.0000 & 0.0000 & 0.0005 & 0.2006 \\
\hline \multirow[t]{2}{*}{ Japao } & 0.4074 & 0.0920 & 0.5551 & 0.4435 & 0.5631 & 0.2091 & 0.1014 \\
\hline & 0.0004 & 0.4453 & 0.0000 & 0.0001 & 0.0000 & 0.0802 & 0.4002 \\
\hline \multirow[t]{2}{*}{ Malasia } & 0.3744 & 0.2720 & 0.2525 & 0.3130 & 0.3102 & 0.3978 & 0.0719 \\
\hline & 0.0013 & 0.0217 & 0.0337 & 0.0079 & 0.0085 & 0.0006 & 0.5513 \\
\hline
\end{tabular}




\begin{tabular}{|c|c|c|c|c|c|c|c|}
\hline \multirow[t]{2}{*}{ Mexico } & 0.6214 & 0.5687 & 0.6831 & 0.6524 & 0.7237 & 0.3931 & 0.1183 \\
\hline & 0.0000 & 0.0000 & 0.0000 & 0.0000 & 0.0000 & 0.0007 & 0.3259 \\
\hline \multirow[t]{2}{*}{ Reino_Unido } & 0.8409 & 0.1874 & 0.6182 & 0.6268 & 0.6742 & 0.5545 & 0.0122 \\
\hline & 0.0000 & 0.1176 & 0.0000 & 0.0000 & 0.0000 & 0.0000 & 0.9195 \\
\hline \multirow[t]{2}{*}{ Suecia } & 0.8717 & 0.2103 & 0.6020 & 0.5842 & 0.6995 & 0.4460 & 0.1230 \\
\hline & 0.0000 & 0.0784 & 0.0000 & 0.0000 & 0.0000 & 0.0001 & 0.3067 \\
\hline \multirow[t]{2}{*}{ Suica } & 0.7992 & 0.1206 & 0.5665 & 0.4966 & 0.5973 & 0.4092 & 0.1163 \\
\hline & 0.0000 & 0.3165 & 0.0000 & 0.0000 & 0.0000 & 0.0004 & 0.3343 \\
\hline \multirow[t]{2}{*}{ Taiwan } & 0.4577 & 0.4718 & 0.4613 & 0.4401 & 0.4615 & 0.3813 & 0.0996 \\
\hline & 0.0001 & 0.0000 & 0.0001 & 0.0001 & 0.0001 & 0.0010 & 0.4085 \\
\hline \multirow[t]{3}{*}{ Venezuela } & 0.0848 & 0.2114 & 0.0446 & 0.2537 & 0.2418 & 0.1514 & 0.1550 \\
\hline & 0.4818 & 0.0768 & 0.7119 & 0.0328 & 0.0422 & 0.2076 & 0.1969 \\
\hline & Cingap a & Coreia & Espanha & EUA & Franca & Holanda & Hong_K q \\
\hline Cingapura & 1.0000 & & & & & & \\
\hline \multirow[t]{2}{*}{ Coreia } & 0.5503 & 1.0000 & & & & & \\
\hline & 0.0000 & & & & & & \\
\hline \multirow[t]{2}{*}{ Espanha } & 0.4657 & 0.5596 & 1.0000 & & & & \\
\hline & 0.0000 & 0.0000 & & & & & \\
\hline \multirow[t]{2}{*}{ EUA } & 0.5906 & 0.6377 & 0.7099 & 1.0000 & & & \\
\hline & 0.0000 & 0.0000 & 0.0000 & & & & \\
\hline \multirow[t]{2}{*}{ Franca } & 0.5230 & 0.5306 & 0.8539 & 0.8144 & 1.0000 & & \\
\hline & 0.0000 & 0.0000 & 0.0000 & 0.0000 & & & \\
\hline \multirow[t]{2}{*}{ Holanda } & 0.5685 & 0.5706 & 0.8199 & 0.7753 & 0.9378 & 1.0000 & \\
\hline & 0.0000 & 0.0000 & 0.0000 & 0.0000 & 0.0000 & & \\
\hline \multirow[t]{2}{*}{ Hong_Kong } & 0.5772 & 0.5808 & 0.6414 & 0.6852 & 0.6092 & 0.5916 & 1.0000 \\
\hline & 0.0000 & 0.0000 & 0.0000 & 0.0000 & 0.0000 & 0.0000 & \\
\hline \multirow[t]{2}{*}{ India } & 0.4958 & 0.6044 & 0.4653 & 0.3763 & 0.3698 & 0.4068 & 0.5068 \\
\hline & 0.0000 & 0.0000 & 0.0000 & 0.0012 & 0.0015 & 0.0004 & 0.0000 \\
\hline \multirow[t]{2}{*}{ Italia } & 0.4616 & 0.4567 & 0.8400 & 0.6413 & 0.8614 & 0.8303 & 0.5961 \\
\hline & 0.0001 & 0.0001 & 0.0000 & 0.0000 & 0.0000 & 0.0000 & 0.0000 \\
\hline \multirow[t]{2}{*}{ Japao } & 0.3971 & 0.5779 & 0.4957 & 0.4822 & 0.4368 & 0.4302 & 0.5049 \\
\hline & 0.0006 & 0.0000 & 0.0000 & 0.0000 & 0.0001 & 0.0002 & 0.0000 \\
\hline \multirow[t]{2}{*}{ Malasia } & 0.4093 & 0.3042 & 0.3222 & 0.2918 & 0.3155 & 0.3430 & 0.3931 \\
\hline & 0.0004 & 0.0099 & 0.0061 & 0.0136 & 0.0074 & 0.0034 & 0.0007 \\
\hline \multirow[t]{2}{*}{ Mexico } & 0.6380 & 0.6611 & 0.6706 & 0.6339 & 0.5938 & 0.6202 & 0.6475 \\
\hline & 0.0000 & 0.0000 & 0.0000 & 0.0000 & 0.0000 & 0.0000 & 0.0000 \\
\hline \multirow[t]{2}{*}{ Reino_Unido } & 0.5479 & 0.5803 & 0.7506 & 0.8633 & 0.8622 & 0.8365 & 0.5987 \\
\hline & 0.0000 & 0.0000 & 0.0000 & 0.0000 & 0.0000 & 0.0000 & 0.0000 \\
\hline \multirow[t]{2}{*}{ Suecia } & 0.4895 & 0.5496 & 0.8493 & 0.7644 & 0.8848 & 0.8386 & 0.6616 \\
\hline & 0.0000 & 0.0000 & 0.0000 & 0.0000 & 0.0000 & 0.0000 & 0.0000 \\
\hline \multirow[t]{2}{*}{ Suica } & 0.4659 & 0.5422 & 0.6284 & 0.7460 & 0.8022 & 0.8288 & 0.5283 \\
\hline & 0.0000 & 0.0000 & 0.0000 & 0.0000 & 0.0000 & 0.0000 & 0.0000 \\
\hline Taiwan & 0.5093 & 0.6427 & 0.4582 & 0.4597 & 0.4379 & 0.4401 & 0.4874 \\
\hline
\end{tabular}




\begin{tabular}{|c|c|c|c|c|c|c|c|}
\hline \multirow{4}{*}{ Venezuela } & 0.0000 & 0.0000 & 0.0001 & 0.0001 & 0.0001 & 0.0001 & 0.0000 \\
\hline & 0.0432 & 0.1875 & 0.1205 & 0.1594 & 0.1103 & 0.0691 & 0.3165 \\
\hline & 0.7202 & 0.1174 & 0.3170 & 0.1844 & 0.3599 & 0.5670 & 0.0072 \\
\hline & India & Italia & Japao & Malasia & Mexico & Reino_ o & Suecia \\
\hline India & 1.0000 & & & & & & \\
\hline \multirow[t]{2}{*}{ Italia } & 0.4484 & 1.0000 & & & & & \\
\hline & 0.0001 & & & & & & \\
\hline \multirow[t]{2}{*}{ Japao } & 0.5724 & 0.4408 & 1.0000 & & & & \\
\hline & 0.0000 & 0.0001 & & & & & \\
\hline \multirow[t]{2}{*}{ Malasia } & 0.3442 & 0.3816 & 0.1275 & 1.0000 & & & \\
\hline & 0.0033 & 0.0010 & 0.2893 & & & & \\
\hline \multirow[t]{2}{*}{ Mexico } & 0.4998 & 0.6285 & 0.5173 & 0.4312 & 1.0000 & & \\
\hline & 0.0000 & 0.0000 & 0.0000 & 0.0002 & & & \\
\hline \multirow[t]{2}{*}{ Reino_Unido } & 0.3881 & 0.7478 & 0.4545 & 0.2978 & 0.5703 & 1.0000 & \\
\hline & 0.0008 & 0.0000 & 0.0001 & 0.0116 & 0.0000 & & \\
\hline \multirow[t]{2}{*}{ Suecia } & 0.4539 & 0.8220 & 0.4219 & 0.3423 & 0.5634 & 0.7521 & 1.0000 \\
\hline & 0.0001 & 0.0000 & 0.0002 & 0.0035 & 0.0000 & 0.0000 & \\
\hline \multirow[t]{2}{*}{ Suica } & 0.3583 & 0.6340 & 0.4546 & 0.2254 & 0.4964 & 0.8006 & 0.6882 \\
\hline & 0.0022 & 0.0000 & 0.0001 & 0.0587 & 0.0000 & 0.0000 & 0.0000 \\
\hline \multirow[t]{2}{*}{ Taiwan } & 0.3841 & 0.3825 & 0.3644 & 0.5972 & 0.5137 & 0.3710 & 0.4121 \\
\hline & 0.0009 & 0.0010 & 0.0018 & 0.0000 & 0.0000 & 0.0014 & 0.0004 \\
\hline \multirow[t]{3}{*}{ Venezuela } & 0.2363 & 0.1813 & 0.1570 & 0.1717 & 0.1350 & 0.0845 & 0.1376 \\
\hline & 0.0472 & 0.1302 & 0.1911 & 0.1521 & 0.2615 & 0.4833 & 0.2526 \\
\hline & Suica & Taiwan & Venezu a & & & & \\
\hline Suica & 1.0000 & & & & & & \\
\hline \multirow[t]{2}{*}{ Taiwan } & 0.3919 & 1.0000 & & & & & \\
\hline & 0.0007 & & & & & & \\
\hline \multirow[t]{2}{*}{ Venezuela } & 0.1434 & 0.2487 & 1.0000 & & & & \\
\hline & 0.2329 & 0.0365 & & & & & \\
\hline
\end{tabular}




\section{Matriz de Correlações para Retornos em Moeda do Próprio País para o Período de 2001 a 2006}

\begin{tabular}{|c|c|c|c|c|c|c|c|}
\hline \multicolumn{4}{|c|}{$\begin{array}{l}\text { Espanha EUA Franca Holanda Hong_Kong Ind } \\
\text { Suecia Suica Taiwan Venezuela, sig } \\
\qquad \text { | Alemanha Argent a Austra a }\end{array}$} & Brasil & Canada & Chile & China \\
\hline Alemanha & \multicolumn{3}{|l|}{1.0000} & & & & \\
\hline Argentina & $\begin{array}{l}0.2687 \\
0.0225\end{array}$ & 1.0000 & & & & & \\
\hline \multirow[t]{2}{*}{ Australia } & 0.7176 & 0.2694 & 1.0000 & & & & \\
\hline & 0.0000 & 0.0221 & & & & & \\
\hline \multirow[t]{2}{*}{ Brasil } & 0.6356 & 0.2823 & 0.6576 & 1.0000 & & & \\
\hline & 0.0000 & 0.0163 & 0.0000 & & & & \\
\hline \multirow[t]{2}{*}{ Canada } & 0.7113 & 0.3850 & 0.6689 & 0.6921 & 1.0000 & & \\
\hline & 0.0000 & 0.0008 & 0.0000 & 0.0000 & & & \\
\hline \multirow[t]{2}{*}{ Chile } & 0.5539 & 0.2111 & 0.5341 & 0.5245 & 0.5748 & 1.0000 & \\
\hline & 0.0000 & 0.0751 & 0.0000 & 0.0000 & 0.0000 & & \\
\hline \multirow[t]{2}{*}{ China } & 0.0889 & 0.0719 & 0.0675 & 0.1749 & 0.1472 & 0.1013 & 1.0000 \\
\hline & 0.4576 & 0.5484 & 0.5732 & 0.1416 & 0.2173 & 0.3973 & \\
\hline \multirow[t]{2}{*}{ Cingapura } & 0.6812 & 0.4673 & 0.6999 & 0.5411 & 0.5911 & 0.5181 & -0.0040 \\
\hline & 0.0000 & 0.0000 & 0.0000 & 0.0000 & 0.0000 & 0.0000 & 0.9735 \\
\hline \multirow[t]{2}{*}{ Coreia } & 0.7118 & 0.3706 & 0.6522 & 0.5561 & 0.6766 & 0.4839 & 0.0693 \\
\hline & 0.0000 & 0.0014 & 0.0000 & 0.0000 & 0.0000 & 0.0000 & 0.5630 \\
\hline \multirow[t]{2}{*}{ Espanha } & 0.8800 & 0.2473 & 0.6794 & 0.6518 & 0.6997 & 0.5598 & 0.0628 \\
\hline & 0.0000 & 0.0362 & 0.0000 & 0.0000 & 0.0000 & 0.0000 & 0.6004 \\
\hline \multirow[t]{2}{*}{ EUA } & 0.8919 & 0.2718 & 0.7070 & 0.7065 & 0.8132 & 0.5794 & 0.0868 \\
\hline & 0.0000 & 0.0209 & 0.0000 & 0.0000 & 0.0000 & 0.0000 & 0.4684 \\
\hline \multirow[t]{2}{*}{ Franca } & 0.9530 & 0.2566 & 0.7188 & 0.6431 & 0.7552 & 0.5623 & 0.0764 \\
\hline & 0.0000 & 0.0296 & 0.0000 & 0.0000 & 0.0000 & 0.0000 & 0.5235 \\
\hline \multirow[t]{2}{*}{ Holanda } & 0.9409 & 0.2132 & 0.6969 & 0.5979 & 0.6938 & 0.4949 & 0.0509 \\
\hline & 0.0000 & 0.0722 & 0.0000 & 0.0000 & 0.0000 & 0.0000 & 0.6711 \\
\hline \multirow[t]{2}{*}{ Hong_Kong } & 0.6440 & 0.2078 & 0.5896 & 0.6443 & 0.7490 & 0.5375 & 0.2395 \\
\hline & 0.0000 & 0.0799 & 0.0000 & 0.0000 & 0.0000 & 0.0000 & 0.0427 \\
\hline \multirow[t]{2}{*}{ India } & 0.4821 & 0.3205 & 0.5665 & 0.5475 & 0.5800 & 0.3666 & 0.0651 \\
\hline & 0.0000 & 0.0060 & 0.0000 & 0.0000 & 0.0000 & 0.0015 & 0.5872 \\
\hline \multirow[t]{2}{*}{ Italia } & 0.8841 & 0.3578 & 0.6358 & 0.6026 & 0.7470 & 0.5614 & 0.0915 \\
\hline & 0.0000 & 0.0020 & 0.0000 & 0.0000 & 0.0000 & 0.0000 & 0.4446 \\
\hline \multirow[t]{2}{*}{ Japao } & 0.4964 & 0.0791 & 0.5556 & 0.4202 & 0.5856 & 0.1878 & 0.1241 \\
\hline & 0.0000 & 0.5090 & 0.0000 & 0.0002 & 0.0000 & 0.1142 & 0.2991 \\
\hline \multirow[t]{2}{*}{ Malasia } & 0.3528 & 0.2956 & 0.3146 & 0.3726 & 0.4066 & 0.4581 & 0.1018 \\
\hline & 0.0024 & 0.0117 & 0.0071 & 0.0013 & 0.0004 & 0.0001 & 0.3946 \\
\hline \multirow[t]{2}{*}{ Mexico } & 0.6721 & 0.5870 & 0.7072 & 0.6398 & 0.7389 & 0.5293 & 0.1635 \\
\hline & 0.0000 & 0.0000 & 0.0000 & 0.0000 & 0.0000 & 0.0000 & 0.1699 \\
\hline
\end{tabular}




\begin{tabular}{|c|c|c|c|c|c|c|c|}
\hline Reino_Unido & $\begin{array}{l}0.8787 \\
0.0000\end{array}$ & $\begin{array}{l}0.2406 \\
0.0418\end{array}$ & $\begin{array}{l}0.7002 \\
0.0000\end{array}$ & $\begin{array}{l}0.6506 \\
0.0000\end{array}$ & $\begin{array}{l}0.7219 \\
0.0000\end{array}$ & $\begin{array}{l}0.5717 \\
0.0000\end{array}$ & $\begin{array}{l}0.0156 \\
0.8966\end{array}$ \\
\hline Suecia & $\begin{array}{l}0.8783 \\
0.0000\end{array}$ & $\begin{array}{l}0.1905 \\
0.1090\end{array}$ & $\begin{array}{l}0.6865 \\
0.0000\end{array}$ & $\begin{array}{l}0.6105 \\
0.0000\end{array}$ & $\begin{array}{l}0.7308 \\
0.0000\end{array}$ & $\begin{array}{l}0.5383 \\
0.0000\end{array}$ & $\begin{array}{l}0.0822 \\
0.4922\end{array}$ \\
\hline Suica & $\begin{array}{l}0.8605 \\
0.0000\end{array}$ & $\begin{array}{l}0.1979 \\
0.0957\end{array}$ & $\begin{array}{l}0.6569 \\
0.0000\end{array}$ & $\begin{array}{l}0.5582 \\
0.0000\end{array}$ & $\begin{array}{l}0.6763 \\
0.0000\end{array}$ & $\begin{array}{l}0.4490 \\
0.0001\end{array}$ & $\begin{array}{l}0.0644 \\
0.5911\end{array}$ \\
\hline Taiwan & $\begin{array}{l}0.5005 \\
0.0000\end{array}$ & $\begin{array}{l}0.4998 \\
0.0000\end{array}$ & $\begin{array}{l}0.5143 \\
0.0000\end{array}$ & $\begin{array}{l}0.4767 \\
0.0000\end{array}$ & $\begin{array}{l}0.5115 \\
0.0000\end{array}$ & $\begin{array}{l}0.3672 \\
0.0015\end{array}$ & $\begin{array}{l}0.1568 \\
0.1885\end{array}$ \\
\hline Venezuela & $\begin{array}{l}0.1449 \\
0.2246\end{array}$ & $\begin{array}{l}0.2464 \\
0.0369\end{array}$ & $\begin{array}{l}0.1323 \\
0.2679\end{array}$ & $\begin{array}{l}0.3146 \\
0.0071\end{array}$ & $\begin{array}{l}0.3233 \\
0.0056\end{array}$ & $\begin{array}{l}0.2203 \\
0.0630\end{array}$ & $\begin{array}{l}0.2719 \\
0.0209\end{array}$ \\
\hline & Cingap a & Coreia & Espanha & EUA & Franca & Holanda & Hong_K g \\
\hline Cingapura & 1.0000 & & & & & & \\
\hline Coreia & $\begin{array}{l}0.6065 \\
0.0000\end{array}$ & 1.0000 & & & & & \\
\hline Espanha & $\begin{array}{l}0.6005 \\
0.0000\end{array}$ & $\begin{array}{l}0.7131 \\
0.0000\end{array}$ & 1.0000 & & & & \\
\hline EUA & $\begin{array}{l}0.6546 \\
0.0000\end{array}$ & $\begin{array}{l}0.6984 \\
0.0000\end{array}$ & $\begin{array}{l}0.8416 \\
0.0000\end{array}$ & 1.0000 & & & \\
\hline Franca & $\begin{array}{l}0.6392 \\
0.0000\end{array}$ & $\begin{array}{l}0.6748 \\
0.0000\end{array}$ & $\begin{array}{l}0.8862 \\
0.0000\end{array}$ & $\begin{array}{l}0.8848 \\
0.0000\end{array}$ & 1.0000 & & \\
\hline Holanda & $\begin{array}{l}0.6577 \\
0.0000\end{array}$ & $\begin{array}{l}0.6936 \\
0.0000\end{array}$ & $\begin{array}{l}0.8567 \\
0.0000\end{array}$ & $\begin{array}{l}0.8418 \\
0.0000\end{array}$ & $\begin{array}{l}0.9410 \\
0.0000\end{array}$ & 1.0000 & \\
\hline Hong_Kong & $\begin{array}{l}0.6544 \\
0.0000\end{array}$ & $\begin{array}{l}0.6434 \\
0.0000\end{array}$ & $\begin{array}{l}0.6540 \\
0.0000\end{array}$ & $\begin{array}{l}0.7542 \\
0.0000\end{array}$ & $\begin{array}{l}0.6430 \\
0.0000\end{array}$ & $\begin{array}{l}0.6277 \\
0.0000\end{array}$ & 1.0000 \\
\hline India & $\begin{array}{l}0.5574 \\
0.0000\end{array}$ & $\begin{array}{l}0.5852 \\
0.0000\end{array}$ & $\begin{array}{l}0.5202 \\
0.0000\end{array}$ & $\begin{array}{l}0.4792 \\
0.0000\end{array}$ & $\begin{array}{l}0.4602 \\
0.0000\end{array}$ & $\begin{array}{l}0.4615 \\
0.0000\end{array}$ & $\begin{array}{l}0.5393 \\
0.0000\end{array}$ \\
\hline Italia & $\begin{array}{l}0.6519 \\
0.0000\end{array}$ & $\begin{array}{l}0.6867 \\
0.0000\end{array}$ & $\begin{array}{l}0.8755 \\
0.0000\end{array}$ & $\begin{array}{l}0.8394 \\
0.0000\end{array}$ & $\begin{array}{l}0.9086 \\
0.0000\end{array}$ & $\begin{array}{l}0.8621 \\
0.0000\end{array}$ & $\begin{array}{l}0.6603 \\
0.0000\end{array}$ \\
\hline Japao & $\begin{array}{l}0.3700 \\
0.0014\end{array}$ & $\begin{array}{l}0.5236 \\
0.0000\end{array}$ & $\begin{array}{l}0.5193 \\
0.0000\end{array}$ & $\begin{array}{l}0.4939 \\
0.0000\end{array}$ & $\begin{array}{l}0.5486 \\
0.0000\end{array}$ & $\begin{array}{l}0.4904 \\
0.0000\end{array}$ & $\begin{array}{l}0.5071 \\
0.0000\end{array}$ \\
\hline Malasia & $\begin{array}{l}0.6070 \\
0.0000\end{array}$ & $\begin{array}{l}0.3671 \\
0.0015\end{array}$ & $\begin{array}{l}0.3181 \\
0.0065\end{array}$ & $\begin{array}{l}0.3319 \\
0.0044\end{array}$ & $\begin{array}{l}0.3006 \\
0.0103\end{array}$ & $\begin{array}{l}0.3377 \\
0.0037\end{array}$ & $\begin{array}{l}0.4761 \\
0.0000\end{array}$ \\
\hline Mexico & $\begin{array}{l}0.6948 \\
0.0000\end{array}$ & $\begin{array}{l}0.7325 \\
0.0000\end{array}$ & $\begin{array}{l}0.6770 \\
0.0000\end{array}$ & $\begin{array}{l}0.6927 \\
0.0000\end{array}$ & $\begin{array}{l}0.6543 \\
0.0000\end{array}$ & $\begin{array}{l}0.6683 \\
0.0000\end{array}$ & $\begin{array}{l}0.6282 \\
0.0000\end{array}$ \\
\hline Reino_Unido & $\begin{array}{l}0.6519 \\
0.0000\end{array}$ & $\begin{array}{l}0.6505 \\
0.0000\end{array}$ & $\begin{array}{l}0.8589 \\
0.0000\end{array}$ & $\begin{array}{l}0.8605 \\
0.0000\end{array}$ & $\begin{array}{l}0.9007 \\
0.0000\end{array}$ & $\begin{array}{l}0.8715 \\
0.0000\end{array}$ & $\begin{array}{l}0.6484 \\
0.0000\end{array}$ \\
\hline Suecia & $\begin{array}{l}0.6283 \\
0.0000\end{array}$ & $\begin{array}{l}0.7100 \\
0.0000\end{array}$ & $\begin{array}{l}0.8473 \\
0.0000\end{array}$ & $\begin{array}{l}0.8873 \\
0.0000\end{array}$ & $\begin{array}{l}0.8921 \\
0.0000\end{array}$ & $\begin{array}{l}0.8543 \\
0.0000\end{array}$ & $\begin{array}{l}0.6999 \\
0.0000\end{array}$ \\
\hline Suica & $\begin{array}{l}0.6098 \\
0.0000\end{array}$ & $\begin{array}{l}0.6547 \\
0.0000\end{array}$ & $\begin{array}{l}0.7971 \\
0.0000\end{array}$ & $\begin{array}{l}0.7822 \\
0.0000\end{array}$ & $\begin{array}{l}0.8489 \\
0.0000\end{array}$ & $\begin{array}{l}0.8844 \\
0.0000\end{array}$ & $\begin{array}{l}0.6128 \\
0.0000\end{array}$ \\
\hline Taiwan & $\begin{array}{l}0.6468 \\
0.0000\end{array}$ & $\begin{array}{l}0.6485 \\
0.0000\end{array}$ & $\begin{array}{l}0.5259 \\
0.0000\end{array}$ & $\begin{array}{l}0.4854 \\
0.0000\end{array}$ & $\begin{array}{l}0.4774 \\
0.0000\end{array}$ & $\begin{array}{l}0.4894 \\
0.0000\end{array}$ & $\begin{array}{l}0.5509 \\
0.0000\end{array}$ \\
\hline Venezuela & $\begin{array}{l}0.2578 \\
0.0288\end{array}$ & $\begin{array}{l}0.1711 \\
0.1508\end{array}$ & $\begin{array}{l}0.1678 \\
0.1589\end{array}$ & $\begin{array}{l}0.2594 \\
0.0278\end{array}$ & $\begin{array}{l}0.1661 \\
0.1633\end{array}$ & $\begin{array}{l}0.1165 \\
0.3298\end{array}$ & $\begin{array}{l}0.4105 \\
0.0003\end{array}$ \\
\hline
\end{tabular}




\begin{tabular}{|c|c|c|c|c|c|c|c|}
\hline & India & Italia & Japao & Malasia & Mexico & Reino_ o & Suecia \\
\hline India & 1.0000 & & & & & & \\
\hline \multirow[t]{2}{*}{ Italia } & 0.5128 & 1.0000 & & & & & \\
\hline & 0.0000 & & & & & & \\
\hline \multirow[t]{2}{*}{ Japao } & 0.5302 & 0.5224 & 1.0000 & & & & \\
\hline & 0.0000 & 0.0000 & & & & & \\
\hline \multirow[t]{2}{*}{ Malasia } & 0.3749 & 0.3463 & 0.0756 & 1.0000 & & & \\
\hline & 0.0012 & 0.0029 & 0.5282 & & & & \\
\hline \multirow[t]{2}{*}{ Mexico } & 0.5428 & 0.6982 & 0.4647 & 0.4997 & 1.0000 & & \\
\hline & 0.0000 & 0.0000 & 0.0000 & 0.0000 & & & \\
\hline \multirow[t]{2}{*}{ Reino_Unido } & 0.4846 & 0.8833 & 0.5223 & 0.2691 & 0.6571 & 1.0000 & \\
\hline & 0.0000 & 0.0000 & 0.0000 & 0.0222 & 0.0000 & & \\
\hline \multirow[t]{2}{*}{ Suecia } & 0.5131 & 0.8292 & 0.5124 & 0.2876 & 0.6152 & 0.8349 & 1.0000 \\
\hline & 0.0000 & 0.0000 & 0.0000 & 0.0143 & 0.0000 & 0.0000 & \\
\hline \multirow[t]{2}{*}{ Suica } & 0.4946 & 0.7729 & 0.5960 & 0.2305 & 0.6696 & 0.8076 & 0.7901 \\
\hline & 0.0000 & 0.0000 & 0.0000 & 0.0514 & 0.0000 & 0.0000 & 0.0000 \\
\hline \multirow[t]{2}{*}{ Taiwan } & 0.3985 & 0.4822 & 0.3380 & 0.5883 & 0.6109 & 0.3624 & 0.4298 \\
\hline & 0.0005 & 0.0000 & 0.0037 & 0.0000 & 0.0000 & 0.0018 & 0.0002 \\
\hline \multirow[t]{3}{*}{ Venezuela } & 0.2683 & 0.2296 & 0.2635 & 0.2226 & 0.2442 & 0.1696 & 0.1698 \\
\hline & 0.0227 & 0.0524 & 0.0253 & 0.0602 & 0.0387 & 0.1543 & 0.1539 \\
\hline & Suica & \multicolumn{2}{|c|}{ Taiwan Venezu a } & & & & \\
\hline Suica & 1.0000 & & & & & & \\
\hline \multirow[t]{2}{*}{ Taiwan } & 0.4068 & 1.0000 & & & & & \\
\hline & 0.0004 & & & & & & \\
\hline \multirow[t]{2}{*}{ Venezuela } & 0.2136 & 0.2583 & 1.0000 & & & & \\
\hline & 0.0716 & 0.0285 & & & & & \\
\hline
\end{tabular}




\section{Matriz de Correlações para Retornos em Moeda do Próprio País para o Período de 2003 a 2006}

\begin{tabular}{|c|c|c|c|c|c|c|c|}
\hline & Alemanha & rgent a & ustra a & Brasil & Canada & Chile & China \\
\hline Alemanha & 1.0000 & & & & & & \\
\hline Argentina & $\begin{array}{l}0.3165 \\
0.0284\end{array}$ & 1.0000 & & & & & \\
\hline Australia & $\begin{array}{l}0.6072 \\
0.0000\end{array}$ & $\begin{array}{l}0.2773 \\
0.0564\end{array}$ & 1.0000 & & & & \\
\hline Brasil & $\begin{array}{l}0.3897 \\
0.0062\end{array}$ & $\begin{array}{l}0.4427 \\
0.0016\end{array}$ & $\begin{array}{l}0.5428 \\
0.0001\end{array}$ & 1.0000 & & & \\
\hline Canada & $\begin{array}{l}0.5855 \\
0.0000\end{array}$ & $\begin{array}{l}0.5140 \\
0.0002\end{array}$ & $\begin{array}{l}0.6602 \\
0.0000\end{array}$ & $\begin{array}{l}0.5776 \\
0.0000\end{array}$ & 1.0000 & & \\
\hline Chile & $\begin{array}{l}0.4514 \\
0.0013\end{array}$ & $\begin{array}{l}0.3340 \\
0.0203\end{array}$ & $\begin{array}{l}0.4161 \\
0.0033\end{array}$ & $\begin{array}{l}0.3538 \\
0.0136\end{array}$ & $\begin{array}{l}0.4223 \\
0.0028\end{array}$ & 1.0000 & \\
\hline China & $\begin{array}{r}-0.0417 \\
0.7786\end{array}$ & $\begin{array}{l}0.1682 \\
0.2532\end{array}$ & $\begin{array}{l}0.0697 \\
0.6377\end{array}$ & $\begin{array}{l}0.2343 \\
0.1090\end{array}$ & $\begin{array}{l}0.1579 \\
0.2836\end{array}$ & $\begin{array}{l}0.0753 \\
0.6108\end{array}$ & 1.0000 \\
\hline Cingapura & $\begin{array}{l}0.5322 \\
0.0001\end{array}$ & $\begin{array}{l}0.4101 \\
0.0038\end{array}$ & $\begin{array}{l}0.5522 \\
0.0000\end{array}$ & $\begin{array}{l}0.3684 \\
0.0100\end{array}$ & $\begin{array}{l}0.5677 \\
0.0000\end{array}$ & $\begin{array}{l}0.4409 \\
0.0017\end{array}$ & $\begin{array}{l}0.0180 \\
0.9035\end{array}$ \\
\hline Coreia & $\begin{array}{l}0.6896 \\
0.0000\end{array}$ & $\begin{array}{l}0.3288 \\
0.0225\end{array}$ & $\begin{array}{l}0.5489 \\
0.0001\end{array}$ & $\begin{array}{l}0.4337 \\
0.0021\end{array}$ & $\begin{array}{l}0.6492 \\
0.0000\end{array}$ & $\begin{array}{l}0.3915 \\
0.0059\end{array}$ & $\begin{array}{l}0.0201 \\
0.8920\end{array}$ \\
\hline Espanha & $\begin{array}{l}0.7954 \\
0.0000\end{array}$ & $\begin{array}{l}0.3857 \\
0.0068\end{array}$ & $\begin{array}{l}0.5706 \\
0.0000\end{array}$ & $\begin{array}{l}0.3261 \\
0.0237\end{array}$ & $\begin{array}{l}0.5366 \\
0.0001\end{array}$ & $\begin{array}{l}0.4527 \\
0.0012\end{array}$ & $\begin{array}{r}-0.0288 \\
0.8458\end{array}$ \\
\hline EUA & $\begin{array}{l}0.7775 \\
0.0000\end{array}$ & $\begin{array}{l}0.3940 \\
0.0056\end{array}$ & $\begin{array}{l}0.6249 \\
0.0000\end{array}$ & $\begin{array}{l}0.5915 \\
0.0000\end{array}$ & $\begin{array}{l}0.6777 \\
0.0000\end{array}$ & $\begin{array}{l}0.4991 \\
0.0003\end{array}$ & $\begin{array}{l}0.0509 \\
0.7312\end{array}$ \\
\hline Franca & $\begin{array}{l}0.9312 \\
0.0000\end{array}$ & $\begin{array}{l}0.2996 \\
0.0386\end{array}$ & $\begin{array}{l}0.6815 \\
0.0000\end{array}$ & $\begin{array}{l}0.4015 \\
0.0047\end{array}$ & $\begin{array}{l}0.6814 \\
0.0000\end{array}$ & $\begin{array}{l}0.4830 \\
0.0005\end{array}$ & $\begin{array}{r}-0.0392 \\
0.7914\end{array}$ \\
\hline Holanda & $\begin{array}{l}0.8947 \\
0.0000\end{array}$ & $\begin{array}{l}0.1663 \\
0.2586\end{array}$ & $\begin{array}{l}0.6328 \\
0.0000\end{array}$ & $\begin{array}{l}0.3463 \\
0.0159\end{array}$ & $\begin{array}{l}0.6000 \\
0.0000\end{array}$ & $\begin{array}{l}0.3741 \\
0.0088\end{array}$ & $\begin{array}{r}-0.0872 \\
0.5558\end{array}$ \\
\hline Hong_Kong & $\begin{array}{l}0.3474 \\
0.0155\end{array}$ & $\begin{array}{l}0.3187 \\
0.0272\end{array}$ & $\begin{array}{l}0.3945 \\
0.0055\end{array}$ & $\begin{array}{l}0.5228 \\
0.0001\end{array}$ & $\begin{array}{l}0.6645 \\
0.0000\end{array}$ & $\begin{array}{l}0.4734 \\
0.0007\end{array}$ & $\begin{array}{l}0.2365 \\
0.1056\end{array}$ \\
\hline India & $\begin{array}{l}0.4177 \\
0.0031\end{array}$ & $\begin{array}{l}0.4167 \\
0.0032\end{array}$ & $\begin{array}{l}0.5302 \\
0.0001\end{array}$ & $\begin{array}{l}0.4187 \\
0.0031\end{array}$ & $\begin{array}{l}0.5277 \\
0.0001\end{array}$ & $\begin{array}{l}0.1898 \\
0.1963\end{array}$ & $\begin{array}{r}-0.0341 \\
0.8178\end{array}$ \\
\hline Italia & $\begin{array}{l}0.7448 \\
0.0000\end{array}$ & $\begin{array}{l}0.4026 \\
0.0046\end{array}$ & $\begin{array}{l}0.5118 \\
0.0002\end{array}$ & $\begin{array}{l}0.3447 \\
0.0164\end{array}$ & $\begin{array}{l}0.6355 \\
0.0000\end{array}$ & $\begin{array}{l}0.4462 \\
0.0015\end{array}$ & $\begin{array}{r}-0.0184 \\
0.9013\end{array}$ \\
\hline Japao & $\begin{array}{l}0.3939 \\
0.0056\end{array}$ & $\begin{array}{l}0.2113 \\
0.1493\end{array}$ & $\begin{array}{l}0.5296 \\
0.0001\end{array}$ & $\begin{array}{l}0.3419 \\
0.0174\end{array}$ & $\begin{array}{l}0.5502 \\
0.0001\end{array}$ & $\begin{array}{l}0.0378 \\
0.7986\end{array}$ & $\begin{array}{r}-0.0230 \\
0.8768\end{array}$ \\
\hline Malasia & $\begin{array}{l}0.2434 \\
0.0956\end{array}$ & $\begin{array}{l}0.2812 \\
0.0529\end{array}$ & $\begin{array}{l}0.3699 \\
0.0097\end{array}$ & $\begin{array}{l}0.2866 \\
0.0483\end{array}$ & $\begin{array}{l}0.4482 \\
0.0014\end{array}$ & $\begin{array}{l}0.4193 \\
0.0030\end{array}$ & $\begin{array}{l}0.2528 \\
0.0829\end{array}$ \\
\hline Mexico & $\begin{array}{l}0.5280 \\
0.0001\end{array}$ & $\begin{array}{l}0.5982 \\
0.0000\end{array}$ & $\begin{array}{l}0.6275 \\
0.0000\end{array}$ & $\begin{array}{l}0.5768 \\
0.0000\end{array}$ & $\begin{array}{l}0.6578 \\
0.0000\end{array}$ & $\begin{array}{l}0.3232 \\
0.0250\end{array}$ & $\begin{array}{l}0.1679 \\
0.2540\end{array}$ \\
\hline Reino_Unido & 0.7221 & 0.3422 & 0.5714 & 0.4265 & 0.5694 & 0.4793 & -0.0908 \\
\hline
\end{tabular}




\begin{tabular}{|c|c|c|c|c|c|c|c|}
\hline & 0.0000 & 0.0173 & 0.0000 & 0.0025 & 0.0000 & 0.0006 & 0.5395 \\
\hline \multirow[t]{2}{*}{ Suecia } & 0.8378 & 0.2517 & 0.6418 & 0.3609 & 0.5636 & 0.4455 & 0.0067 \\
\hline & 0.0000 & 0.0844 & 0.0000 & 0.0117 & 0.0000 & 0.0015 & 0.9637 \\
\hline \multirow[t]{2}{*}{ Suica } & 0.8544 & 0.2590 & 0.5146 & 0.3565 & 0.4947 & 0.3195 & -0.0934 \\
\hline & 0.0000 & 0.0754 & 0.0002 & 0.0129 & 0.0004 & 0.0269 & 0.5276 \\
\hline \multirow[t]{2}{*}{ Taiwan } & 0.2759 & 0.1990 & 0.4276 & 0.2528 & 0.4686 & 0.2310 & 0.2787 \\
\hline & 0.0577 & 0.1750 & 0.0024 & 0.0830 & 0.0008 & 0.1143 & 0.0551 \\
\hline \multirow[t]{3}{*}{ Venezuela } & 0.1355 & 0.3958 & 0.0836 & 0.3251 & 0.3560 & 0.2475 & 0.3282 \\
\hline & 0.3586 & 0.0054 & 0.5719 & 0.0242 & 0.0130 & 0.0898 & 0.0227 \\
\hline & Cingap a & Coreia & Espanha & EUA & Franca & Holanda & Hong_K q \\
\hline Cingapura & 1.0000 & & & & & & \\
\hline \multirow[t]{2}{*}{ Coreia } & 0.5581 & 1.0000 & & & & & \\
\hline & 0.0000 & & & & & & \\
\hline \multirow[t]{2}{*}{ Espanha } & 0.5459 & 0.6432 & 1.0000 & & & & \\
\hline & 0.0001 & 0.0000 & & & & & \\
\hline \multirow[t]{2}{*}{ EUA } & 0.5434 & 0.6486 & 0.6767 & 1.0000 & & & \\
\hline & 0.0001 & 0.0000 & 0.0000 & & & & \\
\hline \multirow[t]{2}{*}{ Franca } & 0.5399 & 0.7299 & 0.8035 & 0.7376 & 1.0000 & & \\
\hline & 0.0001 & 0.0000 & 0.0000 & 0.0000 & & & \\
\hline \multirow[t]{2}{*}{ Holanda } & 0.5464 & 0.7349 & 0.7562 & 0.6788 & 0.9298 & 1.0000 & \\
\hline & 0.0001 & 0.0000 & 0.0000 & 0.0000 & 0.0000 & & \\
\hline \multirow[t]{2}{*}{ Hong_Kong } & 0.6225 & 0.5299 & 0.3712 & 0.5832 & 0.4042 & 0.4083 & 1.0000 \\
\hline & 0.0000 & 0.0001 & 0.0094 & 0.0000 & 0.0044 & 0.0040 & \\
\hline \multirow[t]{2}{*}{ India } & 0.6741 & 0.5659 & 0.5099 & 0.4312 & 0.4485 & 0.4180 & 0.4670 \\
\hline & 0.0000 & 0.0000 & 0.0002 & 0.0022 & 0.0014 & 0.0031 & 0.0008 \\
\hline \multirow[t]{2}{*}{ Italia } & 0.5165 & 0.6549 & 0.7505 & 0.6387 & 0.7844 & 0.7235 & 0.4173 \\
\hline & 0.0002 & 0.0000 & 0.0000 & 0.0000 & 0.0000 & 0.0000 & 0.0032 \\
\hline \multirow[t]{2}{*}{ Japao } & 0.4893 & 0.5481 & 0.3664 & 0.3987 & 0.4752 & 0.4807 & 0.2936 \\
\hline & 0.0004 & 0.0001 & 0.0104 & 0.0050 & 0.0006 & 0.0005 & 0.0428 \\
\hline \multirow[t]{2}{*}{ Malasia } & 0.5672 & 0.4340 & 0.3147 & 0.3861 & 0.2626 & 0.2311 & 0.5893 \\
\hline & 0.0000 & 0.0021 & 0.0294 & 0.0067 & 0.0713 & 0.1139 & 0.0000 \\
\hline \multirow[t]{2}{*}{ Mexico } & 0.5636 & 0.6989 & 0.6191 & 0.6210 & 0.5753 & 0.5724 & 0.5098 \\
\hline & 0.0000 & 0.0000 & 0.0000 & 0.0000 & 0.0000 & 0.0000 & 0.0002 \\
\hline \multirow[t]{2}{*}{ Reino_Unido } & 0.5054 & 0.6311 & 0.6884 & 0.6716 & 0.7465 & 0.7044 & 0.3836 \\
\hline & 0.0002 & 0.0000 & 0.0000 & 0.0000 & 0.0000 & 0.0000 & 0.0071 \\
\hline \multirow[t]{2}{*}{ Suecia } & 0.5996 & 0.6724 & 0.7617 & 0.6760 & 0.8527 & 0.8231 & 0.3941 \\
\hline & 0.0000 & 0.0000 & 0.0000 & 0.0000 & 0.0000 & 0.0000 & 0.0056 \\
\hline \multirow[t]{2}{*}{ Suica } & 0.5558 & 0.6706 & 0.7180 & 0.6714 & 0.8456 & 0.8759 & 0.3502 \\
\hline & 0.0000 & 0.0000 & 0.0000 & 0.0000 & 0.0000 & 0.0000 & 0.0147 \\
\hline \multirow[t]{2}{*}{ Taiwan } & 0.5456 & 0.5319 & 0.2635 & 0.4089 & 0.3009 & 0.3415 & 0.5920 \\
\hline & 0.0001 & 0.0001 & 0.0703 & 0.0039 & 0.0377 & 0.0175 & 0.0000 \\
\hline \multirow[t]{2}{*}{ Venezuela } & 0.4425 & 0.1882 & 0.1304 & 0.3418 & 0.1612 & 0.1122 & 0.5225 \\
\hline & 0.0016 & 0.2001 & 0.3770 & 0.0174 & 0.2738 & 0.4479 & 0.0001 \\
\hline
\end{tabular}




\begin{tabular}{|c|c|c|c|c|c|c|c|}
\hline & India & Italia & Japao & Malasia & Mexico & Reino_ o & Suecia \\
\hline India & 1.0000 & & & & & & \\
\hline Italia & $\begin{array}{l}0.4657 \\
0.0009\end{array}$ & 1.0000 & & & & & \\
\hline Japao & $\begin{array}{l}0.6360 \\
0.0000\end{array}$ & $\begin{array}{l}0.3967 \\
0.0052\end{array}$ & 1.0000 & & & & \\
\hline Malasia & $\begin{array}{l}0.3950 \\
0.0055\end{array}$ & $\begin{array}{l}0.2082 \\
0.1556\end{array}$ & $\begin{array}{l}0.2610 \\
0.0732\end{array}$ & 1.0000 & & & \\
\hline Mexico & $\begin{array}{l}0.5036 \\
0.0003\end{array}$ & $\begin{array}{l}0.5964 \\
0.0000\end{array}$ & $\begin{array}{l}0.4914 \\
0.0004\end{array}$ & $\begin{array}{l}0.4051 \\
0.0043\end{array}$ & 1.0000 & & \\
\hline Reino_Unido & $\begin{array}{l}0.4696 \\
0.0008\end{array}$ & $\begin{array}{l}0.7551 \\
0.0000\end{array}$ & $\begin{array}{l}0.4129 \\
0.0035\end{array}$ & $\begin{array}{l}0.1083 \\
0.4636\end{array}$ & $\begin{array}{l}0.5501 \\
0.0001\end{array}$ & 1.0000 & \\
\hline Suecia & $\begin{array}{l}0.4448 \\
0.0015\end{array}$ & $\begin{array}{l}0.6811 \\
0.0000\end{array}$ & $\begin{array}{l}0.4841 \\
0.0005\end{array}$ & $\begin{array}{l}0.3116 \\
0.0311\end{array}$ & $\begin{array}{l}0.5750 \\
0.0000\end{array}$ & $\begin{array}{l}0.6943 \\
0.0000\end{array}$ & 1.0000 \\
\hline Suica & $\begin{array}{l}0.4280 \\
0.0024\end{array}$ & $\begin{array}{l}0.6551 \\
0.0000\end{array}$ & $\begin{array}{l}0.4620 \\
0.0009\end{array}$ & $\begin{array}{l}0.1451 \\
0.3251\end{array}$ & $\begin{array}{l}0.5946 \\
0.0000\end{array}$ & $\begin{array}{l}0.6717 \\
0.0000\end{array}$ & $\begin{array}{l}0.7664 \\
0.0000\end{array}$ \\
\hline Taiwan & $\begin{array}{l}0.4147 \\
0.0034\end{array}$ & $\begin{array}{l}0.1770 \\
0.2287\end{array}$ & $\begin{array}{l}0.4158 \\
0.0033\end{array}$ & $\begin{array}{l}0.5854 \\
0.0000\end{array}$ & $\begin{array}{l}0.4019 \\
0.0046\end{array}$ & $\begin{array}{l}0.0103 \\
0.9448\end{array}$ & $\begin{array}{l}0.3177 \\
0.0278\end{array}$ \\
\hline Venezuela & $\begin{array}{l}0.2445 \\
0.0940\end{array}$ & $\begin{array}{l}0.3152 \\
0.0291\end{array}$ & $\begin{array}{l}0.2397 \\
0.1008\end{array}$ & $\begin{array}{l}0.3929 \\
0.0057\end{array}$ & $\begin{array}{l}0.2663 \\
0.0673\end{array}$ & $\begin{array}{l}0.1568 \\
0.2871\end{array}$ & $\begin{array}{l}0.1159 \\
0.4329\end{array}$ \\
\hline & Suica & Taiwan & Venezu a & & & & \\
\hline Suica & 1.0000 & & & & & & \\
\hline Taiwan & $\begin{array}{l}0.2755 \\
0.0581\end{array}$ & 1.0000 & & & & & \\
\hline Venezuela & $\begin{array}{l}0.1531 \\
0.2990\end{array}$ & $\begin{array}{l}0.3881 \\
0.0064\end{array}$ & 1.0000 & & & & \\
\hline
\end{tabular}




\section{Matriz de Correlações entre Retornos em Reais para o Período de 2000 a 2005}

\begin{tabular}{|c|c|c|c|c|c|c|c|}
\hline & Alemanha & Argent a & Austra a & Brasil & Canada & Chile & China \\
\hline Alemanha & 1.0000 & & & & & & \\
\hline Argentina & $\begin{array}{l}0.1615 \\
0.1785\end{array}$ & 1.0000 & & & & & \\
\hline Australia & $\begin{array}{l}0.4742 \\
0.0000\end{array}$ & $\begin{array}{l}0.2270 \\
0.0569\end{array}$ & 1.0000 & & & & \\
\hline Brasil & $\begin{array}{l}0.3230 \\
0.0060\end{array}$ & $\begin{array}{l}0.1436 \\
0.2322\end{array}$ & $\begin{array}{r}-0.0193 \\
0.8729\end{array}$ & 1.0000 & & & \\
\hline Canada & $\begin{array}{l}0.5453 \\
0.0000\end{array}$ & $\begin{array}{l}0.2886 \\
0.0147\end{array}$ & $\begin{array}{l}0.7744 \\
0.0000\end{array}$ & $\begin{array}{l}0.1223 \\
0.3095\end{array}$ & 1.0000 & & \\
\hline Chile & $\begin{array}{l}0.4906 \\
0.0000\end{array}$ & $\begin{array}{l}0.3471 \\
0.0030\end{array}$ & $\begin{array}{l}0.6319 \\
0.0000\end{array}$ & $\begin{array}{l}0.0819 \\
0.4974\end{array}$ & $\begin{array}{l}0.5693 \\
0.0000\end{array}$ & 1.0000 & \\
\hline China & $\begin{array}{l}0.2173 \\
0.0687\end{array}$ & $\begin{array}{l}0.2412 \\
0.0428\end{array}$ & $\begin{array}{l}0.4816 \\
0.0000\end{array}$ & $\begin{array}{r}-0.3350 \\
0.0043\end{array}$ & $\begin{array}{l}0.4997 \\
0.0000\end{array}$ & $\begin{array}{l}0.2951 \\
0.0125\end{array}$ & 1.0000 \\
\hline Cingapura & $\begin{array}{l}0.4011 \\
0.0005\end{array}$ & $\begin{array}{l}0.2382 \\
0.0455\end{array}$ & $\begin{array}{l}0.7489 \\
0.0000\end{array}$ & $\begin{array}{r}-0.0655 \\
0.5875\end{array}$ & $\begin{array}{l}0.6309 \\
0.0000\end{array}$ & $\begin{array}{l}0.5208 \\
0.0000\end{array}$ & $\begin{array}{l}0.3262 \\
0.0055\end{array}$ \\
\hline Coreia & $\begin{array}{l}0.4683 \\
0.0000\end{array}$ & $\begin{array}{l}0.1677 \\
0.1621\end{array}$ & $\begin{array}{l}0.6700 \\
0.0000\end{array}$ & $\begin{array}{l}0.1862 \\
0.1201\end{array}$ & $\begin{array}{l}0.5851 \\
0.0000\end{array}$ & $\begin{array}{l}0.5958 \\
0.0000\end{array}$ & $\begin{array}{l}0.2271 \\
0.0569\end{array}$ \\
\hline Espanha & $\begin{array}{l}0.7483 \\
0.0000\end{array}$ & $\begin{array}{l}0.3229 \\
0.0060\end{array}$ & $\begin{array}{l}0.6888 \\
0.0000\end{array}$ & $\begin{array}{l}0.1320 \\
0.2725\end{array}$ & $\begin{array}{l}0.6996 \\
0.0000\end{array}$ & $\begin{array}{l}0.6057 \\
0.0000\end{array}$ & $\begin{array}{l}0.4039 \\
0.0005\end{array}$ \\
\hline EUA & $\begin{array}{l}0.6001 \\
0.0000\end{array}$ & $\begin{array}{l}0.2021 \\
0.0909\end{array}$ & $\begin{array}{l}0.7236 \\
0.0000\end{array}$ & $\begin{array}{r}-0.0687 \\
0.5694\end{array}$ & $\begin{array}{l}0.8054 \\
0.0000\end{array}$ & $\begin{array}{l}0.6358 \\
0.0000\end{array}$ & $\begin{array}{l}0.4739 \\
0.0000\end{array}$ \\
\hline Franca & $\begin{array}{l}0.8805 \\
0.0000\end{array}$ & $\begin{array}{l}0.2338 \\
0.0497\end{array}$ & $\begin{array}{l}0.6604 \\
0.0000\end{array}$ & $\begin{array}{l}0.1426 \\
0.2353\end{array}$ & $\begin{array}{l}0.7105 \\
0.0000\end{array}$ & $\begin{array}{l}0.5765 \\
0.0000\end{array}$ & $\begin{array}{l}0.4223 \\
0.0002\end{array}$ \\
\hline Holanda & $\begin{array}{l}0.8803 \\
0.0000\end{array}$ & $\begin{array}{l}0.1008 \\
0.4029\end{array}$ & $\begin{array}{l}0.6023 \\
0.0000\end{array}$ & $\begin{array}{l}0.1852 \\
0.1220\end{array}$ & $\begin{array}{l}0.6097 \\
0.0000\end{array}$ & $\begin{array}{l}0.5174 \\
0.0000\end{array}$ & $\begin{array}{l}0.3195 \\
0.0066\end{array}$ \\
\hline Hong_Kong & $\begin{array}{l}0.5899 \\
0.0000\end{array}$ & $\begin{array}{l}0.2624 \\
0.0270\end{array}$ & $\begin{array}{l}0.7323 \\
0.0000\end{array}$ & $\begin{array}{l}0.1032 \\
0.3918\end{array}$ & $\begin{array}{l}0.7942 \\
0.0000\end{array}$ & $\begin{array}{l}0.6104 \\
0.0000\end{array}$ & $\begin{array}{l}0.5043 \\
0.0000\end{array}$ \\
\hline India & $\begin{array}{l}0.3526 \\
0.0026\end{array}$ & $\begin{array}{l}0.3516 \\
0.0026\end{array}$ & $\begin{array}{l}0.6579 \\
0.0000\end{array}$ & $\begin{array}{l}0.0841 \\
0.4858\end{array}$ & $\begin{array}{l}0.5838 \\
0.0000\end{array}$ & $\begin{array}{l}0.5293 \\
0.0000\end{array}$ & $\begin{array}{l}0.3589 \\
0.0021\end{array}$ \\
\hline Italia & $\begin{array}{l}0.7490 \\
0.0000\end{array}$ & $\begin{array}{l}0.3026 \\
0.0103\end{array}$ & $\begin{array}{l}0.6459 \\
0.0000\end{array}$ & $\begin{array}{l}0.0198 \\
0.8696\end{array}$ & $\begin{array}{l}0.6917 \\
0.0000\end{array}$ & $\begin{array}{l}0.5662 \\
0.0000\end{array}$ & $\begin{array}{l}0.4837 \\
0.0000\end{array}$ \\
\hline Japao & $\begin{array}{l}0.3178 \\
0.0069\end{array}$ & $\begin{array}{l}0.1165 \\
0.3332\end{array}$ & $\begin{array}{l}0.7106 \\
0.0000\end{array}$ & $\begin{array}{r}-0.0622 \\
0.6065\end{array}$ & $\begin{array}{l}0.7120 \\
0.0000\end{array}$ & $\begin{array}{l}0.4859 \\
0.0000\end{array}$ & $\begin{array}{l}0.4756 \\
0.0000\end{array}$ \\
\hline Malasia & $\begin{array}{l}0.3185 \\
0.0068\end{array}$ & $\begin{array}{l}0.2264 \\
0.0576\end{array}$ & $\begin{array}{l}0.5220 \\
0.0000\end{array}$ & $\begin{array}{r}-0.2719 \\
0.0218\end{array}$ & $\begin{array}{l}0.4883 \\
0.0000\end{array}$ & $\begin{array}{l}0.5445 \\
0.0000\end{array}$ & $\begin{array}{l}0.5011 \\
0.0000\end{array}$ \\
\hline Mexico & $\begin{array}{l}0.5060 \\
0.0000\end{array}$ & $\begin{array}{l}0.4057 \\
0.0004\end{array}$ & $\begin{array}{l}0.6156 \\
0.0000\end{array}$ & $\begin{array}{l}0.1688 \\
0.1594\end{array}$ & $\begin{array}{l}0.6595 \\
0.0000\end{array}$ & $\begin{array}{l}0.5324 \\
0.0000\end{array}$ & $\begin{array}{l}0.3363 \\
0.0041\end{array}$ \\
\hline Reino_Unido & $\begin{array}{l}0.6151 \\
0.0000\end{array}$ & $\begin{array}{l}0.2532 \\
0.0331\end{array}$ & $\begin{array}{l}0.7481 \\
0.0000\end{array}$ & $\begin{array}{r}-0.1176 \\
0.3288\end{array}$ & $\begin{array}{l}0.7221 \\
0.0000\end{array}$ & $\begin{array}{l}0.6559 \\
0.0000\end{array}$ & $\begin{array}{l}0.5362 \\
0.0000\end{array}$ \\
\hline
\end{tabular}




\begin{tabular}{|c|c|c|c|c|c|c|c|}
\hline \multirow[t]{2}{*}{ Suecia } & 0.8152 & 0.2833 & 0.5695 & 0.2603 & 0.6693 & 0.5341 & 0.3024 \\
\hline & 0.0000 & 0.0167 & 0.0000 & 0.0283 & 0.0000 & 0.0000 & 0.0104 \\
\hline \multirow[t]{2}{*}{ Suica } & 0.5621 & 0.1031 & 0.6979 & -0.1638 & 0.6436 & 0.5451 & 0.5841 \\
\hline & 0.0000 & 0.3924 & 0.0000 & 0.1723 & 0.0000 & 0.0000 & 0.0000 \\
\hline \multirow[t]{2}{*}{ Taiwan } & 0.3639 & 0.3487 & 0.4735 & 0.0768 & 0.4465 & 0.4974 & 0.3314 \\
\hline & 0.0018 & 0.0029 & 0.0000 & 0.5243 & 0.0001 & 0.0000 & 0.0048 \\
\hline \multirow[t]{3}{*}{ Venezuela } & 0.3263 & 0.3561 & 0.4292 & -0.0666 & 0.4921 & 0.4462 & 0.3376 \\
\hline & 0.0055 & 0.0023 & 0.0002 & 0.5812 & 0.0000 & 0.0001 & 0.0040 \\
\hline & Cingap a & Coreia & Espanha & EUA & Franca & Holanda & Hong_K g \\
\hline Cingapura & 1.0000 & & & & & & \\
\hline \multirow[t]{2}{*}{ Coreia } & 0.5684 & 1.0000 & & & & & \\
\hline & 0.0000 & & & & & & \\
\hline \multirow[t]{2}{*}{ Espanha } & 0.4624 & 0.5167 & 1.0000 & & & & \\
\hline & 0.0000 & 0.0000 & & & & & \\
\hline \multirow[t]{2}{*}{ EUA } & 0.6770 & 0.6288 & 0.6622 & 1.0000 & & & \\
\hline & 0.0000 & 0.0000 & 0.0000 & & & & \\
\hline \multirow[t]{2}{*}{ Franca } & 0.4890 & 0.4800 & 0.8429 & 0.7419 & 1.0000 & & \\
\hline & 0.0000 & 0.0000 & 0.0000 & 0.0000 & & & \\
\hline \multirow[t]{2}{*}{ Holanda } & 0.4961 & 0.5132 & 0.7628 & 0.6583 & 0.9153 & 1.0000 & \\
\hline & 0.0000 & 0.0000 & 0.0000 & 0.0000 & 0.0000 & & \\
\hline \multirow[t]{2}{*}{ Hong_Kong } & 0.6568 & 0.6054 & 0.7278 & 0.7494 & 0.6979 & 0.6349 & 1.0000 \\
\hline & 0.0000 & 0.0000 & 0.0000 & 0.0000 & 0.0000 & 0.0000 & \\
\hline \multirow[t]{2}{*}{ India } & 0.5861 & 0.6040 & 0.5344 & 0.4701 & 0.4251 & 0.4110 & 0.5579 \\
\hline & 0.0000 & 0.0000 & 0.0000 & 0.0000 & 0.0002 & 0.0004 & 0.0000 \\
\hline \multirow[t]{2}{*}{ Italia } & 0.4929 & 0.4126 & 0.8600 & 0.6433 & 0.8737 & 0.8064 & 0.6933 \\
\hline & 0.0000 & 0.0003 & 0.0000 & 0.0000 & 0.0000 & 0.0000 & 0.0000 \\
\hline \multirow[t]{2}{*}{ Japao } & 0.5404 & 0.6090 & 0.5657 & 0.6943 & 0.5002 & 0.4586 & 0.6420 \\
\hline & 0.0000 & 0.0000 & 0.0000 & 0.0000 & 0.0000 & 0.0001 & 0.0000 \\
\hline \multirow[t]{2}{*}{ Malasia } & 0.6038 & 0.3756 & 0.4635 & 0.5453 & 0.4429 & 0.3826 & 0.5608 \\
\hline & 0.0000 & 0.0012 & 0.0000 & 0.0000 & 0.0001 & 0.0010 & 0.0000 \\
\hline \multirow[t]{2}{*}{ Mexico } & 0.6373 & 0.6577 & 0.5704 & 0.6463 & 0.5104 & 0.5077 & 0.6417 \\
\hline & 0.0000 & 0.0000 & 0.0000 & 0.0000 & 0.0000 & 0.0000 & 0.0000 \\
\hline \multirow[t]{2}{*}{ Reino_Unido } & 0.6527 & 0.4990 & 0.7378 & 0.8609 & 0.8110 & 0.7092 & 0.7320 \\
\hline & 0.0000 & 0.0000 & 0.0000 & 0.0000 & 0.0000 & 0.0000 & 0.0000 \\
\hline \multirow[t]{2}{*}{ Suecia } & 0.4363 & 0.5146 & 0.7826 & 0.6712 & 0.8387 & 0.7784 & 0.6781 \\
\hline & 0.0001 & 0.0000 & 0.0000 & 0.0000 & 0.0000 & 0.0000 & 0.0000 \\
\hline \multirow[t]{2}{*}{ Suica } & 0.5178 & 0.4524 & 0.6508 & 0.7313 & 0.7622 & 0.7121 & 0.6590 \\
\hline & 0.0000 & 0.0001 & 0.0000 & 0.0000 & 0.0000 & 0.0000 & 0.0000 \\
\hline \multirow[t]{2}{*}{ Taiwan } & 0.5091 & 0.6393 & 0.4419 & 0.4819 & 0.4012 & 0.3786 & 0.5362 \\
\hline & 0.0000 & 0.0000 & 0.0001 & 0.0000 & 0.0005 & 0.0011 & 0.0000 \\
\hline \multirow[t]{2}{*}{ Venezuela } & 0.3848 & 0.3034 & 0.4955 & 0.5132 & 0.4593 & 0.4115 & 0.5314 \\
\hline & 0.0009 & 0.0101 & 0.0000 & 0.0000 & 0.0001 & 0.0004 & 0.0000 \\
\hline
\end{tabular}




\begin{tabular}{|c|c|c|c|c|c|c|c|}
\hline & India & Italia & Japao & Malasia & Mexico & Reino_ o & Suecia \\
\hline India & 1.0000 & & & & & & \\
\hline Italia & $\begin{array}{l}0.5278 \\
0.0000\end{array}$ & 1.0000 & & & & & \\
\hline Japao & $\begin{array}{l}0.6470 \\
0.0000\end{array}$ & $\begin{array}{l}0.5232 \\
0.0000\end{array}$ & 1.0000 & & & & \\
\hline Malasia & $\begin{array}{l}0.4788 \\
0.0000\end{array}$ & $\begin{array}{l}0.5366 \\
0.0000\end{array}$ & $\begin{array}{l}0.4473 \\
0.0001\end{array}$ & 1.0000 & & & \\
\hline Mexico & $\begin{array}{l}0.4839 \\
0.0000\end{array}$ & $\begin{array}{l}0.5597 \\
0.0000\end{array}$ & $\begin{array}{l}0.5319 \\
0.0000\end{array}$ & $\begin{array}{l}0.4828 \\
0.0000\end{array}$ & 1.0000 & & \\
\hline Reino_Unido & $\begin{array}{l}0.4492 \\
0.0001\end{array}$ & $\begin{array}{l}0.7228 \\
0.0000\end{array}$ & $\begin{array}{l}0.6500 \\
0.0000\end{array}$ & $\begin{array}{l}0.5817 \\
0.0000\end{array}$ & $\begin{array}{l}0.5576 \\
0.0000\end{array}$ & 1.0000 & \\
\hline Suecia & $\begin{array}{l}0.4870 \\
0.0000\end{array}$ & $\begin{array}{l}0.7774 \\
0.0000\end{array}$ & $\begin{array}{l}0.4398 \\
0.0001\end{array}$ & $\begin{array}{l}0.3530 \\
0.0025\end{array}$ & $\begin{array}{l}0.5240 \\
0.0000\end{array}$ & $\begin{array}{l}0.6298 \\
0.0000\end{array}$ & 1.0000 \\
\hline Suica & $\begin{array}{l}0.4488 \\
0.0001\end{array}$ & $\begin{array}{l}0.6951 \\
0.0000\end{array}$ & $\begin{array}{l}0.6184 \\
0.0000\end{array}$ & $\begin{array}{l}0.4893 \\
0.0000\end{array}$ & $\begin{array}{l}0.4035 \\
0.0005\end{array}$ & $\begin{array}{l}0.8302 \\
0.0000\end{array}$ & $\begin{array}{l}0.5685 \\
0.0000\end{array}$ \\
\hline Taiwan & $\begin{array}{l}0.4301 \\
0.0002\end{array}$ & $\begin{array}{l}0.3706 \\
0.0015\end{array}$ & $\begin{array}{l}0.4048 \\
0.0005\end{array}$ & $\begin{array}{l}0.6038 \\
0.0000\end{array}$ & $\begin{array}{l}0.5121 \\
0.0000\end{array}$ & $\begin{array}{l}0.3889 \\
0.0008\end{array}$ & $\begin{array}{l}0.3647 \\
0.0018\end{array}$ \\
\hline Venezuela & $\begin{array}{l}0.4008 \\
0.0005\end{array}$ & $\begin{array}{l}0.5575 \\
0.0000\end{array}$ & $\begin{array}{l}0.4095 \\
0.0004\end{array}$ & $\begin{array}{l}0.4143 \\
0.0003\end{array}$ & $\begin{array}{l}0.4227 \\
0.0002\end{array}$ & $\begin{array}{l}0.5551 \\
0.0000\end{array}$ & $\begin{array}{l}0.3846 \\
0.0009\end{array}$ \\
\hline & Suica & Taiwan & Venezu a & & & & \\
\hline Suica & 1.0000 & & & & & & \\
\hline Taiwan & $\begin{array}{l}0.3373 \\
0.0040\end{array}$ & 1.0000 & & & & & \\
\hline Venezuela & $\begin{array}{l}0.5271 \\
0.0000\end{array}$ & $\begin{array}{l}0.3069 \\
0.0092\end{array}$ & 1.0000 & & & & \\
\hline
\end{tabular}


Matriz de Correlações para Retornos em Reais para o Período de 2001 a 2006

\begin{tabular}{|c|c|c|c|c|c|c|c|}
\hline & Alemanha & Argent a & Austra a & Brasil & Canada & Chile & China \\
\hline Alemanha & 1.0000 & & & & & & \\
\hline Argentina & $\begin{array}{l}0.1545 \\
0.1950\end{array}$ & 1.0000 & & & & & \\
\hline Australia & $\begin{array}{l}0.5639 \\
0.0000\end{array}$ & $\begin{array}{l}0.2478 \\
0.0359\end{array}$ & 1.0000 & & & & \\
\hline Brasil & $\begin{array}{l}0.2578 \\
0.0288\end{array}$ & $\begin{array}{l}0.1360 \\
0.2547\end{array}$ & $\begin{array}{r}-0.0743 \\
0.5352\end{array}$ & 1.0000 & & & \\
\hline Canada & $\begin{array}{l}0.6050 \\
0.0000\end{array}$ & $\begin{array}{l}0.2916 \\
0.0129\end{array}$ & $\begin{array}{l}0.8283 \\
0.0000\end{array}$ & $\begin{array}{r}-0.0140 \\
0.9070\end{array}$ & 1.0000 & & \\
\hline Chile & $\begin{array}{l}0.5685 \\
0.0000\end{array}$ & $\begin{array}{l}0.3784 \\
0.0010\end{array}$ & $\begin{array}{l}0.6741 \\
0.0000\end{array}$ & $\begin{array}{l}0.0901 \\
0.4516\end{array}$ & $\begin{array}{l}0.6491 \\
0.0000\end{array}$ & 1.0000 & \\
\hline China & $\begin{array}{l}0.2803 \\
0.0171\end{array}$ & $\begin{array}{l}0.2532 \\
0.0319\end{array}$ & $\begin{array}{l}0.5088 \\
0.0000\end{array}$ & $\begin{array}{r}-0.2739 \\
0.0199\end{array}$ & $\begin{array}{l}0.4967 \\
0.0000\end{array}$ & $\begin{array}{l}0.3460 \\
0.0029\end{array}$ & 1.0000 \\
\hline Cingapura & $\begin{array}{l}0.5377 \\
0.0000\end{array}$ & $\begin{array}{l}0.2800 \\
0.0172\end{array}$ & $\begin{array}{l}0.7667 \\
0.0000\end{array}$ & $\begin{array}{r}-0.1050 \\
0.3799\end{array}$ & $\begin{array}{l}0.6539 \\
0.0000\end{array}$ & $\begin{array}{l}0.6465 \\
0.0000\end{array}$ & $\begin{array}{l}0.3940 \\
0.0006\end{array}$ \\
\hline Coreia & $\begin{array}{l}0.5978 \\
0.0000\end{array}$ & $\begin{array}{l}0.1848 \\
0.1201\end{array}$ & $\begin{array}{l}0.6723 \\
0.0000\end{array}$ & $\begin{array}{l}0.1023 \\
0.3923\end{array}$ & $\begin{array}{l}0.6413 \\
0.0000\end{array}$ & $\begin{array}{l}0.6323 \\
0.0000\end{array}$ & $\begin{array}{l}0.3124 \\
0.0076\end{array}$ \\
\hline Espanha & $\begin{array}{l}0.7696 \\
0.0000\end{array}$ & $\begin{array}{l}0.2808 \\
0.0169\end{array}$ & $\begin{array}{l}0.7734 \\
0.0000\end{array}$ & $\begin{array}{l}0.0134 \\
0.9108\end{array}$ & $\begin{array}{l}0.7516 \\
0.0000\end{array}$ & $\begin{array}{l}0.6893 \\
0.0000\end{array}$ & $\begin{array}{l}0.4712 \\
0.0000\end{array}$ \\
\hline EUA & $\begin{array}{l}0.7019 \\
0.0000\end{array}$ & $\begin{array}{l}0.2434 \\
0.0394\end{array}$ & $\begin{array}{l}0.7920 \\
0.0000\end{array}$ & $\begin{array}{r}-0.1492 \\
0.2110\end{array}$ & $\begin{array}{l}0.8424 \\
0.0000\end{array}$ & $\begin{array}{l}0.6931 \\
0.0000\end{array}$ & $\begin{array}{l}0.5015 \\
0.0000\end{array}$ \\
\hline Franca & $\begin{array}{l}0.8941 \\
0.0000\end{array}$ & $\begin{array}{l}0.2434 \\
0.0394\end{array}$ & $\begin{array}{l}0.7205 \\
0.0000\end{array}$ & $\begin{array}{l}0.0747 \\
0.5329\end{array}$ & $\begin{array}{l}0.7610 \\
0.0000\end{array}$ & $\begin{array}{l}0.6297 \\
0.0000\end{array}$ & $\begin{array}{l}0.4394 \\
0.0001\end{array}$ \\
\hline Holanda & $\begin{array}{l}0.9026 \\
0.0000\end{array}$ & $\begin{array}{l}0.0997 \\
0.4048\end{array}$ & $\begin{array}{l}0.6305 \\
0.0000\end{array}$ & $\begin{array}{l}0.1221 \\
0.3070\end{array}$ & $\begin{array}{l}0.6511 \\
0.0000\end{array}$ & $\begin{array}{l}0.5592 \\
0.0000\end{array}$ & $\begin{array}{l}0.3359 \\
0.0039\end{array}$ \\
\hline Hong_Kong & $\begin{array}{l}0.5976 \\
0.0000\end{array}$ & $\begin{array}{l}0.2423 \\
0.0403\end{array}$ & $\begin{array}{l}0.7787 \\
0.0000\end{array}$ & $\begin{array}{r}-0.0321 \\
0.7889\end{array}$ & $\begin{array}{l}0.7910 \\
0.0000\end{array}$ & $\begin{array}{l}0.7065 \\
0.0000\end{array}$ & $\begin{array}{l}0.5382 \\
0.0000\end{array}$ \\
\hline India & $\begin{array}{l}0.3939 \\
0.0006\end{array}$ & $\begin{array}{l}0.3579 \\
0.0020\end{array}$ & $\begin{array}{l}0.5987 \\
0.0000\end{array}$ & $\begin{array}{l}0.0585 \\
0.6255\end{array}$ & $\begin{array}{l}0.5790 \\
0.0000\end{array}$ & $\begin{array}{l}0.5197 \\
0.0000\end{array}$ & $\begin{array}{l}0.3184 \\
0.0064\end{array}$ \\
\hline Italia & $\begin{array}{l}0.7866 \\
0.0000\end{array}$ & $\begin{array}{l}0.3010 \\
0.0102\end{array}$ & $\begin{array}{l}0.7345 \\
0.0000\end{array}$ & $\begin{array}{r}-0.0383 \\
0.7496\end{array}$ & $\begin{array}{l}0.7816 \\
0.0000\end{array}$ & $\begin{array}{l}0.6534 \\
0.0000\end{array}$ & $\begin{array}{l}0.4871 \\
0.0000\end{array}$ \\
\hline Japao & $\begin{array}{l}0.4252 \\
0.0002\end{array}$ & $\begin{array}{l}0.1350 \\
0.2583\end{array}$ & $\begin{array}{l}0.7333 \\
0.0000\end{array}$ & $\begin{array}{r}-0.1628 \\
0.1720\end{array}$ & $\begin{array}{l}0.7565 \\
0.0000\end{array}$ & $\begin{array}{l}0.4896 \\
0.0000\end{array}$ & $\begin{array}{l}0.5031 \\
0.0000\end{array}$ \\
\hline Malasia & $\begin{array}{l}0.3529 \\
0.0024\end{array}$ & $\begin{array}{l}0.2550 \\
0.0306\end{array}$ & $\begin{array}{l}0.6195 \\
0.0000\end{array}$ & $\begin{array}{r}-0.2907 \\
0.0132\end{array}$ & $\begin{array}{l}0.5857 \\
0.0000\end{array}$ & $\begin{array}{l}0.5812 \\
0.0000\end{array}$ & $\begin{array}{l}0.5285 \\
0.0000\end{array}$ \\
\hline Mexico & $\begin{array}{l}0.5167 \\
0.0000\end{array}$ & $\begin{array}{l}0.4045 \\
0.0004\end{array}$ & $\begin{array}{l}0.6603 \\
0.0000\end{array}$ & $\begin{array}{l}0.0717 \\
0.5497\end{array}$ & $\begin{array}{l}0.6290 \\
0.0000\end{array}$ & $\begin{array}{l}0.6341 \\
0.0000\end{array}$ & $\begin{array}{l}0.3620 \\
0.0018\end{array}$ \\
\hline Reino_Unido & 0.6752 & 0.2833 & 0.8156 & -0.1817 & 0.7943 & 0.6876 & 0.5703 \\
\hline
\end{tabular}




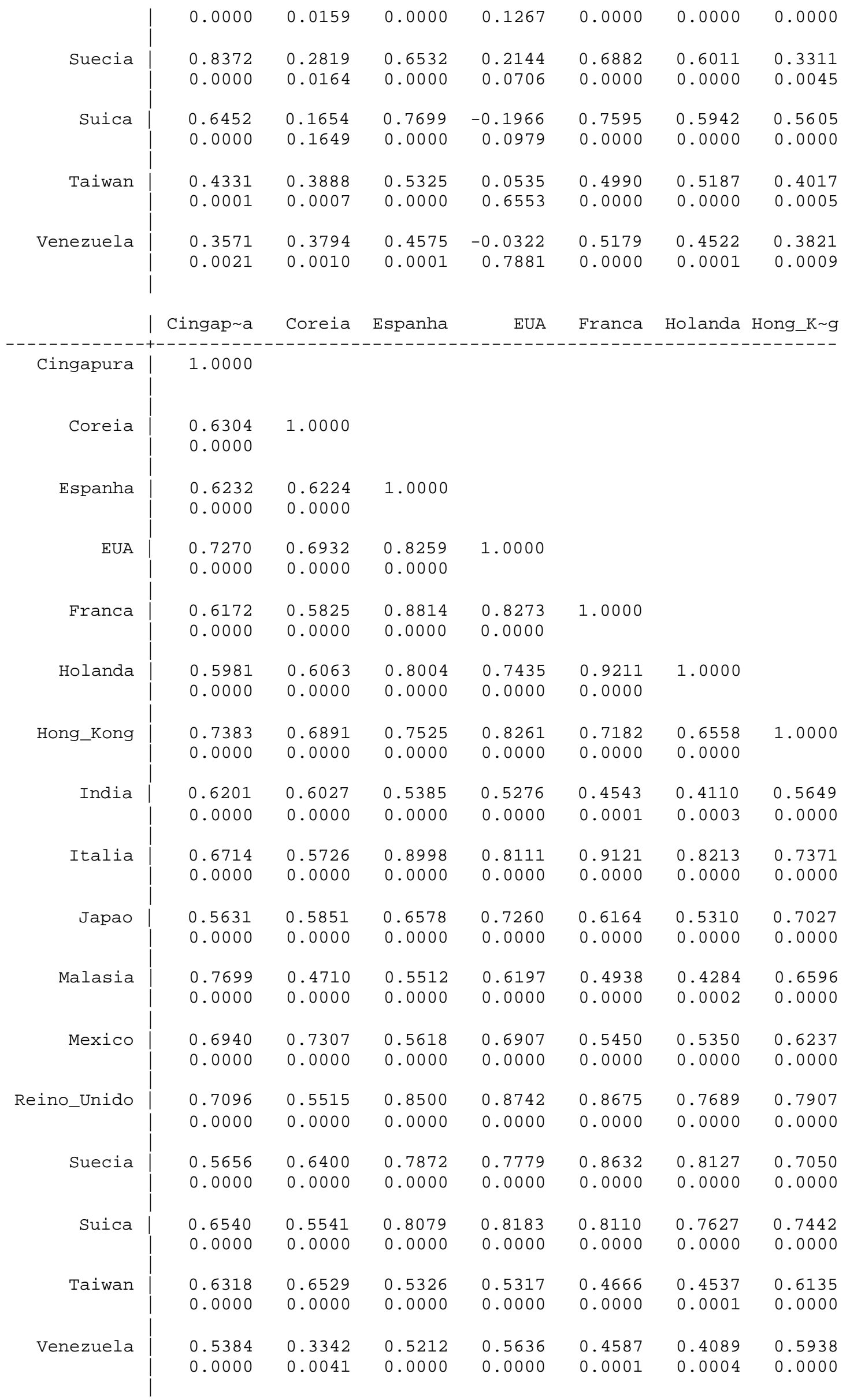




\begin{tabular}{|c|c|c|c|c|c|c|c|}
\hline & India & Italia & Japao & Malasia & Mexico & Reino_ o & Suecia \\
\hline India & 1.0000 & & & & & & \\
\hline Italia & $\begin{array}{l}0.5267 \\
0.0000\end{array}$ & 1.0000 & & & & & \\
\hline Japao & $\begin{array}{l}0.6377 \\
0.0000\end{array}$ & $\begin{array}{l}0.6349 \\
0.0000\end{array}$ & 1.0000 & & & & \\
\hline Malasia & $\begin{array}{l}0.4880 \\
0.0000\end{array}$ & $\begin{array}{l}0.5766 \\
0.0000\end{array}$ & $\begin{array}{l}0.4918 \\
0.0000\end{array}$ & 1.0000 & & & \\
\hline Mexico & $\begin{array}{l}0.4934 \\
0.0000\end{array}$ & $\begin{array}{l}0.5740 \\
0.0000\end{array}$ & $\begin{array}{l}0.5050 \\
0.0000\end{array}$ & $\begin{array}{l}0.5251 \\
0.0000\end{array}$ & 1.0000 & & \\
\hline Reino_Unido & $\begin{array}{l}0.4812 \\
0.0000\end{array}$ & $\begin{array}{l}0.8691 \\
0.0000\end{array}$ & $\begin{array}{l}0.7135 \\
0.0000\end{array}$ & $\begin{array}{l}0.6495 \\
0.0000\end{array}$ & $\begin{array}{l}0.6110 \\
0.0000\end{array}$ & 1.0000 & \\
\hline Suecia & $\begin{array}{l}0.5139 \\
0.0000\end{array}$ & $\begin{array}{l}0.7952 \\
0.0000\end{array}$ & $\begin{array}{l}0.5341 \\
0.0000\end{array}$ & $\begin{array}{l}0.3603 \\
0.0019\end{array}$ & $\begin{array}{l}0.5251 \\
0.0000\end{array}$ & $\begin{array}{l}0.7193 \\
0.0000\end{array}$ & 1.0000 \\
\hline Suica & $\begin{array}{l}0.5057 \\
0.0000\end{array}$ & $\begin{array}{l}0.8133 \\
0.0000\end{array}$ & $\begin{array}{l}0.7464 \\
0.0000\end{array}$ & $\begin{array}{l}0.5854 \\
0.0000\end{array}$ & $\begin{array}{l}0.5529 \\
0.0000\end{array}$ & $\begin{array}{l}0.8901 \\
0.0000\end{array}$ & $\begin{array}{l}0.6863 \\
0.0000\end{array}$ \\
\hline Taiwan & $\begin{array}{l}0.4361 \\
0.0001\end{array}$ & $\begin{array}{l}0.4773 \\
0.0000\end{array}$ & $\begin{array}{l}0.4061 \\
0.0004\end{array}$ & $\begin{array}{l}0.6322 \\
0.0000\end{array}$ & $\begin{array}{l}0.5692 \\
0.0000\end{array}$ & $\begin{array}{l}0.4400 \\
0.0001\end{array}$ & $\begin{array}{l}0.3959 \\
0.0006\end{array}$ \\
\hline Venezuela & $\begin{array}{l}0.4191 \\
0.0002\end{array}$ & $\begin{array}{l}0.5709 \\
0.0000\end{array}$ & $\begin{array}{l}0.4917 \\
0.0000\end{array}$ & $\begin{array}{l}0.4548 \\
0.0001\end{array}$ & $\begin{array}{l}0.5271 \\
0.0000\end{array}$ & $\begin{array}{l}0.5997 \\
0.0000\end{array}$ & $\begin{array}{l}0.4149 \\
0.0003\end{array}$ \\
\hline & Suica & Taiwan & Venezu a & & & & \\
\hline Suica & 1.0000 & & & & & & \\
\hline Taiwan & $\begin{array}{l}0.4125 \\
0.0003\end{array}$ & 1.0000 & & & & & \\
\hline Venezuela & $\begin{array}{l}0.5238 \\
0.0000\end{array}$ & $\begin{array}{l}0.3330 \\
0.0043\end{array}$ & 1.0000 & & & & \\
\hline
\end{tabular}




\section{Matriz de Correlações para Retornos em Reais para Período de 2003 a 2006}

\begin{tabular}{|c|c|c|c|c|c|c|c|}
\hline & Alemanha & Argent a & Austra a & Brasil & Canada & Chile & China \\
\hline Alemanha & 1.0000 & & & & & & \\
\hline Argentina & $\begin{array}{l}0.2979 \\
0.0397\end{array}$ & 1.0000 & & & & & \\
\hline Australia & $\begin{array}{l}0.6574 \\
0.0000\end{array}$ & $\begin{array}{l}0.4162 \\
0.0033\end{array}$ & 1.0000 & & & & \\
\hline Brasil & $\begin{array}{l}0.2545 \\
0.0808\end{array}$ & $\begin{array}{l}0.2858 \\
0.0489\end{array}$ & $\begin{array}{l}0.2466 \\
0.0911\end{array}$ & 1.0000 & & & \\
\hline Canada & $\begin{array}{l}0.6498 \\
0.0000\end{array}$ & $\begin{array}{l}0.3336 \\
0.0205\end{array}$ & $\begin{array}{l}0.8589 \\
0.0000\end{array}$ & $\begin{array}{l}0.1904 \\
0.1948\end{array}$ & 1.0000 & & \\
\hline Chile & $\begin{array}{l}0.6296 \\
0.0000\end{array}$ & $\begin{array}{l}0.2767 \\
0.0570\end{array}$ & $\begin{array}{l}0.6055 \\
0.0000\end{array}$ & $\begin{array}{l}0.2855 \\
0.0492\end{array}$ & $\begin{array}{l}0.5593 \\
0.0000\end{array}$ & 1.0000 & \\
\hline China & $\begin{array}{l}0.3814 \\
0.0075\end{array}$ & $\begin{array}{l}0.1881 \\
0.2003\end{array}$ & $\begin{array}{l}0.5602 \\
0.0000\end{array}$ & $\begin{array}{l}0.0340 \\
0.8185\end{array}$ & $\begin{array}{l}0.4753 \\
0.0006\end{array}$ & $\begin{array}{l}0.2385 \\
0.1026\end{array}$ & 1.0000 \\
\hline Cingapura & $\begin{array}{l}0.6123 \\
0.0000\end{array}$ & $\begin{array}{l}0.2904 \\
0.0453\end{array}$ & $\begin{array}{l}0.7342 \\
0.0000\end{array}$ & $\begin{array}{l}0.0284 \\
0.8480\end{array}$ & $\begin{array}{l}0.6796 \\
0.0000\end{array}$ & $\begin{array}{l}0.5606 \\
0.0000\end{array}$ & $\begin{array}{l}0.4773 \\
0.0006\end{array}$ \\
\hline Coreia & $\begin{array}{l}0.6391 \\
0.0000\end{array}$ & $\begin{array}{l}0.2122 \\
0.1476\end{array}$ & $\begin{array}{l}0.5786 \\
0.0000\end{array}$ & $\begin{array}{l}0.2228 \\
0.1281\end{array}$ & $\begin{array}{l}0.5947 \\
0.0000\end{array}$ & $\begin{array}{l}0.4948 \\
0.0003\end{array}$ & $\begin{array}{l}0.3098 \\
0.0322\end{array}$ \\
\hline Espanha & $\begin{array}{l}0.8312 \\
0.0000\end{array}$ & $\begin{array}{l}0.3625 \\
0.0113\end{array}$ & $\begin{array}{l}0.7935 \\
0.0000\end{array}$ & $\begin{array}{l}0.1146 \\
0.4382\end{array}$ & $\begin{array}{l}0.7369 \\
0.0000\end{array}$ & $\begin{array}{l}0.6214 \\
0.0000\end{array}$ & $\begin{array}{l}0.5211 \\
0.0001\end{array}$ \\
\hline EUA & $\begin{array}{l}0.7900 \\
0.0000\end{array}$ & $\begin{array}{l}0.1538 \\
0.2966\end{array}$ & $\begin{array}{l}0.7292 \\
0.0000\end{array}$ & $\begin{array}{l}0.0130 \\
0.9302\end{array}$ & $\begin{array}{l}0.7891 \\
0.0000\end{array}$ & $\begin{array}{l}0.5900 \\
0.0000\end{array}$ & $\begin{array}{l}0.4929 \\
0.0004\end{array}$ \\
\hline Franca & $\begin{array}{l}0.9258 \\
0.0000\end{array}$ & $\begin{array}{l}0.2839 \\
0.0506\end{array}$ & $\begin{array}{l}0.7732 \\
0.0000\end{array}$ & $\begin{array}{l}0.1773 \\
0.2279\end{array}$ & $\begin{array}{l}0.7836 \\
0.0000\end{array}$ & $\begin{array}{l}0.6353 \\
0.0000\end{array}$ & $\begin{array}{l}0.5019 \\
0.0003\end{array}$ \\
\hline Holanda & $\begin{array}{l}0.9151 \\
0.0000\end{array}$ & $\begin{array}{l}0.1667 \\
0.2574\end{array}$ & $\begin{array}{l}0.6984 \\
0.0000\end{array}$ & $\begin{array}{l}0.1919 \\
0.1913\end{array}$ & $\begin{array}{l}0.6951 \\
0.0000\end{array}$ & $\begin{array}{l}0.6083 \\
0.0000\end{array}$ & $\begin{array}{l}0.4078 \\
0.0040\end{array}$ \\
\hline Hong_Kong & $\begin{array}{l}0.5911 \\
0.0000\end{array}$ & $\begin{array}{l}0.1425 \\
0.3341\end{array}$ & $\begin{array}{l}0.7725 \\
0.0000\end{array}$ & $\begin{array}{l}0.1414 \\
0.3378\end{array}$ & $\begin{array}{l}0.7463 \\
0.0000\end{array}$ & $\begin{array}{l}0.6454 \\
0.0000\end{array}$ & $\begin{array}{l}0.5343 \\
0.0001\end{array}$ \\
\hline India & $\begin{array}{l}0.4155 \\
0.0033\end{array}$ & $\begin{array}{l}0.3695 \\
0.0097\end{array}$ & $\begin{array}{l}0.5277 \\
0.0001\end{array}$ & $\begin{array}{l}0.2590 \\
0.0754\end{array}$ & $\begin{array}{l}0.4912 \\
0.0004\end{array}$ & $\begin{array}{l}0.3709 \\
0.0095\end{array}$ & $\begin{array}{l}0.1467 \\
0.3199\end{array}$ \\
\hline Italia & $\begin{array}{l}0.8054 \\
0.0000\end{array}$ & $\begin{array}{l}0.3481 \\
0.0153\end{array}$ & $\begin{array}{l}0.7538 \\
0.0000\end{array}$ & $\begin{array}{l}0.1096 \\
0.4582\end{array}$ & $\begin{array}{l}0.7882 \\
0.0000\end{array}$ & $\begin{array}{l}0.6024 \\
0.0000\end{array}$ & $\begin{array}{l}0.4947 \\
0.0004\end{array}$ \\
\hline Japao & $\begin{array}{l}0.4798 \\
0.0006\end{array}$ & $\begin{array}{l}0.1998 \\
0.1733\end{array}$ & $\begin{array}{l}0.6558 \\
0.0000\end{array}$ & $\begin{array}{l}0.1179 \\
0.4248\end{array}$ & $\begin{array}{l}0.7110 \\
0.0000\end{array}$ & $\begin{array}{l}0.3148 \\
0.0293\end{array}$ & $\begin{array}{l}0.3522 \\
0.0141\end{array}$ \\
\hline Malasia & $\begin{array}{l}0.4979 \\
0.0003\end{array}$ & $\begin{array}{l}0.2105 \\
0.1510\end{array}$ & $\begin{array}{l}0.7410 \\
0.0000\end{array}$ & $\begin{array}{r}-0.0511 \\
0.7300\end{array}$ & $\begin{array}{l}0.6594 \\
0.0000\end{array}$ & $\begin{array}{l}0.5082 \\
0.0002\end{array}$ & $\begin{array}{l}0.6058 \\
0.0000\end{array}$ \\
\hline Mexico & $\begin{array}{l}0.5690 \\
0.0000\end{array}$ & $\begin{array}{l}0.3741 \\
0.0088\end{array}$ & $\begin{array}{l}0.6213 \\
0.0000\end{array}$ & $\begin{array}{l}0.3235 \\
0.0249\end{array}$ & $\begin{array}{l}0.5355 \\
0.0001\end{array}$ & $\begin{array}{l}0.4156 \\
0.0033\end{array}$ & $\begin{array}{l}0.3288 \\
0.0225\end{array}$ \\
\hline Reino_Unido & 0.7950 & 0.2465 & 0.7948 & 0.1306 & 0.7597 & 0.6079 & 0.5195 \\
\hline
\end{tabular}




\begin{tabular}{|c|c|c|c|c|c|c|c|}
\hline & 0.0000 & 0.0912 & 0.0000 & 0.3763 & 0.0000 & 0.0000 & 0.0002 \\
\hline \multirow[t]{2}{*}{ Suecia } & 0.8657 & 0.3313 & 0.7109 & 0.2584 & 0.6906 & 0.6603 & 0.4883 \\
\hline & 0.0000 & 0.0214 & 0.0000 & 0.0761 & 0.0000 & 0.0000 & 0.0004 \\
\hline \multirow[t]{2}{*}{ Suica } & 0.8376 & 0.2253 & 0.6981 & 0.1264 & 0.6893 & 0.5374 & 0.5001 \\
\hline & 0.0000 & 0.1236 & 0.0000 & 0.3918 & 0.0000 & 0.0001 & 0.0003 \\
\hline \multirow[t]{2}{*}{ Taiwan } & 0.4876 & 0.2095 & 0.6890 & 0.0678 & 0.5854 & 0.4333 & 0.5405 \\
\hline & 0.0004 & 0.1530 & 0.0000 & 0.6471 & 0.0000 & 0.0021 & 0.0001 \\
\hline \multirow[t]{3}{*}{ Venezuela } & 0.4099 & 0.3457 & 0.4403 & 0.1772 & 0.4461 & 0.3270 & 0.3332 \\
\hline & 0.0038 & 0.0161 & 0.0017 & 0.2282 & 0.0015 & 0.0233 & 0.0207 \\
\hline & Cingap a & Coreia & Espanha & EUA & Franca & Holanda & Hong_K q \\
\hline Cingapura & 1.0000 & & & & & & \\
\hline \multirow[t]{2}{*}{ Coreia } & 0.6192 & 1.0000 & & & & & \\
\hline & 0.0000 & & & & & & \\
\hline \multirow[t]{2}{*}{ Espanha } & 0.6963 & 0.5522 & 1.0000 & & & & \\
\hline & 0.0000 & 0.0000 & & & & & \\
\hline \multirow[t]{2}{*}{ EUA } & 0.7995 & 0.6148 & 0.8442 & 1.0000 & & & \\
\hline & 0.0000 & 0.0000 & 0.0000 & & & & \\
\hline \multirow[t]{2}{*}{ Franca } & 0.7150 & 0.6503 & 0.8944 & 0.8804 & 1.0000 & & \\
\hline & 0.0000 & 0.0000 & 0.0000 & 0.0000 & & & \\
\hline \multirow[t]{2}{*}{ Holanda } & 0.7010 & 0.7221 & 0.8216 & 0.8480 & 0.9392 & 1.0000 & \\
\hline & 0.0000 & 0.0000 & 0.0000 & 0.0000 & 0.0000 & & \\
\hline \multirow[t]{2}{*}{ Hong_Kong } & 0.8047 & 0.6144 & 0.6958 & 0.7769 & 0.7246 & 0.7119 & 1.0000 \\
\hline & 0.0000 & 0.0000 & 0.0000 & 0.0000 & 0.0000 & 0.0000 & \\
\hline \multirow[t]{2}{*}{ India } & 0.6484 & 0.5438 & 0.4660 & 0.4315 & 0.4323 & 0.4415 & 0.4633 \\
\hline & 0.0000 & 0.0001 & 0.0008 & 0.0022 & 0.0022 & 0.0017 & 0.0009 \\
\hline \multirow[t]{2}{*}{ Italia } & 0.7087 & 0.5545 & 0.8987 & 0.8241 & 0.8965 & 0.8109 & 0.7002 \\
\hline & 0.0000 & 0.0000 & 0.0000 & 0.0000 & 0.0000 & 0.0000 & 0.0000 \\
\hline \multirow[t]{2}{*}{ Japao } & 0.7052 & 0.5955 & 0.5596 & 0.7195 & 0.5995 & 0.5951 & 0.5969 \\
\hline & 0.0000 & 0.0000 & 0.0000 & 0.0000 & 0.0000 & 0.0000 & 0.0000 \\
\hline \multirow[t]{2}{*}{ Malasia } & 0.7986 & 0.5455 & 0.6295 & 0.7306 & 0.6236 & 0.5725 & 0.7754 \\
\hline & 0.0000 & 0.0001 & 0.0000 & 0.0000 & 0.0000 & 0.0000 & 0.0000 \\
\hline \multirow[t]{2}{*}{ Mexico } & 0.6287 & 0.6800 & 0.5906 & 0.5814 & 0.5993 & 0.6709 & 0.5468 \\
\hline & 0.0000 & 0.0000 & 0.0000 & 0.0000 & 0.0000 & 0.0000 & 0.0001 \\
\hline \multirow[t]{2}{*}{ Reino_Unido } & 0.7250 & 0.5258 & 0.8576 & 0.8497 & 0.8972 & 0.8495 & 0.7494 \\
\hline & 0.0000 & 0.0001 & 0.0000 & 0.0000 & 0.0000 & 0.0000 & 0.0000 \\
\hline \multirow[t]{2}{*}{ Suecia } & 0.6997 & 0.6420 & 0.8225 & 0.7986 & 0.8914 & 0.8428 & 0.6820 \\
\hline & 0.0000 & 0.0000 & 0.0000 & 0.0000 & 0.0000 & 0.0000 & 0.0000 \\
\hline \multirow[t]{2}{*}{ Suica } & 0.7285 & 0.5936 & 0.8446 & 0.8698 & 0.9023 & 0.8865 & 0.7238 \\
\hline & 0.0000 & 0.0000 & 0.0000 & 0.0000 & 0.0000 & 0.0000 & 0.0000 \\
\hline \multirow[t]{2}{*}{ Taiwan } & 0.6789 & 0.6793 & 0.5419 & 0.6224 & 0.5677 & 0.5826 & 0.7347 \\
\hline & 0.0000 & 0.0000 & 0.0001 & 0.0000 & 0.0000 & 0.0000 & 0.0000 \\
\hline \multirow[t]{2}{*}{ Venezuela } & 0.5955 & 0.2935 & 0.4910 & 0.5046 & 0.4620 & 0.4348 & 0.5370 \\
\hline & 0.0000 & 0.0429 & 0.0004 & 0.0003 & 0.0009 & 0.0020 & 0.0001 \\
\hline
\end{tabular}




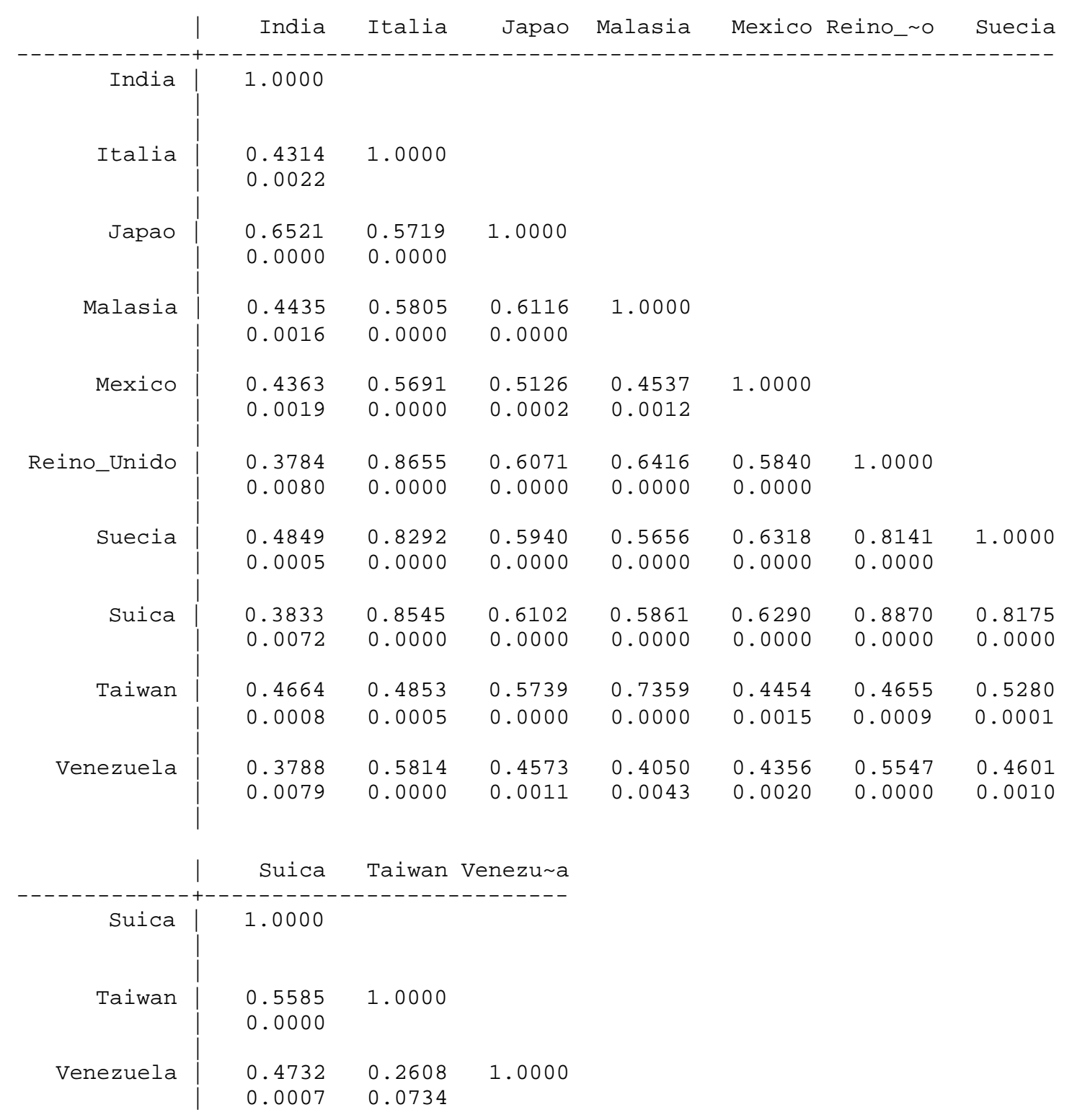


APÊNDICE C - RETORNO, RISCO E PESOS DOS ATIVOS NAS CARTEIRAS DA FRONTEIRA EFICIENTE FORMADA POR ÍNDICES DE MERCADOS DE AÇÕES

\begin{tabular}{|l|l|}
\hline Coluna 1 & Alemanha \\
\hline Coluna 2 & Argentina \\
\hline Coluna 3 & Austrália \\
\hline Coluna 4 & Brasil \\
\hline Coluna 5 & Canadá \\
\hline Coluna 6 & Chile \\
\hline Coluna 7 & China \\
\hline Coluna 8 & Cingapura \\
\hline Coluna 9 & Coréia \\
\hline Coluna 10 & Espanha \\
\hline Coluna 11 & Estados Unidos \\
\hline Coluna 12 & França \\
\hline Coluna 13 & Holanda \\
\hline Coluna 14 & Hong Kong \\
\hline Coluna 15 & Índia \\
\hline Coluna 16 & Itália \\
\hline Coluna 17 & Japão \\
\hline Coluna 18 & Malásia \\
\hline Coluna 19 & México \\
\hline Coluna 20 & Reino Unido \\
\hline Coluna 21 & Suécia \\
\hline Coluna 22 & Suíça \\
\hline Coluna 23 & Taiwan \\
\hline Coluna 24 & Venezuela \\
\hline
\end{tabular}


Fronteira Eficiente para Retornos Dados na Moeda do Próprio País (Processamento dos Dados Realizado no Software Matlab)

[PortRisk, PortReturn, PortWts] $=$ frontcon(ExpRetIntLocFinal,ExpCovIntLocFinal)

PortRisk $=$
0.0249
0.0256
0.0279
0.0316
0.0364
0.0421
0.0484
0.0553
0.0659
0.0896

PortReturn $=$
0.0045
0.0066
0.0086
0.0106
0.0127
0.0147
0.0167
0.0188
0.0208
0.0228

PortWts =

Columns 1 through 8

$\begin{array}{rrrrrrrr}-0.0000 & -0.0000 & 0.5815 & -0.0000 & -0.0000 & 0.0458 & 0.1837 & -0.0000 \\ 0.0000 & 0.0000 & 0.6393 & 0.0000 & 0.0000 & 0.0918 & 0.1327 & -0.0000 \\ 0.0000 & 0.0172 & 0.6508 & 0.0000 & 0.0000 & 0.1224 & 0.0695 & 0.0000 \\ 0.0000 & 0.0256 & 0.6082 & 0.0000 & 0.0000 & 0.1313 & 0 & -0.0000 \\ 0.0000 & 0.0206 & 0.4247 & 0.0000 & 0.0000 & 0.1424 & 0.0000 & -0.0000 \\ -0.0000 & 0.0155 & 0.2412 & 0.0000 & 0.0000 & 0.1536 & 0.0000 & 0.0000 \\ -0.0000 & 0.0104 & 0.0577 & 0.0000 & 0.0000 & 0.1647 & 0.0000 & 0.0000 \\ -0.0000 & 0.0157 & 0 & 0.0000 & -0.0000 & 0.0411 & 0.0000 & 0.0000 \\ -0.0000 & 0.1280 & 0.0000 & -0.0000 & -0.0000 & 0.0000 & -0.0000 & 0.0000 \\ 0.0000 & 0 & 0.0000 & -0.0000 & -0.0000 & 0.0000 & -0.0000 & -0.0000\end{array}$

Columns 9 through 16

$\begin{array}{rrrrrrrr}-0.0000 & -0.0000 & 0.0000 & -0.0000 & 0.0000 & 0.0000 & -0.0000 & -0.0000 \\ 0.0000 & -0.0000 & 0.0000 & 0.0000 & -0.0000 & -0.0000 & 0.0000 & 0.0000 \\ 0.0000 & 0.0000 & 0.0000 & 0.0000 & -0.0000 & -0.0000 & -0.0000 & -0.0000 \\ 0.0000 & 0.0000 & 0.0000 & 0.0000 & -0.0000 & -0.0000 & 0.0000 & -0.0000 \\ 0.0000 & 0.0000 & 0.0000 & -0.0000 & 0.0000 & -0.0000 & 0.0000 & 0.0000 \\ 0.0000 & -0.0000 & 0.0000 & -0.0000 & -0.0000 & 0.0000 & 0.0000 & 0.0000 \\ 0.0000 & 0 & -0.0000 & 0.0000 & 0.0000 & -0.0000 & -0.0000 & 0.0000\end{array}$




$$
\begin{array}{rrrrrrrr}
0.0000 & 0.0000 & -0.0000 & 0.0000 & -0.0000 & -0.0000 & -0.0000 & 0.0000 \\
-0.0000 & -0.0000 & 0.0000 & 0.0000 & 0.0000 & -0.0000 & -0.0000 & -0.0000 \\
0.0000 & -0.0000 & 0.0000 & -0.0000 & 0.0000 & 0.0000 & -0.0000 & 0.0000
\end{array}
$$

Columns 17 through 24

$\begin{array}{rrrrrrrc}0.0000 & 0.1038 & -0.0000 & 0.0496 & 0.0000 & -0.0000 & 0.0000 & 0.0356 \\ -0.0000 & 0.0496 & -0.0000 & -0.0000 & -0.0000 & -0.0000 & -0.0000 & 0.0865 \\ -0.0000 & -0.0000 & 0.0000 & -0.0000 & 0.0000 & 0.0000 & -0.0000 & 0.1402 \\ -0.0000 & 0.0000 & 0.0415 & -0.0000 & 0.0000 & 0.0000 & 0.0000 & 0.1933 \\ -0.0000 & 0.0000 & 0.1663 & 0.0000 & 0.0000 & 0.0000 & 0.0000 & 0.2460 \\ 0.0000 & 0.0000 & 0.2910 & 0.0000 & 0.0000 & 0.0000 & 0.0000 & 0.2988 \\ 0.0000 & -0.0000 & 0.4158 & 0.0000 & -0.0000 & 0.0000 & 0.0000 & 0.3515 \\ 0.0000 & -0.0000 & 0.5151 & 0.0000 & -0.0000 & -0.0000 & 0.0000 & 0.4282 \\ 0.0000 & -0.0000 & 0.2757 & 0.0000 & 0.0000 & -0.0000 & 0.0000 & 0.5963 \\ -0.0000 & 0.0000 & 0 & 0.0000 & 0.0000 & -0.0000 & 0.0000 & 1.0000\end{array}$

Fronteira Eficiente para Retornos Dados em Reais (Processamento dos Dados Realizado no Software Matlab)

PortRisk $=$
0.5087
0.5144
0.5314
0.5555
0.5854
0.6205
0.6627
0.7387
0.8503
1.0000

PortReturn $=$
0.0090
0.0101
0.0112
0.0123
0.0134
0.0145
0.0156
0.0167
0.0177
0.0188

PortWts =

Columns 1 through 8
$\begin{array}{lll}0.0000 & 0.0731 & 0.0000\end{array}$
$\begin{array}{lll}0.3776 & -0.0000 & -0.0000\end{array}$
$\begin{array}{ll}0.2223 & 0.0440\end{array}$
$\begin{array}{lll}-0.0000 & 0.0660 & 0.0000\end{array}$
$\begin{array}{lll}0.3794 & 0.0000 & 0.0000\end{array}$
$0.2042 \quad 0.0263$
$-0.0000$
0.0563
0.0087
$\begin{array}{lll}0.3719 & 0.0000 & 0.0000\end{array}$
$0.1642-0.0000$ 


$\begin{array}{rrrrrrrr}-0.0000 & 0.0392 & 0.0116 & 0.3630 & -0.0000 & 0.0000 & 0.1305 & -0.0000 \\ -0.0000 & 0.0220 & 0.0143 & 0.3540 & 0.0002 & 0.0000 & 0.0969 & -0.0000 \\ -0.0000 & 0.0018 & 0.0144 & 0.3461 & 0.0033 & 0.0000 & 0.0522 & 0.0000 \\ -0.0000 & -0.0000 & 0 & 0.3196 & 0.0000 & 0.0000 & 0.0000 & -0.0000 \\ 0.0000 & -0.0000 & -0.0000 & 0.2520 & -0.0000 & -0.0000 & -0.0000 & 0.0000 \\ -0.0000 & -0.0000 & -0.0000 & 0.1790 & 0.0000 & -0.0000 & 0.0000 & -0.0000 \\ 0.0000 & -0.0000 & 0.0000 & 0 & 0.0000 & 0.0000 & -0.0000 & -0.0000\end{array}$

Columns 9 through 16

$\begin{array}{rrcccccc}0.0000 & 0.0000 & 0.0000 & -0.0000 & 0.0000 & 0.0000 & -0.0000 & -0.0000 \\ 0.0567 & -0.0000 & -0.0000 & -0.0000 & -0.0000 & 0.0000 & -0.0000 & 0.0000 \\ 0.0645 & -0.0000 & 0.0000 & 0.0000 & -0.0000 & -0.0000 & 0.0319 & -0.0000 \\ 0.0451 & 0.0000 & 0.0000 & 0.0000 & 0.0000 & -0.0000 & 0.0654 & 0.0000 \\ 0.0257 & -0.0000 & 0.0000 & 0.0000 & 0.0000 & -0.0000 & 0.0990 & 0.0000 \\ 0.0023 & -0.0000 & 0.0000 & 0.0000 & 0.0000 & -0.0000 & 0.1320 & 0.0000 \\ 0 & 0.0000 & 0.0000 & 0.0000 & -0.0000 & -0.0000 & 0.1453 & -0.0000 \\ -0.0000 & -0.0000 & -0.0000 & 0.0000 & -0.0000 & -0.0000 & 0.0977 & 0.0000 \\ -0.0000 & 0.0000 & 0.0000 & 0.0000 & -0.0000 & 0.0000 & 0.0390 & 0.0000 \\ 0 & 0.0000 & 0.0000 & -0.0000 & 0.0000 & -0.0000 & 0 & -0.0000\end{array}$

Columns 17 through 24

$\begin{array}{rrrrrrrc}0.0278 & 0.1476 & 0.0000 & -0.0000 & 0.0302 & 0.0000 & 0.0000 & 0.0774 \\ -0.0000 & 0.1325 & 0.0000 & -0.0000 & 0.0000 & -0.0000 & 0.0000 & 0.1350 \\ -0.0000 & 0.1034 & 0.0374 & -0.0000 & -0.0000 & 0.0000 & -0.0000 & 0.1617 \\ 0.0000 & 0.0634 & 0.1033 & 0.0000 & 0.0000 & 0.0000 & 0.0000 & 0.1785 \\ 0.0000 & 0.0233 & 0.1691 & -0.0000 & -0.0000 & -0.0000 & -0.0000 & 0.1954 \\ 0.0000 & 0.0000 & 0.2379 & -0.0000 & 0.0000 & -0.0000 & -0.0000 & 0.2100 \\ -0.0000 & -0.0000 & 0.3386 & -0.0000 & 0.0000 & 0.0000 & -0.0000 & 0.1966 \\ 0.0000 & -0.0000 & 0.5590 & 0.0000 & 0.0000 & -0.0000 & -0.0000 & 0.0913 \\ 0.0000 & 0.0000 & 0.7820 & -0.0000 & -0.0000 & 0.0000 & 0.0000 & 0.0000 \\ -0.0000 & 0.0000 & 1.0000 & 0.0000 & 0.0000 & 0.0000 & -0.0000 & 0.0000\end{array}$




\section{APÊNDICE D - FRONTEIRAS EFICIENTES DE FUNDOS DE PENSÃO COM RETORNOS EM MOEDA LOCAL PARA DIFERENTES GRAUS DE ABERTURA PARA INVESTIMENTOS NO EXTERIOR}

Ativos da Fronteira Nacional
\begin{tabular}{|l|l|}
\hline Coluna 1 & CDI \\
\hline Coluna 2 & IGPM + Cupom \\
\hline Coluna 3 & IRF-M \\
\hline Coluna 4 & FIEX \\
\hline Coluna 5 & IBOV \\
\hline Coluna 6 & Imóveis \\
\hline Coluna 7 & Empréstimos \\
\hline Coluna 8 & Financiamentos \\
\hline
\end{tabular}

\section{Ativos da Fronteira com Investimento em Ações Exterior}

\begin{tabular}{|l|l|}
\hline Coluna 1 & CDI \\
\hline Coluna 2 & IGPM + Cupom \\
\hline Coluna 3 & IRF-M \\
\hline Coluna 4 & FIEX \\
\hline Coluna 5 & Alemanha \\
\hline Coluna 6 & Argentina \\
\hline Coluna 7 & Austrália \\
\hline Coluna 8 & Brasil \\
\hline Coluna 9 & Canadá \\
\hline Coluna 10 & Chile \\
\hline Coluna 11 & China \\
\hline Coluna 12 & Cingapura \\
\hline Coluna 13 & Coréia \\
\hline Coluna 14 & Espanha \\
\hline Coluna 15 & Estados Unidos \\
\hline Coluna 16 & França \\
\hline Coluna 17 & Holanda \\
\hline Coluna 18 & Hong Kong \\
\hline Coluna 19 & Índia \\
\hline Coluna 20 & Itália \\
\hline Coluna 21 & Japão \\
\hline Coluna 22 & Malásia \\
\hline Coluna 23 & México \\
\hline Coluna 24 & Reino Unido \\
\hline Coluna 25 & Suécia \\
\hline Coluna 26 & Suíça \\
\hline Coluna 27 & Taiwan \\
\hline Coluna 28 & Venezuela \\
\hline Coluna 29 & Imóveis \\
\hline Coluna 30 & Empréstimos \\
\hline Coluna 31 & Financiamentos \\
\hline & \\
\hline
\end{tabular}




\section{Restrição Total a Ativos Internacionais (2000 a 2005)}

[PortRisk, PortReturn, PortWts] = frontcon(ExpRetIntPais05, ExpCovIntPais05, 10, [], AssetBoundsInt05,GroupsInt05,GroupsBoundsInt05)

PortRisk $=$
0.0020
0.0020
0.0021
0.0023
0.0030
0.0039
0.0050
0.0061
0.0080
0.0103

PortReturn $=$
0.0136
0.0139
0.0143
0.0147
0.0150
0.0154
0.0158
0.0161
0.0165
0.0169

PortWts =

Columns 1 through 8

$\begin{array}{rrrrrrrr}0.8394 & 0.0133 & -0.0000 & 0.0000 & -0.0000 & -0.0000 & 0.0000 & 0.0000 \\ 0.8555 & 0.0246 & 0 & 0 & 0.0000 & 0.0000 & -0.0000 & 0.0000 \\ 0.8739 & 0.0488 & 0.0000 & 0.0000 & 0.0000 & 0.0000 & -0.0000 & 0.0000 \\ 0.8707 & 0.1041 & 0.0252 & 0.0000 & 0.0000 & 0.0000 & -0.0000 & 0.0000 \\ 0.6320 & 0.1866 & 0.1814 & 0.0000 & 0.0000 & 0.0000 & 0.0000 & -0.0000 \\ 0.3933 & 0.2691 & 0.3376 & -0.0000 & -0.0000 & 0.0000 & 0.0000 & 0.0000 \\ 0.1546 & 0.3516 & 0.4937 & -0.0000 & -0.0000 & 0.0000 & 0.0000 & 0.0000 \\ 0 & 0.4942 & 0.5058 & -0.0000 & -0.0000 & 0.0000 & 0.0000 & 0.0000 \\ 0 & 0.7471 & 0.2529 & -0.0000 & -0.0000 & 0.0000 & 0.0000 & 0.0000 \\ 0.0000 & 1.0000 & 0.0000 & 0 & 0.0000 & -0.0000 & 0.0000 & 0.0000\end{array}$

Columns 9 through 16 


$\begin{array}{rrrrrrrr}0.0000 & -0.0000 & -0.0000 & 0.0000 & 0.0000 & -0.0000 & -0.0000 & -0.0000 \\ 0.0000 & -0.0000 & -0.0000 & 0.0000 & -0.0000 & -0.0000 & -0.0000 & 0.0000 \\ 0.0000 & -0.0000 & -0.0000 & 0.0000 & -0.0000 & -0.0000 & -0.0000 & 0.0000 \\ 0.0000 & -0.0000 & -0.0000 & 0.0000 & -0.0000 & -0.0000 & -0.0000 & 0.0000 \\ 0.0000 & 0.0000 & -0.0000 & 0.0000 & 0.0000 & 0.0000 & -0.0000 & 0.0000 \\ -0.0000 & -0.0000 & -0.0000 & 0.0000 & 0.0000 & 0.0000 & -0.0000 & -0.0000 \\ -0.0000 & 0.0000 & -0.0000 & 0.0000 & 0.0000 & 0.0000 & -0.0000 & -0.0000 \\ -0.0000 & 0.0000 & -0.0000 & 0.0000 & 0.0000 & 0.0000 & -0.0000 & -0.0000 \\ -0.0000 & 0.0000 & 0.0000 & 0.0000 & 0.0000 & 0.0000 & 0.0000 & -0.0000 \\ 0.0000 & -0.0000 & -0.0000 & -0.0000 & -0.0000 & -0.0000 & -0.0000 & -0.0000\end{array}$

Columns 17 through 24

$\begin{array}{rrrrrrrr}0.0000 & 0.0000 & 0.0000 & -0.0000 & -0.0000 & -0.0000 & -0.0000 & 0.0000 \\ -0.0000 & 0.0000 & -0.0000 & -0.0000 & -0.0000 & -0.0000 & 0.0000 & -0.0000 \\ -0.0000 & 0.0000 & -0.0000 & -0.0000 & -0.0000 & -0.0000 & 0.0000 & -0.0000 \\ -0.0000 & 0.0000 & -0.0000 & -0.0000 & -0.0000 & -0.0000 & 0.0000 & -0.0000 \\ 0.0000 & 0.0000 & 0.0000 & -0.0000 & -0.0000 & 0.0000 & 0.0000 & -0.0000 \\ -0.0000 & 0.0000 & 0.0000 & -0.0000 & -0.0000 & 0.0000 & 0.0000 & 0.0000 \\ -0.0000 & 0.0000 & 0.0000 & -0.0000 & -0.0000 & 0.0000 & 0.0000 & 0.0000 \\ 0.0000 & 0.0000 & 0.0000 & -0.0000 & -0.0000 & 0.0000 & 0.0000 & 0.0000 \\ -0.0000 & 0.0000 & 0.0000 & -0.0000 & -0.0000 & 0.0000 & 0.0000 & 0.0000 \\ -0.0000 & 0.0000 & 0.0000 & -0.0000 & 0.0000 & -0.0000 & -0.0000 & 0.0000\end{array}$

Columns 25 through 31

$\begin{array}{rrrrrrr}-0.0000 & 0.0000 & 0.0000 & -0.0000 & 0.0473 & 0 & 0.1000 \\ 0.0000 & -0.0000 & -0.0000 & 0.0000 & 0.0200 & 0.0000 & 0.1000 \\ 0.0000 & -0.0000 & -0.0000 & 0.0000 & 0 & 0.0000 & 0.0773 \\ 0.0000 & -0.0000 & -0.0000 & 0.0000 & 0.0000 & 0.0000 & -0.0000 \\ 0.0000 & 0.0000 & -0.0000 & 0.0000 & -0.0000 & -0.0000 & 0.0000 \\ -0.0000 & 0.0000 & -0.0000 & 0.0000 & 0 & 0.0000 & 0 \\ -0.0000 & 0.0000 & 0.0000 & 0.0000 & 0 & 0.0000 & 0 \\ -0.0000 & 0.0000 & 0.0000 & 0.0000 & 0.0000 & 0.0000 & -0.0000 \\ -0.0000 & 0.0000 & 0.0000 & 0.0000 & 0.0000 & 0.0000 & -0.0000 \\ 0.0000 & 0.0000 & -0.0000 & -0.0000 & 0.0000 & -0.0000 & -0.0000\end{array}$




\section{Restrição de 10\% de Ativos Internacionais (2000 a 2005)}

[PortRisk, PortReturn, PortWts] $=$ frontcon(ExpRetIntPais05, ExpCovIntPais05, 10, [], AssetBoundsInt05,GroupsInt05,GroupsBoundsInt05)

PortRisk $=$
0.0020
0.0020
0.0021
0.0026
0.0035
0.0046
0.0058
0.0075
0.0096
0.0124

PortReturn $=$
0.0135
0.0139
0.0144
0.0148
0.0152
0.0157
0.0161
0.0166
0.0170
0.0175

PortWts $=$

Columns 1 through 8
$\begin{array}{llllllll}0.8254 & 0.0196 & 0.0000 & 0.0000 & -0.0000 & 0.0000 & 0.0047 & 0.0000\end{array}$
$\begin{array}{llllllll}0.8477 & 0.0310 & -0.0000 & -0.0000 & 0.0000 & -0.0000 & 0.0028 & 0.0000\end{array}$
$\begin{array}{llllllll}0.8990 & 0.0500 & -0.0000 & -0.0000 & 0.0000 & -0.0000 & 0 & 0.0000\end{array}$
$\begin{array}{llllllll}0.7856 & 0.1344 & 0.0780 & -0.0000 & -0.0000 & -0.0000 & -0.0000 & 0.0000\end{array}$
$\begin{array}{llllllll}0.5251 & 0.2267 & 0.2412 & -0.0000 & -0.0000 & -0.0000 & -0.0000 & -0.0000\end{array}$
$\begin{array}{llllllll}0.2646 & 0.3190 & 0.4042 & -0.0000 & 0.0000 & 0.0000 & -0.0000 & -0.0000\end{array}$
$\begin{array}{llllllll}0.0042 & 0.4113 & 0.5672 & 0.0000 & -0.0000 & 0.0000 & 0.0000 & -0.0000\end{array}$
$\begin{array}{llllllll}0.0000 & 0.6155 & 0.3433 & -0.0000 & -0.0000 & 0.0023 & 0.0000 & -0.0000\end{array}$
$\begin{array}{llllllll}-0.0000 & 0.8226 & 0.1075 & -0.0000 & 0.0000 & 0.0049 & 0.0000 & 0.0000\end{array}$
$\begin{array}{llllllll}0 & 0.9000 & 0.0000 & 0.0000 & 0.0000 & 0.0000 & -0.0000 & -0.0000\end{array}$ 
Columns 9 through 16

$\begin{array}{rrrrrrrr}-0.0000 & -0.0000 & 0.0045 & -0.0000 & 0.0000 & -0.0000 & 0.0000 & 0.0000 \\ -0.0000 & -0.0000 & 0.0039 & -0.0000 & 0.0000 & -0.0000 & -0.0000 & 0.0000 \\ -0.0000 & -0.0000 & 0.0001 & -0.0000 & -0.0000 & 0.0000 & -0.0000 & -0.0000 \\ -0.0000 & 0.0000 & -0.0000 & -0.0000 & 0.0000 & 0.0000 & 0.0000 & 0.0000 \\ -0.0000 & 0.0000 & 0.0000 & 0.0000 & -0.0000 & 0.0000 & 0.0000 & 0.0000 \\ -0.0000 & -0.0000 & 0.0000 & -0.0000 & -0.0000 & -0.0000 & -0.0000 & -0.0000 \\ -0.0000 & 0.0000 & 0.0000 & -0.0000 & 0.0000 & -0.0000 & 0.0000 & 0.0000 \\ -0.0000 & 0.0000 & 0.0000 & -0.0000 & 0 & -0.0000 & -0.0000 & -0.0000 \\ -0.0000 & 0.0000 & -0.0000 & -0.0000 & 0.0000 & -0.0000 & -0.0000 & 0.0000 \\ -0.0000 & 0.0000 & -0.0000 & -0.0000 & 0.0000 & -0.0000 & 0.0000 & -0.0000\end{array}$

Columns 17 through 24

$\begin{array}{rrrrrrrr}0.0000 & 0.0000 & -0.0000 & -0.0000 & 0.0000 & -0.0000 & -0.0000 & 0.0000 \\ -0.0000 & -0.0000 & -0.0000 & -0.0000 & -0.0000 & -0.0000 & -0.0000 & 0.0000 \\ 0.0000 & -0.0000 & -0.0000 & -0.0000 & -0.0000 & -0.0000 & 0.0000 & 0.0000 \\ 0.0000 & 0.0000 & -0.0000 & 0.0000 & 0.0000 & 0.0000 & 0.0001 & -0.0000 \\ 0.0000 & 0.0000 & -0.0000 & 0.0000 & -0.0000 & -0.0000 & 0.0000 & -0.0000 \\ -0.0000 & -0.0000 & -0.0000 & 0.0000 & 0.0000 & -0.0000 & 0.0000 & -0.0000 \\ -0.0000 & 0.0000 & -0.0000 & -0.0000 & 0.0000 & -0.0000 & 0.0000 & -0.0000 \\ 0.0000 & -0.0000 & -0.0000 & -0.0000 & 0.0000 & -0.0000 & 0.0048 & -0.0000 \\ -0.0000 & -0.0000 & -0.0000 & -0.0000 & -0.0000 & -0.0000 & 0.0148 & -0.0000 \\ -0.0000 & 0.0000 & 0.0000 & 0.0000 & 0.0000 & 0.0000 & -0.0000 & 0.0000\end{array}$

Columns 25 through 31

$\begin{array}{rrrrrrr}-0.0000 & -0.0000 & -0.0000 & -0.0000 & 0.0459 & -0.0000 & 0.1000 \\ -0.0000 & -0.0000 & -0.0000 & 0.0000 & 0.0145 & -0.0000 & 0.1000 \\ 0.0000 & 0.0000 & 0.0000 & -0.0000 & -0.0000 & -0.0000 & 0.0510 \\ 0.0000 & -0.0000 & 0.0000 & 0.0019 & -0.0000 & -0.0000 & -0.0000 \\ 0.0000 & -0.0000 & 0.0000 & 0.0070 & 0.0000 & 0.0000 & -0.0000 \\ 0.0000 & -0.0000 & 0.0000 & 0.0122 & -0.0000 & -0.0000 & 0.0000 \\ -0.0000 & -0.0000 & 0.0000 & 0.0174 & -0.0000 & 0.0000 & -0.0000 \\ 0.0000 & -0.0000 & 0.0000 & 0.0341 & 0.0000 & 0.0000 & -0.0000 \\ 0.0000 & -0.0000 & 0.0000 & 0.0501 & 0.0000 & 0.0000 & -0.0000 \\ 0.0000 & -0.0000 & 0.0000 & 0.1000 & -0.0000 & -0.0000 & 0\end{array}$




\section{Restrição de 20\% de Ativos Internacionais (2000 a 2005)}

[PortRisk, PortReturn, PortWts] = frontcon(ExpRetIntPais05, ExpCovIntPais05, 10, [], AssetBoundsInt05,GroupsInt05,GroupsBoundsInt05)

PortRisk $=$
0.0020
0.0020
0.0022
0.0029
0.0042
0.0055
0.0073
0.0097
0.0129
0.0192

PortReturn $=$

0.0135

0.0140

0.0145

0.0150

0.0155

0.0160

0.0165

0.0170

0.0175

0.0180

PortWts =

Columns 1 through 8

$\begin{array}{rrrrrrrr}0.8254 & 0.0196 & 0.0000 & 0.0000 & -0.0000 & 0.0000 & 0.0047 & 0.0000 \\ 0.8511 & 0.0328 & -0.0000 & -0.0000 & 0.0000 & -0.0000 & 0.0026 & 0.0000 \\ 0.9451 & 0.0520 & 0 & -0.0000 & -0.0000 & 0.0000 & 0.0000 & -0.0000 \\ 0.6684 & 0.1759 & 0.1515 & -0.0000 & -0.0000 & 0.0000 & -0.0000 & 0.0000 \\ 0.3690 & 0.2820 & 0.3389 & 0.0000 & 0.0000 & 0.0000 & 0.0000 & -0.0000 \\ 0.0696 & 0.3881 & 0.5263 & -0.0000 & -0.0000 & -0.0000 & -0.0000 & 0.0000 \\ 0.0000 & 0.5945 & 0.3671 & 0.0000 & -0.0000 & 0.0020 & -0.0000 & -0.0000 \\ 0.0000 & 0.8327 & 0.0960 & -0.0000 & -0.0000 & 0.0050 & 0.0000 & -0.0000 \\ -0.0000 & 0.8799 & -0.0000 & -0.0000 & -0.0000 & 0.0228 & -0.0000 & 0.0000 \\ 0 & 0.8000 & 0.0000 & 0.0000 & 0.0000 & 0.0000 & -0.0000 & -0.0000\end{array}$


Columns 9 through 16

$\begin{array}{rrrrrrrr}-0.0000 & -0.0000 & 0.0045 & -0.0000 & 0.0000 & -0.0000 & 0.0000 & 0.0000 \\ 0.0000 & -0.0000 & 0.0038 & 0.0000 & -0.0000 & -0.0000 & -0.0000 & -0.0000 \\ -0.0000 & -0.0000 & 0.0000 & 0.0000 & -0.0000 & 0.0000 & 0.0000 & -0.0000 \\ -0.0000 & 0.0000 & -0.0000 & 0.0000 & -0.0000 & 0.0000 & -0.0000 & 0.0000 \\ -0.0000 & 0.0000 & 0.0000 & -0.0000 & -0.0000 & 0.0000 & 0.0000 & -0.0000 \\ -0.0000 & 0.0000 & 0.0000 & 0.0000 & 0.0000 & 0.0000 & 0.0000 & 0.0000 \\ -0.0000 & 0.0000 & 0.0000 & -0.0000 & 0.0000 & -0.0000 & 0.0000 & 0.0000 \\ -0.0000 & 0.0000 & -0.0000 & -0.0000 & 0.0000 & -0.0000 & 0.0000 & 0.0000 \\ -0.0000 & 0.0000 & -0.0000 & -0.0000 & 0.0000 & -0.0000 & -0.0000 & 0.0000 \\ -0.0000 & 0.0000 & -0.0000 & -0.0000 & 0.0000 & -0.0000 & 0.0000 & -0.0000\end{array}$

Columns 17 through 24

$\begin{array}{rrrrrrrr}0.0000 & 0.0000 & -0.0000 & -0.0000 & 0.0000 & -0.0000 & -0.0000 & 0.0000 \\ -0.0000 & 0.0000 & -0.0000 & 0.0000 & 0.0000 & 0.0000 & -0.0000 & -0.0000 \\ 0.0000 & 0.0000 & -0.0000 & 0.0000 & 0.0000 & 0.0000 & -0.0000 & 0.0000 \\ 0.0000 & -0.0000 & -0.0000 & 0.0000 & -0.0000 & 0.0000 & 0.0000 & -0.0000 \\ 0.0000 & 0.0000 & -0.0000 & -0.0000 & 0.0000 & -0.0000 & -0.0000 & 0.0000 \\ -0.0000 & 0.0000 & -0.0000 & -0.0000 & 0.0000 & -0.0000 & 0.0000 & -0.0000 \\ -0.0000 & 0.0000 & -0.0000 & -0.0000 & -0.0000 & -0.0000 & 0.0038 & -0.0000 \\ 0.0000 & -0.0000 & -0.0000 & 0.0000 & -0.0000 & 0.0000 & 0.0153 & -0.0000 \\ 0.0000 & -0.0000 & -0.0000 & -0.0000 & -0.0000 & 0.0000 & 0 & -0.0000 \\ -0.0000 & 0.0000 & 0.0000 & 0.0000 & 0.0000 & 0.0000 & -0.0000 & 0.0000\end{array}$

Columns 25 through 31

$\begin{array}{rrrrrrr}-0.0000 & -0.0000 & -0.0000 & -0.0000 & 0.0459 & -0.0000 & 0.1000 \\ 0.0000 & -0.0000 & 0.0000 & 0.0000 & 0.0098 & -0.0000 & 0.1000 \\ 0.0000 & -0.0000 & -0.0000 & 0.0000 & 0.0000 & -0.0000 & 0.0029 \\ -0.0000 & 0.0000 & -0.0000 & 0.0042 & 0.0000 & 0.0000 & 0.0000 \\ 0.0000 & -0.0000 & 0.0000 & 0.0101 & -0.0000 & 0.0000 & -0.0000 \\ -0.0000 & 0.0000 & -0.0000 & 0.0161 & 0.0000 & -0.0000 & -0.0000 \\ -0.0000 & -0.0000 & 0.0000 & 0.0325 & -0.0000 & 0.0000 & -0.0000 \\ -0.0000 & 0.0000 & -0.0000 & 0.0509 & -0.0000 & 0.0000 & -0.0000 \\ -0.0000 & -0.0000 & 0.0000 & 0.0974 & -0.0000 & 0.0000 & 0.0000 \\ 0.0000 & -0.0000 & 0.0000 & 0.2000 & -0.0000 & -0.0000 & 0\end{array}$




\section{Restrição de 30\% de Ativos Internacionais (2000 a 2005)}

[PortRisk, PortReturn, PortWts] $=$ frontcon(ExpRetIntPais05, ExpCovIntPais05, 10, [], AssetBoundsInt05,GroupsInt05,GroupsBoundsInt05)

PortRisk $=$
0.0020
0.0020
0.0023
0.0034
0.0049
0.0065
0.0091
0.0125
0.0186
0.0274

PortReturn $=$

0.0135

0.0140

0.0146

0.0152

0.0158

0.0163

0.0169

0.0175

0.0181

0.0186

PortWts $=$

Columns 1 through 8

$\begin{array}{rrrrrrrr}0.8254 & 0.0196 & 0.0000 & 0.0000 & -0.0000 & 0.0000 & 0.0047 & 0.0000 \\ 0.8544 & 0.0345 & -0.0000 & -0.0000 & 0.0000 & -0.0000 & 0.0023 & 0.0000 \\ 0.8930 & 0.0982 & 0.0079 & -0.0000 & -0.0000 & -0.0000 & -0.0000 & -0.0000 \\ 0.5514 & 0.2173 & 0.2247 & -0.0000 & -0.0000 & -0.0000 & -0.0000 & -0.0000 \\ 0.2129 & 0.3373 & 0.4365 & -0.0000 & 0.0000 & -0.0000 & -0.0000 & -0.0000 \\ 0.0000 & 0.5117 & 0.4613 & -0.0000 & -0.0000 & 0.0009 & -0.0000 & -0.0000 \\ 0.0000 & 0.7807 & 0.1552 & -0.0000 & 0.0000 & 0.0044 & 0.0000 & -0.0000 \\ 0.0000 & 0.8878 & -0.0000 & -0.0000 & -0.0000 & 0.0210 & -0.0000 & 0.0000 \\ 0 & 0.7861 & -0.0000 & -0.0000 & -0.0000 & 0.0434 & 0.0000 & 0.0000 \\ 0 & 0.7000 & 0.0000 & 0.0000 & 0.0000 & 0.0000 & -0.0000 & -0.0000\end{array}$


Columns 9 through 16

$\begin{array}{rrrrrrrr}-0.0000 & -0.0000 & 0.0045 & -0.0000 & 0.0000 & -0.0000 & 0.0000 & 0.0000 \\ -0.0000 & -0.0000 & 0.0037 & -0.0000 & -0.0000 & -0.0000 & -0.0000 & -0.0000 \\ -0.0000 & 0.0000 & 0.0000 & 0.0000 & -0.0000 & -0.0000 & -0.0000 & 0.0000 \\ -0.0000 & 0.0000 & -0.0000 & 0.0000 & -0.0000 & -0.0000 & -0.0000 & -0.0000 \\ -0.0000 & 0.0000 & -0.0000 & -0.0000 & 0.0000 & 0.0000 & 0.0000 & -0.0000 \\ -0.0000 & -0.0000 & 0.0000 & 0.0000 & -0.0000 & -0.0000 & -0.0000 & -0.0000 \\ -0.0000 & -0.0000 & -0.0000 & 0.0000 & -0.0000 & 0.0000 & 0.0000 & 0.0000 \\ -0.0000 & -0.0000 & 0.0000 & 0.0000 & 0.0000 & -0.0000 & -0.0000 & 0.0000 \\ -0.0000 & 0.0000 & -0.0000 & 0.0000 & -0.0000 & -0.0000 & 0.0000 & 0.0000 \\ -0.0000 & 0.0000 & -0.0000 & -0.0000 & 0.0000 & -0.0000 & 0.0000 & -0.0000\end{array}$

Columns 17 through 24

$\begin{array}{rrrrrrrr}0.0000 & 0.0000 & -0.0000 & -0.0000 & 0.0000 & -0.0000 & -0.0000 & 0.0000 \\ 0.0000 & -0.0000 & -0.0000 & -0.0000 & 0.0000 & -0.0000 & 0.0000 & 0.0000 \\ 0.0000 & -0.0000 & -0.0000 & -0.0000 & 0.0000 & -0.0000 & 0.0009 & -0.0000 \\ -0.0000 & 0.0000 & -0.0000 & 0.0000 & 0.0000 & 0.0000 & 0.0000 & -0.0000 \\ 0.0000 & 0.0000 & -0.0000 & 0.0000 & 0.0000 & -0.0000 & 0.0000 & -0.0000 \\ -0.0000 & 0.0000 & -0.0000 & -0.0000 & -0.0000 & -0.0000 & -0.0000 & -0.0000 \\ -0.0000 & 0.0000 & -0.0000 & -0.0000 & -0.0000 & 0.0000 & 0.0128 & -0.0000 \\ -0.0000 & -0.0000 & -0.0000 & -0.0000 & 0.0000 & -0.0000 & 0 & -0.0000 \\ -0.0000 & -0.0000 & -0.0000 & 0.0000 & 0.0000 & -0.0000 & 0 & -0.0000 \\ -0.0000 & 0.0000 & 0.0000 & 0.0000 & 0.0000 & 0.0000 & -0.0000 & 0.0000\end{array}$

Columns 25 through 31

$\begin{array}{rrrrrrr}-0.0000 & -0.0000 & -0.0000 & -0.0000 & 0.0459 & -0.0000 & 0.1000 \\ -0.0000 & 0.0000 & -0.0000 & -0.0000 & 0.0051 & -0.0000 & 0.1000 \\ -0.0000 & 0.0000 & 0.0000 & 0 & -0.0000 & -0.0000 & 0.0000 \\ 0.0000 & 0.0000 & 0.0000 & 0.0065 & 0.0000 & 0.0000 & -0.0000 \\ -0.0000 & -0.0000 & -0.0000 & 0.0132 & 0.0000 & 0.0000 & 0.0000 \\ -0.0000 & -0.0000 & 0.0000 & 0.0261 & 0.0000 & 0.0000 & -0.0000 \\ 0.0000 & 0.0000 & 0.0000 & 0.0469 & 0.0000 & 0.0000 & -0.0000 \\ -0.0000 & -0.0000 & 0.0000 & 0.0912 & 0.0000 & 0.0000 & 0.0000 \\ -0.0000 & -0.0000 & -0.0000 & 0.1705 & 0.0000 & 0.0000 & 0.0000 \\ 0.0000 & -0.0000 & 0.0000 & 0.3000 & -0.0000 & -0.0000 & 0\end{array}$




\section{Restrição de 40\% de Ativos Internacionais (2000 a 2005)}

[PortRisk, PortReturn, PortWts] = frontcon(ExpRetIntPais05, ExpCovIntPais05, 10, [], AssetBoundsInt05,GroupsInt05,GroupsBoundsInt05)

PortRisk $=$
0.0020
0.0020
0.0025
0.0039
0.0056
0.0079
0.0112
0.0173
0.0254
0.0360

PortReturn $=$

0.0135

0.0141

0.0148

0.0154

0.0160

0.0167

0.0173

0.0180

0.0186

0.0192

PortWts $=$

Columns 1 through 8

$\begin{array}{rrrrrrrr}0.8254 & 0.0196 & 0.0000 & 0.0000 & -0.0000 & 0.0000 & 0.0047 & 0.0000 \\ 0.8578 & 0.0362 & -0.0000 & -0.0000 & -0.0000 & -0.0000 & 0.0020 & -0.0000 \\ 0.8124 & 0.1254 & 0.0606 & -0.0000 & -0.0000 & -0.0000 & -0.0000 & -0.0000 \\ 0.4343 & 0.2588 & 0.2980 & -0.0000 & -0.0000 & -0.0000 & 0.0000 & -0.0000 \\ 0.0569 & 0.3926 & 0.5342 & 0.0000 & -0.0000 & -0.0000 & 0.0000 & -0.0000 \\ 0.0000 & 0.6667 & 0.2850 & -0.0000 & 0.0000 & 0.0029 & -0.0000 & -0.0000 \\ 0 & 0.9119 & -0.0000 & -0.0000 & -0.0000 & 0.0128 & 0.0000 & -0.0000 \\ -0.0000 & 0.8057 & -0.0000 & -0.0000 & -0.0000 & 0.0391 & 0.0000 & -0.0000 \\ -0.0000 & 0.6923 & -0.0000 & -0.0000 & 0 & 0.0641 & -0.0000 & -0.0000 \\ 0 & 0.6000 & -0.0000 & 0.0000 & 0.0000 & 0.0000 & -0.0000 & -0.0000\end{array}$


Columns 9 through 16

$\begin{array}{rrrrrrrr}-0.0000 & -0.0000 & 0.0045 & -0.0000 & 0.0000 & -0.0000 & 0.0000 & 0.0000 \\ -0.0000 & 0.0000 & 0.0036 & -0.0000 & -0.0000 & -0.0000 & 0.0000 & -0.0000 \\ -0.0000 & -0.0000 & -0.0000 & 0.0000 & -0.0000 & 0.0000 & -0.0000 & -0.0000 \\ -0.0000 & 0.0000 & 0.0000 & -0.0000 & 0.0000 & 0.0000 & -0.0000 & -0.0000 \\ 0.0000 & -0.0000 & 0.0000 & -0.0000 & 0.0000 & 0.0000 & -0.0000 & -0.0000 \\ -0.0000 & -0.0000 & -0.0000 & -0.0000 & 0.0000 & 0.0000 & -0.0000 & 0.0000 \\ -0.0000 & -0.0000 & 0.0000 & 0.0000 & -0.0000 & -0.0000 & -0.0000 & 0.0000 \\ 0.0000 & 0.0000 & -0.0000 & 0.0000 & -0.0000 & -0.0000 & -0.0000 & -0.0000 \\ 0.0000 & -0.0000 & -0.0000 & -0.0000 & 0.0000 & -0.0000 & 0.0000 & -0.0000 \\ -0.0000 & 0.0000 & -0.0000 & -0.0000 & 0.0000 & -0.0000 & 0.0000 & -0.0000\end{array}$

Columns 17 through 24

$\begin{array}{rrrrrrrr}0.0000 & 0.0000 & -0.0000 & -0.0000 & 0.0000 & -0.0000 & -0.0000 & 0.0000 \\ 0.0000 & 0.0000 & -0.0000 & 0.0000 & -0.0000 & -0.0000 & -0.0000 & 0.0000 \\ 0.0000 & 0.0000 & -0.0000 & 0.0000 & -0.0000 & 0.0000 & 0.0003 & 0.0000 \\ 0.0000 & 0.0000 & -0.0000 & -0.0000 & -0.0000 & 0.0000 & 0.0000 & 0.0000 \\ 0.0000 & -0.0000 & -0.0000 & -0.0000 & 0.0000 & -0.0000 & 0.0000 & 0.0000 \\ -0.0000 & -0.0000 & -0.0000 & -0.0000 & -0.0000 & 0.0000 & 0.0073 & -0.0000 \\ 0.0000 & -0.0000 & -0.0000 & -0.0000 & -0.0000 & 0.0000 & 0.0068 & -0.0000 \\ -0.0000 & -0.0000 & -0.0000 & 0.0000 & -0.0000 & -0.0000 & 0 & 0.0000 \\ -0.0000 & -0.0000 & -0.0000 & -0.0000 & -0.0000 & 0.0000 & -0.0000 & -0.0000 \\ -0.0000 & 0.0000 & 0.0000 & 0.0000 & 0.0000 & 0.0000 & -0.0000 & 0.0000\end{array}$

Columns 25 through 31

$\begin{array}{rrrrrrr}-0.0000 & -0.0000 & -0.0000 & -0.0000 & 0.0459 & -0.0000 & 0.1000 \\ 0.0000 & 0.0000 & 0.0000 & -0.0000 & 0.0004 & -0.0000 & 0.1000 \\ -0.0000 & 0.0000 & 0.0000 & 0.0014 & -0.0000 & 0.0000 & 0.0000 \\ 0.0000 & -0.0000 & -0.0000 & 0.0088 & 0.0000 & 0.0000 & 0 \\ -0.0000 & 0.0000 & 0.0000 & 0.0163 & 0.0000 & 0.0000 & -0.0000 \\ 0.0000 & -0.0000 & 0.0000 & 0.0381 & -0.0000 & 0.0000 & -0.0000 \\ 0.0000 & -0.0000 & -0.0000 & 0.0686 & 0.0000 & -0.0000 & 0.0000 \\ 0.0000 & 0.0000 & 0.0000 & 0.1552 & 0.0000 & -0.0000 & 0.0000 \\ -0.0000 & -0.0000 & -0.0000 & 0.2436 & -0.0000 & -0.0000 & 0.0000 \\ 0.0000 & -0.0000 & 0.0000 & 0.4000 & -0.0000 & -0.0000 & 0\end{array}$




\section{Restrição de 50\% de Ativos Internacionais (2000 a 2005)}

[PortRisk, PortReturn, PortWts] $=$ frontcon(ExpRetIntPais05, ExpCovIntPais05, 10, [], AssetBoundsInt05,GroupsInt05,GroupsBoundsInt05)

PortRisk $=$
0.0020
0.0020
0.0027
0.0044
0.0064
0.0096
0.0146
0.0231
0.0325
0.0448

PortReturn $=$

0.0135

0.0142

0.0149

0.0156

0.0163

0.0170

0.0177

0.0184

0.0191

0.0198

PortWts $=$

Columns 1 through 8

$\begin{array}{rrrrrrrr}0.8254 & 0.0196 & 0.0000 & 0.0000 & -0.0000 & 0.0000 & 0.0047 & 0.0000 \\ 0.8563 & 0.0420 & -0.0000 & -0.0000 & -0.0000 & -0.0000 & -0.0000 & -0.0000 \\ 0.7338 & 0.1527 & 0.1106 & -0.0000 & 0.0000 & -0.0000 & 0.0000 & -0.0000 \\ 0.3173 & 0.3003 & 0.3712 & -0.0000 & -0.0000 & -0.0000 & -0.0000 & -0.0000 \\ 0.0000 & 0.4916 & 0.4836 & -0.0000 & -0.0000 & 0.0004 & -0.0000 & -0.0000 \\ 0.0000 & 0.8219 & 0.1084 & -0.0000 & -0.0000 & 0.0049 & 0.0000 & -0.0000 \\ -0.0000 & 0.8488 & -0.0000 & -0.0000 & 0.0000 & 0.0296 & -0.0000 & -0.0000 \\ -0.0000 & 0.7237 & -0.0000 & -0.0000 & 0 & 0.0572 & -0.0000 & -0.0000 \\ -0.0000 & 0.5985 & -0.0000 & -0.0000 & -0.0000 & 0.0847 & -0.0000 & -0.0000 \\ 0 & 0.5000 & -0.0000 & 0.0000 & 0.0000 & 0.0000 & -0.0000 & -0.0000\end{array}$


Columns 9 through 16

$\begin{array}{rrrrrrrr}-0.0000 & -0.0000 & 0.0045 & -0.0000 & 0.0000 & -0.0000 & 0.0000 & 0.0000 \\ -0.0000 & -0.0000 & 0.0018 & -0.0000 & 0 & -0.0000 & 0.0000 & -0.0000 \\ -0.0000 & -0.0000 & -0.0000 & 0.0000 & 0.0000 & 0.0000 & -0.0000 & -0.0000 \\ -0.0000 & -0.0000 & 0.0000 & -0.0000 & -0.0000 & 0.0000 & -0.0000 & -0.0000 \\ -0.0000 & -0.0000 & 0.0000 & -0.0000 & -0.0000 & -0.0000 & 0.0000 & 0.0000 \\ -0.0000 & -0.0000 & -0.0000 & -0.0000 & 0.0000 & -0.0000 & -0.0000 & -0.0000 \\ -0.0000 & -0.0000 & -0.0000 & -0.0000 & -0.0000 & -0.0000 & -0.0000 & -0.0000 \\ -0.0000 & -0.0000 & -0.0000 & -0.0000 & 0.0000 & -0.0000 & 0.0000 & 0.0000 \\ -0.0000 & -0.0000 & -0.0000 & -0.0000 & 0.0000 & -0.0000 & 0.0000 & 0.0000 \\ -0.0000 & 0.0000 & -0.0000 & -0.0000 & 0.0000 & -0.0000 & 0.0000 & -0.0000\end{array}$

Columns 17 through 24

$\begin{array}{rrrrrrrr}0.0000 & 0.0000 & -0.0000 & -0.0000 & 0.0000 & -0.0000 & -0.0000 & 0.0000 \\ -0.0000 & 0.0000 & -0.0000 & 0.0000 & -0.0000 & -0.0000 & 0.0000 & 0.0000 \\ -0.0000 & 0.0000 & -0.0000 & 0.0000 & -0.0000 & -0.0000 & -0.0000 & -0.0000 \\ 0.0000 & -0.0000 & -0.0000 & 0.0000 & 0.0000 & 0.0000 & 0.0000 & 0.0000 \\ -0.0000 & 0.0000 & -0.0000 & -0.0000 & 0.0000 & -0.0000 & -0.0000 & 0.0000 \\ -0.0000 & 0.0000 & -0.0000 & 0.0000 & -0.0000 & 0.0000 & 0.0148 & 0.0000 \\ -0.0000 & -0.0000 & -0.0000 & -0.0000 & 0.0000 & 0.0000 & 0 & -0.0000 \\ 0.0000 & 0.0000 & -0.0000 & 0.0000 & -0.0000 & 0.0000 & 0 & -0.0000 \\ 0.0000 & -0.0000 & -0.0000 & 0.0000 & 0.0000 & 0.0000 & 0 & 0.0000 \\ -0.0000 & 0.0000 & 0.0000 & 0.0000 & 0.0000 & 0.0000 & -0.0000 & 0.0000\end{array}$

Columns 25 through 31

$\begin{array}{rrrrrrr}-0.0000 & -0.0000 & -0.0000 & -0.0000 & 0.0459 & -0.0000 & 0.1000 \\ 0.0000 & -0.0000 & 0.0000 & -0.0000 & 0.0000 & -0.0000 & 0.1000 \\ -0.0000 & -0.0000 & -0.0000 & 0.0029 & 0.0000 & 0.0000 & -0.0000 \\ 0.0000 & -0.0000 & -0.0000 & 0.0112 & -0.0000 & -0.0000 & 0 \\ 0.0000 & -0.0000 & -0.0000 & 0.0244 & 0.0000 & -0.0000 & 0.0000 \\ 0.0000 & -0.0000 & -0.0000 & 0.0501 & 0.0000 & -0.0000 & -0.0000 \\ 0.0000 & -0.0000 & -0.0000 & 0.1216 & -0.0000 & -0.0000 & -0.0000 \\ -0.0000 & -0.0000 & -0.0000 & 0.2192 & 0.0000 & -0.0000 & -0.0000 \\ -0.0000 & -0.0000 & -0.0000 & 0.3168 & 0.0000 & -0.0000 & 0.0000 \\ 0.0000 & -0.0000 & 0.0000 & 0.5000 & -0.0000 & -0.0000 & 0\end{array}$




\section{Restrição Total a Ativos Internacionais (2001 a 2006)}

[PortRisk, PortReturn, PortWts] = frontcon(ExpRetIntPais06, ExpCovIntPais06, 10, [], AssetBoundsInt05,GroupsInt05,GroupsBoundsInt05)

PortRisk $=$
0.0021
0.0024
0.0028
0.0036
0.0046
0.0059
0.0086
0.0137
0.0259
0.0398

PortReturn $=$
0.0138
0.0142
0.0145
0.0149
0.0153
0.0156
0.0160
0.0164
0.0167
0.0171

PortWts $=$

Columns 1 through 8

$\begin{array}{rrrrrrrr}0.8727 & 0.0142 & -0.0000 & 0.0000 & -0.0000 & -0.0000 & 0.0000 & 0.0000 \\ 0.9326 & 0.0542 & 0.0067 & 0.0000 & -0.0000 & -0.0000 & 0.0000 & 0.0000 \\ 0.7058 & 0.1203 & 0.1739 & 0.0000 & -0.0000 & -0.0000 & -0.0000 & 0.0000 \\ 0.4412 & 0.1957 & 0.3631 & 0.0000 & -0.0000 & -0.0000 & -0.0000 & 0.0000 \\ 0.1765 & 0.2712 & 0.5523 & 0.0000 & -0.0000 & 0.0000 & -0.0000 & 0.0000 \\ -0.0000 & 0.4560 & 0.5419 & 0.0000 & -0.0000 & 0.0000 & -0.0000 & 0.0021 \\ -0.0000 & 0.7782 & 0.1889 & 0.0000 & -0.0000 & -0.0000 & -0.0000 & 0.0329 \\ -0.0000 & 0.8657 & 0 & 0.0000 & 0.0000 & -0.0000 & 0.0000 & 0.1343 \\ -0.0000 & 0.6828 & 0 & 0.0000 & 0.0000 & -0.0000 & 0.0000 & 0.3172 \\ 0.0000 & 0.5000 & 0 & 0.0000 & 0.0000 & -0.0000 & 0.0000 & 0.5000\end{array}$

Columns 9 through 16 


$\begin{array}{rrrrrrrr}0.0000 & -0.0000 & -0.0000 & 0.0000 & 0.0000 & -0.0000 & -0.0000 & -0.0000 \\ 0.0000 & -0.0000 & -0.0000 & -0.0000 & -0.0000 & 0.0000 & 0.0000 & 0.0000 \\ 0.0000 & -0.0000 & -0.0000 & -0.0000 & -0.0000 & 0.0000 & 0.0000 & 0.0000 \\ 0.0000 & 0.0000 & -0.0000 & -0.0000 & -0.0000 & 0.0000 & 0.0000 & 0.0000 \\ 0.0000 & 0.0000 & -0.0000 & -0.0000 & -0.0000 & 0.0000 & 0.0000 & 0.0000 \\ 0.0000 & 0.0000 & -0.0000 & -0.0000 & -0.0000 & 0.0000 & 0.0000 & 0.0000 \\ 0.0000 & -0.0000 & -0.0000 & 0.0000 & -0.0000 & 0.0000 & 0.0000 & 0.0000 \\ 0.0000 & -0.0000 & -0.0000 & 0.0000 & -0.0000 & 0.0000 & -0.0000 & -0.0000 \\ 0.0000 & -0.0000 & -0.0000 & 0.0000 & -0.0000 & 0.0000 & -0.0000 & -0.0000 \\ 0.0000 & 0.0000 & 0.0000 & 0.0000 & -0.0000 & -0.0000 & -0.0000 & 0.0000\end{array}$

Columns 17 through 24

$\begin{array}{rrrrrrrr}0.0000 & 0.0000 & 0.0000 & -0.0000 & -0.0000 & -0.0000 & -0.0000 & 0.0000 \\ 0.0000 & 0.0000 & -0.0000 & 0.0000 & 0.0000 & 0.0000 & 0.0000 & 0.0000 \\ 0.0000 & 0.0000 & -0.0000 & 0.0000 & 0.0000 & 0.0000 & 0.0000 & 0.0000 \\ 0.0000 & 0.0000 & 0.0000 & 0.0000 & -0.0000 & 0.0000 & 0.0000 & 0.0000 \\ 0.0000 & 0.0000 & 0.0000 & 0.0000 & -0.0000 & -0.0000 & 0.0000 & 0.0000 \\ 0.0000 & 0.0000 & 0.0000 & 0.0000 & -0.0000 & -0.0000 & 0.0000 & 0.0000 \\ 0.0000 & 0.0000 & 0.0000 & 0.0000 & 0.0000 & -0.0000 & 0.0000 & 0.0000 \\ 0.0000 & 0.0000 & 0.0000 & 0.0000 & 0.0000 & -0.0000 & 0.0000 & 0.0000 \\ 0.0000 & 0.0000 & 0.0000 & 0.0000 & 0.0000 & -0.0000 & 0.0000 & 0.0000 \\ -0.0000 & 0.0000 & 0.0000 & -0.0000 & 0.0000 & -0.0000 & -0.0000 & -0.0000\end{array}$

Columns 25 through 31

$\begin{array}{rrrrrrr}-0.0000 & 0.0000 & 0.0000 & -0.0000 & 0.0130 & 0 & 0.1000 \\ -0.0000 & -0.0000 & -0.0000 & 0.0000 & 0.0065 & -0.0000 & 0.0000 \\ -0.0000 & -0.0000 & -0.0000 & -0.0000 & -0.0000 & -0.0000 & -0.0000 \\ -0.0000 & -0.0000 & -0.0000 & -0.0000 & -0.0000 & 0.0000 & -0.0000 \\ 0.0000 & -0.0000 & -0.0000 & -0.0000 & -0.0000 & 0.0000 & -0.0000 \\ 0.0000 & -0.0000 & -0.0000 & -0.0000 & -0.0000 & 0.0000 & -0.0000 \\ 0.0000 & -0.0000 & -0.0000 & 0.0000 & 0.0000 & 0.0000 & 0 \\ 0.0000 & -0.0000 & -0.0000 & 0.0000 & -0.0000 & 0.0000 & 0 \\ 0.0000 & -0.0000 & -0.0000 & 0.0000 & 0.0000 & 0.0000 & 0 \\ 0.0000 & 0.0000 & 0.0000 & -0.0000 & 0.0000 & 0.0000 & -0.0000\end{array}$




\section{Restrição de 10\% de Ativos Internacionais (2001 a 2006)}

[PortRisk, PortReturn, PortWts] = frontcon(ExpRetIntPais06, ExpCovIntPais06, 10, [], AssetBoundsInt05,GroupsInt05,GroupsBoundsInt05)

PortRisk $=$
0.0020
0.0023
0.0030
0.0040
0.0053
0.0066
0.0080
0.0106
0.0174
0.0358

PortReturn $=$

0.0137

0.0142

0.0148

0.0153

0.0159

0.0164

0.0169

0.0175

0.0180

0.0185

PortWts $=$

Columns 1 through 8

$\begin{array}{rrrrrrrr}0.8430 & 0.0282 & 0.0000 & 0.0000 & -0.0000 & -0.0000 & 0.0087 & -0.0000 \\ 0.9071 & 0.0713 & 0.0000 & 0.0000 & 0.0000 & 0.0000 & 0.0000 & -0.0000 \\ 0.7614 & 0.1477 & 0.0643 & -0.0000 & -0.0000 & 0.0000 & 0.0000 & 0.0000 \\ 0.5203 & 0.2370 & 0.2017 & -0.0000 & 0.0000 & 0.0000 & -0.0000 & -0.0000 \\ 0.2793 & 0.3263 & 0.3391 & -0.0000 & 0.0000 & 0.0000 & 0.0000 & 0.0000 \\ 0.0382 & 0.4156 & 0.4766 & 0.0000 & 0.0000 & -0.0000 & 0.0000 & 0.0000 \\ 0 & 0.5359 & 0.3641 & -0.0000 & 0.0000 & 0.0000 & 0.0000 & 0 \\ 0.0000 & 0.7294 & 0.1706 & 0.0000 & -0.0000 & 0.0128 & 0.0000 & -0.0000 \\ 0 & 0.7663 & 0.0000 & -0.0000 & 0.0000 & 0.0000 & -0.0000 & 0.1337 \\ -0.0000 & 0.5000 & 0.0000 & -0.0000 & 0.0000 & -0.0000 & -0.0000 & 0.4000\end{array}$

Columns 9 through 16

$\begin{array}{llllllll}0.0000 & 0.0000 & 0.0093 & 0.0000 & -0.0000 & 0.0000 & 0.0000 & -0.0000\end{array}$ 


$\begin{array}{rrrrrrrr}0.0000 & 0.0000 & 0.0068 & -0.0000 & 0.0000 & -0.0000 & -0.0000 & -0.0000 \\ 0.0000 & 0.0000 & 0.0000 & -0.0000 & 0.0000 & 0.0000 & -0.0000 & 0.0000 \\ -0.0000 & 0.0000 & 0.0000 & 0.0000 & -0.0000 & 0.0000 & 0.0000 & -0.0000 \\ -0.0000 & 0.0000 & -0.0000 & 0.0000 & -0.0000 & 0.0000 & 0.0000 & 0.0000 \\ -0.0000 & 0.0000 & 0.0000 & 0.0000 & -0.0000 & 0.0000 & 0.0000 & -0.0000 \\ -0.0000 & 0.0000 & 0.0000 & 0.0000 & -0.0000 & 0.0000 & -0.0000 & 0.0000 \\ -0.0000 & 0.0000 & 0.0000 & 0.0000 & 0.0000 & 0.0000 & -0.0000 & 0.0000 \\ -0.0000 & 0.0000 & 0.0000 & 0.0000 & 0.0000 & 0.0000 & 0.0000 & 0.0000 \\ 0.0000 & 0.0000 & 0.0000 & -0.0000 & -0.0000 & -0.0000 & 0.0000 & 0.0000\end{array}$

Columns 17 through 24

$\begin{array}{rrrrrrrr}0.0000 & -0.0000 & -0.0000 & 0.0000 & 0.0000 & -0.0000 & 0.0000 & 0.0000 \\ -0.0000 & 0.0000 & 0.0000 & 0.0000 & 0.0000 & 0.0000 & 0.0089 & 0.0000 \\ -0.0000 & 0.0000 & 0.0000 & 0.0000 & 0.0000 & 0.0000 & 0.0178 & -0.0000 \\ 0.0000 & -0.0000 & 0.0000 & 0.0000 & -0.0000 & 0.0000 & 0.0247 & 0.0000 \\ 0.0000 & -0.0000 & 0.0000 & -0.0000 & 0.0000 & 0.0000 & 0.0315 & 0.0000 \\ 0.0000 & -0.0000 & 0.0000 & -0.0000 & 0.0000 & -0.0000 & 0.0384 & 0.0000 \\ 0.0000 & 0.0000 & -0.0000 & 0.0000 & 0.0000 & -0.0000 & 0.0529 & 0.0000 \\ -0.0000 & -0.0000 & -0.0000 & 0.0000 & 0.0000 & 0.0000 & 0.0091 & -0.0000 \\ -0.0000 & 0.0000 & 0.0000 & 0.0000 & 0.0000 & 0.0000 & 0 & 0.0000 \\ -0.0000 & -0.0000 & 0.0000 & -0.0000 & 0.0000 & 0.0000 & 0 & -0.0000\end{array}$

Columns 25 through 31

$\begin{array}{rrrrrrr}-0.0000 & -0.0000 & -0.0000 & -0.0000 & 0.0109 & 0.0000 & 0.1000 \\ 0.0000 & -0.0000 & 0.0000 & 0.0012 & 0.0047 & 0.0000 & -0.0000 \\ 0.0000 & -0.0000 & 0.0000 & 0.0088 & -0.0000 & 0.0000 & -0.0000 \\ -0.0000 & -0.0000 & -0.0000 & 0.0163 & 0.0000 & 0.0000 & 0.0000 \\ 0.0000 & -0.0000 & -0.0000 & 0.0238 & 0.0000 & 0.0000 & -0.0000 \\ -0.0000 & -0.0000 & -0.0000 & 0.0313 & 0.0000 & -0.0000 & -0.0000 \\ -0.0000 & 0.0000 & 0.0000 & 0.0471 & 0.0000 & -0.0000 & -0.0000 \\ -0.0000 & 0.0000 & 0.0000 & 0.0781 & -0.0000 & 0.0000 & -0.0000 \\ 0.0000 & 0.0000 & 0.0000 & 0.1000 & -0.0000 & 0.0000 & 0.0000 \\ 0.0000 & -0.0000 & -0.0000 & 0.1000 & 0.0000 & 0.0000 & 0\end{array}$




\section{Restrição de 20\% de Ativos Internacionais (2001 a 2006)}

[PortRisk, PortReturn, PortWts] = frontcon(ExpRetIntPais06,ExpCovIntPais06,10,[], AssetBoundsInt05,GroupsInt05,GroupsBoundsInt05)

PortRisk $=$
0.0020
0.0025
0.0036
0.0051
0.0068
0.0088
0.0111
0.0138
0.0181
0.0344

PortReturn $=$

0.0137
0.0144
0.0151
0.0158
0.0165
0.0172
0.0179
0.0186
0.0193
0.0200

PortWts $=$

Columns 1 through 8

$\begin{array}{rrrrrrrr}0.8430 & 0.0282 & 0.0000 & 0.0000 & -0.0000 & -0.0000 & 0.0087 & -0.0000 \\ 0.8841 & 0.0943 & 0.0000 & 0.0000 & -0.0000 & 0.0000 & 0.0000 & 0.0000 \\ 0.6185 & 0.2006 & 0.1457 & 0.0000 & 0.0000 & 0.0000 & -0.0000 & 0 \\ 0.3060 & 0.3164 & 0.3239 & -0.0000 & 0.0000 & 0.0000 & 0.0000 & 0.0000 \\ 0.0000 & 0.4327 & 0.4944 & 0.0000 & 0.0000 & -0.0000 & 0.0000 & 0 \\ 0 & 0.5736 & 0.3031 & -0.0000 & 0.0000 & 0.0000 & -0.0000 & 0.0000 \\ 0 & 0.7145 & 0.1119 & 0.0000 & -0.0000 & 0.0000 & 0.0000 & -0.0000 \\ 0 & 0.8000 & 0.0000 & 0.0000 & 0.0000 & 0.0086 & 0.0000 & -0.0000 \\ 0 & 0.8000 & 0.0000 & 0.0000 & 0.0000 & 0.0329 & -0.0000 & 0 \\ 0 & 0.5000 & 0.0000 & -0.0000 & 0.0000 & 0.0000 & -0.0000 & 0.3000\end{array}$

Columns 9 through 16

$\begin{array}{llllllll}0.0000 & 0.0000 & 0.0093 & 0.0000 & -0.0000 & 0.0000 & 0.0000 & -0.0000\end{array}$ 


$\begin{array}{rrrrrrrr}-0.0000 & 0.0000 & 0.0046 & 0.0000 & 0.0000 & -0.0000 & 0.0000 & 0.0000 \\ -0.0000 & 0.0000 & 0.0000 & 0.0000 & -0.0000 & -0.0000 & 0.0000 & -0.0000 \\ -0.0000 & 0.0000 & -0.0000 & 0.0000 & -0.0000 & 0.0000 & 0.0000 & -0.0000 \\ -0.0000 & 0.0000 & 0.0000 & 0.0000 & -0.0000 & -0.0000 & 0.0000 & -0.0000 \\ -0.0000 & 0.0000 & 0.0000 & 0.0000 & -0.0000 & -0.0000 & -0.0000 & 0.0000 \\ -0.0000 & 0.0000 & -0.0000 & 0.0000 & 0.0000 & -0.0000 & -0.0000 & 0.0000 \\ -0.0000 & 0.0000 & 0.0000 & -0.0000 & 0.0000 & 0.0000 & -0.0000 & 0.0000 \\ -0.0000 & 0.0000 & -0.0000 & 0.0000 & -0.0000 & -0.0000 & 0.0000 & 0.0000 \\ 0.0000 & 0.0000 & 0.0000 & -0.0000 & -0.0000 & -0.0000 & 0.0000 & -0.0000\end{array}$

Columns 17 through 24

$\begin{array}{rrrrrrrr}0.0000 & -0.0000 & -0.0000 & 0.0000 & 0.0000 & -0.0000 & 0.0000 & 0.0000 \\ 0.0000 & -0.0000 & 0.0000 & 0.0000 & 0.0000 & 0.0000 & 0.0123 & -0.0000 \\ 0.0000 & 0.0000 & 0.0000 & 0.0000 & -0.0000 & 0.0000 & 0.0219 & 0.0000 \\ 0.0000 & 0.0000 & 0.0000 & -0.0000 & -0.0000 & 0.0000 & 0.0308 & 0.0000 \\ 0.0000 & 0.0000 & 0.0000 & -0.0000 & 0.0000 & -0.0000 & 0.0401 & 0.0000 \\ -0.0000 & 0.0000 & 0.0000 & 0.0000 & 0.0000 & 0.0000 & 0.0718 & -0.0000 \\ -0.0000 & 0.0000 & -0.0000 & -0.0000 & -0.0000 & 0.0000 & 0.1035 & -0.0000 \\ -0.0000 & 0.0000 & -0.0000 & -0.0000 & 0.0000 & 0.0000 & 0.0827 & 0.0000 \\ -0.0000 & 0.0000 & -0.0000 & 0.0000 & -0.0000 & 0.0000 & 0 & -0.0000 \\ 0.0000 & -0.0000 & 0.0000 & -0.0000 & 0.0000 & 0.0000 & 0 & -0.0000\end{array}$

Columns 25 through 31

$\begin{array}{rrrrrrr}-0.0000 & -0.0000 & -0.0000 & -0.0000 & 0.0109 & 0.0000 & 0.1000 \\ 0.0000 & -0.0000 & -0.0000 & 0.0034 & 0.0013 & 0.0000 & 0.0000 \\ -0.0000 & 0.0000 & -0.0000 & 0.0132 & -0.0000 & 0.0000 & 0.0000 \\ 0.0000 & 0.0000 & -0.0000 & 0.0229 & 0.0000 & 0.0000 & -0.0000 \\ -0.0000 & -0.0000 & -0.0000 & 0.0328 & -0.0000 & -0.0000 & -0.0000 \\ 0.0000 & 0.0000 & 0.0000 & 0.0515 & 0.0000 & -0.0000 & -0.0000 \\ 0.0000 & 0.0000 & 0.0000 & 0.0701 & 0.0000 & 0.0000 & 0.0000 \\ -0.0000 & 0.0000 & 0.0000 & 0.1087 & -0.0000 & 0.0000 & 0.0000 \\ -0.0000 & -0.0000 & 0.0000 & 0.1671 & 0.0000 & 0.0000 & 0.0000 \\ 0.0000 & -0.0000 & -0.0000 & 0.2000 & 0.0000 & 0.0000 & 0\end{array}$




\section{Restrição de 30\% de Ativos Internacionais (2001 a 2006)}

[PortRisk, PortReturn, PortWts] = frontcon(ExpRetIntPais06,ExpCovIntPais06,10,[], AssetBoundsInt05,GroupsInt05,GroupsBoundsInt05)

PortRisk

0.0020
0.0026
0.0043
0.0063
0.0086
0.0114
0.0145
0.0182
0.0234
0.0358

PortReturn $=$

0.0137

0.0146

0.0154

0.0163

0.0171

0.0180

0.0188

0.0197

0.0205

0.0214

PortWts =

Columns 1 through 8

$\begin{array}{rrrrrrrr}0.8430 & 0.0282 & 0.0000 & 0.0000 & -0.0000 & -0.0000 & 0.0087 & -0.0000 \\ 0.8399 & 0.1162 & 0.0211 & 0.0000 & -0.0000 & 0.0000 & 0.0000 & -0.0000 \\ 0.4757 & 0.2535 & 0.2272 & 0.0000 & 0.0000 & 0.0000 & -0.0000 & -0.0000 \\ 0.0917 & 0.3958 & 0.4460 & 0.0000 & 0.0000 & -0.0000 & 0.0000 & 0 \\ 0 & 0.5615 & 0.3195 & -0.0000 & 0.0000 & 0.0000 & -0.0000 & 0.0000 \\ 0 & 0.7346 & 0.0845 & 0.0000 & 0.0000 & 0.0000 & -0.0000 & 0.0000 \\ 0 & 0.7518 & 0.0000 & -0.0000 & 0.0000 & 0.0000 & 0.0000 & 0.0000 \\ 0 & 0.7000 & 0.0000 & 0.0000 & 0.0000 & 0.0117 & -0.0000 & -0.0000 \\ 0 & 0.7000 & 0.0000 & 0.0000 & 0.0000 & 0.0502 & 0.0000 & 0 \\ 0 & 0.5000 & 0.0000 & -0.0000 & 0.0000 & -0.0000 & -0.0000 & 0.2000\end{array}$

Columns 9 through 16 


$\begin{array}{rrrrrrrr}0.0000 & 0.0000 & 0.0093 & 0.0000 & -0.0000 & 0.0000 & 0.0000 & -0.0000 \\ -0.0000 & 0.0000 & 0.0024 & 0.0000 & -0.0000 & -0.0000 & 0.0000 & -0.0000 \\ -0.0000 & 0.0000 & 0.0000 & 0.0000 & -0.0000 & 0.0000 & 0.0000 & -0.0000 \\ -0.0000 & 0.0000 & 0.0000 & -0.0000 & -0.0000 & 0.0000 & 0.0000 & -0.0000 \\ -0.0000 & 0.0000 & 0.0000 & 0.0000 & -0.0000 & -0.0000 & -0.0000 & 0.0000 \\ -0.0000 & 0.0000 & -0.0000 & 0.0000 & 0.0000 & 0.0000 & -0.0000 & 0.0000 \\ -0.0000 & 0.0000 & -0.0000 & 0.0000 & 0.0000 & -0.0000 & 0.0000 & 0.0000 \\ -0.0000 & 0.0000 & -0.0000 & 0.0000 & 0.0000 & -0.0000 & 0.0000 & -0.0000 \\ -0.0000 & 0.0000 & -0.0000 & 0.0000 & 0.0000 & -0.0000 & 0.0000 & 0.0000 \\ 0.0000 & 0.0000 & 0.0000 & -0.0000 & -0.0000 & -0.0000 & 0.0000 & -0.0000\end{array}$

Columns 17 through 24

$\begin{array}{rrrrrrrr}0.0000 & -0.0000 & -0.0000 & 0.0000 & 0.0000 & -0.0000 & 0.0000 & 0.0000 \\ 0.0000 & 0.0000 & 0.0000 & 0.0000 & 0.0000 & 0.0000 & 0.0148 & 0.0000 \\ 0.0000 & 0.0000 & 0.0000 & 0.0000 & -0.0000 & 0.0000 & 0.0259 & 0.0000 \\ 0.0000 & 0.0000 & 0.0000 & -0.0000 & 0.0000 & -0.0000 & 0.0368 & 0.0000 \\ 0.0000 & 0.0000 & 0.0000 & 0.0000 & 0.0000 & 0.0000 & 0.0691 & -0.0000 \\ 0.0000 & 0.0000 & 0.0000 & -0.0000 & 0.0000 & 0.0000 & 0.1081 & -0.0000 \\ 0.0000 & 0.0000 & -0.0000 & 0.0000 & 0.0000 & 0.0000 & 0.1425 & 0.0000 \\ -0.0000 & 0.0000 & -0.0000 & 0.0000 & 0.0000 & 0.0000 & 0.1381 & -0.0000 \\ 0.0000 & 0.0000 & 0.0000 & 0.0000 & -0.0000 & 0.0000 & 0.0339 & 0.0000 \\ 0.0000 & -0.0000 & 0.0000 & -0.0000 & 0.0000 & 0.0000 & 0 & -0.0000\end{array}$

Columns 25 through 31

$\begin{array}{rrrrrrr}-0.0000 & -0.0000 & -0.0000 & -0.0000 & 0.0109 & 0.0000 & 0.1000 \\ 0.0000 & -0.0000 & -0.0000 & 0.0056 & 0.0000 & 0.0000 & -0.0000 \\ 0.0000 & -0.0000 & -0.0000 & 0.0177 & 0.0000 & 0.0000 & 0.0000 \\ 0.0000 & -0.0000 & -0.0000 & 0.0296 & 0.0000 & -0.0000 & -0.0000 \\ 0.0000 & 0.0000 & 0.0000 & 0.0499 & 0.0000 & -0.0000 & -0.0000 \\ 0.0000 & -0.0000 & 0.0000 & 0.0728 & 0.0000 & 0.0000 & -0.0000 \\ -0.0000 & 0.0000 & 0.0000 & 0.1057 & 0.0000 & 0.0000 & 0.0000 \\ -0.0000 & 0.0000 & 0.0000 & 0.1502 & -0.0000 & 0.0000 & -0.0000 \\ -0.0000 & 0.0000 & 0.0000 & 0.2159 & -0.0000 & 0.0000 & 0.0000 \\ 0.0000 & -0.0000 & -0.0000 & 0.3000 & 0.0000 & 0.0000 & 0\end{array}$




\section{Restrição de 40\% de Ativos Internacionais (2001 a 2006)}

[PortRisk, PortReturn, PortWts] = frontcon(ExpRetIntPais06,ExpCovIntPais06,10,[], AssetBoundsInt05,GroupsInt05,GroupsBoundsInt05)

PortRisk $=$
0.0020
0.0029
0.0050
0.0075
0.0107
0.0143
0.0186
0.0234
0.0293
0.0399

PortReturn $=$

0.0137
0.0147
0.0157
0.0167
0.0178
0.0188
0.0198
0.0208
0.0218
0.0228

PortWts $=$

Columns 1 through 8

$\begin{array}{rrrrrrrr}0.8430 & 0.0282 & 0.0000 & 0.0000 & -0.0000 & -0.0000 & 0.0087 & -0.0000 \\ 0.7869 & 0.1381 & 0.0498 & 0.0000 & -0.0000 & 0.0000 & 0.0000 & 0.0000 \\ 0.3328 & 0.3065 & 0.3086 & 0.0000 & 0.0000 & 0.0000 & 0.0000 & 0.0000 \\ 0 & 0.4850 & 0.4233 & 0.0000 & 0.0000 & -0.0000 & 0.0000 & 0.0000 \\ 0 & 0.6903 & 0.1446 & 0.0000 & 0.0000 & 0.0000 & -0.0000 & -0.0000 \\ 0 & 0.7568 & 0.0000 & 0.0000 & 0.0000 & 0.0000 & -0.0000 & -0.0000 \\ 0 & 0.6761 & 0.0000 & 0.0000 & 0.0000 & 0.0049 & 0.0000 & -0.0000 \\ -0.0000 & 0.6000 & 0.0000 & 0.0000 & 0.0000 & 0.0148 & 0.0000 & 0.0000 \\ -0.0000 & 0.6000 & 0.0000 & 0.0000 & 0.0000 & 0.0605 & 0.0000 & 0 \\ 0 & 0.5000 & 0.0000 & -0.0000 & 0.0000 & -0.0000 & -0.0000 & 0.1000\end{array}$

Columns 9 through 16

$\begin{array}{llllllll}0.0000 & 0.0000 & 0.0093 & 0.0000 & -0.0000 & 0.0000 & 0.0000 & -0.0000\end{array}$ 


$\begin{array}{rrrrrrrr}-0.0000 & 0.0000 & 0.0002 & -0.0000 & -0.0000 & -0.0000 & 0.0000 & -0.0000 \\ -0.0000 & 0.0000 & 0.0000 & -0.0000 & 0 & 0.0000 & 0.0000 & -0.0000 \\ -0.0000 & 0.0000 & 0.0000 & -0.0000 & -0.0000 & 0.0000 & 0.0000 & 0.0000 \\ -0.0000 & 0.0000 & -0.0000 & 0.0000 & -0.0000 & -0.0000 & -0.0000 & 0.0000 \\ -0.0000 & -0.0000 & -0.0000 & 0.0000 & 0.0000 & 0.0000 & -0.0000 & 0.0000 \\ -0.0000 & 0.0000 & -0.0000 & -0.0000 & 0.0000 & -0.0000 & -0.0000 & 0.0000 \\ -0.0000 & 0.0000 & -0.0000 & 0.0000 & 0.0000 & 0.0000 & 0.0000 & 0.0000 \\ -0.0000 & 0.0000 & 0.0000 & 0.0000 & -0.0000 & -0.0000 & 0.0000 & 0.0000 \\ 0.0000 & 0.0000 & 0.0000 & -0.0000 & -0.0000 & -0.0000 & 0.0000 & -0.0000\end{array}$

Columns 17 through 24

$\begin{array}{rrrrrrrr}0.0000 & -0.0000 & -0.0000 & 0.0000 & 0.0000 & -0.0000 & 0.0000 & 0.0000 \\ -0.0000 & 0.0000 & 0.0000 & 0.0000 & -0.0000 & 0.0000 & 0.0171 & -0.0000 \\ 0.0000 & 0.0000 & 0.0000 & -0.0000 & -0.0000 & 0.0000 & 0.0300 & 0.0000 \\ 0.0000 & 0.0000 & 0.0000 & -0.0000 & 0.0000 & -0.0000 & 0.0519 & -0.0000 \\ 0.0000 & 0.0000 & 0.0000 & 0.0000 & 0.0000 & 0.0000 & 0.0981 & 0.0000 \\ 0.0000 & 0.0000 & 0.0000 & -0.0000 & 0.0000 & 0.0000 & 0.1403 & -0.0000 \\ -0.0000 & 0.0000 & 0.0000 & 0.0000 & 0.0000 & 0.0000 & 0.1717 & -0.0000 \\ 0.0000 & 0.0000 & -0.0000 & -0.0000 & -0.0000 & 0.0000 & 0.1935 & -0.0000 \\ 0.0000 & 0.0000 & 0.0000 & -0.0000 & 0.0000 & 0.0000 & 0.0699 & -0.0000 \\ 0.0000 & -0.0000 & 0.0000 & 0.0000 & 0.0000 & 0.0000 & 0 & 0.0000\end{array}$

Columns 25 through 31

$\begin{array}{rrrrrrr}-0.0000 & -0.0000 & -0.0000 & -0.0000 & 0.0109 & 0.0000 & 0.1000 \\ 0.0000 & 0.0000 & -0.0000 & 0.0080 & 0.0000 & 0.0000 & -0.0000 \\ 0.0000 & 0.0000 & -0.0000 & 0.0221 & -0.0000 & 0.0000 & -0.0000 \\ 0.0000 & 0.0000 & -0.0000 & 0.0398 & 0.0000 & -0.0000 & -0.0000 \\ -0.0000 & -0.0000 & 0.0000 & 0.0669 & 0.0000 & -0.0000 & -0.0000 \\ 0.0000 & 0.0000 & 0.0000 & 0.1030 & -0.0000 & 0.0000 & -0.0000 \\ 0.0000 & 0.0000 & 0.0000 & 0.1473 & -0.0000 & -0.0000 & -0.0000 \\ 0.0000 & -0.0000 & 0.0000 & 0.1917 & 0.0000 & 0.0000 & -0.0000 \\ -0.0000 & -0.0000 & 0.0000 & 0.2696 & 0.0000 & -0.0000 & -0.0000 \\ 0.0000 & -0.0000 & -0.0000 & 0.4000 & 0.0000 & 0.0000 & 0\end{array}$




\section{Restrição de 50\% de Ativos Internacionais (2001 a 2006)}

[PortRisk, PortReturn, PortWts] = frontcon(ExpRetIntPais06,ExpCovIntPais06,10,[], AssetBoundsInt05,GroupsInt05,GroupsBoundsInt05)

PortRisk $=$
0.0020
0.0032
0.0057
0.0089
0.0128
0.0177
0.0231
0.0288
0.0354
0.0458

PortReturn $=$

0.0137
0.0149
0.0161
0.0172
0.0184
0.0196
0.0207
0.0219
0.0231
0.0242

PortWts $=$

Columns 1 through 8

$\begin{array}{rrrrrrrr}0.8430 & 0.0282 & 0.0000 & 0.0000 & -0.0000 & -0.0000 & 0.0087 & -0.0000 \\ 0.7167 & 0.1642 & 0.0897 & 0.0000 & -0.0000 & -0.0000 & 0.0000 & -0.0000 \\ 0.1899 & 0.3594 & 0.3901 & 0.0000 & -0.0000 & 0.0000 & -0.0000 & -0.0000 \\ 0 & 0.5816 & 0.2922 & -0.0000 & 0.0000 & 0.0000 & 0.0000 & -0.0000 \\ -0.0000 & 0.7878 & -0.0000 & 0.0000 & 0.0000 & 0.0000 & 0.0000 & 0.0000 \\ -0.0000 & 0.6930 & -0.0000 & -0.0000 & -0.0000 & 0.0031 & 0.0000 & -0.0000 \\ 0.0000 & 0.6021 & -0.0000 & 0.0000 & 0.0000 & 0.0131 & -0.0000 & -0.0000 \\ -0.0000 & 0.5112 & -0.0000 & -0.0000 & -0.0000 & 0.0232 & -0.0000 & -0.0000 \\ -0.0000 & 0.5000 & 0.0000 & -0.0000 & 0.0000 & 0.0707 & -0.0000 & -0.0000 \\ 0 & 0.5000 & 0.0000 & -0.0000 & 0.0000 & -0.0000 & 0.0000 & 0.0000\end{array}$

Columns 9 through 16

$\begin{array}{llllllll}0.0000 & 0.0000 & 0.0093 & 0.0000 & -0.0000 & 0.0000 & 0.0000 & -0.0000\end{array}$ 


$\begin{array}{rrrrrrrr}0.0000 & 0.0000 & -0.0000 & -0.0000 & 0.0000 & 0.0000 & 0.0000 & -0.0000 \\ -0.0000 & -0.0000 & 0.0000 & 0.0000 & -0.0000 & 0.0000 & 0.0000 & 0.0000 \\ -0.0000 & -0.0000 & 0.0000 & -0.0000 & -0.0000 & 0.0000 & 0.0000 & 0.0000 \\ -0.0000 & -0.0000 & -0.0000 & 0.0000 & 0.0000 & -0.0000 & 0.0000 & 0.0000 \\ 0.0000 & -0.0000 & -0.0000 & -0.0000 & 0.0000 & 0.0000 & 0.0000 & 0.0000 \\ -0.0000 & -0.0000 & -0.0000 & 0.0000 & 0.0000 & 0.0000 & 0.0000 & 0.0000 \\ -0.0000 & -0.0000 & 0.0000 & -0.0000 & 0.0000 & -0.0000 & 0.0000 & -0.0000 \\ -0.0000 & 0.0000 & -0.0000 & 0.0000 & 0 & -0.0000 & 0.0000 & -0.0000 \\ 0.0000 & 0.0000 & 0.0000 & -0.0000 & -0.0000 & -0.0000 & 0.0000 & -0.0000\end{array}$

Columns 17 through 24

$\begin{array}{rrrrrrrr}0.0000 & -0.0000 & -0.0000 & 0.0000 & 0.0000 & -0.0000 & 0.0000 & 0.0000 \\ -0.0000 & 0.0000 & -0.0000 & -0.0000 & 0.0000 & -0.0000 & 0.0191 & 0.0000 \\ 0.0000 & 0.0000 & -0.0000 & -0.0000 & -0.0000 & -0.0000 & 0.0341 & -0.0000 \\ -0.0000 & 0.0000 & 0.0000 & -0.0000 & -0.0000 & -0.0000 & 0.0736 & 0.0000 \\ 0.0000 & -0.0000 & -0.0000 & -0.0000 & 0.0000 & -0.0000 & 0.1262 & -0.0000 \\ 0.0000 & -0.0000 & -0.0000 & 0.0000 & 0.0000 & -0.0000 & 0.1660 & -0.0000 \\ -0.0000 & -0.0000 & -0.0000 & -0.0000 & -0.0000 & -0.0000 & 0.1967 & -0.0000 \\ 0.0000 & -0.0000 & -0.0000 & 0.0000 & 0.0000 & -0.0000 & 0.2275 & 0.0000 \\ 0.0000 & -0.0000 & 0.0000 & 0.0000 & -0.0000 & -0.0000 & 0.1059 & -0.0000 \\ 0.0000 & -0.0000 & 0.0000 & 0.0000 & 0.0000 & 0.0000 & 0 & 0.0000\end{array}$

Columns 25 through 31

$\begin{array}{rrrrrrr}-0.0000 & -0.0000 & -0.0000 & -0.0000 & 0.0109 & 0.0000 & 0.1000 \\ -0.0000 & -0.0000 & 0.0000 & 0.0102 & -0.0000 & 0.0000 & -0.0000 \\ 0.0000 & -0.0000 & -0.0000 & 0.0265 & 0.0000 & -0.0000 & -0.0000 \\ -0.0000 & 0.0000 & -0.0000 & 0.0525 & 0.0000 & -0.0000 & -0.0000 \\ 0.0000 & 0.0000 & -0.0000 & 0.0860 & -0.0000 & 0.0000 & 0.0000 \\ 0.0000 & -0.0000 & -0.0000 & 0.1380 & 0.0000 & 0.0000 & 0.0000 \\ -0.0000 & -0.0000 & -0.0000 & 0.1881 & 0.0000 & -0.0000 & -0.0000 \\ 0.0000 & -0.0000 & 0.0000 & 0.2382 & 0.0000 & -0.0000 & -0.0000 \\ 0.0000 & 0.0000 & 0.0000 & 0.3234 & 0.0000 & -0.0000 & -0.0000 \\ 0.0000 & -0.0000 & -0.0000 & 0.5000 & 0.0000 & 0.0000 & 0\end{array}$




\section{Restrição Total a Ativos Internacionais (2003 a 2006)}

[PortRisk, PortReturn, PortWts] = frontcon(ExpRetIntPais03,ExpCovIntPais03,10,[], AssetBoundsInt05,GroupsInt05,GroupsBoundsInt05)

PortRisk $=$
0.0022
0.0034
0.0057
0.0088
0.0126
0.0166
0.0207
0.0249
0.0291
0.0333

PortReturn $=$

0.0137
0.0148
0.0159
0.0169
0.0180
0.0190
0.0201
0.0212
0.0222
0.0233

PortWts $=$

Columns 1 through 8

$\begin{array}{rrrrrrrc}0.7686 & 0.1187 & -0.0000 & 0.0000 & -0.0000 & -0.0000 & 0.0000 & 0.0008 \\ 0.5491 & 0.0713 & 0.3656 & 0.0000 & 0.0000 & 0.0000 & 0.0000 & 0.0135 \\ 0.0687 & 0.0000 & 0.9037 & 0.0000 & -0.0000 & -0.0000 & 0.0000 & 0.0275 \\ 0.0000 & -0.0000 & 0.9103 & 0.0000 & -0.0000 & -0.0000 & 0.0000 & 0.0897 \\ 0.0000 & 0.0000 & 0.8419 & 0 & -0.0000 & -0.0000 & 0.0000 & 0.1581 \\ 0.0000 & 0 & 0.7736 & 0 & -0.0000 & -0.0000 & 0.0000 & 0.2264 \\ 0.0000 & 0.0000 & 0.7052 & 0 & -0.0000 & -0.0000 & 0.0000 & 0.2948 \\ 0.0000 & 0 & 0.6368 & 0 & -0.0000 & -0.0000 & 0.0000 & 0.3632 \\ 0.0000 & 0.0000 & 0.5684 & 0 & -0.0000 & -0.0000 & 0.0000 & 0.4316 \\ 0 & 0 & 0.5000 & -0.0000 & -0.0000 & 0.0000 & 0.0000 & 0.5000\end{array}$

Columns 9 through 16

$\begin{array}{llllllll}0.0000 & -0.0000 & -0.0000 & 0.0000 & 0.0000 & -0.0000 & -0.0000 & -0.0000\end{array}$ 


$\begin{array}{rrrrrrrr}0.0000 & -0.0000 & -0.0000 & -0.0000 & -0.0000 & 0.0000 & -0.0000 & 0.0000 \\ 0.0000 & -0.0000 & -0.0000 & -0.0000 & 0.0000 & 0.0000 & 0.0000 & -0.0000 \\ -0.0000 & -0.0000 & -0.0000 & -0.0000 & 0.0000 & 0.0000 & 0.0000 & -0.0000 \\ -0.0000 & -0.0000 & -0.0000 & -0.0000 & 0.0000 & 0.0000 & 0.0000 & -0.0000 \\ -0.0000 & -0.0000 & -0.0000 & -0.0000 & 0.0000 & 0.0000 & 0.0000 & -0.0000 \\ -0.0000 & -0.0000 & -0.0000 & -0.0000 & 0.0000 & 0.0000 & 0.0000 & -0.0000 \\ -0.0000 & -0.0000 & -0.0000 & -0.0000 & 0.0000 & 0.0000 & -0.0000 & -0.0000 \\ -0.0000 & -0.0000 & -0.0000 & -0.0000 & 0.0000 & 0.0000 & 0.0000 & -0.0000 \\ -0.0000 & 0.0000 & 0.0000 & 0.0000 & 0.0000 & 0.0000 & -0.0000 & 0.0000\end{array}$

Columns 17 through 24

$\begin{array}{rrrrrrrr}0.0000 & 0.0000 & 0.0000 & -0.0000 & -0.0000 & -0.0000 & -0.0000 & 0.0000 \\ 0.0000 & 0.0000 & 0.0000 & 0.0000 & 0.0000 & -0.0000 & -0.0000 & 0.0000 \\ -0.0000 & 0.0000 & 0.0000 & -0.0000 & 0.0000 & 0.0000 & -0.0000 & 0.0000 \\ -0.0000 & 0.0000 & -0.0000 & -0.0000 & 0.0000 & 0.0000 & 0.0000 & 0.0000 \\ -0.0000 & 0.0000 & -0.0000 & -0.0000 & 0.0000 & 0.0000 & -0.0000 & 0.0000 \\ -0.0000 & 0.0000 & -0.0000 & -0.0000 & 0.0000 & 0.0000 & -0.0000 & 0.0000 \\ -0.0000 & 0.0000 & -0.0000 & -0.0000 & 0.0000 & 0.0000 & -0.0000 & 0.0000 \\ -0.0000 & 0.0000 & -0.0000 & -0.0000 & 0.0000 & 0.0000 & -0.0000 & 0.0000 \\ -0.0000 & 0.0000 & -0.0000 & -0.0000 & 0.0000 & 0.0000 & -0.0000 & 0.0000 \\ 0.0000 & -0.0000 & 0.0000 & -0.0000 & 0.0000 & 0.0000 & -0.0000 & -0.0000\end{array}$

Columns 25 through 31

$\begin{array}{rrrrrrr}-0.0000 & 0.0000 & 0.0000 & -0.0000 & 0.0118 & -0.0000 & 0.1000 \\ -0.0000 & -0.0000 & 0.0000 & 0.0000 & 0.0006 & -0.0000 & -0.0000 \\ 0.0000 & -0.0000 & 0.0000 & 0.0000 & -0.0000 & -0.0000 & 0 \\ 0.0000 & -0.0000 & 0.0000 & 0.0000 & 0 & -0.0000 & 0 \\ 0.0000 & -0.0000 & 0.0000 & 0.0000 & 0 & -0.0000 & 0.0000 \\ 0.0000 & -0.0000 & 0.0000 & -0.0000 & 0 & -0.0000 & 0.0000 \\ 0.0000 & -0.0000 & 0.0000 & 0.0000 & 0 & -0.0000 & 0.0000 \\ 0.0000 & -0.0000 & 0.0000 & 0.0000 & 0 & -0.0000 & 0.0000 \\ 0.0000 & -0.0000 & 0.0000 & 0.0000 & 0.0000 & -0.0000 & 0.0000 \\ 0.0000 & -0.0000 & 0.0000 & -0.0000 & 0.0000 & -0.0000 & 0\end{array}$




\section{Restrição de 10\% de Ativos Internacionais (2003 a 2006)}

[PortRisk, PortReturn, PortWts] $=$ frontcon(ExpRetIntPais03,ExpCovIntPais03,10,[], AssetBoundsInt05,GroupsInt05,GroupsBoundsInt05)

PortRisk $=$
0.0020
0.0027
0.0047
0.0071
0.0104
0.0143
0.0185
0.0229
0.0273
0.0318

PortReturn $=$

0.0137
0.0149
0.0161
0.0173
0.0185
0.0198
0.0210
0.0222
0.0234
0.0246

PortWts $=$

Columns 1 through 8

$\begin{array}{rrrrrrrr}0.6929 & 0.1617 & 0.0000 & -0.0000 & -0.0000 & -0.0000 & 0.0106 & 0.0000 \\ 0.7735 & 0.1665 & -0.0000 & 0.0000 & 0.0000 & -0.0000 & -0.0000 & -0.0000 \\ 0.5087 & 0.1643 & 0.2347 & -0.0000 & -0.0000 & 0.0000 & -0.0000 & 0.0000 \\ -0.0000 & 0.0654 & 0.8346 & 0.0000 & -0.0000 & 0.0000 & -0.0000 & -0.0000 \\ -0.0000 & -0.0000 & 0.8450 & -0.0000 & 0.0000 & -0.0000 & -0.0000 & 0.0550 \\ 0.0000 & 0 & 0.7806 & 0.0000 & 0.0000 & 0.0000 & -0.0000 & 0.1194 \\ 0.0000 & 0 & 0.7161 & 0.0000 & -0.0000 & -0.0000 & -0.0000 & 0.1839 \\ -0.0000 & -0.0000 & 0.6517 & 0.0000 & -0.0000 & -0.0000 & -0.0000 & 0.2483 \\ -0.0000 & 0.0000 & 0.5784 & 0.0000 & 0.0000 & -0.0000 & -0.0000 & 0.3216 \\ 0 & -0.0000 & 0.5000 & 0.0000 & -0.0000 & -0.0000 & -0.0000 & 0.4000\end{array}$

Columns 9 through 16

$\begin{array}{llllllll}0.0000 & 0.0000 & 0.0090 & 0.0005 & 0.0000 & -0.0000 & -0.0000 & 0.0000\end{array}$ 


$\begin{array}{rrrrrrrr}-0.0000 & 0.0000 & 0.0063 & -0.0000 & -0.0000 & -0.0000 & -0.0000 & -0.0000 \\ 0.0000 & 0.0000 & -0.0000 & 0.0000 & -0.0000 & 0.0000 & 0.0000 & 0.0000 \\ 0.0000 & -0.0000 & -0.0000 & 0.0000 & 0.0000 & 0.0000 & -0.0000 & 0.0000 \\ 0.0000 & -0.0000 & -0.0000 & 0.0000 & 0.0000 & 0.0000 & 0.0000 & -0.0000 \\ 0.0000 & -0.0000 & 0.0000 & -0.0000 & 0.0000 & -0.0000 & 0.0000 & -0.0000 \\ 0.0000 & 0.0000 & -0.0000 & 0.0000 & -0.0000 & 0.0000 & 0.0000 & -0.0000 \\ 0.0000 & -0.0000 & 0.0000 & 0.0000 & -0.0000 & -0.0000 & 0.0000 & -0.0000 \\ 0.0000 & 0 & 0.0000 & 0.0000 & -0.0000 & -0.0000 & 0.0000 & -0.0000 \\ 0.0000 & -0.0000 & 0.0000 & 0.0000 & 0.0000 & 0.0000 & 0.0000 & 0.0000\end{array}$

Columns 17 through 24

$\begin{array}{rrrrrrrr}0.0101 & 0.0000 & -0.0000 & -0.0000 & -0.0000 & 0.0000 & 0.0012 & 0.0050 \\ 0.0000 & 0.0000 & 0.0068 & 0.0000 & -0.0000 & -0.0000 & 0.0411 & 0.0000 \\ 0.0000 & -0.0000 & 0.0061 & 0.0000 & -0.0000 & -0.0000 & 0.0732 & 0.0000 \\ -0.0000 & 0.0000 & -0.0000 & -0.0000 & -0.0000 & 0.0000 & 0.0752 & 0.0000 \\ 0.0000 & 0.0000 & -0.0000 & 0.0000 & -0.0000 & -0.0000 & 0.0581 & 0.0000 \\ -0.0000 & 0.0000 & 0 & 0.0000 & -0.0000 & -0.0000 & 0.0408 & -0.0000 \\ -0.0000 & 0.0000 & -0.0000 & -0.0000 & -0.0000 & -0.0000 & 0.0236 & 0.0000 \\ -0.0000 & -0.0000 & 0.0000 & -0.0000 & -0.0000 & -0.0000 & 0.0063 & 0.0000 \\ 0.0000 & 0.0000 & 0 & -0.0000 & -0.0000 & -0.0000 & 0.0000 & 0.0000 \\ 0.0000 & 0.0000 & -0.0000 & -0.0000 & 0.0000 & -0.0000 & 0 & -0.0000\end{array}$

Columns 25 through 31

$\begin{array}{rrrrrrr}0.0000 & 0.0000 & -0.0000 & -0.0000 & 0.0090 & 0.0000 & 0.1000 \\ -0.0000 & 0.0000 & 0.0000 & 0.0023 & 0.0034 & -0.0000 & 0.0000 \\ -0.0000 & 0.0000 & 0.0000 & 0.0130 & 0.0000 & 0.0000 & 0.0000 \\ -0.0000 & -0.0000 & -0.0000 & 0.0248 & 0.0000 & 0.0000 & -0.0000 \\ -0.0000 & 0.0000 & -0.0000 & 0.0419 & 0.0000 & 0.0000 & 0.0000 \\ 0.0000 & 0.0000 & 0.0000 & 0.0592 & -0.0000 & -0.0000 & -0.0000 \\ 0.0000 & 0.0000 & 0.0000 & 0.0764 & -0.0000 & 0.0000 & 0.0000 \\ 0.0000 & 0.0000 & 0.0000 & 0.0937 & -0.0000 & 0.0000 & -0.0000 \\ 0.0000 & 0.0000 & 0.0000 & 0.1000 & -0.0000 & 0.0000 & -0.0000 \\ 0.0000 & -0.0000 & 0.0000 & 0.1000 & -0.0000 & 0.0000 & 0\end{array}$




\section{Restrição de 20\% de Ativos Internacionais (2003 a 2006)}

[PortRisk, PortReturn, PortWts] = frontcon(ExpRetIntPais03,ExpCovIntPais03,10,[], AssetBoundsInt05,GroupsInt05,GroupsBoundsInt05)

PortRisk $=$
0.0020
0.0029
0.0052
0.0079
0.0106
0.0142
0.0186
0.0232
0.0280
0.0335

PortReturn $=$

0.0137
0.0150
0.0164
0.0178
0.0191
0.0205
0.0219
0.0232
0.0246
0.0260

PortWts $=$

Columns 1 through 8

$\begin{array}{rrrrrrrr}0.6929 & 0.1617 & 0.0000 & -0.0000 & -0.0000 & -0.0000 & 0.0106 & 0.0000 \\ 0.7465 & 0.1677 & 0.0221 & 0.0000 & -0.0000 & 0.0000 & 0.0000 & 0.0000 \\ 0.4392 & 0.1616 & 0.2969 & -0.0000 & 0.0000 & -0.0000 & 0.0000 & 0.0000 \\ 0.1207 & 0.1493 & 0.5819 & -0.0000 & 0.0000 & 0.0000 & -0.0000 & -0.0000 \\ 0.0000 & 0.0665 & 0.7335 & -0.0000 & 0.0000 & 0.0000 & -0.0000 & 0.0000 \\ 0.0000 & 0 & 0.7402 & -0.0000 & 0.0000 & -0.0000 & -0.0000 & 0.0598 \\ -0.0000 & -0.0000 & 0.6679 & 0.0000 & -0.0000 & -0.0000 & -0.0000 & 0.1321 \\ 0.0000 & -0.0000 & 0.5956 & 0.0000 & 0.0000 & -0.0000 & -0.0000 & 0.2044 \\ -0.0000 & 0.0000 & 0.5232 & 0.0000 & -0.0000 & 0.0000 & -0.0000 & 0.2768 \\ 0.0000 & -0.0000 & 0.5000 & 0.0000 & -0.0000 & -0.0000 & -0.0000 & 0.3000\end{array}$

Columns 9 through 16

$\begin{array}{llllllll}0.0000 & 0.0000 & 0.0090 & 0.0005 & 0.0000 & -0.0000 & -0.0000 & 0.0000\end{array}$ 


$\begin{array}{rrrrrrrr}-0.0000 & 0.0000 & 0.0056 & -0.0000 & 0.0000 & 0.0000 & 0.0000 & 0.0000 \\ -0.0000 & 0.0000 & -0.0000 & 0.0000 & 0.0000 & 0.0000 & -0.0000 & 0.0000 \\ -0.0000 & -0.0000 & 0.0000 & 0.0000 & 0.0000 & 0.0000 & -0.0000 & 0.0000 \\ -0.0000 & 0 & 0.0000 & -0.0000 & 0.0000 & -0.0000 & 0.0000 & -0.0000 \\ 0.0000 & 0.0000 & -0.0000 & 0.0000 & -0.0000 & -0.0000 & 0.0000 & -0.0000 \\ 0.0000 & 0.0000 & -0.0000 & 0.0000 & -0.0000 & -0.0000 & 0.0000 & -0.0000 \\ 0.0000 & 0 & 0.0000 & 0.0000 & -0.0000 & -0.0000 & 0.0000 & -0.0000 \\ -0.0000 & 0 & -0.0000 & -0.0000 & -0.0000 & -0.0000 & -0.0000 & -0.0000 \\ 0.0000 & -0.0000 & 0.0000 & 0.0000 & 0.0000 & 0.0000 & 0.0000 & 0.0000\end{array}$

Columns 17 through 24

$\begin{array}{rrrrrrrr}0.0101 & 0.0000 & -0.0000 & -0.0000 & -0.0000 & 0.0000 & 0.0012 & 0.0050 \\ 0.0000 & -0.0000 & 0.0070 & 0.0000 & 0.0000 & -0.0000 & 0.0453 & -0.0000 \\ -0.0000 & 0.0000 & 0.0061 & 0.0000 & 0.0000 & -0.0000 & 0.0808 & 0.0000 \\ -0.0000 & -0.0000 & 0.0061 & 0.0000 & 0.0000 & -0.0000 & 0.1155 & 0.0000 \\ 0.0000 & -0.0000 & 0.0051 & -0.0000 & -0.0000 & -0.0000 & 0.1556 & -0.0000 \\ 0.0000 & -0.0000 & 0 & 0.0000 & -0.0000 & 0.0000 & 0.1379 & 0.0000 \\ 0.0000 & 0.0000 & 0.0000 & 0.0000 & -0.0000 & -0.0000 & 0.1185 & 0.0000 \\ 0.0000 & 0.0000 & -0.0000 & 0.0000 & -0.0000 & -0.0000 & 0.0992 & 0.0000 \\ 0.0000 & 0.0000 & 0 & 0.0000 & 0.0000 & 0.0000 & 0.0798 & 0.0000 \\ 0.0000 & 0.0000 & -0.0000 & -0.0000 & 0.0000 & -0.0000 & 0 & -0.0000\end{array}$

Columns 25 through 31

$\begin{array}{rrrrrrr}0.0000 & 0.0000 & -0.0000 & -0.0000 & 0.0090 & 0.0000 & 0.1000 \\ -0.0000 & -0.0000 & -0.0000 & 0.0036 & 0.0023 & -0.0000 & 0.0000 \\ 0.0000 & 0.0000 & 0.0000 & 0.0155 & -0.0000 & 0.0000 & -0.0000 \\ 0.0000 & -0.0000 & 0.0000 & 0.0266 & 0.0000 & 0.0000 & -0.0000 \\ 0.0000 & 0.0000 & 0.0000 & 0.0393 & -0.0000 & 0.0000 & -0.0000 \\ -0.0000 & -0.0000 & 0.0000 & 0.0621 & -0.0000 & -0.0000 & -0.0000 \\ 0.0000 & -0.0000 & 0.0000 & 0.0815 & 0.0000 & 0.0000 & 0.0000 \\ 0.0000 & 0.0000 & 0.0000 & 0.1008 & -0.0000 & 0.0000 & 0.0000 \\ -0.0000 & -0.0000 & -0.0000 & 0.1202 & -0.0000 & -0.0000 & 0.0000 \\ 0.0000 & -0.0000 & 0.0000 & 0.2000 & -0.0000 & 0.0000 & 0\end{array}$




\section{Restrição de 30\% de Ativos Internacionais (2003 a 2006)}

[PortRisk, PortReturn, PortWts] $=$ frontcon(ExpRetIntPais03,ExpCovIntPais03, 10,[], AssetBoundsInt05,GroupsInt05,GroupsBoundsInt05)

PortRisk $=$
0.0020
0.0032
0.0058
0.0087
0.0118
0.0151
0.0193
0.0241
0.0296
0.0380

PortReturn $=$
0.0137
0.0152
0.0167
0.0182
0.0197
0.0213
0.0228
0.0243
0.0258
0.0273

PortWts =

Columns 1 through 8

$\begin{array}{rrrrrrrc}0.6929 & 0.1617 & 0.0000 & -0.0000 & -0.0000 & -0.0000 & 0.0106 & 0.0000 \\ 0.7135 & 0.1681 & 0.0517 & 0.0000 & 0.0000 & -0.0000 & 0.0000 & 0.0000 \\ 0.3696 & 0.1589 & 0.3592 & -0.0000 & 0.0000 & -0.0000 & -0.0000 & -0.0000 \\ 0.0163 & 0.1453 & 0.6752 & -0.0000 & 0.0000 & 0.0000 & 0.0000 & 0.0000 \\ 0.0000 & 0.0560 & 0.7128 & 0.0000 & 0.0000 & 0.0000 & -0.0000 & 0.0000 \\ -0.0000 & -0.0000 & 0.6992 & 0.0000 & -0.0000 & -0.0000 & -0.0000 & 0.0008 \\ -0.0000 & 0.0000 & 0.6195 & 0.0000 & 0.0000 & -0.0000 & -0.0000 & 0.0805 \\ 0.0000 & -0.0000 & 0.5394 & 0.0000 & -0.0000 & 0.0000 & -0.0000 & 0.1606 \\ 0.0000 & -0.0000 & 0.5000 & 0.0000 & 0.0000 & 0.0000 & 0.0000 & 0.2000 \\ 0.0000 & -0.0000 & 0.5000 & 0.0000 & -0.0000 & -0.0000 & -0.0000 & 0.2000\end{array}$

Columns 9 through 16 


$\begin{array}{rrrrrrrr}0.0000 & 0.0000 & 0.0090 & 0.0005 & 0.0000 & -0.0000 & -0.0000 & 0.0000 \\ -0.0000 & -0.0000 & 0.0049 & -0.0000 & 0.0000 & 0.0000 & 0.0000 & -0.0000 \\ -0.0000 & 0.0000 & -0.0000 & -0.0000 & 0.0000 & 0.0000 & -0.0000 & 0.0000 \\ -0.0000 & -0.0000 & 0.0000 & -0.0000 & 0.0000 & -0.0000 & -0.0000 & -0.0000 \\ -0.0000 & -0.0000 & 0.0000 & -0.0000 & 0.0000 & 0.0000 & 0.0000 & -0.0000 \\ 0.0000 & 0 & 0.0000 & 0.0000 & -0.0000 & -0.0000 & 0.0000 & -0.0000 \\ 0.0000 & 0 & 0.0000 & -0.0000 & -0.0000 & 0.0000 & -0.0000 & -0.0000 \\ 0.0000 & -0.0000 & 0.0000 & -0.0000 & -0.0000 & 0.0000 & -0.0000 & 0.0000 \\ 0.0000 & 0 & -0.0000 & -0.0000 & -0.0000 & 0.0000 & -0.0000 & 0.0000 \\ 0.0000 & -0.0000 & 0.0000 & -0.0000 & -0.0000 & 0.0000 & 0.0000 & 0.0000\end{array}$

Columns 17 through 24

$\begin{array}{rrrrrrrc}0.0101 & 0.0000 & -0.0000 & -0.0000 & -0.0000 & 0.0000 & 0.0012 & 0.0050 \\ -0.0000 & -0.0000 & 0.0069 & 0.0000 & 0.0000 & 0.0000 & 0.0490 & -0.0000 \\ -0.0000 & 0.0000 & 0.0061 & 0.0000 & 0.0000 & 0.0000 & 0.0883 & 0.0000 \\ -0.0000 & -0.0000 & 0.0060 & -0.0000 & 0.0000 & -0.0000 & 0.1269 & 0.0000 \\ 0.0000 & -0.0000 & 0.0082 & -0.0000 & -0.0000 & -0.0000 & 0.1787 & -0.0000 \\ 0.0000 & 0.0000 & 0.0106 & 0.0000 & -0.0000 & -0.0000 & 0.2251 & 0.0000 \\ 0.0000 & 0.0000 & 0.0024 & 0.0000 & -0.0000 & 0.0000 & 0.2112 & 0.0000 \\ 0.0000 & 0.0000 & 0 & 0.0000 & 0.0000 & 0.0000 & 0.1920 & -0.0000 \\ -0.0000 & -0.0000 & 0 & 0.0000 & 0.0000 & 0.0000 & 0.1203 & 0.0000 \\ 0.0000 & 0.0000 & -0.0000 & -0.0000 & 0.0000 & -0.0000 & 0.0000 & -0.0000\end{array}$

Columns 25 through 31

$\begin{array}{rrrrrrr}0.0000 & 0.0000 & -0.0000 & -0.0000 & 0.0090 & 0.0000 & 0.1000 \\ -0.0000 & 0.0000 & 0.0000 & 0.0048 & 0.0011 & 0.0000 & 0.0000 \\ 0.0000 & -0.0000 & 0.0000 & 0.0179 & -0.0000 & 0.0000 & -0.0000 \\ -0.0000 & 0.0000 & -0.0000 & 0.0302 & -0.0000 & 0.0000 & -0.0000 \\ 0.0000 & 0.0000 & 0.0000 & 0.0443 & -0.0000 & 0.0000 & -0.0000 \\ -0.0000 & -0.0000 & 0.0000 & 0.0643 & 0.0000 & -0.0000 & 0.0000 \\ -0.0000 & -0.0000 & -0.0000 & 0.0864 & -0.0000 & -0.0000 & 0.0000 \\ -0.0000 & -0.0000 & -0.0000 & 0.1080 & -0.0000 & -0.0000 & 0.0000 \\ 0.0000 & -0.0000 & -0.0000 & 0.1797 & 0.0000 & 0.0000 & 0.0000 \\ 0.0000 & -0.0000 & 0.0000 & 0.3000 & -0.0000 & 0.0000 & 0\end{array}$




\section{Restrição de 40\% de Ativos Internacionais (2003 a 2006)}

[PortRisk, PortReturn, PortWts] = frontcon(ExpRetIntPais03,ExpCovIntPais03,10,[], AssetBoundsInt05,GroupsInt05,GroupsBoundsInt05)

PortRisk $=$
0.0020
0.0034
0.0064
0.0096
0.0131
0.0167
0.0206
0.0254
0.0337
0.0444

PortReturn $=$

0.0137
0.0153
0.0170
0.0187
0.0203
0.0220
0.0237
0.0253
0.0270
0.0287

PortWts $=$

Columns 1 through 8

$\begin{array}{rrrrrrrr}0.6929 & 0.1617 & 0.0000 & -0.0000 & -0.0000 & -0.0000 & 0.0106 & 0.0000 \\ 0.6804 & 0.1683 & 0.0813 & 0.0000 & -0.0000 & -0.0000 & -0.0000 & -0.0000 \\ 0.3000 & 0.1562 & 0.4215 & 0.0000 & -0.0000 & -0.0000 & 0.0000 & -0.0000 \\ -0.0000 & 0.1215 & 0.6958 & -0.0000 & 0.0000 & 0.0000 & 0.0000 & -0.0000 \\ 0 & 0.0193 & 0.7221 & -0.0000 & 0.0000 & 0.0000 & -0.0000 & -0.0000 \\ -0.0000 & 0.0000 & 0.6522 & 0.0000 & -0.0000 & 0.0000 & -0.0000 & -0.0000 \\ 0.0000 & -0.0000 & 0.5703 & 0.0000 & -0.0000 & 0.0000 & -0.0000 & 0.0297 \\ -0.0000 & -0.0000 & 0.5000 & 0.0000 & 0.0000 & 0.0000 & 0.0000 & 0.1000 \\ -0.0000 & 0.0000 & 0.5000 & 0.0000 & 0.0000 & 0.0000 & 0.0000 & 0.1000 \\ 0 & -0.0000 & 0.5000 & 0.0000 & -0.0000 & -0.0000 & -0.0000 & 0.1000\end{array}$

Columns 9 through 16

$\begin{array}{llllllll}0.0000 & 0.0000 & 0.0090 & 0.0005 & 0.0000 & -0.0000 & -0.0000 & 0.0000\end{array}$ 


$\begin{array}{rrrrrrrr}-0.0000 & -0.0000 & 0.0042 & -0.0000 & 0.0000 & 0.0000 & 0.0000 & -0.0000 \\ 0.0000 & 0.0000 & 0.0000 & 0.0000 & 0.0000 & 0.0000 & 0.0000 & -0.0000 \\ -0.0000 & 0.0000 & -0.0000 & -0.0000 & 0.0000 & 0.0000 & -0.0000 & -0.0000 \\ 0.0000 & 0.0003 & 0.0000 & 0.0000 & -0.0000 & -0.0000 & 0.0000 & -0.0000 \\ 0.0000 & 0.0037 & 0.0000 & 0.0000 & -0.0000 & -0.0000 & 0.0000 & 0.0000 \\ 0.0000 & 0.0000 & 0.0000 & -0.0000 & -0.0000 & 0.0000 & -0.0000 & 0.0000 \\ 0.0000 & 0 & -0.0000 & 0.0000 & -0.0000 & -0.0000 & -0.0000 & -0.0000 \\ 0.0000 & -0.0000 & -0.0000 & -0.0000 & -0.0000 & -0.0000 & -0.0000 & -0.0000 \\ 0.0000 & -0.0000 & -0.0000 & -0.0000 & -0.0000 & 0.0000 & 0.0000 & -0.0000\end{array}$

Columns 17 through 24

$\begin{array}{rrrrrrrr}0.0101 & 0.0000 & -0.0000 & -0.0000 & -0.0000 & 0.0000 & 0.0012 & 0.0050 \\ -0.0000 & 0.0000 & 0.0069 & -0.0000 & 0.0000 & -0.0000 & 0.0528 & -0.0000 \\ -0.0000 & -0.0000 & 0.0061 & -0.0000 & 0.0000 & -0.0000 & 0.0959 & 0.0000 \\ -0.0000 & -0.0000 & 0.0066 & 0.0000 & 0.0000 & 0.0000 & 0.1418 & 0.0000 \\ 0.0000 & 0.0000 & 0.0090 & 0.0000 & -0.0000 & 0.0000 & 0.1994 & 0.0000 \\ 0.0000 & 0.0000 & 0.0176 & 0.0000 & -0.0000 & -0.0000 & 0.2612 & -0.0000 \\ 0.0000 & 0.0000 & 0.0186 & 0.0000 & 0.0000 & 0.0000 & 0.2911 & 0.0000 \\ -0.0000 & -0.0000 & 0.0040 & -0.0000 & 0.0000 & 0.0000 & 0.2602 & -0.0000 \\ 0.0000 & -0.0000 & 0 & 0.0000 & 0.0000 & 0.0000 & 0.1321 & 0.0000 \\ 0.0000 & -0.0000 & -0.0000 & 0.0000 & 0.0000 & -0.0000 & 0 & -0.0000\end{array}$

Columns 25 through 31

$\begin{array}{rrrrrrr}0.0000 & 0.0000 & -0.0000 & -0.0000 & 0.0090 & 0.0000 & 0.1000 \\ -0.0000 & -0.0000 & 0.0000 & 0.0061 & -0.0000 & 0.0000 & 0.0000 \\ 0.0000 & -0.0000 & 0.0000 & 0.0203 & -0.0000 & 0.0000 & 0.0000 \\ -0.0000 & 0.0000 & 0.0000 & 0.0343 & -0.0000 & 0.0000 & 0.0000 \\ -0.0000 & -0.0000 & 0.0000 & 0.0499 & 0.0000 & -0.0000 & -0.0000 \\ -0.0000 & -0.0000 & 0.0000 & 0.0654 & 0.0000 & -0.0000 & 0.0000 \\ -0.0000 & -0.0000 & -0.0000 & 0.0903 & -0.0000 & -0.0000 & 0.0000 \\ -0.0000 & 0.0000 & -0.0000 & 0.1358 & -0.0000 & -0.0000 & 0.0000 \\ 0.0000 & -0.0000 & -0.0000 & 0.2679 & 0.0000 & -0.0000 & 0.0000 \\ -0.0000 & -0.0000 & 0.0000 & 0.4000 & -0.0000 & 0.0000 & 0\end{array}$




\section{Restrição de 50\% de Ativos Internacionais (2003 a 2006)}

[PortRisk, PortReturn, PortWts] = frontcon(ExpRetIntPais03,ExpCovIntPais03,10,[], AssetBoundsInt05,GroupsInt05,GroupsBoundsInt05)

PortRisk $=$
0.0020
0.0036
0.0069
0.0106
0.0144
0.0183
0.0223
0.0287
0.0395
0.0521

PortReturn $=$

0.0137
0.0155
0.0173
0.0191
0.0209
0.0227
0.0246
0.0264
0.0282
0.0300

PortWts $=$

Columns 1 through 8

$\begin{array}{rrrrrrrr}0.6929 & 0.1617 & 0.0000 & -0.0000 & -0.0000 & -0.0000 & 0.0106 & 0.0000 \\ 0.6473 & 0.1676 & 0.1109 & 0.0000 & -0.0000 & 0.0000 & -0.0000 & -0.0000 \\ 0.2304 & 0.1536 & 0.4837 & -0.0000 & 0.0000 & -0.0000 & 0.0000 & 0.0000 \\ 0.0000 & 0.0940 & 0.7029 & 0.0000 & -0.0000 & 0.0000 & -0.0000 & 0.0000 \\ 0.0000 & -0.0000 & 0.7111 & 0.0000 & -0.0000 & 0.0000 & 0.0000 & 0.0000 \\ -0.0000 & -0.0000 & 0.6110 & 0.0000 & 0.0000 & 0.0000 & 0.0000 & 0.0000 \\ -0.0000 & -0.0000 & 0.5109 & -0.0000 & 0.0000 & -0.0000 & 0.0000 & 0.0000 \\ -0.0000 & 0.0000 & 0.5000 & -0.0000 & -0.0000 & 0.0000 & 0.0000 & 0.0000 \\ -0.0000 & 0.0000 & 0.5000 & -0.0000 & 0.0000 & 0.0000 & 0.0000 & 0.0000 \\ 0 & -0.0000 & 0.5000 & 0.0000 & -0.0000 & -0.0000 & -0.0000 & 0.0000\end{array}$

Columns 9 through 16

$\begin{array}{llllllll}0.0000 & 0.0000 & 0.0090 & 0.0005 & 0.0000 & -0.0000 & -0.0000 & 0.0000\end{array}$ 


$\begin{array}{rrrrrrrr}0.0000 & -0.0000 & 0.0033 & 0.0000 & -0.0000 & -0.0000 & 0.0000 & -0.0000 \\ 0.0000 & 0.0000 & -0.0000 & -0.0000 & -0.0000 & 0.0000 & -0.0000 & 0.0000 \\ 0.0000 & 0.0000 & 0.0000 & 0.0000 & 0.0000 & 0.0000 & 0.0000 & 0.0000 \\ -0.0000 & 0.0015 & -0.0000 & -0.0000 & -0.0000 & -0.0000 & -0.0000 & 0.0000 \\ -0.0000 & 0.0051 & 0.0000 & 0.0000 & -0.0000 & 0.0000 & -0.0000 & 0.0000 \\ 0.0000 & 0.0088 & -0.0000 & -0.0000 & -0.0000 & 0.0000 & -0.0000 & 0.0000 \\ 0.0000 & -0.0000 & -0.0000 & -0.0000 & -0.0000 & 0.0000 & -0.0000 & 0.0000 \\ 0.0000 & 0 & 0.0000 & 0.0000 & -0.0000 & 0.0000 & -0.0000 & 0.0000 \\ -0.0000 & -0.0000 & -0.0000 & -0.0000 & -0.0000 & 0.0000 & 0.0000 & -0.0000\end{array}$

Columns 17 through 24

$\begin{array}{rrrrrrrr}0.0101 & 0.0000 & -0.0000 & -0.0000 & -0.0000 & 0.0000 & 0.0012 & 0.0050 \\ 0.0000 & 0.0000 & 0.0067 & 0.0000 & 0.0000 & -0.0000 & 0.0568 & 0.0000 \\ -0.0000 & -0.0000 & 0.0061 & -0.0000 & 0.0000 & 0.0000 & 0.1035 & -0.0000 \\ -0.0000 & -0.0000 & 0.0073 & -0.0000 & -0.0000 & 0.0000 & 0.1573 & 0.0000 \\ -0.0000 & 0.0000 & 0.0112 & 0.0000 & 0.0000 & 0.0000 & 0.2208 & 0.0000 \\ -0.0000 & 0.0000 & 0.0220 & -0.0000 & 0.0000 & 0.0000 & 0.2894 & 0.0000 \\ -0.0000 & -0.0000 & 0.0328 & -0.0000 & 0.0000 & 0.0000 & 0.3581 & -0.0000 \\ -0.0000 & 0.0000 & 0.0009 & -0.0000 & 0.0000 & 0.0000 & 0.2870 & 0.0000 \\ -0.0000 & -0.0000 & 0 & 0.0000 & 0.0000 & -0.0000 & 0.1439 & -0.0000 \\ -0.0000 & -0.0000 & -0.0000 & 0.0000 & -0.0000 & -0.0000 & 0 & -0.0000\end{array}$

Columns 25 through 31

$\begin{array}{rrrrrrr}0.0000 & 0.0000 & -0.0000 & -0.0000 & 0.0090 & 0.0000 & 0.1000 \\ -0.0000 & 0.0000 & 0.0000 & 0.0074 & -0.0000 & -0.0000 & 0.0000 \\ 0.0000 & 0.0000 & 0.0000 & 0.0227 & -0.0000 & -0.0000 & 0.0000 \\ -0.0000 & -0.0000 & -0.0000 & 0.0385 & -0.0000 & 0.0000 & -0.0000 \\ 0.0000 & -0.0000 & 0.0000 & 0.0554 & -0.0000 & 0.0000 & 0.0000 \\ 0.0000 & -0.0000 & 0.0000 & 0.0724 & 0.0000 & -0.0000 & 0.0000 \\ -0.0000 & -0.0000 & 0.0000 & 0.0895 & 0.0000 & 0.0000 & 0.0000 \\ -0.0000 & -0.0000 & 0.0000 & 0.2121 & 0 & 0.0000 & 0.0000 \\ -0.0000 & -0.0000 & 0.0000 & 0.3561 & -0.0000 & 0.0000 & -0.0000 \\ -0.0000 & -0.0000 & 0.0000 & 0.5000 & -0.0000 & 0.0000 & 0\end{array}$




\section{APÊNDICE E - FRONTEIRAS EFICIENTES DE FUNDOS DE PENSÃO COM RETORNOS EM REAIS PARA DIFERENTES GRAUS DE ABERTURA PARA INVESTIMENTOS NO EXTERIOR}

\section{Ativos da Fronteira Nacional}

\begin{tabular}{|l|l|}
\hline Coluna 1 & CDI \\
\hline Coluna 2 & IGPM + Cupom \\
\hline Coluna 3 & IRF-M \\
\hline Coluna 4 & FIEX \\
\hline Coluna 5 & IBOV \\
\hline Coluna 6 & Imóveis \\
\hline Coluna 7 & Empréstimos \\
\hline Coluna 8 & Financiamentos \\
\hline
\end{tabular}

Ativos da Fronteira com Investimento em Ações Exterior

\begin{tabular}{|l|l|}
\hline Coluna 1 & CDI \\
\hline Coluna 2 & IGPM + Cupom \\
\hline Coluna 3 & IRF-M \\
\hline Coluna 4 & FIEX \\
\hline Coluna 5 & Alemanha \\
\hline Coluna 6 & Argentina \\
\hline Coluna 7 & Austrália \\
\hline Coluna 8 & Brasil \\
\hline Coluna 9 & Canadá \\
\hline Coluna 10 & Chile \\
\hline Coluna 11 & China \\
\hline Coluna 12 & Cingapura \\
\hline Coluna 13 & Coréia \\
\hline Coluna 14 & Espanha \\
\hline Coluna 15 & Estados Unidos \\
\hline Coluna 16 & França \\
\hline Coluna 17 & Holanda \\
\hline Coluna 18 & Hong Kong \\
\hline Coluna 19 & Índia \\
\hline Coluna 20 & Itália \\
\hline Coluna 21 & Japão \\
\hline Coluna 22 & Malásia \\
\hline Coluna 23 & México \\
\hline Coluna 24 & Reino Unido \\
\hline Coluna 25 & Suécia \\
\hline Coluna 26 & Suíça \\
\hline Coluna 27 & Taiwan \\
\hline Coluna 28 & Venezuela \\
\hline Coluna 29 & Imóveis \\
\hline Coluna 30 & Empréstimos \\
\hline Coluna 31 & Financiamentos \\
\hline
\end{tabular}




\section{Restrição Total a Ativos Internacionais (2000 a 2005)}

[PortRisk, PortReturn, PortWts] = frontcon $($ ExpRetNac05, ExpCovNac05, 10, [], AssetBoundsNac05, GroupsNac05, GroupsBoundsNac05)

PortRisk $=$
0.0020
0.0020
0.0021
0.0023
0.0030
0.0039
0.0050
0.0061
0.0080
0.0103

PortReturn $=$

0.0136

0.0139

0.0143

0.0147

0.0150

0.0154

0.0158

0.0161

0.0165

0.0169

PortWts $=$

$\begin{array}{rrrrrrrr}0.8394 & 0.0133 & -0.0000 & -0.0000 & -0.0000 & 0.0473 & 0.0000 & 0.1000 \\ 0.8555 & 0.0246 & 0.0000 & -0.0000 & 0.0000 & 0.0200 & -0.0000 & 0.1000 \\ 0.8739 & 0.0488 & 0.0000 & -0.0000 & -0.0000 & 0 & -0.0000 & 0.0773 \\ 0.8707 & 0.1041 & 0.0252 & -0.0000 & -0.0000 & 0.0000 & 0.0000 & 0 \\ 0.6320 & 0.1866 & 0.1814 & 0.0000 & -0.0000 & -0.0000 & 0.0000 & 0.0000 \\ 0.3933 & 0.2691 & 0.3376 & -0.0000 & -0.0000 & 0.0000 & 0.0000 & -0.0000 \\ 0.1546 & 0.3516 & 0.4937 & -0.0000 & -0.0000 & 0.0000 & 0.0000 & -0.0000 \\ 0 & 0.4942 & 0.5058 & 0.0000 & -0.0000 & -0.0000 & 0.0000 & -0.0000 \\ 0 & 0.7471 & 0.2529 & 0.0000 & -0.0000 & -0.0000 & 0.0000 & -0.0000 \\ 0 & 1.0000 & 0.0000 & 0.0000 & -0.0000 & -0.0000 & -0.0000 & 0\end{array}$




\section{Restrição de 10\% de Ativos Internacionais (2000 a 2005)}

[PortRisk, PortReturn, PortWts] = frontcon (ExpRetInt05, ExpCovInt05, 10, [], AssetBoundsInt05, GroupsInt05, GroupsBoundsInt05)

PortRisk $=$
0.0019
0.0020
0.0020
0.0023
0.0031
0.0040
0.0051
0.0063
0.0084
0.0111

PortReturn $=$

0.0135

0.0139

0.0143

0.0147

0.0151

0.0155

0.0159

0.0163

0.0167

0.0171

PortWts =

Columns 1 through 8
$\begin{array}{llllllll}0.8322 & 0.0142 & -0.0000 & -0.0000 & -0.0000 & 0.0000 & -0.0000 & -0.0000\end{array}$
$\begin{array}{lllllllll}0.8493 & 0.0263 & -0.0000 & 0.0000 & -0.0000 & 0.0000 & 0.0000 & -0.0000\end{array}$
$\begin{array}{llllllll}0.8733 & 0.0503 & 0.0000 & 0.0000 & -0.0000 & -0.0000 & -0.0000 & 0.0000\end{array}$
$\begin{array}{lllllllll}0.8593 & 0.1052 & 0.0290 & 0.0000 & 0.0000 & -0.0000 & -0.0000 & -0.0000\end{array}$
$\begin{array}{llllllll}0.6123 & 0.1884 & 0.1877 & 0.0000 & 0.0000 & -0.0000 & -0.0000 & 0.0000\end{array}$
$\begin{array}{llllllll}0.3653 & 0.2716 & 0.3464 & -0.0000 & 0.0000 & 0.0000 & -0.0000 & 0.0000\end{array}$
$\begin{array}{llllllll}0.1183 & 0.3547 & 0.5052 & -0.0000 & -0.0000 & -0.0000 & 0.0000 & -0.0000\end{array}$
$\begin{array}{llllllll}0.0000 & 0.5169 & 0.4507 & -0.0000 & 0.0000 & -0.0000 & 0.0000 & 0.0000\end{array}$
$\begin{array}{llllllll}0 & 0.7518 & 0.2004 & -0.0000 & -0.0000 & 0.0000 & 0.0000 & 0.0000\end{array}$
$\begin{array}{llllllll}0 & 0.9000 & 0.0000 & 0.0000 & 0.0000 & -0.0000 & -0.0000 & -0.0000\end{array}$ 
Columns 9 through 16

$\begin{array}{rrrrrrrr}-0.0000 & -0.0000 & 0.0037 & 0.0000 & 0.0000 & 0.0000 & 0.0000 & -0.0000 \\ -0.0000 & 0.0000 & 0.0034 & -0.0000 & 0.0000 & 0.0000 & -0.0000 & 0.0000 \\ -0.0000 & 0.0000 & 0.0019 & -0.0000 & -0.0000 & 0.0000 & -0.0000 & -0.0000 \\ 0.0000 & -0.0000 & 0.0000 & 0.0000 & -0.0000 & 0.0000 & -0.0000 & 0.0000 \\ 0.0000 & -0.0000 & 0.0000 & -0.0000 & 0.0000 & -0.0000 & -0.0000 & 0.0000 \\ -0.0000 & -0.0000 & 0.0000 & -0.0000 & 0 & -0.0000 & -0.0000 & 0.0000 \\ -0.0000 & 0.0000 & 0.0000 & -0.0000 & 0.0000 & -0.0000 & 0.0000 & -0.0000 \\ -0.0000 & -0.0000 & 0.0000 & -0.0000 & 0.0000 & 0.0000 & 0.0000 & -0.0000 \\ -0.0000 & 0.0000 & 0.0000 & 0.0000 & 0 & -0.0000 & -0.0000 & -0.0000 \\ 0.0000 & -0.0000 & -0.0000 & -0.0000 & -0.0000 & 0.0000 & -0.0000 & 0.0000\end{array}$

Columns 17 through 24

$\begin{array}{rrrrrrrr}-0.0000 & 0.0000 & -0.0000 & -0.0000 & -0.0000 & -0.0000 & 0.0010 & 0.0000 \\ 0.0000 & 0.0000 & 0.0000 & 0.0000 & -0.0000 & 0.0000 & 0.0012 & -0.0000 \\ 0.0000 & 0.0000 & -0.0000 & -0.0000 & 0.0000 & -0.0000 & 0.0027 & -0.0000 \\ 0.0000 & 0.0000 & -0.0000 & 0.0000 & 0.0000 & -0.0000 & 0.0065 & 0.0000 \\ 0.0000 & -0.0000 & -0.0000 & 0.0000 & -0.0000 & -0.0000 & 0.0116 & -0.0000 \\ -0.0000 & 0.0000 & -0.0000 & 0.0000 & -0.0000 & -0.0000 & 0.0167 & -0.0000 \\ 0.0000 & -0.0000 & 0.0000 & -0.0000 & -0.0000 & 0.0000 & 0.0218 & -0.0000 \\ 0.0000 & -0.0000 & -0.0000 & 0.0000 & -0.0000 & 0.0000 & 0.0323 & 0.0000 \\ 0.0000 & 0.0000 & -0.0000 & 0.0000 & 0.0000 & -0.0000 & 0.0479 & 0.0000 \\ -0.0000 & 0.0000 & -0.0000 & 0.0000 & 0.0000 & -0.0000 & 0.1000 & 0.0000\end{array}$

Columns 25 through 31

$\begin{array}{rrrrrrr}-0.0000 & 0.0010 & -0.0000 & 0.0000 & 0.0479 & -0.0000 & 0.1000 \\ -0.0000 & 0.0010 & 0.0000 & 0.0000 & 0.0188 & 0.0000 & 0.1000 \\ 0.0000 & 0.0006 & 0.0000 & -0.0000 & 0.0000 & 0.0000 & 0.0712 \\ -0.0000 & 0.0000 & 0.0000 & 0.0000 & 0.0000 & 0.0000 & -0.0000 \\ -0.0000 & -0.0000 & 0.0000 & 0.0000 & -0.0000 & 0.0000 & -0.0000 \\ -0.0000 & -0.0000 & 0.0000 & -0.0000 & 0.0000 & 0.0000 & 0.0000 \\ -0.0000 & -0.0000 & 0.0000 & 0.0000 & -0.0000 & -0.0000 & -0.0000 \\ 0.0000 & -0.0000 & 0.0000 & 0.0000 & -0.0000 & -0.0000 & -0.0000 \\ -0.0000 & -0.0000 & 0.0000 & 0.0000 & -0.0000 & -0.0000 & -0.0000 \\ 0.0000 & -0.0000 & -0.0000 & 0.0000 & 0.0000 & -0.0000 & 0\end{array}$




\section{Restrição Total a Ativos Internacionais (2001 a 2006)}

[PortRisk, PortReturn, PortWts] = frontcon (ExpRetNac06, ExpCovNac06, 10, [], AssetBoundsNac05, GroupsNac05, GroupsBoundsNac05)

PortRisk
0.0021
0.0024
0.0028
0.0036
0.0046
0.0059
0.0086
0.0137
0.0259
0.0398

PortReturn $=$

0.0138

0.0142

0.0145

0.0149

0.0153

0.0156

0.0160

0.0164

0.0167

0.0171

PortWts $=$

$\begin{array}{rrrrrrrr}0.8727 & 0.0142 & -0.0000 & -0.0000 & 0.0000 & 0.0130 & -0.0000 & 0.1000 \\ 0.9326 & 0.0542 & 0.0067 & 0.0000 & -0.0000 & 0.0065 & -0.0000 & 0.0000 \\ 0.7058 & 0.1203 & 0.1739 & 0.0000 & 0 & -0.0000 & 0.0000 & 0.0000 \\ 0.4411 & 0.1957 & 0.3631 & 0.0000 & 0 & 0.0000 & 0.0000 & 0.0000 \\ 0.1764 & 0.2712 & 0.5524 & 0.0000 & -0.0000 & 0.0000 & 0.0000 & -0.0000 \\ 0.0000 & 0.4561 & 0.5418 & -0.0000 & 0.0021 & -0.0000 & 0.0000 & -0.0000 \\ 0 & 0.7783 & 0.1888 & -0.0000 & 0.0329 & -0.0000 & 0.0000 & -0.0000 \\ -0.0000 & 0.8656 & -0.0000 & -0.0000 & 0.1344 & -0.0000 & 0.0000 & -0.0000 \\ -0.0000 & 0.6828 & 0.0000 & 0.0000 & 0.3172 & -0.0000 & 0.0000 & -0.0000 \\ 0 & 0.5000 & -0.0000 & 0.0000 & 0.5000 & 0.0000 & -0.0000 & 0\end{array}$




\section{Restrição de 10\% de Ativos Internacionais (2001 a 2006)}

[PortRisk, PortReturn, PortWts] = frontcon $($ ExpRetInt06, ExpCovInt06, 10, [], AssetBoundsInt05, GroupsInt05, GroupsBoundsInt05)

PortRisk

0.0021
0.0023
0.0027
0.0035
0.0044
0.0055
0.0071
0.0097
0.0179
0.0336

PortReturn $=$
0.0138
0.0142
0.0147
0.0151
0.0155
0.0159
0.0163
0.0168
0.0172
0.0176

PortWts =

Columns 1 through 8

$\begin{array}{rrrrrrrr}0.8629 & 0.0171 & 0.0000 & -0.0000 & 0.0000 & -0.0000 & -0.0000 & -0.0000 \\ 0.8922 & 0.0499 & 0.0385 & 0.0000 & 0.0000 & 0.0000 & 0.0000 & -0.0000 \\ 0.6728 & 0.1101 & 0.1953 & 0.0000 & 0.0000 & 0.0000 & 0.0000 & 0.0000 \\ 0.4256 & 0.1777 & 0.3650 & -0.0000 & 0.0000 & -0.0000 & 0.0000 & 0.0000 \\ 0.1784 & 0.2453 & 0.5347 & 0.0000 & 0.0000 & -0.0000 & 0.0000 & 0.0000 \\ 0.0000 & 0.3200 & 0.6269 & -0.0000 & 0.0000 & -0.0000 & 0.0000 & -0.0000 \\ 0 & 0.4469 & 0.4597 & -0.0000 & 0.0000 & -0.0000 & 0.0000 & -0.0000 \\ -0.0000 & 0.7739 & 0.0976 & -0.0000 & -0.0000 & -0.0000 & 0.0000 & 0.0285 \\ 0.0000 & 0.7083 & 0.0000 & 0.0000 & -0.0000 & -0.0000 & 0.0000 & 0.1917 \\ -0.0000 & 0.5000 & -0.0000 & -0.0000 & 0.0000 & 0.0000 & 0.0000 & 0.4000\end{array}$

Columns 9 through 16 


$\begin{array}{rrrrrrrr}0.0000 & 0.0000 & 0.0054 & 0.0000 & -0.0000 & 0.0000 & -0.0000 & -0.0000 \\ -0.0000 & 0.0000 & 0.0052 & 0.0000 & 0.0000 & 0.0000 & -0.0000 & 0.0000 \\ -0.0000 & -0.0000 & 0.0055 & -0.0000 & 0.0000 & 0.0000 & -0.0000 & -0.0000 \\ -0.0000 & -0.0000 & 0.0053 & 0.0000 & 0.0000 & 0.0000 & -0.0000 & -0.0000 \\ -0.0000 & -0.0000 & 0.0051 & 0.0000 & 0.0000 & 0.0000 & 0.0000 & -0.0000 \\ -0.0000 & -0.0000 & 0.0003 & -0.0000 & -0.0000 & -0.0000 & 0.0000 & 0.0000 \\ 0.0000 & -0.0000 & -0.0000 & -0.0000 & -0.0000 & -0.0000 & 0.0000 & 0.0000 \\ 0.0000 & -0.0000 & -0.0000 & -0.0000 & 0.0073 & -0.0000 & 0.0000 & -0.0000 \\ 0.0000 & 0.0000 & 0.0000 & -0.0000 & 0.0033 & 0.0000 & -0.0000 & -0.0000 \\ 0.0000 & 0.0000 & -0.0000 & -0.0000 & 0.1000 & -0.0000 & -0.0000 & 0.0000\end{array}$

Columns 17 through 24

$\begin{array}{rrrrrrrr}-0.0000 & -0.0000 & -0.0000 & -0.0000 & -0.0000 & -0.0000 & 0.0030 & 0.0000 \\ 0.0000 & -0.0000 & -0.0000 & -0.0000 & 0.0000 & 0.0000 & 0.0075 & 0.0000 \\ -0.0000 & 0.0000 & 0.0000 & -0.0000 & -0.0000 & -0.0000 & 0.0163 & 0.0000 \\ -0.0000 & -0.0000 & -0.0000 & -0.0000 & -0.0000 & -0.0000 & 0.0264 & -0.0000 \\ -0.0000 & -0.0000 & -0.0000 & -0.0000 & -0.0000 & -0.0000 & 0.0365 & 0.0000 \\ 0.0000 & 0.0000 & 0.0027 & -0.0000 & 0.0000 & -0.0000 & 0.0501 & 0.0000 \\ -0.0000 & 0.0000 & 0.0144 & -0.0000 & 0.0000 & -0.0000 & 0.0790 & -0.0000 \\ -0.0000 & 0.0000 & 0.0102 & 0.0000 & 0.0000 & -0.0000 & 0.0825 & -0.0000 \\ -0.0000 & 0.0000 & 0.0000 & 0.0000 & 0.0000 & 0.0000 & 0.0967 & -0.0000 \\ 0.0000 & 0.0000 & -0.0000 & 0.0000 & -0.0000 & 0.0000 & 0 & -0.0000\end{array}$

Columns 25 through 31

$\begin{array}{rrrrrrr}0.0000 & 0.0000 & 0.0000 & -0.0000 & 0.0117 & 0.0000 & 0.1000 \\ -0.0000 & -0.0000 & 0.0000 & 0.0000 & 0.0066 & 0.0000 & -0.0000 \\ 0.0000 & 0.0000 & -0.0000 & 0.0000 & -0.0000 & 0.0000 & -0.0000 \\ 0.0000 & -0.0000 & -0.0000 & 0.0000 & -0.0000 & 0.0000 & -0.0000 \\ 0.0000 & -0.0000 & -0.0000 & 0.0000 & -0.0000 & 0.0000 & -0.0000 \\ 0.0000 & -0.0000 & -0.0000 & 0.0000 & 0.0000 & 0.0000 & -0.0000 \\ -0.0000 & -0.0000 & -0.0000 & 0.0000 & 0.0000 & 0.0000 & -0.0000 \\ -0.0000 & -0.0000 & -0.0000 & 0.0000 & 0.0000 & 0.0000 & -0.0000 \\ 0.0000 & -0.0000 & -0.0000 & -0.0000 & 0.0000 & 0.0000 & 0 \\ -0.0000 & 0.0000 & -0.0000 & -0.0000 & 0.0000 & 0.0000 & 0\end{array}$




\section{Restrição de 20\% de Ativos Internacionais (2001 a 2006)}

[PortRisk, PortReturn, PortWts] = frontcon (ExpRetInt06, ExpCovInt06, 10, [], AssetBoundsInt05, GroupsInt05, GroupsBoundsInt05)

PortRisk
0.0021
0.0023
0.0029
0.0039
0.0050
0.0065
0.0088
0.0115
0.0148
0.0300

PortReturn $=$
0.0138
0.0143
0.0148
0.0153
0.0157
0.0162
0.0167
0.0172
0.0176
0.0181

PortWts $=$

Columns 1 through 8

$\begin{array}{rrrrrrrr}0.8629 & 0.0171 & 0.0000 & -0.0000 & 0.0000 & -0.0000 & -0.0000 & -0.0000 \\ 0.8656 & 0.0572 & 0.0582 & -0.0000 & 0.0000 & -0.0000 & 0.0000 & 0.0000 \\ 0.6063 & 0.1283 & 0.2409 & 0.0000 & 0.0000 & -0.0000 & 0.0000 & 0.0000 \\ 0.3259 & 0.2050 & 0.4335 & 0.0000 & 0.0000 & -0.0000 & 0.0000 & 0.0000 \\ 0.0454 & 0.2816 & 0.6260 & -0.0000 & 0.0000 & -0.0000 & 0.0000 & 0.0000 \\ -0.0000 & 0.4051 & 0.5149 & -0.0000 & 0.0000 & -0.0000 & 0.0000 & 0.0000 \\ 0.0000 & 0.5531 & 0.3167 & -0.0000 & -0.0000 & -0.0000 & 0.0000 & 0.0070 \\ -0.0000 & 0.7039 & 0.1124 & -0.0000 & -0.0000 & -0.0000 & 0.0000 & 0.0199 \\ 0.0000 & 0.7282 & -0.0000 & -0.0000 & -0.0000 & -0.0000 & -0.0000 & 0.0718 \\ 0 & 0.5000 & -0.0000 & -0.0000 & 0.0000 & 0.0000 & 0.0000 & 0.3000\end{array}$

Columns 9 through 16 


$\begin{array}{rrrrrrrr}0.0000 & 0.0000 & 0.0054 & 0.0000 & -0.0000 & 0.0000 & -0.0000 & -0.0000 \\ 0.0000 & -0.0000 & 0.0053 & -0.0000 & 0.0000 & -0.0000 & 0.0000 & 0.0000 \\ 0.0000 & -0.0000 & 0.0055 & 0.0000 & 0.0000 & 0.0000 & 0.0000 & 0.0000 \\ -0.0000 & -0.0000 & 0.0052 & 0.0000 & 0.0000 & 0.0000 & -0.0000 & -0.0000 \\ -0.0000 & -0.0000 & 0.0050 & 0.0000 & 0.0000 & 0.0000 & 0.0000 & 0.0000 \\ 0.0000 & -0.0000 & -0.0000 & -0.0000 & -0.0000 & -0.0000 & 0.0000 & 0.0000 \\ 0.0000 & -0.0000 & -0.0000 & -0.0000 & -0.0000 & -0.0000 & 0.0000 & 0.0000 \\ 0.0000 & 0.0000 & -0.0000 & -0.0000 & -0.0000 & 0.0000 & -0.0000 & -0.0000 \\ 0.0000 & 0.0000 & 0.0000 & -0.0000 & 0.0107 & 0.0000 & -0.0000 & -0.0000 \\ 0.0000 & -0.0000 & -0.0000 & -0.0000 & 0.2000 & -0.0000 & 0.0000 & 0.0000\end{array}$

Columns 17 through 24

$\begin{array}{rrrrrrrr}-0.0000 & -0.0000 & -0.0000 & -0.0000 & -0.0000 & -0.0000 & 0.0030 & 0.0000 \\ -0.0000 & -0.0000 & -0.0000 & -0.0000 & -0.0000 & -0.0000 & 0.0086 & -0.0000 \\ 0.0000 & 0.0000 & -0.0000 & -0.0000 & 0.0000 & 0.0000 & 0.0190 & -0.0000 \\ -0.0000 & -0.0000 & 0.0000 & -0.0000 & -0.0000 & 0.0000 & 0.0305 & 0.0000 \\ 0.0000 & 0.0000 & -0.0000 & -0.0000 & -0.0000 & -0.0000 & 0.0420 & -0.0000 \\ 0.0000 & 0.0000 & 0.0105 & -0.0000 & 0.0000 & -0.0000 & 0.0695 & 0.0000 \\ -0.0000 & 0.0000 & 0.0232 & -0.0000 & -0.0000 & -0.0000 & 0.1000 & 0.0000 \\ -0.0000 & 0.0000 & 0.0353 & -0.0000 & 0.0000 & 0.0000 & 0.1285 & 0.0000 \\ -0.0000 & -0.0000 & 0.0136 & 0.0000 & 0.0000 & 0.0000 & 0.1757 & -0.0000 \\ 0.0000 & 0.0000 & -0.0000 & 0.0000 & -0.0000 & 0.0000 & 0 & -0.0000\end{array}$

Columns 25 through 31

$\begin{array}{rrrrrrr}0.0000 & 0.0000 & 0.0000 & -0.0000 & 0.0117 & 0.0000 & 0.1000 \\ 0.0000 & 0.0000 & -0.0000 & 0.0000 & 0.0050 & 0.0000 & 0.0000 \\ 0.0000 & -0.0000 & -0.0000 & -0.0000 & -0.0000 & 0.0000 & -0.0000 \\ 0.0000 & 0.0000 & -0.0000 & 0.0000 & 0.0000 & 0.0000 & -0.0000 \\ 0.0000 & -0.0000 & -0.0000 & 0.0000 & -0.0000 & 0.0000 & -0.0000 \\ 0.0000 & -0.0000 & -0.0000 & 0.0000 & 0.0000 & 0.0000 & -0.0000 \\ 0.0000 & -0.0000 & -0.0000 & 0.0000 & 0.0000 & 0.0000 & -0.0000 \\ 0.0000 & -0.0000 & -0.0000 & 0.0000 & -0.0000 & 0.0000 & -0.0000 \\ -0.0000 & -0.0000 & -0.0000 & -0.0000 & 0.0000 & 0.0000 & -0.0000 \\ -0.0000 & 0.0000 & -0.0000 & -0.0000 & 0.0000 & 0.0000 & 0\end{array}$




\section{Restrição de 30\% de Ativos Internacionais (2001 a 2006)}

[PortRisk, PortReturn, PortWts] = frontcon (ExpRetInt06, ExpCovInt06, 10, [], AssetBoundsInt05, GroupsInt05, GroupsBoundsInt05)

PortRisk

0.0021
0.0024
0.0031
0.0043
0.0056
0.0078
0.0107
0.0138
0.0174
0.0300

PortReturn $=$

0.0138

0.0143

0.0149

0.0154

0.0160

0.0165

0.0170

0.0176

0.0181

0.0186

PortWts =

Columns 1 through 8

$\begin{array}{rrrrrrrr}0.8629 & 0.0171 & 0.0000 & -0.0000 & 0.0000 & -0.0000 & -0.0000 & -0.0000 \\ 0.8390 & 0.0646 & 0.0779 & 0.0000 & -0.0000 & -0.0000 & 0.0000 & -0.0000 \\ 0.5398 & 0.1465 & 0.2865 & 0.0000 & 0.0000 & -0.0000 & 0.0000 & 0.0000 \\ 0.2261 & 0.2322 & 0.5019 & 0.0000 & -0.0000 & -0.0000 & 0.0000 & 0.0000 \\ -0.0000 & 0.3290 & 0.6153 & -0.0000 & 0.0000 & -0.0000 & 0.0000 & 0.0000 \\ 0 & 0.4917 & 0.3999 & -0.0000 & 0.0000 & -0.0000 & -0.0000 & 0.0017 \\ 0.0000 & 0.6604 & 0.1714 & -0.0000 & -0.0000 & -0.0000 & -0.0000 & 0.0162 \\ 0.0000 & 0.7662 & -0.0000 & -0.0000 & -0.0000 & -0.0000 & -0.0000 & 0.0286 \\ 0.0000 & 0.6836 & -0.0000 & -0.0000 & -0.0000 & -0.0000 & -0.0000 & 0.0349 \\ -0.0000 & 0.5000 & -0.0000 & -0.0000 & 0.0000 & 0.0000 & 0.0000 & 0.2000\end{array}$

Columns 9 through 16 


$\begin{array}{rrrrrrrr}0.0000 & 0.0000 & 0.0054 & 0.0000 & -0.0000 & 0.0000 & -0.0000 & -0.0000 \\ -0.0000 & -0.0000 & 0.0054 & 0.0000 & -0.0000 & 0.0000 & 0.0000 & -0.0000 \\ 0.0000 & -0.0000 & 0.0054 & 0.0000 & -0.0000 & 0.0000 & -0.0000 & 0.0000 \\ -0.0000 & -0.0000 & 0.0052 & -0.0000 & -0.0000 & -0.0000 & -0.0000 & 0.0000 \\ -0.0000 & -0.0000 & -0.0000 & -0.0000 & -0.0000 & 0.0000 & 0.0000 & 0.0000 \\ 0.0000 & -0.0000 & -0.0000 & -0.0000 & 0.0000 & -0.0000 & 0.0000 & -0.0000 \\ 0.0000 & 0.0000 & -0.0000 & -0.0000 & -0.0000 & 0.0000 & -0.0000 & -0.0000 \\ 0.0000 & 0.0000 & 0.0000 & -0.0000 & -0.0000 & 0.0000 & -0.0000 & -0.0000 \\ 0.0000 & 0.0000 & 0.0000 & -0.0000 & -0.0000 & -0.0000 & -0.0000 & -0.0000 \\ 0.0000 & -0.0000 & -0.0000 & -0.0000 & 0.3000 & -0.0000 & 0.0000 & 0.0000\end{array}$

Columns 17 through 24

$\begin{array}{rrrrrrrr}-0.0000 & -0.0000 & -0.0000 & -0.0000 & -0.0000 & -0.0000 & 0.0030 & 0.0000 \\ -0.0000 & -0.0000 & -0.0000 & -0.0000 & -0.0000 & -0.0000 & 0.0096 & -0.0000 \\ -0.0000 & -0.0000 & -0.0000 & -0.0000 & -0.0000 & -0.0000 & 0.0217 & 0.0000 \\ -0.0000 & -0.0000 & -0.0000 & -0.0000 & 0.0000 & 0.0000 & 0.0346 & 0.0000 \\ -0.0000 & 0.0000 & 0.0035 & -0.0000 & -0.0000 & 0.0000 & 0.0522 & 0.0000 \\ -0.0000 & -0.0000 & 0.0182 & -0.0000 & -0.0000 & -0.0000 & 0.0884 & 0.0000 \\ 0.0000 & 0.0000 & 0.0318 & -0.0000 & 0.0000 & 0.0000 & 0.1203 & -0.0000 \\ -0.0000 & -0.0000 & 0.0463 & -0.0000 & 0.0000 & 0.0000 & 0.1590 & -0.0000 \\ -0.0000 & -0.0000 & 0.0635 & -0.0000 & -0.0000 & 0.0000 & 0.2180 & -0.0000 \\ 0.0000 & 0.0000 & -0.0000 & 0.0000 & -0.0000 & 0.0000 & 0 & -0.0000\end{array}$

Columns 25 through 31

$\begin{array}{rrrrrrr}0.0000 & 0.0000 & 0.0000 & -0.0000 & 0.0117 & 0.0000 & 0.1000 \\ 0.0000 & 0.0000 & 0.0000 & 0.0000 & 0.0034 & 0.0000 & -0.0000 \\ 0.0000 & 0.0000 & 0.0000 & 0.0000 & -0.0000 & 0.0000 & 0.0000 \\ 0.0000 & -0.0000 & -0.0000 & -0.0000 & 0.0000 & 0.0000 & -0.0000 \\ 0.0000 & 0.0000 & -0.0000 & 0.0000 & 0.0000 & 0.0000 & -0.0000 \\ 0.0000 & -0.0000 & -0.0000 & 0.0000 & 0.0000 & 0.0000 & -0.0000 \\ -0.0000 & -0.0000 & -0.0000 & 0.0000 & 0.0000 & 0.0000 & -0.0000 \\ -0.0000 & -0.0000 & -0.0000 & -0.0000 & 0.0000 & 0.0000 & -0.0000 \\ -0.0000 & -0.0000 & -0.0000 & -0.0000 & 0.0000 & 0.0000 & -0.0000 \\ -0.0000 & 0.0000 & -0.0000 & -0.0000 & 0.0000 & 0.0000 & 0\end{array}$




\section{Restrição de 40\% de Ativos Internacionais (2001 a 2006)}

[PortRisk, PortReturn, PortWts] = frontcon (ExpRetInt06, ExpCovInt06, 10, [], AssetBoundsInt05, GroupsInt05, GroupsBoundsInt05)

PortRisk
0.0021
0.0024
0.0033
0.0047
0.0064
0.0093
0.0126
0.0164
0.0208
0.0336

PortReturn $=$
0.0138
0.0144
0.0150
0.0156
0.0162
0.0168
0.0174
0.0180
0.0186
0.0191

PortWts =

Columns 1 through 8
$\begin{array}{llllllll}0.8629 & 0.0171 & 0.0000 & -0.0000 & 0.0000 & -0.0000 & -0.0000 & -0.0000\end{array}$
$\begin{array}{llllllll}0.8125 & 0.0719 & 0.0976 & 0.0000 & -0.0000 & -0.0000 & 0.0000 & -0.0000\end{array}$
$\begin{array}{llllllll}0.4734 & 0.1646 & 0.3322 & -0.0000 & -0.0000 & -0.0000 & 0.0000 & 0.0000\end{array}$
$\begin{array}{lllllllll}0.1264 & 0.2595 & 0.5704 & 0.0000 & 0.0000 & -0.0000 & 0.0000 & 0.0000\end{array}$
$\begin{array}{llllllll}-0.0000 & 0.3976 & 0.5248 & -0.0000 & 0.0000 & -0.0000 & 0.0000 & 0.0000\end{array}$
$\begin{array}{llllllll}0.0000 & 0.5811 & 0.2788 & -0.0000 & -0.0000 & -0.0000 & -0.0000 & 0.0094\end{array}$
$\begin{array}{llllllll}-0.0000 & 0.7676 & 0.0261 & 0.0000 & -0.0000 & -0.0000 & -0.0000 & 0.0253\end{array}$
$\begin{array}{llllllll}0.0000 & 0.7049 & -0.0000 & -0.0000 & -0.0000 & -0.0000 & -0.0000 & 0.0333\end{array}$
$\begin{array}{llllllll}0.0000 & 0.6136 & 0 & -0.0000 & -0.0000 & -0.0000 & -0.0000 & 0.0403\end{array}$
$\begin{array}{llllllll}-0.0000 & 0.5000 & -0.0000 & -0.0000 & 0.0000 & 0.0000 & 0.0000 & 0.1000\end{array}$

Columns 9 through 16 


$\begin{array}{rrrrrrrr}0.0000 & 0.0000 & 0.0054 & 0.0000 & -0.0000 & 0.0000 & -0.0000 & -0.0000 \\ -0.0000 & -0.0000 & 0.0055 & 0.0000 & -0.0000 & 0.0000 & -0.0000 & -0.0000 \\ -0.0000 & -0.0000 & 0.0054 & -0.0000 & 0.0000 & -0.0000 & 0.0000 & 0.0000 \\ 0.0000 & -0.0000 & 0.0051 & -0.0000 & 0.0000 & -0.0000 & -0.0000 & 0.0000 \\ -0.0000 & -0.0000 & -0.0000 & -0.0000 & -0.0000 & 0.0000 & 0.0000 & 0.0000 \\ 0.0000 & -0.0000 & 0.0000 & -0.0000 & -0.0000 & -0.0000 & 0.0000 & 0.0000 \\ 0.0000 & 0.0000 & 0.0000 & -0.0000 & -0.0000 & -0.0000 & -0.0000 & -0.0000 \\ 0.0000 & 0.0000 & 0.0000 & -0.0000 & -0.0000 & 0.0000 & -0.0000 & -0.0000 \\ 0.0000 & 0.0000 & -0.0000 & -0.0000 & 0.0000 & 0.0000 & -0.0000 & 0.0000 \\ 0.0000 & -0.0000 & -0.0000 & -0.0000 & 0.4000 & -0.0000 & 0.0000 & 0.0000\end{array}$

Columns 17 through 24

$\begin{array}{rrrrrrrr}-0.0000 & -0.0000 & -0.0000 & -0.0000 & -0.0000 & -0.0000 & 0.0030 & 0.0000 \\ -0.0000 & -0.0000 & -0.0000 & -0.0000 & -0.0000 & -0.0000 & 0.0106 & -0.0000 \\ 0.0000 & -0.0000 & 0.0000 & -0.0000 & -0.0000 & -0.0000 & 0.0244 & -0.0000 \\ -0.0000 & -0.0000 & -0.0000 & -0.0000 & -0.0000 & 0.0000 & 0.0386 & 0.0000 \\ -0.0000 & 0.0000 & 0.0098 & -0.0000 & -0.0000 & 0.0000 & 0.0678 & -0.0000 \\ -0.0000 & 0.0000 & 0.0254 & -0.0000 & -0.0000 & -0.0000 & 0.1053 & 0.0000 \\ -0.0000 & 0.0000 & 0.0404 & -0.0000 & 0.0000 & 0.0000 & 0.1406 & -0.0000 \\ -0.0000 & -0.0000 & 0.0590 & -0.0000 & 0.0000 & 0.0000 & 0.2028 & -0.0000 \\ -0.0000 & -0.0000 & 0.0780 & -0.0000 & -0.0000 & 0.0000 & 0.2681 & -0.0000 \\ 0.0000 & 0.0000 & -0.0000 & 0.0000 & -0.0000 & 0.0000 & 0 & -0.0000\end{array}$

Columns 25 through 31

$\begin{array}{rrrrrrr}0.0000 & 0.0000 & 0.0000 & -0.0000 & 0.0117 & 0.0000 & 0.1000 \\ 0.0000 & 0.0000 & 0.0000 & 0.0000 & 0.0019 & 0.0000 & -0.0000 \\ 0.0000 & -0.0000 & 0.0000 & 0.0000 & -0.0000 & 0.0000 & -0.0000 \\ 0.0000 & -0.0000 & 0.0000 & 0.0000 & 0.0000 & 0.0000 & -0.0000 \\ -0.0000 & -0.0000 & -0.0000 & 0.0000 & 0.0000 & 0.0000 & -0.0000 \\ -0.0000 & 0.0000 & -0.0000 & 0.0000 & 0.0000 & 0.0000 & -0.0000 \\ -0.0000 & 0.0000 & -0.0000 & -0.0000 & 0.0000 & 0.0000 & -0.0000 \\ -0.0000 & -0.0000 & -0.0000 & -0.0000 & 0.0000 & 0.0000 & -0.0000 \\ 0.0000 & 0.0000 & -0.0000 & -0.0000 & 0.0000 & 0.0000 & -0.0000 \\ -0.0000 & 0.0000 & -0.0000 & -0.0000 & 0.0000 & 0.0000 & 0\end{array}$




\section{Restrição de 50\% de Ativos Internacionais (2001 a 2006)}

[PortRisk, PortReturn, PortWts] = frontcon(ExpRetInt06, ExpCovInt06, 10, [], AssetBoundsInt05, GroupsInt05x, GroupsBoundsInt05x)

PortRisk

0.0021
0.0025
0.0036
0.0051
0.0074
0.0109
0.0147
0.0193
0.0244
0.0399

PortReturn $=$

0.0138

0.0145

0.0151

0.0158

0.0164

0.0171

0.0177

0.0184

0.0190

0.0197

PortWts $=$

Columns 1 through 8

$\begin{array}{rrrrrrrr}0.8629 & 0.0171 & 0.0000 & -0.0000 & -0.0000 & -0.0000 & -0.0000 & -0.0000 \\ 0.7859 & 0.0792 & 0.1173 & 0.0000 & 0.0000 & -0.0000 & -0.0000 & -0.0000 \\ 0.4069 & 0.1828 & 0.3778 & 0.0000 & 0.0000 & -0.0000 & -0.0000 & 0.0000 \\ 0.0267 & 0.2868 & 0.6389 & -0.0000 & -0.0000 & -0.0000 & -0.0000 & -0.0000 \\ -0.0000 & 0.4663 & 0.4343 & 0.0000 & -0.0000 & -0.0000 & 0.0000 & 0.0000 \\ -0.0000 & 0.6704 & 0.1578 & 0.0000 & -0.0000 & -0.0000 & -0.0000 & 0.0170 \\ -0.0000 & 0.7437 & -0.0000 & 0.0000 & -0.0000 & -0.0000 & -0.0000 & 0.0303 \\ -0.0000 & 0.6437 & -0.0000 & -0.0000 & 0.0000 & -0.0000 & -0.0000 & 0.0380 \\ -0.0000 & 0.5436 & -0.0000 & 0.0000 & -0.0000 & -0.0000 & -0.0000 & 0.0456 \\ 0.0000 & 0.5000 & 0 & -0.0000 & 0.0000 & 0.0000 & -0.0000 & 0.0000\end{array}$

Columns 9 through 16 


$\begin{array}{rrrrrrrr}0.0000 & -0.0000 & 0.0054 & 0.0000 & 0.0000 & 0.0000 & -0.0000 & -0.0000 \\ -0.0000 & -0.0000 & 0.0056 & -0.0000 & -0.0000 & -0.0000 & -0.0000 & -0.0000 \\ -0.0000 & -0.0000 & 0.0053 & -0.0000 & 0.0000 & -0.0000 & -0.0000 & -0.0000 \\ -0.0000 & -0.0000 & 0.0050 & 0.0000 & 0.0000 & -0.0000 & 0.0000 & 0.0000 \\ 0.0000 & -0.0000 & 0.0000 & 0.0000 & 0.0000 & -0.0000 & 0.0000 & 0.0000 \\ -0.0000 & -0.0000 & 0.0000 & 0.0000 & -0.0000 & -0.0000 & 0.0000 & -0.0000 \\ -0.0000 & -0.0000 & 0.0000 & -0.0000 & 0 & -0.0000 & -0.0000 & -0.0000 \\ -0.0000 & -0.0000 & 0.0000 & -0.0000 & 0.0000 & -0.0000 & -0.0000 & 0.0000 \\ -0.0000 & -0.0000 & 0.0000 & -0.0000 & -0.0000 & 0.0000 & -0.0000 & 0.0000 \\ 0.0000 & -0.0000 & -0.0000 & -0.0000 & 0.5000 & 0.0000 & 0.0000 & -0.0000\end{array}$

Columns 17 through 24

$\begin{array}{rrrrrrrr}0.0000 & 0.0000 & 0.0000 & 0.0000 & 0.0000 & -0.0000 & 0.0030 & -0.0000 \\ 0.0000 & -0.0000 & 0.0000 & -0.0000 & 0.0000 & -0.0000 & 0.0117 & 0.0000 \\ -0.0000 & 0.0000 & -0.0000 & -0.0000 & -0.0000 & -0.0000 & 0.0272 & 0.0000 \\ -0.0000 & -0.0000 & 0.0000 & -0.0000 & 0.0000 & -0.0000 & 0.0427 & -0.0000 \\ 0.0000 & -0.0000 & 0.0161 & -0.0000 & -0.0000 & -0.0000 & 0.0833 & -0.0000 \\ -0.0000 & -0.0000 & 0.0326 & -0.0000 & -0.0000 & -0.0000 & 0.1222 & -0.0000 \\ 0.0000 & 0.0000 & 0.0509 & -0.0000 & 0.0000 & -0.0000 & 0.1750 & -0.0000 \\ -0.0000 & 0.0000 & 0.0718 & -0.0000 & -0.0000 & -0.0000 & 0.2466 & -0.0000 \\ -0.0000 & -0.0000 & 0.0926 & -0.0000 & 0.0000 & -0.0000 & 0.3181 & 0.0000 \\ -0.0000 & 0.0000 & 0.0000 & 0.0000 & 0.0000 & 0.0000 & 0.0000 & 0.0000\end{array}$

Columns 25 through 31

$\begin{array}{rrrrrrr}0.0000 & 0.0000 & -0.0000 & -0.0000 & 0.0117 & 0.0000 & 0.1000 \\ 0.0000 & -0.0000 & -0.0000 & -0.0000 & 0.0003 & 0.0000 & -0.0000 \\ -0.0000 & 0.0000 & -0.0000 & -0.0000 & 0.0000 & 0.0000 & 0.0000 \\ -0.0000 & 0.0000 & -0.0000 & -0.0000 & -0.0000 & 0.0000 & -0.0000 \\ -0.0000 & -0.0000 & -0.0000 & 0.0000 & 0.0000 & 0.0000 & -0.0000 \\ 0.0000 & -0.0000 & -0.0000 & 0.0000 & 0.0000 & 0.0000 & -0.0000 \\ 0.0000 & 0.0000 & -0.0000 & 0.0000 & 0.0000 & -0.0000 & -0.0000 \\ -0.0000 & 0.0000 & -0.0000 & 0.0000 & -0.0000 & 0.0000 & -0.0000 \\ -0.0000 & 0.0000 & -0.0000 & -0.0000 & -0.0000 & 0.0000 & -0.0000 \\ 0.0000 & -0.0000 & -0.0000 & 0.0000 & 0.0000 & 0.0000 & -0.0000\end{array}$




\section{Restrição Total a Ativos Internacionais (2003 a 2006)}

[PortRisk, PortReturn, PortWts] = frontcon(ExpRetNac03, ExpCovNac03, 10, [], AssetBoundsNac05,GroupsNac05,GroupsBoundsNac05)

PortRisk
0.0022
0.0034
0.0057
0.0088
0.0126
0.0166
0.0207
0.0249
0.0291
0.0333

PortReturn $=$
0.0137
0.0148
0.0159
0.0169
0.0180
0.0190
0.0201
0.0212
0.0222
0.0233

\begin{tabular}{|c|c|c|c|c|c|c|c|}
\hline 0.7686 & 0.1187 & -0.0000 & -0.0000 & 0.0008 & 0.0118 & 0.0000 & 0.1000 \\
\hline 0.5491 & 0.0713 & 0.3656 & 0.0000 & 0.0135 & 0.0006 & 0.0000 & 0.0000 \\
\hline 0.0687 & -0.0000 & 0.9038 & 0.0000 & 0.0275 & 0 & 0.0000 & 0 \\
\hline 0.0000 & -0.0000 & 0.9103 & 0.0000 & 0.0897 & -0.0000 & 0.0000 & 0 \\
\hline 0 & 0 & 0.8419 & -0.0000 & 0.1581 & 0 & 0.0000 & 0.0000 \\
\hline 0.0000 & 0 & 0.7735 & 0 & 0.2265 & 0 & 0.0000 & 0.0000 \\
\hline 0.0000 & 0 & 0.7052 & 0.0000 & 0.2948 & 0 & 0.0000 & -0.0000 \\
\hline 0.0000 & 0.0000 & 0.6368 & 0 & 0.3632 & 0 & 0.0000 & 0.0000 \\
\hline 0.0000 & -0.0000 & 0.5684 & -0.0000 & 0.4316 & 0.0000 & 0.0000 & 0.0000 \\
\hline & 0.0000 & 0.5000 & -0.0000 & 0.5000 & 0.0000 & -0.0000 & 0.0000 \\
\hline
\end{tabular}




\section{Restrição de 10\% de Ativos Internacionais (2003 a 2006)}

[PortRisk, PortReturn, PortWts] = frontcon(ExpRetInt03, ExpCovInt03, 10, [], AssetBoundsInt05,GroupsInt05,GroupsBoundsInt05)

PortRisk $=$
0.0021
0.0030
0.0053
0.0083
0.0121
0.0160
0.0200
0.0240
0.0281
0.0333

PortReturn $=$

0.0137

0.0148

0.0159

0.0169

0.0180

0.0190

0.0201

0.0212

0.0222

0.0233

PortWts =

Columns 1 through 8

$\begin{array}{rrrrrrrr}0.7299 & 0.1387 & 0.0000 & -0.0000 & -0.0000 & 0.0000 & 0.0000 & 0.0000 \\ 0.4609 & 0.1090 & 0.3956 & 0.0000 & -0.0000 & -0.0000 & 0.0000 & 0.0021 \\ -0.0000 & 0.0441 & 0.9004 & -0.0000 & -0.0000 & -0.0000 & -0.0000 & 0.0116 \\ -0.0000 & -0.0000 & 0.8791 & -0.0000 & -0.0000 & 0.0000 & -0.0000 & 0.0679 \\ 0.0000 & -0.0000 & 0.8048 & 0.0000 & -0.0000 & 0.0019 & 0.0000 & 0.1278 \\ 0.0000 & 0.0000 & 0.7304 & -0.0000 & 0.0000 & 0.0047 & -0.0000 & 0.1876 \\ 0.0000 & 0.0000 & 0.6559 & -0.0000 & 0.0000 & 0.0076 & -0.0000 & 0.2473 \\ -0.0000 & -0.0000 & 0.5890 & -0.0000 & 0.0000 & 0.0085 & 0.0000 & 0.3110 \\ -0.0000 & -0.0000 & 0.5243 & -0.0000 & 0.0000 & 0.0088 & 0.0000 & 0.3757 \\ 0 & -0.0000 & 0.5000 & 0.0000 & 0.0000 & -0.0000 & 0.0000 & 0.5000\end{array}$


Columns 9 through 16

$\begin{array}{rrrrrrrr}0.0000 & -0.0000 & 0.0031 & -0.0000 & -0.0000 & -0.0000 & 0.0000 & -0.0000 \\ -0.0000 & 0.0000 & 0.0028 & -0.0000 & 0.0000 & 0.0000 & 0.0000 & 0.0000 \\ 0.0000 & -0.0000 & -0.0000 & 0.0000 & 0.0000 & 0.0000 & 0.0000 & -0.0000 \\ 0.0000 & 0.0000 & 0.0000 & 0.0000 & 0.0000 & -0.0000 & -0.0000 & 0.0000 \\ 0.0000 & 0.0000 & -0.0000 & 0.0000 & -0.0000 & 0.0000 & 0.0000 & -0.0000 \\ -0.0000 & 0.0000 & 0.0000 & -0.0000 & -0.0000 & -0.0000 & 0.0000 & 0.0000 \\ -0.0000 & -0.0000 & 0.0000 & 0.0000 & -0.0000 & 0.0000 & -0.0000 & 0.0000 \\ -0.0000 & -0.0000 & -0.0000 & -0.0000 & -0.0000 & 0.0000 & -0.0000 & 0.0000 \\ -0.0000 & -0.0000 & 0.0000 & 0.0000 & -0.0000 & -0.0000 & -0.0000 & 0.0000 \\ -0.0000 & -0.0000 & -0.0000 & -0.0000 & -0.0000 & 0.0000 & 0.0000 & 0.0000\end{array}$

Columns 17 through 24

$\begin{array}{rrrrrrrr}-0.0000 & -0.0000 & 0.0000 & 0.0000 & -0.0000 & -0.0000 & 0.0131 & 0.0051 \\ 0.0000 & -0.0000 & 0.0000 & -0.0000 & 0.0000 & -0.0000 & 0.0296 & -0.0000 \\ -0.0000 & 0.0000 & 0.0000 & 0.0000 & -0.0000 & 0.0000 & 0.0400 & 0.0000 \\ -0.0000 & 0.0000 & 0.0028 & -0.0000 & -0.0000 & 0.0000 & 0.0411 & -0.0000 \\ 0.0000 & 0.0000 & 0.0131 & -0.0000 & -0.0000 & 0.0000 & 0.0389 & 0.0000 \\ -0.0000 & 0.0000 & 0.0232 & -0.0000 & 0.0000 & -0.0000 & 0.0364 & 0.0000 \\ -0.0000 & 0.0000 & 0.0333 & -0.0000 & 0.0000 & -0.0000 & 0.0340 & -0.0000 \\ -0.0000 & -0.0000 & 0.0413 & 0.0000 & 0.0000 & 0.0000 & 0.0233 & -0.0000 \\ -0.0000 & 0.0000 & 0.0488 & -0.0000 & 0.0000 & -0.0000 & 0.0104 & -0.0000 \\ 0.0000 & 0.0000 & -0.0000 & 0.0000 & -0.0000 & -0.0000 & 0.0000 & 0.0000\end{array}$

Columns 25 through 31

$\begin{array}{rrrrrrr}-0.0000 & 0.0000 & -0.0000 & -0.0000 & 0.0102 & 0.0000 & 0.1000 \\ 0.0000 & 0.0000 & 0.0000 & 0.0000 & 0.0000 & 0.0000 & -0.0000 \\ 0.0000 & -0.0000 & -0.0000 & 0.0039 & 0.0000 & 0.0000 & -0.0000 \\ 0.0000 & -0.0000 & -0.0000 & 0.0092 & -0.0000 & 0.0000 & 0.0000 \\ 0.0000 & -0.0000 & 0.0000 & 0.0135 & -0.0000 & 0.0000 & 0.0000 \\ 0.0000 & -0.0000 & -0.0000 & 0.0176 & 0.0000 & 0.0000 & 0.0000 \\ 0.0000 & 0.0000 & 0.0000 & 0.0218 & -0.0000 & 0.0000 & 0.0000 \\ 0.0000 & 0.0000 & 0.0000 & 0.0268 & -0.0000 & 0.0000 & 0.0000 \\ 0.0000 & -0.0000 & -0.0000 & 0.0321 & -0.0000 & -0.0000 & 0.0000 \\ 0.0000 & -0.0000 & 0.0000 & 0.0000 & 0 & -0.0000 & 0\end{array}$




\section{Restrição de 20\% de Ativos Internacionais (2003 a 2006)}

[PortRisk, PortReturn, PortWts] = frontcon(ExpRetInt03, ExpCovInt03, 10, [], AssetBoundsInt05, GroupsInt05, GroupsBoundsInt05)

PortRisk $=$
0.0021
0.0030
0.0053
0.0083
0.0121
0.0160
0.0200
0.0240
0.0281
0.0333

PortReturn $=$

0.0137

0.0148

0.0159

0.0169

0.0180

0.0190

0.0201

0.0212

0.0222

0.0233

PortWts =

Columns 1 through 8

$\begin{array}{rrrrrrrr}0.7299 & 0.1387 & 0.0000 & -0.0000 & -0.0000 & 0.0000 & 0.0000 & 0.0000 \\ 0.4609 & 0.1090 & 0.3956 & 0.0000 & -0.0000 & 0.0000 & -0.0000 & 0.0021 \\ 0.0000 & 0.0441 & 0.9004 & 0.0000 & -0.0000 & 0.0000 & -0.0000 & 0.0116 \\ 0.0000 & 0.0000 & 0.8791 & 0.0000 & 0.0000 & -0.0000 & 0.0000 & 0.0679 \\ -0.0000 & 0.0000 & 0.8048 & 0.0000 & 0.0000 & 0.0019 & -0.0000 & 0.1278 \\ 0.0000 & 0.0000 & 0.7304 & -0.0000 & 0.0000 & 0.0047 & -0.0000 & 0.1876 \\ -0.0000 & 0.0000 & 0.6559 & -0.0000 & 0.0000 & 0.0076 & -0.0000 & 0.2473 \\ -0.0000 & -0.0000 & 0.5815 & -0.0000 & 0.0000 & 0.0104 & 0.0000 & 0.3070 \\ -0.0000 & -0.0000 & 0.5071 & -0.0000 & 0.0000 & 0.0133 & 0.0000 & 0.3668 \\ 0 & -0.0000 & 0.5000 & 0.0000 & 0.0000 & -0.0000 & 0.0000 & 0.5000\end{array}$


Columns 9 through 16

$$
\begin{array}{rrrrrrrr}
0.0000 & -0.0000 & 0.0031 & -0.0000 & -0.0000 & -0.0000 & 0.0000 & -0.0000 \\
-0.0000 & 0.0000 & 0.0028 & -0.0000 & -0.0000 & -0.0000 & -0.0000 & 0.0000 \\
-0.0000 & -0.0000 & 0.0000 & 0.0000 & -0.0000 & 0.0000 & -0.0000 & 0.0000 \\
0.0000 & -0.0000 & 0.0000 & 0.0000 & -0.0000 & 0.0000 & -0.0000 & -0.0000 \\
0.0000 & -0.0000 & -0.0000 & 0.0000 & -0.0000 & -0.0000 & -0.0000 & 0.0000 \\
-0.0000 & 0.0000 & 0.0000 & 0.0000 & -0.0000 & -0.0000 & -0.0000 & 0.0000 \\
-0.0000 & -0.0000 & -0.0000 & -0.0000 & -0.0000 & -0.0000 & -0.0000 & 0.0000 \\
-0.0000 & -0.0000 & -0.0000 & -0.0000 & -0.0000 & 0.0000 & -0.0000 & 0.0000 \\
-0.0000 & -0.0000 & 0.0000 & 0.0000 & 0.0000 & -0.0000 & -0.0000 & 0.0000 \\
-0.0000 & -0.0000 & -0.0000 & -0.0000 & -0.0000 & 0.0000 & 0.0000 & 0.0000
\end{array}
$$

Columns 17 through 24

$\begin{array}{rrrrrrrr}-0.0000 & -0.0000 & 0.0000 & 0.0000 & -0.0000 & -0.0000 & 0.0131 & 0.0051 \\ -0.0000 & 0.0000 & 0.0000 & -0.0000 & 0.0000 & 0.0000 & 0.0296 & 0.0000 \\ -0.0000 & -0.0000 & 0.0000 & -0.0000 & 0.0000 & 0.0000 & 0.0400 & -0.0000 \\ 0.0000 & -0.0000 & 0.0028 & -0.0000 & -0.0000 & 0.0000 & 0.0411 & -0.0000 \\ 0.0000 & 0.0000 & 0.0131 & -0.0000 & -0.0000 & -0.0000 & 0.0389 & -0.0000 \\ -0.0000 & -0.0000 & 0.0232 & -0.0000 & 0.0000 & -0.0000 & 0.0364 & -0.0000 \\ -0.0000 & 0.0000 & 0.0333 & -0.0000 & 0.0000 & 0.0000 & 0.0340 & -0.0000 \\ -0.0000 & -0.0000 & 0.0434 & 0.0000 & 0.0000 & 0.0000 & 0.0316 & -0.0000 \\ -0.0000 & 0.0000 & 0.0535 & -0.0000 & 0.0000 & -0.0000 & 0.0291 & -0.0000 \\ 0.0000 & 0.0000 & -0.0000 & 0.0000 & -0.0000 & -0.0000 & 0.0000 & 0.0000\end{array}$

Columns 25 through 31

$\begin{array}{rrrrrrr}-0.0000 & 0.0000 & -0.0000 & -0.0000 & 0.0102 & 0.0000 & 0.1000 \\ 0.0000 & 0.0000 & 0.0000 & 0.0000 & 0.0000 & -0.0000 & 0.0000 \\ 0.0000 & 0.0000 & -0.0000 & 0.0039 & -0.0000 & 0.0000 & -0.0000 \\ 0.0000 & 0.0000 & -0.0000 & 0.0092 & 0.0000 & 0.0000 & 0.0000 \\ 0.0000 & 0.0000 & -0.0000 & 0.0135 & -0.0000 & -0.0000 & 0.0000 \\ 0.0000 & 0.0000 & 0.0000 & 0.0176 & -0.0000 & 0.0000 & 0.0000 \\ 0.0000 & 0.0000 & -0.0000 & 0.0218 & -0.0000 & 0.0000 & 0.0000 \\ 0.0000 & 0.0000 & 0.0000 & 0.0260 & -0.0000 & 0.0000 & 0.0000 \\ 0.0000 & -0.0000 & -0.0000 & 0.0302 & -0.0000 & -0.0000 & 0.0000 \\ 0.0000 & -0.0000 & 0.0000 & 0.0000 & 0 & -0.0000 & 0\end{array}$


APÊNDICE F - FRONTEIRAS EFICIENTES COM RETORNOS EM MOEDA LOCAL PARA DIFERENTES GRAUS DE ABERTURA A INVESTIMENTOS NO EXTERIOR DADOS RETORNOS DAS CARTEIRAS DA FRONTEIRA EM INTERVALOS DE $0,05 \%$

Ativos da Fronteira

\begin{tabular}{|l|l|}
\hline Coluna 1 & CDI \\
\hline Coluna 2 & IGPM + Cupom \\
\hline Coluna 3 & IRF-M \\
\hline Coluna 4 & FIEX \\
\hline Coluna 5 & Alemanha \\
\hline Coluna 6 & Argentina \\
\hline Coluna 7 & Austrália \\
\hline Coluna 8 & Brasil \\
\hline Coluna 9 & Canadá \\
\hline Coluna 10 & Chile \\
\hline Coluna 11 & China \\
\hline Coluna 12 & Cingapura \\
\hline Coluna 13 & Coréia \\
\hline Coluna 14 & Espanha \\
\hline Coluna 15 & Estados Unidos \\
\hline Coluna 16 & França \\
\hline Coluna 17 & Holanda \\
\hline Coluna 18 & Hong Kong \\
\hline Coluna 19 & Índia \\
\hline Coluna 20 & Itália \\
\hline Coluna 21 & Japão \\
\hline Coluna 22 & Malásia \\
\hline Coluna 23 & México \\
\hline Coluna 24 & Reino Unido \\
\hline Coluna 25 & Suécia \\
\hline Coluna 26 & Suíça \\
\hline Coluna 27 & Taiwan \\
\hline Coluna 28 & Venezuela \\
\hline Coluna 29 & Imóveis \\
\hline Coluna 30 & Empréstimos \\
\hline Coluna 31 & Financiamentos \\
\hline & \\
\hline
\end{tabular}




\section{Restrição Total a Ativos Internacionais (2000 a 2005)}

[PortRisk, PortReturn, PortWts] = frontcon(ExpRetIntPais05, ExpCovIntPais05, [], PortReturnInt06,AssetBoundsInt05,GroupsInt05,GroupsBoundsInt05)

PortRisk $=$
0.0020
0.0022
0.0030
0.0043
0.0057
0.0081
PortReturn $=$
0.0140
0.0145
0.0150
0.0155
0.0160
0.0165

PortWts $=$

Columns 1 through 8

$\begin{array}{rrrrrrrr}0.8591 & 0.0271 & 0 & 0 & 0.0000 & 0.0000 & -0.0000 & 0.0000 \\ 0.9464 & 0.0536 & 0.0000 & 0.0000 & 0.0000 & 0.0000 & -0.0000 & 0.0000 \\ 0.6443 & 0.1824 & 0.1734 & 0.0000 & 0.0000 & 0.0000 & 0.0000 & -0.0000 \\ 0.3192 & 0.2948 & 0.3861 & -0.0000 & -0.0000 & 0.0000 & 0.0000 & 0.0000 \\ 0 & 0.4114 & 0.5886 & -0.0000 & -0.0000 & 0.0000 & 0.0000 & 0.0000 \\ 0 & 0.7559 & 0.2441 & -0.0000 & -0.0000 & 0.0000 & 0.0000 & 0.0000\end{array}$

Columns 9 through 16

$\begin{array}{rrrrrrrr}0.0000 & -0.0000 & -0.0000 & 0.0000 & -0.0000 & -0.0000 & -0.0000 & 0.0000 \\ 0.0000 & -0.0000 & -0.0000 & 0.0000 & -0.0000 & -0.0000 & -0.0000 & 0.0000 \\ -0.0000 & -0.0000 & -0.0000 & 0.0000 & 0.0000 & -0.0000 & -0.0000 & 0.0000 \\ -0.0000 & -0.0000 & -0.0000 & 0.0000 & 0.0000 & 0.0000 & -0.0000 & -0.0000 \\ -0.0000 & 0.0000 & -0.0000 & 0.0000 & 0.0000 & 0.0000 & -0.0000 & -0.0000 \\ -0.0000 & 0.0000 & -0.0000 & 0.0000 & 0.0000 & 0.0000 & -0.0000 & -0.0000 \\ \text { Columns } & 17 \text { through } 24 & & & & & \\ -0.0000 & 0.0000 & -0.0000 & -0.0000 & -0.0000 & -0.0000 & 0.0000 & -0.0000 \\ -0.0000 & 0.0000 & -0.0000 & -0.0000 & -0.0000 & -0.0000 & 0.0000 & -0.0000 \\ -0.0000 & 0.0000 & -0.0000 & -0.0000 & -0.0000 & 0.0000 & 0.0000 & -0.0000 \\ -0.0000 & 0.0000 & 0.0000 & -0.0000 & -0.0000 & 0.0000 & 0.0000 & 0.0000 \\ -0.0000 & 0.0000 & 0.0000 & -0.0000 & -0.0000 & 0.0000 & 0.0000 & 0.0000 \\ 0.0000 & 0.0000 & 0.0000 & -0.0000 & -0.0000 & 0.0000 & 0.0000 & 0.0000 \\ \text { Columns } & 25 \text { through } 31 & & & & & \\ 0.0000 & -0.0000 & -0.0000 & 0.0000 & 0.0138 & -0.0000 & 0.1000 & \\ 0.0000 & -0.0000 & -0.0000 & 0.0000 & 0 & 0.0000 & 0 & \\ -0.0000 & 0.0000 & -0.0000 & 0.0000 & -0.0000 & -0.0000 & 0.0000 & \\ -0.0000 & 0.0000 & 0.0000 & 0.0000 & 0 & 0.0000 & 0 & \\ -0.0000 & 0.0000 & 0.0000 & 0.0000 & 0.0000 & 0.0000 & -0.0000 & \\ -0.0000 & 0.0000 & 0.0000 & 0.0000 & 0.0000 & 0.0000 & -0.0000 & \end{array}$




\section{Restrição de $10 \%$ a Ativos Internacionais (2000 a 2005)}

[PortRisk, PortReturn, PortWts] = frontcon(ExpRetIntPais05, ExpCovIntPais05, [], PortReturnInt06,AssetBoundsInt05,GroupsInt05,GroupsBoundsInt05)

PortRisk $=$
0.0020
0.0020
0.0022
0.0030
0.0042
0.0055
0.0072
0.0095

PortReturn $=$

0.0135

0.0140

0.0145

0.0150

0.0155

0.0160

0.0165

0.0170

PortWts =

Columns 1 through 8

$\begin{array}{rrrrrrrr}0.8269 & 0.0203 & -0.0000 & -0.0000 & -0.0000 & -0.0000 & 0.0046 & -0.0000 \\ 0.8521 & 0.0333 & -0.0000 & -0.0000 & -0.0000 & -0.0000 & 0.0025 & -0.0000 \\ 0.9464 & 0.0536 & 0.0000 & -0.0000 & -0.0000 & 0.0000 & -0.0000 & -0.0000 \\ 0.6665 & 0.1766 & 0.1527 & -0.0000 & 0.0000 & -0.0000 & 0.0000 & -0.0000 \\ 0.3719 & 0.2810 & 0.3371 & -0.0000 & -0.0000 & -0.0000 & -0.0000 & -0.0000 \\ 0.0773 & 0.3854 & 0.5214 & -0.0000 & -0.0000 & 0.0000 & 0.0000 & 0.0000 \\ 0.0000 & 0.5845 & 0.3786 & -0.0000 & 0.0000 & 0.0019 & 0.0000 & 0.0000 \\ 0.0000 & 0.8188 & 0.1119 & -0.0000 & -0.0000 & 0.0048 & 0.0000 & 0.0000\end{array}$

Columns 9 through 16

$\begin{array}{rrrrrrrr}-0.0000 & -0.0000 & 0.0044 & -0.0000 & 0.0000 & -0.0000 & -0.0000 & 0.0000 \\ -0.0000 & -0.0000 & 0.0037 & -0.0000 & -0.0000 & -0.0000 & 0.0000 & -0.0000 \\ -0.0000 & -0.0000 & 0.0000 & 0.0000 & 0 & -0.0000 & 0.0000 & 0.0000 \\ 0.0000 & 0.0000 & -0.0000 & 0.0000 & 0.0000 & 0.0000 & -0.0000 & 0.0000 \\ -0.0000 & -0.0000 & 0.0000 & -0.0000 & -0.0000 & 0.0000 & -0.0000 & -0.0000 \\ -0.0000 & 0.0000 & 0.0000 & -0.0000 & 0.0000 & -0.0000 & 0.0000 & 0.0000 \\ -0.0000 & 0.0000 & 0.0000 & -0.0000 & 0.0000 & -0.0000 & -0.0000 & -0.0000 \\ -0.0000 & -0.0000 & -0.0000 & 0.0000 & 0.0000 & -0.0000 & -0.0000 & -0.0000\end{array}$


Columns 17 through 24

$\begin{array}{rrrrrrrr}-0.0000 & -0.0000 & -0.0000 & -0.0000 & -0.0000 & -0.0000 & 0.0000 & -0.0000 \\ 0.0000 & -0.0000 & -0.0000 & -0.0000 & 0.0000 & -0.0000 & 0.0000 & 0.0000 \\ -0.0000 & 0.0000 & -0.0000 & 0.0000 & -0.0000 & 0.0000 & 0 & 0.0000 \\ -0.0000 & -0.0000 & -0.0000 & 0.0000 & -0.0000 & -0.0000 & -0.0000 & -0.0000 \\ 0.0000 & -0.0000 & -0.0000 & 0.0000 & -0.0000 & 0.0000 & 0.0000 & -0.0000 \\ 0.0000 & -0.0000 & -0.0000 & 0.0000 & 0.0000 & 0.0000 & -0.0000 & -0.0000 \\ 0.0000 & 0.0000 & -0.0000 & 0.0000 & 0.0000 & 0.0000 & 0.0033 & -0.0000 \\ 0.0000 & -0.0000 & -0.0000 & -0.0000 & 0.0000 & -0.0000 & 0.0146 & -0.0000\end{array}$

Columns 25 through 31

$\begin{array}{rrrrrrr}0.0000 & 0.0000 & 0.0000 & 0.0000 & 0.0439 & -0.0000 & 0.1000 \\ 0.0000 & 0.0000 & -0.0000 & 0.0000 & 0.0084 & -0.0000 & 0.1000 \\ -0.0000 & 0.0000 & -0.0000 & 0.0000 & -0.0000 & -0.0000 & 0.0000 \\ -0.0000 & -0.0000 & 0.0000 & 0.0042 & 0.0000 & 0.0000 & 0.0000 \\ 0.0000 & -0.0000 & -0.0000 & 0.0101 & 0.0000 & 0.0000 & -0.0000 \\ 0.0000 & -0.0000 & 0.0000 & 0.0159 & 0.0000 & 0.0000 & -0.0000 \\ 0.0000 & -0.0000 & 0.0000 & 0.0317 & -0.0000 & 0.0000 & -0.0000 \\ 0.0000 & -0.0000 & -0.0000 & 0.0498 & 0.0000 & 0.0000 & 0.0000\end{array}$


Restrição de 20\% a Ativos Internacionais (2000 a 2005)

[PortRisk, PortReturn, PortWts] = frontcon(ExpRetIntPais05, ExpCovIntPais05, [], PortReturnInt06,AssetBoundsInt05,GroupsInt05,GroupsBoundsInt05)

PortRisk
0.0020
0.0020
0.0022
0.0030
0.0042
0.0055
0.0072
0.0095
0.0126
0.0179

PortReturn $=$

0.0135

0.0140

0.0145

0.0150

0.0155

0.0160

0.0165

0.0170

0.0175

0.0180

PortWts $=$

Columns 1 through 8

$\begin{array}{rrrrrrrr}0.8269 & 0.0203 & -0.0000 & -0.0000 & 0.0000 & -0.0000 & 0.0046 & 0.0000 \\ 0.8521 & 0.0333 & -0.0000 & -0.0000 & 0.0000 & -0.0000 & 0.0025 & -0.0000 \\ 0.9464 & 0.0536 & 0 & -0.0000 & 0.0000 & -0.0000 & -0.0000 & -0.0000 \\ 0.6665 & 0.1766 & 0.1527 & -0.0000 & -0.0000 & -0.0000 & -0.0000 & -0.0000 \\ 0.3719 & 0.2810 & 0.3371 & -0.0000 & 0.0000 & -0.0000 & 0.0000 & 0.0000 \\ 0.0773 & 0.3854 & 0.5214 & 0.0000 & -0.0000 & -0.0000 & 0.0000 & -0.0000 \\ 0.0000 & 0.5845 & 0.3786 & 0.0000 & 0.0000 & 0.0019 & -0.0000 & -0.0000 \\ 0.0000 & 0.8188 & 0.1119 & -0.0000 & 0.0000 & 0.0048 & 0.0000 & -0.0000 \\ -0.0000 & 0.8866 & -0.0000 & -0.0000 & 0.0000 & 0.0213 & -0.0000 & 0.0000 \\ -0.0000 & 0.8000 & -0.0000 & 0.0000 & 0.0000 & 0.0328 & -0.0000 & -0.0000\end{array}$

Columns 9 through 16

$\begin{array}{rrrrrrrr}0.0000 & -0.0000 & 0.0044 & -0.0000 & 0.0000 & 0.0000 & -0.0000 & 0.0000\end{array}$

$\begin{array}{llllllll}-0.0000 & 0.0000 & 0.0037 & -0.0000 & -0.0000 & -0.0000 & -0.0000 & -0.0000\end{array}$ 


$\begin{array}{rrrrrrrr}-0.0000 & -0.0000 & 0.0000 & -0.0000 & 0.0000 & 0.0000 & 0.0000 & -0.0000 \\ -0.0000 & 0.0000 & -0.0000 & -0.0000 & -0.0000 & 0.0000 & -0.0000 & -0.0000 \\ -0.0000 & 0.0000 & 0.0000 & -0.0000 & -0.0000 & -0.0000 & 0.0000 & -0.0000 \\ -0.0000 & 0.0000 & 0.0000 & -0.0000 & 0.0000 & -0.0000 & 0.0000 & 0.0000 \\ -0.0000 & -0.0000 & 0.0000 & -0.0000 & 0.0000 & 0.0000 & 0.0000 & 0.0000 \\ -0.0000 & -0.0000 & 0.0000 & 0.0000 & 0.0000 & -0.0000 & -0.0000 & -0.0000 \\ -0.0000 & -0.0000 & 0.0000 & 0.0000 & 0.0000 & 0.0000 & 0.0000 & -0.0000 \\ -0.0000 & 0.0000 & -0.0000 & 0.0000 & 0.0000 & -0.0000 & -0.0000 & -0.0000\end{array}$

Columns 17 through 24

$\begin{array}{rrrrrrrr}0.0000 & 0.0000 & -0.0000 & 0.0000 & -0.0000 & -0.0000 & -0.0000 & -0.0000 \\ -0.0000 & 0.0000 & -0.0000 & 0.0000 & 0.0000 & -0.0000 & -0.0000 & 0.0000 \\ -0.0000 & 0.0000 & -0.0000 & 0.0000 & 0.0000 & 0.0000 & 0 & 0.0000 \\ 0.0000 & 0.0000 & -0.0000 & 0.0000 & -0.0000 & 0.0000 & -0.0000 & -0.0000 \\ 0.0000 & 0.0000 & -0.0000 & -0.0000 & -0.0000 & -0.0000 & 0.0000 & 0.0000 \\ -0.0000 & 0.0000 & -0.0000 & -0.0000 & -0.0000 & -0.0000 & -0.0000 & 0.0000 \\ -0.0000 & 0.0000 & -0.0000 & -0.0000 & 0.0000 & -0.0000 & 0.0033 & -0.0000 \\ 0.0000 & -0.0000 & -0.0000 & 0.0000 & 0.0000 & -0.0000 & 0.0146 & -0.0000 \\ 0.0000 & -0.0000 & -0.0000 & 0.0000 & 0.0000 & -0.0000 & 0.0000 & 0.0000 \\ 0.0000 & 0.0000 & -0.0000 & 0.0000 & -0.0000 & -0.0000 & 0 & -0.0000\end{array}$

Columns 25 through 31

$\begin{array}{rrrrrrr}0.0000 & 0.0000 & -0.0000 & 0.0000 & 0.0439 & -0.0000 & 0.1000 \\ 0.0000 & -0.0000 & -0.0000 & 0.0000 & 0.0084 & -0.0000 & 0.1000 \\ 0.0000 & -0.0000 & 0.0000 & -0.0000 & -0.0000 & -0.0000 & 0.0000 \\ 0.0000 & 0.0000 & -0.0000 & 0.0042 & -0.0000 & -0.0000 & 0.0000 \\ -0.0000 & -0.0000 & -0.0000 & 0.0101 & -0.0000 & 0.0000 & -0.0000 \\ -0.0000 & -0.0000 & 0.0000 & 0.0159 & -0.0000 & 0.0000 & -0.0000 \\ -0.0000 & -0.0000 & 0.0000 & 0.0317 & 0.0000 & 0.0000 & -0.0000 \\ 0.0000 & 0.0000 & 0.0000 & 0.0498 & 0.0000 & 0.0000 & -0.0000 \\ -0.0000 & -0.0000 & -0.0000 & 0.0921 & 0.0000 & -0.0000 & 0.0000 \\ 0.0000 & -0.0000 & -0.0000 & 0.1672 & -0.0000 & 0.0000 & 0.0000\end{array}$




\section{Restrição de 30\% a Ativos Internacionais (2000 a 2005)}

[PortRisk, PortReturn, PortWts] = frontcon(ExpRetIntPais05, ExpCovIntPais05, [], PortReturnInt06,AssetBoundsInt05,GroupsInt05,GroupsBoundsInt05)

PortRisk $=$
0.0020
0.0020
0.0022
0.0030
0.0042
0.0055
0.0072
0.0095
0.0126
0.0178
0.0241

PortReturn $=$

0.0135

0.0140

0.0145

0.0150

0.0155

0.0160

0.0165

0.0170

0.0175

0.0180

0.0185

PortWts =

Columns 1 through 8

$\begin{array}{rrrrrrrr}0.8269 & 0.0203 & -0.0000 & -0.0000 & 0.0000 & 0.0000 & 0.0046 & 0.0000 \\ 0.8521 & 0.0333 & -0.0000 & -0.0000 & -0.0000 & -0.0000 & 0.0025 & -0.0000 \\ 0.9464 & 0.0536 & -0.0000 & -0.0000 & 0.0000 & -0.0000 & -0.0000 & -0.0000 \\ 0.6665 & 0.1766 & 0.1527 & -0.0000 & -0.0000 & -0.0000 & -0.0000 & -0.0000 \\ 0.3719 & 0.2810 & 0.3371 & -0.0000 & 0.0000 & 0.0000 & -0.0000 & 0.0000 \\ 0.0773 & 0.3854 & 0.5214 & 0.0000 & 0.0000 & -0.0000 & -0.0000 & -0.0000 \\ 0.0000 & 0.5845 & 0.3786 & -0.0000 & -0.0000 & 0.0019 & 0.0000 & -0.0000 \\ 0.0000 & 0.8188 & 0.1119 & -0.0000 & -0.0000 & 0.0048 & 0.0000 & -0.0000 \\ -0.0000 & 0.8866 & -0.0000 & -0.0000 & -0.0000 & 0.0213 & -0.0000 & 0.0000 \\ -0.0000 & 0.7981 & -0.0000 & 0.0000 & -0.0000 & 0.0408 & 0.0000 & 0.0000 \\ -0.0000 & 0.7096 & -0.0000 & -0.0000 & 0.0000 & 0.0603 & -0.0000 & -0.0000\end{array}$


Columns 9 through 16

$\begin{array}{rrrrrrrr}-0.0000 & 0.0000 & 0.0044 & 0.0000 & -0.0000 & -0.0000 & 0.0000 & 0.0000 \\ -0.0000 & -0.0000 & 0.0037 & -0.0000 & -0.0000 & -0.0000 & 0.0000 & -0.0000 \\ -0.0000 & 0.0000 & 0.0000 & -0.0000 & -0.0000 & 0.0000 & 0.0000 & -0.0000 \\ -0.0000 & 0.0000 & -0.0000 & 0.0000 & 0.0000 & 0.0000 & -0.0000 & -0.0000 \\ -0.0000 & 0.0000 & 0.0000 & 0.0000 & -0.0000 & -0.0000 & 0.0000 & -0.0000 \\ -0.0000 & 0.0000 & 0.0000 & -0.0000 & -0.0000 & -0.0000 & 0.0000 & -0.0000 \\ -0.0000 & 0.0000 & 0.0000 & -0.0000 & 0.0000 & -0.0000 & 0.0000 & 0.0000 \\ -0.0000 & -0.0000 & 0.0000 & 0.0000 & -0.0000 & 0.0000 & -0.0000 & -0.0000 \\ -0.0000 & 0.0000 & 0.0000 & -0.0000 & 0.0000 & -0.0000 & 0.0000 & 0.0000 \\ 0.0000 & -0.0000 & -0.0000 & 0.0000 & -0.0000 & -0.0000 & 0.0000 & 0.0000 \\ -0.0000 & -0.0000 & -0.0000 & 0.0000 & -0.0000 & 0.0000 & 0.0000 & -0.0000\end{array}$

Columns 17 through 24

$\begin{array}{rrrrrrrr}-0.0000 & 0.0000 & -0.0000 & 0.0000 & 0.0000 & -0.0000 & 0.0000 & -0.0000 \\ 0.0000 & 0.0000 & -0.0000 & 0.0000 & -0.0000 & -0.0000 & -0.0000 & 0.0000 \\ 0.0000 & 0.0000 & -0.0000 & 0.0000 & 0.0000 & 0.0000 & 0 & 0.0000 \\ -0.0000 & 0.0000 & -0.0000 & 0.0000 & -0.0000 & 0.0000 & 0.0000 & 0.0000 \\ 0.0000 & -0.0000 & -0.0000 & 0.0000 & -0.0000 & -0.0000 & 0 & 0.0000 \\ 0.0000 & 0.0000 & -0.0000 & -0.0000 & -0.0000 & -0.0000 & 0 & 0.0000 \\ -0.0000 & 0.0000 & -0.0000 & -0.0000 & 0.0000 & -0.0000 & 0.0033 & -0.0000 \\ 0.0000 & -0.0000 & -0.0000 & 0.0000 & -0.0000 & 0.0000 & 0.0146 & 0.0000 \\ 0.0000 & 0.0000 & -0.0000 & -0.0000 & -0.0000 & -0.0000 & -0.0000 & -0.0000 \\ -0.0000 & -0.0000 & -0.0000 & -0.0000 & -0.0000 & -0.0000 & 0 & 0.0000 \\ -0.0000 & 0.0000 & -0.0000 & 0.0000 & -0.0000 & 0.0000 & 0 & -0.0000\end{array}$

Columns 25 through 31

$\begin{array}{rcccccc}-0.0000 & -0.0000 & -0.0000 & -0.0000 & 0.0439 & -0.0000 & 0.1000 \\ 0.0000 & 0.0000 & 0.0000 & -0.0000 & 0.0084 & -0.0000 & 0.1000 \\ -0.0000 & 0.0000 & -0.0000 & -0.0000 & -0.0000 & -0.0000 & 0.0000 \\ 0.0000 & 0.0000 & 0.0000 & 0.0042 & -0.0000 & -0.0000 & -0.0000 \\ -0.0000 & -0.0000 & 0.0000 & 0.0101 & -0.0000 & 0.0000 & -0.0000 \\ -0.0000 & -0.0000 & 0.0000 & 0.0159 & 0.0000 & 0.0000 & -0.0000 \\ 0.0000 & -0.0000 & 0.0000 & 0.0317 & -0.0000 & 0.0000 & -0.0000 \\ 0.0000 & 0.0000 & 0.0000 & 0.0498 & 0.0000 & 0.0000 & -0.0000 \\ -0.0000 & 0.0000 & 0.0000 & 0.0921 & 0.0000 & 0.0000 & 0.0000 \\ 0.0000 & -0.0000 & -0.0000 & 0.1611 & -0.0000 & -0.0000 & 0.0000 \\ 0.0000 & -0.0000 & -0.0000 & 0.2301 & -0.0000 & 0.0000 & 0.0000\end{array}$




\section{Restrição de 40\% a Ativos Internacionais (2000 a 2005)}

[PortRisk, PortReturn, PortWts] = frontcon(ExpRetIntPais05, ExpCovIntPais05, [], PortReturnInt06,AssetBoundsInt05,GroupsInt05,GroupsBoundsInt05)

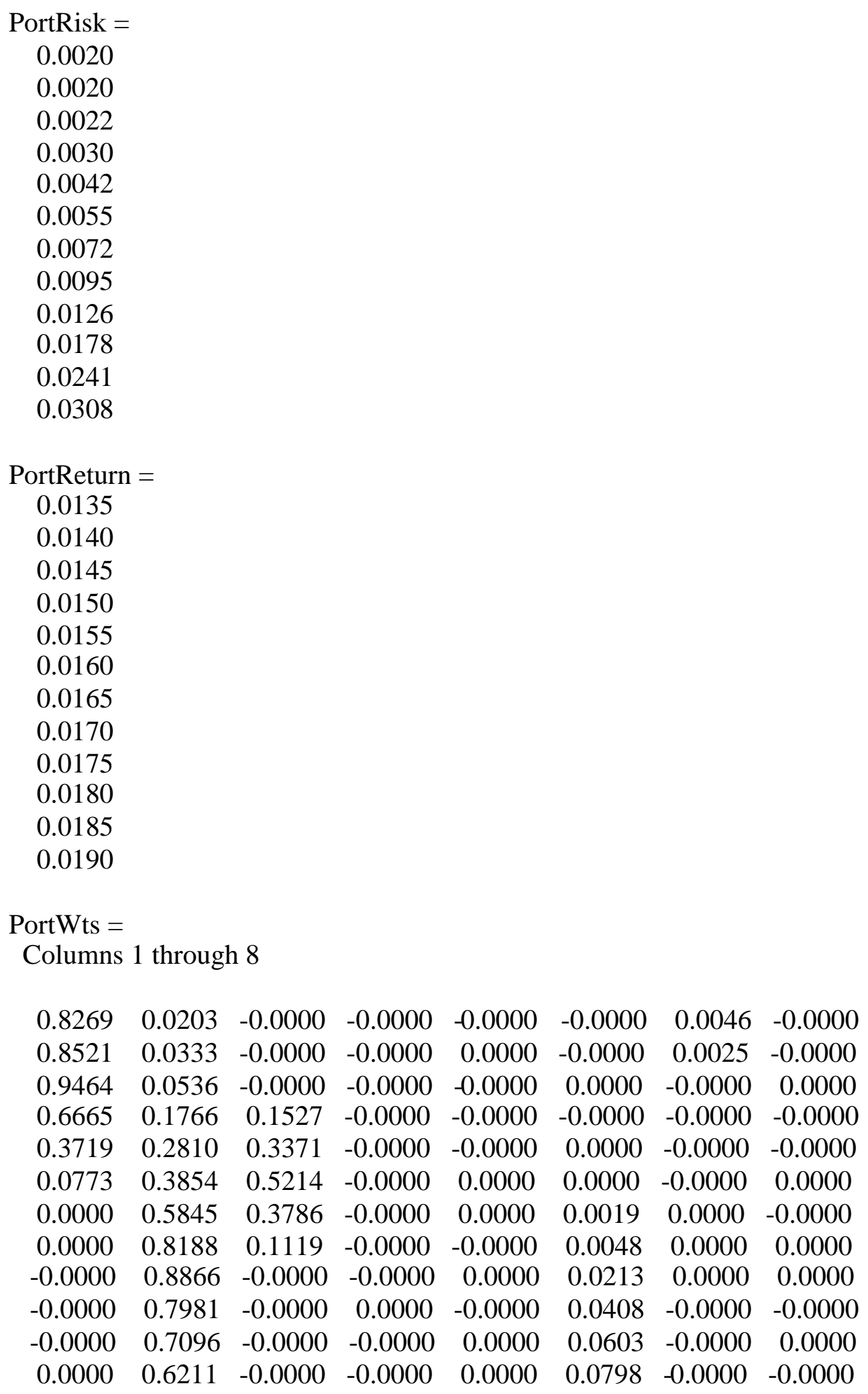

Columns 9 through 16 


$\begin{array}{rrrrrrrr}-0.0000 & 0.0000 & 0.0044 & 0.0000 & 0.0000 & 0.0000 & 0.0000 & -0.0000 \\ -0.0000 & 0.0000 & 0.0037 & -0.0000 & -0.0000 & -0.0000 & 0.0000 & -0.0000 \\ -0.0000 & 0.0000 & 0.0000 & -0.0000 & 0.0000 & 0.0000 & 0.0000 & -0.0000 \\ -0.0000 & 0.0000 & -0.0000 & 0.0000 & 0.0000 & 0.0000 & 0.0000 & 0.0000 \\ -0.0000 & 0.0000 & 0.0000 & -0.0000 & -0.0000 & -0.0000 & -0.0000 & 0.0000 \\ -0.0000 & -0.0000 & 0.0000 & 0.0000 & -0.0000 & -0.0000 & -0.0000 & 0.0000 \\ -0.0000 & 0.0000 & 0.0000 & -0.0000 & 0.0000 & -0.0000 & -0.0000 & -0.0000 \\ -0.0000 & 0.0000 & 0.0000 & 0.0000 & -0.0000 & 0.0000 & 0.0000 & 0.0000 \\ -0.0000 & 0.0000 & -0.0000 & 0.0000 & 0.0000 & -0.0000 & -0.0000 & -0.0000 \\ 0.0000 & 0.0000 & 0.0000 & 0.0000 & -0.0000 & -0.0000 & 0.0000 & 0.0000 \\ -0.0000 & 0.0000 & -0.0000 & -0.0000 & -0.0000 & 0.0000 & -0.0000 & 0.0000 \\ -0.0000 & -0.0000 & -0.0000 & 0.0000 & -0.0000 & -0.0000 & 0.0000 & 0.0000\end{array}$

Columns 17 through 24

$\begin{array}{rrrrrrrr}-0.0000 & -0.0000 & -0.0000 & 0.0000 & -0.0000 & -0.0000 & 0.0000 & 0.0000 \\ -0.0000 & 0.0000 & -0.0000 & 0.0000 & 0.0000 & 0.0000 & 0.0000 & 0.0000 \\ 0.0000 & 0.0000 & -0.0000 & 0.0000 & -0.0000 & -0.0000 & 0 & 0.0000 \\ 0.0000 & 0.0000 & -0.0000 & 0.0000 & 0.0000 & 0.0000 & -0.0000 & 0.0000 \\ -0.0000 & 0.0000 & -0.0000 & 0.0000 & 0.0000 & -0.0000 & -0.0000 & 0.0000 \\ 0.0000 & 0.0000 & -0.0000 & -0.0000 & -0.0000 & -0.0000 & 0.0000 & 0.0000 \\ 0.0000 & -0.0000 & -0.0000 & 0.0000 & 0.0000 & -0.0000 & 0.0033 & -0.0000 \\ -0.0000 & 0.0000 & -0.0000 & 0.0000 & 0.0000 & 0.0000 & 0.0146 & 0.0000 \\ -0.0000 & 0.0000 & -0.0000 & 0.0000 & 0.0000 & 0.0000 & 0 & 0.0000 \\ -0.0000 & -0.0000 & -0.0000 & 0.0000 & 0.0000 & 0.0000 & -0.0000 & -0.0000 \\ -0.0000 & -0.0000 & -0.0000 & 0.0000 & -0.0000 & 0.0000 & 0.0000 & -0.0000 \\ 0.0000 & -0.0000 & -0.0000 & 0.0000 & 0.0000 & -0.0000 & 0 & -0.0000\end{array}$

Columns 25 through 31

$\begin{array}{rrrrrrr}0.0000 & 0.0000 & 0.0000 & -0.0000 & 0.0439 & -0.0000 & 0.1000 \\ 0.0000 & -0.0000 & 0.0000 & 0.0000 & 0.0084 & -0.0000 & 0.1000 \\ 0.0000 & -0.0000 & 0.0000 & 0.0000 & 0.0000 & -0.0000 & 0.0000 \\ 0.0000 & 0.0000 & -0.0000 & 0.0042 & -0.0000 & 0.0000 & -0.0000 \\ 0.0000 & -0.0000 & 0.0000 & 0.0101 & 0.0000 & 0.0000 & -0.0000 \\ -0.0000 & -0.0000 & 0.0000 & 0.0159 & -0.0000 & 0.0000 & -0.0000 \\ 0.0000 & -0.0000 & 0.0000 & 0.0317 & -0.0000 & 0.0000 & 0.0000 \\ -0.0000 & 0.0000 & 0.0000 & 0.0498 & 0.0000 & 0.0000 & 0.0000 \\ 0.0000 & 0.0000 & -0.0000 & 0.0921 & 0.0000 & 0.0000 & 0 \\ -0.0000 & 0.0000 & 0.0000 & 0.1611 & 0.0000 & 0.0000 & 0.0000 \\ -0.0000 & -0.0000 & 0.0000 & 0.2301 & 0.0000 & 0.0000 & -0.0000 \\ 0.0000 & -0.0000 & 0.0000 & 0.2992 & -0.0000 & 0.0000 & 0.0000\end{array}$




\section{Restrição de 50\% a Ativos Internacionais (2000 a 2005)}

[PortRisk, PortReturn, PortWts] = frontcon(ExpRetIntPais05, ExpCovIntPais05, [], PortReturnInt06,AssetBoundsInt05,GroupsInt05,GroupsBoundsInt05)

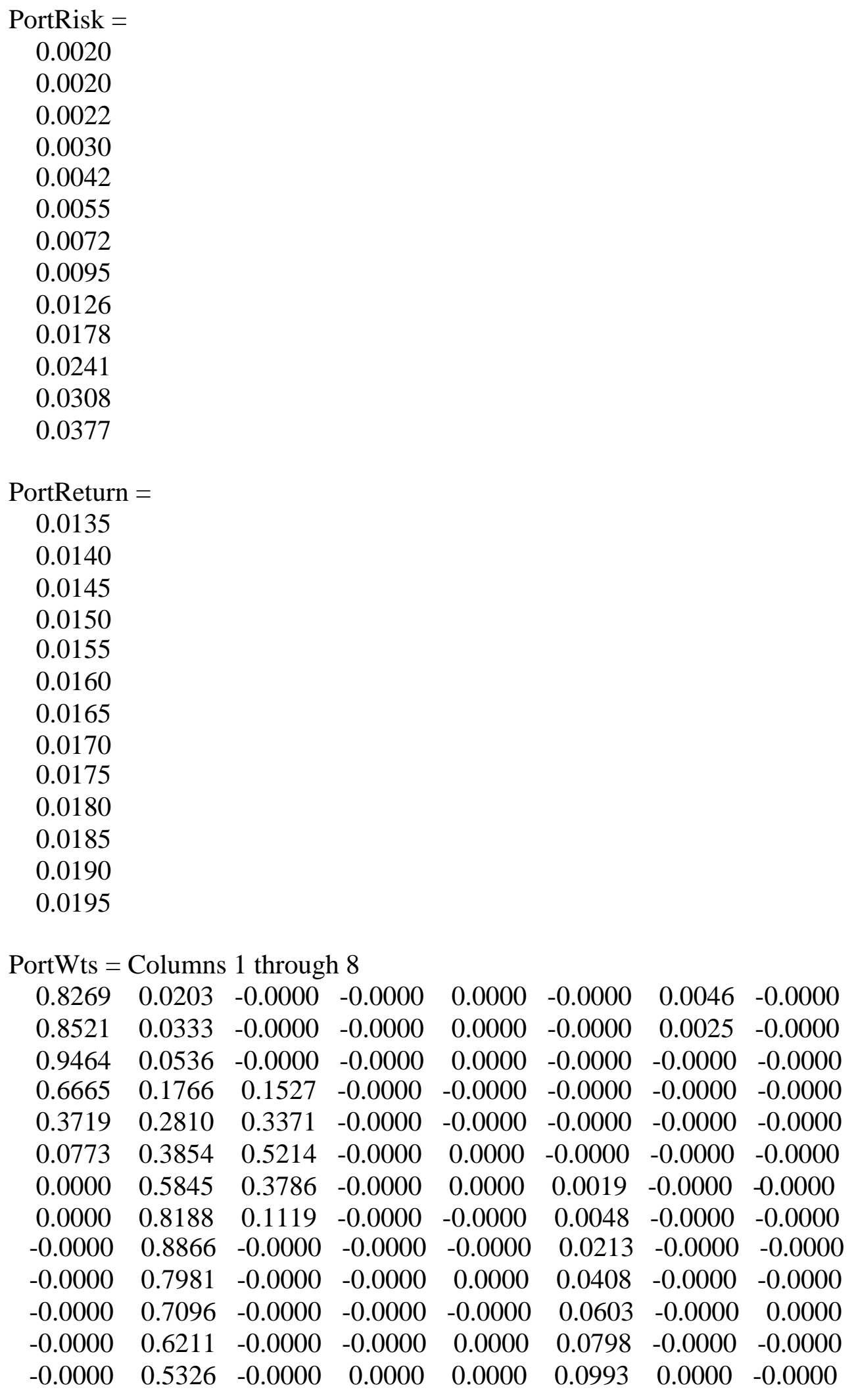

PortWts = Columns 1 through 8

$\begin{array}{rrrrrrrr}0.8269 & 0.0203 & -0.0000 & -0.0000 & 0.0000 & -0.0000 & 0.0046 & -0.0000 \\ 0.8521 & 0.0333 & -0.0000 & -0.0000 & 0.0000 & -0.0000 & 0.0025 & -0.0000 \\ 0.9464 & 0.0536 & -0.0000 & -0.0000 & 0.0000 & -0.0000 & -0.0000 & -0.0000 \\ 0.6665 & 0.1766 & 0.1527 & -0.0000 & -0.0000 & -0.0000 & -0.0000 & -0.0000 \\ 0.3719 & 0.2810 & 0.3371 & -0.0000 & -0.0000 & -0.0000 & -0.0000 & -0.0000 \\ 0.0773 & 0.3854 & 0.5214 & -0.0000 & 0.0000 & -0.0000 & -0.0000 & -0.0000 \\ 0.0000 & 0.5845 & 0.3786 & -0.0000 & 0.0000 & 0.0019 & -0.0000 & -0.0000 \\ 0.0000 & 0.8188 & 0.1119 & -0.0000 & -0.0000 & 0.0048 & -0.0000 & -0.0000 \\ -0.0000 & 0.8866 & -0.0000 & -0.0000 & -0.0000 & 0.0213 & -0.0000 & -0.0000 \\ -0.0000 & 0.7981 & -0.0000 & -0.0000 & 0.0000 & 0.0408 & -0.0000 & -0.0000 \\ -0.0000 & 0.7096 & -0.0000 & -0.0000 & -0.0000 & 0.0603 & -0.0000 & 0.0000 \\ -0.0000 & 0.6211 & -0.0000 & -0.0000 & 0.0000 & 0.0798 & -0.0000 & -0.0000 \\ -0.0000 & 0.5326 & -0.0000 & 0.0000 & 0.0000 & 0.0993 & 0.0000 & -0.0000\end{array}$


Columns 9 through 16

$\begin{array}{rrrrrrrr}-0.0000 & -0.0000 & 0.0044 & -0.0000 & -0.0000 & -0.0000 & -0.0000 & -0.0000 \\ -0.0000 & 0.0000 & 0.0037 & 0.0000 & -0.0000 & -0.0000 & -0.0000 & 0.0000 \\ -0.0000 & -0.0000 & 0.0000 & -0.0000 & 0.0000 & 0.0000 & 0.0000 & 0.0000 \\ -0.0000 & -0.0000 & -0.0000 & -0.0000 & -0.0000 & -0.0000 & 0.0000 & 0.0000 \\ -0.0000 & -0.0000 & 0.0000 & -0.0000 & -0.0000 & 0.0000 & -0.0000 & -0.0000 \\ -0.0000 & 0.0000 & 0.0000 & -0.0000 & 0.0000 & 0.0000 & -0.0000 & 0.0000 \\ -0.0000 & -0.0000 & 0.0000 & -0.0000 & 0.0000 & -0.0000 & -0.0000 & -0.0000 \\ -0.0000 & -0.0000 & -0.0000 & -0.0000 & -0.0000 & -0.0000 & -0.0000 & 0.0000 \\ -0.0000 & -0.0000 & -0.0000 & -0.0000 & 0.0000 & -0.0000 & 0.0000 & -0.0000 \\ -0.0000 & -0.0000 & 0.0000 & -0.0000 & 0 & -0.0000 & 0.0000 & 0.0000 \\ 0.0000 & 0.0000 & -0.0000 & 0.0000 & 0.0000 & -0.0000 & 0.0000 & -0.0000 \\ -0.0000 & -0.0000 & -0.0000 & -0.0000 & -0.0000 & -0.0000 & 0.0000 & 0.0000 \\ -0.0000 & 0.0000 & -0.0000 & 0.0000 & 0.0000 & 0.0000 & -0.0000 & -0.0000\end{array}$

Columns 17 through 24

$\begin{array}{rrrrrrrr}-0.0000 & -0.0000 & -0.0000 & -0.0000 & -0.0000 & 0.0000 & 0.0000 & 0.0000 \\ -0.0000 & -0.0000 & -0.0000 & 0.0000 & 0.0000 & 0.0000 & -0.0000 & -0.0000 \\ -0.0000 & 0.0000 & -0.0000 & 0.0000 & -0.0000 & 0.0000 & 0 & 0.0000 \\ 0.0000 & 0.0000 & -0.0000 & 0.0000 & -0.0000 & 0.0000 & 0.0000 & 0.0000 \\ 0.0000 & -0.0000 & -0.0000 & 0.0000 & -0.0000 & 0.0000 & -0.0000 & 0.0000 \\ -0.0000 & 0.0000 & -0.0000 & 0.0000 & 0.0000 & 0.0000 & 0.0000 & 0.0000 \\ -0.0000 & -0.0000 & -0.0000 & 0.0000 & 0.0000 & -0.0000 & 0.0033 & -0.0000 \\ 0.0000 & 0.0000 & -0.0000 & -0.0000 & 0.0000 & -0.0000 & 0.0146 & 0.0000 \\ 0.0000 & 0.0000 & -0.0000 & -0.0000 & -0.0000 & 0.0000 & 0 & -0.0000 \\ -0.0000 & 0.0000 & -0.0000 & -0.0000 & -0.0000 & -0.0000 & -0.0000 & 0.0000 \\ -0.0000 & 0.0000 & -0.0000 & -0.0000 & -0.0000 & 0.0000 & -0.0000 & -0.0000 \\ -0.0000 & -0.0000 & 0.0000 & 0.0000 & 0.0000 & 0.0000 & 0 & -0.0000 \\ -0.0000 & 0.0000 & -0.0000 & -0.0000 & -0.0000 & 0.0000 & 0 & -0.0000\end{array}$

Columns 25 through 31

$\begin{array}{rrrrrrr}-0.0000 & -0.0000 & 0.0000 & -0.0000 & 0.0439 & -0.0000 & 0.1000 \\ 0.0000 & 0 & -0.0000 & -0.0000 & 0.0084 & -0.0000 & 0.1000 \\ 0.0000 & -0.0000 & -0.0000 & -0.0000 & 0.0000 & -0.0000 & 0.0000 \\ 0.0000 & 0.0000 & -0.0000 & 0.0042 & -0.0000 & -0.0000 & 0.0000 \\ -0.0000 & -0.0000 & -0.0000 & 0.0101 & -0.0000 & -0.0000 & 0.0000 \\ 0.0000 & -0.0000 & 0.0000 & 0.0159 & -0.0000 & 0.0000 & -0.0000 \\ 0.0000 & -0.0000 & 0.0000 & 0.0317 & 0.0000 & -0.0000 & 0.0000 \\ 0.0000 & -0.0000 & -0.0000 & 0.0498 & 0.0000 & -0.0000 & -0.0000 \\ -0.0000 & 0.0000 & -0.0000 & 0.0921 & -0.0000 & -0.0000 & -0.0000 \\ 0.0000 & 0.0000 & -0.0000 & 0.1611 & -0.0000 & -0.0000 & -0.0000 \\ 0.0000 & -0.0000 & -0.0000 & 0.2301 & 0.0000 & -0.0000 & -0.0000 \\ -0.0000 & -0.0000 & -0.0000 & 0.2992 & 0.0000 & -0.0000 & -0.0000 \\ 0.0000 & -0.0000 & -0.0000 & 0.3682 & 0.0000 & 0.0000 & 0.0000\end{array}$




\section{Restrição Total a Ativos Internacionais (2001 a 2006)}

[PortRisk, PortReturn, PortWts] = frontcon(ExpRetIntPais06, ExpCovIntPais06, [], PortReturnInt06,AssetBoundsInt05,GroupsInt05,GroupsBoundsInt05)

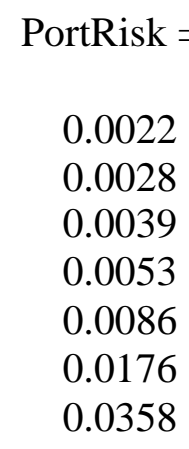

PortReturn $=$

0.0140

0.0145

0.0150

0.0155

0.0160

0.0165

0.0170

PortWts $=$

Columns 1 through 8

$\begin{array}{rrrrrrrr}0.8954 & 0.0437 & 0 & 0.0000 & -0.0000 & -0.0000 & 0.0000 & 0.0000 \\ 0.7276 & 0.1141 & 0.1583 & 0.0000 & -0.0000 & -0.0000 & -0.0000 & 0.0000 \\ 0.3676 & 0.2167 & 0.4157 & 0.0000 & -0.0000 & -0.0000 & -0.0000 & 0 \\ 0.0076 & 0.3193 & 0.6730 & 0.0000 & -0.0000 & 0.0000 & -0.0000 & -0.0000 \\ 0.0000 & 0.7777 & 0.1895 & 0.0000 & -0.0000 & -0.0000 & -0.0000 & 0.0328 \\ 0.0000 & 0.8001 & 0 & 0.0000 & 0.0000 & -0.0000 & 0.0000 & 0.1999 \\ -0.0000 & 0.5514 & 0 & 0.0000 & 0.0000 & -0.0000 & 0.0000 & 0.4486\end{array}$

Columns 9 through 16

$\begin{array}{rrrrrrrr}0.0000 & -0.0000 & -0.0000 & -0.0000 & -0.0000 & 0.0000 & 0.0000 & 0.0000 \\ 0.0000 & -0.0000 & -0.0000 & -0.0000 & -0.0000 & 0.0000 & 0.0000 & 0.0000 \\ 0.0000 & 0.0000 & -0.0000 & -0.0000 & -0.0000 & 0.0000 & 0.0000 & 0.0000 \\ 0.0000 & 0.0000 & -0.0000 & -0.0000 & -0.0000 & 0.0000 & 0.0000 & 0.0000 \\ 0.0000 & -0.0000 & -0.0000 & 0.0000 & -0.0000 & 0.0000 & 0.0000 & 0.0000 \\ 0.0000 & -0.0000 & -0.0000 & 0.0000 & -0.0000 & 0.0000 & -0.0000 & -0.0000 \\ 0.0000 & -0.0000 & -0.0000 & 0.0000 & -0.0000 & 0.0000 & -0.0000 & -0.0000\end{array}$

Columns 17 through 24 


$\begin{array}{rrrrrrrr}0.0000 & 0.0000 & -0.0000 & 0.0000 & 0.0000 & 0.0000 & 0.0000 & 0.0000 \\ 0.0000 & 0.0000 & -0.0000 & 0.0000 & 0.0000 & 0.0000 & 0.0000 & 0.0000 \\ 0.0000 & 0.0000 & 0.0000 & 0.0000 & -0.0000 & -0.0000 & 0.0000 & 0.0000 \\ 0.0000 & 0.0000 & 0.0000 & 0.0000 & -0.0000 & -0.0000 & 0.0000 & 0.0000 \\ 0.0000 & 0.0000 & 0.0000 & 0.0000 & 0.0000 & -0.0000 & 0.0000 & 0.0000 \\ 0.0000 & 0.0000 & 0.0000 & 0.0000 & 0.0000 & -0.0000 & 0.0000 & 0.0000 \\ 0.0000 & 0.0000 & 0.0000 & 0.0000 & 0.0000 & -0.0000 & 0.0000 & 0.0000\end{array}$

Columns 25 through 31

$\begin{array}{rrrrrrr}-0.0000 & -0.0000 & -0.0000 & 0.0000 & 0.0079 & -0.0000 & 0.0530 \\ -0.0000 & -0.0000 & -0.0000 & -0.0000 & 0.0000 & -0.0000 & -0.0000 \\ -0.0000 & -0.0000 & -0.0000 & -0.0000 & 0.0000 & -0.0000 & 0.0000 \\ 0.0000 & -0.0000 & -0.0000 & -0.0000 & -0.0000 & 0.0000 & -0.0000 \\ 0.0000 & -0.0000 & -0.0000 & 0.0000 & 0.0000 & 0.0000 & 0 \\ 0.0000 & -0.0000 & -0.0000 & 0.0000 & -0.0000 & 0.0000 & 0 \\ 0.0000 & -0.0000 & -0.0000 & 0.0000 & 0.0000 & 0.0000 & 0\end{array}$




\section{Restrição de 10\% a Ativos Internacionais (2001 a 2006)}

[PortRisk, PortReturn, PortWts] = frontcon(ExpRetIntPais06, ExpCovIntPais06, [], PortReturnInt06,AssetBoundsInt05,GroupsInt05,GroupsBoundsInt05)

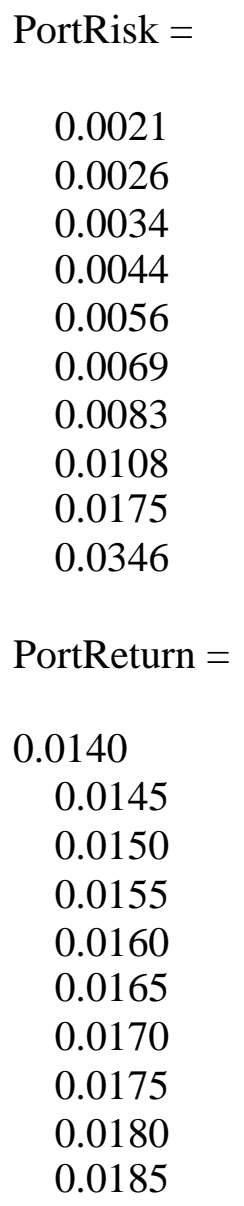

PortWts =

Columns 1 through 8

$\begin{array}{rrrrrrrr}0.8534 & 0.0561 & -0.0000 & 0.0000 & -0.0000 & 0.0000 & -0.0000 & -0.0000 \\ 0.8617 & 0.1072 & 0.0092 & -0.0000 & 0.0000 & 0.0000 & -0.0000 & 0.0000 \\ 0.6639 & 0.1838 & 0.1199 & 0.0000 & 0.0000 & -0.0000 & -0.0000 & 0.0000 \\ 0.4387 & 0.2672 & 0.2482 & 0.0000 & -0.0000 & 0.0000 & 0.0000 & -0.0000 \\ 0.2136 & 0.3506 & 0.3766 & -0.0000 & 0.0000 & 0.0000 & 0.0000 & 0.0000 \\ -0.0000 & 0.4350 & 0.4913 & 0.0000 & 0.0000 & -0.0000 & 0.0000 & -0.0000 \\ 0 & 0.5686 & 0.3314 & -0.0000 & 0.0000 & 0.0000 & 0.0000 & 0 \\ 0.0000 & 0.7429 & 0.1571 & 0.0000 & -0.0000 & 0.0140 & 0.0000 & -0.0000 \\ 0 & 0.7642 & 0.0000 & -0.0000 & 0.0000 & 0.0000 & -0.0000 & 0.1358 \\ 0.0000 & 0.5154 & 0.0000 & 0.0000 & -0.0000 & 0.0000 & -0.0000 & 0.3846\end{array}$

Columns 9 through 16

$\begin{array}{llllllll}-0.0000 & 0.0000 & 0.0075 & -0.0000 & 0.0000 & -0.0000 & -0.0000 & 0.0000\end{array}$ 


$\begin{array}{rrrrrrrr}0.0000 & 0.0000 & 0.0033 & -0.0000 & 0.0000 & -0.0000 & -0.0000 & -0.0000 \\ 0.0000 & 0.0000 & -0.0000 & -0.0000 & -0.0000 & 0.0000 & -0.0000 & -0.0000 \\ -0.0000 & 0.0000 & 0.0000 & 0.0000 & -0.0000 & 0.0000 & 0.0000 & 0.0000 \\ -0.0000 & 0.0000 & -0.0000 & 0.0000 & -0.0000 & 0.0000 & 0.0000 & -0.0000 \\ -0.0000 & 0.0000 & 0.0000 & 0.0000 & -0.0000 & -0.0000 & 0.0000 & -0.0000 \\ -0.0000 & 0.0000 & 0.0000 & 0.0000 & -0.0000 & 0.0000 & -0.0000 & -0.0000 \\ -0.0000 & 0.0000 & 0.0000 & 0.0000 & 0.0000 & 0.0000 & -0.0000 & 0.0000 \\ -0.0000 & 0.0000 & 0.0000 & 0.0000 & 0.0000 & 0.0000 & 0.0000 & 0.0000 \\ 0.0000 & -0.0000 & -0.0000 & 0.0000 & -0.0000 & 0.0000 & -0.0000 & -0.0000\end{array}$

Columns 17 through 24

$\begin{array}{rrrrrrrr}-0.0000 & 0.0000 & 0.0000 & 0.0000 & 0.0000 & 0.0000 & 0.0069 & 0.0000 \\ 0.0000 & 0.0000 & 0.0000 & 0.0000 & 0.0000 & 0.0000 & 0.0139 & -0.0000 \\ 0.0000 & -0.0000 & -0.0000 & -0.0000 & 0.0000 & 0.0000 & 0.0206 & -0.0000 \\ 0.0000 & -0.0000 & 0.0000 & 0.0000 & -0.0000 & 0.0000 & 0.0270 & 0.0000 \\ 0.0000 & -0.0000 & 0.0000 & -0.0000 & 0.0000 & 0.0000 & 0.0334 & 0.0000 \\ 0.0000 & 0.0000 & 0.0000 & -0.0000 & 0.0000 & -0.0000 & 0.0406 & 0.0000 \\ 0.0000 & 0.0000 & -0.0000 & 0.0000 & 0.0000 & 0.0000 & 0.0478 & 0.0000 \\ -0.0000 & -0.0000 & -0.0000 & 0.0000 & 0.0000 & 0.0000 & 0.0057 & -0.0000 \\ -0.0000 & 0.0000 & 0.0000 & 0.0000 & 0.0000 & 0.0000 & 0 & 0.0000 \\ 0.0000 & -0.0000 & -0.0000 & -0.0000 & -0.0000 & -0.0000 & 0 & 0.0000\end{array}$

Columns 25 through 31

$\begin{array}{rrrrrrr}-0.0000 & 0.0000 & 0.0000 & 0.0001 & 0.0061 & 0.0000 & 0.0698 \\ 0.0000 & -0.0000 & 0.0000 & 0.0047 & 0.0000 & 0.0000 & 0.0000 \\ 0.0000 & -0.0000 & 0.0000 & 0.0118 & -0.0000 & 0.0000 & -0.0000 \\ 0.0000 & 0.0000 & -0.0000 & 0.0188 & 0.0000 & 0.0000 & 0.0000 \\ 0.0000 & -0.0000 & -0.0000 & 0.0258 & 0.0000 & 0.0000 & -0.0000 \\ -0.0000 & -0.0000 & 0.0000 & 0.0331 & -0.0000 & -0.0000 & -0.0000 \\ -0.0000 & 0.0000 & 0.0000 & 0.0522 & 0.0000 & -0.0000 & -0.0000 \\ -0.0000 & 0.0000 & 0.0000 & 0.0803 & -0.0000 & 0.0000 & -0.0000 \\ 0.0000 & 0.0000 & 0.0000 & 0.1000 & -0.0000 & 0.0000 & 0.0000 \\ 0.0000 & -0.0000 & -0.0000 & 0.1000 & 0.0000 & 0.0000 & 0.0000\end{array}$




\section{Restrição de 20\% a Ativos Internacionais (2001 a 2006)}

[PortRisk, PortReturn, PortWts] = frontcon(ExpRetIntPais06,ExpCovIntPais06,[], PortReturnInt06,AssetBoundsInt05,GroupsInt05,GroupsBoundsInt05)

PortRisk $=$
0.0021
0.0026
0.0034
0.0044
0.0056
0.0069
0.0082
0.0098
0.0115
0.0134
0.0163

PortReturn $=$

0.0140

0.0145

0.0150

0.0155

0.0160

0.0165

0.0170

0.0175

0.0180

0.0185

0.0190

PortWts =

Columns 1 through 8

$\begin{array}{rrrrrrrr}0.8534 & 0.0561 & -0.0000 & -0.0000 & 0.0000 & 0.0000 & -0.0000 & 0.0000 \\ 0.8617 & 0.1072 & 0.0092 & 0.0000 & -0.0000 & 0.0000 & -0.0000 & 0.0000 \\ 0.6639 & 0.1838 & 0.1199 & 0.0000 & -0.0000 & 0.0000 & -0.0000 & -0.0000 \\ 0.4387 & 0.2672 & 0.2482 & 0.0000 & 0.0000 & 0.0000 & 0.0000 & -0.0000 \\ 0.2136 & 0.3506 & 0.3766 & -0.0000 & 0.0000 & 0.0000 & 0.0000 & 0.0000 \\ 0.0000 & 0.4350 & 0.4913 & 0.0000 & 0.0000 & -0.0000 & 0.0000 & 0 \\ 0 & 0.5365 & 0.3535 & -0.0000 & 0.0000 & 0.0000 & 0.0000 & -0.0000 \\ 0 & 0.6380 & 0.2157 & -0.0000 & -0.0000 & 0.0000 & 0.0000 & -0.0000 \\ -0.0000 & 0.7395 & 0.0779 & 0.0000 & 0.0000 & 0.0000 & 0.0000 & -0.0000 \\ 0 & 0.8000 & 0.0000 & 0.0000 & 0.0000 & 0.0054 & 0.0000 & -0.0000 \\ 0 & 0.8000 & 0.0000 & 0.0000 & 0.0000 & 0.0280 & -0.0000 & 0\end{array}$

Columns 9 through 16 


$\begin{array}{rrrrrrrr}-0.0000 & 0.0000 & 0.0075 & 0.0000 & 0.0000 & -0.0000 & -0.0000 & -0.0000 \\ -0.0000 & 0.0000 & 0.0033 & 0.0000 & -0.0000 & -0.0000 & 0.0000 & -0.0000 \\ -0.0000 & 0.0000 & 0.0000 & 0.0000 & 0.0000 & 0.0000 & 0.0000 & -0.0000 \\ -0.0000 & 0.0000 & 0.0000 & 0.0000 & -0.0000 & 0.0000 & 0.0000 & -0.0000 \\ -0.0000 & 0.0000 & -0.0000 & 0.0000 & -0.0000 & 0.0000 & 0.0000 & -0.0000 \\ -0.0000 & 0.0000 & 0.0000 & 0.0000 & -0.0000 & -0.0000 & 0.0000 & -0.0000 \\ -0.0000 & 0.0000 & 0.0000 & 0.0000 & -0.0000 & 0.0000 & -0.0000 & 0.0000 \\ -0.0000 & 0.0000 & -0.0000 & 0.0000 & 0 & -0.0000 & -0.0000 & 0.0000 \\ -0.0000 & 0.0000 & 0.0000 & 0.0000 & 0.0000 & -0.0000 & -0.0000 & -0.0000 \\ -0.0000 & 0.0000 & 0.0000 & -0.0000 & 0.0000 & 0.0000 & -0.0000 & 0.0000 \\ -0.0000 & 0.0000 & -0.0000 & 0.0000 & -0.0000 & -0.0000 & 0.0000 & 0.0000\end{array}$

Columns 17 through 24

$\begin{array}{rrrrrrrr}0.0000 & -0.0000 & 0.0000 & -0.0000 & 0.0000 & 0.0000 & 0.0069 & -0.0000 \\ 0.0000 & -0.0000 & 0.0000 & 0.0000 & -0.0000 & 0.0000 & 0.0139 & -0.0000 \\ -0.0000 & 0.0000 & 0.0000 & 0.0000 & -0.0000 & 0.0000 & 0.0206 & 0.0000 \\ 0.0000 & 0.0000 & 0.0000 & 0.0000 & -0.0000 & 0.0000 & 0.0270 & 0.0000 \\ 0.0000 & 0.0000 & 0.0000 & -0.0000 & 0.0000 & 0.0000 & 0.0334 & 0.0000 \\ 0.0000 & 0.0000 & 0.0000 & -0.0000 & 0.0000 & -0.0000 & 0.0406 & 0.0000 \\ 0.0000 & 0.0000 & 0.0000 & 0.0000 & 0.0000 & 0.0000 & 0.0635 & 0.0000 \\ 0.0000 & 0.0000 & -0.0000 & 0.0000 & 0.0000 & 0.0000 & 0.0863 & 0.0000 \\ 0.0000 & 0.0000 & 0.0000 & 0.0000 & 0.0000 & 0.0000 & 0.1092 & 0.0000 \\ -0.0000 & 0.0000 & -0.0000 & -0.0000 & 0.0000 & 0.0000 & 0.0914 & 0.0000 \\ -0.0000 & 0.0000 & -0.0000 & 0.0000 & -0.0000 & 0.0000 & 0.0302 & -0.0000\end{array}$

Columns 25 through 31

$\begin{array}{rrrrrrr}-0.0000 & 0.0000 & -0.0000 & 0.0001 & 0.0061 & 0.0000 & 0.0698 \\ 0.0000 & -0.0000 & -0.0000 & 0.0047 & -0.0000 & 0.0000 & -0.0000 \\ -0.0000 & 0.0000 & -0.0000 & 0.0118 & 0.0000 & 0.0000 & 0.0000 \\ 0.0000 & -0.0000 & -0.0000 & 0.0188 & 0.0000 & 0.0000 & 0.0000 \\ 0.0000 & -0.0000 & -0.0000 & 0.0258 & 0.0000 & -0.0000 & -0.0000 \\ -0.0000 & -0.0000 & -0.0000 & 0.0331 & -0.0000 & -0.0000 & -0.0000 \\ 0.0000 & 0.0000 & 0.0000 & 0.0466 & -0.0000 & -0.0000 & -0.0000 \\ -0.0000 & 0.0000 & 0.0000 & 0.0600 & 0.0000 & -0.0000 & -0.0000 \\ 0.0000 & -0.0000 & 0.0000 & 0.0734 & -0.0000 & 0.0000 & 0.0000 \\ -0.0000 & 0.0000 & 0.0000 & 0.1032 & -0.0000 & 0.0000 & 0.0000 \\ -0.0000 & 0.0000 & 0.0000 & 0.1417 & 0.0000 & 0.0000 & 0.0000\end{array}$




\section{Restrição de 30\% a Ativos Internacionais (2001 a 2006)}

[PortRisk, PortReturn, PortWts] = frontcon(ExpRetIntPais06,ExpCovIntPais06,[], PortReturnInt06,AssetBoundsInt05,GroupsInt05,GroupsBoundsInt05)

PortRisk $=$
0.0021
0.0026
0.0034
0.0044
0.0056
0.0069
0.0082
0.0098
0.0115
0.0132
0.0152
0.0174
0.0200
0.0232
0.0278

PortReturn $=$
0.0140
0.0145
0.0150
0.0155
0.0160
0.0165
0.0170
0.0175
0.0180
0.0185
0.0190
0.0195
0.0200
0.0205
0.0210

PortWts $=$

Columns 1 through 8

$\begin{array}{rrrrrrrr}0.8534 & 0.0561 & -0.0000 & -0.0000 & 0.0000 & 0.0000 & -0.0000 & 0.0000 \\ 0.8617 & 0.1072 & 0.0092 & -0.0000 & -0.0000 & 0.0000 & 0.0000 & 0.0000 \\ 0.6639 & 0.1838 & 0.1199 & 0.0000 & 0.0000 & 0.0000 & -0.0000 & -0.0000 \\ 0.4387 & 0.2672 & 0.2482 & 0.0000 & 0.0000 & 0.0000 & 0.0000 & -0.0000 \\ 0.2136 & 0.3506 & 0.3766 & 0.0000 & 0.0000 & 0.0000 & 0.0000 & 0.0000 \\ 0.0000 & 0.4350 & 0.4913 & 0.0000 & 0.0000 & -0.0000 & 0.0000 & 0 \\ 0 & 0.5365 & 0.3535 & -0.0000 & 0.0000 & 0.0000 & -0.0000 & -0.0000\end{array}$




$\begin{array}{rrrrrrrr}0 & 0.6380 & 0.2157 & 0.0000 & 0.0000 & 0.0000 & -0.0000 & -0.0000 \\ 0 & 0.7395 & 0.0779 & 0.0000 & 0.0000 & 0.0000 & -0.0000 & 0.0000 \\ 0 & 0.7790 & 0.0000 & -0.0000 & 0.0000 & 0.0000 & 0.0000 & -0.0000 \\ 0 & 0.7377 & 0.0000 & -0.0000 & -0.0000 & 0.0000 & 0.0000 & 0.0000 \\ -0.0000 & 0.7000 & 0.0000 & 0.0000 & 0.0000 & 0.0035 & 0.0000 & 0.0000 \\ 0.0000 & 0.7000 & 0.0000 & 0.0000 & 0.0000 & 0.0261 & 0.0000 & -0.0000 \\ 0 & 0.7000 & 0.0000 & 0.0000 & 0.0000 & 0.0487 & 0.0000 & 0 \\ -0.0000 & 0.6615 & 0.0000 & -0.0000 & -0.0000 & 0.0224 & -0.0000 & 0.0385\end{array}$

Columns 9 through 16

$\begin{array}{rrrrrrrr}-0.0000 & 0.0000 & 0.0075 & 0.0000 & 0.0000 & 0.0000 & -0.0000 & -0.0000 \\ -0.0000 & 0.0000 & 0.0033 & 0.0000 & -0.0000 & -0.0000 & 0.0000 & -0.0000 \\ -0.0000 & 0.0000 & 0.0000 & 0.0000 & 0.0000 & 0.0000 & 0.0000 & -0.0000 \\ -0.0000 & 0.0000 & 0.0000 & -0.0000 & -0.0000 & 0.0000 & 0.0000 & -0.0000 \\ -0.0000 & 0.0000 & -0.0000 & -0.0000 & -0.0000 & 0.0000 & 0.0000 & -0.0000 \\ -0.0000 & 0.0000 & 0.0000 & -0.0000 & -0.0000 & -0.0000 & 0.0000 & -0.0000 \\ -0.0000 & 0.0000 & 0.0000 & 0.0000 & -0.0000 & 0.0000 & -0.0000 & 0.0000 \\ -0.0000 & 0.0000 & -0.0000 & 0.0000 & -0.0000 & 0.0000 & -0.0000 & 0.0000 \\ -0.0000 & 0.0000 & -0.0000 & 0.0000 & 0.0000 & 0.0000 & -0.0000 & 0.0000 \\ -0.0000 & 0.0000 & -0.0000 & 0.0000 & 0.0000 & -0.0000 & -0.0000 & 0.0000 \\ -0.0000 & 0.0000 & -0.0000 & 0.0000 & 0 & 0.0000 & -0.0000 & 0.0000 \\ -0.0000 & 0.0000 & 0.0000 & -0.0000 & 0 & -0.0000 & 0.0000 & 0.0000 \\ -0.0000 & 0.0000 & -0.0000 & 0.0000 & 0.0000 & 0.0000 & 0.0000 & 0.0000 \\ -0.0000 & 0.0000 & -0.0000 & 0.0000 & 0.0000 & -0.0000 & 0.0000 & 0.0000 \\ 0.0000 & -0.0000 & 0.0000 & -0.0000 & -0.0000 & -0.0000 & 0.0000 & -0.0000\end{array}$

Columns 17 through 24

$\begin{array}{rrrrrrrr}0.0000 & -0.0000 & 0.0000 & 0.0000 & 0.0000 & 0.0000 & 0.0069 & -0.0000 \\ 0.0000 & 0.0000 & 0.0000 & 0.0000 & 0.0000 & 0.0000 & 0.0139 & 0.0000 \\ 0.0000 & 0.0000 & 0.0000 & 0.0000 & -0.0000 & 0.0000 & 0.0206 & -0.0000 \\ 0.0000 & 0.0000 & 0.0000 & 0.0000 & -0.0000 & 0.0000 & 0.0270 & 0.0000 \\ 0.0000 & 0.0000 & 0.0000 & -0.0000 & 0.0000 & 0.0000 & 0.0334 & 0.0000 \\ 0.0000 & 0.0000 & 0.0000 & -0.0000 & 0.0000 & -0.0000 & 0.0406 & 0.0000 \\ 0.0000 & 0.0000 & 0.0000 & 0.0000 & -0.0000 & 0.0000 & 0.0635 & 0.0000 \\ 0.0000 & 0.0000 & 0.0000 & 0.0000 & 0.0000 & 0.0000 & 0.0863 & 0.0000 \\ 0.0000 & 0.0000 & 0.0000 & -0.0000 & 0.0000 & 0.0000 & 0.1092 & -0.0000 \\ 0.0000 & 0.0000 & -0.0000 & 0.0000 & 0.0000 & 0.0000 & 0.1302 & 0.0000 \\ 0.0000 & 0.0000 & -0.0000 & -0.0000 & -0.0000 & 0.0000 & 0.1489 & 0.0000 \\ -0.0000 & 0.0000 & -0.0000 & -0.0000 & 0.0000 & 0.0000 & 0.1603 & -0.0000 \\ 0.0000 & 0.0000 & -0.0000 & -0.0000 & -0.0000 & 0.0000 & 0.0991 & 0.0000 \\ 0.0000 & 0.0000 & 0.0000 & 0.0000 & -0.0000 & 0.0000 & 0.0380 & 0.0000 \\ 0.0000 & 0.0000 & -0.0000 & 0.0000 & 0.0000 & 0.0000 & 0.0000 & 0.0000\end{array}$

Columns 25 through 31

$\begin{array}{rrrrrrc}-0.0000 & 0.0000 & -0.0000 & 0.0001 & 0.0061 & 0.0000 & 0.0698 \\ -0.0000 & -0.0000 & -0.0000 & 0.0047 & 0.0000 & 0.0000 & -0.0000 \\ -0.0000 & 0.0000 & -0.0000 & 0.0118 & 0.0000 & 0.0000 & 0.0000\end{array}$




$\begin{array}{rrrrrrr}0.0000 & -0.0000 & -0.0000 & 0.0188 & 0.0000 & 0.0000 & 0.0000 \\ 0.0000 & -0.0000 & -0.0000 & 0.0258 & 0.0000 & -0.0000 & -0.0000 \\ -0.0000 & -0.0000 & -0.0000 & 0.0331 & -0.0000 & -0.0000 & -0.0000 \\ 0.0000 & 0.0000 & 0.0000 & 0.0466 & 0.0000 & -0.0000 & -0.0000 \\ -0.0000 & 0.0000 & 0.0000 & 0.0600 & 0.0000 & -0.0000 & -0.0000 \\ 0.0000 & -0.0000 & 0.0000 & 0.0734 & 0.0000 & 0.0000 & -0.0000 \\ -0.0000 & 0.0000 & 0.0000 & 0.0908 & -0.0000 & 0.0000 & 0.0000 \\ 0.0000 & 0.0000 & 0.0000 & 0.1134 & -0.0000 & 0.0000 & -0.0000 \\ -0.0000 & -0.0000 & 0.0000 & 0.1362 & 0.0000 & 0.0000 & -0.0000 \\ 0.0000 & -0.0000 & 0.0000 & 0.1748 & -0.0000 & 0.0000 & -0.0000 \\ -0.0000 & 0.0000 & 0.0000 & 0.2133 & -0.0000 & 0.0000 & 0.0000 \\ 0.0000 & -0.0000 & -0.0000 & 0.2776 & 0.0000 & 0.0000 & -0.0000\end{array}$


Restrição de 40\% a Ativos Internacionais (2001 a 2006)

[PortRisk, PortReturn, PortWts] = frontcon(ExpRetIntPais06,ExpCovIntPais06,[], PortReturnInt06,AssetBoundsInt05,GroupsInt05,GroupsBoundsInt05)

PortRisk

0.0021
0.0026
0.0034
0.0044
0.0056
0.0069
0.0082
0.0098
0.0115
0.0132
0.0152
0.0174
0.0196
0.0220
0.0244
0.0273
0.0306
0.0346

PortReturn $=$

0.0140

0.0145

0.0150

0.0155

0.0160

0.0165

0.0170

0.0175

0.0180

0.0185

0.0190

0.0195

0.0200

0.0205

0.0210

0.0215

0.0220

0.0225

PortWts = 
Columns 1 through 8

$\begin{array}{rrrrrrrr}0.8534 & 0.0561 & -0.0000 & -0.0000 & 0.0000 & 0.0000 & -0.0000 & 0.0000 \\ 0.8617 & 0.1072 & 0.0092 & -0.0000 & -0.0000 & 0.0000 & -0.0000 & 0.0000 \\ 0.6639 & 0.1838 & 0.1199 & 0.0000 & 0.0000 & 0.0000 & -0.0000 & 0.0000 \\ 0.4387 & 0.2672 & 0.2482 & 0.0000 & 0.0000 & 0.0000 & 0.0000 & -0.0000 \\ 0.2136 & 0.3506 & 0.3766 & 0.0000 & 0.0000 & 0.0000 & 0.0000 & 0.0000 \\ -0.0000 & 0.4350 & 0.4913 & 0.0000 & 0.0000 & -0.0000 & 0.0000 & 0.0000 \\ 0.0000 & 0.5365 & 0.3535 & -0.0000 & 0.0000 & 0.0000 & -0.0000 & -0.0000 \\ -0.0000 & 0.6380 & 0.2157 & 0.0000 & 0.0000 & 0.0000 & -0.0000 & -0.0000 \\ 0 & 0.7395 & 0.0779 & 0.0000 & 0.0000 & 0.0000 & -0.0000 & 0.0000 \\ 0 & 0.7790 & 0.0000 & 0.0000 & 0.0000 & 0.0000 & -0.0000 & 0 \\ 0 & 0.7377 & 0.0000 & -0.0000 & 0.0000 & 0.0000 & 0.0000 & -0.0000 \\ 0 & 0.6979 & 0.0000 & -0.0000 & 0.0000 & 0.0025 & 0.0000 & 0.0000 \\ 0.0000 & 0.6590 & 0.0000 & 0.0000 & 0.0000 & 0.0068 & 0.0000 & 0.0000 \\ -0.0000 & 0.6202 & 0.0000 & 0.0000 & 0.0000 & 0.0111 & 0.0000 & -0.0000 \\ 0.0000 & 0.6000 & 0.0000 & 0.0000 & 0.0000 & 0.0242 & 0.0000 & 0.0000 \\ 0 & 0.6000 & 0.0000 & 0.0000 & 0.0000 & 0.0468 & 0.0000 & -0.0000 \\ -0.0000 & 0.6000 & 0.0000 & 0.0000 & 0.0000 & 0.0694 & 0.0000 & 0 \\ 0.0000 & 0.5891 & -0.0000 & -0.0000 & -0.0000 & 0.0489 & 0.0000 & 0.0109\end{array}$

Columns 9 through 16

$\begin{array}{rrrrrrrr}-0.0000 & 0.0000 & 0.0075 & -0.0000 & 0.0000 & 0.0000 & 0.0000 & 0.0000 \\ -0.0000 & 0.0000 & 0.0033 & -0.0000 & -0.0000 & 0.0000 & 0.0000 & -0.0000 \\ -0.0000 & 0.0000 & 0.0000 & -0.0000 & -0.0000 & -0.0000 & 0.0000 & -0.0000 \\ -0.0000 & 0.0000 & 0.0000 & -0.0000 & 0 & 0.0000 & -0.0000 & -0.0000 \\ -0.0000 & 0.0000 & -0.0000 & -0.0000 & -0.0000 & 0.0000 & 0.0000 & -0.0000 \\ -0.0000 & 0.0000 & 0.0000 & -0.0000 & -0.0000 & -0.0000 & 0.0000 & -0.0000 \\ -0.0000 & 0.0000 & 0.0000 & 0.0000 & -0.0000 & 0.0000 & -0.0000 & 0.0000 \\ -0.0000 & 0.0000 & -0.0000 & 0.0000 & -0.0000 & 0.0000 & -0.0000 & 0.0000 \\ -0.0000 & 0.0000 & 0.0000 & 0.0000 & 0.0000 & 0.0000 & -0.0000 & 0.0000 \\ -0.0000 & -0.0000 & -0.0000 & 0.0000 & 0.0000 & 0.0000 & -0.0000 & 0.0000 \\ -0.0000 & -0.0000 & -0.0000 & 0.0000 & 0.0000 & -0.0000 & -0.0000 & 0.0000 \\ -0.0000 & 0.0000 & -0.0000 & -0.0000 & -0.0000 & 0.0000 & -0.0000 & 0.0000 \\ -0.0000 & 0.0000 & -0.0000 & -0.0000 & -0.0000 & 0.0000 & -0.0000 & 0.0000 \\ -0.0000 & 0.0000 & 0.0000 & -0.0000 & 0.0000 & -0.0000 & 0.0000 & 0.0000 \\ -0.0000 & 0.0000 & -0.0000 & 0.0000 & 0.0000 & 0.0000 & 0.0000 & 0.0000 \\ -0.0000 & 0.0000 & 0.0000 & 0.0000 & -0.0000 & 0.0000 & 0.0000 & -0.0000 \\ -0.0000 & 0.0000 & 0.0000 & 0.0000 & -0.0000 & -0.0000 & 0.0000 & 0.0000 \\ 0.0000 & -0.0000 & -0.0000 & 0.0000 & -0.0000 & 0.0000 & -0.0000 & 0.0000\end{array}$

Columns 17 through 24

$\begin{array}{cccccccc}-0.0000 & -0.0000 & 0.0000 & -0.0000 & 0.0000 & 0.0000 & 0.0069 & 0.0000 \\ 0.0000 & 0.0000 & 0.0000 & 0.0000 & 0.0000 & 0.0000 & 0.0139 & 0.0000 \\ 0.0000 & 0.0000 & 0.0000 & 0.0000 & -0.0000 & 0.0000 & 0.0206 & -0.0000 \\ 0.0000 & 0.0000 & 0.0000 & 0.0000 & -0.0000 & 0.0000 & 0.0270 & 0.0000 \\ 0.0000 & 0.0000 & 0.0000 & -0.0000 & 0.0000 & 0.0000 & 0.0334 & 0.0000 \\ 0.0000 & 0.0000 & 0.0000 & -0.0000 & 0.0000 & -0.0000 & 0.0406 & 0.0000\end{array}$




$\begin{array}{rrrrrrrr}0.0000 & 0.0000 & 0.0000 & 0.0000 & -0.0000 & 0.0000 & 0.0635 & 0.0000 \\ 0.0000 & 0.0000 & 0.0000 & 0.0000 & 0.0000 & 0.0000 & 0.0863 & 0.0000 \\ 0.0000 & 0.0000 & 0.0000 & -0.0000 & 0.0000 & 0.0000 & 0.1092 & -0.0000 \\ 0.0000 & 0.0000 & 0.0000 & -0.0000 & 0.0000 & 0.0000 & 0.1302 & -0.0000 \\ 0.0000 & 0.0000 & -0.0000 & -0.0000 & 0.0000 & 0.0000 & 0.1489 & 0.0000 \\ -0.0000 & 0.0000 & 0.0000 & 0.0000 & -0.0000 & 0.0000 & 0.1643 & 0.0000 \\ -0.0000 & 0.0000 & 0.0000 & -0.0000 & -0.0000 & 0.0000 & 0.1775 & -0.0000 \\ -0.0000 & 0.0000 & -0.0000 & -0.0000 & 0.0000 & 0.0000 & 0.1906 & -0.0000 \\ 0.0000 & 0.0000 & -0.0000 & -0.0000 & -0.0000 & 0.0000 & 0.1680 & -0.0000 \\ 0.0000 & 0.0000 & -0.0000 & -0.0000 & -0.0000 & 0.0000 & 0.1069 & -0.0000 \\ 0.0000 & 0.0000 & 0.0000 & -0.0000 & 0.0000 & 0.0000 & 0.0458 & 0.0000 \\ 0.0000 & 0.0000 & 0.0000 & -0.0000 & -0.0000 & 0.0000 & 0 & -0.0000\end{array}$

Columns 25 through 31

$\begin{array}{rrrrrrr}-0.0000 & -0.0000 & -0.0000 & 0.0001 & 0.0061 & 0.0000 & 0.0698 \\ -0.0000 & -0.0000 & -0.0000 & 0.0047 & 0.0000 & 0.0000 & -0.0000 \\ 0.0000 & 0.0000 & -0.0000 & 0.0118 & 0.0000 & 0.0000 & 0.0000 \\ 0.0000 & -0.0000 & -0.0000 & 0.0188 & 0.0000 & 0.0000 & 0.0000 \\ 0.0000 & -0.0000 & -0.0000 & 0.0258 & 0.0000 & -0.0000 & -0.0000 \\ -0.0000 & -0.0000 & -0.0000 & 0.0331 & -0.0000 & -0.0000 & -0.0000 \\ 0.0000 & 0.0000 & 0.0000 & 0.0466 & 0.0000 & -0.0000 & -0.0000 \\ -0.0000 & -0.0000 & 0.0000 & 0.0600 & 0.0000 & -0.0000 & -0.0000 \\ 0.0000 & -0.0000 & 0.0000 & 0.0734 & 0.0000 & -0.0000 & -0.0000 \\ 0.0000 & 0.0000 & 0.0000 & 0.0908 & -0.0000 & 0.0000 & -0.0000 \\ -0.0000 & 0.0000 & 0.0000 & 0.1134 & -0.0000 & 0.0000 & 0.0000 \\ -0.0000 & 0.0000 & 0.0000 & 0.1353 & -0.0000 & 0.0000 & -0.0000 \\ -0.0000 & 0.0000 & 0.0000 & 0.1567 & -0.0000 & 0.0000 & -0.0000 \\ 0.0000 & -0.0000 & 0.0000 & 0.1781 & 0.0000 & 0.0000 & -0.0000 \\ 0.0000 & -0.0000 & 0.0000 & 0.2078 & 0.0000 & 0.0000 & -0.0000 \\ 0.0000 & -0.0000 & 0.0000 & 0.2463 & 0.0000 & 0.0000 & -0.0000 \\ -0.0000 & -0.0000 & 0.0000 & 0.2848 & 0.0000 & -0.0000 & -0.0000 \\ -0.0000 & -0.0000 & -0.0000 & 0.3511 & -0.0000 & 0.0000 & -0.0000\end{array}$


Restrição de 50\% a Ativos Internacionais (2001 a 2006)

[PortRisk, PortReturn, PortWts] = frontcon(ExpRetIntPais06,ExpCovIntPais06,[], PortReturnInt06,AssetBoundsInt05,GroupsInt05,GroupsBoundsInt05)

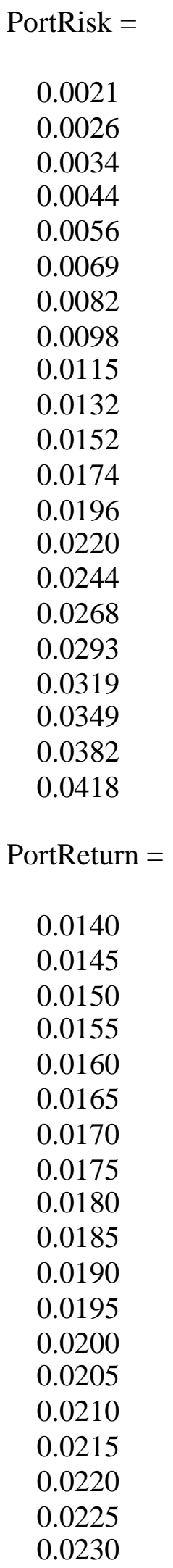


0.0235

0.0240

PortWts $=$ Columns 1 through 8

$\begin{array}{rrrrrrrr}0.8534 & 0.0561 & -0.0000 & 0.0000 & -0.0000 & -0.0000 & 0.0000 & -0.0000 \\ 0.8617 & 0.1072 & 0.0092 & 0.0000 & 0.0000 & -0.0000 & -0.0000 & -0.0000 \\ 0.6639 & 0.1838 & 0.1199 & 0.0000 & -0.0000 & -0.0000 & -0.0000 & 0.0000 \\ 0.4387 & 0.2672 & 0.2482 & 0.0000 & -0.0000 & -0.0000 & -0.0000 & 0.0000 \\ 0.2136 & 0.3506 & 0.3766 & 0.0000 & -0.0000 & -0.0000 & -0.0000 & -0.0000 \\ 0 & 0.4350 & 0.4913 & -0.0000 & -0.0000 & -0.0000 & -0.0000 & -0.0000 \\ 0 & 0.5365 & 0.3535 & -0.0000 & 0.0000 & -0.0000 & 0.0000 & 0.0000 \\ 0 & 0.6380 & 0.2157 & -0.0000 & -0.0000 & -0.0000 & 0.0000 & -0.0000 \\ 0.0000 & 0.7395 & 0.0779 & -0.0000 & -0.0000 & -0.0000 & -0.0000 & -0.0000 \\ -0.0000 & 0.7790 & 0.0000 & 0.0000 & 0.0000 & -0.0000 & 0.0000 & -0.0000 \\ 0 & 0.7377 & 0.0000 & 0.0000 & -0.0000 & -0.0000 & -0.0000 & -0.0000 \\ 0.0000 & 0.6979 & 0.0000 & 0.0000 & -0.0000 & 0.0025 & -0.0000 & -0.0000 \\ -0.0000 & 0.6590 & -0.0000 & 0.0000 & 0.0000 & 0.0068 & 0.0000 & 0.0000 \\ 0.0000 & 0.6202 & 0.0000 & -0.0000 & 0.0000 & 0.0111 & 0.0000 & 0.0000 \\ -0.0000 & 0.5813 & 0.0000 & 0.0000 & 0.0000 & 0.0154 & 0.0000 & 0.0000 \\ -0.0000 & 0.5424 & -0.0000 & 0.0000 & 0.0000 & 0.0197 & -0.0000 & -0.0000 \\ -0.0000 & 0.5036 & -0.0000 & -0.0000 & 0.0000 & 0.0240 & -0.0000 & -0.0000 \\ -0.0000 & 0.5000 & 0.0000 & -0.0000 & 0.0000 & 0.0449 & 0.0000 & 0.0000 \\ -0.0000 & 0.5000 & 0.0000 & -0.0000 & 0.0000 & 0.0675 & -0.0000 & 0.0000 \\ -0.0000 & 0.5000 & 0.0000 & -0.0000 & 0.0000 & 0.0900 & -0.0000 & 0.0000 \\ -0.0000 & 0.5000 & 0.0000 & -0.0000 & -0.0000 & 0.0877 & 0.0000 & -0.0000\end{array}$

Columns 9 through 16

$\begin{array}{rrrrrrrr}0.0000 & 0.0000 & 0.0075 & -0.0000 & 0.0000 & -0.0000 & 0.0000 & -0.0000 \\ -0.0000 & 0.0000 & 0.0033 & 0.0000 & 0.0000 & 0.0000 & -0.0000 & 0.0000 \\ -0.0000 & -0.0000 & -0.0000 & -0.0000 & 0 & 0.0000 & -0.0000 & 0.0000 \\ -0.0000 & 0.0000 & -0.0000 & -0.0000 & 0.0000 & -0.0000 & -0.0000 & -0.0000 \\ -0.0000 & -0.0000 & -0.0000 & 0.0000 & 0.0000 & -0.0000 & 0.0000 & 0.0000 \\ -0.0000 & -0.0000 & -0.0000 & 0.0000 & 0.0000 & 0.0000 & 0.0000 & -0.0000 \\ 0.0000 & 0.0000 & -0.0000 & 0.0000 & -0.0000 & 0.0000 & -0.0000 & -0.0000 \\ 0.0000 & -0.0000 & 0.0000 & 0.0000 & -0.0000 & 0.0000 & -0.0000 & 0.0000 \\ -0.0000 & -0.0000 & 0.0000 & 0.0000 & 0.0000 & -0.0000 & 0.0000 & 0.0000 \\ -0.0000 & 0.0000 & -0.0000 & 0.0000 & -0.0000 & 0.0000 & 0.0000 & 0.0000 \\ -0.0000 & 0.0000 & -0.0000 & -0.0000 & 0.0000 & 0.0000 & -0.0000 & 0.0000 \\ -0.0000 & -0.0000 & -0.0000 & 0.0000 & 0.0000 & 0.0000 & 0.0000 & 0.0000 \\ -0.0000 & -0.0000 & -0.0000 & 0.0000 & -0.0000 & -0.0000 & 0.0000 & 0.0000 \\ 0.0000 & 0.0000 & -0.0000 & 0.0000 & -0.0000 & -0.0000 & -0.0000 & 0.0000 \\ 0.0000 & 0.0000 & -0.0000 & 0.0000 & 0 & -0.0000 & 0.0000 & 0.0000 \\ -0.0000 & -0.0000 & -0.0000 & 0.0000 & -0.0000 & -0.0000 & 0.0000 & 0.0000 \\ -0.0000 & -0.0000 & -0.0000 & 0.0000 & -0.0000 & -0.0000 & 0.0000 & 0.0000 \\ -0.0000 & -0.0000 & 0.0000 & -0.0000 & -0.0000 & -0.0000 & -0.0000 & -0.0000 \\ -0.0000 & -0.0000 & -0.0000 & -0.0000 & 0.0000 & -0.0000 & -0.0000 & 0.0000 \\ 0.0000 & 0.0000 & 0.0000 & -0.0000 & 0.0000 & 0.0000 & 0.0000 & -0.0000 \\ 0.0000 & -0.0000 & 0.0000 & -0.0000 & 0.0000 & 0.0000 & 0.0000 & 0.0000\end{array}$

Columns 17 through 24 


$\begin{array}{rrrrrrrr}-0.0000 & 0.0000 & 0.0000 & -0.0000 & -0.0000 & -0.0000 & 0.0069 & 0.0000 \\ 0.0000 & -0.0000 & -0.0000 & -0.0000 & 0.0000 & -0.0000 & 0.0139 & -0.0000 \\ -0.0000 & -0.0000 & 0.0000 & -0.0000 & -0.0000 & -0.0000 & 0.0206 & 0.0000 \\ 0.0000 & -0.0000 & 0.0000 & -0.0000 & -0.0000 & -0.0000 & 0.0270 & 0.0000 \\ 0.0000 & -0.0000 & -0.0000 & -0.0000 & -0.0000 & -0.0000 & 0.0334 & 0.0000 \\ 0.0000 & -0.0000 & 0.0000 & -0.0000 & 0.0000 & -0.0000 & 0.0406 & -0.0000 \\ 0.0000 & -0.0000 & -0.0000 & 0.0000 & -0.0000 & -0.0000 & 0.0635 & 0.0000 \\ -0.0000 & -0.0000 & 0.0000 & 0.0000 & -0.0000 & -0.0000 & 0.0863 & 0.0000 \\ 0.0000 & -0.0000 & 0.0000 & -0.0000 & -0.0000 & -0.0000 & 0.1092 & -0.0000 \\ -0.0000 & -0.0000 & 0.0000 & -0.0000 & 0.0000 & -0.0000 & 0.1302 & 0.0000 \\ 0.0000 & -0.0000 & 0.0000 & 0.0000 & -0.0000 & -0.0000 & 0.1489 & -0.0000 \\ -0.0000 & -0.0000 & 0.0000 & -0.0000 & -0.0000 & -0.0000 & 0.1643 & -0.0000 \\ -0.0000 & -0.0000 & -0.0000 & 0.0000 & 0.0000 & -0.0000 & 0.1775 & 0.0000 \\ -0.0000 & -0.0000 & -0.0000 & 0.0000 & -0.0000 & -0.0000 & 0.1906 & -0.0000 \\ -0.0000 & -0.0000 & 0.0000 & 0.0000 & 0.0000 & -0.0000 & 0.2038 & -0.0000 \\ 0.0000 & -0.0000 & 0.0000 & -0.0000 & -0.0000 & -0.0000 & 0.2169 & -0.0000 \\ 0.0000 & -0.0000 & 0.0000 & -0.0000 & -0.0000 & -0.0000 & 0.2301 & -0.0000 \\ -0.0000 & -0.0000 & 0.0000 & -0.0000 & -0.0000 & -0.0000 & 0.1758 & 0.0000 \\ 0.0000 & -0.0000 & 0.0000 & 0.0000 & -0.0000 & -0.0000 & 0.1147 & -0.0000 \\ 0.0000 & 0.0000 & -0.0000 & 0.0000 & -0.0000 & -0.0000 & 0.0536 & -0.0000 \\ 0.0000 & 0.0000 & 0.0000 & 0.0000 & -0.0000 & 0.0000 & 0 & -0.0000\end{array}$

Columns 25 through 31

$\begin{array}{rrrrrrr}-0.0000 & 0.0000 & 0.0000 & 0.0001 & 0.0061 & 0.0000 & 0.0698 \\ 0.0000 & 0.0000 & -0.0000 & 0.0047 & -0.0000 & -0.0000 & 0.0000 \\ -0.0000 & -0.0000 & 0.0000 & 0.0118 & -0.0000 & 0.0000 & -0.0000 \\ -0.0000 & 0.0000 & -0.0000 & 0.0188 & -0.0000 & 0.0000 & -0.0000 \\ -0.0000 & 0.0000 & -0.0000 & 0.0258 & 0.0000 & -0.0000 & -0.0000 \\ -0.0000 & -0.0000 & -0.0000 & 0.0331 & -0.0000 & -0.0000 & -0.0000 \\ 0.0000 & 0.0000 & 0.0000 & 0.0466 & -0.0000 & -0.0000 & 0.0000 \\ -0.0000 & 0.0000 & 0.0000 & 0.0600 & 0.0000 & -0.0000 & 0.0000 \\ 0.0000 & 0.0000 & -0.0000 & 0.0734 & 0.0000 & -0.0000 & -0.0000 \\ -0.0000 & -0.0000 & 0.0000 & 0.0908 & -0.0000 & 0.0000 & -0.0000 \\ -0.0000 & 0.0000 & -0.0000 & 0.1134 & 0.0000 & -0.0000 & -0.0000 \\ -0.0000 & -0.0000 & -0.0000 & 0.1353 & 0.0000 & -0.0000 & -0.0000 \\ 0.0000 & -0.0000 & -0.0000 & 0.1567 & 0.0000 & 0.0000 & 0.0000 \\ 0.0000 & 0.0000 & 0.0000 & 0.1781 & 0.0000 & 0.0000 & -0.0000 \\ 0.0000 & 0.0000 & 0.0000 & 0.1995 & -0.0000 & -0.0000 & 0.0000 \\ -0.0000 & -0.0000 & -0.0000 & 0.2209 & 0.0000 & -0.0000 & -0.0000 \\ -0.0000 & -0.0000 & -0.0000 & 0.2423 & 0.0000 & -0.0000 & -0.0000 \\ -0.0000 & 0.0000 & 0.0000 & 0.2793 & -0.0000 & -0.0000 & -0.0000 \\ -0.0000 & -0.0000 & 0.0000 & 0.3178 & -0.0000 & -0.0000 & -0.0000 \\ -0.0000 & -0.0000 & -0.0000 & 0.3563 & -0.0000 & -0.0000 & -0.0000 \\ -0.0000 & -0.0000 & 0.0000 & 0.4123 & -0.0000 & -0.0000 & -0.0000\end{array}$


Restrição Total a Ativos Internacionais (2003 a 2006)

[PortRisk, PortReturn, PortWts] = frontcon(ExpRetIntPais03,ExpCovIntPais03,[], PortReturnInt06,AssetBoundsInt05,GroupsInt05,GroupsBoundsInt05)

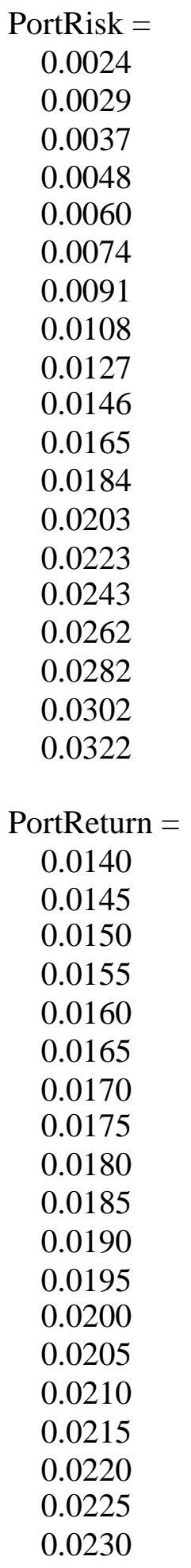


Columns 1 through 8

$\begin{array}{rrrrrrrr}0.7871 & 0.1077 & 0.0334 & 0.0000 & 0.0000 & 0.0000 & 0.0000 & 0.0061 \\ 0.6782 & 0.0896 & 0.2171 & 0.0000 & 0.0000 & 0.0000 & 0.0000 & 0.0102 \\ 0.4611 & 0.0568 & 0.4662 & 0.0000 & 0.0000 & 0.0000 & 0.0000 & 0.0160 \\ 0.2395 & 0.0189 & 0.7191 & 0.0000 & -0.0000 & 0.0000 & 0.0000 & 0.0226 \\ 0 & 0.0000 & 0.9697 & 0.0000 & -0.0000 & -0.0000 & 0.0000 & 0.0303 \\ 0.0000 & -0.0000 & 0.9375 & 0.0000 & -0.0000 & -0.0000 & 0.0000 & 0.0625 \\ 0 & -0.0000 & 0.9052 & 0.0000 & -0.0000 & -0.0000 & 0.0000 & 0.0948 \\ 0.0000 & -0.0000 & 0.8730 & 0.0000 & -0.0000 & -0.0000 & 0.0000 & 0.1270 \\ 0.0000 & 0.0000 & 0.8407 & 0 & -0.0000 & -0.0000 & 0.0000 & 0.1593 \\ 0 & -0.0000 & 0.8085 & 0 & -0.0000 & -0.0000 & 0.0000 & 0.1915 \\ 0.0000 & 0.0000 & 0.7762 & -0.0000 & -0.0000 & -0.0000 & 0.0000 & 0.2238 \\ 0.0000 & -0.0000 & 0.7440 & 0 & -0.0000 & -0.0000 & 0.0000 & 0.2560 \\ 0.0000 & 0 & 0.7117 & -0.0000 & -0.0000 & -0.0000 & 0.0000 & 0.2883 \\ 0.0000 & 0 & 0.6795 & -0.0000 & -0.0000 & -0.0000 & 0.0000 & 0.3205 \\ 0.0000 & 0 & 0.6472 & 0 & -0.0000 & -0.0000 & 0.0000 & 0.3528 \\ -0.0000 & 0 & 0.6150 & 0 & -0.0000 & -0.0000 & 0.0000 & 0.3850 \\ 0.0000 & 0.0000 & 0.5827 & 0.0000 & -0.0000 & -0.0000 & 0.0000 & 0.4173 \\ 0.0000 & 0.0000 & 0.5505 & -0.0000 & -0.0000 & -0.0000 & 0.0000 & 0.4495 \\ 0.0000 & 0.0000 & 0.5182 & 0.0000 & -0.0000 & -0.0000 & 0.0000 & 0.4818\end{array}$

Columns 9 through 16

$\begin{array}{rrrrrrrr}0.0000 & 0.0000 & -0.0000 & 0.0000 & -0.0000 & 0.0000 & 0.0000 & 0.0000 \\ 0.0000 & 0.0000 & -0.0000 & -0.0000 & -0.0000 & 0.0000 & 0.0000 & 0.0000 \\ 0.0000 & -0.0000 & -0.0000 & -0.0000 & -0.0000 & 0.0000 & 0.0000 & 0.0000 \\ 0.0000 & -0.0000 & -0.0000 & -0.0000 & 0.0000 & 0.0000 & 0.0000 & -0.0000 \\ -0.0000 & -0.0000 & -0.0000 & -0.0000 & 0.0000 & 0.0000 & 0.0000 & -0.0000 \\ -0.0000 & -0.0000 & -0.0000 & -0.0000 & 0.0000 & 0.0000 & 0.0000 & -0.0000 \\ -0.0000 & -0.0000 & -0.0000 & -0.0000 & 0.0000 & 0.0000 & 0.0000 & -0.0000 \\ -0.0000 & -0.0000 & -0.0000 & -0.0000 & 0.0000 & 0.0000 & 0.0000 & -0.0000 \\ -0.0000 & -0.0000 & -0.0000 & -0.0000 & 0.0000 & 0.0000 & 0.0000 & -0.0000 \\ -0.0000 & -0.0000 & -0.0000 & -0.0000 & 0.0000 & 0.0000 & 0.0000 & -0.0000 \\ -0.0000 & -0.0000 & -0.0000 & -0.0000 & 0.0000 & 0.0000 & -0.0000 & -0.0000 \\ -0.0000 & -0.0000 & -0.0000 & -0.0000 & 0.0000 & 0.0000 & 0.0000 & -0.0000 \\ -0.0000 & -0.0000 & -0.0000 & -0.0000 & 0.0000 & 0.0000 & 0.0000 & -0.0000 \\ -0.0000 & -0.0000 & -0.0000 & -0.0000 & 0.0000 & 0.0000 & 0.0000 & -0.0000 \\ -0.0000 & -0.0000 & -0.0000 & -0.0000 & 0.0000 & 0.0000 & 0.0000 & -0.0000 \\ -0.0000 & -0.0000 & -0.0000 & -0.0000 & 0.0000 & 0.0000 & 0.0000 & -0.0000 \\ -0.0000 & -0.0000 & -0.0000 & -0.0000 & 0.0000 & 0.0000 & 0.0000 & -0.0000 \\ -0.0000 & -0.0000 & -0.0000 & -0.0000 & 0.0000 & 0.0000 & -0.0000 & -0.0000 \\ -0.0000 & -0.0000 & -0.0000 & -0.0000 & 0.0000 & 0.0000 & 0.0000 & -0.0000\end{array}$

Columns 17 through 24

$\begin{array}{rrrrrrrr}0.0000 & 0.0000 & 0.0000 & 0.0000 & 0.0000 & -0.0000 & -0.0000 & 0.0000 \\ 0.0000 & 0.0000 & 0.0000 & 0.0000 & 0.0000 & -0.0000 & -0.0000 & 0.0000 \\ 0.0000 & 0.0000 & 0.0000 & 0.0000 & 0.0000 & -0.0000 & -0.0000 & 0.0000 \\ 0.0000 & 0.0000 & 0.0000 & -0.0000 & 0.0000 & 0.0000 & -0.0000 & 0.0000\end{array}$




$\begin{array}{rrrrrrrr}0.0000 & 0.0000 & -0.0000 & -0.0000 & 0.0000 & 0.0000 & -0.0000 & 0.0000 \\ -0.0000 & 0.0000 & -0.0000 & -0.0000 & 0.0000 & 0.0000 & -0.0000 & 0.0000 \\ -0.0000 & 0.0000 & -0.0000 & -0.0000 & 0.0000 & 0.0000 & -0.0000 & 0.0000 \\ -0.0000 & 0.0000 & -0.0000 & -0.0000 & 0.0000 & 0.0000 & -0.0000 & 0.0000 \\ -0.0000 & 0.0000 & -0.0000 & -0.0000 & 0.0000 & 0.0000 & -0.0000 & 0.0000 \\ -0.0000 & 0.0000 & -0.0000 & -0.0000 & 0.0000 & 0.0000 & -0.0000 & 0.0000 \\ -0.0000 & 0.0000 & -0.0000 & -0.0000 & 0.0000 & 0.0000 & -0.0000 & 0.0000 \\ -0.0000 & 0.0000 & -0.0000 & -0.0000 & 0.0000 & 0.0000 & -0.0000 & 0.0000 \\ -0.0000 & 0.0000 & -0.0000 & -0.0000 & 0.0000 & 0.0000 & -0.0000 & 0.0000 \\ -0.0000 & 0.0000 & -0.0000 & -0.0000 & 0.0000 & 0.0000 & -0.0000 & 0.0000 \\ -0.0000 & 0.0000 & -0.0000 & -0.0000 & 0.0000 & 0.0000 & -0.0000 & 0.0000 \\ -0.0000 & 0.0000 & -0.0000 & -0.0000 & 0.0000 & 0.0000 & -0.0000 & 0.0000 \\ -0.0000 & 0.0000 & -0.0000 & -0.0000 & 0.0000 & 0.0000 & -0.0000 & 0.0000 \\ -0.0000 & 0.0000 & -0.0000 & -0.0000 & 0.0000 & 0.0000 & -0.0000 & 0.0000 \\ -0.0000 & 0.0000 & -0.0000 & -0.0000 & 0.0000 & 0.0000 & -0.0000 & 0.0000\end{array}$

Columns 25 through 31

$\begin{array}{rrrrrrr}-0.0000 & -0.0000 & 0.0000 & 0.0000 & 0.0097 & 0.0000 & 0.0560 \\ -0.0000 & -0.0000 & 0.0000 & 0.0000 & 0.0049 & 0.0000 & 0.0000 \\ -0.0000 & -0.0000 & 0.0000 & 0.0000 & -0.0000 & -0.0000 & 0.0000 \\ -0.0000 & -0.0000 & 0.0000 & 0.0000 & -0.0000 & -0.0000 & -0.0000 \\ 0.0000 & -0.0000 & 0.0000 & 0.0000 & -0.0000 & -0.0000 & 0.0000 \\ 0.0000 & -0.0000 & 0.0000 & 0.0000 & 0 & -0.0000 & 0 \\ 0.0000 & -0.0000 & 0.0000 & -0.0000 & 0 & -0.0000 & 0.0000 \\ 0.0000 & -0.0000 & 0.0000 & -0.0000 & 0 & -0.0000 & -0.0000 \\ 0.0000 & -0.0000 & 0.0000 & 0.0000 & 0 & -0.0000 & 0.0000 \\ 0.0000 & -0.0000 & 0.0000 & 0.0000 & 0 & -0.0000 & 0.0000 \\ 0.0000 & -0.0000 & 0.0000 & -0.0000 & 0 & -0.0000 & 0.0000 \\ 0.0000 & -0.0000 & 0.0000 & 0.0000 & 0 & -0.0000 & 0.0000 \\ 0.0000 & -0.0000 & 0.0000 & -0.0000 & 0 & -0.0000 & 0.0000 \\ 0.0000 & -0.0000 & 0.0000 & -0.0000 & 0 & -0.0000 & 0.0000 \\ 0.0000 & -0.0000 & 0.0000 & -0.0000 & 0 & -0.0000 & 0.0000 \\ 0.0000 & -0.0000 & 0.0000 & 0.0000 & 0 & -0.0000 & 0.0000 \\ 0.0000 & -0.0000 & 0.0000 & 0.0000 & 0 & -0.0000 & 0.0000 \\ 0.0000 & -0.0000 & 0.0000 & -0.0000 & 0 & -0.0000 & 0.0000 \\ 0.0000 & -0.0000 & 0.0000 & -0.0000 & 0 & -0.0000 & 0.0000\end{array}$


Restrição de 10\% a Ativos Internacionais (2003 a 2006)

[PortRisk, PortReturn, PortWts] $=$ frontcon(ExpRetIntPais03,ExpCovIntPais03,[], PortReturnInt06,AssetBoundsInt05,GroupsInt05,GroupsBoundsInt05)

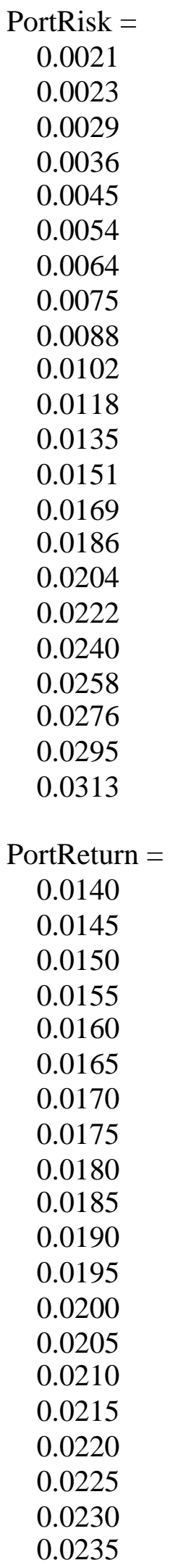


0.0240

0.0245

PortWts =

Columns 1 through 8

$\begin{array}{rrrrrrrr}0.7093 & 0.1499 & -0.0000 & -0.0000 & 0.0000 & -0.0000 & 0.0026 & -0.0000 \\ 0.7943 & 0.1583 & 0.0000 & -0.0000 & -0.0000 & -0.0000 & -0.0000 & -0.0000 \\ 0.7566 & 0.1676 & 0.0131 & 0.0000 & 0.0000 & -0.0000 & -0.0000 & -0.0000 \\ 0.6457 & 0.1676 & 0.1123 & 0.0000 & 0.0000 & -0.0000 & -0.0000 & 0.0000 \\ 0.5345 & 0.1651 & 0.2117 & 0.0000 & -0.0000 & 0.0000 & -0.0000 & 0.0000 \\ 0.3851 & 0.1451 & 0.3697 & -0.0000 & -0.0000 & 0.0000 & -0.0000 & 0.0000 \\ 0.1545 & 0.0960 & 0.6495 & 0.0000 & -0.0000 & 0.0000 & -0.0000 & -0.0000 \\ -0.0000 & 0.0122 & 0.8865 & 0.0000 & -0.0000 & 0.0000 & -0.0000 & 0.0013 \\ 0.0000 & -0.0000 & 0.8738 & 0.0000 & -0.0000 & 0.0000 & -0.0000 & 0.0262 \\ 0 & -0.0000 & 0.8473 & -0.0000 & 0.0000 & -0.0000 & -0.0000 & 0.0527 \\ 0.0000 & -0.0000 & 0.8209 & 0.0000 & -0.0000 & 0.0000 & -0.0000 & 0.0791 \\ 0.0000 & 0 & 0.7944 & 0.0000 & 0.0000 & 0.0000 & -0.0000 & 0.1056 \\ 0.0000 & 0 & 0.7679 & 0.0000 & -0.0000 & 0.0000 & -0.0000 & 0.1321 \\ -0.0000 & 0.0000 & 0.7414 & -0.0000 & -0.0000 & -0.0000 & -0.0000 & 0.1586 \\ 0.0000 & 0 & 0.7149 & 0.0000 & -0.0000 & -0.0000 & -0.0000 & 0.1851 \\ -0.0000 & 0 & 0.6884 & 0.0000 & -0.0000 & -0.0000 & -0.0000 & 0.2116 \\ 0.0000 & 0.0000 & 0.6619 & 0.0000 & -0.0000 & -0.0000 & -0.0000 & 0.2381 \\ 0.0000 & 0 & 0.6354 & 0.0000 & 0.0000 & -0.0000 & -0.0000 & 0.2646 \\ 0.0000 & 0 & 0.6048 & 0.0000 & 0.0000 & -0.0000 & -0.0000 & 0.2952 \\ 0.0000 & 0.0000 & 0.5725 & 0.0000 & 0.0000 & -0.0000 & -0.0000 & 0.3275 \\ 0.0000 & -0.0000 & 0.5403 & 0.0000 & 0.0000 & -0.0000 & -0.0000 & 0.3597 \\ 0.0000 & 0.0000 & 0.5080 & 0.0000 & 0.0000 & -0.0000 & 0.0000 & 0.3920\end{array}$

Columns 9 through 16

$\begin{array}{rrrrrrrr}-0.0000 & -0.0000 & 0.0082 & -0.0000 & 0.0000 & 0.0063 & 0.0000 & 0.0000 \\ -0.0000 & -0.0000 & 0.0082 & -0.0000 & -0.0000 & 0.0047 & -0.0000 & 0.0000 \\ -0.0000 & 0.0000 & 0.0058 & -0.0000 & -0.0000 & -0.0000 & -0.0000 & -0.0000 \\ -0.0000 & 0.0000 & 0.0033 & -0.0000 & -0.0000 & 0.0000 & 0.0000 & -0.0000 \\ 0.0000 & 0.0000 & 0.0003 & 0.0000 & -0.0000 & 0.0000 & 0.0000 & 0.0000 \\ 0.0000 & 0.0000 & -0.0000 & 0.0000 & -0.0000 & 0.0000 & 0.0000 & 0.0000 \\ 0.0000 & 0.0000 & 0.0000 & 0.0000 & -0.0000 & -0.0000 & -0.0000 & -0.0000 \\ 0.0000 & -0.0000 & -0.0000 & 0.0000 & 0.0000 & -0.0000 & -0.0000 & -0.0000 \\ 0.0000 & -0.0000 & -0.0000 & 0.0000 & 0.0000 & -0.0000 & -0.0000 & 0.0000 \\ 0.0000 & -0.0000 & -0.0000 & 0.0000 & 0.0000 & 0.0000 & 0.0000 & -0.0000 \\ -0.0000 & 0.0000 & -0.0000 & 0.0000 & 0.0000 & -0.0000 & 0.0000 & -0.0000 \\ -0.0000 & 0.0000 & 0.0000 & -0.0000 & 0.0000 & -0.0000 & 0.0000 & -0.0000 \\ 0.0000 & 0.0000 & -0.0000 & 0.0000 & 0.0000 & -0.0000 & 0.0000 & -0.0000 \\ 0.0000 & 0.0000 & 0.0000 & 0.0000 & -0.0000 & -0.0000 & 0.0000 & -0.0000 \\ 0.0000 & -0.0000 & -0.0000 & 0.0000 & -0.0000 & -0.0000 & 0.0000 & -0.0000 \\ 0.0000 & 0.0000 & -0.0000 & 0.0000 & -0.0000 & -0.0000 & 0.0000 & -0.0000 \\ 0.0000 & 0.0000 & -0.0000 & 0.0000 & -0.0000 & 0.0000 & 0.0000 & -0.0000 \\ 0.0000 & -0.0000 & 0.0000 & 0.0000 & -0.0000 & 0.0000 & 0.0000 & -0.0000 \\ 0.0000 & -0.0000 & 0.0000 & 0.0000 & -0.0000 & 0.0000 & 0.0000 & -0.0000 \\ 0.0000 & -0.0000 & 0.0000 & 0.0000 & -0.0000 & 0.0000 & 0.0000 & -0.0000 \\ -0.0000 & 0 & 0.0000 & -0.0000 & -0.0000 & 0.0000 & 0.0000 & -0.0000\end{array}$


$\begin{array}{llllllll}-0.0000 & -0.0000 & -0.0000 & 0.0000 & 0.0000 & -0.0000 & 0.0000 & 0.0000\end{array}$

Columns 17 through 24

$\begin{array}{rrrrrrrr}0.0028 & 0.0000 & 0.0017 & -0.0000 & -0.0000 & -0.0000 & 0.0118 & 0.0000 \\ -0.0000 & -0.0000 & 0.0039 & 0.0000 & -0.0000 & -0.0000 & 0.0244 & 0.0000 \\ 0.0000 & 0.0000 & 0.0070 & 0.0000 & -0.0000 & 0.0000 & 0.0441 & -0.0000 \\ 0.0000 & 0.0000 & 0.0067 & -0.0000 & -0.0000 & -0.0000 & 0.0569 & -0.0000 \\ 0.0000 & 0.0000 & 0.0062 & 0.0000 & -0.0000 & -0.0000 & 0.0702 & 0.0000 \\ -0.0000 & -0.0000 & 0.0040 & 0.0000 & -0.0000 & -0.0000 & 0.0795 & 0.0000 \\ -0.0000 & 0.0000 & -0.0000 & 0.0000 & -0.0000 & 0.0000 & 0.0784 & -0.0000 \\ -0.0000 & 0.0000 & -0.0000 & -0.0000 & -0.0000 & -0.0000 & 0.0727 & -0.0000 \\ 0.0000 & -0.0000 & -0.0000 & -0.0000 & -0.0000 & 0.0000 & 0.0658 & 0.0000 \\ 0.0000 & 0.0000 & -0.0000 & 0.0000 & -0.0000 & -0.0000 & 0.0587 & 0.0000 \\ -0.0000 & 0.0000 & -0.0000 & 0.0000 & 0.0000 & -0.0000 & 0.0516 & 0.0000 \\ -0.0000 & 0.0000 & 0.0000 & -0.0000 & 0.0000 & -0.0000 & 0.0445 & -0.0000 \\ -0.0000 & 0.0000 & 0.0000 & -0.0000 & -0.0000 & -0.0000 & 0.0374 & 0.0000 \\ -0.0000 & 0.0000 & -0.0000 & -0.0000 & -0.0000 & -0.0000 & 0.0304 & 0.0000 \\ -0.0000 & 0.0000 & 0.0000 & -0.0000 & -0.0000 & -0.0000 & 0.0233 & 0.0000 \\ -0.0000 & 0.0000 & 0.0000 & -0.0000 & -0.0000 & -0.0000 & 0.0162 & 0.0000 \\ -0.0000 & -0.0000 & 0 & -0.0000 & -0.0000 & -0.0000 & 0.0091 & 0.0000 \\ 0.0000 & 0.0000 & 0 & -0.0000 & -0.0000 & -0.0000 & 0.0020 & 0.0000 \\ 0.0000 & 0.0000 & 0 & -0.0000 & -0.0000 & -0.0000 & 0 & 0.0000 \\ -0.0000 & -0.0000 & 0 & -0.0000 & -0.0000 & -0.0000 & 0.0000 & 0.0000 \\ -0.0000 & -0.0000 & 0 & -0.0000 & -0.0000 & -0.0000 & 0.0000 & 0.0000 \\ 0.0000 & -0.0000 & -0.0000 & -0.0000 & 0.0000 & -0.0000 & 0.0000 & -0.0000\end{array}$

Columns 25 through 31

$\begin{array}{rrrrrrr}-0.0000 & 0.0000 & -0.0000 & -0.0000 & 0.0073 & 0.0000 & 0.1000 \\ -0.0000 & 0.0000 & -0.0000 & 0.0000 & 0.0063 & -0.0000 & 0.0000 \\ 0.0000 & 0.0000 & 0.0000 & 0.0032 & 0.0026 & -0.0000 & 0.0000 \\ -0.0000 & 0.0000 & 0.0000 & 0.0075 & -0.0000 & 0.0000 & -0.0000 \\ -0.0000 & 0.0000 & 0.0000 & 0.0121 & 0.0000 & 0.0000 & 0.0000 \\ -0.0000 & 0.0000 & 0.0000 & 0.0165 & -0.0000 & 0.0000 & 0.0000 \\ -0.0000 & 0.0000 & 0.0000 & 0.0216 & -0.0000 & 0.0000 & -0.0000 \\ -0.0000 & -0.0000 & -0.0000 & 0.0273 & 0.0000 & 0.0000 & -0.0000 \\ 0.0000 & -0.0000 & 0.0000 & 0.0342 & 0.0000 & 0.0000 & -0.0000 \\ -0.0000 & 0.0000 & -0.0000 & 0.0413 & -0.0000 & 0.0000 & 0 \\ 0.0000 & -0.0000 & -0.0000 & 0.0484 & 0.0000 & -0.0000 & 0.0000 \\ -0.0000 & 0.0000 & -0.0000 & 0.0555 & -0.0000 & -0.0000 & -0.0000 \\ -0.0000 & 0.0000 & 0.0000 & 0.0626 & 0.0000 & 0.0000 & 0 \\ -0.0000 & 0.0000 & 0.0000 & 0.0696 & 0.0000 & -0.0000 & -0.0000 \\ 0.0000 & 0.0000 & 0.0000 & 0.0767 & -0.0000 & 0.0000 & 0.0000 \\ 0.0000 & 0.0000 & 0.0000 & 0.0838 & 0.0000 & 0.0000 & -0.0000 \\ 0.0000 & 0.0000 & 0.0000 & 0.0909 & -0.0000 & 0.0000 & -0.0000 \\ 0.0000 & 0.0000 & 0.0000 & 0.0980 & -0.0000 & 0.0000 & 0.0000 \\ 0.0000 & 0.0000 & 0.0000 & 0.1000 & -0.0000 & 0.0000 & 0.0000 \\ -0.0000 & 0.0000 & 0.0000 & 0.1000 & -0.0000 & 0.0000 & 0.0000 \\ 0.0000 & 0.0000 & 0.0000 & 0.1000 & -0.0000 & 0.0000 & 0.0000 \\ 0.0000 & -0.0000 & 0.0000 & 0.1000 & 0.0000 & -0.0000 & 0.0000\end{array}$


Restrição de 20\% a Ativos Internacionais (2003 a 2006)

[PortRisk, PortReturn, PortWts] = frontcon(ExpRetIntPais03,ExpCovIntPais03,[], PortReturnInt06,AssetBoundsInt05,GroupsInt05,GroupsBoundsInt05)

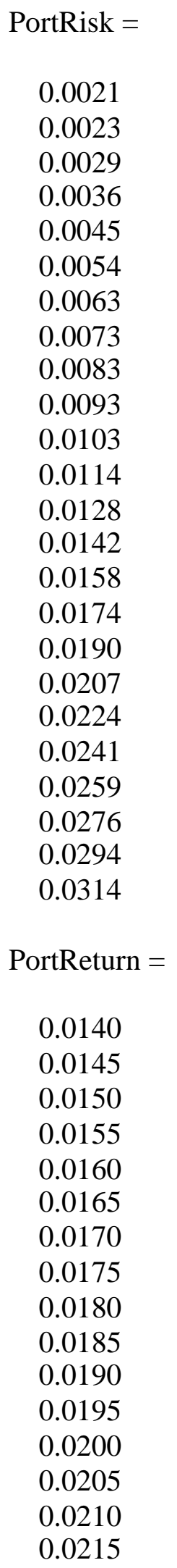


0.0220
0.0225
0.0230
0.0235
0.0240
0.0245
0.0250
0.0255

PortWts =

Columns 1 through 8

$\begin{array}{rrrrrrrr}0.7093 & 0.1499 & -0.0000 & 0.0000 & -0.0000 & 0.0000 & 0.0026 & -0.0000 \\ 0.7943 & 0.1583 & -0.0000 & -0.0000 & 0.0000 & 0.0000 & 0.0000 & -0.0000 \\ 0.7566 & 0.1676 & 0.0131 & 0.0000 & -0.0000 & 0.0000 & 0.0000 & 0.0000 \\ 0.6457 & 0.1676 & 0.1123 & 0.0000 & -0.0000 & -0.0000 & 0.0000 & 0.0000 \\ 0.5345 & 0.1651 & 0.2117 & -0.0000 & -0.0000 & -0.0000 & -0.0000 & -0.0000 \\ 0.4183 & 0.1608 & 0.3156 & -0.0000 & 0.0000 & -0.0000 & -0.0000 & 0.0000 \\ 0.3017 & 0.1563 & 0.4199 & -0.0000 & 0.0000 & -0.0000 & -0.0000 & 0.0000 \\ 0.1850 & 0.1518 & 0.5243 & -0.0000 & 0.0000 & 0.0000 & -0.0000 & 0.0000 \\ 0.0684 & 0.1473 & 0.6286 & -0.0000 & 0.0000 & 0.0000 & 0.0000 & 0.0000 \\ 0.0000 & 0.1320 & 0.6931 & -0.0000 & 0.0000 & 0.0000 & -0.0000 & 0.0000 \\ 0.0000 & 0.1013 & 0.7011 & -0.0000 & 0.0000 & 0.0000 & 0.0000 & 0.0000 \\ 0.0000 & -0.0000 & 0.7935 & 0.0000 & 0.0000 & 0.0000 & -0.0000 & 0.0065 \\ 0.0000 & -0.0000 & 0.7670 & 0.0000 & 0.0000 & 0.0000 & -0.0000 & 0.0330 \\ 0.0000 & 0 & 0.7405 & -0.0000 & 0.0000 & -0.0000 & -0.0000 & 0.0595 \\ 0.0000 & -0.0000 & 0.7140 & 0.0000 & -0.0000 & -0.0000 & -0.0000 & 0.0860 \\ -0.0000 & 0.0000 & 0.6876 & 0.0000 & -0.0000 & -0.0000 & -0.0000 & 0.1124 \\ -0.0000 & 0.0000 & 0.6611 & 0.0000 & -0.0000 & -0.0000 & -0.0000 & 0.1389 \\ -0.0000 & 0 & 0.6346 & 0.0000 & 0.0000 & -0.0000 & -0.0000 & 0.1654 \\ -0.0000 & 0.0000 & 0.6081 & 0.0000 & 0.0000 & -0.0000 & -0.0000 & 0.1919 \\ 0.0000 & -0.0000 & 0.5816 & 0.0000 & -0.0000 & -0.0000 & -0.0000 & 0.2184 \\ 0.0000 & -0.0000 & 0.5551 & 0.0000 & 0.0000 & -0.0000 & -0.0000 & 0.2449 \\ 0.0000 & -0.0000 & 0.5286 & 0.0000 & 0.0000 & 0.0000 & -0.0000 & 0.2714 \\ -0.0000 & 0.0000 & 0.5021 & 0.0000 & -0.0000 & 0.0000 & 0.0000 & 0.2979 \\ -0.0000 & -0.0000 & 0.5000 & -0.0000 & -0.0000 & 0.0000 & 0.0000 & 0.3000\end{array}$

Columns 9 through 16

$\begin{array}{rrrrrrrr}0.0000 & -0.0000 & 0.0082 & 0.0000 & -0.0000 & 0.0063 & -0.0000 & 0.0000 \\ 0.0000 & -0.0000 & 0.0082 & -0.0000 & 0.0000 & 0.0047 & -0.0000 & -0.0000 \\ -0.0000 & 0.0000 & 0.0058 & -0.0000 & 0.0000 & -0.0000 & 0.0000 & 0.0000 \\ -0.0000 & -0.0000 & 0.0033 & 0.0000 & 0.0000 & 0.0000 & -0.0000 & 0.0000 \\ -0.0000 & -0.0000 & 0.0003 & 0.0000 & 0.0000 & -0.0000 & -0.0000 & 0.0000 \\ -0.0000 & 0.0000 & -0.0000 & 0.0000 & 0.0000 & 0.0000 & -0.0000 & 0.0000 \\ -0.0000 & 0.0000 & 0.0000 & 0.0000 & 0.0000 & 0.0000 & -0.0000 & 0.0000 \\ -0.0000 & 0.0000 & 0.0000 & 0.0000 & 0.0000 & 0.0000 & -0.0000 & 0.0000 \\ -0.0000 & -0.0000 & 0.0000 & 0.0000 & 0.0000 & -0.0000 & -0.0000 & 0.0000 \\ -0.0000 & -0.0000 & 0.0000 & -0.0000 & 0.0000 & -0.0000 & -0.0000 & -0.0000\end{array}$




$\begin{array}{rrrrrrrr}-0.0000 & -0.0000 & 0.0000 & -0.0000 & 0.0000 & -0.0000 & 0.0000 & -0.0000 \\ -0.0000 & 0.0000 & 0.0000 & -0.0000 & 0.0000 & -0.0000 & 0.0000 & 0.0000 \\ -0.0000 & 0.0000 & 0.0000 & -0.0000 & 0.0000 & -0.0000 & 0.0000 & -0.0000 \\ 0.0000 & -0.0000 & -0.0000 & 0.0000 & -0.0000 & -0.0000 & 0.0000 & -0.0000 \\ 0.0000 & 0.0000 & 0.0000 & 0.0000 & -0.0000 & -0.0000 & 0.0000 & -0.0000 \\ 0.0000 & 0.0000 & 0.0000 & 0.0000 & -0.0000 & -0.0000 & 0.0000 & -0.0000 \\ 0.0000 & 0.0000 & 0.0000 & 0.0000 & -0.0000 & -0.0000 & 0.0000 & -0.0000 \\ 0.0000 & -0.0000 & 0.0000 & -0.0000 & -0.0000 & 0.0000 & -0.0000 & -0.0000 \\ 0.0000 & 0 & 0.0000 & -0.0000 & -0.0000 & 0.0000 & -0.0000 & -0.0000 \\ 0.0000 & -0.0000 & 0.0000 & -0.0000 & -0.0000 & 0.0000 & -0.0000 & -0.0000 \\ 0.0000 & 0 & 0.0000 & 0.0000 & -0.0000 & -0.0000 & 0.0000 & -0.0000 \\ 0.0000 & 0 & 0.0000 & 0.0000 & -0.0000 & -0.0000 & 0.0000 & -0.0000 \\ 0.0000 & 0 & -0.0000 & -0.0000 & -0.0000 & -0.0000 & -0.0000 & -0.0000 \\ 0.0000 & 0 & -0.0000 & -0.0000 & -0.0000 & -0.0000 & -0.0000 & 0.0000\end{array}$

Columns 17 through 24

$\begin{array}{rrrrrrrr}0.0028 & 0.0000 & 0.0017 & -0.0000 & 0.0000 & -0.0000 & 0.0118 & 0.0000 \\ -0.0000 & -0.0000 & 0.0039 & -0.0000 & 0.0000 & 0.0000 & 0.0244 & -0.0000 \\ -0.0000 & -0.0000 & 0.0070 & 0.0000 & 0.0000 & -0.0000 & 0.0441 & -0.0000 \\ 0.0000 & 0.0000 & 0.0067 & 0.0000 & 0.0000 & 0.0000 & 0.0569 & 0.0000 \\ -0.0000 & 0.0000 & 0.0062 & -0.0000 & 0.0000 & -0.0000 & 0.0702 & -0.0000 \\ -0.0000 & 0.0000 & 0.0061 & 0.0000 & 0.0000 & -0.0000 & 0.0830 & 0.0000 \\ -0.0000 & 0.0000 & 0.0061 & 0.0000 & 0.0000 & 0.0000 & 0.0958 & 0.0000 \\ -0.0000 & 0.0000 & 0.0061 & -0.0000 & 0.0000 & 0.0000 & 0.1085 & 0.0000 \\ 0.0000 & -0.0000 & 0.0061 & 0.0000 & 0.0000 & -0.0000 & 0.1212 & 0.0000 \\ -0.0000 & -0.0000 & 0.0063 & -0.0000 & -0.0000 & -0.0000 & 0.1358 & 0.0000 \\ 0.0000 & -0.0000 & 0.0071 & -0.0000 & -0.0000 & -0.0000 & 0.1532 & -0.0000 \\ 0.0000 & -0.0000 & -0.0000 & -0.0000 & -0.0000 & -0.0000 & 0.1522 & -0.0000 \\ 0.0000 & 0.0000 & 0 & -0.0000 & -0.0000 & -0.0000 & 0.1451 & -0.0000 \\ 0.0000 & -0.0000 & 0 & 0.0000 & -0.0000 & 0.0000 & 0.1380 & 0.0000 \\ 0.0000 & 0.0000 & -0.0000 & 0.0000 & -0.0000 & -0.0000 & 0.1309 & 0.0000 \\ 0.0000 & 0.0000 & -0.0000 & 0.0000 & -0.0000 & -0.0000 & 0.1238 & 0.0000 \\ 0.0000 & 0.0000 & 0.0000 & 0.0000 & -0.0000 & -0.0000 & 0.1167 & 0.0000 \\ 0.0000 & 0.0000 & 0.0000 & 0.0000 & -0.0000 & 0.0000 & 0.1096 & 0.0000 \\ 0.0000 & 0.0000 & 0 & 0.0000 & -0.0000 & 0.0000 & 0.1025 & 0.0000 \\ 0.0000 & 0.0000 & 0 & 0.0000 & -0.0000 & 0.0000 & 0.0954 & 0.0000 \\ 0.0000 & 0.0000 & -0.0000 & 0.0000 & -0.0000 & -0.0000 & 0.0883 & 0.0000 \\ 0.0000 & 0.0000 & -0.0000 & 0.0000 & -0.0000 & -0.0000 & 0.0812 & 0.0000 \\ 0.0000 & 0.0000 & 0 & 0.0000 & 0.0000 & 0.0000 & 0.0742 & -0.0000 \\ 0.0000 & 0.0000 & 0 & 0.0000 & 0.0000 & 0.0000 & 0.0371 & -0.0000\end{array}$

Columns 25 through 31

$\begin{array}{rrrrrrr}0.0000 & 0.0000 & -0.0000 & 0.0000 & 0.0073 & -0.0000 & 0.1000 \\ -0.0000 & 0.0000 & -0.0000 & -0.0000 & 0.0063 & 0.0000 & 0.0000 \\ -0.0000 & -0.0000 & -0.0000 & 0.0032 & 0.0026 & 0.0000 & -0.0000 \\ -0.0000 & -0.0000 & -0.0000 & 0.0075 & -0.0000 & 0.0000 & -0.0000 \\ -0.0000 & 0.0000 & -0.0000 & 0.0121 & 0.0000 & 0.0000 & 0.0000 \\ 0.0000 & -0.0000 & -0.0000 & 0.0162 & 0.0000 & 0.0000 & -0.0000\end{array}$




$\begin{array}{ccccccc}0.0000 & -0.0000 & -0.0000 & 0.0203 & -0.0000 & 0.0000 & -0.0000 \\ 0.0000 & -0.0000 & -0.0000 & 0.0243 & -0.0000 & 0.0000 & -0.0000 \\ -0.0000 & -0.0000 & -0.0000 & 0.0284 & -0.0000 & 0.0000 & -0.0000 \\ -0.0000 & 0.0000 & -0.0000 & 0.0327 & -0.0000 & 0.0000 & -0.0000 \\ 0.0000 & 0.0000 & 0.0000 & 0.0374 & -0.0000 & 0.0000 & -0.0000 \\ 0.0000 & 0.0000 & -0.0000 & 0.0478 & -0.0000 & 0.0000 & -0.0000 \\ 0.0000 & 0.0000 & 0.0000 & 0.0549 & -0.0000 & 0.0000 & -0.0000 \\ -0.0000 & -0.0000 & 0.0000 & 0.0620 & -0.0000 & -0.0000 & -0.0000 \\ -0.0000 & -0.0000 & 0.0000 & 0.0691 & 0.0000 & -0.0000 & 0.0000 \\ -0.0000 & -0.0000 & 0.0000 & 0.0762 & 0.0000 & -0.0000 & 0.0000 \\ -0.0000 & -0.0000 & 0.0000 & 0.0833 & 0.0000 & -0.0000 & 0.0000 \\ -0.0000 & -0.0000 & 0.0000 & 0.0904 & -0.0000 & 0.0000 & 0.0000 \\ -0.0000 & -0.0000 & 0.0000 & 0.0975 & -0.0000 & 0.0000 & 0.0000 \\ -0.0000 & -0.0000 & -0.0000 & 0.1046 & -0.0000 & -0.0000 & 0.0000 \\ 0.0000 & 0.0000 & 0.0000 & 0.1117 & -0.0000 & 0.0000 & 0.0000 \\ 0.0000 & 0.0000 & 0.0000 & 0.1188 & -0.0000 & -0.0000 & 0.0000 \\ -0.0000 & -0.0000 & -0.0000 & 0.1258 & -0.0000 & -0.0000 & 0.0000 \\ -0.0000 & -0.0000 & -0.0000 & 0.1629 & -0.0000 & -0.0000 & 0.0000\end{array}$


Restrição de 30\% a Ativos Internacionais (2003 a 2006)

[PortRisk, PortReturn, PortWts] = frontcon(ExpRetIntPais03,ExpCovIntPais03,[], PortReturnInt06,AssetBoundsInt05,GroupsInt05,GroupsBoundsInt05)

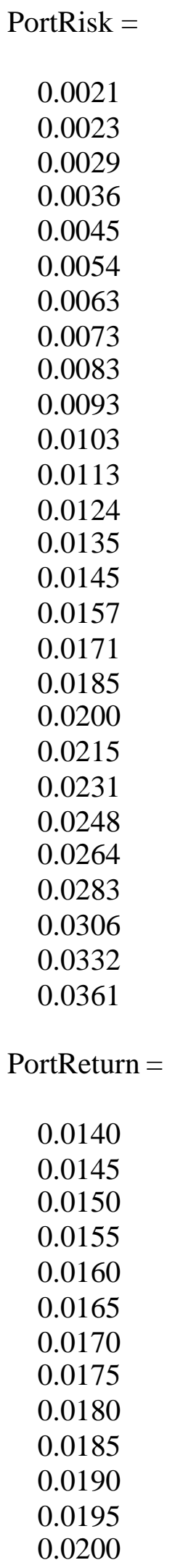


0.0205
0.0210
0.0215
0.0220
0.0225
0.0230
0.0235
0.0240
0.0245
0.0250
0.0255
0.0260
0.0265
0.0270

PortWts $=$

Columns 1 through 8

$\begin{array}{rrrrrrrr}0.7093 & 0.1499 & -0.0000 & 0.0000 & -0.0000 & -0.0000 & 0.0026 & -0.0000 \\ 0.7943 & 0.1583 & -0.0000 & 0.0000 & 0.0000 & 0.0000 & 0.0000 & -0.0000 \\ 0.7566 & 0.1676 & 0.0131 & 0.0000 & 0.0000 & 0.0000 & 0.0000 & 0.0000 \\ 0.6457 & 0.1676 & 0.1123 & 0.0000 & 0.0000 & -0.0000 & 0.0000 & -0.0000 \\ 0.5345 & 0.1651 & 0.2117 & -0.0000 & 0.0000 & -0.0000 & 0.0000 & -0.0000 \\ 0.4183 & 0.1608 & 0.3156 & -0.0000 & 0.0000 & -0.0000 & -0.0000 & -0.0000 \\ 0.3017 & 0.1563 & 0.4199 & -0.0000 & 0.0000 & -0.0000 & -0.0000 & -0.0000 \\ 0.1850 & 0.1518 & 0.5243 & -0.0000 & 0.0000 & -0.0000 & -0.0000 & -0.0000 \\ 0.0684 & 0.1473 & 0.6286 & -0.0000 & 0.0000 & 0.0000 & 0.0000 & 0.0000 \\ 0.0000 & 0.1320 & 0.6931 & -0.0000 & 0.0000 & 0.0000 & 0.0000 & 0.0000 \\ 0.0000 & 0.1013 & 0.7011 & -0.0000 & 0.0000 & 0.0000 & 0.0000 & -0.0000 \\ 0.0000 & 0.0706 & 0.7090 & 0.0000 & 0.0000 & 0.0000 & 0.0000 & -0.0000 \\ 0.0000 & 0.0399 & 0.7170 & 0.0000 & 0.0000 & 0.0000 & -0.0000 & 0.0000 \\ 0.0000 & 0.0091 & 0.7246 & -0.0000 & 0.0000 & -0.0000 & -0.0000 & -0.0000 \\ 0.0000 & -0.0000 & 0.7073 & 0.0000 & -0.0000 & -0.0000 & -0.0000 & 0.0000 \\ -0.0000 & -0.0000 & 0.6862 & 0.0000 & -0.0000 & -0.0000 & -0.0000 & 0.0138 \\ 0.0000 & -0.0000 & 0.6598 & 0.0000 & -0.0000 & -0.0000 & -0.0000 & 0.0402 \\ 0.0000 & 0.0000 & 0.6335 & 0.0000 & -0.0000 & -0.0000 & -0.0000 & 0.0665 \\ -0.0000 & 0.0000 & 0.6072 & 0.0000 & 0.0000 & -0.0000 & -0.0000 & 0.0928 \\ 0.0000 & -0.0000 & 0.5807 & 0.0000 & 0.0000 & 0.0000 & -0.0000 & 0.1193 \\ 0.0000 & -0.0000 & 0.5543 & 0.0000 & 0.0000 & 0.0000 & -0.0000 & 0.1457 \\ -0.0000 & 0.0000 & 0.5278 & -0.0000 & 0.0000 & 0.0000 & 0.0000 & 0.1722 \\ -0.0000 & 0.0000 & 0.5013 & -0.0000 & 0.0000 & 0.0000 & 0.0000 & 0.1987 \\ -0.0000 & -0.0000 & 0.5000 & 0.0000 & -0.0000 & 0.0000 & 0.0000 & 0.2000 \\ -0.0000 & 0.0000 & 0.5000 & 0.0000 & 0.0000 & 0.0000 & 0.0000 & 0.2000 \\ -0.0000 & 0.0000 & 0.5000 & 0.0000 & 0.0000 & 0.0000 & 0.0000 & 0.2000 \\ 0.0000 & 0.0000 & 0.5000 & 0.0000 & 0.0000 & 0.0000 & 0.0000 & 0.2000\end{array}$

Columns 9 through 16

$\begin{array}{llllllll}-0.0000 & 0.0000 & 0.0082 & 0.0000 & 0.0000 & 0.0063 & -0.0000 & 0.0000\end{array}$ 


$\begin{array}{rrrrrrrr}-0.0000 & 0.0000 & 0.0082 & 0.0000 & 0.0000 & 0.0047 & -0.0000 & 0.0000 \\ -0.0000 & -0.0000 & 0.0058 & 0.0000 & 0.0000 & -0.0000 & 0.0000 & -0.0000 \\ -0.0000 & 0.0000 & 0.0033 & -0.0000 & 0.0000 & -0.0000 & -0.0000 & -0.0000 \\ -0.0000 & 0.0000 & 0.0003 & 0.0000 & 0.0000 & 0.0000 & -0.0000 & 0.0000 \\ -0.0000 & 0.0000 & -0.0000 & 0.0000 & 0.0000 & 0.0000 & -0.0000 & 0.0000 \\ -0.0000 & 0.0000 & 0.0000 & 0.0000 & 0.0000 & 0.0000 & -0.0000 & 0.0000 \\ -0.0000 & 0.0000 & 0.0000 & -0.0000 & 0.0000 & 0.0000 & -0.0000 & 0.0000 \\ -0.0000 & -0.0000 & 0.0000 & 0.0000 & 0.0000 & -0.0000 & -0.0000 & 0.0000 \\ -0.0000 & -0.0000 & 0.0000 & -0.0000 & 0.0000 & -0.0000 & -0.0000 & -0.0000 \\ -0.0000 & -0.0000 & 0.0000 & -0.0000 & 0.0000 & -0.0000 & 0.0000 & -0.0000 \\ -0.0000 & -0.0000 & 0.0000 & -0.0000 & 0.0000 & -0.0000 & 0.0000 & 0.0000 \\ -0.0000 & -0.0000 & 0.0000 & -0.0000 & 0.0000 & 0.0000 & 0.0000 & -0.0000 \\ 0.0000 & 0.0006 & -0.0000 & 0.0000 & -0.0000 & -0.0000 & 0.0000 & -0.0000 \\ 0.0000 & 0.0017 & -0.0000 & 0.0000 & -0.0000 & -0.0000 & 0.0000 & -0.0000 \\ 0.0000 & 0.0000 & 0.0000 & 0.0000 & -0.0000 & -0.0000 & 0.0000 & -0.0000 \\ 0.0000 & 0.0000 & 0.0000 & 0.0000 & -0.0000 & -0.0000 & 0.0000 & -0.0000 \\ 0.0000 & 0.0000 & 0.0000 & 0.0000 & -0.0000 & 0.0000 & 0.0000 & 0.0000 \\ 0.0000 & 0 & 0.0000 & -0.0000 & -0.0000 & 0.0000 & -0.0000 & -0.0000 \\ 0.0000 & 0 & 0.0000 & 0.0000 & -0.0000 & -0.0000 & 0.0000 & -0.0000 \\ 0.0000 & 0 & -0.0000 & 0.0000 & -0.0000 & -0.0000 & 0.0000 & -0.0000 \\ 0.0000 & 0 & -0.0000 & 0.0000 & -0.0000 & -0.0000 & -0.0000 & -0.0000 \\ 0.0000 & 0 & -0.0000 & 0.0000 & -0.0000 & -0.0000 & -0.0000 & -0.0000 \\ 0.0000 & -0.0000 & -0.0000 & -0.0000 & -0.0000 & 0.0000 & -0.0000 & -0.0000 \\ 0.0000 & -0.0000 & -0.0000 & -0.0000 & -0.0000 & -0.0000 & -0.0000 & -0.0000 \\ 0.0000 & -0.0000 & -0.0000 & -0.0000 & -0.0000 & -0.0000 & -0.0000 & -0.0000 \\ 0.0000 & -0.0000 & -0.0000 & -0.0000 & -0.0000 & -0.0000 & 0.0000 & 0.0000\end{array}$

Columns 17 through 24

$\begin{array}{rrrrrrrr}0.0028 & 0.0000 & 0.0017 & -0.0000 & 0.0000 & 0.0000 & 0.0118 & 0.0000 \\ -0.0000 & -0.0000 & 0.0039 & -0.0000 & 0.0000 & -0.0000 & 0.0244 & 0.0000 \\ -0.0000 & -0.0000 & 0.0070 & 0.0000 & 0.0000 & 0.0000 & 0.0441 & 0.0000 \\ 0.0000 & 0.0000 & 0.0067 & -0.0000 & 0.0000 & 0.0000 & 0.0569 & 0.0000 \\ -0.0000 & 0.0000 & 0.0062 & 0.0000 & 0.0000 & 0.0000 & 0.0702 & 0.0000 \\ -0.0000 & 0.0000 & 0.0061 & 0.0000 & 0.0000 & 0.0000 & 0.0830 & 0.0000 \\ -0.0000 & 0.0000 & 0.0061 & 0.0000 & 0.0000 & 0.0000 & 0.0958 & 0.0000 \\ -0.0000 & 0.0000 & 0.0061 & 0.0000 & 0.0000 & 0.0000 & 0.1085 & 0.0000 \\ 0.0000 & -0.0000 & 0.0061 & 0.0000 & 0.0000 & 0.0000 & 0.1212 & 0.0000 \\ -0.0000 & -0.0000 & 0.0063 & -0.0000 & 0.0000 & -0.0000 & 0.1358 & 0.0000 \\ 0.0000 & 0.0000 & 0.0071 & -0.0000 & -0.0000 & -0.0000 & 0.1532 & -0.0000 \\ 0.0000 & -0.0000 & 0.0078 & -0.0000 & -0.0000 & -0.0000 & 0.1705 & -0.0000 \\ 0.0000 & 0.0000 & 0.0086 & -0.0000 & -0.0000 & -0.0000 & 0.1878 & -0.0000 \\ 0.0000 & 0.0000 & 0.0093 & 0.0000 & -0.0000 & 0.0000 & 0.2050 & 0.0000 \\ 0.0000 & -0.0000 & 0.0116 & 0.0000 & -0.0000 & -0.0000 & 0.2234 & 0.0000 \\ 0.0000 & 0.0000 & 0.0093 & 0.0000 & -0.0000 & -0.0000 & 0.2228 & 0.0000 \\ 0.0000 & 0.0000 & 0.0066 & 0.0000 & -0.0000 & -0.0000 & 0.2182 & -0.0000 \\ 0.0000 & 0.0000 & 0.0039 & 0.0000 & -0.0000 & -0.0000 & 0.2136 & -0.0000 \\ 0.0000 & 0.0000 & 0.0012 & 0.0000 & -0.0000 & 0.0000 & 0.2091 & 0.0000 \\ 0.0000 & 0.0000 & -0.0000 & 0.0000 & -0.0000 & -0.0000 & 0.2031 & 0.0000 \\ 0.0000 & 0.0000 & -0.0000 & 0.0000 & 0.0000 & -0.0000 & 0.1960 & 0.0000\end{array}$




$\begin{array}{rrrrrrrr}-0.0000 & -0.0000 & 0.0000 & -0.0000 & 0.0000 & 0.0000 & 0.1889 & -0.0000 \\ -0.0000 & -0.0000 & 0.0000 & -0.0000 & 0.0000 & 0.0000 & 0.1818 & -0.0000 \\ -0.0000 & 0.0000 & 0 & 0.0000 & 0.0000 & 0.0000 & 0.1437 & 0.0000 \\ 0.0000 & -0.0000 & 0 & 0.0000 & 0.0000 & 0.0000 & 0.1039 & 0.0000 \\ 0.0000 & -0.0000 & 0 & 0.0000 & 0.0000 & 0.0000 & 0.0642 & 0.0000 \\ 0.0000 & -0.0000 & 0 & 0.0000 & 0.0000 & 0.0000 & 0.0245 & -0.0000\end{array}$

Columns 25 through 31

$\begin{array}{rrrrrrr}0.0000 & -0.0000 & 0.0000 & -0.0000 & 0.0073 & -0.0000 & 0.1000 \\ -0.0000 & -0.0000 & -0.0000 & -0.0000 & 0.0063 & -0.0000 & 0.0000 \\ -0.0000 & -0.0000 & 0.0000 & 0.0032 & 0.0026 & -0.0000 & 0.0000 \\ 0.0000 & 0.0000 & -0.0000 & 0.0075 & -0.0000 & 0.0000 & 0.0000 \\ 0.0000 & 0.0000 & 0.0000 & 0.0121 & 0.0000 & 0.0000 & -0.0000 \\ 0.0000 & -0.0000 & 0.0000 & 0.0162 & -0.0000 & 0.0000 & -0.0000 \\ 0.0000 & -0.0000 & 0.0000 & 0.0203 & -0.0000 & 0.0000 & -0.0000 \\ 0.0000 & -0.0000 & 0.0000 & 0.0243 & -0.0000 & 0.0000 & -0.0000 \\ -0.0000 & 0.0000 & -0.0000 & 0.0284 & -0.0000 & 0.0000 & -0.0000 \\ -0.0000 & 0.0000 & -0.0000 & 0.0327 & -0.0000 & 0.0000 & -0.0000 \\ 0.0000 & -0.0000 & -0.0000 & 0.0374 & -0.0000 & 0.0000 & -0.0000 \\ 0.0000 & 0.0000 & -0.0000 & 0.0421 & -0.0000 & 0.0000 & -0.0000 \\ 0.0000 & 0.0000 & 0.0000 & 0.0468 & -0.0000 & 0.0000 & -0.0000 \\ -0.0000 & -0.0000 & 0.0000 & 0.0514 & -0.0000 & -0.0000 & -0.0000 \\ 0.0000 & -0.0000 & 0.0000 & 0.0561 & -0.0000 & 0.0000 & 0.0000 \\ -0.0000 & -0.0000 & 0.0000 & 0.0679 & 0.0000 & -0.0000 & 0.0000 \\ -0.0000 & -0.0000 & 0.0000 & 0.0752 & 0.0000 & -0.0000 & 0.0000 \\ -0.0000 & -0.0000 & 0.0000 & 0.0825 & 0.0000 & -0.0000 & 0.0000 \\ -0.0000 & -0.0000 & -0.0000 & 0.0898 & -0.0000 & -0.0000 & 0.0000 \\ 0.0000 & 0.0000 & 0.0000 & 0.0969 & -0.0000 & -0.0000 & 0.0000 \\ 0.0000 & 0.0000 & 0.0000 & 0.1040 & -0.0000 & -0.0000 & 0.0000 \\ -0.0000 & 0.0000 & -0.0000 & 0.1111 & 0.0000 & -0.0000 & 0.0000 \\ -0.0000 & 0.0000 & -0.0000 & 0.1182 & 0.0000 & -0.0000 & 0.0000 \\ -0.0000 & -0.0000 & -0.0000 & 0.1563 & 0.0000 & -0.0000 & 0.0000 \\ 0.0000 & -0.0000 & -0.0000 & 0.1961 & 0.0000 & -0.0000 & 0.0000 \\ 0.0000 & -0.0000 & -0.0000 & 0.2358 & 0.0000 & -0.0000 & 0.0000 \\ -0.0000 & 0.0000 & -0.0000 & 0.2755 & -0.0000 & 0.0000 & -0.0000\end{array}$


Restrição de 40\% a Ativos Internacionais (2003 a 2006)

[PortRisk, PortReturn, PortWts] = frontcon(ExpRetIntPais03,ExpCovIntPais03,[], PortReturnInt06,AssetBoundsInt05,GroupsInt05,GroupsBoundsInt05)

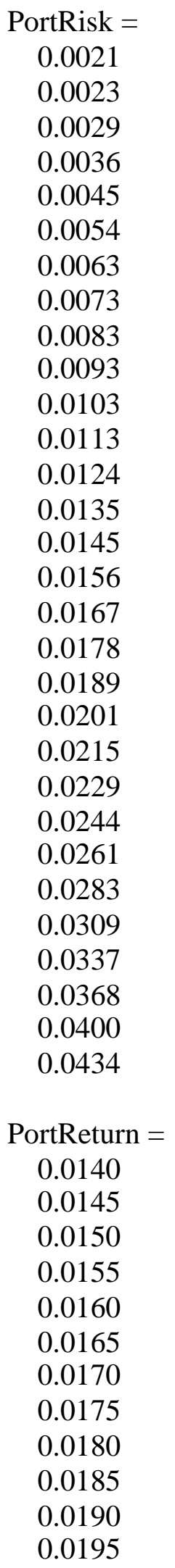


0.0200
0.0205
0.0210
0.0215
0.0220
0.0225
0.0230
0.0235
0.0240
0.0245
0.0250
0.0255
0.0260
0.0265
0.0270
0.0275
0.0280
0.0285

PortWts =

Columns 1 through 8

$\begin{array}{rrrrrrrr}0.7093 & 0.1499 & 0.0000 & -0.0000 & -0.0000 & -0.0000 & 0.0026 & 0.0000 \\ 0.7943 & 0.1583 & -0.0000 & 0.0000 & 0.0000 & 0.0000 & 0.0000 & -0.0000 \\ 0.7566 & 0.1676 & 0.0131 & 0.0000 & -0.0000 & 0.0000 & 0.0000 & -0.0000 \\ 0.6457 & 0.1676 & 0.1123 & 0.0000 & -0.0000 & -0.0000 & 0.0000 & -0.0000 \\ 0.5345 & 0.1651 & 0.2117 & 0.0000 & -0.0000 & -0.0000 & -0.0000 & -0.0000 \\ 0.4183 & 0.1608 & 0.3156 & 0.0000 & 0.0000 & -0.0000 & -0.0000 & -0.0000 \\ 0.3017 & 0.1563 & 0.4199 & 0.0000 & -0.0000 & -0.0000 & 0.0000 & -0.0000 \\ 0.1850 & 0.1518 & 0.5243 & -0.0000 & -0.0000 & -0.0000 & -0.0000 & 0.0000 \\ 0.0684 & 0.1473 & 0.6286 & -0.0000 & -0.0000 & -0.0000 & -0.0000 & 0.0000 \\ -0.0000 & 0.1320 & 0.6931 & -0.0000 & 0.0000 & 0.0000 & -0.0000 & -0.0000 \\ 0 & 0.1013 & 0.7011 & -0.0000 & 0.0000 & 0.0000 & 0.0000 & -0.0000 \\ 0.0000 & 0.0706 & 0.7090 & 0.0000 & 0.0000 & -0.0000 & -0.0000 & -0.0000 \\ 0.0000 & 0.0399 & 0.7170 & -0.0000 & 0.0000 & -0.0000 & -0.0000 & -0.0000 \\ -0.0000 & 0.0091 & 0.7246 & -0.0000 & 0.0000 & 0.0000 & -0.0000 & 0.0000 \\ 0.0000 & 0.0000 & 0.7073 & 0.0000 & -0.0000 & 0.0000 & -0.0000 & 0.0000 \\ -0.0000 & -0.0000 & 0.6797 & 0.0000 & -0.0000 & 0.0000 & -0.0000 & -0.0000 \\ -0.0000 & 0.0000 & 0.6521 & 0.0000 & -0.0000 & 0.0000 & -0.0000 & -0.0000 \\ -0.0000 & 0.0000 & 0.6244 & 0.0000 & -0.0000 & 0.0000 & -0.0000 & 0.0000 \\ -0.0000 & 0.0000 & 0.6000 & 0.0000 & 0.0000 & 0.0000 & -0.0000 & 0.0000 \\ 0.0000 & -0.0000 & 0.5788 & 0.0000 & -0.0000 & 0.0000 & -0.0000 & 0.0212 \\ -0.0000 & -0.0000 & 0.5524 & 0.0000 & -0.0000 & 0.0000 & -0.0000 & 0.0476 \\ -0.0000 & 0.0000 & 0.5261 & 0.0000 & 0.0000 & 0.0000 & 0.0000 & 0.0739 \\ -0.0000 & 0.0000 & 0.5000 & 0.0000 & 0.0000 & 0.0000 & 0.0000 & 0.1000 \\ -0.0000 & -0.0000 & 0.5000 & 0.0000 & 0.0000 & 0.0000 & 0.0000 & 0.1000 \\ -0.0000 & -0.0000 & 0.5000 & -0.0000 & 0.0000 & 0.0000 & 0.0000 & 0.1000 \\ -0.0000 & 0.0000 & 0.5000 & 0.0000 & 0.0000 & 0.0000 & 0.0000 & 0.1000 \\ -0.0000 & 0.0000 & 0.5000 & 0.0000 & 0.0000 & 0.0000 & 0.0000 & 0.1000 \\ 0.0000 & -0.0000 & 0.5000 & -0.0000 & 0.0000 & 0.0000 & 0.0000 & 0.1000\end{array}$


$\begin{array}{rrrrrrrr}-0.0000 & 0.0000 & 0.5000 & 0.0000 & 0.0000 & 0.0000 & 0.0000 & 0.1000 \\ -0.0000 & -0.0000 & 0.5000 & 0.0000 & 0.0000 & 0.0000 & 0.0000 & 0.1000\end{array}$

Columns 9 through 16

$\begin{array}{rrrrrrrr}0.0000 & 0.0000 & 0.0082 & 0.0000 & 0.0000 & 0.0063 & 0.0000 & 0.0000 \\ 0.0000 & -0.0000 & 0.0082 & -0.0000 & 0.0000 & 0.0047 & 0.0000 & -0.0000 \\ -0.0000 & 0.0000 & 0.0058 & -0.0000 & 0.0000 & -0.0000 & -0.0000 & 0.0000 \\ -0.0000 & -0.0000 & 0.0033 & -0.0000 & 0.0000 & 0.0000 & 0.0000 & 0.0000 \\ -0.0000 & 0.0000 & 0.0003 & 0.0000 & 0.0000 & -0.0000 & -0.0000 & 0.0000 \\ -0.0000 & 0.0000 & 0.0000 & -0.0000 & 0.0000 & 0.0000 & -0.0000 & -0.0000 \\ 0.0000 & 0.0000 & 0.0000 & 0.0000 & 0.0000 & 0.0000 & 0.0000 & -0.0000 \\ -0.0000 & -0.0000 & 0.0000 & 0.0000 & 0.0000 & -0.0000 & -0.0000 & 0.0000 \\ -0.0000 & 0.0000 & 0.0000 & 0.0000 & 0.0000 & -0.0000 & -0.0000 & -0.0000 \\ -0.0000 & -0.0000 & 0.0000 & -0.0000 & 0.0000 & -0.0000 & -0.0000 & -0.0000 \\ -0.0000 & 0.0000 & 0.0000 & -0.0000 & 0.0000 & -0.0000 & -0.0000 & -0.0000 \\ -0.0000 & 0.0000 & 0.0000 & -0.0000 & 0.0000 & 0.0000 & 0.0000 & -0.0000 \\ -0.0000 & -0.0000 & -0.0000 & -0.0000 & 0.0000 & 0.0000 & 0.0000 & -0.0000 \\ 0.0000 & 0.0006 & 0.0000 & 0.0000 & -0.0000 & -0.0000 & 0.0000 & -0.0000 \\ 0.0000 & 0.0017 & 0.0000 & 0.0000 & -0.0000 & -0.0000 & 0.0000 & -0.0000 \\ 0.0000 & 0.0027 & 0.0000 & 0.0000 & -0.0000 & -0.0000 & 0.0000 & 0.0000 \\ 0.0000 & 0.0037 & 0.0000 & 0.0000 & -0.0000 & -0.0000 & 0.0000 & 0.0000 \\ 0.0000 & 0.0047 & 0.0000 & 0.0000 & -0.0000 & 0.0000 & 0.0000 & 0.0000 \\ 0.0000 & 0.0016 & 0.0000 & -0.0000 & -0.0000 & 0.0000 & -0.0000 & 0.0000 \\ 0.0000 & 0.0000 & 0.0000 & -0.0000 & -0.0000 & 0.0000 & -0.0000 & 0.0000 \\ 0.0000 & 0.0000 & 0.0000 & -0.0000 & -0.0000 & 0.0000 & -0.0000 & 0.0000 \\ 0.0000 & -0.0000 & -0.0000 & 0.0000 & -0.0000 & -0.0000 & -0.0000 & -0.0000 \\ 0.0000 & 0 & -0.0000 & 0.0000 & -0.0000 & -0.0000 & -0.0000 & -0.0000 \\ 0.0000 & 0 & -0.0000 & 0.0000 & -0.0000 & -0.0000 & -0.0000 & -0.0000 \\ 0.0000 & 0.0000 & -0.0000 & -0.0000 & -0.0000 & 0.0000 & -0.0000 & 0.0000 \\ 0.0000 & -0.0000 & -0.0000 & -0.0000 & -0.0000 & -0.0000 & -0.0000 & -0.0000 \\ 0.0000 & -0.0000 & -0.0000 & -0.0000 & -0.0000 & -0.0000 & -0.0000 & -0.0000 \\ 0.0000 & -0.0000 & -0.0000 & -0.0000 & -0.0000 & 0.0000 & -0.0000 & 0.0000 \\ 0.0000 & -0.0000 & -0.0000 & -0.0000 & -0.0000 & 0.0000 & -0.0000 & -0.0000 \\ 0.0000 & 0.0000 & -0.0000 & -0.0000 & -0.0000 & -0.0000 & 0.0000 & 0.0000\end{array}$

Columns 17 through 24

$\begin{array}{rccccccc}0.0028 & 0.0000 & 0.0017 & 0.0000 & 0.0000 & -0.0000 & 0.0118 & 0.0000 \\ -0.0000 & -0.0000 & 0.0039 & 0.0000 & 0.0000 & 0.0000 & 0.0244 & -0.0000 \\ 0.0000 & -0.0000 & 0.0070 & 0.0000 & 0.0000 & 0.0000 & 0.0441 & 0.0000 \\ 0.0000 & 0.0000 & 0.0067 & -0.0000 & 0.0000 & 0.0000 & 0.0569 & 0.0000 \\ -0.0000 & -0.0000 & 0.0062 & -0.0000 & 0.0000 & -0.0000 & 0.0702 & -0.0000 \\ -0.0000 & -0.0000 & 0.0061 & -0.0000 & 0.0000 & 0.0000 & 0.0830 & -0.0000 \\ -0.0000 & -0.0000 & 0.0061 & -0.0000 & 0.0000 & -0.0000 & 0.0958 & 0.0000 \\ -0.0000 & -0.0000 & 0.0061 & 0.0000 & 0.0000 & -0.0000 & 0.1085 & -0.0000 \\ -0.0000 & -0.0000 & 0.0061 & 0.0000 & 0.0000 & -0.0000 & 0.1212 & -0.0000 \\ -0.0000 & -0.0000 & 0.0063 & 0.0000 & 0.0000 & 0.0000 & 0.1358 & 0.0000 \\ -0.0000 & -0.0000 & 0.0071 & -0.0000 & -0.0000 & -0.0000 & 0.1532 & 0.0000 \\ 0.0000 & 0.0000 & 0.0078 & -0.0000 & -0.0000 & 0.0000 & 0.1705 & -0.0000 \\ -0.0000 & -0.0000 & 0.0086 & 0.0000 & -0.0000 & 0.0000 & 0.1878 & -0.0000 \\ 0.0000 & 0.0000 & 0.0093 & 0.0000 & -0.0000 & 0.0000 & 0.2050 & 0.0000\end{array}$




$\begin{array}{rrrrrrrr}0.0000 & 0.0000 & 0.0116 & 0.0000 & -0.0000 & -0.0000 & 0.2234 & -0.0000 \\ 0.0000 & 0.0000 & 0.0146 & 0.0000 & -0.0000 & -0.0000 & 0.2423 & -0.0000 \\ 0.0000 & 0.0000 & 0.0176 & 0.0000 & -0.0000 & -0.0000 & 0.2613 & -0.0000 \\ 0.0000 & 0.0000 & 0.0206 & 0.0000 & 0.0000 & -0.0000 & 0.2802 & -0.0000 \\ 0.0000 & 0.0000 & 0.0233 & 0.0000 & 0.0000 & 0.0000 & 0.2994 & 0.0000 \\ 0.0000 & 0.0000 & 0.0195 & 0.0000 & 0.0000 & 0.0000 & 0.2926 & 0.0000 \\ 0.0000 & -0.0000 & 0.0168 & 0.0000 & 0.0000 & 0.0000 & 0.2880 & 0.0000 \\ -0.0000 & -0.0000 & 0.0141 & -0.0000 & 0.0000 & 0.0000 & 0.2834 & -0.0000 \\ -0.0000 & -0.0000 & 0.0113 & -0.0000 & 0.0000 & 0.0000 & 0.2786 & -0.0000 \\ -0.0000 & -0.0000 & 0.0001 & -0.0000 & 0.0000 & 0.0000 & 0.2502 & -0.0000 \\ -0.0000 & -0.0000 & 0 & 0.0000 & 0.0000 & 0.0000 & 0.2105 & 0.0000 \\ 0.0000 & -0.0000 & 0 & 0.0000 & 0.0000 & 0.0000 & 0.1708 & 0.0000 \\ 0.0000 & -0.0000 & -0.0000 & 0.0000 & 0.0000 & 0.0000 & 0.1311 & 0.0000 \\ 0.0000 & 0.0000 & 0 & 0.0000 & 0.0000 & 0.0000 & 0.0914 & 0.0000 \\ 0.0000 & -0.0000 & 0 & 0.0000 & 0.0000 & 0.0000 & 0.0517 & 0.0000 \\ 0.0000 & -0.0000 & 0 & -0.0000 & 0.0000 & -0.0000 & 0.0120 & 0.0000\end{array}$

Columns 25 through 31

$\begin{array}{rrrrrrr}-0.0000 & 0.0000 & -0.0000 & 0.0000 & 0.0073 & 0.0000 & 0.1000 \\ -0.0000 & 0.0000 & -0.0000 & 0.0000 & 0.0063 & 0.0000 & 0.0000 \\ -0.0000 & -0.0000 & 0.0000 & 0.0032 & 0.0026 & 0.0000 & 0.0000 \\ 0.0000 & -0.0000 & 0.0000 & 0.0075 & 0.0000 & 0.0000 & 0.0000 \\ -0.0000 & 0.0000 & -0.0000 & 0.0121 & -0.0000 & 0.0000 & 0.0000 \\ -0.0000 & 0.0000 & -0.0000 & 0.0162 & 0.0000 & 0.0000 & 0.0000 \\ 0.0000 & -0.0000 & 0.0000 & 0.0203 & -0.0000 & 0.0000 & 0.0000 \\ -0.0000 & 0.0000 & 0.0000 & 0.0243 & 0.0000 & 0.0000 & -0.0000 \\ -0.0000 & 0.0000 & 0.0000 & 0.0284 & -0.0000 & -0.0000 & -0.0000 \\ -0.0000 & 0.0000 & 0.0000 & 0.0327 & -0.0000 & 0.0000 & 0.0000 \\ 0.0000 & 0.0000 & 0.0000 & 0.0374 & -0.0000 & 0.0000 & -0.0000 \\ 0.0000 & 0.0000 & -0.0000 & 0.0421 & -0.0000 & 0.0000 & -0.0000 \\ -0.0000 & -0.0000 & -0.0000 & 0.0468 & -0.0000 & 0.0000 & -0.0000 \\ -0.0000 & -0.0000 & 0.0000 & 0.0514 & 0.0000 & -0.0000 & -0.0000 \\ -0.0000 & -0.0000 & 0.0000 & 0.0561 & 0.0000 & -0.0000 & 0.0000 \\ -0.0000 & -0.0000 & 0.0000 & 0.0608 & -0.0000 & -0.0000 & 0.0000 \\ -0.0000 & -0.0000 & 0.0000 & 0.0655 & 0.0000 & -0.0000 & 0.0000 \\ -0.0000 & -0.0000 & -0.0000 & 0.0702 & 0.0000 & -0.0000 & 0.0000 \\ -0.0000 & -0.0000 & -0.0000 & 0.0757 & -0.0000 & -0.0000 & 0.0000 \\ -0.0000 & -0.0000 & -0.0000 & 0.0879 & -0.0000 & -0.0000 & 0.0000 \\ -0.0000 & -0.0000 & -0.0000 & 0.0952 & -0.0000 & -0.0000 & 0.0000 \\ -0.0000 & 0.0000 & -0.0000 & 0.1025 & 0.0000 & -0.0000 & 0.0000 \\ -0.0000 & 0.0000 & -0.0000 & 0.1101 & 0.0000 & -0.0000 & 0.0000 \\ -0.0000 & 0.0000 & -0.0000 & 0.1498 & -0.0000 & -0.0000 & 0.0000 \\ 0.0000 & -0.0000 & -0.0000 & 0.1895 & 0.0000 & 0.0000 & 0.0000 \\ 0.0000 & -0.0000 & -0.0000 & 0.2292 & 0.0000 & -0.0000 & 0.0000 \\ 0.0000 & -0.0000 & -0.0000 & 0.2689 & 0.0000 & -0.0000 & 0.0000 \\ -0.0000 & -0.0000 & 0.0000 & 0.3086 & -0.0000 & 0.0000 & 0.0000 \\ -0.0000 & -0.0000 & -0.0000 & 0.3483 & 0.0000 & -0.0000 & 0.0000 \\ 0.0000 & 0.0000 & -0.0000 & 0.3880 & 0.0000 & 0.0000 & -0.0000\end{array}$


Restrição de 50\% a Ativos Internacionais (2003 a 2006)

[PortRisk, PortReturn, PortWts] = frontcon(ExpRetIntPais03,ExpCovIntPais03, [], PortReturnInt06,AssetBoundsInt05,GroupsInt05,GroupsBoundsInt05)

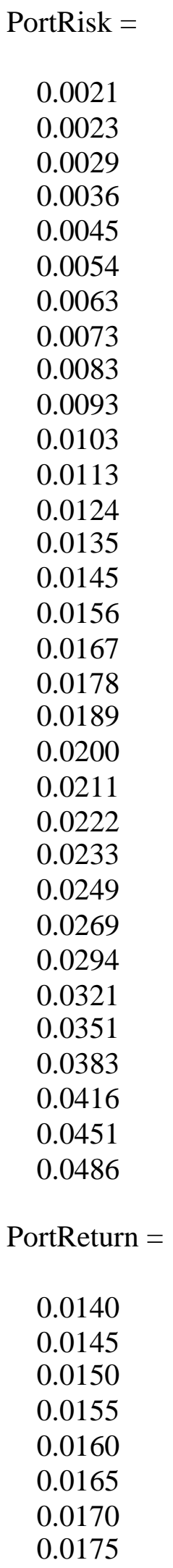




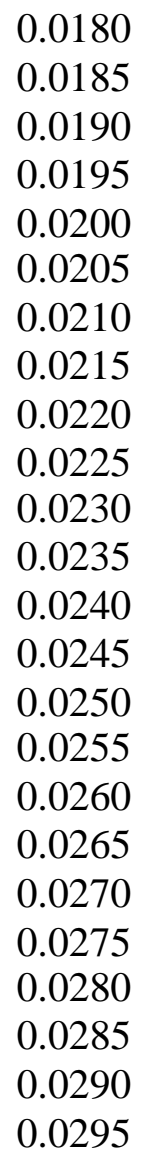

PortWts =

Columns 1 through 8

$\begin{array}{rrrrrrrr}0.7093 & 0.1499 & -0.0000 & 0.0000 & -0.0000 & 0.0000 & 0.0026 & -0.0000 \\ 0.7943 & 0.1583 & 0.0000 & -0.0000 & -0.0000 & 0.0000 & 0.0000 & -0.0000 \\ 0.7566 & 0.1676 & 0.0131 & 0.0000 & 0.0000 & 0.0000 & 0.0000 & -0.0000 \\ 0.6457 & 0.1676 & 0.1123 & 0.0000 & -0.0000 & 0.0000 & -0.0000 & -0.0000 \\ 0.5345 & 0.1651 & 0.2117 & 0.0000 & -0.0000 & 0.0000 & -0.0000 & -0.0000 \\ 0.4183 & 0.1608 & 0.3156 & -0.0000 & 0.0000 & -0.0000 & -0.0000 & 0.0000 \\ 0.3017 & 0.1563 & 0.4199 & -0.0000 & 0.0000 & -0.0000 & 0.0000 & 0.0000 \\ 0.1850 & 0.1518 & 0.5243 & -0.0000 & 0.0000 & -0.0000 & 0.0000 & 0.0000 \\ 0.0684 & 0.1473 & 0.6286 & 0.0000 & -0.0000 & 0.0000 & -0.0000 & 0.0000 \\ -0.0000 & 0.1320 & 0.6931 & -0.0000 & -0.0000 & 0.0000 & -0.0000 & 0.0000 \\ 0.0000 & 0.1013 & 0.7011 & 0.0000 & -0.0000 & 0.0000 & -0.0000 & 0.0000 \\ -0.0000 & 0.0706 & 0.7090 & 0.0000 & -0.0000 & 0.0000 & -0.0000 & 0.0000 \\ 0.0000 & 0.0399 & 0.7170 & 0.0000 & -0.0000 & 0.0000 & -0.0000 & 0.0000 \\ 0.0000 & 0.0091 & 0.7246 & 0.0000 & -0.0000 & 0.0000 & -0.0000 & 0.0000 \\ -0.0000 & -0.0000 & 0.7073 & 0.0000 & -0.0000 & 0.0000 & 0.0000 & 0.0000 \\ 0.0000 & 0.0000 & 0.6797 & 0.0000 & 0.0000 & 0.0000 & 0.0000 & 0.0000 \\ -0.0000 & -0.0000 & 0.6521 & 0.0000 & 0.0000 & 0.0000 & 0.0000 & 0.0000 \\ -0.0000 & -0.0000 & 0.6244 & 0.0000 & 0.0000 & 0.0000 & 0.0000 & 0.0000 \\ -0.0000 & -0.0000 & 0.5968 & 0.0000 & 0.0000 & 0.0000 & 0.0000 & 0.0000 \\ -0.0000 & -0.0000 & 0.5692 & 0.0000 & 0.0000 & 0.0000 & 0.0000 & 0.0000 \\ -0.0000 & 0 & 0.5416 & -0.0000 & -0.0000 & 0.0000 & 0.0000 & 0.0000\end{array}$




$\begin{array}{rrrrrrrr}-0.0000 & -0.0000 & 0.5140 & -0.0000 & 0.0000 & -0.0000 & 0.0000 & 0.0000 \\ 0.0000 & 0.0000 & 0.5000 & -0.0000 & -0.0000 & -0.0000 & 0.0000 & 0.0000 \\ 0.0000 & 0.0000 & 0.5000 & -0.0000 & -0.0000 & 0.0000 & 0.0000 & 0.0000 \\ -0.0000 & 0.0000 & 0.5000 & -0.0000 & -0.0000 & 0.0000 & 0.0000 & 0.0000 \\ 0.0000 & 0.0000 & 0.5000 & -0.0000 & -0.0000 & 0.0000 & 0.0000 & 0.0000 \\ -0.0000 & 0.0000 & 0.5000 & -0.0000 & -0.0000 & 0.0000 & 0.0000 & 0.0000 \\ -0.0000 & -0.0000 & 0.5000 & -0.0000 & 0.0000 & 0.0000 & 0.0000 & 0.0000 \\ -0.0000 & -0.0000 & 0.5000 & -0.0000 & 0.0000 & 0.0000 & 0.0000 & 0.0000 \\ -0.0000 & 0.0000 & 0.5000 & -0.0000 & 0.0000 & 0.0000 & 0.0000 & -0.0000 \\ -0.0000 & 0.0000 & 0.5000 & -0.0000 & 0.0000 & 0.0000 & 0.0000 & -0.0000 \\ -0.0000 & 0.0000 & 0.5000 & -0.0000 & 0.0000 & 0.0000 & 0.0000 & 0.0000\end{array}$

Columns 9 through 16

$\begin{array}{rrrrrrrr}0.0000 & -0.0000 & 0.0082 & 0.0000 & -0.0000 & 0.0063 & -0.0000 & -0.0000 \\ 0.0000 & -0.0000 & 0.0082 & 0.0000 & -0.0000 & 0.0047 & 0.0000 & 0.0000 \\ 0.0000 & -0.0000 & 0.0058 & -0.0000 & -0.0000 & -0.0000 & -0.0000 & -0.0000 \\ 0.0000 & -0.0000 & 0.0033 & 0.0000 & -0.0000 & -0.0000 & 0.0000 & -0.0000 \\ 0.0000 & -0.0000 & 0.0003 & -0.0000 & -0.0000 & -0.0000 & 0.0000 & -0.0000 \\ 0.0000 & 0.0000 & -0.0000 & -0.0000 & -0.0000 & 0.0000 & 0.0000 & -0.0000 \\ 0.0000 & -0.0000 & -0.0000 & -0.0000 & -0.0000 & -0.0000 & -0.0000 & -0.0000 \\ 0.0000 & 0.0000 & -0.0000 & 0.0000 & -0.0000 & -0.0000 & -0.0000 & -0.0000 \\ 0.0000 & 0.0000 & 0.0000 & -0.0000 & 0.0000 & -0.0000 & -0.0000 & -0.0000 \\ 0.0000 & 0.0000 & 0.0000 & 0.0000 & 0.0000 & -0.0000 & -0.0000 & 0.0000 \\ 0.0000 & 0.0000 & 0.0000 & 0.0000 & 0.0000 & 0.0000 & 0.0000 & 0.0000 \\ 0.0000 & 0.0000 & 0.0000 & 0.0000 & 0.0000 & 0.0000 & 0.0000 & 0.0000 \\ 0.0000 & -0.0000 & 0.0000 & 0.0000 & -0.0000 & 0.0000 & 0.0000 & 0.0000 \\ 0.0000 & 0.0006 & -0.0000 & -0.0000 & -0.0000 & -0.0000 & -0.0000 & 0.0000 \\ -0.0000 & 0.0017 & 0.0000 & -0.0000 & -0.0000 & 0.0000 & -0.0000 & 0.0000 \\ -0.0000 & 0.0027 & -0.0000 & -0.0000 & -0.0000 & 0.0000 & -0.0000 & 0.0000 \\ -0.0000 & 0.0037 & 0.0000 & 0.0000 & -0.0000 & 0.0000 & -0.0000 & 0.0000 \\ -0.0000 & 0.0047 & 0.0000 & 0.0000 & -0.0000 & 0.0000 & -0.0000 & 0.0000 \\ -0.0000 & 0.0057 & 0.0000 & 0.0000 & -0.0000 & 0.0000 & 0.0000 & 0.0000 \\ -0.0000 & 0.0066 & 0.0000 & 0.0000 & -0.0000 & 0.0000 & 0.0000 & 0.0000 \\ 0.0000 & 0.0076 & 0.0000 & -0.0000 & 0.0000 & -0.0000 & 0.0000 & -0.0000 \\ 0.0000 & 0.0086 & -0.0000 & -0.0000 & -0.0000 & 0.0000 & -0.0000 & 0.0000 \\ 0.0000 & 0 & -0.0000 & -0.0000 & -0.0000 & -0.0000 & -0.0000 & 0.0000 \\ 0.0000 & -0.0000 & -0.0000 & -0.0000 & -0.0000 & -0.0000 & -0.0000 & 0.0000 \\ 0.0000 & -0.0000 & -0.0000 & -0.0000 & -0.0000 & 0.0000 & -0.0000 & 0.0000 \\ 0.0000 & -0.0000 & -0.0000 & -0.0000 & -0.0000 & 0.0000 & -0.0000 & 0.0000 \\ 0.0000 & -0.0000 & -0.0000 & -0.0000 & -0.0000 & 0.0000 & -0.0000 & 0.0000 \\ 0.0000 & -0.0000 & -0.0000 & -0.0000 & -0.0000 & 0.0000 & -0.0000 & 0.0000 \\ 0.0000 & -0.0000 & -0.0000 & -0.0000 & -0.0000 & 0.0000 & -0.0000 & 0.0000 \\ 0.0000 & 0 & 0.0000 & 0.0000 & -0.0000 & 0.0000 & -0.0000 & 0.0000 \\ 0.0000 & 0 & 0.0000 & 0.0000 & -0.0000 & 0.0000 & -0.0000 & 0.0000 \\ 0.0000 & -0.0000 & 0.0000 & 0.0000 & -0.0000 & 0.0000 & -0.0000 & 0.0000\end{array}$

Columns 17 through 24

$\begin{array}{llllllll}0.0028 & 0.0000 & 0.0017 & -0.0000 & 0.0000 & 0.0000 & 0.0118 & 0.0000\end{array}$ 


$\begin{array}{rrrrrrrr}-0.0000 & 0.0000 & 0.0039 & -0.0000 & 0.0000 & 0.0000 & 0.0244 & -0.0000 \\ 0.0000 & 0.0000 & 0.0070 & 0.0000 & 0.0000 & -0.0000 & 0.0441 & 0.0000 \\ 0.0000 & 0.0000 & 0.0067 & 0.0000 & 0.0000 & -0.0000 & 0.0569 & 0.0000 \\ -0.0000 & 0.0000 & 0.0062 & 0.0000 & 0.0000 & 0.0000 & 0.0702 & 0.0000 \\ -0.0000 & -0.0000 & 0.0061 & 0.0000 & 0.0000 & 0.0000 & 0.0830 & 0.0000 \\ -0.0000 & 0.0000 & 0.0061 & 0.0000 & 0.0000 & -0.0000 & 0.0958 & -0.0000 \\ -0.0000 & -0.0000 & 0.0061 & -0.0000 & 0.0000 & 0.0000 & 0.1085 & -0.0000 \\ 0.0000 & -0.0000 & 0.0061 & -0.0000 & -0.0000 & -0.0000 & 0.1212 & -0.0000 \\ -0.0000 & -0.0000 & 0.0063 & -0.0000 & -0.0000 & 0.0000 & 0.1358 & 0.0000 \\ -0.0000 & -0.0000 & 0.0071 & -0.0000 & -0.0000 & 0.0000 & 0.1532 & 0.0000 \\ -0.0000 & -0.0000 & 0.0078 & -0.0000 & -0.0000 & 0.0000 & 0.1705 & 0.0000 \\ -0.0000 & -0.0000 & 0.0086 & 0.0000 & -0.0000 & 0.0000 & 0.1878 & 0.0000 \\ -0.0000 & 0.0000 & 0.0093 & 0.0000 & 0.0000 & 0.0000 & 0.2050 & 0.0000 \\ -0.0000 & 0.0000 & 0.0116 & 0.0000 & 0.0000 & 0.0000 & 0.2234 & 0.0000 \\ -0.0000 & 0.0000 & 0.0146 & 0.0000 & 0.0000 & 0.0000 & 0.2423 & 0.0000 \\ -0.0000 & 0.0000 & 0.0176 & -0.0000 & 0.0000 & 0.0000 & 0.2613 & 0.0000 \\ -0.0000 & 0.0000 & 0.0206 & -0.0000 & 0.0000 & 0.0000 & 0.2802 & 0.0000 \\ -0.0000 & 0.0000 & 0.0235 & -0.0000 & 0.0000 & 0.0000 & 0.2991 & 0.0000 \\ -0.0000 & 0.0000 & 0.0265 & -0.0000 & 0.0000 & 0.0000 & 0.3181 & 0.0000 \\ -0.0000 & -0.0000 & 0.0295 & -0.0000 & 0.0000 & 0.0000 & 0.3370 & 0.0000 \\ -0.0000 & -0.0000 & 0.0325 & -0.0000 & 0.0000 & 0.0000 & 0.3559 & -0.0000 \\ -0.0000 & -0.0000 & 0.0317 & -0.0000 & 0.0000 & 0.0000 & 0.3648 & 0.0000 \\ -0.0000 & -0.0000 & 0.0204 & -0.0000 & 0.0000 & 0.0000 & 0.3364 & 0.0000 \\ -0.0000 & 0.0000 & 0.0092 & -0.0000 & 0.0000 & 0.0000 & 0.3079 & 0.0000 \\ -0.0000 & -0.0000 & 0 & -0.0000 & 0.0000 & 0.0000 & 0.2774 & -0.0000 \\ -0.0000 & 0.0000 & 0 & -0.0000 & 0.0000 & 0.0000 & 0.2377 & 0.0000 \\ -0.0000 & 0.0000 & 0 & -0.0000 & 0.0000 & 0.0000 & 0.1980 & 0.0000 \\ -0.0000 & 0.0000 & 0.0000 & -0.0000 & 0.0000 & 0.0000 & 0.1583 & 0.0000 \\ -0.0000 & -0.0000 & 0 & 0.0000 & 0.0000 & -0.0000 & 0.1186 & -0.0000 \\ -0.0000 & -0.0000 & 0 & 0.0000 & 0.0000 & -0.0000 & 0.0789 & -0.0000 \\ -0.0000 & -0.0000 & 0 & 0.0000 & 0.0000 & -0.0000 & 0.0392 & -0.0000\end{array}$

Columns 25 through 31

$\begin{array}{rrrrrrr}0.0000 & 0.0000 & 0.0000 & -0.0000 & 0.0073 & 0.0000 & 0.1000 \\ -0.0000 & 0.0000 & -0.0000 & 0.0000 & 0.0063 & -0.0000 & 0.0000 \\ -0.0000 & 0.0000 & -0.0000 & 0.0032 & 0.0026 & 0.0000 & -0.0000 \\ -0.0000 & 0.0000 & 0.0000 & 0.0075 & -0.0000 & -0.0000 & 0.0000 \\ -0.0000 & 0.0000 & -0.0000 & 0.0121 & 0.0000 & -0.0000 & 0.0000 \\ -0.0000 & 0.0000 & 0.0000 & 0.0162 & 0.0000 & 0.0000 & 0.0000 \\ 0.0000 & 0.0000 & 0.0000 & 0.0203 & 0.0000 & 0.0000 & -0.0000 \\ 0.0000 & 0.0000 & -0.0000 & 0.0243 & -0.0000 & -0.0000 & 0.0000 \\ 0.0000 & 0.0000 & 0.0000 & 0.0284 & -0.0000 & 0.0000 & -0.0000 \\ -0.0000 & -0.0000 & -0.0000 & 0.0327 & -0.0000 & 0.0000 & -0.0000 \\ -0.0000 & -0.0000 & -0.0000 & 0.0374 & -0.0000 & 0.0000 & -0.0000 \\ -0.0000 & -0.0000 & -0.0000 & 0.0421 & -0.0000 & 0.0000 & -0.0000 \\ -0.0000 & -0.0000 & -0.0000 & 0.0468 & -0.0000 & 0.0000 & -0.0000 \\ 0.0000 & -0.0000 & 0.0000 & 0.0514 & 0.0000 & 0.0000 & -0.0000 \\ 0.0000 & -0.0000 & 0.0000 & 0.0561 & 0.0000 & 0.0000 & 0.0000 \\ 0.0000 & -0.0000 & 0.0000 & 0.0608 & -0.0000 & 0.0000 & 0.0000\end{array}$




$\begin{array}{rrrrrrr}0.0000 & -0.0000 & 0.0000 & 0.0655 & 0.0000 & -0.0000 & 0.0000 \\ 0.0000 & -0.0000 & 0.0000 & 0.0702 & 0.0000 & -0.0000 & 0.0000 \\ 0.0000 & -0.0000 & 0.0000 & 0.0748 & 0.0000 & -0.0000 & 0.0000 \\ 0.0000 & -0.0000 & 0.0000 & 0.0795 & 0.0000 & -0.0000 & 0.0000 \\ -0.0000 & -0.0000 & 0.0000 & 0.0842 & 0.0000 & 0.0000 & 0.0000 \\ -0.0000 & -0.0000 & 0.0000 & 0.0889 & 0.0000 & 0.0000 & 0.0000 \\ -0.0000 & -0.0000 & 0.0000 & 0.1035 & -0.0000 & 0.0000 & 0.0000 \\ -0.0000 & -0.0000 & 0.0000 & 0.1432 & -0.0000 & 0.0000 & 0.0000 \\ -0.0000 & -0.0000 & 0.0000 & 0.1829 & 0 & 0.0000 & 0.0000 \\ 0.0000 & -0.0000 & -0.0000 & 0.2226 & -0.0000 & -0.0000 & 0.0000 \\ -0.0000 & -0.0000 & 0.0000 & 0.2623 & 0 & 0.0000 & 0.0000 \\ -0.0000 & -0.0000 & 0.0000 & 0.3020 & -0.0000 & 0.0000 & 0.0000 \\ -0.0000 & -0.0000 & 0.0000 & 0.3417 & -0.0000 & 0.0000 & 0.0000 \\ -0.0000 & -0.0000 & 0.0000 & 0.3814 & -0.0000 & 0.0000 & -0.0000 \\ -0.0000 & -0.0000 & 0.0000 & 0.4211 & -0.0000 & 0.0000 & -0.0000 \\ -0.0000 & -0.0000 & 0.0000 & 0.4608 & -0.0000 & 0.0000 & -0.0000\end{array}$




\section{APÊNDICE G - FRONTEIRAS EFICIENTES COM RETORNOS EM REAIS PARA DIFERENTES GRAUS DE ABERTURA A INVESTIMENTOS NO EXTERIOR DADOS RETORNOS DAS CARTEIRAS DA FRONTEIRA EM INTERVALOS DE $0,05 \%$}

Ativos da Fronteira

\begin{tabular}{|l|l|}
\hline Coluna 1 & CDI \\
\hline Coluna 2 & IGPM + Cupom \\
\hline Coluna 3 & IRF-M \\
\hline Coluna 4 & FIEX \\
\hline Coluna 5 & Alemanha \\
\hline Coluna 6 & Argentina \\
\hline Coluna 7 & Austrália \\
\hline Coluna 8 & Brasil \\
\hline Coluna 9 & Canadá \\
\hline Coluna 10 & Chile \\
\hline Coluna 11 & China \\
\hline Coluna 12 & Cingapura \\
\hline Coluna 13 & Coréia \\
\hline Coluna 14 & Espanha \\
\hline Coluna 15 & Estados Unidos \\
\hline Coluna 16 & França \\
\hline Coluna 17 & Holanda \\
\hline Coluna 18 & Hong Kong \\
\hline Coluna 19 & Índia \\
\hline Coluna 20 & Itália \\
\hline Coluna 21 & Japão \\
\hline Coluna 22 & Malásia \\
\hline Coluna 23 & México \\
\hline Coluna 24 & Reino Unido \\
\hline Coluna 25 & Suécia \\
\hline Coluna 26 & Suíça \\
\hline Coluna 27 & Taiwan \\
\hline Coluna 28 & Venezuela \\
\hline Coluna 29 & Imóveis \\
\hline Coluna 30 & Empréstimos \\
\hline Coluna 31 & Financiamentos \\
\hline
\end{tabular}


Restrição Total a Ativos Internacionais (2001 a 2006)

[PortRisk, PortReturn, PortWts] = frontcon(ExpRetNac06, ExpCovNac06, [], PortReturnInt06, AssetBoundsNac05, GroupsNac05, GroupsBoundsNac05)

PortRisk $=$
0.0022
0.0028
0.0039
0.0053
0.0086
0.0176
0.0358

PortReturn $=$

0.0140

0.0145

0.0150

0.0155

0.0160

0.0165

0.0170

PortWts =

$\begin{array}{rrrrrrrr}0.8954 & 0.0437 & 0 & 0.0000 & -0.0000 & 0.0079 & -0.0000 & 0.0530 \\ 0.7276 & 0.1141 & 0.1583 & 0.0000 & 0 & -0.0000 & 0.0000 & 0.0000 \\ 0.3676 & 0.2167 & 0.4157 & 0.0000 & 0 & 0.0000 & 0.0000 & 0.0000 \\ 0.0076 & 0.3193 & 0.6730 & 0.0000 & -0.0000 & 0.0000 & 0.0000 & -0.0000 \\ 0 & 0.7777 & 0.1895 & -0.0000 & 0.0328 & -0.0000 & 0.0000 & -0.0000 \\ -0.0000 & 0.8001 & -0.0000 & -0.0000 & 0.1999 & -0.0000 & 0.0000 & -0.0000 \\ -0.0000 & 0.5515 & 0.0000 & 0.0000 & 0.4485 & -0.0000 & 0.0000 & -0.0000\end{array}$




\section{Restrição de 10\% aos Ativos Internacionais (2001 a 2006)}

[PortRisk, PortReturn, PortWts] = frontcon (ExpRetInt06, ExpCovInt06, [], PortReturnInt06, AssetBoundsInt05, GroupsInt05, GroupsBoundsInt05)

PortRisk $=$
0.0021
0.0025
0.0033
0.0044
0.0057
0.0079
0.0125
0.0287

PortReturn $=$
0.0140
0.0145
0.0150
0.0155
0.0160
0.0165
0.0170
0.0175

PortWts =

Columns 1 through 8

$\begin{array}{rrrrrrrc}0.8064 & 0.0454 & 0.0353 & 0.0000 & 0.0000 & -0.0000 & 0.0000 & 0 \\ 0.7650 & 0.0849 & 0.1320 & 0.0000 & 0.0000 & 0.0000 & 0.0000 & 0.0000 \\ 0.4723 & 0.1649 & 0.3329 & 0.0000 & 0.0000 & -0.0000 & 0.0000 & 0.0000 \\ 0.1797 & 0.2449 & 0.5338 & 0.0000 & 0.0000 & -0.0000 & 0.0000 & 0.0000 \\ -0.0000 & 0.3421 & 0.5980 & -0.0000 & 0.0000 & -0.0000 & 0.0000 & 0.0000 \\ 0 & 0.5409 & 0.3525 & -0.0000 & -0.0000 & -0.0000 & 0.0000 & 0.0066 \\ 0.0000 & 0.8039 & 0.0000 & -0.0000 & -0.0000 & -0.0000 & 0.0000 & 0.0961 \\ -0.0000 & 0.5550 & 0 & 0.0000 & -0.0000 & -0.0000 & -0.0000 & 0.3450\end{array}$

Columns 9 through 16

$\begin{array}{rrrrrrrr}-0.0000 & 0.0000 & 0.0048 & 0.0000 & -0.0000 & -0.0000 & -0.0000 & 0.0000 \\ -0.0000 & 0.0000 & 0.0056 & -0.0000 & -0.0000 & -0.0000 & 0.0000 & -0.0000 \\ -0.0000 & -0.0000 & 0.0054 & 0.0000 & 0.0000 & -0.0000 & -0.0000 & 0.0000 \\ -0.0000 & -0.0000 & 0.0051 & 0.0000 & 0.0000 & 0.0000 & 0.0000 & -0.0000 \\ -0.0000 & -0.0000 & -0.0000 & -0.0000 & -0.0000 & -0.0000 & 0.0000 & 0.0000 \\ 0.0000 & -0.0000 & -0.0000 & -0.0000 & 0.0009 & -0.0000 & 0.0000 & 0.0000\end{array}$




$$
\begin{array}{llllllll}
0.0000 & 0.0000 & -0.0000 & -0.0000 & 0.0099 & 0.0000 & -0.0000 & -0.0000 \\
0.0000 & 0.0000 & -0.0000 & -0.0000 & 0.0000 & 0.0000 & -0.0000 & -0.0000
\end{array}
$$

Columns 17 through 24

$\begin{array}{rccccccc}-0.0000 & -0.0000 & -0.0000 & -0.0000 & -0.0000 & -0.0000 & 0.0071 & -0.0000 \\ 0.0000 & 0.0000 & 0.0000 & -0.0000 & -0.0000 & -0.0000 & 0.0125 & 0.0000 \\ -0.0000 & -0.0000 & 0.0000 & -0.0000 & -0.0000 & -0.0000 & 0.0245 & -0.0000 \\ -0.0000 & -0.0000 & -0.0000 & -0.0000 & -0.0000 & -0.0000 & 0.0365 & 0.0000 \\ 0.0000 & 0.0000 & 0.0047 & -0.0000 & 0.0000 & -0.0000 & 0.0552 & 0.0000 \\ -0.0000 & 0.0000 & 0.0151 & -0.0000 & 0.0000 & -0.0000 & 0.0840 & -0.0000 \\ -0.0000 & 0.0000 & -0.0000 & 0.0000 & 0.0000 & -0.0000 & 0.0901 & -0.0000 \\ -0.0000 & 0.0000 & 0.0000 & -0.0000 & -0.0000 & 0.0000 & 0.1000 & -0.0000\end{array}$

Columns 25 through 31

$$
\begin{array}{rrrrrrr}
-0.0000 & -0.0000 & 0.0000 & 0.0000 & 0.0062 & 0.0000 & 0.0947 \\
-0.0000 & -0.0000 & 0.0000 & -0.0000 & -0.0000 & 0.0000 & -0.0000 \\
-0.0000 & -0.0000 & -0.0000 & 0.0000 & -0.0000 & 0.0000 & 0.0000 \\
0.0000 & -0.0000 & -0.0000 & 0.0000 & -0.0000 & 0.0000 & -0.0000 \\
0.0000 & -0.0000 & -0.0000 & 0.0000 & 0.0000 & 0.0000 & -0.0000 \\
-0.0000 & -0.0000 & -0.0000 & 0.0000 & 0.0000 & 0.0000 & -0.0000 \\
-0.0000 & -0.0000 & -0.0000 & -0.0000 & 0.0000 & -0.0000 & -0.0000 \\
-0.0000 & 0.0000 & -0.0000 & -0.0000 & 0.0000 & 0.0000 & 0.0000
\end{array}
$$


Restrição de 20\% aos Ativos Internacionais (2001 a 2006)

[PortRisk, PortReturn, PortWts] = frontcon (ExpRetInt06, ExpCovInt06, [], PortReturnInt06, AssetBoundsInt05, GroupsInt05, GroupsBoundsInt05)

PortRisk $=$
0.0021
0.0025
0.0033
0.0044
0.0057
0.0079
0.0105
0.0134
0.0237

PortReturn $=$

0.0140

0.0145

0.0150

0.0155

0.0160

0.0165

0.0170

0.0175

0.0180

PortWts =

Columns 1 through 8

$\begin{array}{ccccccccc}0.8064 & 0.0454 & 0.0353 & -0.0000 & 0.0000 & -0.0000 & 0.0000 & -0.0000 \\ 0.7650 & 0.0849 & 0.1320 & 0.0000 & 0.0000 & -0.0000 & 0.0000 & 0.0000 \\ 0.4723 & 0.1649 & 0.3329 & -0.0000 & 0.0000 & -0.0000 & 0.0000 & -0.0000 \\ 0.1797 & 0.2449 & 0.5338 & 0.0000 & 0.0000 & -0.0000 & 0.0000 & 0.0000 \\ -0.0000 & 0.3421 & 0.5980 & -0.0000 & 0.0000 & -0.0000 & 0.0000 & 0.0000 \\ 0 & 0.4940 & 0.3968 & -0.0000 & 0.0000 & -0.0000 & 0.0000 & 0.0019 \\ 0.0000 & 0.6513 & 0.1836 & -0.0000 & -0.0000 & -0.0000 & 0.0000 & 0.0154 \\ -0.0000 & 0.7761 & -0.0000 & 0.0000 & -0.0000 & -0.0000 & -0.0000 & 0.0278 \\ 0.0000 & 0.5587 & -0.0000 & -0.0000 & -0.0000 & -0.0000 & -0.0000 & 0.2413\end{array}$

Columns 9 through 16

$\begin{array}{rrrrrrrr}-0.0000 & -0.0000 & 0.0048 & 0.0000 & 0.0000 & 0.0000 & 0.0000 & 0.0000 \\ 0.0000 & -0.0000 & 0.0056 & -0.0000 & 0.0000 & 0.0000 & 0.0000 & 0.0000 \\ -0.0000 & -0.0000 & 0.0054 & 0.0000 & -0.0000 & 0.0000 & -0.0000 & -0.0000\end{array}$




$\begin{array}{rrrrrrrr}-0.0000 & -0.0000 & 0.0051 & 0.0000 & 0.0000 & 0.0000 & -0.0000 & -0.0000 \\ 0.0000 & -0.0000 & -0.0000 & -0.0000 & -0.0000 & -0.0000 & 0.0000 & 0.0000 \\ 0.0000 & -0.0000 & -0.0000 & -0.0000 & 0.0000 & -0.0000 & 0.0000 & -0.0000 \\ 0.0000 & 0.0000 & -0.0000 & -0.0000 & -0.0000 & 0.0000 & -0.0000 & -0.0000 \\ 0.0000 & 0.0000 & 0.0000 & -0.0000 & 0.0000 & -0.0000 & -0.0000 & -0.0000 \\ 0.0000 & 0.0000 & 0.0000 & -0.0000 & 0.0059 & 0.0000 & -0.0000 & -0.0000\end{array}$

Columns 17 through 24

$\begin{array}{rrrrrrrr}-0.0000 & 0.0000 & -0.0000 & -0.0000 & -0.0000 & 0.0000 & 0.0071 & 0.0000 \\ -0.0000 & -0.0000 & -0.0000 & -0.0000 & -0.0000 & -0.0000 & 0.0125 & -0.0000 \\ -0.0000 & -0.0000 & 0.0000 & -0.0000 & 0.0000 & -0.0000 & 0.0245 & 0.0000 \\ -0.0000 & -0.0000 & 0.0000 & -0.0000 & -0.0000 & 0.0000 & 0.0365 & 0.0000 \\ 0.0000 & 0.0000 & 0.0047 & -0.0000 & -0.0000 & -0.0000 & 0.0552 & 0.0000 \\ -0.0000 & 0.0000 & 0.0184 & -0.0000 & -0.0000 & -0.0000 & 0.0888 & 0.0000 \\ -0.0000 & 0.0000 & 0.0311 & -0.0000 & 0.0000 & 0.0000 & 0.1186 & -0.0000 \\ -0.0000 & 0.0000 & 0.0442 & 0.0000 & 0.0000 & 0.0000 & 0.1519 & -0.0000 \\ -0.0000 & -0.0000 & 0.0000 & -0.0000 & 0.0000 & 0.0000 & 0.1941 & -0.0000\end{array}$

Columns 25 through 31

$\begin{array}{rrrrrrr}0.0000 & 0.0000 & 0.0000 & 0.0000 & 0.0062 & 0.0000 & 0.0947 \\ -0.0000 & 0.0000 & -0.0000 & 0.0000 & -0.0000 & 0.0000 & -0.0000 \\ 0.0000 & -0.0000 & -0.0000 & 0.0000 & -0.0000 & 0.0000 & -0.0000 \\ 0.0000 & -0.0000 & -0.0000 & 0.0000 & 0.0000 & 0.0000 & -0.0000 \\ 0.0000 & -0.0000 & -0.0000 & 0.0000 & 0.0000 & 0.0000 & -0.0000 \\ 0.0000 & -0.0000 & -0.0000 & 0.0000 & 0.0000 & 0.0000 & -0.0000 \\ -0.0000 & -0.0000 & -0.0000 & 0.0000 & 0.0000 & 0.0000 & -0.0000 \\ -0.0000 & -0.0000 & -0.0000 & -0.0000 & 0.0000 & 0.0000 & -0.0000 \\ -0.0000 & -0.0000 & -0.0000 & -0.0000 & 0.0000 & 0.0000 & 0\end{array}$




\section{Restrição de 30\% aos Ativos Internacionais (2001 a 2006)}

[PortRisk, PortReturn, PortWts] = frontcon (ExpRetInt06, ExpCovInt06, [], PortReturnInt06, AssetBoundsInt05, GroupsInt05, GroupsBoundsInt05)

PortRisk $=$
0.0021
0.0025
0.0033
0.0044
0.0057
0.0079
0.0105
0.0134
0.0167
0.0223

PortReturn $=$

0.0140

0.0145

0.0150

0.0155

0.0160

0.0165

0.0170

0.0175

0.0180

0.0185

PortWts =

Columns 1 through 8

$\begin{array}{rrrrrrrr}0.8064 & 0.0454 & 0.0353 & -0.0000 & -0.0000 & -0.0000 & 0.0000 & -0.0000 \\ 0.7650 & 0.0849 & 0.1320 & -0.0000 & 0.0000 & -0.0000 & 0.0000 & 0.0000 \\ 0.4723 & 0.1649 & 0.3329 & -0.0000 & 0.0000 & -0.0000 & 0.0000 & -0.0000 \\ 0.1797 & 0.2449 & 0.5338 & 0.0000 & 0.0000 & -0.0000 & 0.0000 & 0.0000 \\ -0.0000 & 0.3421 & 0.5980 & -0.0000 & 0.0000 & -0.0000 & 0.0000 & 0.0000 \\ 0 & 0.4940 & 0.3968 & -0.0000 & 0.0000 & -0.0000 & -0.0000 & 0.0019 \\ 0.0000 & 0.6513 & 0.1836 & -0.0000 & -0.0000 & -0.0000 & -0.0000 & 0.0154 \\ -0.0000 & 0.7761 & -0.0000 & 0.0000 & -0.0000 & -0.0000 & -0.0000 & 0.0278 \\ -0.0000 & 0.6991 & -0.0000 & -0.0000 & -0.0000 & -0.0000 & -0.0000 & 0.0337 \\ 0.0000 & 0.5626 & -0.0000 & -0.0000 & -0.0000 & -0.0000 & -0.0000 & 0.1374\end{array}$

Columns 9 through 16 


$\begin{array}{rrrrrrrr}-0.0000 & -0.0000 & 0.0048 & 0.0000 & 0.0000 & 0.0000 & 0.0000 & 0.0000 \\ 0.0000 & -0.0000 & 0.0056 & -0.0000 & -0.0000 & -0.0000 & 0.0000 & 0.0000 \\ 0.0000 & -0.0000 & 0.0054 & -0.0000 & 0 & -0.0000 & 0.0000 & 0.0000 \\ -0.0000 & -0.0000 & 0.0051 & 0.0000 & 0.0000 & 0.0000 & -0.0000 & -0.0000 \\ -0.0000 & -0.0000 & -0.0000 & -0.0000 & -0.0000 & 0.0000 & 0.0000 & 0.0000 \\ 0.0000 & -0.0000 & 0.0000 & -0.0000 & -0.0000 & -0.0000 & -0.0000 & -0.0000 \\ 0.0000 & 0.0000 & -0.0000 & -0.0000 & -0.0000 & 0.0000 & -0.0000 & -0.0000 \\ 0.0000 & 0.0000 & 0.0000 & -0.0000 & 0.0000 & -0.0000 & -0.0000 & -0.0000 \\ 0.0000 & 0.0000 & 0.0000 & -0.0000 & 0.0000 & 0.0000 & -0.0000 & 0.0000 \\ 0.0000 & 0.0000 & 0.0000 & -0.0000 & 0.0191 & -0.0000 & -0.0000 & -0.0000\end{array}$

Columns 17 through 24

$\begin{array}{rrrrrrrr}0.0000 & -0.0000 & -0.0000 & -0.0000 & -0.0000 & -0.0000 & 0.0071 & -0.0000 \\ -0.0000 & -0.0000 & -0.0000 & -0.0000 & 0.0000 & -0.0000 & 0.0125 & -0.0000 \\ -0.0000 & 0.0000 & -0.0000 & -0.0000 & 0.0000 & -0.0000 & 0.0245 & 0.0000 \\ -0.0000 & -0.0000 & 0.0000 & -0.0000 & -0.0000 & 0.0000 & 0.0365 & 0.0000 \\ -0.0000 & 0.0000 & 0.0047 & -0.0000 & -0.0000 & 0.0000 & 0.0552 & 0.0000 \\ -0.0000 & 0.0000 & 0.0184 & -0.0000 & 0.0000 & -0.0000 & 0.0888 & 0.0000 \\ 0.0000 & 0.0000 & 0.0311 & -0.0000 & 0.0000 & 0.0000 & 0.1186 & -0.0000 \\ -0.0000 & 0.0000 & 0.0442 & -0.0000 & 0.0000 & 0.0000 & 0.1519 & -0.0000 \\ -0.0000 & -0.0000 & 0.0602 & -0.0000 & 0.0000 & 0.0000 & 0.2069 & -0.0000 \\ -0.0000 & -0.0000 & 0.0000 & -0.0000 & -0.0000 & 0.0000 & 0.2809 & -0.0000\end{array}$

Columns 25 through 31

$\begin{array}{rrrrrrr}0.0000 & 0.0000 & 0.0000 & 0.0000 & 0.0062 & 0.0000 & 0.0947 \\ 0.0000 & 0.0000 & 0.0000 & 0.0000 & -0.0000 & 0.0000 & -0.0000 \\ 0.0000 & -0.0000 & 0.0000 & -0.0000 & 0.0000 & 0.0000 & -0.0000 \\ 0.0000 & -0.0000 & -0.0000 & 0.0000 & -0.0000 & 0.0000 & -0.0000 \\ 0.0000 & 0.0000 & -0.0000 & 0.0000 & 0.0000 & 0.0000 & -0.0000 \\ -0.0000 & -0.0000 & -0.0000 & 0.0000 & 0.0000 & 0.0000 & -0.0000 \\ -0.0000 & -0.0000 & -0.0000 & 0.0000 & 0.0000 & 0.0000 & -0.0000 \\ -0.0000 & -0.0000 & -0.0000 & -0.0000 & 0.0000 & 0.0000 & -0.0000 \\ 0.0000 & -0.0000 & -0.0000 & -0.0000 & -0.0000 & 0.0000 & 0.0000 \\ -0.0000 & -0.0000 & -0.0000 & -0.0000 & 0.0000 & 0.0000 & -0.0000\end{array}$




\section{Restrição de 40\% de Ativos Internacionais (2001 a 2006)}

[PortRisk, PortReturn, PortWts] = frontcon (ExpRetInt06, ExpCovInt06, [], PortReturnInt06, AssetBoundsInt05, GroupsInt05, GroupsBoundsInt05)

PortRisk $=$
0.0021
0.0025
0.0033
0.0044
0.0057
0.0079
0.0105
0.0134
0.0167
0.0204
0.0244

PortReturn $=$

0.0140

0.0145

0.0150

0.0155

0.0160

0.0165

0.0170

0.0175

0.0180

0.0185

0.0190

PortWts =

Columns 1 through 8

$\begin{array}{rrrrrrrr}0.8064 & 0.0454 & 0.0353 & -0.0000 & -0.0000 & -0.0000 & 0.0000 & -0.0000 \\ 0.7650 & 0.0849 & 0.1320 & 0.0000 & -0.0000 & -0.0000 & 0.0000 & 0.0000 \\ 0.4723 & 0.1649 & 0.3329 & 0.0000 & -0.0000 & -0.0000 & 0.0000 & 0.0000 \\ 0.1797 & 0.2449 & 0.5338 & 0.0000 & 0.0000 & -0.0000 & 0.0000 & -0.0000 \\ -0.0000 & 0.3421 & 0.5980 & -0.0000 & 0.0000 & -0.0000 & 0.0000 & 0.0000 \\ 0.0000 & 0.4940 & 0.3968 & -0.0000 & 0.0000 & -0.0000 & 0.0000 & 0.0019 \\ 0.0000 & 0.6513 & 0.1836 & -0.0000 & -0.0000 & -0.0000 & -0.0000 & 0.0154 \\ -0.0000 & 0.7761 & 0.0000 & 0.0000 & -0.0000 & -0.0000 & -0.0000 & 0.0278 \\ 0.0000 & 0.6991 & -0.0000 & -0.0000 & -0.0000 & -0.0000 & -0.0000 & 0.0337 \\ -0.0000 & 0.6221 & 0 & -0.0000 & -0.0000 & -0.0000 & -0.0000 & 0.0396 \\ 0.0000 & 0.5302 & 0 & -0.0000 & -0.0000 & -0.0000 & -0.0000 & 0.0698\end{array}$


Columns 9 through 16

$\begin{array}{rrrrrrrr}0.0000 & -0.0000 & 0.0048 & -0.0000 & 0.0000 & 0.0000 & 0.0000 & 0.0000 \\ -0.0000 & -0.0000 & 0.0056 & 0.0000 & -0.0000 & -0.0000 & -0.0000 & -0.0000 \\ -0.0000 & -0.0000 & 0.0054 & -0.0000 & -0.0000 & 0.0000 & 0.0000 & 0.0000 \\ 0.0000 & -0.0000 & 0.0051 & 0.0000 & -0.0000 & 0.0000 & -0.0000 & -0.0000 \\ -0.0000 & -0.0000 & -0.0000 & -0.0000 & -0.0000 & 0.0000 & 0.0000 & 0.0000 \\ -0.0000 & -0.0000 & -0.0000 & -0.0000 & -0.0000 & -0.0000 & 0.0000 & 0.0000 \\ 0.0000 & 0.0000 & -0.0000 & -0.0000 & -0.0000 & 0.0000 & -0.0000 & -0.0000 \\ 0.0000 & 0.0000 & 0.0000 & -0.0000 & 0.0000 & -0.0000 & -0.0000 & -0.0000 \\ 0.0000 & 0.0000 & 0.0000 & -0.0000 & -0.0000 & 0.0000 & -0.0000 & -0.0000 \\ 0.0000 & 0.0000 & 0.0000 & -0.0000 & 0.0000 & 0.0000 & -0.0000 & 0.0000 \\ 0.0000 & 0.0000 & -0.0000 & -0.0000 & -0.0000 & 0.0000 & -0.0000 & 0.0000\end{array}$

Columns 17 through 24

$\begin{array}{rrrrrrrr}0.0000 & -0.0000 & -0.0000 & -0.0000 & 0.0000 & -0.0000 & 0.0071 & -0.0000 \\ -0.0000 & -0.0000 & -0.0000 & -0.0000 & 0.0000 & -0.0000 & 0.0125 & 0.0000 \\ -0.0000 & -0.0000 & -0.0000 & -0.0000 & -0.0000 & -0.0000 & 0.0245 & -0.0000 \\ -0.0000 & -0.0000 & -0.0000 & -0.0000 & -0.0000 & -0.0000 & 0.0365 & 0.0000 \\ -0.0000 & 0.0000 & 0.0047 & -0.0000 & -0.0000 & 0.0000 & 0.0552 & 0.0000 \\ -0.0000 & -0.0000 & 0.0184 & -0.0000 & -0.0000 & 0.0000 & 0.0888 & -0.0000 \\ 0.0000 & 0.0000 & 0.0311 & -0.0000 & -0.0000 & 0.0000 & 0.1186 & -0.0000 \\ -0.0000 & 0.0000 & 0.0442 & -0.0000 & 0.0000 & 0.0000 & 0.1519 & -0.0000 \\ -0.0000 & -0.0000 & 0.0602 & -0.0000 & 0.0000 & 0.0000 & 0.2069 & -0.0000 \\ -0.0000 & -0.0000 & 0.0762 & -0.0000 & -0.0000 & 0.0000 & 0.2620 & -0.0000 \\ -0.0000 & -0.0000 & 0.0743 & -0.0000 & 0.0000 & 0.0000 & 0.3257 & -0.0000\end{array}$

Columns 25 through 31

$\begin{array}{rrrrrrr}0.0000 & 0.0000 & 0.0000 & -0.0000 & 0.0062 & 0.0000 & 0.0947 \\ 0.0000 & 0.0000 & 0.0000 & 0.0000 & -0.0000 & 0.0000 & -0.0000 \\ -0.0000 & -0.0000 & 0.0000 & -0.0000 & 0.0000 & 0.0000 & -0.0000 \\ -0.0000 & -0.0000 & 0.0000 & -0.0000 & -0.0000 & 0.0000 & -0.0000 \\ -0.0000 & -0.0000 & -0.0000 & 0.0000 & 0.0000 & 0.0000 & -0.0000 \\ -0.0000 & 0.0000 & -0.0000 & 0.0000 & 0.0000 & 0.0000 & -0.0000 \\ 0.0000 & -0.0000 & -0.0000 & 0.0000 & 0.0000 & 0.0000 & -0.0000 \\ -0.0000 & 0.0000 & -0.0000 & -0.0000 & 0.0000 & 0.0000 & -0.0000 \\ -0.0000 & -0.0000 & -0.0000 & -0.0000 & 0.0000 & 0.0000 & -0.0000 \\ 0.0000 & 0.0000 & -0.0000 & -0.0000 & -0.0000 & 0.0000 & -0.0000 \\ 0.0000 & 0.0000 & -0.0000 & -0.0000 & 0.0000 & 0.0000 & 0.0000\end{array}$




\section{Restrição de 50\% de Ativos Internacionais (2001 a 2006)}

[PortRisk, PortReturn, PortWts] = frontcon(ExpRetInt06, ExpCovInt06, [], PortReturnInt06, AssetBoundsInt05, GroupsInt05x, GroupsBoundsInt05x)

PortRisk

0.0021
0.0025
0.0033
0.0044
0.0057
0.0079
0.0105
0.0134
0.0167
0.0204
0.0243
0.0286

PortReturn $=$
0.0140
0.0145
0.0150
0.0155
0.0160
0.0165
0.0170
0.0175
0.0180
0.0185
0.0190
0.0195

PortWts $=$ Columns 1 through 8
0.8064
$\begin{array}{lll}0.0454 & 0.0353 & -0.0000\end{array}$
$\begin{array}{llll}0.0000 & -0.0000 & -0.0000 & -0.0000\end{array}$
0.7650
$\begin{array}{llll}0.0849 & 0.1320 & -0.0000\end{array}$
$\begin{array}{llll}0.0000 & -0.0000 & -0.0000 & -0.0000\end{array}$
0.4723
$\begin{array}{lll}0.1649 & 0.3329 & 0.0000\end{array}$
$\begin{array}{llll}0.0000 & -0.0000 & -0.0000 & 0.0000\end{array}$
0.1797
0.2449
$0.5338-0.0000$
$\begin{array}{llll}0.0000 & -0.0000 & -0.0000 & -0.0000\end{array}$
$\begin{array}{llllllll}0 & 0.3421 & 0.5980 & -0.0000 & -0.0000 & -0.0000 & -0.0000 & -0.0000\end{array}$
$\begin{array}{llllllll}-0.0000 & 0.4940 & 0.3968 & 0.0000 & -0.0000 & -0.0000 & -0.0000 & 0.0019\end{array}$
$\begin{array}{llllllll}-0.0000 & 0.6513 & 0.1836 & -0.0000 & -0.0000 & -0.0000 & 0.0000 & 0.0154\end{array}$
$\begin{array}{llllllll}-0.0000 & 0.7761 & -0.0000 & 0.0000 & -0.0000 & -0.0000 & -0.0000 & 0.0278\end{array}$
$\begin{array}{lllllllll}-0.0000 & 0.6991 & -0.0000 & 0.0000 & -0.0000 & -0.0000 & -0.0000 & 0.0337\end{array}$
$\begin{array}{llllllll}-0.0000 & 0.6221 & -0.0000 & 0.0000 & -0.0000 & -0.0000 & -0.0000 & 0.0396\end{array}$
$\begin{array}{llllllll}-0.0000 & 0.5451 & -0.0000 & 0.0000 & -0.0000 & -0.0000 & -0.0000 & 0.0455\end{array}$
$\begin{array}{lllllllll}-0.0000 & 0.5000 & -0.0000 & -0.0000 & -0.0000 & -0.0000 & -0.0000 & 0.0086\end{array}$ 
Columns 9 through 16

$\begin{array}{rrrrrrrr}-0.0000 & -0.0000 & 0.0048 & 0.0000 & 0.0000 & 0.0000 & 0.0000 & -0.0000 \\ -0.0000 & -0.0000 & 0.0056 & -0.0000 & 0.0000 & 0.0000 & 0.0000 & -0.0000 \\ -0.0000 & -0.0000 & 0.0054 & 0.0000 & -0.0000 & -0.0000 & -0.0000 & 0.0000 \\ -0.0000 & -0.0000 & 0.0051 & -0.0000 & 0.0000 & -0.0000 & -0.0000 & 0.0000 \\ 0.0000 & -0.0000 & 0.0000 & -0.0000 & -0.0000 & -0.0000 & -0.0000 & 0.0000 \\ 0.0000 & -0.0000 & -0.0000 & -0.0000 & -0.0000 & 0.0000 & 0.0000 & -0.0000 \\ -0.0000 & -0.0000 & -0.0000 & -0.0000 & -0.0000 & -0.0000 & 0.0000 & 0.0000 \\ 0.0000 & -0.0000 & 0.0000 & 0.0000 & -0.0000 & -0.0000 & -0.0000 & -0.0000 \\ -0.0000 & -0.0000 & 0.0000 & 0.0000 & -0.0000 & 0.0000 & -0.0000 & 0.0000 \\ -0.0000 & -0.0000 & 0.0000 & -0.0000 & -0.0000 & -0.0000 & -0.0000 & 0.0000 \\ -0.0000 & -0.0000 & 0.0000 & -0.0000 & -0.0000 & 0.0000 & -0.0000 & 0.0000 \\ -0.0000 & -0.0000 & -0.0000 & 0.0000 & 0 & -0.0000 & 0.0000 & -0.0000\end{array}$

Columns 17 through 24

$\begin{array}{rrrrrrrr}-0.0000 & -0.0000 & 0.0000 & -0.0000 & -0.0000 & -0.0000 & 0.0071 & -0.0000 \\ 0.0000 & 0.0000 & -0.0000 & -0.0000 & -0.0000 & -0.0000 & 0.0125 & -0.0000 \\ -0.0000 & 0.0000 & -0.0000 & -0.0000 & 0.0000 & -0.0000 & 0.0245 & 0.0000 \\ 0.0000 & -0.0000 & 0.0000 & -0.0000 & 0.0000 & -0.0000 & 0.0365 & 0.0000 \\ 0.0000 & -0.0000 & 0.0047 & -0.0000 & 0.0000 & -0.0000 & 0.0552 & -0.0000 \\ 0.0000 & 0.0000 & 0.0184 & -0.0000 & -0.0000 & -0.0000 & 0.0888 & 0.0000 \\ -0.0000 & 0.0000 & 0.0311 & -0.0000 & 0.0000 & -0.0000 & 0.1186 & 0.0000 \\ -0.0000 & -0.0000 & 0.0442 & -0.0000 & -0.0000 & -0.0000 & 0.1519 & -0.0000 \\ 0.0000 & -0.0000 & 0.0602 & -0.0000 & 0.0000 & -0.0000 & 0.2069 & -0.0000 \\ -0.0000 & -0.0000 & 0.0762 & -0.0000 & 0.0000 & -0.0000 & 0.2620 & 0.0000 \\ -0.0000 & -0.0000 & 0.0923 & -0.0000 & 0.0000 & -0.0000 & 0.3171 & 0.0000 \\ -0.0000 & 0.0000 & 0.0997 & -0.0000 & 0.0000 & -0.0000 & 0.3918 & -0.0000\end{array}$

Columns 25 through 31

$\begin{array}{rrrrrrr}-0.0000 & -0.0000 & -0.0000 & -0.0000 & 0.0062 & 0.0000 & 0.0947 \\ 0.0000 & 0.0000 & -0.0000 & -0.0000 & 0.0000 & 0.0000 & 0.0000 \\ -0.0000 & 0.0000 & -0.0000 & 0.0000 & -0.0000 & 0.0000 & 0.0000 \\ 0.0000 & 0.0000 & -0.0000 & 0.0000 & 0.0000 & 0.0000 & -0.0000 \\ -0.0000 & -0.0000 & -0.0000 & 0.0000 & -0.0000 & 0.0000 & -0.0000 \\ -0.0000 & 0.0000 & -0.0000 & 0.0000 & -0.0000 & 0.0000 & -0.0000 \\ 0.0000 & 0.0000 & -0.0000 & -0.0000 & 0.0000 & 0.0000 & -0.0000 \\ 0.0000 & 0.0000 & -0.0000 & 0.0000 & 0.0000 & 0.0000 & -0.0000 \\ -0.0000 & 0.0000 & 0.0000 & 0.0000 & 0.0000 & 0.0000 & -0.0000 \\ -0.0000 & 0.0000 & -0.0000 & 0.0000 & 0.0000 & 0.0000 & -0.0000 \\ -0.0000 & 0.0000 & -0.0000 & -0.0000 & -0.0000 & 0.0000 & -0.0000 \\ -0.0000 & -0.0000 & -0.0000 & 0.0000 & -0.0000 & 0.0000 & -0.0000\end{array}$




\section{Restrição Total a Ativos Internacionais (2003 a 2006)}

[PortRisk, PortReturn, PortWts] $=$ frontcon(ExpRetNac03, ExpCovNac03, [], PortReturnNac03,AssetBoundsNac05,GroupsNac05,GroupsBoundsNac05)

PortRisk $=$
0.0024
0.0037
0.0060
0.0091
0.0127
0.0165
0.0203
0.0243
0.0282
0.0322

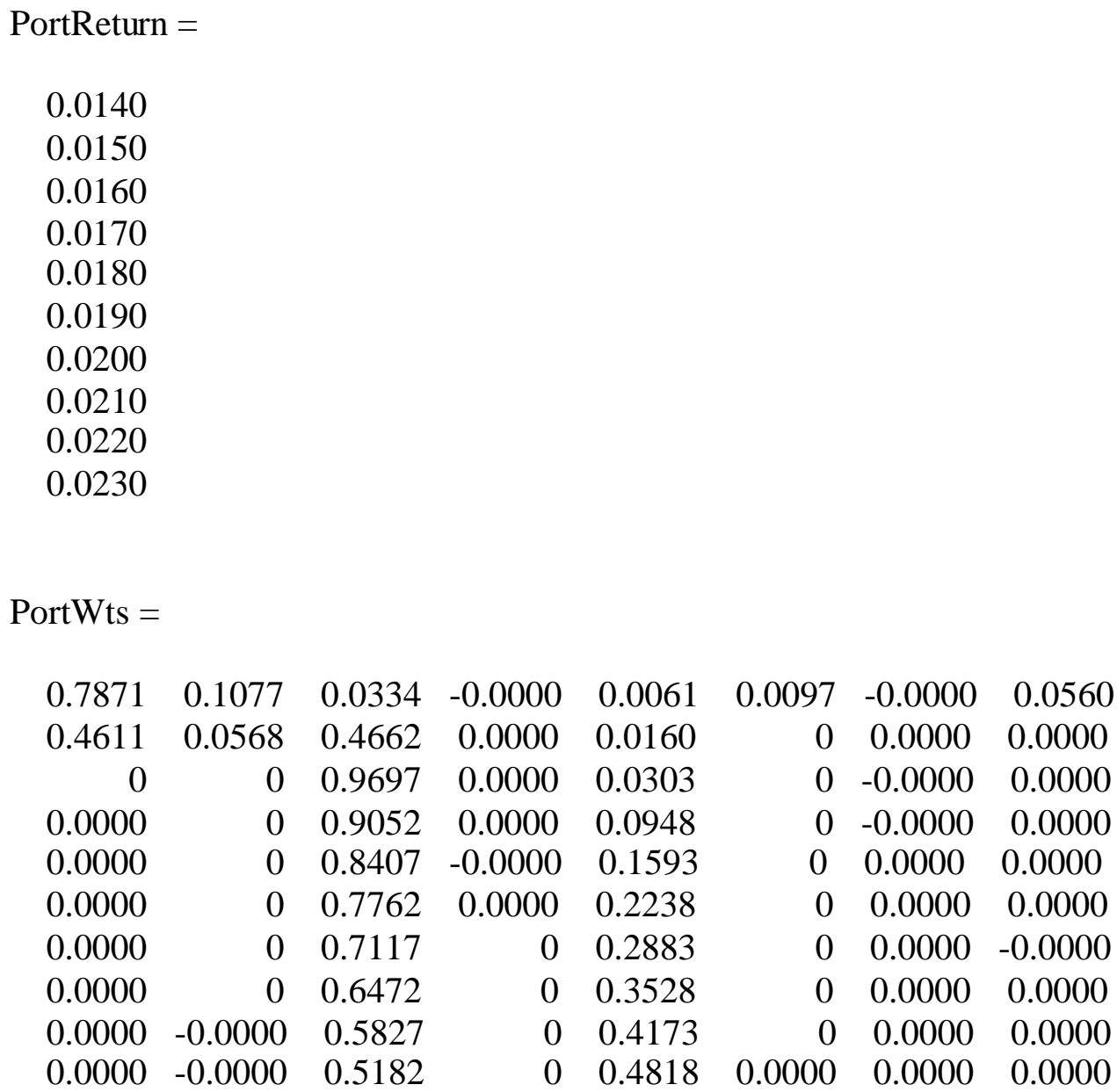




\section{Restrição de 10\% de Ativos Internacionais (2003 a 2006)}

[PortRisk, PortReturn, PortWts] = frontcon(ExpRetInt03, ExpCovInt03, [], PortReturnNac03,AssetBoundsInt05,GroupsInt05,GroupsBoundsInt05)

PortRisk $=$
0.0022
0.0034
0.0056
0.0086
0.0121
0.0158
0.0196
0.0234
0.0273
0.0313

PortReturn $=$

0.0140

0.0150

0.0160

0.0170

0.0180

0.0190

0.0200

0.0210

0.0220

0.0230

PortWts =

Columns 1 through 8

$\begin{array}{rccccccc}0.6847 & 0.1287 & 0.0780 & 0.0000 & -0.0000 & -0.0000 & 0.0000 & -0.0000 \\ 0.3658 & 0.0982 & 0.4975 & 0.0000 & -0.0000 & -0.0000 & 0.0000 & 0.0039 \\ -0.0000 & 0.0106 & 0.9291 & 0.0000 & -0.0000 & -0.0000 & -0.0000 & 0.0158 \\ -0.0000 & 0.0000 & 0.8731 & 0.0000 & -0.0000 & 0.0000 & 0.0000 & 0.0728 \\ -0.0000 & -0.0000 & 0.8031 & 0.0000 & -0.0000 & 0.0019 & -0.0000 & 0.1292 \\ 0.0000 & 0.0000 & 0.7330 & -0.0000 & -0.0000 & 0.0046 & -0.0000 & 0.1855 \\ -0.0000 & -0.0000 & 0.6628 & -0.0000 & 0.0000 & 0.0073 & -0.0000 & 0.2418 \\ 0.0000 & -0.0000 & 0.5988 & -0.0000 & 0.0000 & 0.0084 & -0.0000 & 0.3012 \\ -0.0000 & -0.0000 & 0.5378 & -0.0000 & 0.0000 & 0.0087 & 0.0000 & 0.3622 \\ -0.0000 & -0.0000 & 0.5000 & 0.0000 & 0.0000 & 0 & 0.0000 & 0.4409\end{array}$

Columns 9 through 16 


$\begin{array}{rrrrrrrr}0.0000 & -0.0000 & 0.0034 & -0.0000 & 0.0000 & -0.0000 & -0.0000 & -0.0000 \\ -0.0000 & -0.0000 & 0.0020 & -0.0000 & 0.0000 & 0.0000 & 0.0000 & 0.0000 \\ -0.0000 & 0.0000 & 0.0000 & 0.0000 & 0.0000 & 0.0000 & 0.0000 & -0.0000 \\ 0.0000 & -0.0000 & -0.0000 & 0.0000 & 0.0000 & -0.0000 & 0.0000 & 0.0000 \\ 0.0000 & 0.0000 & 0.0000 & 0.0000 & -0.0000 & 0.0000 & -0.0000 & -0.0000 \\ -0.0000 & 0.0000 & -0.0000 & -0.0000 & -0.0000 & -0.0000 & -0.0000 & 0.0000 \\ 0.0000 & 0.0000 & -0.0000 & -0.0000 & 0.0000 & -0.0000 & 0.0000 & -0.0000 \\ -0.0000 & 0.0000 & -0.0000 & 0.0000 & -0.0000 & -0.0000 & -0.0000 & 0.0000 \\ 0.0000 & 0.0000 & -0.0000 & 0.0000 & 0.0000 & -0.0000 & -0.0000 & 0.0000 \\ -0.0000 & 0.0000 & -0.0000 & -0.0000 & 0.0000 & 0.0000 & -0.0000 & -0.0000\end{array}$

Columns 17 through 24

$\begin{array}{rrrrrrrr}0.0000 & -0.0000 & -0.0000 & -0.0000 & 0.0000 & -0.0000 & 0.0191 & 0.0000 \\ 0.0000 & 0.0000 & 0.0000 & -0.0000 & 0.0000 & -0.0000 & 0.0323 & -0.0000 \\ -0.0000 & 0.0000 & -0.0000 & 0.0000 & -0.0000 & -0.0000 & 0.0400 & 0.0000 \\ 0.0000 & 0.0000 & 0.0037 & -0.0000 & 0.0000 & -0.0000 & 0.0409 & 0.0000 \\ 0.0000 & 0.0000 & 0.0134 & -0.0000 & 0.0000 & -0.0000 & 0.0388 & -0.0000 \\ 0.0000 & 0.0000 & 0.0229 & -0.0000 & -0.0000 & 0.0000 & 0.0365 & -0.0000 \\ 0.0000 & 0.0000 & 0.0324 & -0.0000 & -0.0000 & -0.0000 & 0.0342 & -0.0000 \\ -0.0000 & -0.0000 & 0.0402 & -0.0000 & -0.0000 & -0.0000 & 0.0253 & -0.0000 \\ -0.0000 & -0.0000 & 0.0472 & -0.0000 & 0.0000 & 0.0000 & 0.0131 & -0.0000 \\ 0.0000 & -0.0000 & 0.0160 & 0.0000 & -0.0000 & 0.0000 & 0 & -0.0000\end{array}$

Columns 25 through 31

$\begin{array}{rrrrrrr}0.0000 & 0.0000 & 0.0000 & 0.0000 & 0.0072 & -0.0000 & 0.0788 \\ 0.0000 & 0.0000 & -0.0000 & 0.0004 & -0.0000 & -0.0000 & 0.0000 \\ 0.0000 & -0.0000 & 0.0000 & 0.0045 & 0.0000 & 0.0000 & -0.0000 \\ 0.0000 & -0.0000 & -0.0000 & 0.0095 & 0.0000 & 0.0000 & 0.0000 \\ 0.0000 & -0.0000 & -0.0000 & 0.0136 & 0.0000 & 0.0000 & 0.0000 \\ 0.0000 & -0.0000 & 0.0000 & 0.0175 & -0.0000 & 0.0000 & 0.0000 \\ -0.0000 & -0.0000 & -0.0000 & 0.0214 & -0.0000 & 0.0000 & 0.0000 \\ 0.0000 & 0.0000 & 0.0000 & 0.0260 & -0.0000 & 0.0000 & 0.0000 \\ 0.0000 & 0.0000 & 0.0000 & 0.0310 & -0.0000 & 0.0000 & 0.0000 \\ 0.0000 & 0.0000 & -0.0000 & 0.0430 & 0.0000 & -0.0000 & 0.0000\end{array}$




\section{Restrição de 20\% de Ativos Internacionais (2003 a 2006)}

[PortRisk, PortReturn, PortWts] = frontcon(ExpRetInt03, ExpCovInt03, [], PortReturnNac03,AssetBoundsInt05,GroupsInt05,GroupsBoundsInt05)

PortRisk $=$
0.0022
0.0034
0.0056
0.0086
0.0121
0.0158
0.0196
0.0234
0.0272
0.0313

PortReturn $=$

0.0140

0.0150

0.0160

0.0170

0.0180

0.0190

0.0200

0.0210

0.0220

0.0230

PortWts =

Columns 1 through 8

$\begin{array}{rrrrrrrr}0.6847 & 0.1287 & 0.0780 & 0.0000 & -0.0000 & 0.0000 & -0.0000 & -0.0000 \\ 0.3658 & 0.0982 & 0.4975 & -0.0000 & -0.0000 & 0.0000 & -0.0000 & 0.0039 \\ -0.0000 & 0.0106 & 0.9291 & -0.0000 & 0.0000 & -0.0000 & -0.0000 & 0.0158 \\ 0.0000 & 0.0000 & 0.8731 & 0.0000 & -0.0000 & -0.0000 & 0.0000 & 0.0728 \\ -0.0000 & 0.0000 & 0.8031 & 0.0000 & 0.0000 & 0.0019 & -0.0000 & 0.1292 \\ 0.0000 & 0.0000 & 0.7330 & -0.0000 & 0.0000 & 0.0046 & -0.0000 & 0.1855 \\ 0.0000 & 0.0000 & 0.6628 & -0.0000 & 0.0000 & 0.0073 & 0.0000 & 0.2418 \\ 0.0000 & -0.0000 & 0.5927 & -0.0000 & 0.0000 & 0.0100 & 0.0000 & 0.2981 \\ -0.0000 & -0.0000 & 0.5226 & -0.0000 & 0.0000 & 0.0127 & 0.0000 & 0.3544 \\ -0.0000 & -0.0000 & 0.5000 & 0.0000 & 0.0000 & 0 & 0.0000 & 0.4409\end{array}$

Columns 9 through 16 


$\begin{array}{rrrrrrrr}-0.0000 & 0.0000 & 0.0034 & 0.0000 & 0.0000 & -0.0000 & -0.0000 & 0.0000 \\ -0.0000 & -0.0000 & 0.0020 & -0.0000 & -0.0000 & 0.0000 & 0.0000 & -0.0000 \\ 0.0000 & 0.0000 & 0.0000 & 0.0000 & 0.0000 & 0.0000 & 0.0000 & -0.0000 \\ 0.0000 & 0.0000 & 0.0000 & -0.0000 & -0.0000 & 0.0000 & 0.0000 & 0.0000 \\ 0.0000 & 0.0000 & -0.0000 & -0.0000 & -0.0000 & -0.0000 & -0.0000 & 0.0000 \\ -0.0000 & 0.0000 & 0.0000 & 0.0000 & -0.0000 & -0.0000 & -0.0000 & 0.0000 \\ -0.0000 & -0.0000 & -0.0000 & -0.0000 & 0.0000 & 0.0000 & -0.0000 & 0.0000 \\ -0.0000 & 0.0000 & -0.0000 & 0.0000 & 0.0000 & -0.0000 & -0.0000 & 0.0000 \\ 0.0000 & 0.0000 & -0.0000 & 0.0000 & 0.0000 & 0.0000 & -0.0000 & 0.0000 \\ -0.0000 & 0.0000 & -0.0000 & -0.0000 & 0.0000 & 0.0000 & -0.0000 & -0.0000\end{array}$

Columns 17 through 24

$\begin{array}{rrrrrrrr}-0.0000 & -0.0000 & -0.0000 & -0.0000 & -0.0000 & 0.0000 & 0.0191 & 0.0000 \\ 0.0000 & -0.0000 & -0.0000 & -0.0000 & 0.0000 & -0.0000 & 0.0323 & -0.0000 \\ 0.0000 & -0.0000 & -0.0000 & 0.0000 & 0.0000 & -0.0000 & 0.0400 & -0.0000 \\ -0.0000 & 0.0000 & 0.0037 & -0.0000 & 0.0000 & -0.0000 & 0.0409 & -0.0000 \\ 0.0000 & 0.0000 & 0.0134 & -0.0000 & -0.0000 & -0.0000 & 0.0388 & -0.0000 \\ -0.0000 & -0.0000 & 0.0229 & -0.0000 & 0.0000 & -0.0000 & 0.0365 & -0.0000 \\ -0.0000 & 0.0000 & 0.0324 & 0.0000 & -0.0000 & 0.0000 & 0.0342 & -0.0000 \\ -0.0000 & -0.0000 & 0.0419 & -0.0000 & -0.0000 & -0.0000 & 0.0319 & -0.0000 \\ -0.0000 & -0.0000 & 0.0514 & -0.0000 & 0.0000 & 0.0000 & 0.0296 & -0.0000 \\ 0.0000 & -0.0000 & 0.0160 & 0.0000 & -0.0000 & 0.0000 & 0 & -0.0000\end{array}$

Columns 25 through 31

$\begin{array}{rrrrrrr}-0.0000 & -0.0000 & 0.0000 & 0.0000 & 0.0072 & -0.0000 & 0.0788 \\ 0.0000 & -0.0000 & 0.0000 & 0.0004 & -0.0000 & 0.0000 & -0.0000 \\ -0.0000 & -0.0000 & 0.0000 & 0.0045 & 0.0000 & 0.0000 & 0.0000 \\ -0.0000 & 0.0000 & -0.0000 & 0.0095 & 0.0000 & 0.0000 & 0.0000 \\ 0.0000 & 0.0000 & 0.0000 & 0.0136 & -0.0000 & -0.0000 & 0.0000 \\ 0.0000 & 0.0000 & 0.0000 & 0.0175 & -0.0000 & 0.0000 & 0.0000 \\ 0.0000 & -0.0000 & 0.0000 & 0.0214 & -0.0000 & 0.0000 & 0.0000 \\ 0.0000 & 0.0000 & 0.0000 & 0.0254 & -0.0000 & 0.0000 & 0.0000 \\ 0.0000 & 0.0000 & 0.0000 & 0.0293 & -0.0000 & 0.0000 & 0.0000 \\ 0.0000 & 0.0000 & -0.0000 & 0.0430 & 0.0000 & -0.0000 & 0.0000\end{array}$

